Supporting Information For

Gold Catalyzed Decarboxylative Cross-Coupling of Iodoarenes

\author{
Ryan A. Daley ${ }^{1}$, Aaron S. Morrenzin ${ }^{2}$, Sharon R. Neufeldt ${ }^{2 *}$, and Joseph J. Topczewski ${ }^{1 *}$ \\ ${ }^{1}$ Department of Chemistry, University of Minnesota - Twin Cities, Minneapolis, Minnesota 55455 \\ ${ }^{2}$ Department of Chemistry, Montana State University, Bozeman, Montana 59717
}

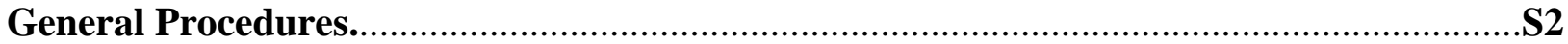

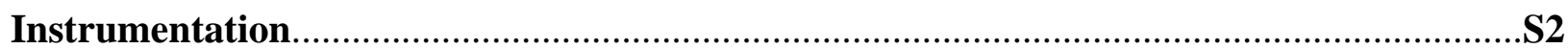

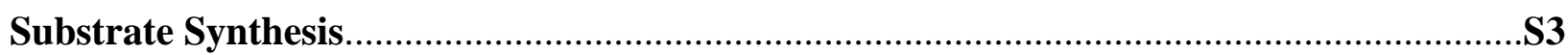

Procedures for Optimization of Decarboxylative Cross-Coupling.......................................S4

Table S1. Gold Precatalyst/Silver Screen................................................................S5

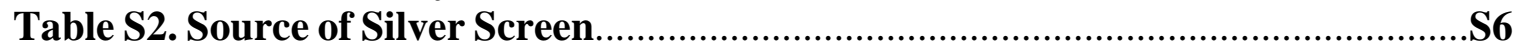

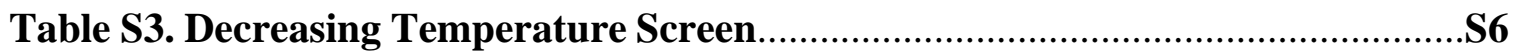

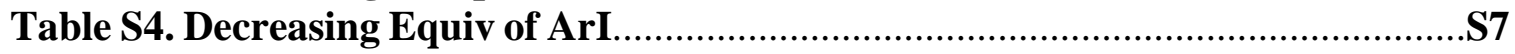

Table S5 Field effect Parameter vs. Optimal Conditions.............................................S7

General Procedure for Gold Cross-Coupling and Characterization Data.............................S8

Synthesis of Gold and Silver Complexes and Characterization Data..............................S19

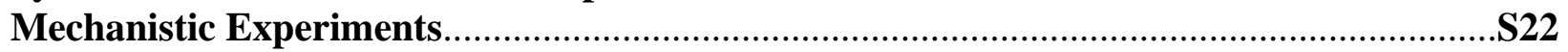

Table S6. Gold Carboxylate and Gold Aryl as precatalyst......................................S24

Table S7. Role of Silver/Cationic Gold....................................................................S25

Table S8: Comparison of Chemical Shifts of Cationic Gold Complexes.....................S26

Table S9. Mercury Drop Test...................................................................................S26

Table S10 Comparison of Silver Aryl Ag1 to Silver Carboxylate 1a..........................S27

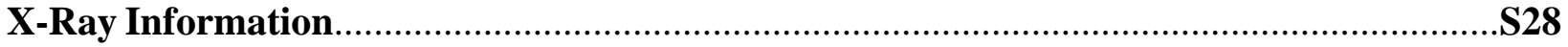

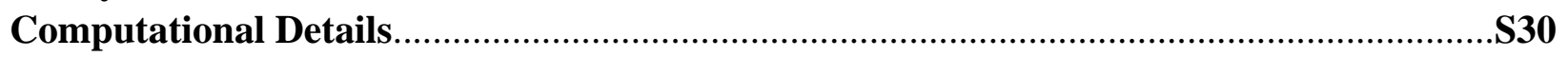

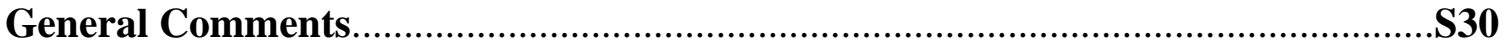

Graphical Guide to Oxidative Addition Structures.....................................................S30

Oxidative Addition Free Energy Diagrams.............................................................S33

Table S11. Energies, Entropies, Frequencies for Oxidative Addition.........................S44

Graphical Guide to Decarboxylation Structures.......................................................S45

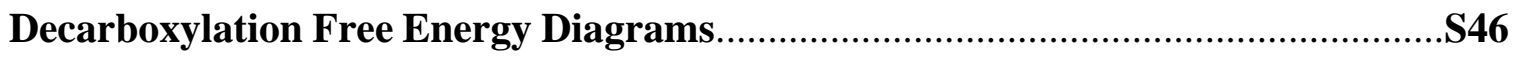

Table S12. Energies, Entropies, Frequencies for Decarboxylation...........................S49

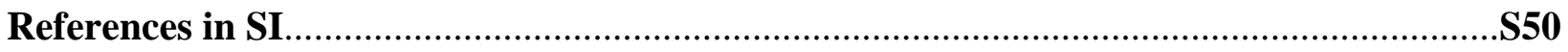

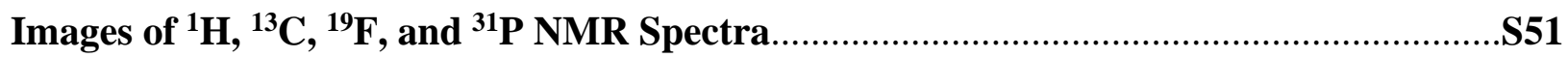

Cartesian Coordinates of Minimum Energy Calculated Structures...................................S139 
General: All reactions sensitive to air or moisture were carried out in oven-dried glassware using standard Schlenk line techniques or in a nitrogen filled glovebox. Dry THF and DMF were obtained from a commercial solvent purification system using activated alumina columns and stored under a positive pressure of argon. Dichlorobenzene and DMSO was dried over activated mol sieves $(3 \AA)$ for at least $24 \mathrm{~h}$. All other solvents and all reagents were purchased from commercial suppliers and used as received. Reactions were monitored by gas chromatography, ${ }^{19} \mathrm{~F}$ NMR spectroscopy, or thin layer chromatography (TLC) using pre-coated plastic plates with a fluorescent indicator $(254 \mathrm{~nm})$. Visualization was carried out with UV light $(254 \mathrm{~nm})$. Column chromatography was performed using a Teledyne Isco CombiFlash Rf purification system utilizing normal phase pre-column load cartridges and gold high performance columns. Preparatory thin layer chromatography was performed using Silicycle Siliplate glass backed, $60 \AA$, $2000 \mu$ mol thickness, fluorescent indicator $(254 \mathrm{~nm})$ TLC plates.

All decarboxylation reactions were stirred at $300 \mathrm{rpm}$ on an IKA RTC hot plate on an aluminum block with an external thermocouple. The hot plate was covered with aluminum foil to protect from light.

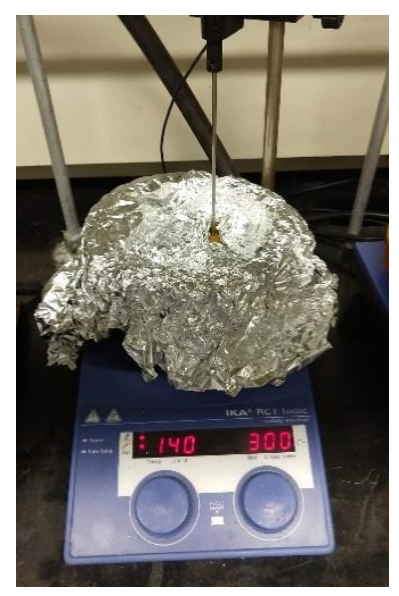

Instrumentation: All proton $\left({ }^{1} \mathrm{H}\right) \mathrm{NMR}$ spectra were recorded at $400 \mathrm{MHz}$ or $500 \mathrm{MHz}$ on a Bruker spectrometer. All carbon $\left({ }^{13} \mathrm{C}\right) \mathrm{NMR}$ spectra were recorded at $126 \mathrm{MHz}$ on a Bruker spectrometer. All fluorine $\left({ }^{19} \mathrm{~F}\right)$ NMR spectra for characterization were proton decoupled and recorded at $376 \mathrm{MHz}$ on a Bruker spectrometer. Chemical shifts are expressed in ppm and are referenced to residual solvent as an internal standard $\left({ }^{1} \mathrm{H}: \mathrm{CHCl}_{3}, 7.27 \mathrm{ppm} ;{ }^{13} \mathrm{C}: \mathrm{CDCl}_{3}, 77.2 \mathrm{ppm}\right)$ when possible. Infrared (IR) spectra were performed as a film on $\mathrm{NaCl}$ plates on a Nexus $670 \mathrm{FT}$ IR and are reported in $\mathrm{cm}^{-1}$. Mass spectra were taken on a Bruker BioTOF II or an Agilent 7890B GC/Agilent 7200 Accurate Mass GQ-TOF. All crude fluorine $\left({ }^{19} \mathrm{~F}\right)$ NMR spectra were proton coupled and recorded at $471 \mathrm{MHz}$ on a Bruker spectrometer. Yields reported based on ${ }^{19} \mathrm{~F} \mathrm{NMR}$ were determined by integration with 1-fluoronaphthalene or trifluorotoluene as an internal standard. Gas chromatography (GC) was performed on a Shimadzu GC-2010 Plus using an SHRxi-5ms 15 m column and a flame ionization detector. The standard GC temperature ramp was as follows: Hold at $100{ }^{\circ} \mathrm{C}(1 \mathrm{~min}), 40^{\circ} \mathrm{C}$ min gradient $\left(100-200{ }^{\circ} \mathrm{C}\right), 35^{\circ} \mathrm{C} / \mathrm{min}$ gradient $(200-250)$, hold at $250{ }^{\circ} \mathrm{C}(3 \mathrm{~min})$. Yields reported based on $\mathrm{GC}$ analysis of products $3 \mathbf{a}$ and $4 \mathbf{a}$ were determined by linear regression of a 5-point calibration curve with 1-fluoronaphthalene, naphthalene, or anthrocene as the internal standard. 


\section{Synthesis of Silver Carboxylates}

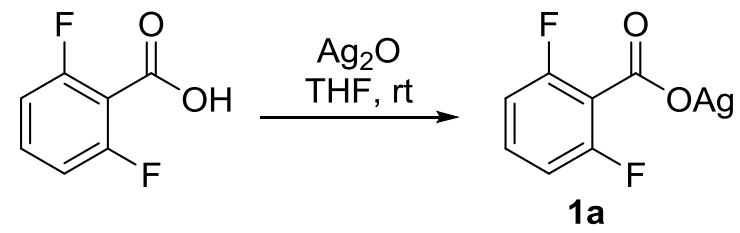

Method A: In air, a $100 \mathrm{~mL}$ round bottom flask was charged with silver oxide (769 mg, 3.32 mmol) and dry THF (30 mL) and covered with black plastic to protect from light. A $20 \mathrm{~mL}$ vial was charged with 2,6-difluorobenzoic acid (1.01 g, $6.37 \mathrm{mmol})$ and dry THF (15 mL). The resulting solution of acid was added slowly at $\mathrm{rt}$ to the flask containing silver oxide. The vial was rinsed with additional THF ( 3 X $5 \mathrm{~mL})$. After $2 \mathrm{~h}$, the solution was filtered through celite. The celite was washed with dry THF $(20 \mathrm{~mL})$, and the filtrate was concentrated under reduced pressure. The resulting solid was transferred to a $20 \mathrm{~mL}$ vial and heated under reduced pressure $(<200 \mathrm{mbar}$ at $30^{\circ} \mathrm{C}$ ) for approximately $18 \mathrm{~h}$ to afford carboxylate $1 \mathrm{a}$ as a white solid $(1.62 \mathrm{~g}, 6.10 \mathrm{mmol}$, 96\%). The carboxylate was shielded from light, stored in a glovebox freezer, and was used within of 1 month of synthesis. The following salts were prepared by method A: silver 2,6-difluoro-3nitrobenzoate (1n), silver 2,3,6-trifluorobenzoate (1o), silver 3-chloro-2,6-fluorobenzoate (1p), silver 2,4,6-trifluobenzoate (1s), silver 2,6-difluoro-3-methylbenzoate (1r), 2-chloro-6fluorobenzoate (1u), 2-fluoro-6-trifluoromethylbenzoate (1v), silver 4-bromo-2,6difluorobenzoate (1t), 2-fluorobenzoate (1x), silver 2,3,5,6-tetrafluoroisonicotinate $(\mathbf{1 z})$ and silver benzoate.

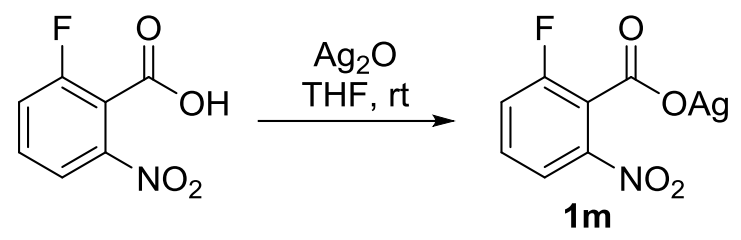

Method B: In air, a $100 \mathrm{~mL}$ round bottom flask was charged with silver oxide (231 mg, 0.997 $\mathrm{mmol})$ and dry THF $(10 \mathrm{~mL})$ and covered with black plastic to protect from light. A $20 \mathrm{~mL}$ vial was charged with 2-fluoro-6-nitrobenzoic acid $(368 \mathrm{mg}, 1.99 \mathrm{mmol})$ and dry THF $(7 \mathrm{~mL})$. The resulting solution of acid was added slowly at $\mathrm{rt}$ to the flask containing silver oxide. The vial was rinsed with additional THF ( 3 X $1 \mathrm{~mL})$. After $2 \mathrm{~h}$, the solution was concentrated under reduced pressure. The resulting solid was transferred to a $20 \mathrm{~mL}$ vial and heated under reduced pressure $(<$ $200 \mathrm{mbar}$ at $30^{\circ} \mathrm{C}$ ) for $18 \mathrm{~h}$ to afford carboxylate $\mathbf{1 m}$ as a white solid (486 $\mathrm{mg}, 1.66 \mathrm{mmol}, 85 \%$ ). The carboxylate was shielded from light, stored in a glovebox freezer, and used within of 1 month of synthesis. Select salts were insufficiently soluble in THF to be prepared by Method A. The following salts were prepared by method B: silver 3-bromo-2,6-difluorobenzoate (1q), silver 2nitrobenzoate (1w), silver 2-chlorobenzoate (1y), silver 2,6-dichloronicotinate (1aa).

Note: Qualitatively, silver carboxylates synthesized in $\mathrm{CH}_{3} \mathrm{CN}$ appear to decompose more rapidly than those isolated in THF. All decarboxylation reactions reported used silver carboxylates synthesized in THF. 


\section{Procedure for Optimization of Gold Catalyzed Decarboxylative Cross-Coupling}
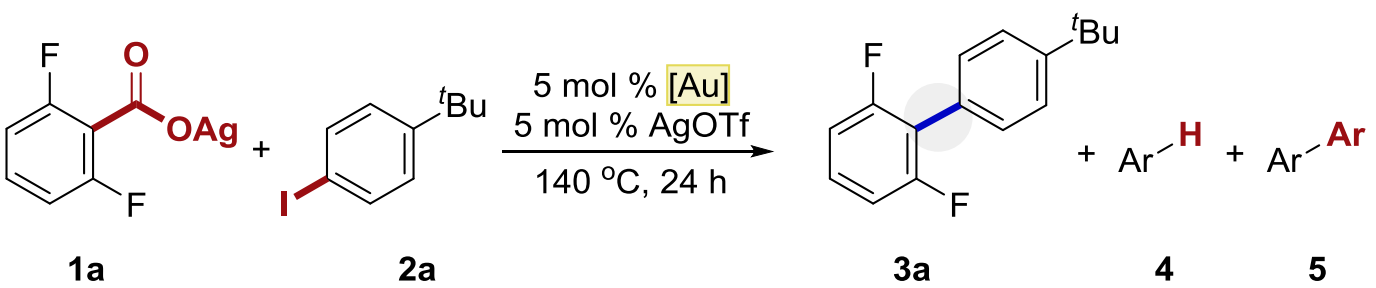

$\mathrm{Ar}=2,6-\mathrm{F}_{2} \mathrm{C}_{6} \mathrm{H}_{3}$

Precatalyst Screen: In a glovebox, separate $4 \mathrm{~mL}$ vials were charged with AgOTf (1.3 - $1.4 \mathrm{mg}$, 5.0 - $5.4 \mu \mathrm{mol}$, ca. $5 \mathrm{~mol} \%$ ), different gold precatalysts $(4.8-5.1 \mu \mathrm{mol}$, ca. $5 \mathrm{~mol} \%)$, silver 2,6-

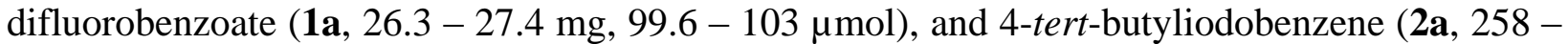
$270 \mathrm{mg}, 0.992-1.02 \mathrm{mmol})$. The vials were sealed with a Teflon lined cap and removed from the glovebox. The caps were sealed with electrical tape. The reactions were heated to $140{ }^{\circ} \mathrm{C}$ and the hot plate was covered with aluminum foil to keep the reactions dark. After $24 \mathrm{~h}$, the reactions were cooled to rt. A stock solution of 1-fluoronaphthalene $(33.0 \mathrm{mg}, 0.226 \mathrm{mmol}$, internal standard) was prepared in $\mathrm{CDCl}_{3}(2.7 \mathrm{~mL})$. Each vial was charged with an aliquot of stock solution $(0.30 \mathrm{~mL})$. The resulting mixture was filtered through a short plug of silica gel and the silica gel was washed with DCM $(2 \mathrm{~mL})$. The filtrate was analyzed by GC-FID and proton coupled ${ }^{19} \mathrm{~F}$ NMR $(471 \mathrm{MHz})$ to determine the percent yield. Reactions were run in duplicate and the average value is reported. See page $\mathbf{S 2 4}$ for a sample crude ${ }^{19}$ F NMR spectrum. All other optimization data reported in Table 1 in the manuscript was collected in an analogous manner. When 1,2-dichlorobenzene solvent was used $(0.2 \mathrm{~mL}, 0.5 \mathrm{M})$ it was added after the addition of 4-tert-butyliodobenzene.<smiles>O=C(O[Na])c1c(F)cccc1F</smiles>

$1 \mathrm{a}$

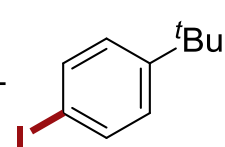

$2 a$
$5 \mathrm{~mol} \%$ MeDalphosAuOTf 1,3 DCB, additive $140{ }^{\circ} \mathrm{C}, 24 \mathrm{~h}$

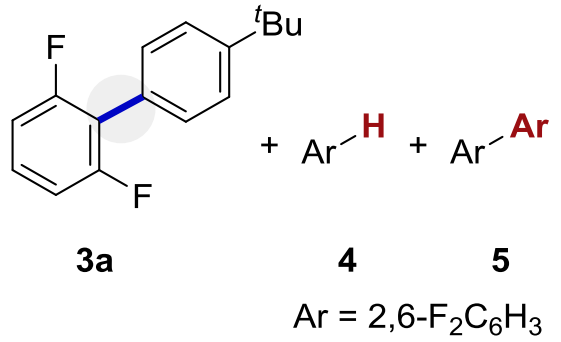

Salt additive Screen: In a glovebox, separate $4 \mathrm{~mL}$ vials were charged with MeDalphosAuOTf. $\mathrm{CH}_{3} \mathrm{CN}(2.1$ - $2.8 \mathrm{mg}, 2.7$ - $3.6 \mu \mathrm{mol}$, ca. 5 mol \%), sodium 2,6difluorobenzoate (1a, $9.8-10 \mathrm{mg}, 49-50 . \mu \mathrm{mol})$, and different additives $(54-72 \mu \mathrm{mol})$. A stock solution of 4-tert-butyliodobenzene (2a, $474 \mathrm{mg}, 1.81 \mathrm{mmol}, 3$ equiv) and naphthalene (internal standard, $25.6 \mathrm{mg}, 0.175 \mathrm{mmol})$ was prepared in 1,3-dichlorobenzene $(3.3 \mathrm{~mL})$. Each vial was charged with an aliquot of stock solution $(0.3 \mathrm{~mL})$. The reactions were heated to $140{ }^{\circ} \mathrm{C}$ and the hot plate was covered with aluminum foil to keep the reactions in the dark. After $24 \mathrm{~h}$, the reactions were cooled to rt. An aliquot of the resulting mixture was filtered through a short plug of silica gel and the silica gel was washed with DCM $(2 \mathrm{~mL})$. The filtrate was analyzed by GC-FID to determine the percent yield. With AgOTf, cross-coupled product 3a was observed in 36\% yield. The following additives gave less than 5\% cross-coupled 3a: CuOTf-toluene, $\mathrm{Cu}(\mathrm{OTf})_{2}$, ZnOTf, LiOTf, NaOTf, BiOTf, CaOTf, Mn(OTf)2, Mg(OTf) 2 , CsOTf, TMSOTf, Na(Bu) ${ }_{4} \mathrm{OTf}$, $\mathrm{Na}(\mathrm{Bu})_{4} \mathrm{SbF}_{6}, \mathrm{Na}(\mathrm{Bu})_{4} \mathrm{BF}_{4}, \mathrm{Na}(\mathrm{Bu})_{4} \mathrm{OAc}, \mathrm{NaBArF}, \mathrm{NaOPh}$. Additionally, Zn, Mg, and Cs 1,2difluorobenzoates afforded less than $5 \%$ product $3 \mathbf{a}$ in the absence of silver. 
$\underbrace{}_{\text {OAg }}$

$1 \mathrm{a}$<smiles>CC(C)(C)c1ccc(I)cc1</smiles>

$2 \mathbf{a}$
$5 \mathrm{~mol} \%[\mathrm{Au}]$

$\underset{140 \mathrm{~mol} \%[\mathrm{Ag}]}{\stackrel{\circ}{\mathrm{C}, 24 \mathrm{~h}}}$

$140^{\circ} \mathrm{C}, 24 \mathrm{~h}$<smiles>C/C=C\C(=C/C)c1c(F)cccc1F</smiles>

$3 \mathbf{a}$
$+\mathrm{Ar}^{-\mathrm{H}}+\mathrm{Ar} r^{-\mathrm{Ar}}$

45

$\mathrm{Ar}=2,6-\mathrm{F}_{2} \mathrm{C}_{6} \mathrm{H}_{3}$

Gold Precatalyst/Silver Screen: In a glovebox, seperate 4-mL vials were charged with different gold complexes (ca. $5 \mathrm{~mol} \%, 4.0$ - $5.9 \mathrm{mg}, 7.5$ - $7.7 \mu \mathrm{mol}$ ), silver 2,6-difluorobenzoate (1a, 39.8$42.0 \mathrm{mg}, 150-159 \mu \mathrm{mol})$, and select vials were charged with different silver salts $(1.7-3.0 \mathrm{mg}$, $6.6-8.5 \mu \mathrm{mol})$. A stock solution of and 4-tert-butyliodobenzene $(\mathbf{2 a}, 3.38 \mathrm{~mL}, 19.1 \mathrm{mmol})$ and 1 fluoronaphthalene (internal standard, $75.3 \mathrm{mg}, 515 \mu \mathrm{mol}$ ) was prepared. Each vial was charged with an aliquot of stock solution $(0.26 \mathrm{~mL})$. The vials were sealed with a Teflon lined cap and removed from the glovebox. The reactions were heated to $140{ }^{\circ} \mathrm{C}$ and the hot plate was covered with aluminum foil to keep the reactions dark. After $24 \mathrm{~h}$, the reactions were cooled to rt. An aliquot of the resulting mixture was filtered through a short plug of silica gel and the silica gel was washed with DCM (2 mL). The filtrate was analyzed by GC-FID to determine the percent yield. The reactions were run in duplicate the average value is reported.

\begin{tabular}{|c|c|c|c|c|}
\hline Entry & {$[\mathrm{Au}]$} & {$[\mathrm{Ag}]$} & Yield 3a $(\%)^{\mathrm{a}}$ & Yield $5(\%)^{\mathrm{a}}$ \\
\hline 1 & JohnphosAuCl & AgOTf & 61 & 20 \\
\hline 2 & JohnphosAuOTf & - & 62 & 22 \\
\hline 3 & JohnphosAuCl & $\mathrm{AgNTf}_{2} \cdot \mathrm{CH}_{3} \mathrm{CN}$ & 59 & 21 \\
\hline 4 & JohnphosAuNTf $_{2}$ & - & 64 & 18 \\
\hline 5 & Johnphos $\mathrm{AuCl}$ & $\mathrm{AgSbF}_{6}$ & 55 & 22 \\
\hline 6 & JohnphosAuSbF $6 \cdot \mathrm{CH}_{3} \mathrm{CN}$ & - & 62 & 12 \\
\hline
\end{tabular}<smiles>COC(=O)c1c(F)cccc1F</smiles>

$1 \mathrm{a}$<smiles>BrC(Br)(Br)c1ccc(I)cc1</smiles>

$2 \mathbf{a}$

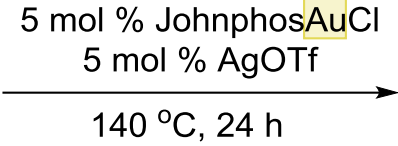

$140{ }^{\circ} \mathrm{C}, 24 \mathrm{~h}$

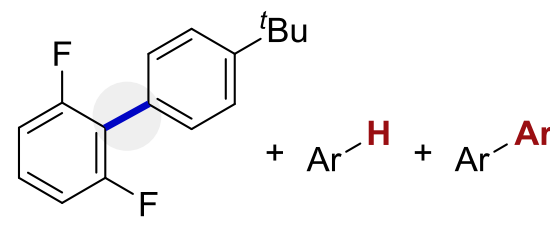

$3 \mathbf{a}$

$$
\begin{array}{cc}
\mathbf{A r}=2,6-\mathrm{F}_{2} \mathrm{C}_{6} \mathrm{H}_{3}
\end{array}
$$

Screen to Study the Effect of the Source of Silver used to Prepare Silver Benzoate:

In a glovebox, seperate 4-mL vials were charged with JohnphosAuCl (ca. $5 \mathrm{~mol} \%, 3.9$ - $4.0 \mathrm{mg}$, $7.3-7.5 \mu \mathrm{mol}$ ), silver 2,6-difluorobenzoate (1a, 39.3 - $40.8 \mathrm{mg}, 0.148$ - $0.154 \mathrm{mmol}$, synthesized from different silver salt precursors), AgOTf $(1.8-1.9 \mathrm{mg}, 7.0-7.4 \mu \mathrm{mol})$, 4-tertbutyliodobenzene (2a, 391 - $399 \mathrm{mg}, 1.50$ - $1.53 \mathrm{mmol}$ ) and anthrocene (internal standard, 7.7 $13.3 \mathrm{mg}, 43-75 \mu \mathrm{mol})$. The vials were sealed with a Teflon lined cap and removed from the glovebox. The reactions were heated to $140{ }^{\circ} \mathrm{C}$ and the hot plate was covered with aluminum foil to keep the reactions dark. After $24 \mathrm{~h}$, the reactions were cooled to rt. An aliquot of the resulting mixture was filtered through a short plug of silica gel and the silica gel was washed with DCM (2 $\mathrm{mL}$ ). The filtrate was analyzed by GC-FID to determine the percent yield. The reactions were run in duplicate the average value is reported. 
Table S2. Source of Silver Screen

$\begin{array}{ccc}\text { Entry } & \mathrm{Ag} \mathrm{Source} & \text { Yield } \mathbf{3 a}(\%)^{\mathrm{a}} \\ 1 & \mathrm{Ag}_{2} \mathrm{O} & 62 \\ 2 & \mathrm{Ag}_{2} \mathrm{CO}_{3} & 55 \\ 3 & \mathrm{AgOAc} & 44 \\ { }^{\text {a }} \text { Yields based on calibrated GC-FID with anthrocene as an internal standard, yields reflect the average of duplicate trials. }\end{array}$

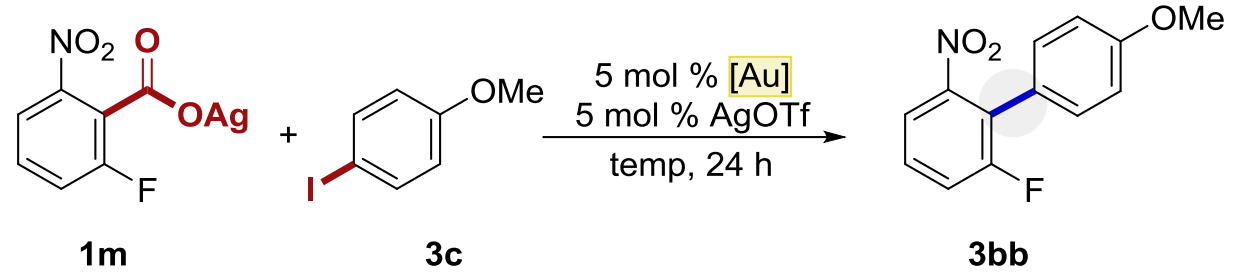

Decreasing Temperature Screen: In a glovebox, seperate 4-mL vials were charged with different gold complexes (ca. $5 \mathrm{~mol} \%, 6.7$ - $6.9 \mathrm{mg}, 7.4-7.9 \mu \mathrm{mol})$, silver 2-fluoro-6-nitrobenzoate (1m, $41.0-45.8 \mathrm{mg}, 0.143-0.157 \mathrm{mmol})$, select vials were charged with AgOTf $(1.8-1.9 \mathrm{mg}, 7.0-$ $7.4 \mu \mathrm{mol})$, and 4-iodoanisole (2a, $173-184 \mathrm{mg}, 0.739-0.786 \mathrm{mmol})$. The vials were sealed with a Teflon lined cap and removed from the glovebox. The reactions were heated to various temperatures and the hot plate was covered with aluminum foil to keep the reactions dark. After 24-72 h, the reactions were cooled to rt. A stock solution of 1-fluoronaphthalene $(51.6 \mathrm{mg}, 0.353$ mmol, ${ }^{19} \mathrm{~F}$ NMR internal standard) was prepared in $\mathrm{CDCl}_{3}(2.7 \mathrm{~mL})$. Each vial was charged with an aliquot of stock solution $(0.30 \mathrm{~mL})$. An aliquot of the resulting mixture was filtered through a short plug of silica gel and the silica gel was washed with DCM $(2 \mathrm{~mL})$. The filtrate was analyzed by proton coupled ${ }^{19} \mathrm{~F}$ NMR $(471 \mathrm{MHz})$ to determine the percent yield. The reactions were run in duplicate the average value is reported.

Table S3. Decreasing Temperature Screen

\begin{tabular}{|c|c|c|c|c|c|}
\hline Entry & {$[\mathrm{Au}]$} & mol \% AgOTf & Temp $\left({ }^{\circ} \mathrm{C}\right)$ & Time (h) & Yield $\mathbf{3 b b}(\%)^{\mathrm{a}}$ \\
\hline 1 & ${ }^{t} \mathrm{BuXPhosAuNTf}_{2}$ & none & 80 & 24 & trace \\
\hline 2 & ${ }^{t} \mathrm{BuXPhosAuNTf}_{2}$ & none & 95 & 72 & 56 \\
\hline 3 & ${ }^{t} \mathrm{BuXPhosAuNTf}_{2}$ & none & 100 & 24 & 50 \\
\hline 4 & ${ }^{t} \mathrm{BuXPhosAuNTf}_{2}$ & none & 100 & 72 & 97 \\
\hline 5 & ${ }^{t} \mathrm{BuXPhosAuNTf}_{2}$ & none & 110 & 24 & 94 \\
\hline 6 & ${ }^{t} \mathrm{BuXPhosAuNTf}_{2}$ & none & 120 & 24 & $>99$ \\
\hline 7 & MeDalphosAuCl & 5 & 100 & 24 & 28 \\
\hline
\end{tabular}

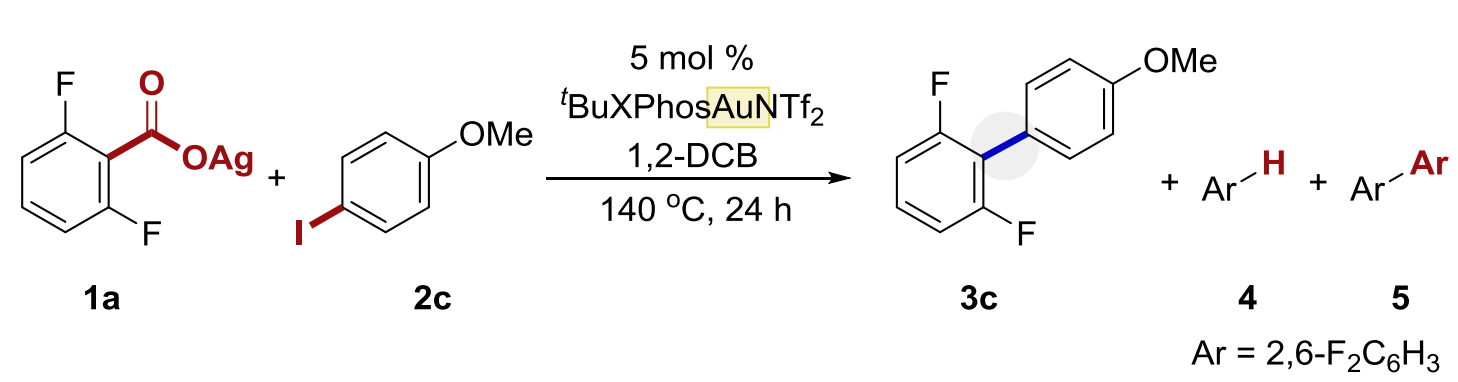

Decreasing Equivalence of Aryl Iodide Screen: In a glovebox, seperate 4-mL vials were charged with ${ }^{t}$ BuXPhosAuNTf $_{2}$ (ca. 5 mol \%, 11.3 - $11.5 \mathrm{mg}, 12.5$ - $12.8 \mu \mathrm{mol}$ ), silver 2,6difluorobenzoate (1a, 67.8 - $70.0 \mathrm{mg}, 0.254-0.264 \mathrm{mmol})$, 4-iodoanisole (2c, 116 - $117 \mathrm{mg}$, $0.496-0.502 \mathrm{mmol})$, and select vials were charged with 1,2-dichlorobenzene (1,2-DCB, $0.25-$ $0.50 \mathrm{~mL}, 1.0-0.50 \mathrm{M})$. The vials were sealed with a Teflon lined cap and removed from the 
glovebox. The reactions were heated to $140{ }^{\circ} \mathrm{C}$ and the hot plate was covered with aluminum foil to keep the reactions dark. After 24nh, the reactions were cooled to rt. A stock solution of 1fluoronaphthalene (96.2 mg, $0.658 \mathrm{mmol},{ }^{19} \mathrm{~F}$ NMR internal standard) was prepared in $\mathrm{CDCl}_{3}(3.3$ $\mathrm{mL})$. Each vial was charged with an aliquot of stock solution $(0.30 \mathrm{~mL})$. An aliquot of the resulting mixture was filtered through a short plug of silica gel and the silica gel was washed with DCM (2 $\mathrm{mL})$. The filtrate was analyzed by proton coupled ${ }^{19} \mathrm{~F} \mathrm{NMR}(471 \mathrm{MHz})$ to determine the percent yield. The reactions were run in duplicate the average value is reported.

Screens with lower equiv of 4-iodoanisole (2c) as conducted in an analogous manner.

Table S4. Decreasing Equiv of ArI

\begin{tabular}{|c|c|c|c|c|c|}
\hline Entry & Equiv ArI (2c) & $\begin{array}{c}\text { Concentration } \\
1,2-\mathrm{DCB}(\mathrm{M})\end{array}$ & Yield 3c $(\%)^{\mathrm{a}}$ & Yield $4(\%)^{\mathrm{a}}$ & Yield $5(\%)^{\mathrm{a}}$ \\
\hline 1 & 2.0 & neat & 72 & 11 & n.d. \\
\hline 2 & 2.0 & 1.0 & 88 & 8 & n.d. \\
\hline 3 & 2.0 & 0.5 & 78 & 10 & 13 \\
\hline 4 & 1.5 & 1.0 & 68 & 9 & 17 \\
\hline 5 & 1.2 & 1.0 & 56 & 13 & 30 \\
\hline
\end{tabular}

\section{Method of Estimating Optimal Conditions with Field Effect Parameter}

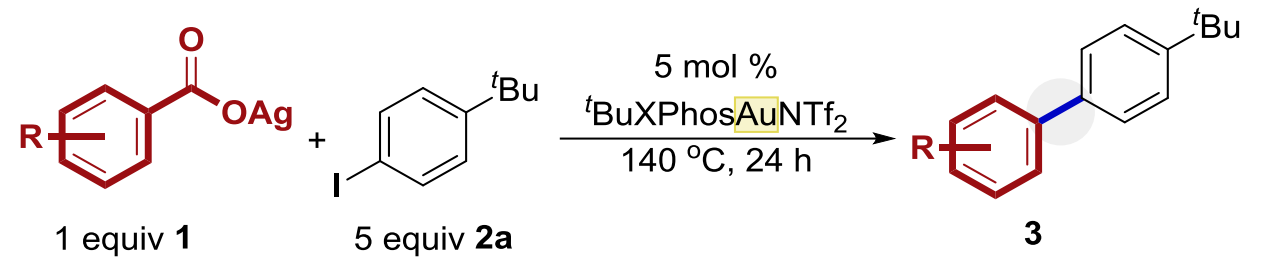

It was observed that the optimal reaction conditions varied depending on the field effect parameter for the substrate $\left(\mathrm{F}_{\text {ortho }}\right)$. For substrates not reported, the optimal conditions can be estimated based on Table S5.

\section{Table S5 Field effect Parameter vs. Optimal Conditions}

\begin{tabular}{ccc}
$\mathrm{R}$ & $\mathrm{F}_{\text {ortho }}{ }^{1}$ & Optimal Conditions \\
$2-\mathrm{OMe}$ & 0.29 & No product observed \\
\hline $2-\mathrm{Cl}$ & 0.42 & $180{ }^{\circ} \mathrm{C}, 10 \mathrm{~mol} \%[\mathrm{Au}]$ \\
$2-\mathrm{F}$ & 0.45 & $180{ }^{\circ} \mathrm{C}, 10 \mathrm{~mol} \%[\mathrm{Au}]$ \\
\hline $2-\mathrm{NO}_{2}$ & 0.65 & $180{ }^{\circ} \mathrm{C}, 5 \mathrm{~mol} \%[\mathrm{Au}]$ \\
$2-\mathrm{F}, 6-\mathrm{CF}_{3}$ & 0.83 & $180{ }^{\circ} \mathrm{C}, 5 \mathrm{~mol} \%[\mathrm{Au}]$ \\
\hline $2-\mathrm{Cl}, 6-\mathrm{F}$ & 0.87 & $140{ }^{\circ} \mathrm{C}, 5 \mathrm{~mol} \%[\mathrm{Au}]$ \\
$2,6-\mathrm{F}$ & 0.90 & $140{ }^{\circ} \mathrm{C}, 5 \mathrm{~mol} \%[\mathrm{Au}]$ \\
\hline $2-\mathrm{NO}_{2}, 6-\mathrm{F}$ & 1.1 & $140{ }^{\circ} \mathrm{C}, 5 \mathrm{~mol} \%[\mathrm{Au}], 0.15 \mathrm{M} 1,2-\mathrm{DCB}$ \\
\hline
\end{tabular}

For compounds with two ortho substituents, the Fortho values for each substituent were added together to estimate Fortho for the substrate. 


\section{General Procedure for Gold Catalyzed Decarboxylative Cross-Coupling}

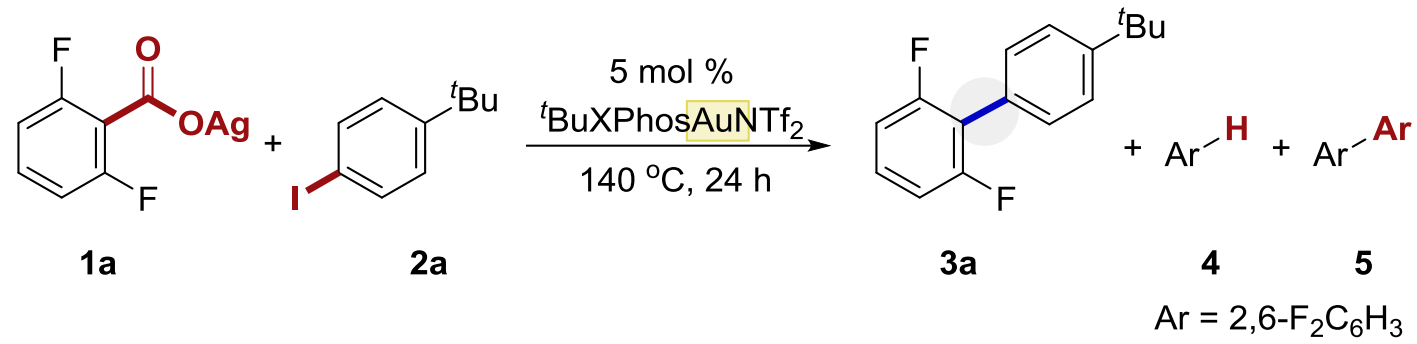

Example given for substrate 3a. In a glovebox, a $4 \mathrm{~mL}$ vial was charged with solid ${ }^{t} \mathrm{BuXPhosAuNTf}_{2}(11.2 \mathrm{mg}, 12.4 \mu \mathrm{mol}$, ca. $5 \mathrm{~mol} \%)$, silver 2,6-difluorobenzoate (1a, $66.4 \mathrm{mg}$, $0.250 \mathrm{mmol})$, and 4-tert-butyliodobenzene (2a, $329 \mathrm{mg}, 1.26 \mathrm{mmol})$. The vial was sealed with a Teflon lined cap and removed from the glovebox. The cap was sealed with electrical tape. The reaction was heated to $140{ }^{\circ} \mathrm{C}$ and the hot plate was covered with aluminum foil to keep the reaction dark. After $24 \mathrm{~h}$, the reaction was cooled to rt. A stock solution of trifluorotoluene ( $33.9 \mathrm{mg}, 0.230$ mmol, ${ }^{19} \mathrm{~F}$ NMR internal standard) was prepared in $\mathrm{CDCl}_{3}(1.2 \mathrm{~mL})$. An aliquot of the stock solution $(0.30 \mathrm{~mL})$ was added to the reaction and the resulting mixture was analyzed by proton coupled ${ }^{19} \mathrm{~F}$ NMR $(376 \mathrm{MHz})$ to determine an assay yield (87\% cross-coupled biaryl 3a, $7 \%$ protodecarboxylated aryl 4). The reaction mixture was then concentrated under reduced pressure. Final purification by preparatory thin layer chromatography (1\% benzene/49\% pentane/petroleum ether) afforded compound 3a as a white solid $(88 \%, 54.5 \mathrm{mg})$. In a duplicate reaction, the product was isolated $(84 \%, 51.6 \mathrm{mg})$. The average isolated yield of $86 \%$ is reported.

${ }^{1} \mathbf{H}$ NMR (500 MHz, $\left.\mathbf{C}_{6} \mathbf{D}_{\mathbf{6}}\right): \delta 7.44(\mathrm{~d}, J=8.2 \mathrm{~Hz}, 2 \mathrm{H}), 7.30(\mathrm{~d}, J=8.2 \mathrm{~Hz}, 2 \mathrm{H}), 6.71-6.60(\mathrm{~m}$, $3 \mathrm{H}), 1.18(\mathrm{~s}, 9 \mathrm{H})$.

${ }^{13}$ C NMR (126 MHz, DMSO): $\delta 160.4\left(\mathrm{dd}, J_{C-F}=248.1,7.2 \mathrm{~Hz}\right), 150.9,130.1,128.5\left(\mathrm{t}, J_{C-F}=\right.$ $10.2 \mathrm{~Hz}), 126.3,125.3,118.2\left(\mathrm{t}, J_{C-F}=18.8 \mathrm{~Hz}\right), 111.6-111.3(\mathrm{~m}), 34.2,31.0$.

${ }^{19}$ F NMR (376 MHz, $\left.\mathbf{C}_{6} \mathbf{D}_{6}\right): \delta-114.2$.

IR (NaCl, thin film, $\left.\mathbf{~ c m}^{-1}\right):$ 2963, 2904, 1624, 1466, 1230, 997.

HRMS (EI-TOF) $m / z:[\mathrm{M}]^{+}$Calculated for $\mathrm{C}_{16} \mathrm{H}_{16} \mathrm{~F}_{2}{ }^{+}: 246.1215$; Observed: 246.1210.

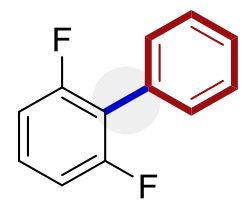

3b $86 \%$ (84\%)

The general procedure was followed with minor modifications. The reaction was run on two-fold the scale $(\mathbf{1 b}, 0.5 \mathrm{mmol})$. The crude reaction mixture was analyzed by ${ }^{19} \mathrm{~F}$ NMR (87\% crosscoupled biaryl 3b, 4\% protodecarboxylated aryl 4) and (84\% cross-coupled biaryl $\mathbf{3 b}, 5 \%$ protodecarboxylated aryl 4) in duplicate trials. The average assay yield of $86 \%$ is reported. Final purification by preparatory thin layer chromatography ( $1 \%$ benzene/49\% pentane/petroleum ether) afforded compound $\mathbf{3 b}$ as a white solid $(83 \%, 82.0 \mathrm{mg})$ and $(84 \%, 82.1 \mathrm{mg})$ in duplicate trials. The average isolated yield of $84 \%$ is reported. Characterization data for this compound has been reported. ${ }^{2}$ The material obtained from this method provided identical ${ }^{1} \mathrm{H}$ and ${ }^{19} \mathrm{~F}$ NMR spectra. An image of the ${ }^{1} \mathrm{H}$ NMR and ${ }^{19} \mathrm{~F}$ NMR spectra is provided below. 


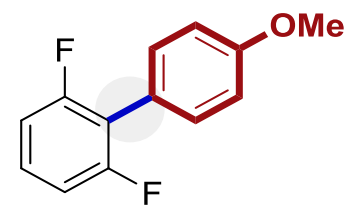

$3 c 75 \%(74 \%)$

The general procedure was followed with minor modifications. The reaction was heated to $120{ }^{\circ} \mathrm{C}$. The crude reaction mixture was analyzed by ${ }^{19} \mathrm{~F}$ NMR $(75 \%$ cross-coupled biaryl 3c, $14 \%$ protodecarboxylated aryl 4) and (75\% cross-coupled biaryl 3c,16\% protodecarboxylated aryl 4) in duplicate trials. The average assay yield of $75 \%$ is reported. Final purification by preparatory thin layer chromatography (10\% benzene/45\% pentane/petroleum ether) afforded compound 3c as a white solid $(73 \%, 49.2 \mathrm{mg})$ and $(75 \%, 55.7 \mathrm{mg})$ in duplicate trials. The average isolated yield of $74 \%$ is reported. Characterization data for this compound has been reported. ${ }^{3}$ The material obtained from this method provided identical ${ }^{1} \mathrm{H}$ and ${ }^{19} \mathrm{~F}$ NMR spectra. An image of the ${ }^{1} \mathrm{H}$ NMR and ${ }^{19} \mathrm{~F}$ NMR spectra is provided below.

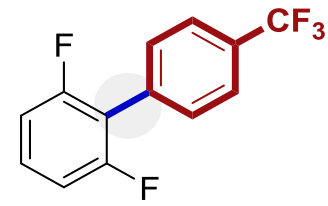

3d n.d. (70\%)

The general procedure was followed with minor modifications. The reaction was heated to $160{ }^{\circ} \mathrm{C}$. Final purification by preparatory thin layer chromatography ( $1 \%$ benzene/49\% pentane/petroleum ether) afforded compound 3d as a thick oil $(73 \%, 47.6 \mathrm{mg})$ and $(67 \%, 43.1 \mathrm{mg})$ in duplicate trials. The average isolated yield of $70 \%$ is reported. Characterization data for this compound has been reported. ${ }^{4}$ The material obtained from this method provided identical ${ }^{1} \mathrm{H}$ and ${ }^{19} \mathrm{~F}$ NMR spectra. An image of the ${ }^{1} \mathrm{H}$ NMR and ${ }^{19} \mathrm{~F}$ NMR spectra is provided below.

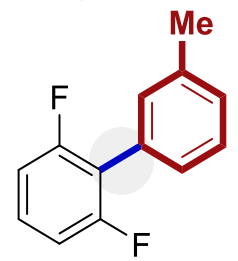

3 e $82 \%(76 \%)$

The general procedure was followed. The crude reaction mixture was analyzed by ${ }^{19} \mathrm{~F} \mathrm{NMR}(82 \%$ cross-coupled biaryl 3e, $4 \%$ protodecarboxylated aryl 4) and (81\% cross-coupled biaryl 3e, $4 \%$ protodecarboxylated aryl 4) in duplicate trials. The average assay yield of $82 \%$ is reported. Final purification by preparatory thin layer chromatography (1\% benzene/49\% pentane/ petroleum ether) afforded compound 3e as a thick oil $(79 \%, 40.1 \mathrm{mg})$ and $(72 \%, 36.8 \mathrm{mg})$ in duplicate trials. The average isolated yield of $76 \%$ is reported.

${ }^{1}$ H NMR (400 MHz, CDCl $): \delta 7.40(\mathrm{t}, J=7.5 \mathrm{~Hz}, 1 \mathrm{H}), 7.35-7.24(\mathrm{~m}, 4 \mathrm{H}), 7.02(\mathrm{t}, J=8.0 \mathrm{~Hz}$, $2 \mathrm{H}), 2.46(\mathrm{~s}, 3 \mathrm{H})$.

${ }^{13}$ C NMR (126 MHz, CDCl $): \delta 160.2\left(\mathrm{dd}, J_{C-F}=248.3,7.2 \mathrm{~Hz}\right), 137.9,131.0,129.1(2 \mathrm{C})$,

$128.7\left(\mathrm{t}, J_{C-F}=10.4 \mathrm{~Hz}\right), 128.2,127.4\left(\mathrm{t}, J_{C-F}=1.4 \mathrm{~Hz}\right), 118.7\left(\mathrm{t}, J_{C-F}=18.9 \mathrm{~Hz}\right), 111.8-111.3$

(m), 21.5.

${ }^{19}$ F NMR (376 MHz, $\left.\mathrm{CDCl}_{3}\right): \delta-114.3$.

IR (NaCl, thin film, $\mathbf{c m}^{-1}$ ): 3056, 2961, 1589, 1539, 1348, 742.

HRMS (EI-TOF) $m / z:[\mathrm{M}]^{+}$Calculated for $\mathrm{C}_{13} \mathrm{H}_{10} \mathrm{~F}_{2}{ }^{+}:$204.0745, Observed: 204.0750 . 


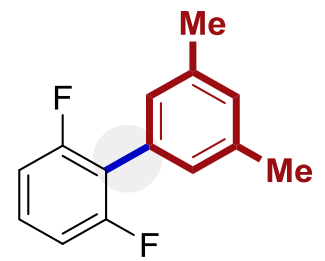

3f $82 \%(71 \%)$

The general procedure was followed. The crude reaction mixture was analyzed by ${ }^{19} \mathrm{~F}$ NMR $(81 \%$ cross-coupled biaryl 3f, $10 \%$ protodecarboxylated aryl 4) and (83\% cross-coupled biaryl 3f, 9\% protodecarboxylated aryl 4) in duplicate trials. The average assay yield of $82 \%$ is reported. Final purification by preparatory thin layer chromatography (1\% benzene/49\% pentane/petroleum ether) afforded compound $\mathbf{3 f}$ as a thick oil $(68 \%, 37.2 \mathrm{mg})$ and $(74 \%, 41.3 \mathrm{mg})$ in duplicate trials. The average isolated yield of $71 \%$ is reported.

${ }^{1} \mathbf{H}$ NMR (400 MHz, CDCl 3 ): $\delta 7.30(\mathrm{tt},=8.7,6.3 \mathrm{~Hz}, 1 \mathrm{H}), 7.13(\mathrm{~s}, 2 \mathrm{H}), 7.10(\mathrm{~s}, 1 \mathrm{H}), 7.01$ (dd, $J=7.9,7.9 \mathrm{~Hz}, 2 \mathrm{H}), 2.43(\mathrm{~s}, 6 \mathrm{H})$.

${ }^{13}$ C NMR (126 MHz, CDCl 3$): \delta 160.2\left(\mathrm{dd}, J_{C-F}=248.0,7.2 \mathrm{~Hz}\right), 137.8,130.0,128.9,128.6(\mathrm{t}$, $\left.J_{C-F}=10.3 \mathrm{~Hz}\right), 128.0\left(\mathrm{t}, J_{C-F}=1.9 \mathrm{~Hz}\right), 118.8\left(\mathrm{t}, J_{C-F}=19.2 \mathrm{~Hz}\right), 111.7-111.4(\mathrm{~m}), 21.4$.

${ }^{19}$ F NMR (376 MHz, $\left.\mathbf{C}_{6} \mathbf{D}_{6}\right): \delta$-114.2.

IR (NaCl, thin film, $\left.\mathbf{c m}^{-1}\right):$ 2920, 1624, 1588, 1469, 1230, 1001.

HRMS (EI-TOF) $\boldsymbol{m} / z:[\mathrm{M}]^{+}$Calculated for $\mathrm{C}_{14} \mathrm{H}_{12} \mathrm{~F}_{2}{ }^{+}:$218.0902; Observed: 218.0889 .<smiles>CC(=O)c1cccc(-c2c(F)cccc2F)c1</smiles>

$3 g 85 \%(68 \%)$

The general procedure was followed. The crude reaction mixture was analyzed by ${ }^{19} \mathrm{~F}$ NMR $(87 \%$ cross-coupled biaryl 3g, 5\% protodecarboxylated aryl 4) and (82\% cross-coupled biaryl 3g, 7\% protodecarboxylated aryl 4) in duplicate trials. The average assay yield of $85 \%$ is reported. Final purification by column chromatography (10\% ethyl acetate/hexanes) afforded compound $\mathbf{3 g}$ as a clear oil $(67 \%, 38.2 \mathrm{mg})$ and $(68 \%, 41.6 \mathrm{mg})$ in duplicate trials. The average isolated yield of $68 \%$ is reported.

${ }^{1}$ H NMR (500 MHz, CDCl $): \delta 8.19(\mathrm{~s}, 1 \mathrm{H}), 8.11(\mathrm{~d}, J=7.8 \mathrm{~Hz}, 1 \mathrm{H}), 7.68(\mathrm{~d}, J=7.6 \mathrm{~Hz}, 1 \mathrm{H})$, $7.56(\mathrm{dd}, J=7.8,7.8 \mathrm{~Hz}, 1 \mathrm{H}), 7.33(\mathrm{~m}, 1 \mathrm{H}), 7.03(\mathrm{dd}, J=7.7,7.7 \mathrm{~Hz}, 2 \mathrm{H}), 3.96(\mathrm{~s}, 3 \mathrm{H})$.

${ }^{13}$ C NMR (126 MHz, CDCl 3$): \delta 166.8,160.1\left(\mathrm{dd}, J_{C-F}=249.1,6.9 \mathrm{~Hz}\right), 134.8\left(\mathrm{~d}, J_{C-F}=2.1\right.$

$\mathrm{Hz}), 131.5\left(\mathrm{~d}, J_{C-F}=2.1 \mathrm{~Hz}\right), 130.4,129.59-129.26(\mathrm{~m}, 3 \mathrm{C}), 128.4,117.6\left(\mathrm{t}, J_{C-F}=18.6 \mathrm{~Hz}\right)$, $112.0-111.5(\mathrm{~m}), 52.2$.

${ }^{19}$ F NMR (376 MHz, CDCl 3$): \delta-114.5$.

IR (NaCl, thin film, $\mathbf{c m}^{-1}$ ): 3068, 2952, 1727, 1626, 1300, 999.

HRMS (EI-TOF) $m / z$ : [M] ${ }^{+}$Calculated for $\mathrm{C}_{14} \mathrm{H}_{10} \mathrm{~F}_{2} \mathrm{O}_{2}{ }^{+}:$248.0643; Observed: 248.0633. 
<smiles>Fc1cccc(F)c1-c1cccc(Br)c1</smiles>

$3 \mathrm{~h} 64 \%(59 \%)$

The general procedure was followed with minor modifications. The reaction was run in a $20 \mathrm{~mL}$ vial. After the addition of 4-tert-butyliodobenzene, the vial was charged with 1,2-dichlorobenzene $(2.5 \mathrm{~mL}, 0.1 \mathrm{M})$. The crude reaction mixture was analyzed by ${ }^{19} \mathrm{~F}$ NMR $(54 \%$ cross-coupled biaryl 3h, $18 \%$ protodecarboxylated aryl 4) and (74\% cross-coupled biaryl $\mathbf{3 h}, 17 \%$ protodecarboxylated aryl 4) in duplicate trials. The average assay yield of $64 \%$ is reported. Final purification by preparatory thin layer chromatography (1\% benzene/49\% pentane/petroleum ether) afforded compound $3 \mathrm{~h}$ as a white solid $(55 \%, 37.1 \mathrm{mg})$ and $(62 \%, 41.8 \mathrm{mg})$ in duplicate trials. The average isolated yield of $59 \%$ is reported.

${ }^{1}$ H NMR (400 MHz, $\left.\mathbf{C D C l}_{3}\right): \delta 7.65(\mathrm{t}, J=1.7 \mathrm{~Hz}, 1 \mathrm{H}), 7.56(\mathrm{ddd}, J=8.0,2.1,1.2 \mathrm{~Hz}, 1 \mathrm{H})$, $7.43(\mathrm{~d}, J=7.8, \mathrm{~Hz}, 1 \mathrm{H}), 7.39-7.28(\mathrm{~m}, 2 \mathrm{H}), 7.02(\mathrm{dd}, J=8.7,7.5 \mathrm{~Hz}, 2 \mathrm{H})$.

${ }^{13}$ C NMR (126 MHz, CDCl $): \delta 160.0\left(\mathrm{dd}, J_{C-F}=249.4,6.8 \mathrm{~Hz}\right), 133.2\left(\mathrm{t}, J_{C-F}=2.0 \mathrm{~Hz}\right), 131.3$, $129.8,129.7-129.3(\mathrm{~m}, 3 \mathrm{C}), 129.0\left(\mathrm{~d}, J_{C-F}=2.0 \mathrm{~Hz}\right), 122.2,112.1-111.5(\mathrm{~m})$.

${ }^{19}$ F NMR (376 MHz, CDCl 3$): \delta-114.3$.

IR (NaCl, thin film, $\mathbf{c m}^{-1}$ ): 3065, 2927, 1625, 1476, 1231, 1000, 760.

HRMS (EI-TOF) $\boldsymbol{m} / z:[\mathrm{M}]^{+}$Calculated for $\mathrm{C}_{12} \mathrm{H}_{7} \mathrm{BrF}_{2}{ }^{+}:$267.9694; Observed: 267.9668 .

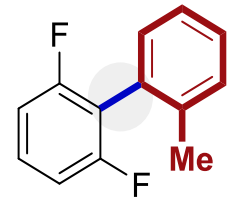

3i $59 \%$ (53\%)

The general procedure was followed with minor modifications. The reaction was heated to $160{ }^{\circ} \mathrm{C}$. The crude reaction mixture was analyzed by ${ }^{19} \mathrm{~F}$ NMR (59\% cross-coupled biaryl 3i, $16 \%$ protodecarboxylated aryl 4) and (59\% cross-coupled biaryl 3i, 23\% protodecarboxylated aryl 4) in duplicate trials. The average assay yield of $59 \%$ is reported. Final purification by preparatory thin layer chromatography (1\% benzene/49\% pentane/petroleum ether) afforded compound $3 \mathbf{i}$ (50\%, $26.2 \mathrm{mg})$ and $(56 \%, 28.8 \mathrm{mg})$ in duplicate trials. The average isolated yield of $53 \%$ is reported.

${ }^{1}$ H NMR (400 MHz, CDCl 3 ): $\delta 7.41-7.24(\mathrm{~m}, 5 \mathrm{H}), 7.02(\mathrm{dd}, J=8.2,6.7 \mathrm{~Hz}, 2 \mathrm{H}), 2.22(\mathrm{~s}, 3 \mathrm{H})$.

${ }^{13}$ C NMR (126 MHz, CDCl $)$ : $\delta 160.2\left(\mathrm{dd}, J_{C-F}=247.4,7.5 \mathrm{~Hz}\right), 137.4,130.6,130.1,129.1(\mathrm{t}, J$ $=10.1 \mathrm{~Hz}), 128.9,128.7,125.6,118.1\left(\mathrm{t}, J_{C-F}=21.3 \mathrm{~Hz}\right), 111.50-111.21(\mathrm{~m}), 19.8$.

${ }^{19}$ F NMR (376 MHz, CDCl 3$): \delta-112.3$.

IR (NaCl, thin film, $\mathbf{c m}^{-1}$ ): 3064, 2927, 1626, 1586, 1462, 1272, 997.

HRMS (EI-TOF) $\boldsymbol{m} / z:[\mathrm{M}]^{+}$Calculated for $\mathrm{C}_{13} \mathrm{H}_{10} \mathrm{~F}_{2}{ }^{+}:$204.0745; Observed: 204.0747.<smiles>Fc1cccc(F)c1-c1ccccc1Cl</smiles>

3j 76\%. (79\%) 
The general procedure was followed with minor modifications. The reaction was run on two-fold the scale $(\mathbf{1 j}, 0.5 \mathrm{mmol})$ The crude reaction mixture was analyzed by ${ }^{19} \mathrm{~F}$ NMR (75\% cross-coupled biaryl $\mathbf{3 j}, \quad 7 \%$ protodecarboxylated aryl $\mathbf{4})$ and $(77 \%$ cross-coupled biaryl $\mathbf{3 j}, \quad 7 \%$ protodecarboxylated aryl 4) in duplicate trials. The average assay yield of $76 \%$ is reported. Final purification by preparatory thin layer chromatography (1\% benzene/49\% pentane/petroleum ether) afforded compound $\mathbf{3 j}$ as a white solid $(77 \%, 87.4 \mathrm{mg})$ and $(80 \%, 89.9 \mathrm{mg})$ in duplicate trials. The average isolated yield of $79 \%$ is reported.

${ }^{1}$ H NMR (400 MHz, $\left.\mathbf{C D C l}_{3}\right): \delta 7.61-7.55(\mathrm{~m}, 1 \mathrm{H}), 7.45-7.35(\mathrm{~m}, 4 \mathrm{H}), 7.05(\mathrm{dd}, J=8.4,7.0$ $\mathrm{Hz}, 2 \mathrm{H})$.

${ }^{13}$ C NMR (126 MHz, $\left.\mathbf{C D C l}_{3}\right): \delta 160.2\left(\mathrm{dd}, J_{C-F}=249.0,7.0 \mathrm{~Hz}\right), 134.5,132.2,130.0,130.0(\mathrm{t}$, $\left.J_{C-F}=8.8 \mathrm{~Hz}\right) 129.7,128.7,126.7,116.2\left(\mathrm{t}, J_{C-F}=20.5 \mathrm{~Hz}\right), 111.7-111.2(\mathrm{~m})$.

${ }^{19}$ F NMR (376 MHz, $\left.\mathbf{C D C l}_{3}\right): \delta-111.8$.

IR (NaCl, thin film, $\mathbf{~ c m}^{-1}$ ): 3063, 2927, 1628, 1585, 1467, 1234, 1009.

HRMS (EI-TOF) $m / z:[\mathrm{M}]^{+}$Calculated for $\mathrm{C}_{12} \mathrm{H}_{7} \mathrm{ClF}_{2}{ }^{+}$: 224.0199; Observed: 224.0201.

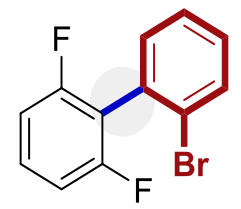

3k $75 \%$ (78\%)

The general procedure was followed. The crude reaction mixture was analyzed by ${ }^{19} \mathrm{~F}$ NMR $(74 \%$ cross-coupled biaryl 3k, 6\% protodecarboxylated aryl 4) and (75\% cross-coupled biaryl 3k, 7\% protodecarboxylated aryl 4) in duplicate trials. The average assay yield of $75 \%$ is reported. Final purification by preparatory thin layer chromatography ( $1 \%$ benzene $/ 45 \%$ pentane/petroleum ether) afforded compound $3 \mathrm{k}$ as a white solid $(79 \%, 53.0 \mathrm{mg})$ and $(77 \%, 51.6 \mathrm{mg})$ in duplicate trials. The average isolated yield of $78 \%$ is reported. Characterization data for this compound has been reported. ${ }^{5}$ The material obtained from this method provided identical ${ }^{1} \mathrm{H}$ and ${ }^{19} \mathrm{~F}$ NMR spectra. An image of the ${ }^{1} \mathrm{H}$ NMR and ${ }^{19} \mathrm{~F}$ NMR spectra is provided below.

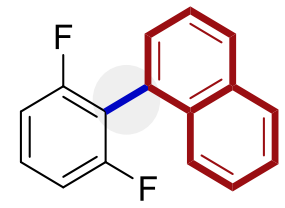

3 I n.d. (84\%)

The general procedure was followed. Final purification by preparatory thin layer chromatography (1\% benzene/49\% pentane/petroleum ether) afforded compound 31 as a white solid (86\%, 52.2 $\mathrm{mg})$ and $(82 \%, 48.9 \mathrm{mg})$ in duplicate trials. The average isolated yield of $84 \%$ is reported.

${ }^{1} \mathbf{H}$ NMR (400 MHz, $\left.\mathbf{C D C l}_{3}\right): \delta 8.02-7.95(\mathrm{~m}, 2 \mathrm{H}), 7.65-7.59(\mathrm{~m}, 2 \mathrm{H}), 7.59-7.48(\mathrm{~m}, 3 \mathrm{H})$, $7.44(\mathrm{tt}, J=8.3,6.3 \mathrm{~Hz}, 1 \mathrm{H}), 7.11(\mathrm{dd}, J=8.4,6.8 \mathrm{~Hz}, 2 \mathrm{H})$.

${ }^{13}$ C NMR $\left(126 \mathrm{MHz}, \mathbf{C D C l}_{3}\right): \delta 160.8\left(\mathrm{dd}, J_{C-F}=248.1,7.2 \mathrm{~Hz}\right), 133.7,132.0,129.6\left(\mathrm{t}, J_{C-F}=\right.$ $10.1 \mathrm{~Hz}), 129.1,128.7,128.5,127.0,126.5,126.0,125.4,125.3,117.0\left(\mathrm{t}, J_{C-F}=21.1 \mathrm{~Hz}\right), 112.3$ $-110.7(\mathrm{~m})$.

${ }^{19}$ F NMR (376 MHz, $\left.\mathbf{C D C l}_{3}\right): \delta-111.3$.

IR (NaCl, thin film, $\left.\mathbf{~ c m}^{-1}\right): 3058,1625,1586,1465,1272,999$.

HRMS (EI-TOF) $m / z:[\mathrm{M}]^{+}$Calculated for $\mathrm{C}_{16} \mathrm{H}_{10} \mathrm{~F}_{2}{ }^{+}: 240.0745$; Observed: 240.0736 . 


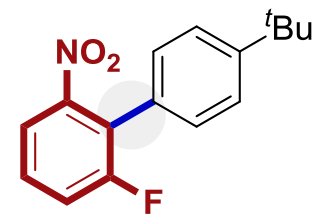

$3 \mathrm{~m} 96 \%(93 \%)$

The general procedure was followed with minor modifications. The reaction was run in a $20 \mathrm{~mL}$ vial. After the addition of 4-tert-butyliodobenzene, the vial was charged with 1,2-dichlorobenzene $(1.5 \mathrm{~mL}, 0.17 \mathrm{M})$. The crude reaction mixture was analyzed by ${ }^{19} \mathrm{~F}$ NMR $(95 \%$ cross-coupled biaryl 3m) and (97\% cross-coupled biaryl 3m) in duplicate trials. The average assay yield of $96 \%$ is reported. Final purification column chromatography (10\% EtOAc/hexanes) afforded 3m as a clear oil $(94 \%, 63.9 \mathrm{mg})$ and $(92 \%, 63.1 \mathrm{mg})$ in duplicate trials. The average isolated yield of $93 \%$ is reported.

${ }^{1}$ H NMR (400 MHz, CDCl 3$): \delta 7.66(\mathrm{~d}, J=8.0 \mathrm{~Hz}, 1 \mathrm{H}), 7.52-7.44(\mathrm{~m}, 3 \mathrm{H}), 7.40(\mathrm{td}, J=8.5$, $1.3 \mathrm{~Hz}, 1 \mathrm{H}), 7.29(\mathrm{~d}, J=7.5 \mathrm{~Hz}, 2 \mathrm{H}), 1.39(\mathrm{~s}, 9 \mathrm{H})$.

${ }^{13}$ C NMR (126 MHz, CDCl $): \delta 159.8\left(\mathrm{~d}, J_{C-F}=250.0 \mathrm{~Hz}\right), 151.8,129.0\left(\mathrm{~d}, J_{C-F}=9.0 \mathrm{~Hz}\right)$, $128.6,126.9,125.6,124.7\left(\mathrm{~d}, J_{C-F}=20.5 \mathrm{~Hz}\right), 119.9,119.7,119.5\left(\mathrm{~d}, J_{C-F}=3.7 \mathrm{~Hz}\right), 34.7,31.3$.

${ }^{19}$ F NMR (376 MHz, CDCl 3$): ~ \delta-111.3$.

IR (NaCl, thin film, $\mathbf{c m}^{-1}$ ): 3093, 2965, 2870, 1535, 1466, 1251, 813.

HRMS (EI-TOF) $\boldsymbol{m} / z$ : $[\mathrm{M}]^{+}$Calculated for $\mathrm{C}_{16} \mathrm{H}_{16} \mathrm{~F}_{2} \mathrm{NO}_{2}{ }^{+}:$273.1160; Observed: 273.1153 .<smiles>CC(C)(C)c1ccc(-c2c(F)ccc([N+](=O)[O-])c2F)cc1</smiles>

3n $80 \%(81 \%)$

The general procedure was followed. The crude reaction mixture was analyzed by ${ }^{19} \mathrm{~F}$ NMR $(81 \%$ cross-coupled biaryl 3n) and (79\% cross-coupled biaryl 3n) in duplicate trials. The average assay yield of $80 \%$ is reported. Final purification by column chromatography (15\% EtOAc/hexanes) afforded compound $\mathbf{3 n}$ as a white solid $(77 \%, 52.9 \mathrm{mg})$ and $(84 \%, 61.8 \mathrm{mg})$ in duplicate trials. The average isolated yield of $81 \%$ is reported.

${ }^{1}$ H NMR (400 MHz, CDCl $): ~ \delta 8.10(\mathrm{ddd}, J=9.3,8.1,5.6 \mathrm{~Hz}, 1 \mathrm{H}), 7.56(\mathrm{~d}, J=8.5 \mathrm{~Hz}, 2 \mathrm{H})$, $7.42(\mathrm{~d}, J=8.4 \mathrm{~Hz}, 2 \mathrm{H}), 7.14$ (ddd, $J=9.3,8.3,1.8 \mathrm{~Hz}, 1 \mathrm{H}), 1.41(\mathrm{~s}, 9 \mathrm{H})$.

${ }^{13}$ C NMR (126 MHz, CDCl $): \delta 162.9\left(\mathrm{dd}, J_{C-F}=258.8,6.2 \mathrm{~Hz}\right), 154.0\left(\mathrm{dd}, J_{C-F}=266.3,8.1\right.$ $\mathrm{Hz}), 152.5,129.9\left(\mathrm{t}, J_{C-F}=1.8 \mathrm{~Hz}\right), 125.8,125.68,125.65,123.9,121.2\left(\mathrm{dd}, J_{C-F}=20.0,18.0\right.$ $\mathrm{Hz}), 112.0\left(\mathrm{dd}, J_{C-F}=25.2,4.2 \mathrm{~Hz}\right), 34.8,31.3$.

${ }^{19}$ F NMR (376 MHz, CDCl 3 ): $\delta-101.31(\mathrm{~d}, J=14.9 \mathrm{~Hz}),-115.77(\mathrm{~d}, J=14.5 \mathrm{~Hz})$.

IR (NaCl, thin film, $\mathbf{c m}^{-1}$ ): 3062, 2927, 1628, 1585, 1467, 1234, 1004.

HRMS (EI-TOF) $m / z:[\mathrm{M}]^{+}$Calculated for $\mathrm{C}_{16} \mathrm{H}_{15} \mathrm{~F}_{2} \mathrm{NO}_{2}{ }^{+}: 291.1065$; Observed: 291.1058.

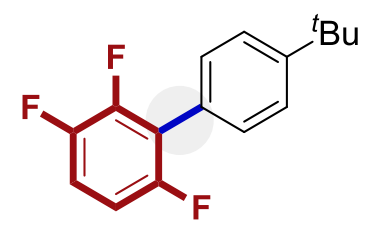

$3090 \%(74 \%)$

The general procedure was followed. The crude reaction mixture was analyzed by ${ }^{19} \mathrm{~F} \mathrm{NMR}(89 \%$ cross-coupled biaryl 3o) and (90\% cross-coupled biaryl 3o) in duplicate trials. The average assay 
yield of $90 \%$ is reported. Final purification by preparatory thin layer chromatography (1\% benzene/45\% pentane/petroleum ether) afforded compound 30 as a thick oil $(72 \%, 47.4 \mathrm{mg})$ and $(76 \%, 50.2 \mathrm{mg})$ in duplicate trials. The average isolated yield of $74 \%$ is reported. Characterization data for this compound has been reported. ${ }^{6}$ The material obtained from this method provided identical ${ }^{1} \mathrm{H}$ and ${ }^{19} \mathrm{~F}$ NMR spectra. An image of the ${ }^{1} \mathrm{H}$ NMR and ${ }^{19} \mathrm{~F}$ NMR spectra is provided below.<smiles>Fc1ccc(Cl)c(-c2ccc(Br)cc2)c1F</smiles>

$3 p$ 91\% $(81 \%)$

The general procedure was followed. The crude reaction mixture was analyzed by ${ }^{19} \mathrm{~F}$ NMR $(92 \%$ cross-coupled biaryl 3p) and (90\% cross-coupled biaryl 3p) in duplicate trials. The average assay yield of $91 \%$ is reported. Final purification by preparatory thin layer chromatography (1\% benzene/49\% pentane/petroleum ether) afforded compound $\mathbf{3 p}$ as a thick oil $(83 \%, 61.7 \mathrm{mg})$ and $(79 \%, 55.1 \mathrm{mg})$ in duplicate trials. The average isolated yield of $81 \%$ is reported. Characterization data for this compound has been reported. ${ }^{6}$ The material obtained from this method provided identical ${ }^{1} \mathrm{H}$ and ${ }^{19} \mathrm{~F}$ NMR spectra. An image of the ${ }^{1} \mathrm{H}$ NMR and ${ }^{19} \mathrm{~F}$ NMR spectra is provided below.<smiles>Fc1ccc(Br)c(-c2ccc(Br)cc2)c1F</smiles>

3q $87 \%$ (71\%)

The general procedure was followed. The crude reaction mixture was analyzed by ${ }^{19} \mathrm{~F}$ NMR $(87 \%$ cross-coupled biaryl 3q) and (86\% cross-coupled biaryl 3q) in duplicate trials. The average assay yield of $87 \%$ is reported. Final purification by preparatory thin layer chromatography (1\% benzene/49\% pentane/petroleum ether) afforded compound $\mathbf{3 q}$ as a clear oil $(67 \%, 55.0 \mathrm{mg})$ and $(74 \%, 61.7 \mathrm{mg})$ in duplicate trials. The average isolated yield of $71 \%$ is reported.

${ }^{1} \mathbf{H}$ NMR $\left(400 \mathrm{MHz}, \mathbf{C D C l}_{3}\right): \delta 7.56-7.48(\mathrm{~m}, 3 \mathrm{H}), 7.43(\mathrm{dt}, J=8.5,1.6 \mathrm{~Hz}, 2 \mathrm{H}), 6.94$ (ddd, $J$ $=8.9,8.9,1.8 \mathrm{~Hz}, 1 \mathrm{H}), 1.41(\mathrm{~s}, 9 \mathrm{H})$.

${ }^{13}$ C NMR (126 MHz, CDCl $): ~ \delta 159.3\left(\mathrm{dd}, J_{C-F}=248.7,5.8 \mathrm{~Hz}\right), 156.4\left(\mathrm{dd}, J_{C-F}=248.6,7.3\right.$ $\mathrm{Hz}), 151.7,131.7\left(\mathrm{dd}, J_{C-F}=9.6,1.8 \mathrm{~Hz}\right), 129.9\left(\mathrm{t}, J_{C-F}=2.1 \mathrm{~Hz}\right), 125.5,125.4,120.0\left(\mathrm{t}, J_{C-F}=\right.$ $19.7 \mathrm{~Hz}), 112.8\left(\mathrm{dd}, J_{C-F}=24.3,4.0 \mathrm{~Hz}\right), 104.5\left(\mathrm{dd}, J_{C-F}=22.8,4.1 \mathrm{~Hz}\right), 34.8,31.3$.

${ }^{19}$ F NMR (376 MHz, CDCl $)$ : $\delta-105.6(\mathrm{~d}, J=8.1 \mathrm{~Hz}),-114.6(\mathrm{~d}, J=8.1 \mathrm{~Hz})$.

IR (NaCl, thin film, $\left.\mathbf{~ c m}^{-1}\right): 3088,2964,2904,1611,1436,1270,837$.

HRMS (EI-TOF) $\boldsymbol{m} / z:[\mathrm{M}]^{+}$Calculated for $\mathrm{C}_{16} \mathrm{H}_{15} \mathrm{BrF}_{2}^{+}:$324.0320; Observed: 324.0312 .

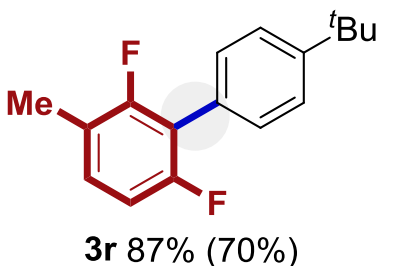

The general procedure was followed. The crude reaction mixture was analyzed by ${ }^{19} \mathrm{~F}$ NMR $(87 \%$ cross-coupled biaryl 3r) and (86\% cross-coupled biaryl 3r) in duplicate trials. The average assay 
yield of $87 \%$ is reported. Final purification by preparatory thin layer chromatography ( $1 \%$ benzene/49\% pentane/petroleum ether) afforded compound $\mathbf{3 r}$ as a clear oil $(68 \%, 44.1 \mathrm{mg})$ and $(71 \%, 47.0 \mathrm{mg})$ in duplicate trials. The average isolated yield of $70 \%$ is reported.

${ }^{1} \mathbf{H}$ NMR $\left(400 \mathrm{MHz}, \mathbf{C D C l}_{3}\right): \delta 7.53(\mathrm{~d}, J=8.6 \mathrm{~Hz}, 2 \mathrm{H}), 7.46(\mathrm{~d}, J=8.5 \mathrm{~Hz}, 2 \mathrm{H}), 7.18-7.10$ $(\mathrm{m}, 1 \mathrm{H}), 6.92$ (ddd, $J=8.9,8.9,1.6 \mathrm{~Hz}, 1 \mathrm{H}), 2.33(\mathrm{dd}, J=2.1,1.0 \mathrm{~Hz}, 3 \mathrm{H}), 1.42(\mathrm{~s}, 9 \mathrm{H})$.

${ }^{13}$ C NMR (126 MHz, CDCl $): ~ \delta 158.4\left(\mathrm{dd}, J_{C-F}=245.3,6.8 \mathrm{~Hz}\right), 158.2\left(\mathrm{dd}, J_{C-F}=246.9,6.9\right.$ $\mathrm{Hz}), 151.0,130.0\left(\mathrm{t}, J_{C-F}=2.1 \mathrm{~Hz}\right), 129.7\left(\mathrm{dd}, J_{C-F}=9.8,6.8 \mathrm{~Hz}\right), 126.6,125.2,120.8(\mathrm{dd}, J=$ $18.9,3.8 \mathrm{~Hz}), 117.8\left(\mathrm{t}, J_{C-F}=19.1 \mathrm{~Hz}\right), 110.9\left(\mathrm{dd}, J_{C-F}=22.8,3.9 \mathrm{~Hz}\right), 34.7,31.4,14.4\left(\mathrm{~d}, J_{C-F}=\right.$ $3.9 \mathrm{~Hz})$.

${ }^{19}$ F NMR (376 MHz, CDCl $): ~ \delta-117.4(\mathrm{~d}, J=6.8 \mathrm{~Hz}),-118.4(\mathrm{~d}, J=6.6 \mathrm{~Hz})$.

IR (NaCl, thin film, $\left.\mathbf{c m}^{-1}\right):$ 2963, 2868, 1483, 1264, 1008.

HRMS (EI-TOF) $\boldsymbol{m} / \boldsymbol{z}:[\mathrm{M}]^{+}$Calculated for $\mathrm{C}_{17} \mathrm{H}_{18} \mathrm{~F}_{2}{ }^{+}: 260.1371$; Observed: 260.1353 .

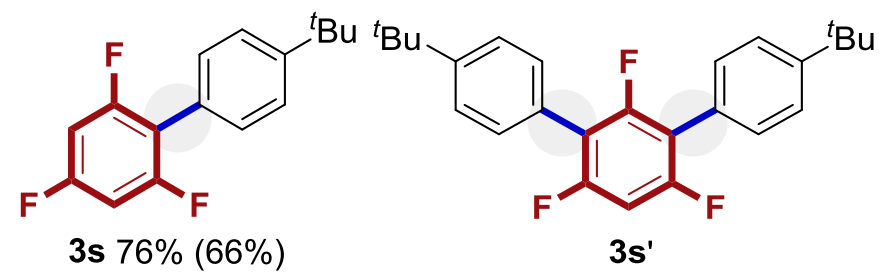

The general procedure was followed with minor modifications. The reaction was run in a $20 \mathrm{~mL}$ vial. After the addition of 4-tert-butyliodobenzene, the vial was charged with 1,2-dichlorobenzene $(2.5 \mathrm{~mL}, 0.1 \mathrm{M})$. The crude reaction mixture was analyzed by ${ }^{19} \mathrm{~F}$ NMR $(77 \%$ cross-coupled biaryl 3s, $2 \%$ C-H activation product 3s') and (75\% cross-coupled biaryl 3s, 3\% C-H activation product 3s') in duplicate trials. The average assay yield of $76 \%$ is reported. Final purification by preparatory thin layer chromatography (1\% benzene $/ 49 \%$ pentane/petroleum ether) afforded compound $3 \mathrm{~s}$ as a clear oil $(67 \%, 44.4 \mathrm{mg})$ and $(65 \%, 43.3 \mathrm{mg})$ in duplicate trials. The average isolated yield of $66 \%$ is reported.

${ }^{1} \mathbf{H}$ NMR (400 MHz, $\left.\mathbf{C D C l}_{3}\right): \delta 7.54(\mathrm{~d}, J=8.3 \mathrm{~Hz}, 2 \mathrm{H}), 7.43(\mathrm{~d}, J=8.1 \mathrm{~Hz}, 2 \mathrm{H}), 6.80(\mathrm{t}, J=$ $8.2 \mathrm{~Hz}, 2 \mathrm{H}), 1.42(\mathrm{~s}, 9 \mathrm{H})$.

${ }^{13}$ C NMR (126 MHz, CDCl $)$ : $\delta 161.6\left(\mathrm{dt}, J_{C-F}=248.8,15.7 \mathrm{~Hz}\right), 160.4\left(\mathrm{ddd}, J_{C-F}=249.3\right.$, $14.8,10.1 \mathrm{~Hz}), 151.4,129.9,125.4(2 \mathrm{C}), 115.0\left(\mathrm{td}, J_{C-F}=19.5,5.1 \mathrm{~Hz}\right), 100.8-100.1(\mathrm{~m}), 34.7$, 31.3.

${ }^{19}$ F NMR (376 MHz, CDCl $)$ : $\delta-109.60(\mathrm{t}, J=5.8 \mathrm{~Hz}),-111.29(\mathrm{~d}, J=6.1 \mathrm{~Hz})$.

IR (NaCl, thin film, $\left.\mathbf{~ c m}^{-1}\right):$ 2965, 1573, 1457, 1434, 1128, 1035, 749.

HRMS (EI-TOF) $m / z:[\mathrm{M}]^{+}$Calculated for $\mathrm{C}_{16} \mathrm{H}_{15} \mathrm{~F}_{3}{ }^{+}: 264.1120$; Observed: 264.1121 .

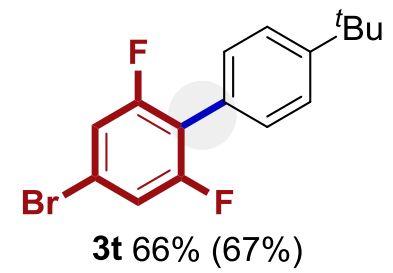

The general procedure was followed with minor modifications. The reaction was run in a $20 \mathrm{~mL}$ vial. After the addition of 4-tert-butyliodobenzene, the vial was charged with 1,2-dichlorobenzene $(2.5 \mathrm{~mL}, 0.1 \mathrm{M})$. The crude reaction mixture was analyzed by ${ }^{19} \mathrm{~F}$ NMR ( $64 \%$ cross-coupled biaryl 3t) and (68\% cross-coupled biaryl 3t) in duplicate trials. The average assay yield of $66 \%$ is reported. Final purification by preparatory thin layer chromatography (1\% benzene/49\% pentane/petroleum ether) afforded compound $\mathbf{3 t}$ as a clear oil $(65 \%, 55.2 \mathrm{mg})$ and $(70 \%, 58.3 \mathrm{mg})$ in duplicate trials. The average isolated yield of $67 \%$ is reported. 
${ }^{1}$ H NMR (400 MHz, $\left.\mathbf{C D C l}_{3}\right): \delta 7.50(\mathrm{~d}, J=8.5 \mathrm{~Hz}, 2 \mathrm{H}), 7.40(\mathrm{~d}, J=8.5 \mathrm{~Hz}, 2 \mathrm{H}), 7.20(\mathrm{~d}, J=$ $7.1 \mathrm{~Hz}, 2 \mathrm{H}), 1.39(\mathrm{~s}, 9 \mathrm{H})$.

${ }^{13}$ C NMR (126 MHz, $\left.\mathbf{C D C l}_{3}\right): \delta 160.1\left(\mathrm{dd}, J_{C-F}=252.1,8.4 \mathrm{~Hz}\right), 151.6,129.8\left(\mathrm{t}, J_{C-F}=2.2 \mathrm{~Hz}\right)$, $125.4,125.2,120.3\left(\mathrm{t}, J_{C-F}=12.6 \mathrm{~Hz}\right), 117.8\left(\mathrm{t}, J_{C-F}=18.7 \mathrm{~Hz}\right), 115.9-115.4(\mathrm{~m}), 34.7,31.3$.

${ }^{19}$ F NMR (376 MHz, $\left.\mathrm{CDCl}_{3}\right): \delta-112.6$.

IR (NaCl, thin film, $\left.\mathbf{c m}^{-1}\right): 2964,2867,1611,1471,1029,838$.

HRMS (EI-TOF) $\boldsymbol{m} / z:[\mathrm{M}]^{+}$Calculated for $\mathrm{C}_{16} \mathrm{H}_{15} \mathrm{BrF}_{2}{ }^{+}: 324.0320$; Observed: 324.0305 .<smiles>Fc1cccc(Cl)c1-c1ccc(Br)cc1</smiles>

3u $70 \%(63 \%)$

The general procedure was followed. The crude reaction mixture was analyzed by ${ }^{19} \mathrm{~F}$ NMR $(71 \%$ cross-coupled biaryl 3u) and (68\% cross-coupled biaryl 3u) in duplicate trials. The average assay yield of $70 \%$ is reported. Final purification by preparatory thin layer chromatography (1\% benzene/49\% pentane/petroleum ether) afforded compound $3 \mathbf{u}$ as a clear oil (64\%, $41.4 \mathrm{mg}$ ) and $(62 \%, 40.3 \mathrm{mg})$ in duplicate trials. The average isolated yield of $63 \%$ is reported.

${ }^{1} \mathbf{H}$ NMR $\left(400 \mathrm{MHz}, \mathbf{C D C l}_{3}\right): \delta 7.51(\mathrm{~d}, J=8.4 \mathrm{~Hz}, 2 \mathrm{H}), 7.37-7.23(\mathrm{~m}, 4 \mathrm{H}), 7.10$ (ddd, $J=9.3$, $8.0,1.5 \mathrm{~Hz}, 1 \mathrm{H}), 1.40(\mathrm{~s}, 9 \mathrm{H})$.

${ }^{13}$ C NMR (126 MHz, $\left.\mathbf{C D C l}_{3}\right): \delta 160.5\left(\mathrm{~d}, J_{C-F}=247.9 \mathrm{~Hz}\right), 151.1,134.6\left(\mathrm{~d}, J_{C-F}=3.9 \mathrm{~Hz}\right)$, $129.8,129.5,128.8\left(\mathrm{~d}, J_{C-F}=9.5 \mathrm{~Hz}\right), 125.5\left(\mathrm{~d}, J_{C-F}=3.5 \mathrm{~Hz}\right), 125.1,114.3\left(\mathrm{~d}, J_{C-F}=23.4 \mathrm{~Hz}\right)$, 34.7, 31.4. *Carbon not detected.

${ }^{19}$ F NMR (376 MHz, $\left.\mathrm{CDCl}_{3}\right): \delta$-111.2.

IR (NaCl, thin film, $\left.\mathbf{~ c m}^{-1}\right):$ 2964, 1603, 1572, 1446, 1242, 895 .

HRMS (EI-TOF) $m / z:$ : [M] $]^{+}$Calculated for $\mathrm{C}_{16} \mathrm{H}_{16} \mathrm{ClF}^{+}: 262.0919$; Observed: 262.0910 .

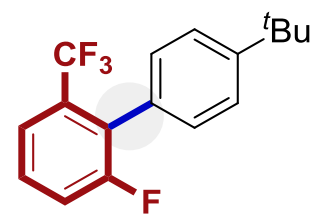

$3 v$ n.d. $(56 \%)$

The general procedure was followed. Final purification by preparatory thin layer chromatography ( $1 \%$ benzene/49\% pentane/petroleum ether) afforded compound $\mathbf{3 v}$ as a clear oil $(56 \%, 41.7 \mathrm{mg}$ ) and $(56 \%, 42.3 \mathrm{mg})$ in duplicate trials. The average isolated yield of $56 \%$ is reported.

${ }^{1} \mathbf{H}$ NMR (400 MHz, CDCl $): \delta 7.58(\mathrm{~d}, J=7.9 \mathrm{~Hz}, 1 \mathrm{H}), 7.47(\mathrm{~m}, 3 \mathrm{H}), 7.35(\mathrm{t}, J=8.6 \mathrm{~Hz}, 1 \mathrm{H})$, $7.24(\mathrm{~d}, J=8.0 \mathrm{~Hz}, 2 \mathrm{H}), 1.40$ (s, 9H).

${ }^{13}$ C NMR (126 MHz, $\left.\mathbf{C D C l}_{3}\right): \delta 160.4\left(\mathrm{~d}, J_{C-F}=245.6 \mathrm{~Hz}\right), 151.1,139.1,129.3,129.1-128.6$ $(\mathrm{m}, 2 \mathrm{C}), 126.9\left(\mathrm{q}, J_{C-F}=210.2 \mathrm{~Hz}\right), 124.8,124.8,121.8-121.5(\mathrm{~m}), 119.1\left(\mathrm{~d}, J_{C-F}=23.8 \mathrm{~Hz}\right)$, 34.7, 31.4 .

${ }^{19}$ F NMR (376 MHz, $\left.\mathbf{C D C l}_{3}\right): \delta-57.15,-111.55$.

IR (NaCl, thin film, $\left.\mathbf{c m}^{-1}\right):$ 2956, 1463, 1319, 1169, 1136, 905.

HRMS (EI-TOF) $\boldsymbol{m} / \boldsymbol{z}:[\mathrm{M}]^{+}$Calculated for $\mathrm{C}_{17} \mathrm{H}_{16} \mathrm{~F}_{4}{ }^{+}: 296.1183$; Observed: 296.1167 . 


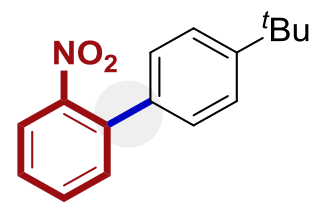

$3 w$ n.d. $(71 \%)$

The general procedure was followed with minor modifications. Th reactions were heated to 180 ${ }^{\circ} \mathrm{C}$. Final purification by flash column chromatography (5\% EtOAc/hexanes) afforded compound 3w as a clear oil $(71 \%, 45.0 \mathrm{mg})$ and $(70 \%, 45.2 \mathrm{mg})$ in duplicate trials. The average isolated yield of $71 \%$ is reported. Characterization data for this compound has been reported. ${ }^{7}$ The material obtained from this method provided an identical ${ }^{1} \mathrm{H}$ NMR spectrum. An image of the ${ }^{1} \mathrm{H}$ NMR spectrum is provided below.

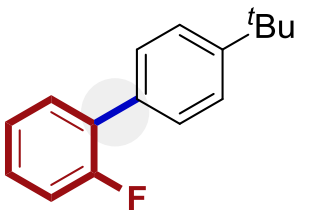

$3 \times 36 \%(41 \%)$

The general procedure was followed with minor modifications. The reactions were heated to $180{ }^{\circ} \mathrm{C}$ with $10 \mathrm{~mol} \%$ [Au] catalyst loading. The crude reaction mixture was analyzed by ${ }^{19} \mathrm{~F}$ NMR (40\% cross-coupled biaryl 3x) and (30\% cross-coupled biaryl 3x) in duplicate trials. Final purification by preparatory thin layer chromatography ( $1 \%$ benzene/49\% pentane/petroleum ether) afforded compound $\mathbf{3 x}$ as a white solid $(41 \%, 22.9 \mathrm{mg})$ and $(40 \%, 23.0 \mathrm{mg})$ in duplicate trials.

In a replicate experiment, the general procedure was followed with minor modifications. The reactions were run on two-fold the scale $(1 \mathbf{x}, 0.5 \mathrm{mmol})$ and were heated to $180{ }^{\circ} \mathrm{C}$ with 10 mol \% [Au] catalyst loading. The crude reaction mixture was analyzed by ${ }^{19} \mathrm{~F}$ NMR (36\% crosscoupled biaryl 3x) and (37\% cross-coupled biaryl 3x) in duplicate trials. Final purification by preparatory thin layer chromatography (1\% benzene/49\% pentane/petroleum ether) afforded compound 3x as a white solid $(43 \%, 46.1 \mathrm{mg})$ and $(38 \%, 40.1 \mathrm{mg})$ in duplicate trials.

The average isolated yield of $41 \%$ is reported (4 replicates). Characterization data for this compound has been reported. ${ }^{8}$ The material obtained from this method provided an identical ${ }^{1} \mathrm{H}$ NMR spectrum. An image of the ${ }^{1} \mathrm{H}$ NMR spectrum is provided below.<smiles>CC(C)(C)c1ccc(-c2ccccc2Cl)cc1</smiles>

3y n.d. (50\%)

The general procedure was followed with minor modifications. The reactions were run on twofold the scale $(1 \mathrm{y}, 0.5 \mathrm{mmol})$ and heated to $180{ }^{\circ} \mathrm{C}$ with $10 \mathrm{~mol} \%$ [Au] catalyst loading. Final purification by preparatory thin layer chromatography ( $1 \%$ benzene/49\% pentane/petroleum ether) afforded compound $3 \mathbf{y}$ as a yellow oil $(53 \%, 64.7 \mathrm{mg})$ and $(46 \%, 57.3 \mathrm{mg})$ in duplicate trials. The average isolated yield of $50 \%$ is reported. Characterization data for this compound has been reported. ${ }^{9}$ The material obtained from this method provided identical ${ }^{1} \mathrm{H}$ NMR spectra. An image of the ${ }^{1} \mathrm{H}$ NMR spectrum is provided below. 
<smiles>CC(C)(C)c1ccc(-c2c(F)c(F)nc(F)c2F)cc1</smiles>

3aa n.d. (66\%)

The general procedure was followed with minor modifications. The reaction was run in a $20 \mathrm{~mL}$ vial. After the addition of 4-tert-butyliodobenzene, the vial was charged with 1,2-dichlorobenzene $(1.5 \mathrm{~mL}, 0.17 \mathrm{M})$. Final purification by preparatory thin layer chromatography (1\% benzene/49\% pentane/petroleum ether) afforded compound 3aa as a white solid $(61 \%, 43.6 \mathrm{mg})$ and $(70 \%, 49.7$ $\mathrm{mg}$ ) in duplicate trials. The average isolated yield of $66 \%$ is reported.

${ }^{1}$ H NMR (400 MHz, $\left.\mathbf{C D C l}_{3}\right): \delta 7.60(\mathrm{~d}, J=8.5 \mathrm{~Hz}, 2 \mathrm{H}), 7.51(\mathrm{dt}, J=8.5,1.7 \mathrm{~Hz}, 2 \mathrm{H}), 1.41(\mathrm{~s}$, 9H).

${ }^{13}$ C NMR (126 MHz, $\left.\mathbf{C D C l}_{3}\right): \delta 154.1,144.1$ (dddd, $\left.J_{C-F}=244.7,17.0,13.5,2.9 \mathrm{~Hz}\right), 140.5-$ $138.0(\mathrm{~m}), 133.5\left(\mathrm{tt}, J_{C-F}=14.3,2.7 \mathrm{~Hz}\right), 129.6\left(\mathrm{t}, J_{C-F}=2.6 \mathrm{~Hz}\right), 125.9,123.0,35.0,31.1$.

${ }^{19}$ F NMR (376 MHz, CDCl $)$ ): $\delta$-91.0 - -91.2 (m), -145.2 - -145.4 (m).

IR (NaCl, thin film, $\left.\mathbf{c m}^{-1}\right):$ 2968, 2865, 1454, 1407, 961, 833.

HRMS (EI-TOF) $\boldsymbol{m} / \boldsymbol{z}:[\mathrm{M}]^{+}$Calculated for $\mathrm{C}_{15} \mathrm{H}_{13} \mathrm{~F}_{4} \mathrm{~N}^{+}: 283.0979$; Observed: 283.0969.<smiles>Clc1ccc(-c2ccc(Br)cc2)c(Cl)n1</smiles>

3 bb n.d. $(48 \%)$

The general procedure was followed with minor modifications. The reactions were heated to 180 ${ }^{\circ} \mathrm{C}$ with $10 \mathrm{~mol} \%$ [Au] catalyst loading. Final purification by column chromatography (5\% EtOAc/hexanes) afforded compound $3 \mathbf{b b}$ as a white solid $(45 \%, 33.3 \mathrm{mg})$ and $(50 \%, 36.0 \mathrm{mg}) \mathrm{in}$ duplicate trials. The average isolated yield of $48 \%$ is reported.

${ }^{1}$ H NMR (400 MHz, CDCl $): \delta 7.66(\mathrm{~d}, J=7.9 \mathrm{~Hz}, 1 \mathrm{H}), 7.51(\mathrm{~d}, J=8.4 \mathrm{~Hz}, 2 \mathrm{H}), 7.40(\mathrm{~d}, J=$ $8.4 \mathrm{~Hz}, 2 \mathrm{H}), 7.36(\mathrm{~d}, J=8.0 \mathrm{~Hz}, 1 \mathrm{H}), 1.39(\mathrm{~s}, 9 \mathrm{H})$.

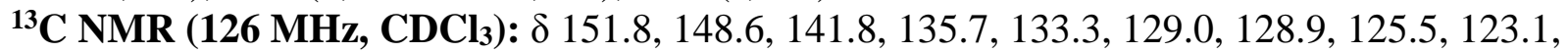
34.7, 31.3 .

IR (NaCl, thin film, $\mathbf{c m}^{-1}$ ): 2961, 1573, 1537, 1427, 1335, 820.

HRMS (EI-TOF) $m / z:[\mathrm{M}]^{+}$Calculated for $\mathrm{C}_{15} \mathrm{H}_{15} \mathrm{Cl}_{2} \mathrm{~N}^{+}:$279.0576; Observed: 279.0560.

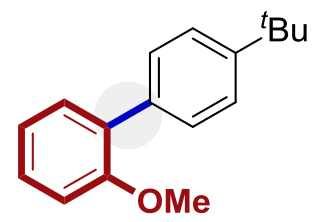

3cc $14 \%$ (n.d.)

The general procedure was followed with minor modifications. The reactions were heated to 180 ${ }^{\circ} \mathrm{C}$ with $10 \mathrm{~mol} \%[\mathrm{Au}$ ] catalyst loading. The crude reaction mixture was analyzed by GC-FID with a 5-point calibration curve with 1-fluoronaphthalene as the internal standard (12\% crosscoupled biaryl 3cc) and (15\% cross-coupled biaryl 3cc) in duplicate trials. The average crude yield of $14 \%$ is reported. The product was not isolated. 


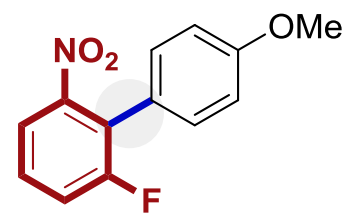

3dd $>95 \%(94 \%)$

The general procedure was followed with minor modifications. The reaction was heated to 120 ${ }^{\circ} \mathrm{C}$. The crude reaction mixture was analyzed by ${ }^{19} \mathrm{~F}$ NMR (>95\% cross-coupled biaryl 3dd) and (>95\% cross-coupled biaryl 3dd) in duplicate trials. Final purification by column chromatography (10\% ethyl acetate/hexanes) afforded compound 3dd as a yellow solid (92\%, $56.3 \mathrm{mg}$ ) and (96\%, $58.5 \mathrm{mg})$ in duplicate trials. The average isolated yield of $94 \%$ is reported.

${ }^{1}$ H NMR (500 MHz, CDCl $\left.)_{3}\right): \delta .65(\mathrm{~d}, J=8.1 \mathrm{~Hz}, 1 \mathrm{H}), 7.46(\mathrm{~m}, 1 \mathrm{H}), 7.39(\mathrm{t}, J=8.5 \mathrm{~Hz}, 1 \mathrm{H})$, $7.27(\mathrm{~d}, J=8.4 \mathrm{~Hz}, 2 \mathrm{H}), 7.01(\mathrm{~d}, J=8.4 \mathrm{~Hz}, 2 \mathrm{H}), 3.87(\mathrm{~s}, 3 \mathrm{H})$.

${ }^{13}$ C NMR (126 MHz, CDCl 3$): \delta 160.0,159.9\left(\mathrm{~d}, J_{C-F}=249.5 \mathrm{~Hz}\right), 150.7\left(\mathrm{~d}, J_{C-F}=3.6 \mathrm{~Hz}\right)$, $130.2\left(\mathrm{~d}, J_{C-F}=1.4 \mathrm{~Hz}\right), 128.9\left(\mathrm{~d}, J_{C-F}=8.9 \mathrm{~Hz}\right), 124.4\left(\mathrm{~d}, J_{C-F}=20.6 \mathrm{~Hz}\right), 121.9,119.7\left(\mathrm{~d}, J_{C-F}\right.$ $=23.7 \mathrm{~Hz}), 119.5\left(\mathrm{~d}, J_{C-F}=3.7 \mathrm{~Hz}\right), 114.2,55.3$.

${ }^{19}$ F NMR (376 MHz, CDCl 3$): \delta-111.5$.

IR (NaCl, thin film, $\left.\mathbf{~ c m}^{-1}\right): 3096,2937,1609,1537,1468,1180,742$.

HRMS (EI-TOF) $m / z:[\mathrm{M}]^{+}$Calculated for $\mathrm{C}_{13} \mathrm{H}_{10} \mathrm{FNO}_{3}{ }^{+}:$247.0639; Observed: 247.0635.

\section{Synthesis of Gold and Silver Complexes}

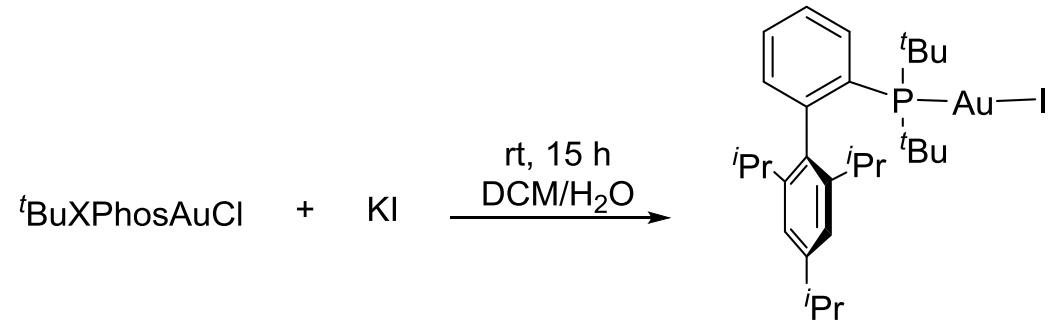

${ }^{t}$ BuXPhosAul, $77 \%$

In air, a $20 \mathrm{~mL}$ vial was charged with ${ }^{t} \mathrm{BuXPhos} \mathrm{AuCl}(51.2 \mathrm{mg}, 77.9 \mu \mathrm{mol})$ and DCM (1 mL, 0.07 M). A separate $20 \mathrm{~mL}$ vial was charged with $\mathrm{KI}(15.6 \mathrm{mg}, 94.0 \mu \mathrm{mol})$ and $\mathrm{H}_{2} \mathrm{O}(1 \mathrm{~mL}, 0.07 \mathrm{M})$. The resulting solution of KI was added slowly at $\mathrm{rt}$ to the vial containing the gold complex. The vial was rinsed with additional $\mathrm{H}_{2} \mathrm{O}(2 \mathrm{X} 0.1 \mathrm{~mL})$. After $15 \mathrm{~h}$, the DCM layer was removed. The $\mathrm{H}_{2} \mathrm{O}$ was extracted with DCM (2 X $\left.2 \mathrm{~mL}\right)$. The organic layers were combined, dried $\left(\mathrm{MgSO}_{4}\right)$, and concentrated to give ${ }^{t} \mathrm{BuXPhos} \mathrm{AuI}$ as a white solid (44.9 $\left.\mathrm{mg}, 60.0 \mathrm{mmol}, 77 \%\right)$.

${ }^{1}$ H NMR (500 MHz, CDCl $): \delta 7.90(\mathrm{t}, J=7.6 \mathrm{~Hz}, 1 \mathrm{H}), 7.56-7.45(\mathrm{~m}, 2 \mathrm{H}), 7.33-7.27(\mathrm{~m}$, $1 \mathrm{H}), 7.08(\mathrm{~s}, 2 \mathrm{H}), 3.06(\mathrm{p}, J=6.9 \mathrm{~Hz}, 1 \mathrm{H}), 2.37(\mathrm{p}, J=6.7 \mathrm{~Hz}, 2 \mathrm{H}), 1.46(\mathrm{~d}, J=15.5 \mathrm{~Hz}, 18 \mathrm{H})$, $1.41(\mathrm{~d}, J=7.0 \mathrm{~Hz}, 6 \mathrm{H}), 1.30(\mathrm{~d}, J=6.9 \mathrm{~Hz}, 6 \mathrm{H}), 0.92(\mathrm{~d}, J=6.7 \mathrm{~Hz}, 6 \mathrm{H})$.

${ }^{13}$ C NMR (126 MHz, CDCl 3$): \delta 150.0,148.5\left(\mathrm{~d}, J_{c-p}=15.4 \mathrm{~Hz}\right), 145.5,135.7\left(\mathrm{~d}, J_{c-p}=5.6 \mathrm{~Hz}\right)$, $135.0\left(\mathrm{~d}, J_{c-p}=7.9 \mathrm{~Hz}\right), 134.8\left(\mathrm{~d}, J_{c-p}=2.3 \mathrm{~Hz}\right), 130.2\left(\mathrm{~d}, J_{c-p}=2.3 \mathrm{~Hz}\right), 128.9\left(\mathrm{~d}, J_{c-p}=39.1\right.$ $\mathrm{Hz}), 126.4\left(\mathrm{~d}, J_{c-p}=6.3 \mathrm{~Hz}\right), 122.4,38.8\left(\mathrm{~d}, J_{c-p}=23.6 \mathrm{~Hz}\right), 33.9,31.3\left(\mathrm{~d}, J_{c-p}=6.7 \mathrm{~Hz}\right), 30.8$, 26.1, 24.5, 23.2.

${ }^{31}$ P NMR (162 MHz, CDCl 3$): \delta 63.0$.

IR (NaCl, thin film, $\mathbf{c m}^{-1}$ ): 2960, 2867, 1460, 1368, 1169.

*HRMS (ESI-TOF) m/z: [M+Na] $]^{+}$Calculated for $\mathrm{C}_{29} \mathrm{H}_{45} \mathrm{AuINaP}^{+}$: 771.1861; Observed: 771.1879. *HRMS was taken in dry THF 


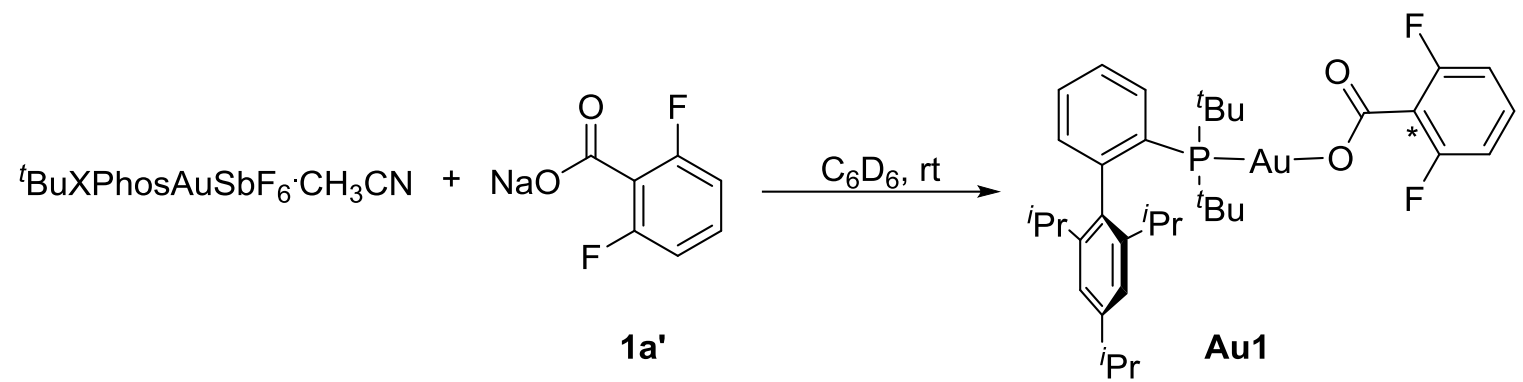

In a glovebox, a $20 \mathrm{~mL}$ vial was charged with ${ }^{t} \mathrm{BuXPhos} \mathrm{AuSbF}_{6} \cdot \mathrm{CH}_{3} \mathrm{CN}(56.1 \mathrm{mg}, 62.4 \mu \mathrm{mol})$ and sodium 2,6-difluorobenzoate (1a', $12.1 \mathrm{mg}, 67.1 \mu \mathrm{mol})$. The vial was opened to air, charged with dry benzene $(2 \mathrm{~mL})$, and stirred at $\mathrm{rt}$. After $2 \mathrm{~h}$, the reaction mixture was filtered through cotton and the cotton was rinsed with benzene $(3 \mathrm{X} 0.5 \mathrm{~mL})$. The filtration was repeated twice. The resulting filtrate was concentrated under reduced pressure to afford Au1 complex (>95\%, 50.9 $\mathrm{mg})$, which was stored in the freezer.

${ }^{1} \mathbf{H}$ NMR (400 MHz, CDCl$\left.)_{3}\right): \delta .92(\mathrm{td}, J=7.8,1.9 \mathrm{~Hz}, 1 \mathrm{H}), 7.52(\mathrm{~m}, 2 \mathrm{H}), 7.39-7.34(\mathrm{~m}, 1 \mathrm{H})$, $7.25-7.11(\mathrm{~m}, 1 \mathrm{H}), 7.09(\mathrm{~s}, 2 \mathrm{H}), 6.85(\mathrm{dd}, J=7.6,7.6 \mathrm{~Hz}, 2 \mathrm{H}), 2.77(\mathrm{p}, J=7.0 \mathrm{~Hz}, 1 \mathrm{H}), 2.37$ (sept, $J=6.7 \mathrm{~Hz}, 2 \mathrm{H}), 1.49(\mathrm{~s}, 9 \mathrm{H}), 1.45(\mathrm{~s}, 9 \mathrm{H}), 1.34(\mathrm{~d}, J=6.7 \mathrm{~Hz}, 6 \mathrm{H}), 1.12(\mathrm{~d}, J=6.9 \mathrm{~Hz}, 6 \mathrm{H})$, $0.94(\mathrm{~d}, J=6.5 \mathrm{~Hz}, 6 \mathrm{H})$.

${ }^{13}$ C NMR (126 MHz, CDCl 3$): \delta 165.7,159.5(\mathrm{dd}, J=249.8,8.7 \mathrm{~Hz}), 149.6,148.5(\mathrm{~d}, J=13.1$ $\mathrm{Hz}), 145.9,135.4(\mathrm{~d}, J=5.6 \mathrm{~Hz}), 134.7(\mathrm{~d}, J=7.9 \mathrm{~Hz}), 134.1(\mathrm{~d}, J=3.6 \mathrm{~Hz}), 130.2(\mathrm{~d}, J=2.4$ $\mathrm{Hz}), 128.7(\mathrm{t}, J=9.8 \mathrm{~Hz}), 127.6(\mathrm{~d}, J=45.2 \mathrm{~Hz}), 126.3(\mathrm{~d}, J=7.1 \mathrm{~Hz}), 121.5,111.4-110.8(\mathrm{~m})$, $38.5(\mathrm{~d}, J=28.0 \mathrm{~Hz}), 34.1,31.2(\mathrm{~d}, J=6.2 \mathrm{~Hz}), 31.0,26.4,23.6,22.8$. *Carbon not detected.

${ }^{19}$ F NMR (376 MHz, CDCl $)$ : $\delta-112.07$.

${ }^{31}$ P NMR (162 MHz, $\left.\mathbf{C D C l}_{3}\right): \delta 53.74$.

IR (NaCl, thin film, $\mathbf{c m}^{-1}$ ): 2960, 2866, 1639, 1621, 1463, 1344, 734.

*HRMS (ESI-TOF) $m / z$ : [M+Na] ${ }^{+}$Calculated for $\mathrm{C}_{36} \mathrm{H}_{48} \mathrm{AuF}_{2} \mathrm{NaO}_{2} \mathrm{P}^{+}$: 801.2918; Observed: 801.2948. *HRMS was taken in dry THF with sodium formate as an additive.

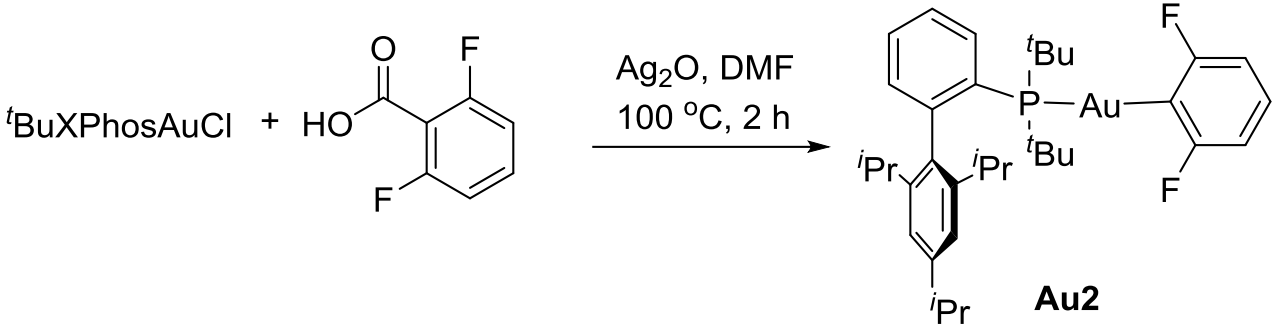

Gold complex Au2 was synthesized following a procedure by Larrosa. ${ }^{10} \mathrm{In}$ air, a $20 \mathrm{~mL}$ vial was charged with ${ }^{t} \mathrm{BuXPhos} \mathrm{AuCl}(203 \mathrm{mg}, 0.309 \mathrm{mmol}), 1,6$-difluorobenzoic acid (82.0 $\mathrm{mg}, 0.519$ $\mathrm{mmol})$, and silver (I) oxide $(78.9 \mathrm{mg}, 0.340 \mathrm{mmol})$. The vial was sealed with a Teflon lined cap and the cap was sealed with electrical tape. The reaction was heated to $100{ }^{\circ} \mathrm{C}$. After $2 \mathrm{~h}$, the reaction was cooled to rt. The vial was charged with TEA (approximately $500 \mathrm{uL}$ ). The reaction was filtered through a short plug of silica and the silica was washed ( $3 \mathrm{X} 1 \mathrm{~mL}, 1 \% \mathrm{TEA} / \mathrm{DCM})$. The reaction was then concentrated under reduced pressure ( $<5$ torr, $\left.40{ }^{\circ} \mathrm{C}\right)$ to afford $\mathrm{Au} 2$ complex as a tan solid (>95\%, $224 \mathrm{mg})$.

${ }^{1} \mathbf{H}$ NMR (400 MHz, CDCl $): \delta 7.96(\mathrm{ddd}, J=6.9,6.9,2.1 \mathrm{~Hz}, 1 \mathrm{H}), 7.55-7.45(\mathrm{~m}, 2 \mathrm{H}), 7.33$ (ddd, $J=6.6,4.2,2.1 \mathrm{~Hz}, 1 \mathrm{H}), 6.98-6.87(\mathrm{~m}, 3 \mathrm{H}), 6.71$ (ddd, $J=7.6,5.3,1.8 \mathrm{~Hz}, 2 \mathrm{H}), 2.53-$ $2.37(\mathrm{~m}, 3 \mathrm{H}), 1.53(\mathrm{~d}, J=14.6 \mathrm{~Hz}, 18 \mathrm{H}), 1.40(\mathrm{~d}, J=6.8 \mathrm{~Hz}, 6 \mathrm{H}), 0.96(\mathrm{~d}, J=6.7 \mathrm{~Hz}, 6 \mathrm{H}), 0.91$ $(\mathrm{d}, J=6.9 \mathrm{~Hz}, 6 \mathrm{H})$. 
${ }^{13}$ C NMR (126 MHz, CDCl $): \delta 168.3(\mathrm{ddd}, J=230.6,24.9,3.9 \mathrm{~Hz}), 148.8(\mathrm{~d}, J=16.8 \mathrm{~Hz})$, $148.4,145.7,141.5(\mathrm{dt}, J=97.1 \mathrm{~Hz}, J=61.7 \mathrm{~Hz}), 136.2(\mathrm{~d}, J=5.0 \mathrm{~Hz}), 135.6,134.7(\mathrm{~d}, J=8.0$ $\mathrm{Hz}), 130.4(\mathrm{~d}, J=33.6 \mathrm{~Hz}), 129.8(\mathrm{~d}, J=2.3 \mathrm{~Hz}), 126.3-126.1(\mathrm{~m}, 2 \mathrm{C}), 121.5,109.3(\mathrm{dt}, J=$ 31.3, 3.1 Hz), $38.3(\mathrm{~d}, J=21.6 \mathrm{~Hz}), 33.0,31.5(\mathrm{~d}, J=6.7 \mathrm{~Hz}), 30.8,26.3,23.2,22.8$.

${ }^{19}$ F NMR (376 MHz, CDCl 3$): \delta-86.41(\mathrm{~d}, J=6.4 \mathrm{~Hz})$.

31P NMR (162 MHz, CDCl $): \delta 64.65(\mathrm{t}, J=6.3 \mathrm{~Hz})$.

IR (NaCl, thin film, $\mathbf{c m}^{-1}$ ): 2956, 2867, 1588, 1434, 956.

*HRMS (ESI-TOF) m/z: [M+Na] ${ }^{+}$Calculated for $\mathrm{C}_{35} \mathrm{H}_{48} \mathrm{AuF}_{2} \mathrm{NaP}^{+}$: 757.3019; Observed: 757.3033. *HRMS was taken in dry DCM.

Crystallization: To obtain X-Ray quality crystals, complex Au2 was dissolved in benzene and crystalized by slow diffusion of $\mathrm{CH}_{3} \mathrm{CN}$.

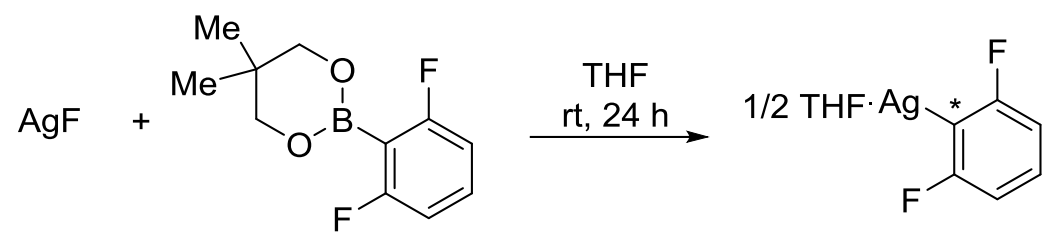

Ag1

Silver complex Ag1 was synthesized by modification of a procedure reported by Hoover. ${ }^{11}$ In a glovebox, a $20 \mathrm{~mL}$ vial was charged with silver fluoride $(60.3 \mathrm{mg}, 0.475 \mathrm{mmol})$ and THF (2 mL). A separate $4 \mathrm{~mL}$ vial was charged with 2,6-difluorophenylboronic acid neopentylglycol ester (102 $\mathrm{mg}, 0.451 \mathrm{mmol})$ and THF (2 mL). At rt, the boronic ester solution was added portion wise to the silver fluoride suspension. The vial was sealed with a Teflon lined cap and the cap was sealed with electrical tape. The reaction was stirred at $\mathrm{rt}$ and the vial was covered with aluminum foil to keep the reaction dark. After $24 \mathrm{~h}$, the solution was cooled in a glovebox freezer. After 3 days, crystals had formed. The THF was decanted to afford Ag1 (2:1 Ag1:THF adduct, determined by ${ }^{1} \mathrm{H}$ NMR) as white crystals (58.4 mg, 50\%). NOTE: Complex Ag1 was exceptionally sensitive to light, and modestly sensitive to air and moisture. It could be stored in a glovebox freezer $\left(-20^{\circ} \mathrm{C}\right)$ in the dark for about 1 month.

${ }^{1} \mathbf{H}$ NMR (500 MHz, CH $\mathbf{3}$ CN): $\delta 7.35(\mathrm{dd}, J=7.6,7.6 \mathrm{~Hz}, 1 \mathrm{H}), 6.91-6.83(\mathrm{~m}, 2 \mathrm{H}), 3.70-3.63$ (m, 2H), $1.87-1.78(\mathrm{~m}, 2 \mathrm{H})$.

${ }^{13}$ C NMR (126 MHz, CH $\mathbf{C H}_{3}$ CN): $\delta 172.42$ (dd, $\left.J=232.8,23.5 \mathrm{~Hz}\right), 134.2-133.9$ (m), 117.3, $110.0-109.3(\mathrm{~m}), 67.3,25.3$. ${ }^{*}$ Carbon bound to silver not detected.

${ }^{19} \mathrm{~F}$ NMR (471 MHz, proton coupled, $\left.\mathrm{CH}_{3} \mathrm{CN}\right): \delta-75.04--77.23(\mathrm{~m})$.

IR (NaCl, thin film, $\mathbf{c m}^{-1}$ ): 1588. 1431, 1215, 963.

*HRMS (ESI-TOF) m/z: [M-THF+Ag] $]^{+}$Calculated for $\mathrm{C}_{6} \mathrm{H}_{3} \mathrm{Ag}_{2} \mathrm{~F}_{2}{ }^{+}$: 328.8296; Observed: 328.8306. *HRMS was taken in dry $\mathrm{CH}_{3} \mathrm{CN}$.

Crystallization: The crystals of complex Ag1 obtained via this method were suitable for X-ray diffraction analysis.<smiles>O=C(O[Al])c1c(F)cccc1F</smiles>

Au1 1.0 equiv

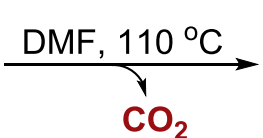

$\mathrm{CO}_{2}$<smiles>CCc1c(F)cccc1F</smiles>

Au2 94\% ${ }^{\mathrm{e}}$ 
Thermolysis of Au1 to Au2: In air, separate $4 \mathrm{~mL}$ vials were charged with Au1 (12.0 mg, 15.4 $\mu \mathrm{mol})$, triphenylmethane $\left({ }^{1} \mathrm{H}\right.$ internal standard, $\left.12.1-12.8 \mathrm{mg}, 49.5-52.4 \mu \mathrm{mol}\right)$, and dry DMSO-d $6(1.5 \mathrm{~mL}, 0.01 \mathrm{M})$. An aliquot $(0.5 \mathrm{~mL})$ was taken and analyzed by ${ }^{1} \mathrm{H}$ NMR (400 $\mathrm{MHz}$ ) to determine the initial ratios of $\mathbf{A u 1}$ to triphenylmethane. The vials were sealed with a Teflon lined cap and the cap was sealed with electrical tape. The reactions were heated to $110^{\circ} \mathrm{C}$ and the hot plate was covered with aluminum foil to keep the reaction dark. After $5 \mathrm{~h}$, the reaction was cooled to $\mathrm{rt}$ and analyzed by ${ }^{1} \mathrm{H}$ NMR (400 MHz) to determine the final ratios of Au2 to triphenylmethane. Based on comparison of the initial and final ratios, Au2 was observed in $91 \%$ and $96 \%$ in duplicate trials. The average of $94 \%$ is reported.

\section{Mechanistic Experiments}

Note: All mechanistic experiments were conducted using unused stir bars and vials to avoid concerns over contamination.

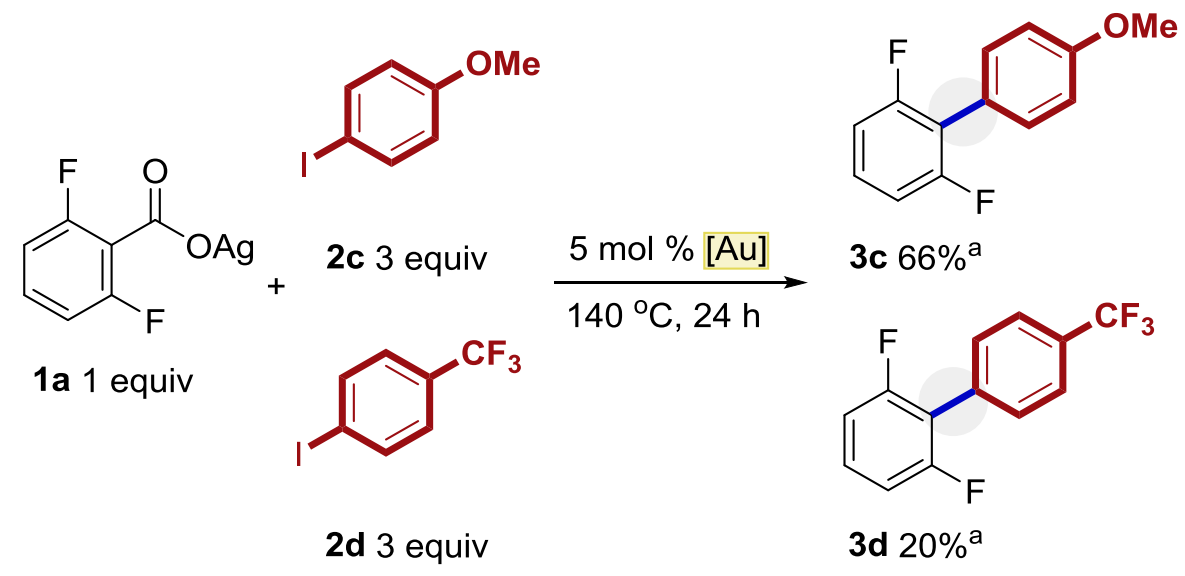

Competition Experiment: In a glovebox, a $4 \mathrm{~mL}$ vial was charged with solid ${ }^{t} \mathrm{BuXPhosAuNTf}_{2}$ (6.7 $\mathrm{mg}, 7.5 \mu \mathrm{mol}$, ca. $5 \mathrm{~mol} \%$ ), silver 2,6-difluorobenzoate (1a, $39.5 \mathrm{mg}, 0.149 \mathrm{mmol}$ ), 4 methoxy-iodobenzene (2c, $108 \mathrm{mg}, 0.460 \mathrm{mmol}$ ), and 4-trifluoromethyl-iodobenzene (2d, $125 \mathrm{mg}$, $0.460 \mathrm{mmol}$ ). The vial was sealed with a Teflon lined cap and removed from the glovebox. The cap was sealed with electrical tape. The reaction was heated to $140^{\circ} \mathrm{C}$ and the hot plate was covered with aluminum foil to keep the reaction dark. After $24 \mathrm{~h}$, the reaction was cooled to rt. A stock solution of 1- fluoronaphthalene ( $30.3 \mathrm{mg}, 0.208 \mathrm{mmol},{ }^{19} \mathrm{~F}$ NMR internal standard) was prepared in $\mathrm{CDCl}_{3}(1.5 \mathrm{~mL})$. An aliquot of stock solution $(0.30 \mathrm{~mL})$ was added to the reaction and the resulting mixture was analyzed by proton coupled ${ }^{19} \mathrm{~F}$ NMR. The following assay yields were obtained: 3c 66\%, 3d 20\%, 4 6\%. In a duplicate reaction the following assay yields were obtained: 3c $65 \% ; 3 \mathbf{d} 20 \%, 4$ 8\%. The average values are reported.

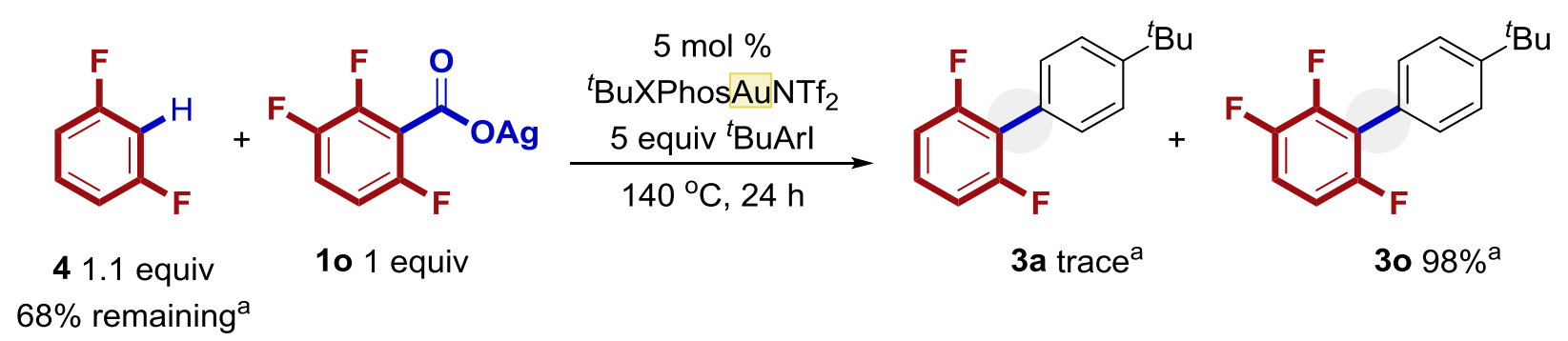

Protodecarboxylation/C-H Activation Sequence: In a glovebox, a $4 \mathrm{~mL}$ vial was charged with solid ${ }^{t}$ BuXPhosAuNTf 2 (6.8 mg, $7.5 \mu \mathrm{mol}$, ca. 5 mol \%), silver 2,3,6-trifluorobenzoate (1o, 43.9 
$\mathrm{mg}, 0.157 \mathrm{mmol}), 1,3$-difluorobenzene $(4,20.4 \mathrm{mg}, 0.179 \mathrm{mmol})$, and 4-tert-butyliodobenzene (2a, $191 \mathrm{mg}, 0.734 \mathrm{mmol})$. The vials were sealed with a Teflon lined cap and removed from the glovebox. The caps were sealed with electrical tape. The reactions were heated to $140{ }^{\circ} \mathrm{C}$ and the hot plate was covered with aluminum foil to keep the reactions dark. After $24 \mathrm{~h}$, the reactions were cooled to rt. A stock solution of 1-fluoronaphthalene $\left(65.8 \mathrm{mg}, 0.576 \mathrm{mmol},{ }^{19} \mathrm{~F}\right.$ NMR internal standard) was prepared in $\mathrm{CDCl}_{3}(3.3 \mathrm{~mL})$. An aliquot of stock solution $(0.30 \mathrm{~mL})$ was added to the reaction and the resulting mixture was analyzed by proton coupled ${ }^{19} \mathrm{~F}$ NMR $(471 \mathrm{MHz})$. The following assay yields were obtained: 4 64\% remaining, 3a 2\%, 3o 95\%. In a duplicate reaction the following assay yields were obtained: $472 \%$ remaining, 3a 5\%, 3o, >99\%. The average values are reported.<smiles>Fc1ccc(F)c(F)c1</smiles>

51.1 equiv<smiles>COC(=O)c1c(F)cccc1F</smiles>

1a 1 equiv

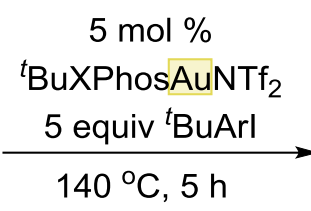

$59 \%$ remaining $^{a}$

Protodecarboxylation/C-H Activation Sequence: In a glovebox, a $4 \mathrm{~mL}$ vial was charged with solid ${ }^{t} \mathrm{BuXPhosAuNTf} 2(6.7 \mathrm{mg}, 7.4 \mu \mathrm{mol}$, ca. $5 \mathrm{~mol} \%$ ), silver 2,6-difluorobenzoate (1a, $39.5 \mathrm{mg}$, $0.149 \mathrm{mmol}), 1,2,4$-trifluorobenzene $(\mathbf{5}, 21.0 \mathrm{mg}, 0.159 \mathrm{mmol})$, and 4-tert-butyliodobenzene (2a, $202 \mathrm{mg}, 0.777 \mathrm{mmol}$ ). The vials were sealed with a Teflon lined cap and removed from the glovebox. The caps were sealed with electrical tape. The reactions were heated to $140{ }^{\circ} \mathrm{C}$ and the hot plate was covered with aluminum foil to keep the reactions dark. After $5 \mathrm{~h}$, the reactions were cooled to rt. A stock solution of 1-fluoronaphthalene $\left(13.7 \mathrm{mg}, 93.7 \mu \mathrm{mol},{ }^{19} \mathrm{~F}\right.$ NMR internal standard) was prepared in $\mathrm{CDCl}_{3}(0.75 \mathrm{~mL})$. An aliquot of stock solution $(0.30 \mathrm{~mL})$ was added to the reaction and the resulting mixture was analyzed by proton coupled ${ }^{19} \mathrm{~F}$ NMR $(471 \mathrm{MHz})$. The following assay yields were obtained: 5 59\% remaining, 3a 64\%, 3o 13\%. In a duplicate reaction the following assay yields were obtained: 5 59\% remaining, 3a 77\%, 3o 13\%. The average values are reported.<smiles>Fc1ccccc1F</smiles>

41 equiv<smiles>CC(C)(Br)c1ccc(I)cc1</smiles>

2a 5 equiv

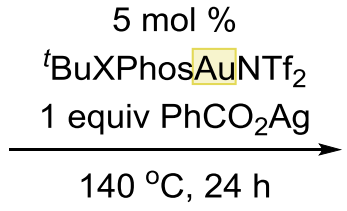

$40^{\circ} \mathrm{C}, 24 \mathrm{~h}$ $72 \%$ remaining ${ }^{\mathrm{a}}$

Protodecarboxylation/C-H Activation Sequence: In a glovebox, a $4 \mathrm{~mL}$ vial was charged with solid ${ }^{t} \mathrm{BuXPhos} \mathrm{AuNTf}_{2}(6.8 \mathrm{mg}, 7.5 \mu \mathrm{mol}$, ca. $5 \mathrm{~mol} \%)$, silver benzoate $(37.2 \mathrm{mg}, 0.162 \mathrm{mmol})$, 1,3-difluorobenzene (4, $18.2 \mathrm{mg}, 0.160 \mathrm{mmol})$, and 4-tert-butyliodobenzene (3a, $194 \mathrm{mg}, 0.746$ mmol). The vials were sealed with a Teflon lined cap and removed from the glovebox. The caps were sealed with electrical tape. The reactions were heated to $140^{\circ} \mathrm{C}$ and the hot plate was covered with aluminum foil to keep the reactions dark. After $24 \mathrm{~h}$, the reactions were cooled to rt. A stock solution of 1-fluoronaphthalene $\left(30.3 \mathrm{mg}, 0.208 \mathrm{mmol},{ }^{19} \mathrm{~F}\right.$ NMR internal standard) was prepared in $\mathrm{CDCl}_{3}(1.5 \mathrm{~mL})$. An aliquot of stock solution $(0.30 \mathrm{~mL})$ was added to the reaction and the resulting mixture was analyzed by proton coupled ${ }^{19} \mathrm{~F}$ NMR $(471 \mathrm{MHz})$. The following assay 
yields were obtained: $467 \%$, 3a 5\%. In a duplicate reaction the following assay yields were obtained: 4 76\%, 3a 5\%. The average values are reported.<smiles>COC(=O)c1c(F)cccc1F</smiles>

$1 \mathrm{a}$<smiles>Brc1ccc(Br)cc1</smiles>

$2 a$
$5 \mathrm{~mol} \%[\mathrm{Au}]$

$\underset{0 \text { or } 1.1 \text { equiv } \mathrm{NaOTf}}{\stackrel{140}{\circ} \mathrm{C}, 24 \mathrm{~h}}$

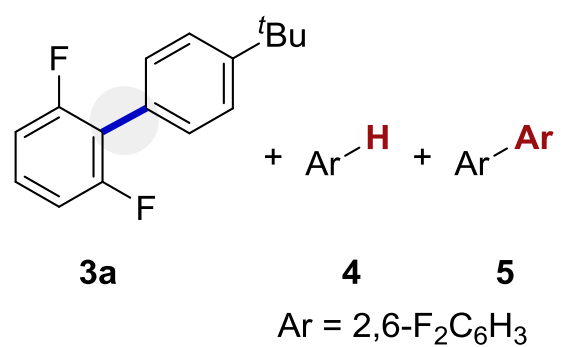

Gold Carboxylate and Gold Aryl as precatalyst: In a glovebox, separate $4 \mathrm{~mL}$ vials were charged with different gold precatalysts $(6.1-7.7 \mu \mathrm{mol}$, ca. $5 \mathrm{~mol} \%)$, silver 2,6-difluorobenzoate (1a, 39.0 - $40.2 \mathrm{mg}, 0.147$ - $0.151 \mathrm{mmol}$ ), and 4-tert-butyliodobenzene (2a, $196-199 \mathrm{mg}, 0.754$ $-0.765 \mathrm{mmol}$ ). The vials were sealed with a Teflon lined cap and removed from the glovebox. The caps were sealed with electrical tape. The reactions were heated to $140{ }^{\circ} \mathrm{C}$ and the hot plate was covered with aluminum foil to keep the reactions dark. After $24 \mathrm{~h}$, the reactions were cooled to rt. A stock solution of 1-fluoronaphthalene (57.6 mg, $0.394 \mathrm{mmol},{ }^{19} \mathrm{~F} \mathrm{NMR}$ internal standard) was prepared in $\mathrm{CDCl}_{3}(3.0 \mathrm{~mL})$. Each vial was charged with an aliquot of stock solution $(0.30$ $\mathrm{mL}$ ). The resulting mixture was filtered through a short plug of silica gel and the silica gel was washed with DCM $(2 \mathrm{~mL})$. The filtrate was analyzed by ${ }^{19} \mathrm{~F}$ NMR $(471 \mathrm{MHz})$ to determine the assay yield. Reactions were run in duplicate and the average values are reported. Entry 4 (Table S4) was conducted in an analogous manner with the addition of sodium triflate $(28.7-29.2 \mathrm{mg}$, $0.167-0.170)$.

Table S6. Gold Carboxylate and Gold Aryl as precatalyst

\begin{tabular}{|c|c|c|c|c|c|}
\hline Entry & {$[\mathrm{Au}]=$} & $\begin{array}{c}\text { Additive (110 mol } \\
\%)\end{array}$ & Yield 3a $(\%)^{\mathrm{a}}$ & Yield $4(\%)^{a}$ & Yield $5(\%)^{\mathrm{a}}$ \\
\hline 1 & ${ }^{t} \mathrm{BuXPhosAuNTf}_{2}$ & none & 97 & 8 & n.d. \\
\hline 2 & ${ }^{t} \mathrm{BuXPhos} \mathrm{AuCO}_{2} \mathrm{Ar}(\mathrm{Au1})$ & none & 66 & 7 & 32 \\
\hline 3 & ${ }^{t} \mathrm{BuXPhosAuAr}(\mathbf{A u 2})$ & none & 60 & 8 & 39 \\
\hline 4 & ${ }^{t} \mathrm{BuXPhosAuAr}(\mathbf{A u 2})$ & NaOTf & 89 & 9 & 5 \\
\hline
\end{tabular}

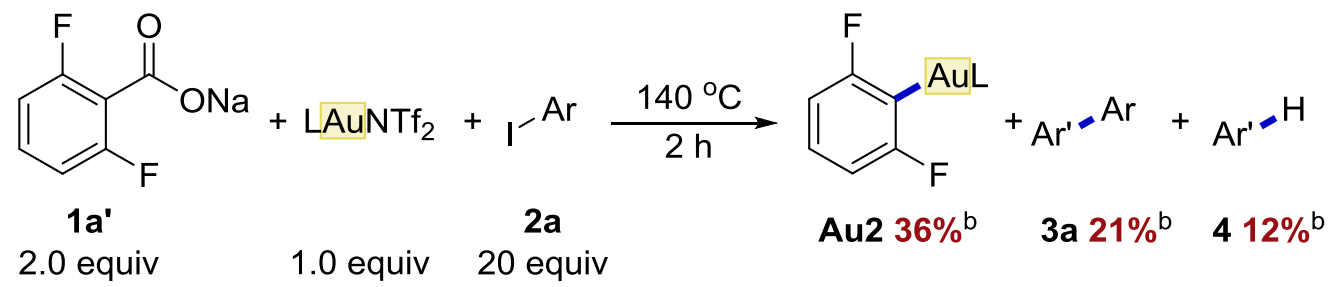

Formation of Gold Aryl in the Absence of Silver: In a glovebox, a $4 \mathrm{~mL}$ vial was charged with solid ${ }^{t} \mathrm{BuXPhosAuNTf} 2(25.2 \mathrm{mg}, 27.9 \mu \mathrm{mol})$, sodium 2,6-difluorobenzoate (1a', $10.1 \mathrm{mg}, 53.1$ $\mu \mathrm{mol})$ and 4-tert-butyliodobenzene $(\mathbf{2 a}, 46 \mathrm{mg}, 0.561 \mathrm{mmol})$. The vials were sealed with a Teflon lined cap and removed from the glovebox. The caps were sealed with electrical tape. The reactions were heated to $140{ }^{\circ} \mathrm{C}$ and the hot plate was covered with aluminum foil to keep the reactions dark. After $2 \mathrm{~h}$, the reactions were cooled to rt. A stock solution of 1-fluoronaphthalene (13.3 mg, 91.0 $\mu \mathrm{mol},{ }^{19} \mathrm{~F}$ NMR internal standard). An aliquot of stock solution $(0.30 \mathrm{~mL})$ was added to the reaction and the resulting mixture was analyzed by proton coupled ${ }^{19} \mathrm{~F}$ NMR $(471 \mathrm{MHz})$. The following assay yields were obtained: Au2 35\%, 3a 19\%, 4 12\%. In a duplicate reaction the following assay yields were obtained: Au2 36\%, 3a 22\%, 4 12\%. The average values are reported. 


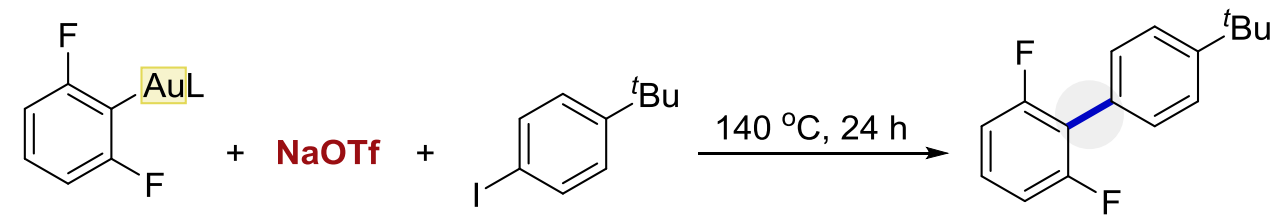

Au2 1 equiv 1.1 equiv 2 2a 20 equiv $3 a 10 \%{ }^{d}$ $60 \%$ remaining ${ }^{\mathrm{C}}$

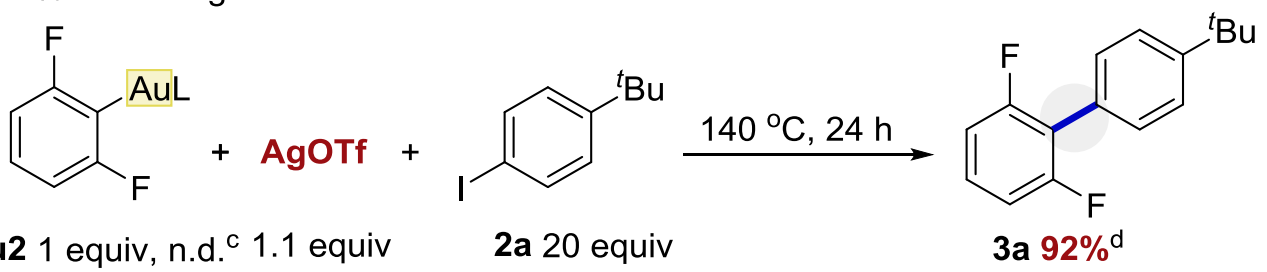

Role of Silver: In a glovebox, separate $4 \mathrm{~mL}$ vials were charged with solid Au2 (19.9-21.3 mg, 27.1-29 $\mu \mathrm{mol})$, NaOTf $(5.2-5.3 \mathrm{mg}, 30-31 \mu \mathrm{mol})$ or AgOTf $(7.6 \mathrm{mg}, 28 \mu \mathrm{mol})$ and 4-tertbutyliodobenzene (2a, 142-145 mg, $0.546-0.558 \mathrm{mmol}$ ). The vials were sealed with a Teflon lined cap and removed from the glovebox. The caps were sealed with electrical tape. The reactions were heated to $140{ }^{\circ} \mathrm{C}$ and the hot plate was covered with aluminum foil to keep the reactions dark. After $24 \mathrm{~h}$, the reactions were cooled to $\mathrm{rt}$. A stock solution of 1- fluoronaphthalene (30.3 $\mathrm{mg}$, $0.143 \mathrm{mmol}$, GC-FID internal standard) was prepared in $\mathrm{CDCl}_{3}(1.5 \mathrm{~mL})$. A separate stock solution of triphenylphosphine oxide $\left(12.8 \mathrm{mg}, 46 \mu \mathrm{mol},{ }^{31} \mathrm{P}\right.$ internal standard) was prepared in $\mathrm{CDCl}_{3}(0.9$ $\mathrm{mL})$. An aliquot of each stock solution $(0.30 \mathrm{~mL})$ was added to the reactions and the resulting mixture was analyzed by proton coupled ${ }^{31} \mathrm{P}$ NMR $(162 \mathrm{MHz})$ and GC-FID.

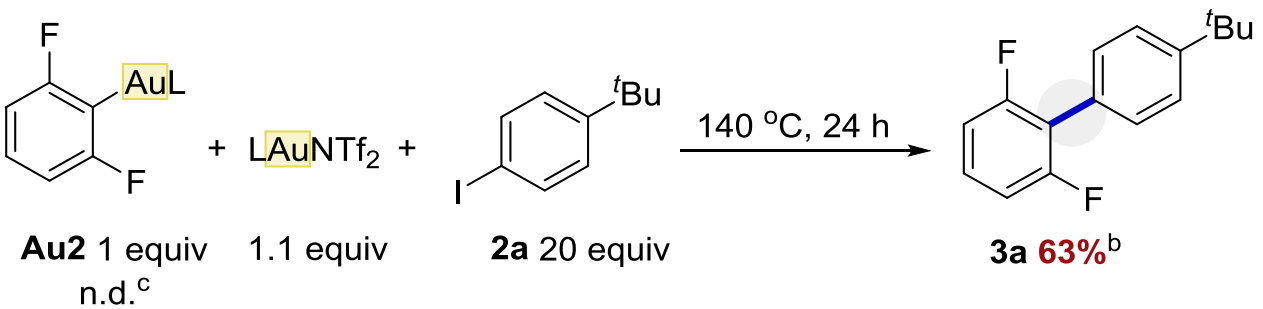

Role of Cationic Gold: In a glovebox, separate $4 \mathrm{~mL}$ vials were charged with solid Au2 (20.1 $20.4 \mathrm{mg}, 30.6$ - $31.0 \mu \mathrm{mol})$, ${ }^{t} \mathrm{BuXPhosAuNTf}_{2}(29.0$ - $29.1 \mathrm{mg}, 32.2$ - $32.3 \mu \mathrm{mol})$, and 4-tertbutyliodobenzene (2a, $165-160 \mathrm{mg}, 0.634-0.616 \mathrm{mmol})$. The vials were sealed with a Teflon lined cap and removed from the glovebox. The caps were sealed with electrical tape. The reactions were heated to $140^{\circ} \mathrm{C}$ and the hot plate was covered with aluminum foil to keep the reactions dark. After $24 \mathrm{~h}$, the reactions were cooled to $\mathrm{rt}$. A stock solution of 1- fluoronaphthalene (33.3 $\mathrm{mg}$, $0.228 \mathrm{mmol},{ }^{19} \mathrm{~F}$ NMR internal standard) was prepared in $\mathrm{CDCl}_{3}(1.8 \mathrm{~mL})$. A separate stock solution of triphenylphosphine oxide $\left(23.9 \mathrm{mg}, 85.9 \mu \mathrm{mol},{ }^{31} \mathrm{P}\right.$ NMR internal standard) was prepared in $\mathrm{CDCl}_{3}(0.9 \mathrm{~mL})$. An aliquot of each stock solution $(0.30 \mathrm{~mL})$ was added to the reactions and the resulting mixture was analyzed by proton coupled ${ }^{19} \mathrm{~F}$ NMR $(471 \mathrm{MHz})$.

Table S7. Role of Silver/Cationic Gold

\begin{tabular}{|c|c|c|c|}
\hline Entry & Additive & Yield 3a (\%) & Yield Au2 (\%) \\
\hline 1 & $\mathrm{NaOTf}$ & $9^{a}$ & $61^{\mathrm{b}}$ \\
\hline 2 & NaOTf & $10^{\mathrm{a}}$ & $59^{\mathrm{b}}$ \\
\hline 3 & AgOTf & $89^{a}$ & n.d. \\
\hline 4 & AgOTf & $95^{\mathrm{a}}$ & n.d. \\
\hline 5 & ${ }^{t} \mathrm{BuXPhosAuNTf}_{2}$ & $64^{c}$ & n.d. \\
\hline 6 & ${ }^{t} \mathrm{BuXPhosAuNTf}_{2}$ & $62^{c}$ & n.d. \\
\hline
\end{tabular}


To identify the fate of Au2 with added AgOTf (entries 3 and 4), the above reaction was replicated with diethyl 1-phenylethyl phosphonate as the ${ }^{31} \mathrm{P}$ NMR internal standard. Approximately $90 \%$ of the gold complex was assigned as a cationic gold complex ( ${ }^{\mathrm{B} u X P h o s A u X)}$ due to a ${ }^{31} \mathrm{P}$ NMR $\left(\mathrm{CDCl}_{3}\right)$ shift at $54.9 \mathrm{ppm}$ by comparison with other cationic gold complexes (page S138). The most likely $\mathrm{X}$ was is ${ }^{-} \mathrm{OTf}$ based on the AgOTf additive and the chemical shift. A pair of doublets were observed in approximately $10 \%$ yield and were identified as a putative ${ }^{t} \mathrm{BuXPhosAgX}$ complex by comparison to other reported silver phosphine complexes.

Doublets- Crude Reaction: ${ }^{31} \mathrm{P}$ NMR (162 MHz, $\left.\mathrm{CDCl}_{3}\right): \delta 41.9$ (d, J107Ag-3lP $=694.5 ;$ d, $J_{109 A g-3 l P}$ $=801.9 \mathrm{~Hz}$ )

$\mathrm{C}_{15} \mathrm{H}_{27} \mathrm{AgF}_{5} \mathrm{O}_{2} \mathrm{P}:{ }^{31} \mathrm{P}$ NMR $\left(101 \mathrm{MHz}, \mathrm{CDCl}_{3}\right): \delta-0.1\left(\mathrm{~d}, J_{107 A g-3 l P}=699 ; \mathrm{d}, J_{109 A g-3 I P}=807\right.$ $\mathrm{Hz}){ }^{12}$

$\mathrm{C}_{33} \mathrm{H}_{42} \mathrm{AgF}_{6} \mathrm{NPSb}:{ }^{31} \mathrm{P} \mathrm{NMR}\left(101 \mathrm{MHz}, \mathrm{CDCl}_{3}\right): \delta 43.7\left(\mathrm{~d}, J_{107 \mathrm{Ag}-31 P}=628.63 ; \mathrm{d}, J_{109 \mathrm{Ag}-31 \mathrm{P}}=\right.$ $725.04 \mathrm{~Hz}){ }^{13}$

Table S8: Comparison of Chemical Shifts of Cationic Gold Complexes

$\begin{array}{cc}{[\mathrm{Au}]} & \delta^{31} \mathrm{P}\left(\mathrm{CDCl}_{3}\right) \\ { }^{t} \mathrm{BuXPhosAuSbF} 6 \mathrm{CH}_{3} \mathrm{CN} & 55.0 \\ { }^{t} \mathrm{BuXPhosAuOCOC} \mathrm{CH}_{3} \mathrm{~F}_{2}(\mathbf{A u 1}) & 53.7 \\ { }^{t} \mathrm{BuXPhos} \mathrm{AuNTf}_{2} & 55.4 \\ { }^{t} \mathrm{BuXPhosAuOTf} & 55.0 \\ \text { Crude Reaction } & 54.9(\mathrm{~b})\end{array}$<smiles>COC(=O)c1c(F)cccc1F</smiles>

$1 \mathrm{a}$

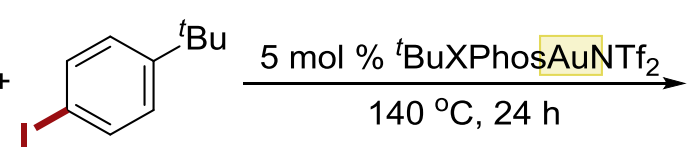

2a<smiles>CC(C)(C)c1ccc(-c2c(F)cccc2F)cc1</smiles>

$3 a$

$$
\mathrm{Ar}=2,6-\mathrm{F}_{2} \mathrm{C}_{6} \mathrm{H}_{3}
$$

Mercury Drop Test: In a glovebox, separate $4 \mathrm{~mL}$ vials were charged with solid ${ }^{t} \mathrm{BuXPhosAuNTf}_{2}(6.7-6.9 \mathrm{mg}, 7.4-7.7 \mu \mathrm{mol})$, silver 2,6-difluorobenzoate (1a, 39.1 - $43.4 \mathrm{mg}$, $0.148-0.164$. mmol), and 4-tert-butyliodobenzene (2a, $189-200 \mathrm{mg}, 0.727-0.769 \mathrm{mmol})$, and elemental mercury $(26.3-139 \mathrm{mg}, 0.131-0.693 \mathrm{mmol})$. The vials were sealed with a Teflon lined cap and removed from the glovebox. The caps were sealed with electrical tape. The reactions were heated to $140{ }^{\circ} \mathrm{C}$ and the hot plate was covered with aluminum foil to keep the reactions dark. After $24 \mathrm{~h}$, the reactions were cooled to rt. A stock solution of 1- fluoronaphthalene (71.5 mg, $0.489 \mathrm{mmol},{ }^{19} \mathrm{~F}$ NMR internal standard) was prepared in $\mathrm{CDCl}_{3}(3.9 \mathrm{~mL})$. An aliquot of the stock solution $(0.30 \mathrm{~mL})$ was added to the reactions and the resulting mixture was analyzed by proton coupled ${ }^{19} \mathrm{~F}$ NMR $(471 \mathrm{MHz})$.

\section{Table S9 Mercury Drop Test}

$\begin{array}{cccc}\text { Entry } & \text { Hg equiv. } & \text { Yield 3a }(\%)^{\mathrm{a}} & \text { Yield } \mathbf{4}(\%)^{\mathrm{a}} \\ 1 & \text { none } & 93 & 7 \\ 2 & 0.9 & 29 & 13 \\ 3 & 1.4 & 9 & \text { trace } \\ 4 & 2.3 & \text { trace } & 22 \\ 5 & 4.5 & \text { n.d. } & 4\end{array}$

${ }^{\text {a }}$ Yields based on ${ }^{19} \mathrm{~F}$ NMR analysis using 1-fluoronaphthalene as an internal standard, yields reflect a single trial., n.d. $=$ not detected 
<smiles>F[Te][GaH]c1c(F)cccc1F</smiles>

Ag1

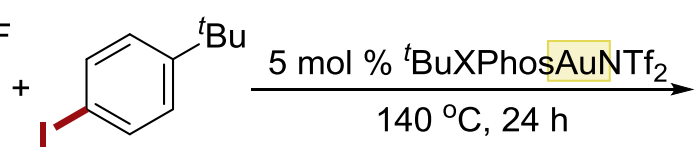

2a

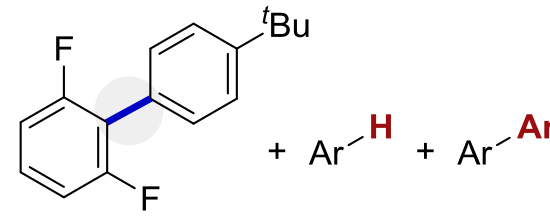

$3 a$
45

$\mathrm{Ar}=2,6-\mathrm{F}_{2} \mathrm{C}_{6} \mathrm{H}_{3}$

Stochiometric Silver Aryl: In a glovebox, separate $4 \mathrm{~mL}$ vials were charged with solid ${ }^{t}$BuXPhosAuNTf$_{2}(4.6 \mathrm{mg}, 5.1 \mu \mathrm{mol}$, ca. $5 \mathrm{~mol} \%$ ). Each $4 \mathrm{~mL}$ vial was charged with silver aryl (Ag1, 29.5 - $32.4 \mathrm{mg}, 0.115$ - 0.126. mmol), and 4-tert-butyliodobenzene (2a, 255 - $261 \mathrm{mg}$, $0.980-1.00 \mathrm{mmol}$ ). The vials were sealed with a Teflon lined cap and removed from the glovebox. The caps were sealed with electrical tape. The reactions were heated to $100{ }^{\circ} \mathrm{C}$ or $140{ }^{\circ} \mathrm{C}$ and the hot plate was covered with aluminum foil to keep the reactions dark. After $24 \mathrm{~h}$, the reactions were cooled to rt. A stock solution of 1-fluoronaphthalene (33.9 mg, $0.232 \mathrm{mmol},{ }^{19} \mathrm{~F}$ internal standard) was prepared in $\mathrm{CDCl}_{3}(2.7 \mathrm{~mL})$. Each vial was charged with an aliquot of stock solution $(0.30$ $\mathrm{mL}$ ). The resulting mixture was filtered through a short plug of silica gel and the silica gel was washed with DCM $(2 \mathrm{~mL})$. The filtrate was analyzed by GC-FID and proton coupled ${ }^{19} \mathrm{~F} \mathrm{NMR}$ (471 MHz) to determine the percent yield. See Table S10 below.<smiles>COC(=O)c1c(F)cccc1F</smiles>

$1 \mathrm{a}$

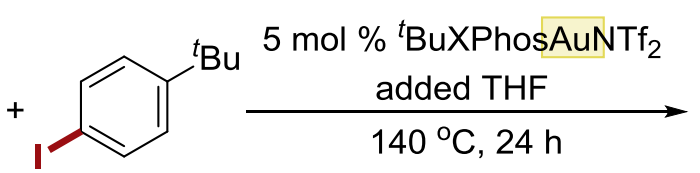

$2 a$

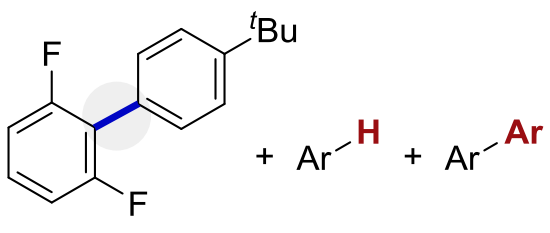

$3 a$

$$
\begin{array}{cc}
4 & 5 \\
\mathrm{Ar}= & 2,6-\mathrm{F}_{2} \mathrm{C}_{6} \mathrm{H}_{3}
\end{array}
$$

Control for effect of THF: In a glovebox, separate $4 \mathrm{~mL}$ vials were charged with solid ${ }^{t}$ BuXPhosAuNTf $_{2}(4.5$ - $4.6 \mathrm{mg}, 5.0$ - $5.1 \mu \mathrm{mol}$, ca. $5 \mathrm{~mol} \%)$, silver 2,6-difluorobenzoate (1a, $25.3-27.0 \mathrm{mg}, 95.5$ - 102. $\mu \mathrm{mol})$, and 4-tert-butyliodobenzene (2a, 257 - $264 \mathrm{mg}, 0.990-1.01$ $\mathrm{mmol})$, and select vials were charged with THF $(9.0 \mu \mathrm{L}, 0.11 \mathrm{mmol})$. The vials were sealed with a Teflon lined cap and removed from the glovebox. The caps were sealed with electrical tape. The reactions were heated to $140{ }^{\circ} \mathrm{C}$ and the hot plate was covered with aluminum foil to keep the reactions dark. After $24 \mathrm{~h}$, the reactions were cooled to rt. A stock solution of 1-fluoronaphthalene (71.5 mg, $0.489 \mathrm{mmol},{ }^{19} \mathrm{~F}$ internal standard) was prepared in $\mathrm{CDCl}_{3}(3.9 \mathrm{~mL}$ ). Each vial was charged with an aliquot of stock solution $(0.30 \mathrm{~mL})$. The resulting mixture was filtered through a short plug of silica gel and the silica gel was washed with DCM $(2 \mathrm{~mL})$. The filtrate was analyzed by GC-FID and proton coupled ${ }^{19} \mathrm{~F}$ NMR (471 MHz) to determine the percent yield.

\begin{tabular}{|c|c|c|c|c|c|c|}
\hline Entry & $\begin{array}{l}\text { Starting } \\
\text { Material }\end{array}$ & Additive, mol \% & Temp $\left({ }^{\circ} \mathrm{C}\right)$ & Yield 3a $(\%)^{\mathrm{a}}$ & Yield $4(\%)^{\mathrm{a}}$ & Yield $5(\%)^{a}$ \\
\hline 1 & $1 a$ & none & 140 & 92 & 7 & n.d. \\
\hline 2 & $1 \mathbf{a}$ & THF, 110 & 140 & 85 & 9 & n.d. \\
\hline 3 & Ag1 & none & 140 & 67 & 2 & 25 \\
\hline 4 & Ag1 & none & 100 & 25 & 5 & 14 \\
\hline
\end{tabular}

\section{Table S10 Comparison of Silver Aryl Ag1 to Silver Carboxylate 1a}




\section{X-Ray Details- Au2}

CCDC: 1980529

Chemical Formula: $\mathrm{C}_{35} \mathrm{H}_{48} \mathrm{AuF}_{2} \mathrm{P}$

Formula Weight: 734.67

Crystal System: triclinic

Space Group: P -1

a (Å): 9.4563(4)

b ( $\AA): 10.1865(5)$

c $(\AA): 17.3631(8)$

$\alpha\left({ }^{\circ}\right): 98.128(2)$

$\beta\left(^{\circ}\right): 93.544(2)$

$\gamma\left({ }^{\circ}\right): 102.231(2)$

$\mathrm{V}\left(\AA^{3}\right): 1610.85(13)$

$\mathrm{Z}: 2$

$D_{\text {Calc }}\left(\mathrm{g} / \mathrm{cm}_{3}\right): 1.515$

Temperature (K) 125(2)

Reflns number total: 9792

$\theta_{\min }: 2.61$

$\theta_{\max }: 30.52$

Data completeness: 0.993

R(reflections: 0.0245( 8864)

$w R 2$ (reflections) $=0.0567$ ( 9792)

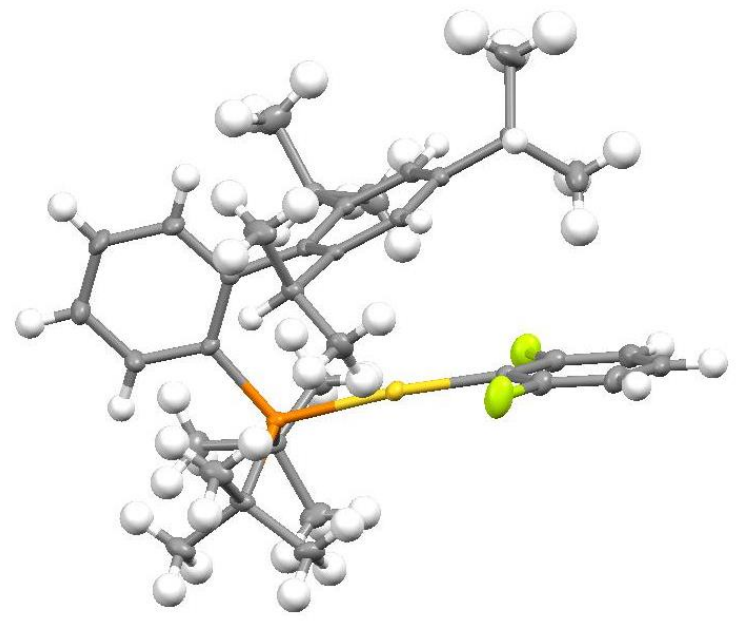




\section{X-Ray Details- Ag1}

CCDC: 2006077

Chemical Formula: $\mathrm{C}_{32} \mathrm{H}_{28} \mathrm{Ag}_{4} \mathrm{~F}_{8} \mathrm{O}_{2}$

Formula Weight: 1028.02

Crystal System: Monoclinic

Space Group: $\mathrm{P} 21 / \mathrm{n}$

a $(\AA): 10.6143(7)$

b $(\AA): 13.1043(7)$

c $(\AA): 11.8990(7)$

$\alpha\left(^{\circ}\right): 90$

$\beta\left(^{\circ}\right): 106.923(2)$

$\gamma\left({ }^{\circ}\right): 90$

$\mathrm{V}\left(\AA^{3}\right): 1583.40(16)$

$\mathrm{Z}: 2$

$D_{\text {Calc }}\left(\mathrm{g} / \mathrm{cm}_{3}\right): 2.156$

Temperature (K) 125(2)

Reflns number total: 4834

$\theta_{\text {min }}: 2.27$

$\theta_{\max }: 30.54$

Data completeness: 0.999

R(reflections): 0.0175( 4611)

$\mathrm{wR} 2($ reflections $)=0.0308(4834)$

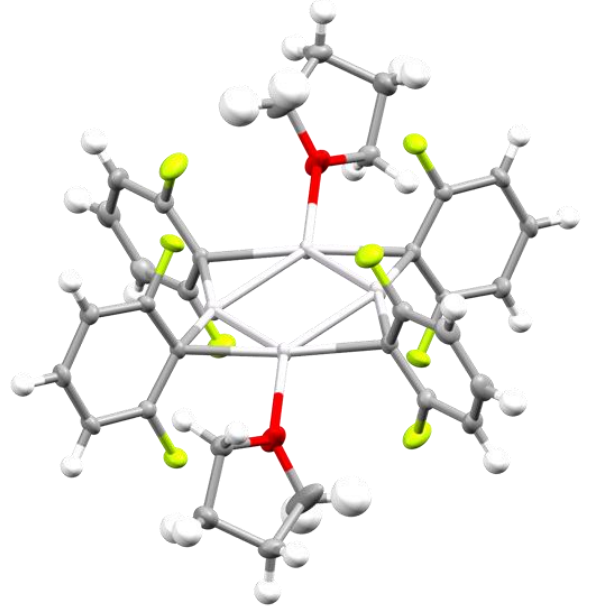




\section{Computational Details}

\section{General Comments}

Calculations were performed with Gaussian $16 .{ }^{14}$ An ultrafine integration grid and the keyword 5d were used for all calculations. Unless otherwise specified, geometry optimizations of stationary points were carried out in the gas phase at $298.15 \mathrm{~K}$ with the MN15L ${ }^{15}$ functional with BS1 (BS1 = the LANL2DZ ${ }^{16}$ pseudopotential for Au, Ag, Sb, and I; the 6-31+G(d) basis set for N and F; and the 6-31G(d) basis set for all other atoms). For the decarboxylation stationary points, $6-31+G(d)$ was also used for oxygen. Frequency analyses were carried out at the same level to evaluate the zero-point vibrational energy and thermal corrections at $298 \mathrm{~K}$. Gibbs free energy values are reported after applying Cramer and Truhlar's anharmonic correction to frequencies that are less than $100 \mathrm{~cm}^{-1} .{ }^{17}$ The nature of the stationary points was determined in each case according to the appropriate number of negative eigenvalues of the Hessian matrix. Forward and reverse intrinsic reaction coordinate (IRC) calculations were carried out on the optimized transition structures to ensure that the TSs indeed connect the appropriate reactants and products. ${ }^{18-20}$ Multiple conformations were considered for all structures, and the lowest energy conformations are reported. Single point energy calculations were performed on the gas-phase optimized geometries using the MN15L functional with BS2 (BS2 = the SDD ${ }^{21,22}$ pseudopotential for $\mathrm{Au}$, $\mathrm{Ag}, \mathrm{Sb}$, and I, and the 6-311++G(2d,p) basis set for all other atoms). Bulk solvent effects in $o^{-}$ dichlorobenzene were considered implicitly in the single point energy calculations through the CPCM continuum solvation model. ${ }^{23}$ Images of optimized structures were generated with CYLview. ${ }^{24}$

\section{Graphical Guide to Numbered Compounds: Oxidative Addition}

\section{Starting $A u(I)$ Complexes}

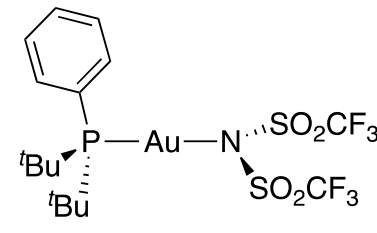

$6 a$

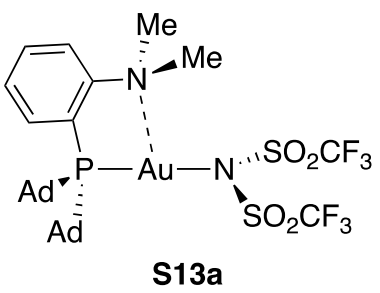

S13a

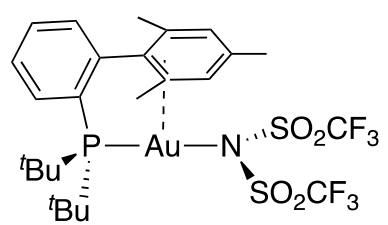

$7 a$ (and S7a-dcb ${ }^{a}$ )

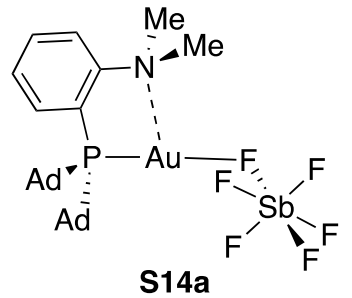

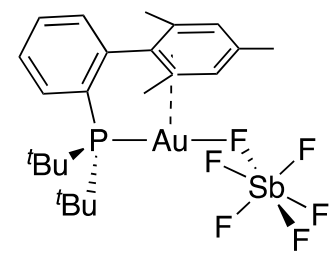

$8 \mathbf{a}$

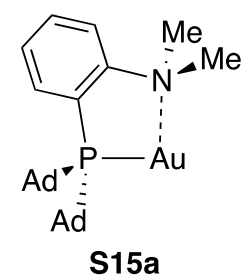

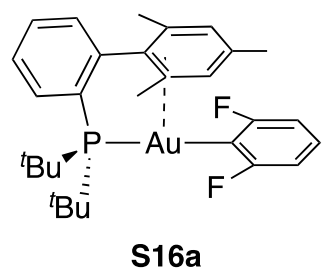

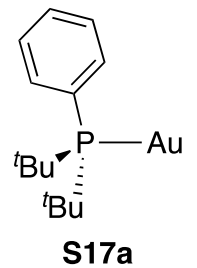


$\underline{A u(I)-I-P h}$ Sigma Complexes
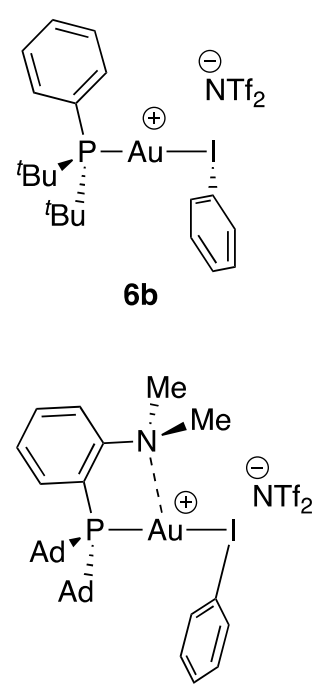

S13b

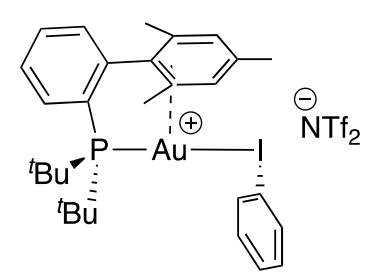

$7 b$

(and S7b-dcb ${ }^{a}$ )

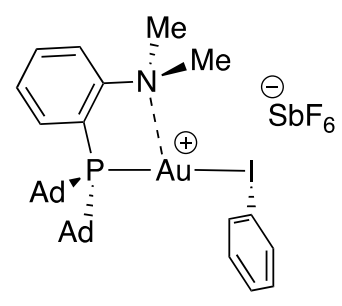

S14b

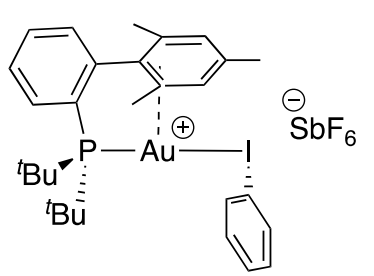

$8 b$

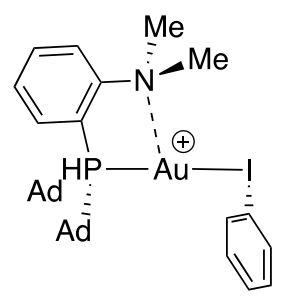

S15b

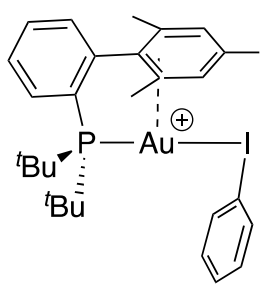

$9 b$

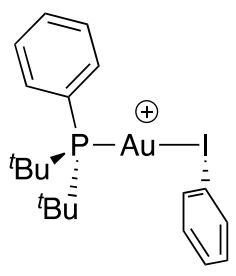

S17b

Transition Structures

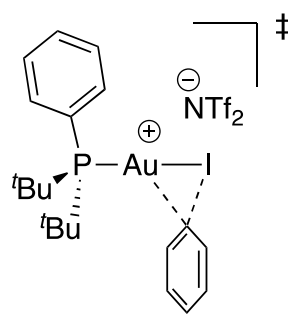

6c-TS

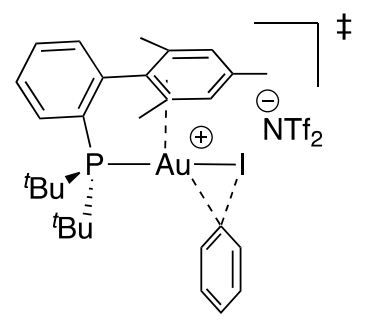

7c-TS (and S7c-TS-dcb ${ }^{\text {}}$ )

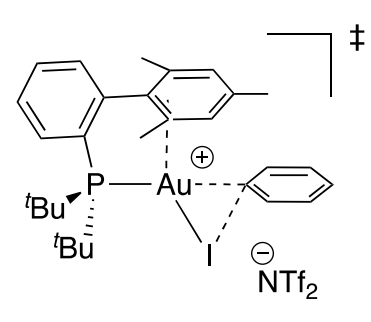

S7c-TS-iso

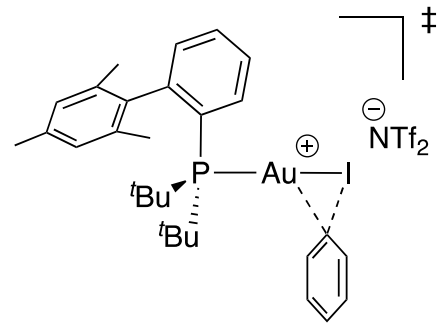

S7c-TS-rot

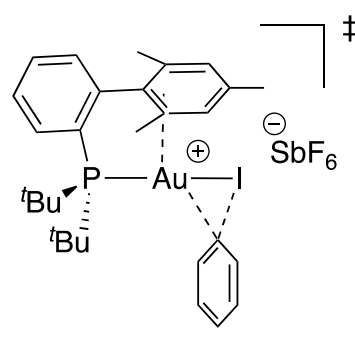

8c-TS

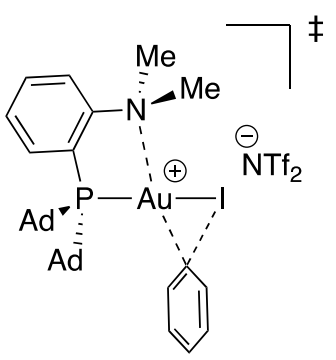

S13c-TS

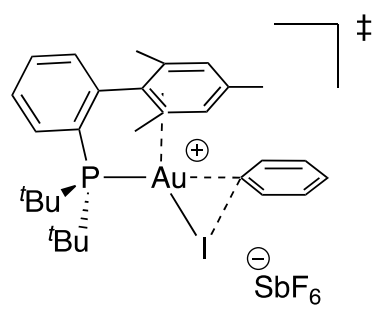

S8c-TS-iso

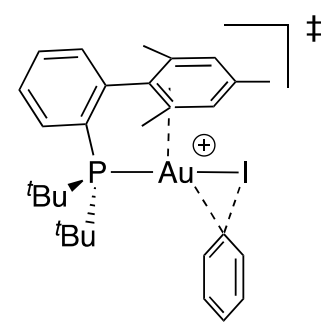

9c-TS

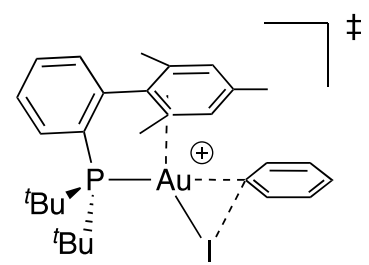

S9c-TS-iso

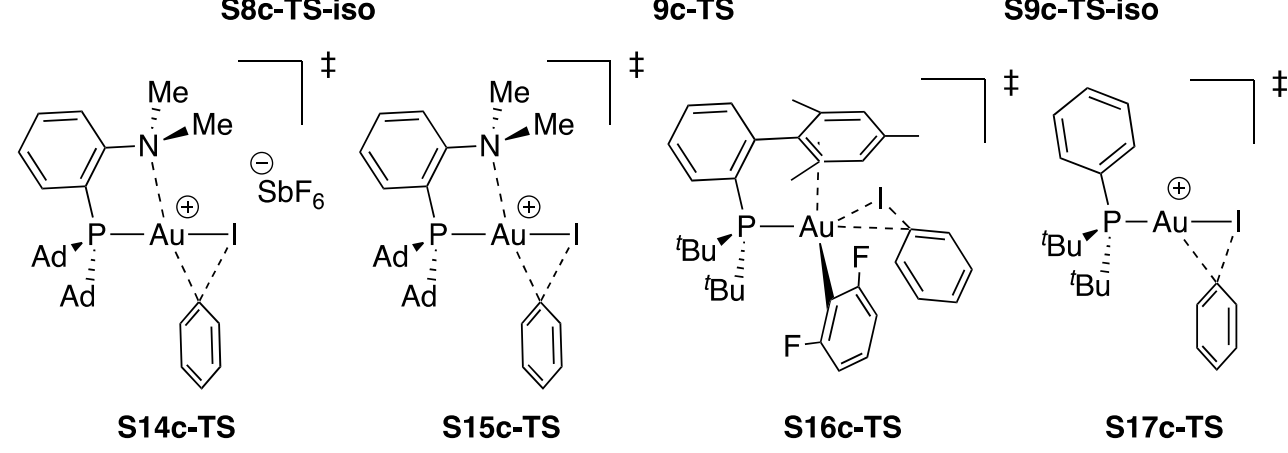




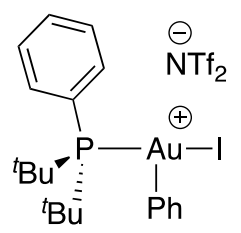

$6 d$

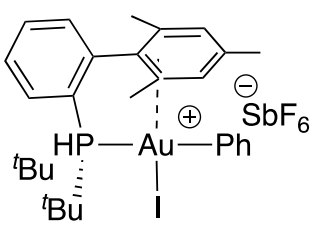

S8d-iso

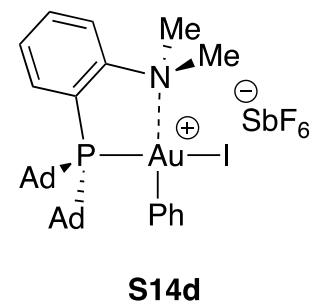

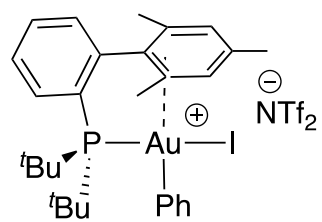

7d (and S7d-dcb ${ }^{a}$ )

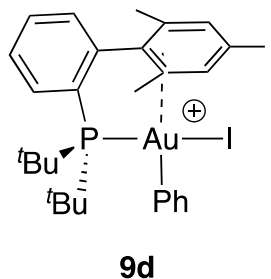

9d

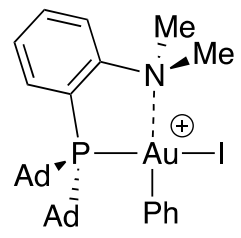

S15d

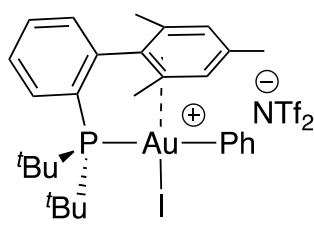

S7d-iso

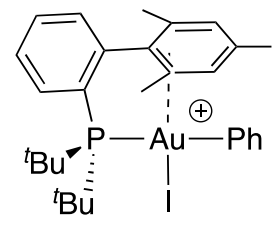

S9d-iso

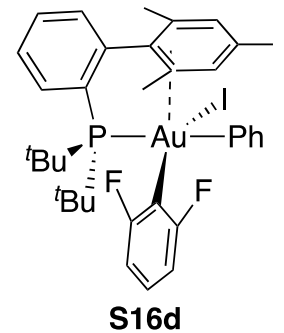

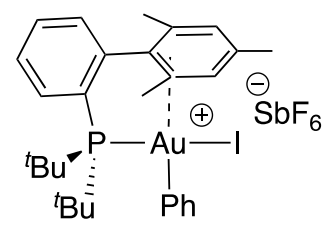

8d
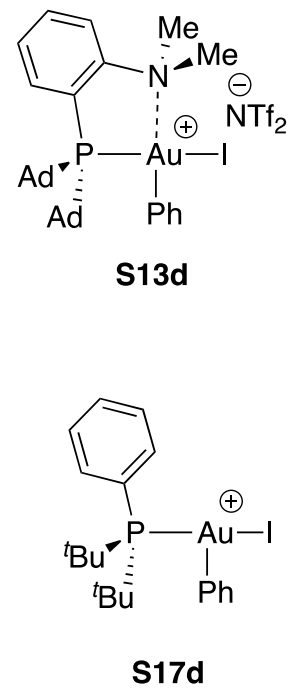

${ }^{a}$ For the structure labels ending in "dcb", geometry optimizations were conducted in solvent using CPCM $(o$ dichlorobenzene). 


\section{Oxidative Addition Free Energy Diagrams}

\section{$\underline{\text { Oxidative Addition of } \mathrm{PhI} \text { at }\left(\mathrm{P}\left({ }^{t} \mathrm{Bu}\right)_{2} \mathrm{Ph}\right) \mathrm{Au}-\mathrm{NTf}_{2}}$}

The barrier to oxidative addition at $\left(\mathrm{P}\left({ }^{t} \mathrm{Bu}\right)_{2} \mathrm{Ph}\right) \mathrm{Au}_{-\mathrm{NTf}}(\mathbf{6 a})$ is similar to at ModPhosAu-NTf 2 (7a), suggesting that coordination of the pendant aryl of ModPhos to $\mathrm{Au}$ is not important for oxidative addition.
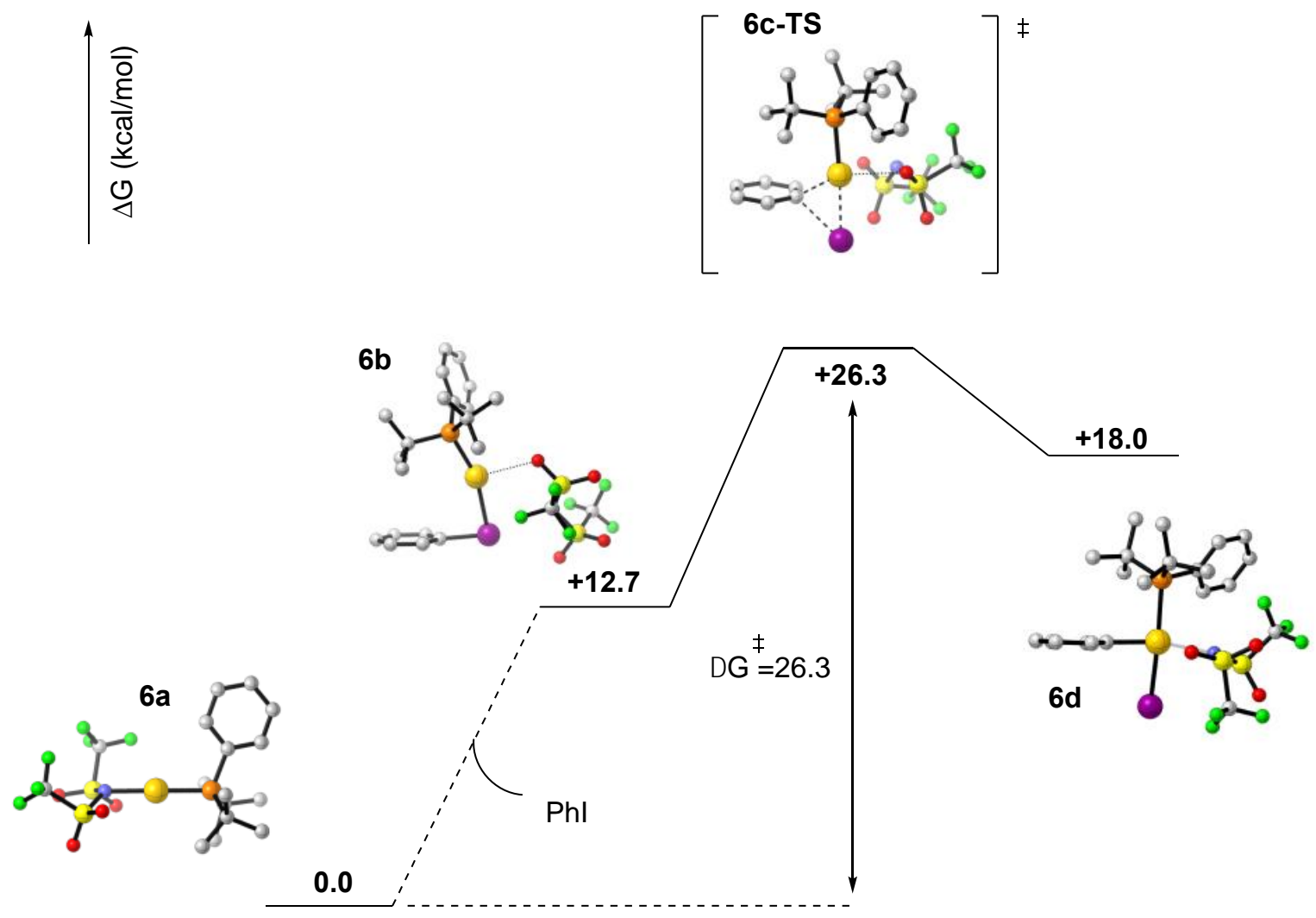


\section{$\underline{\text { Oxidative Addition of } \mathrm{PhI} \text { at ModPhosAu-NTf } 2}$}

The black line illustrates the minimum energy pathway through 7c-TS. The red line illustrates oxidative addition through the other possible configuration at gold (S7c-TS-iso). Although this pathway leads to a slightly more stable oxidative addition adduct (S7d-iso), the barrier to oxidative addition is higher through this isomer. The blue line illustrates oxidative addition through a different conformation of 7c-TS, in which the pendant aryl of ModPhos is rotated away from gold (S7c-TS-rot). This pathway is prohibitively high-energy when the barrier is measured from the ground state (7a) in which the pendant aryl coordinates to $\mathrm{Au}(\mathrm{I})$. However, the results with $\mathrm{P}\left({ }^{t} \mathrm{Bu}\right)_{2} \mathrm{Ph}$ (vide supra) suggest that the pendant aryl likely does not stabilize the transition state any more than it stabilizes the ground state.

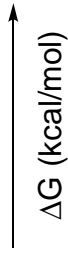

S7c-TS-rot

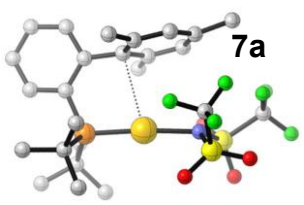

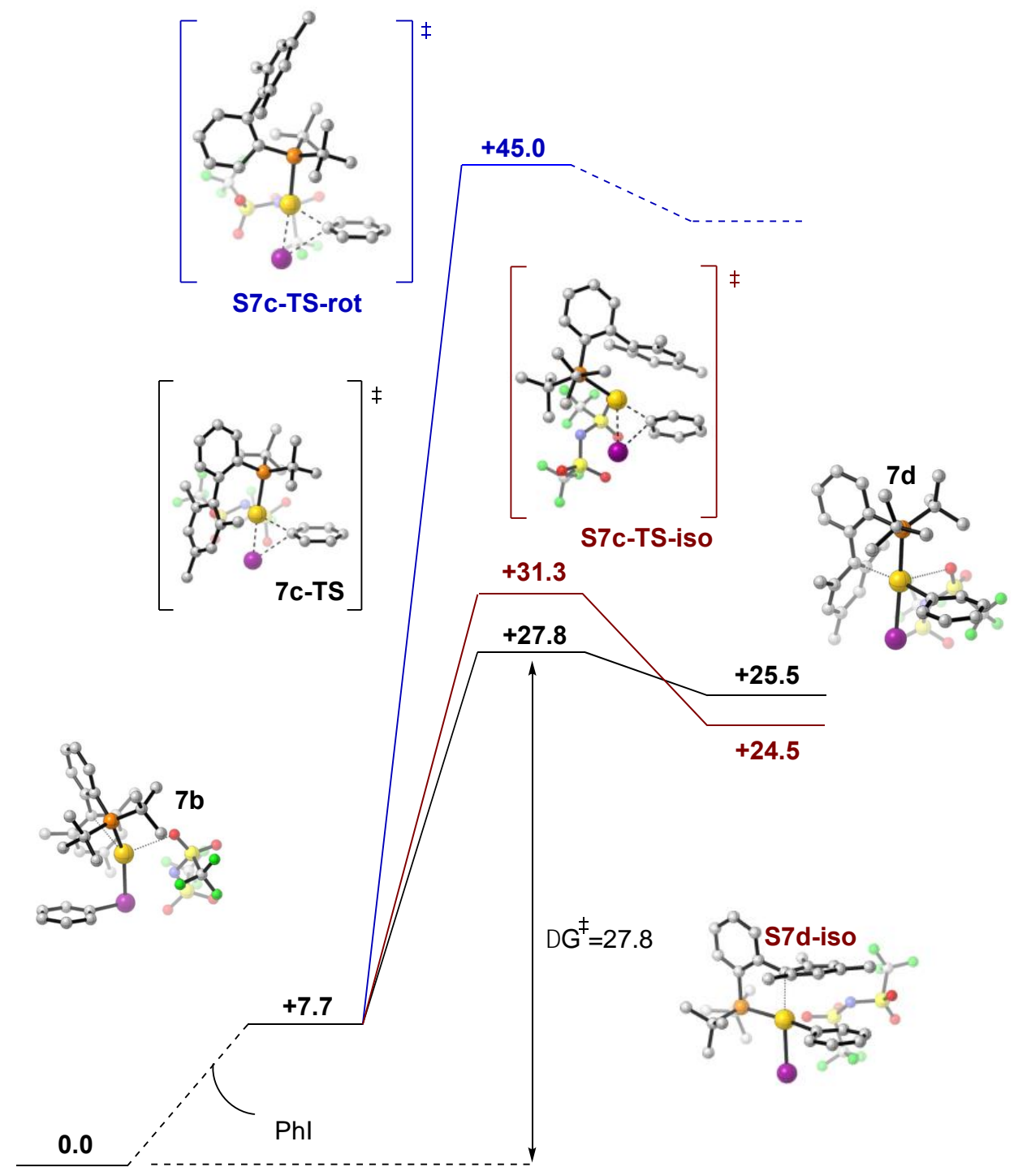

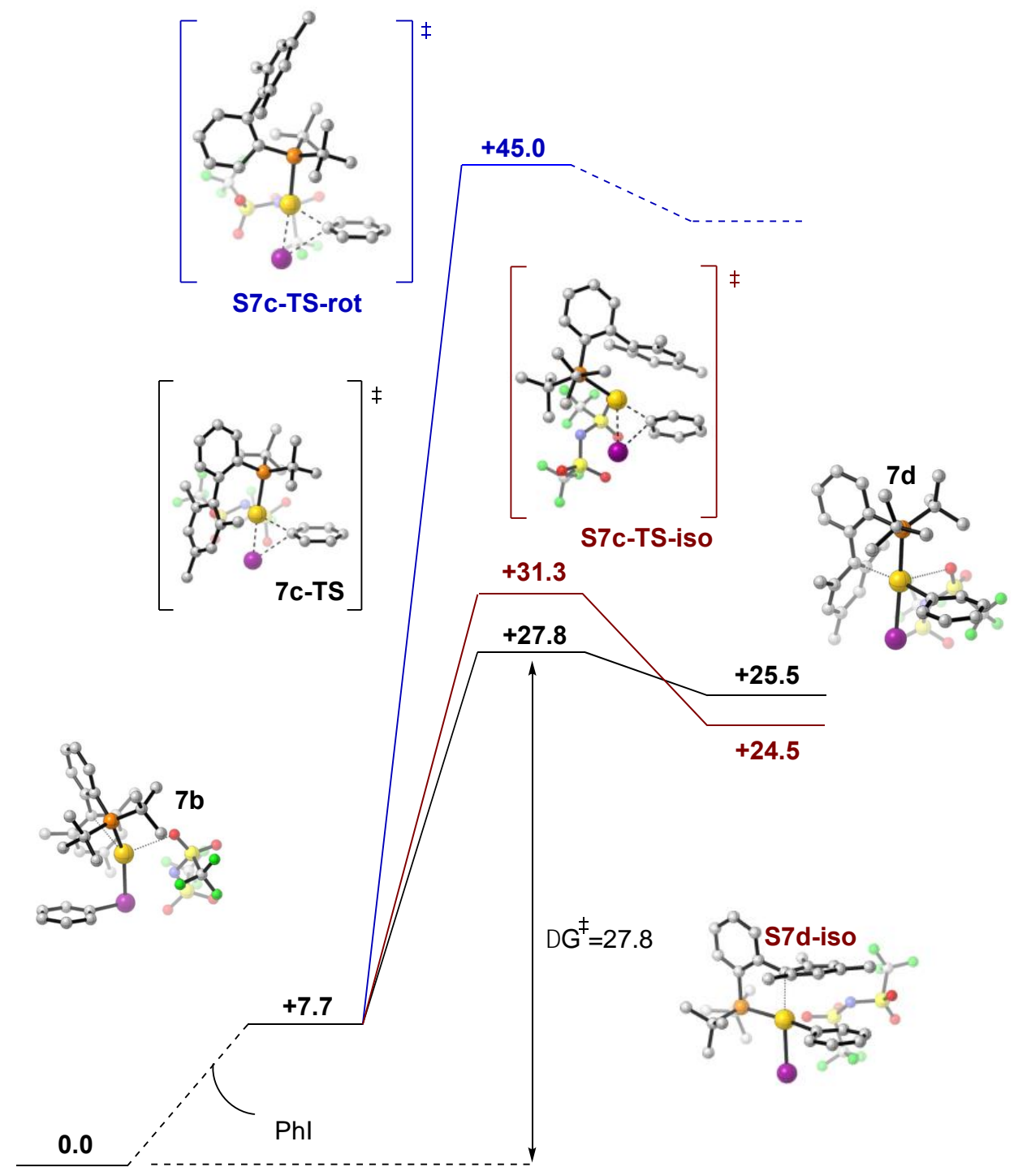


Relevant bond distances $(\AA)$ :
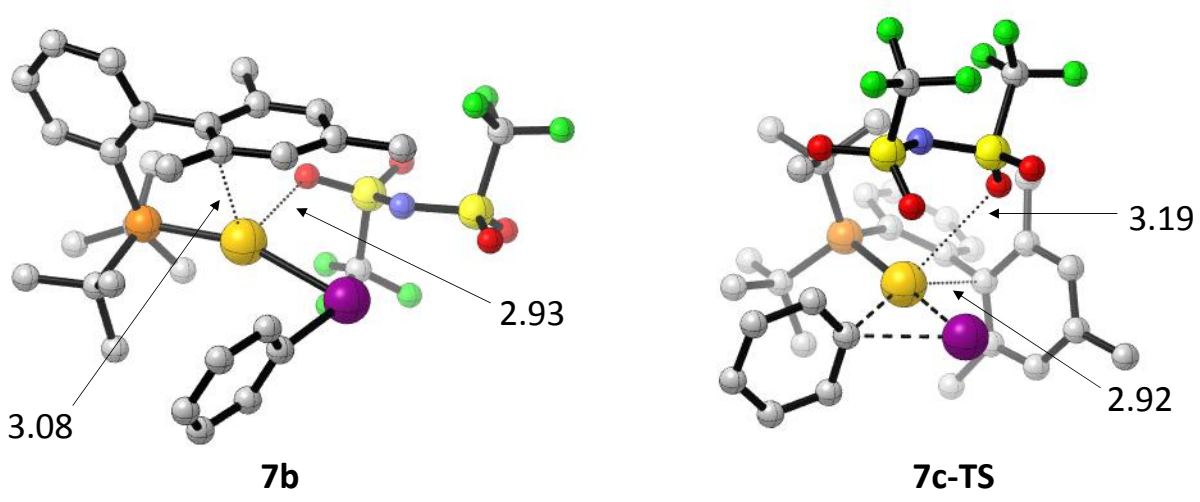


\section{$\underline{\text { Oxidative Addition of PhI at ModPhosAu-NTf }} 2$ (Geometries Optimized in Solvent)}

For the structures below, geometry optimizations were conducted in solvent [CPCM $(o-$ dichlorobenzene)] instead of in the gas phase. Although there are some differences in geometries (in particular, the $\mathrm{Au} \cdots \mathrm{NTf}_{2}$ distances), the energetics are very similar regardless of whether structures were optimized in solvent or gas phase. The biggest energy difference is seen for the $\mathrm{Au}(\mathrm{III})$-aryl 7d, which is stabilized when optimized in solvent $(\Delta \mathrm{G}=21.8 \mathrm{kcal} / \mathrm{mol}$ for $\mathbf{7 d - d c b}$ compared to $25.5 \mathrm{kcal} / \mathrm{mol}$ for $\mathbf{7 d}$ ).

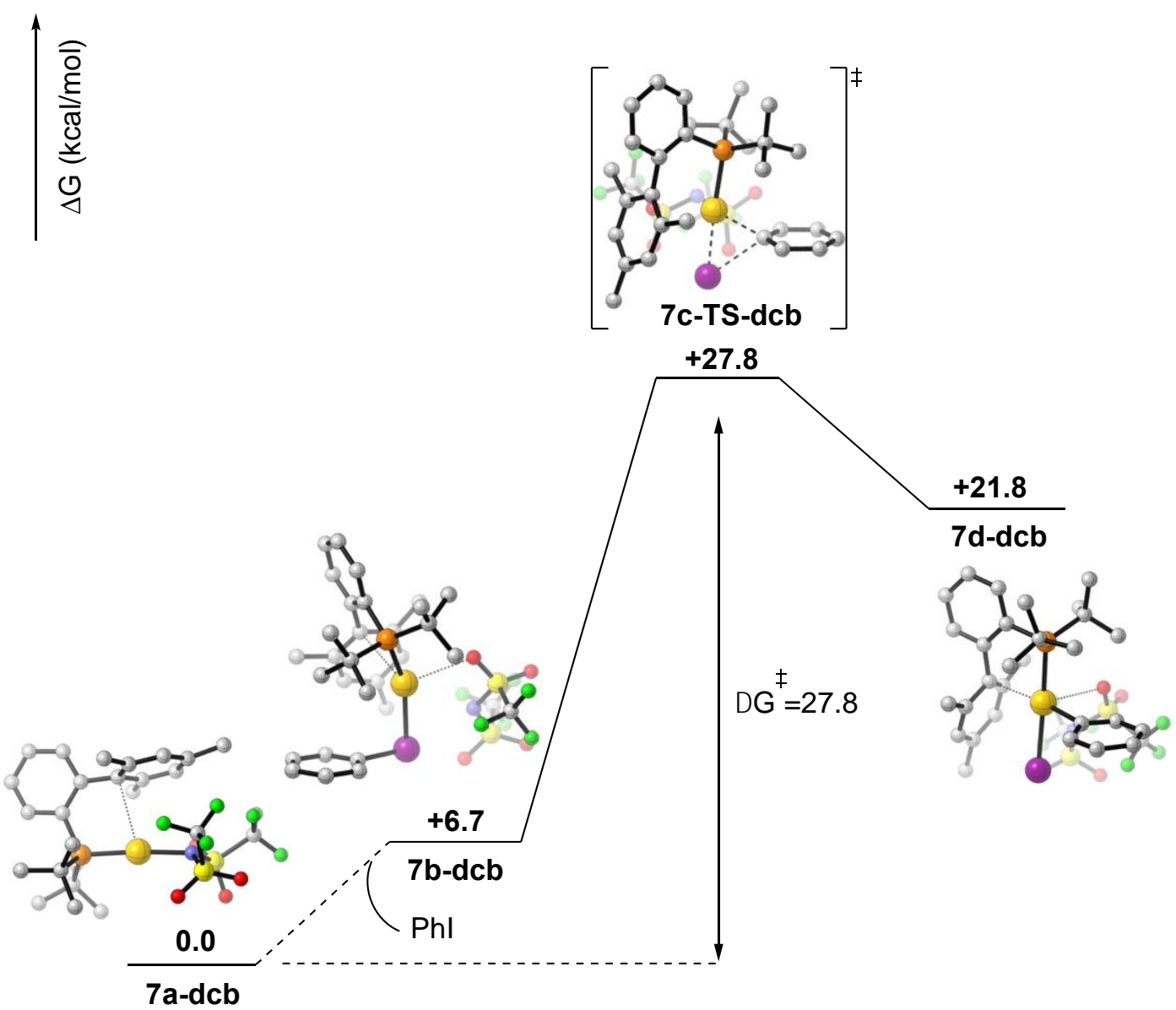

Relevant bond distances $(\AA)$ :

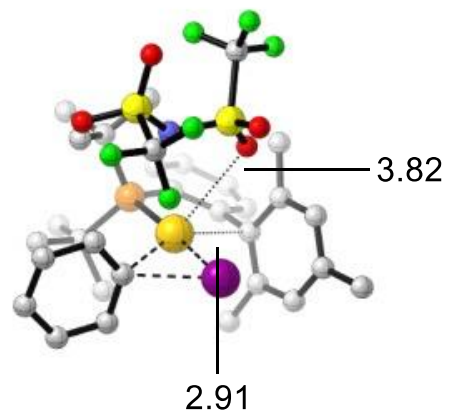




\section{Oxidative Addition of $\mathrm{PhI}$ at ModPhosAu-SbF 6}

The black line illustrates the minimum energy pathway through 8c-TS. The red line illustrates a higher-energy pathway for oxidative addition through the other possible configuration at gold (S8c-TS-iso).
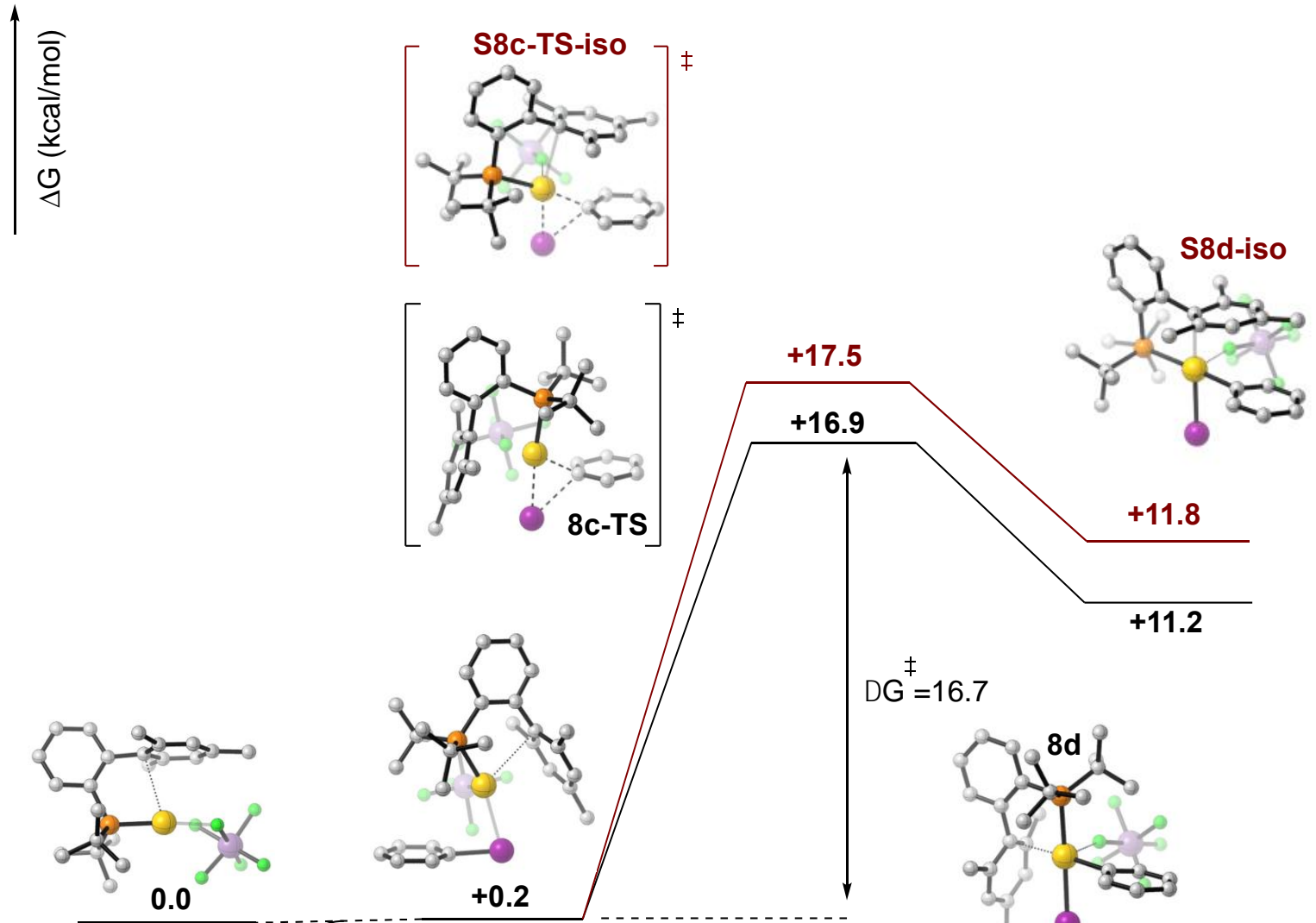

$8 a$

$8 \mathbf{b}$

Phl

Relevant bond distances $(\AA)$ :
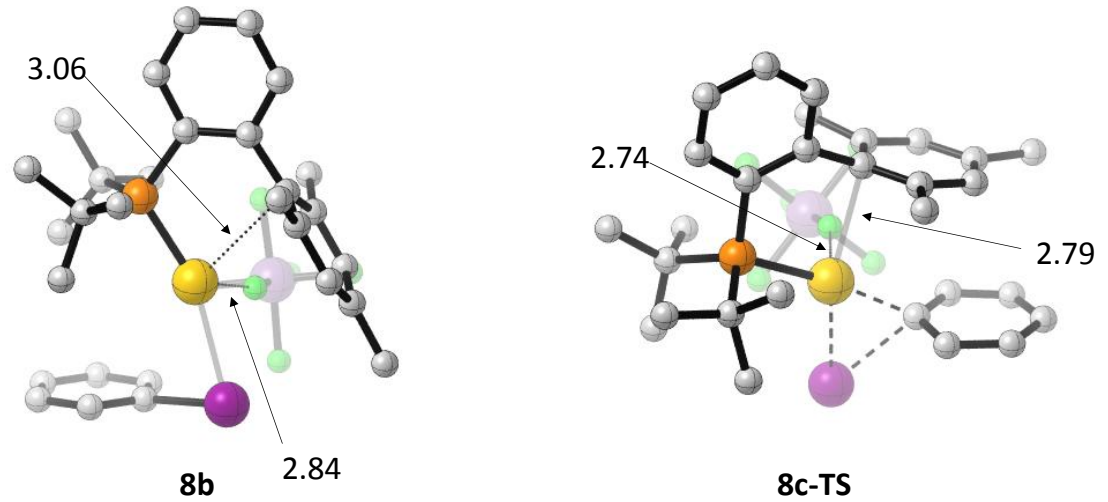


\section{$\underline{\text { Oxidative Addition of PhI at }[\mathrm{ModPhos} \mathrm{Au}]^{+} \text {(Counterion Excluded from Calculations) }}$}

The black line illustrates the minimum energy pathway through 9c-TS. The red line illustrates a higher-energy pathway for oxidative addition through the other possible configuration at gold (S9c-TS-iso). Notably, the barrier to oxidative addition is much smaller when the counterion is excluded from calculations.

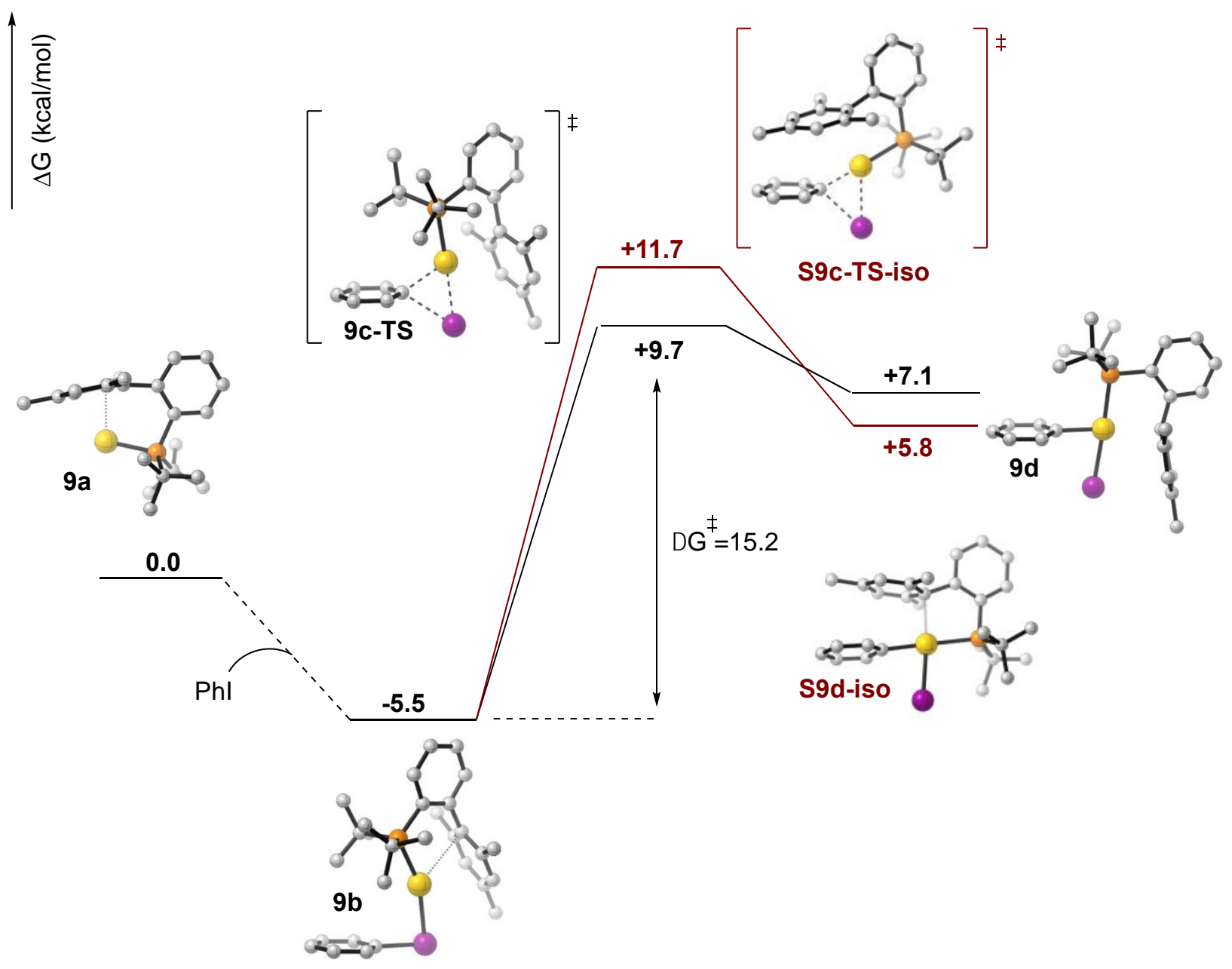




\section{Oxidative Addition of PhI at MeDalPhosAu-NTf 2}

Calculations with MeDalPhos were performed for comparison to calculations previously reported by Amgoune and Bourissou ${ }^{25}$ with this ligand. The energy of S13c-TS $\left(\Delta \mathrm{G}^{*}=15.6 \mathrm{kcal} / \mathrm{mol}\right)$ is comparable to that of the same structure calculated by Amgoune and Bourissou (previously reported $\left.\Delta \mathrm{G}^{*}=13.8 \mathrm{kcal} / \mathrm{mol}\right)$.

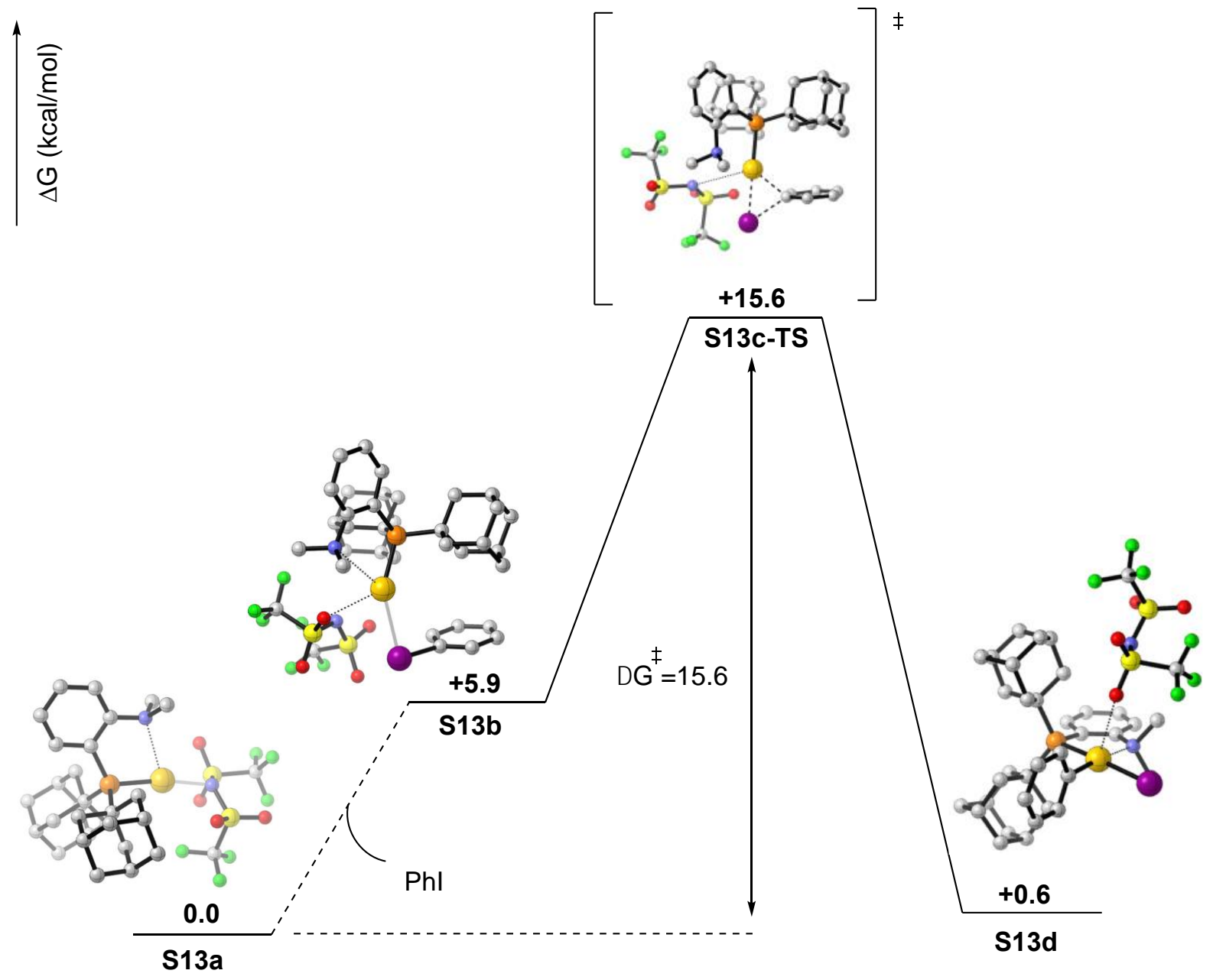

Relevant bond distances $(\AA)$ :
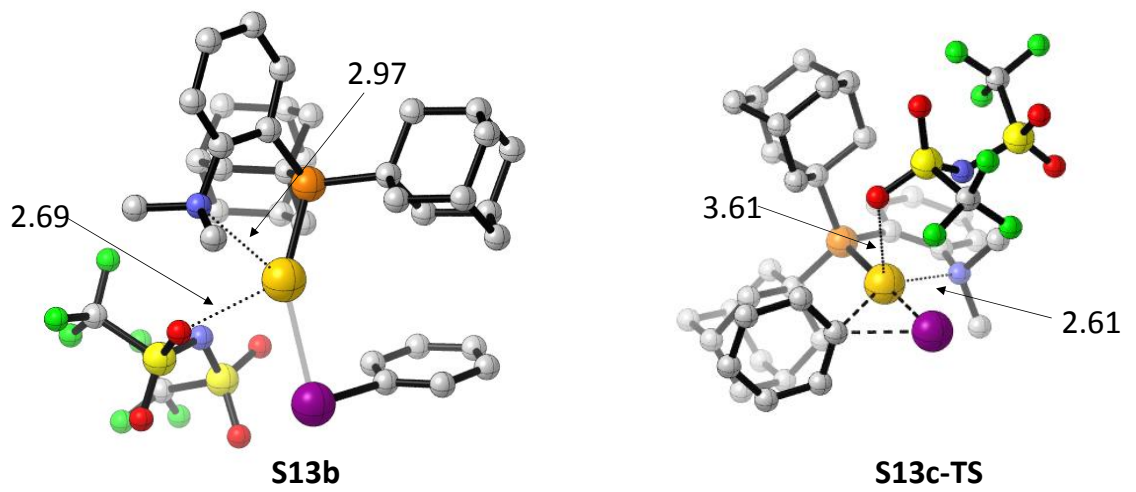


\section{$\underline{\text { Oxidative Addition of PhI at MeDalPhosAu-NTf }}$}

Calculations with MeDalPhos were performed for comparison to calculations previously reported by Amgoune and Bourissou ${ }^{25}$ with this ligand. The energy of S14c-TS $\left(\Delta \mathrm{G}^{\ddagger}=10.2 \mathrm{kcal} / \mathrm{mol}\right.$ measured from S14b) is comparable to that of the same structure calculated by Amgoune and Bourissou (previously reported $\Delta \mathrm{G}^{\ddagger}=11.2 \mathrm{kcal} / \mathrm{mol}$ ).

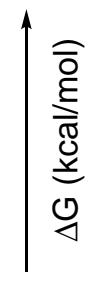

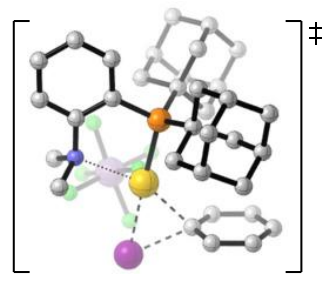

$+7.2$

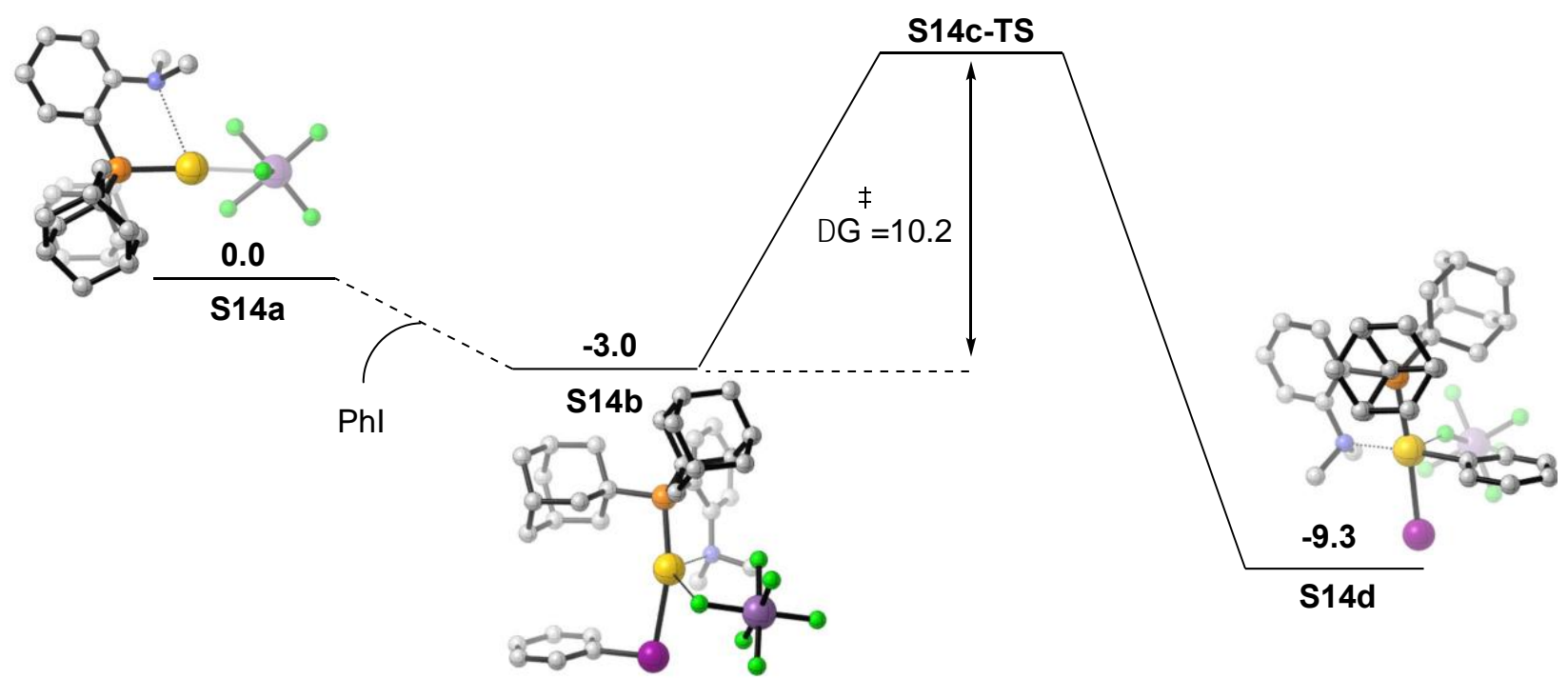

Relevant bond distances $(\AA)$ :
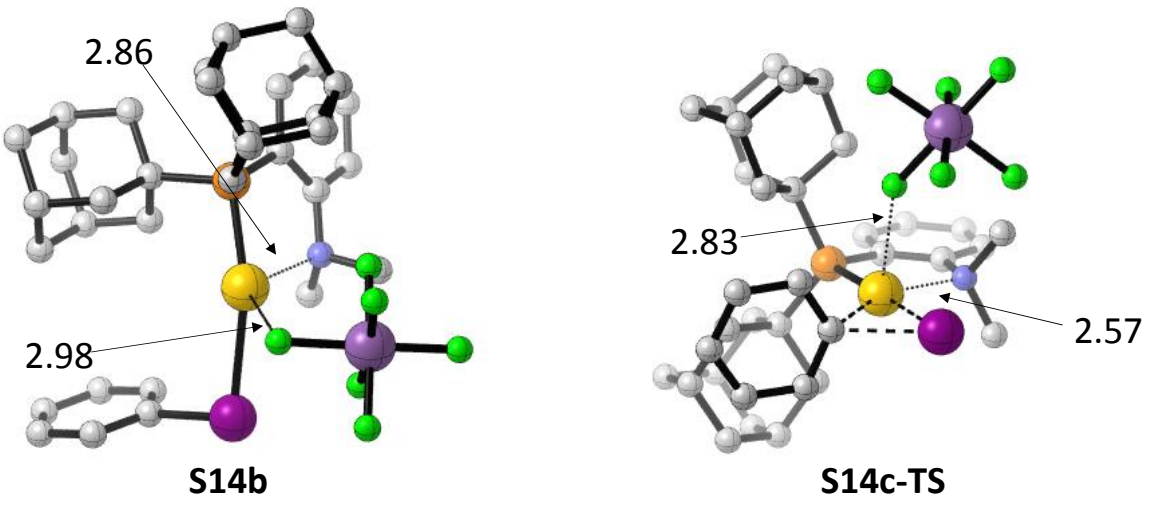


\section{$\underline{\text { Oxidative Addition of } \mathrm{PhI} \text { at }[\mathrm{MeDalPhosAu}]^{+} \text {(Counterion Excluded from Calculations) }}$}

Calculations with MeDalPhos were performed for comparison to calculations previously reported by Amgoune and Bourissou ${ }^{26}$ with this ligand. The energy of S15c-TS $\left(\Delta \mathrm{G}^{*}=9.3 \mathrm{kcal} / \mathrm{mol}\right.$ measured from S15b) is comparable to that of the same structure calculated by Amgoune and Bourissou (previously reported $\Delta \mathrm{G}^{*}=7.7 \mathrm{kcal} / \mathrm{mol}$ ).

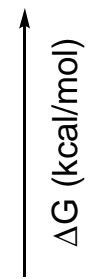
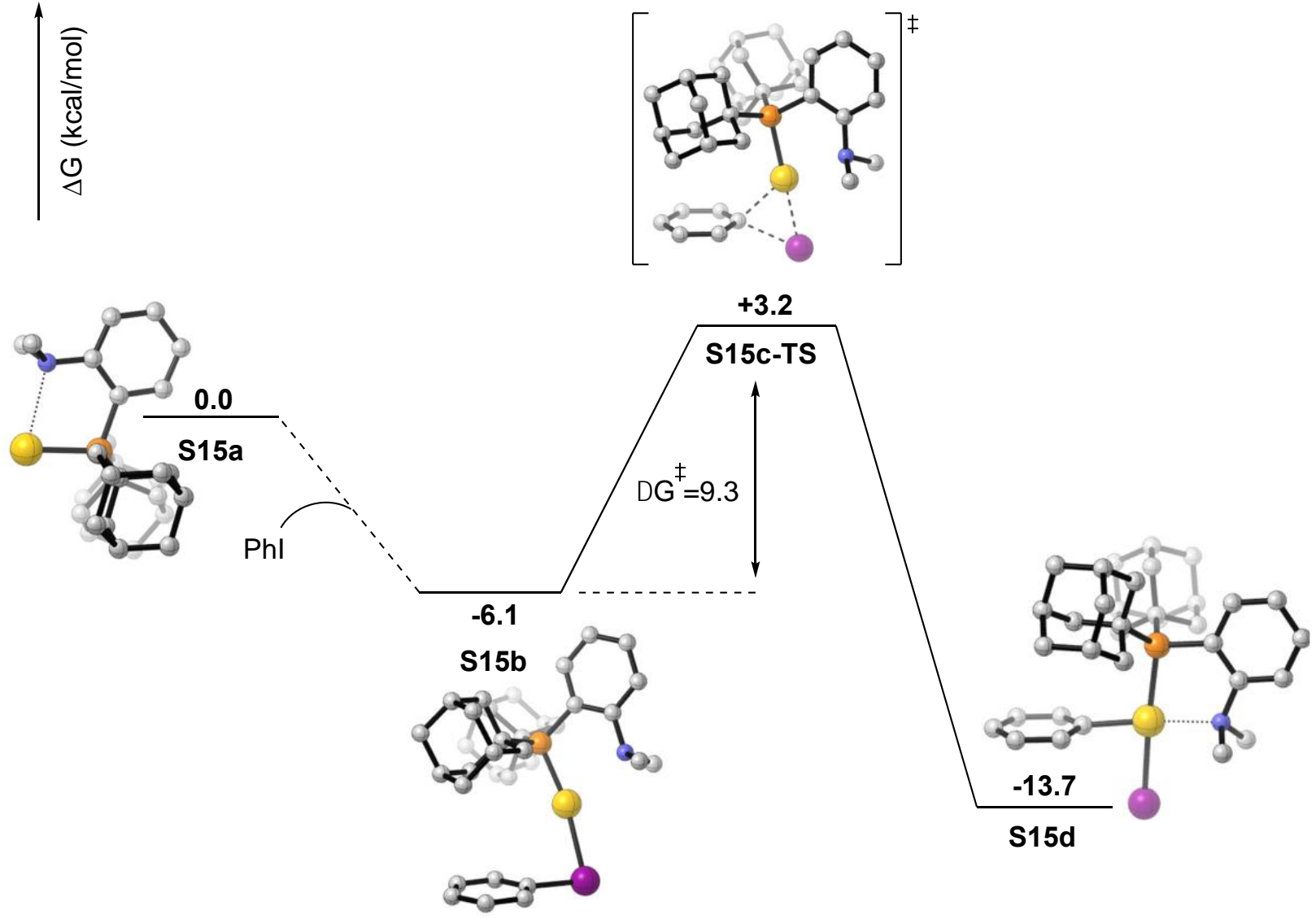


\section{$\underline{\text { Oxidative Addition of } \mathrm{PhI} \text { at ModPhosAu-Ar (Ar = 2,6-difluorophenyl) }}$}

The lowest energy transition state structure for oxidative addition at ModPhosAu-Ar places phosphorus pseudo-trans to the ipso carbon of PhI (S16c-TS). The energy of this structure is extremely high suggesting that oxidative addition at ${ }^{t} \mathrm{BuXPhos} \mathrm{Au}-\mathrm{Ar}$ is unlikely.

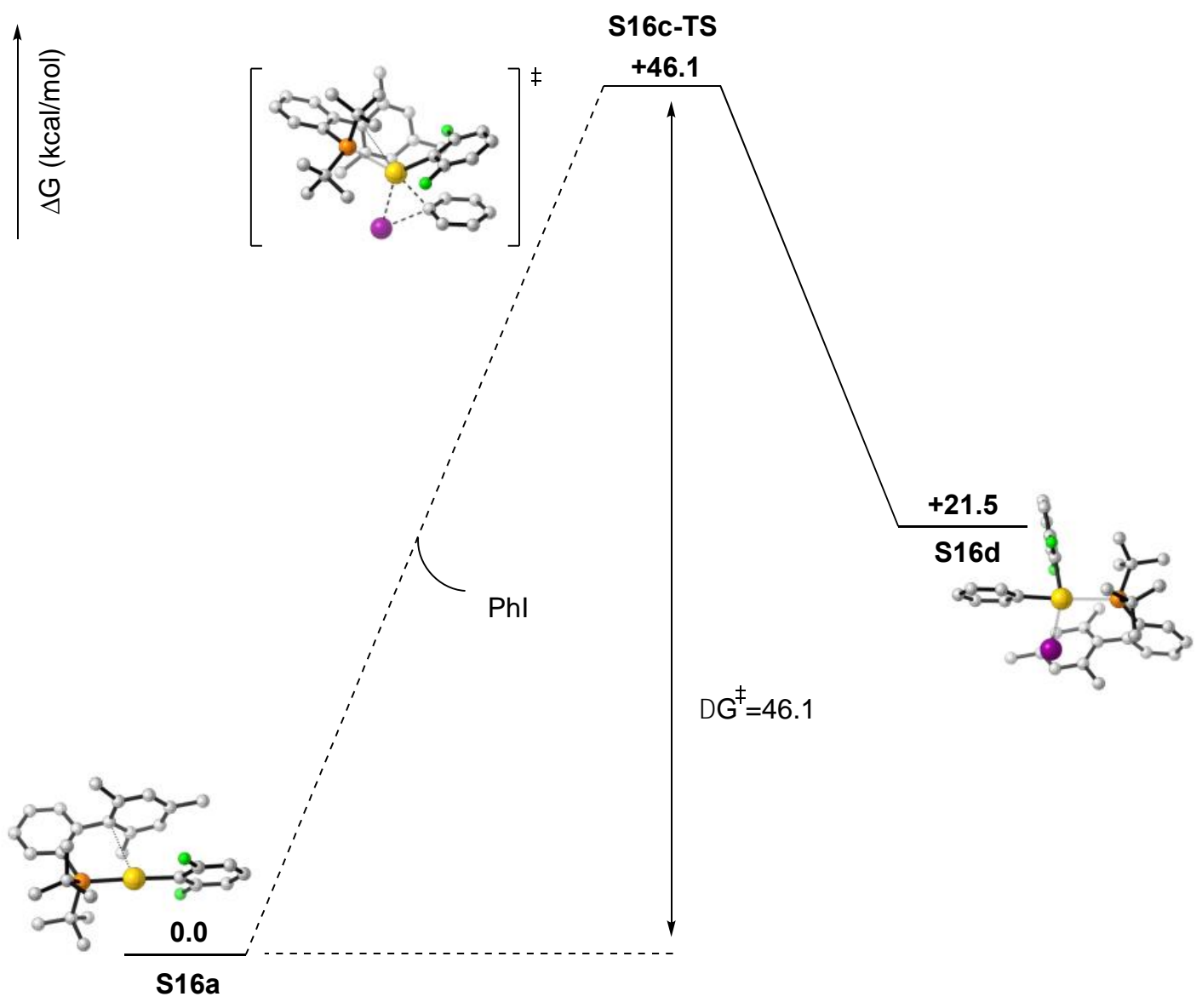




\section{$\underline{\text { Oxidative Addition of } \mathrm{PhI} \text { at }\left[\left(\mathrm{P}\left({ }^{t} \mathrm{Bu}\right)_{2} \mathrm{Ph}\right) \mathrm{Au}\right]^{+} \text {(Counterion Excluded from Calculations) }}$}

As with ModPhos and MeDalPhos, the barrier to oxidative addition using ligand $\mathrm{P}\left({ }^{t} \mathrm{Bu}\right)_{2} \mathrm{Ph}$ is considerably lower when the counterion is excluded from consideration.

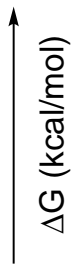
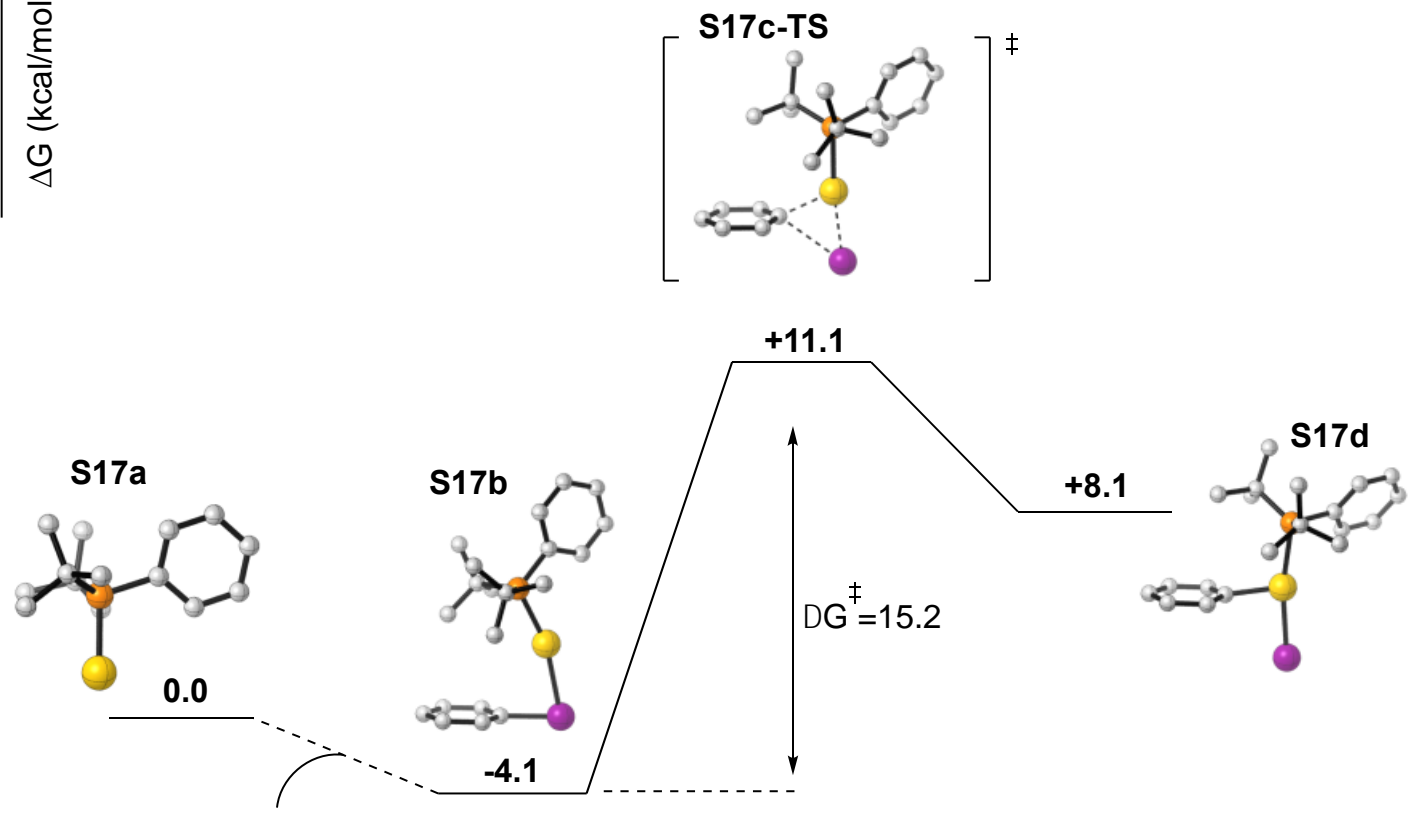

$\mathrm{Phl}$ 
Table S11. Energies, Entropies, and Lowest Frequencies of Minimum Energy Structures: Oxidative Addition ${ }^{\mathrm{a}}$

\begin{tabular}{|c|c|c|c|c|c|c|c|c|}
\hline Structure & $\mathrm{E}_{\text {elec }}$ (Hartree) & $\begin{array}{l}E_{\text {elec }}+\mathrm{ZPE} \\
\text { (Hartree) }\end{array}$ & H (Hartree) & $\mathrm{S}\left(\mathrm{cal} \mathrm{mol} \mathrm{I}^{-1} \mathrm{~K}^{-1}\right)$ & $\mathbf{G}^{b}$ (Hartree) & $\mathbf{G}_{\text {corrected }}{ }^{c}$ (Hartree) & $\begin{array}{c}\text { Lowest } \\
\text { freq. }\left(\mathrm{cm}^{-1}\right)\end{array}$ & $\begin{array}{c}\text { \# of imaginary } \\
\text { freq. }\end{array}$ \\
\hline Phl & -242.875820 & -242.7856808 & -242.7788288 & 81.3 & -242.8174558 & -242.8174558 & 155.1 & 0 \\
\hline Phl-dcb & -242.875820 & -242.7856799 & -242.7788279 & 81.3 & -242.8174549 & -242.8174549 & 155.1 & 0 \\
\hline $6 a$ & -2850.339956 & -2849.943316 & -2849.907748 & 218.4 & -2850.011508 & -2850.002948 & 11.5 & 0 \\
\hline $6 b$ & -3093.220280 & -3092.732886 & -3092.689200 & 261.4 & -3092.813401 & -3092.800149 & 8.7 & 0 \\
\hline $6 c-T S$ & -3093.197786 & -3092.71132 & -3092.668311 & 250.8 & -3092.787494 & -3092.778449 & -173.4 & 1 \\
\hline $6 d$ & -3093.215406 & -3092.725256 & -3092.683019 & 241.9 & -3092.797948 & -3092.791768 & 15.6 & 0 \\
\hline $7 a$ & -3199.142870 & -3198.580622 & -3198.536487 & 247.6 & -3198.654122 & -3198.647259 & 25.8 & 0 \\
\hline S7a-dcb & -3199.143305 & -3198.582168 & -3198.537871 & 248.5 & -3198.655931 & -3198.648972 & 30.2 & 0 \\
\hline $7 b$ & -3442.031457 & -3441.37801 & -3441.325999 & 286.3 & -3441.462035 & -3441.452432 & 22.4 & 0 \\
\hline S7b-dcb & -3442.033617 & -3441.381327 & -3441.329085 & 288.7 & -3441.466241 & -3441.455798 & 23.7 & 0 \\
\hline 7c-TS & -3441.997680 & -3441.346146 & -3441.294067 & 290.3 & -3441.432019 & -3441.420445 & -152.3 & 1 \\
\hline S7c-TS-iso & -3441.993695 & -3441.341304 & -3441.289898 & 284.8 & -3441.425236 & -3441.41479 & -84.5 & 1 \\
\hline S7c-TS-dcb & -3441.998133 & -3441.347521 & -3441.295202 & 287.6 & -3441.434304 & -3441.422083 & -182.7 & 1 \\
\hline S7c-TS-rot & -3441.969915 & -3441.318631 & -3441.266489 & 290.9 & -3441.404721 & -3441.39302 & -132.5 & 1 \\
\hline $7 d$ & -3442.004173 & -3441.350192 & -3441.298327 & 285.2 & -3441.433845 & -3441.42403 & 16.5 & 0 \\
\hline S7d-iso & -3440.753474 & -3441.351537 & -3441.299635 & 284.3 & -3441.434738 & -3441.42553 & 26.3 & 0 \\
\hline S7d-dcb & -3442.009683 & -3441.357123 & -3441.305049 & 285.2 & -3441.440577 & -3441.431632 & 21.1 & 0 \\
\hline $8 a$ & -1976.742513 & -1976.222841 & -1976.183924 & 225.5 & -1976.291062 & -1976.285105 & 25.5 & 0 \\
\hline $8 b$ & -2219.642715 & -2219.032276 & -2218.985412 & 265.6 & -2219.111588 & -2219.102224 & 25.3 & 0 \\
\hline 8c-TS & -2219.616170 & -2219.006108 & -2218.959953 & 259.8 & -2219.083384 & -2219.075624 & -151.0 & 1 \\
\hline S8c-TS-iso & -2219.615794 & -2219.00583 & -2218.959945 & 257.1 & -2219.082078 & -2219.074708 & -128.0 & 1 \\
\hline $8 d$ & -2219.625702 & -2219.014977 & -2218.968233 & 262.6 & -2219.093016 & -2219.084654 & 18.1 & 0 \\
\hline S8d-iso & -2219.625873 & -2219.014882 & -2218.968738 & 257.2 & -2219.090952 & -2219.083746 & 17.1 & 0 \\
\hline $9 a$ & -1372.254491 & -1371.750822 & -1371.721374 & 180.7 & -1371.807232 & -1371.804272 & 42.4 & 0 \\
\hline $9 b$ & -1615.164580 & -1614.569524 & -1614.532211 & 223.8 & -1614.63855 & -1614.630434 & 16.9 & 0 \\
\hline 9c-TS & -1615.140578 & -1614.545685 & -1614.509284 & 215.6 & -1614.611744 & -1614.606217 & -164.4 & 1 \\
\hline S9c-TS-iso & -1615.137979 & -1614.543207 & -1614.507002 & 215.9 & -1614.60956 & -1614.603042 & -125.3 & 1 \\
\hline $9 d$ & -1615.145071 & -1614.549326 & -1614.512204 & 222.4 & -1614.617853 & -1614.610393 & 5.3 & 0 \\
\hline S9d-iso & -1615.147822 & -1614.552104 & -1614.51552 & 216.3 & -1614.618303 & -1614.612419 & 9.6 & 0 \\
\hline S13a & -3448.495878 & -3447.804993 & -3447.761157 & 251.1 & -3447.880444 & -3447.871393 & 20.1 & 0 \\
\hline S13b & -3691.388170 & -3690.605665 & -3690.55406 & 289.1 & -3690.691401 & -3690.679438 & 15.5 & 0 \\
\hline S13c-TS & -3691.373201 & -3690.590796 & -3690.540179 & 279.5 & -3690.672965 & -3690.663986 & -182.7 & 1 \\
\hline S13d & -3691.400118 & -3690.61516 & -3690.564428 & 281.5 & -3690.698189 & -3690.687953 & 19.5 & 0 \\
\hline S14a & -2226.098957 & -2225.449356 & -2225.411305 & 223.2 & -2225.517373 & -2225.510673 & 26.9 & 0 \\
\hline S14b & -2469.003623 & -2468.264029 & -2468.217681 & 266.9 & -2468.344493 & -2468.332962 & 20.7 & 0 \\
\hline S14c-TS & -2468.988341 & -2468.248408 & -2468.203192 & 256.3 & -2468.324991 & -2468.31665 & -187.1 & 1 \\
\hline S14d & -2469.018339 & -2468.275177 & -2468.23004 & 256.3 & -2468.351801 & -2468.34299 & 16.2 & 0 \\
\hline S15a & -1621.615188 & -1620.980848 & -1620.952423 & 179.7 & -1621.037807 & -1621.033213 & 20.4 & 0 \\
\hline S15b & -1864.525570 & -1863.800489 & -1863.764209 & 219.8 & -1863.868658 & -1863.860391 & 18.8 & 0 \\
\hline S15c-TS & -1864.511598 & -1863.786438 & -1863.751152 & 211.4 & -1863.851586 & -1863.845593 & -184.2 & 1 \\
\hline S15d & -1864.541937 & -1863.813798 & -1863.778461 & 211.4 & -1863.878915 & -1863.872585 & 16.7 & 0 \\
\hline S16a & -1802.359609 & -1801.781159 & -1801.745045 & 212 & -1801.84591 & -1801.840413 & 26.0 & 0 \\
\hline S16c-TS & -2045.186204 & -2044.517986 & -2044.474747 & 243 & -2044.590045 & -2044.584324 & -226.0 & 1 \\
\hline S16d & -2045.228057 & -2044.557126 & -2044.513611 & 245 & -2044.6298 & -2044.623548 & 30.2 & 0 \\
\hline S17a & -1023.462663 & -1023.122717 & -1023.102811 & 139.8 & -1023.169237 & -1023.167607 & 38.3 & 0 \\
\hline S17b & -1266.370048 & -1265.938857 & -1265.911214 & 180.8 & -1265.997101 & -1265.991662 & 23.6 & 0 \\
\hline S17c-TS & -1266.344676 & -1265.914726 & -1265.887597 & 175.9 & -1265.971168 & -1265.967352 & -83.2 & 1 \\
\hline S17d & -1266.349561 & -1265.919044 & -1265.891171 & 181.1 & -1265.977228 & -1265.972151 & 21.9 & 0 \\
\hline
\end{tabular}

${ }^{a}$ Energy values calculated at the CPCM(o-dichlorobenzene)-MN15L/BS2//MN15L/BS1 level, where BS2 $=6-311++\mathrm{G}(2 \mathrm{~d}, \mathrm{p}) / \mathrm{SDD}(\mathrm{Au}, \mathrm{Sb}, \mathrm{I})$ and BS1 = 6-31+G(d)(N,F)/6-31G(d)(C,H,O,P,S)/LANL2DZ(Au,Sb,I).

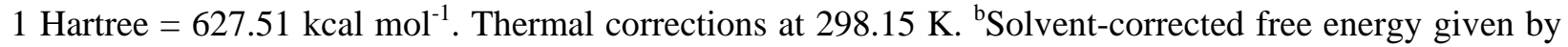
$\mathrm{G}[(\mathrm{CPCM}) / \mathrm{MN} 15 \mathrm{~L} / \mathrm{BS} 2]=\mathrm{E}_{\text {elec }}[(\mathrm{CPCM}) / \mathrm{MN} 15 \mathrm{~L} / \mathrm{BS} 2]+\mathrm{G}_{\text {corr }}[\mathrm{MN} 15 \mathrm{~L} / \mathrm{BS} 1]$, where $\mathrm{G}_{\text {corr }}$ is the thermal

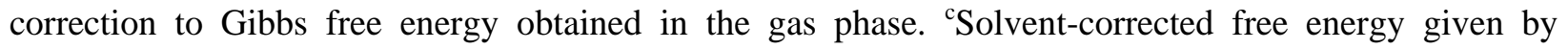
$\mathrm{G}[(\mathrm{CPCM}) / \mathrm{MN} 15 \mathrm{~L} / \mathrm{BS} 2]=\mathrm{E}_{\text {elec }}[(\mathrm{CPCM}) / \mathrm{MN} 15 \mathrm{~L} / \mathrm{BS} 2]+\mathrm{G}_{\text {corr }}[\mathrm{MN} 15 \mathrm{~L} / \mathrm{BS} 1]$, where $\mathrm{G}_{\text {corr* }}$ is the thermal correction to Gibbs free energy obtained in the gas phase after applying Cramer and Truhlar's anharmonic correction to frequencies. 


\section{Graphical Guide to Numbered Compounds: Decarboxylation}

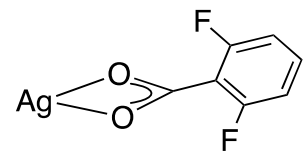

$10 a$

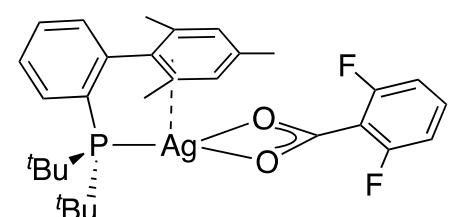

$11 a$

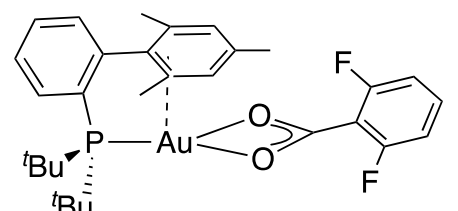

$12 a$

Transition Structures

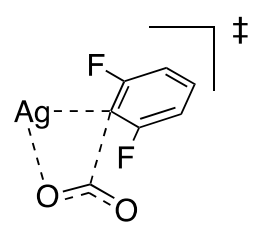

10b-TS

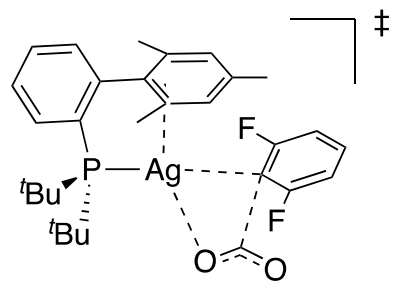

11b-TS

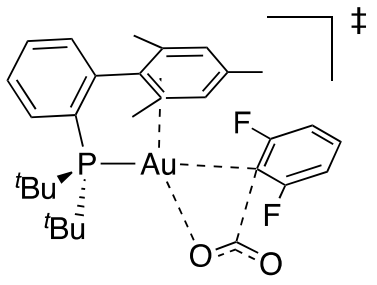

12b-TS

\section{Post-Decarboxylation Metal-Aryl Complexes}
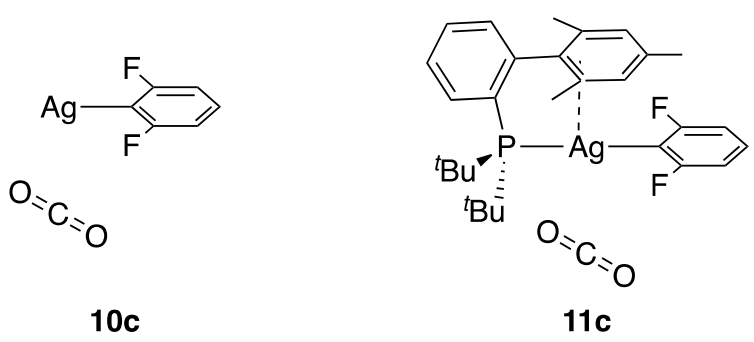

11c

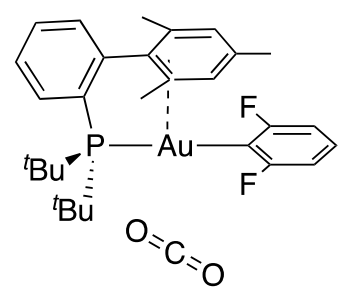

12c 


\section{Decarboxylation Free Energy Diagrams}

Decarboxylation of 2,6-Difluorobenzoate at $\mathrm{Ag}(\mathrm{I})$

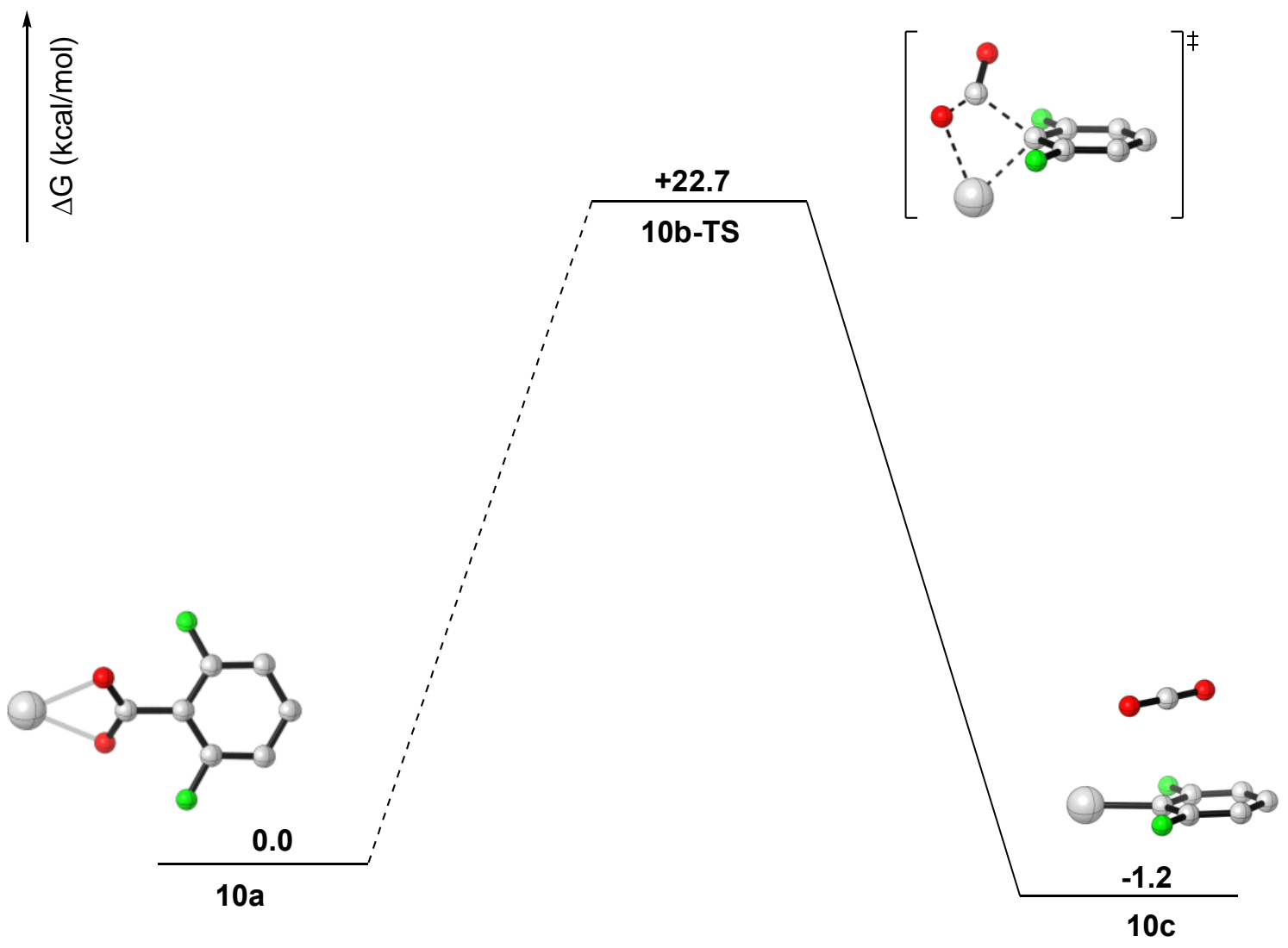


Decarboxylation of 2,6-Difluorobenzoate at ModPhos-Ag(I)

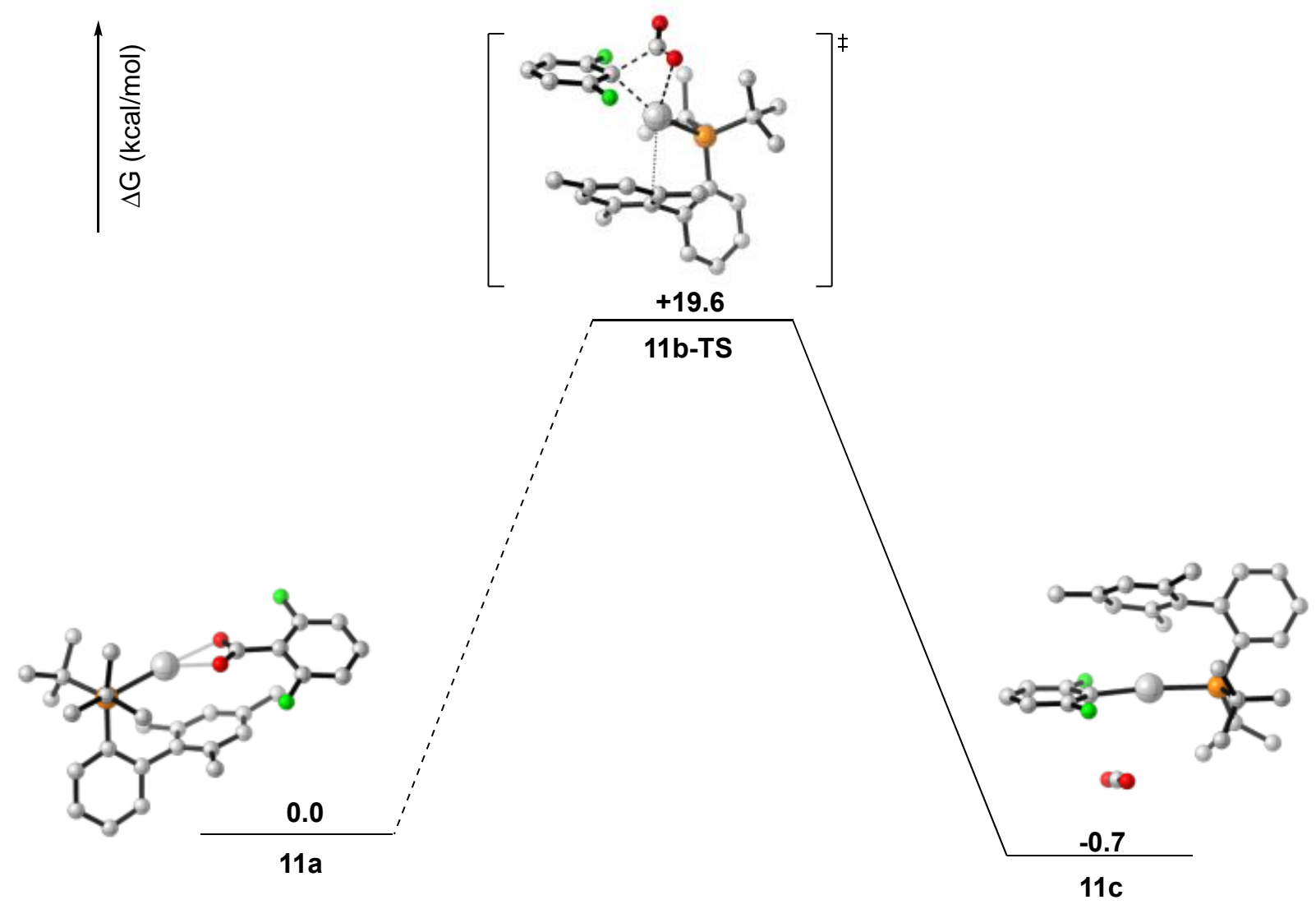


Decarboxylation of 2,6-Difluorobenzoate at ModPhos-Ag(I)

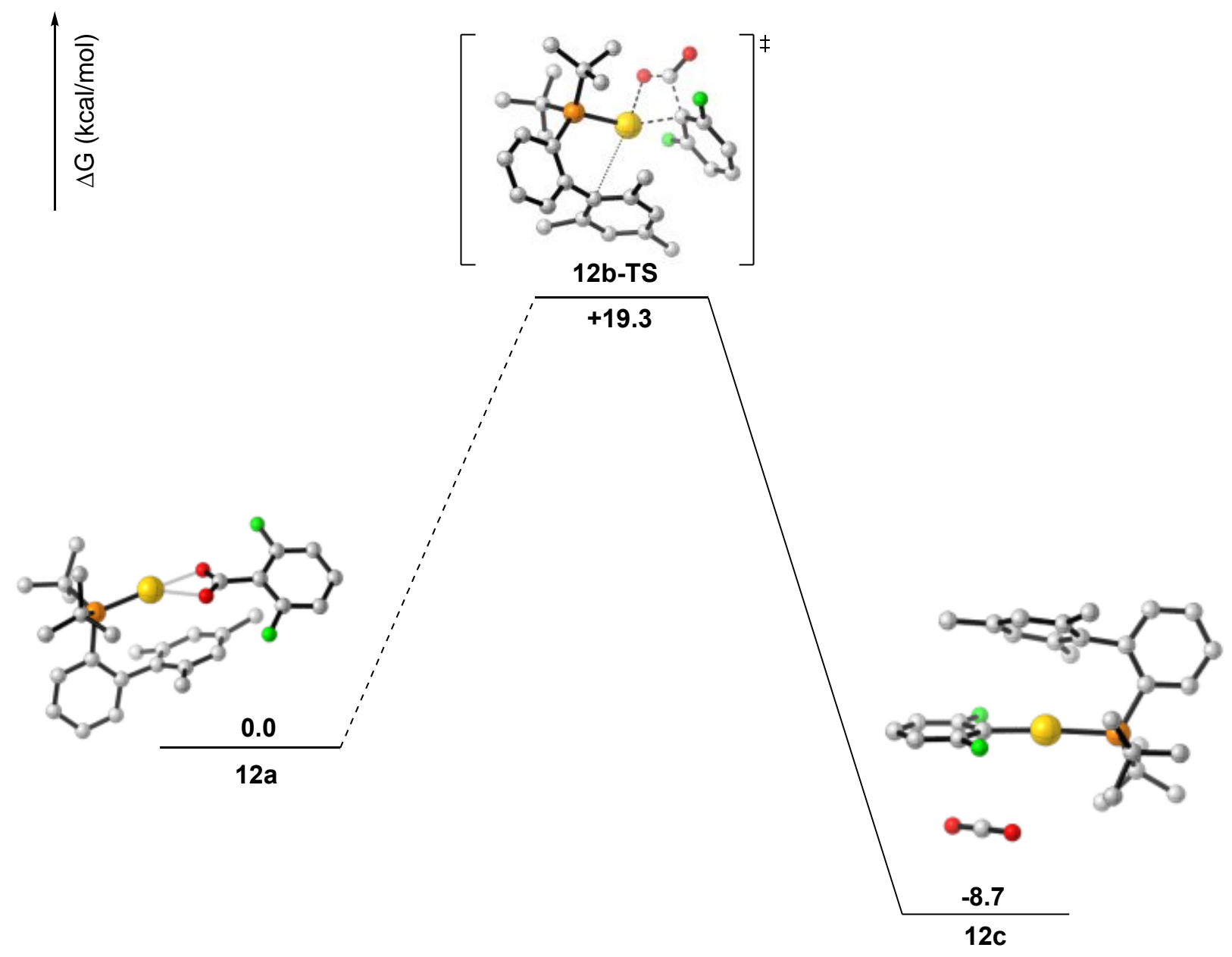


Table S12. Energies, Entropies, and Lowest Frequencies of Minimum Energy Structures: Decarboxylation $^{\mathrm{a}}$

\begin{tabular}{|c|c|c|c|c|c|c|c|c|}
\hline Structure & $\mathrm{E}_{\text {elec }}$ (Hartree) & $\begin{array}{c}E_{\text {elec }}+Z P E \\
\text { (Hartree) }\end{array}$ & H (Hartree) & $\mathrm{S}\left(\mathrm{cal} \mathrm{mol} \mathrm{m}^{-1} \mathrm{~K}^{-1}\right)$ & G (Hartree) & $\mathrm{G}^{\text {corrected }}$ (Hartree) & $\begin{array}{c}\text { Lowest } \\
\text { freq. }\left(\mathrm{cm}^{-1}\right)\end{array}$ & $\begin{array}{c}\text { \# of imaginary } \\
\text { freq. }\end{array}$ \\
\hline $10 a$ & -764.848164 & -764.760261 & -764.748745 & 224.9 & -764.799135 & -764.797819 & 20.7 & 0 \\
\hline 10b-TS & -764.808727 & -764.723834 & -764.712047 & 226.3 & -764.763010 & -764.761562 & -50.7 & 1 \\
\hline $10 c$ & -764.846254 & -764.760525 & -764.747571 & 235.7 & -764.802466 & -764.799812 & 22.2 & 0 \\
\hline 11a & -1990.856628 & -1990.263229 & -1990.224463 & 223.0 & -1990.331334 & -1990.324937 & 28.2 & 0 \\
\hline $11 b-T S$ & -1990.822889 & -1990.232312 & -1990.193347 & 228.3 & -1990.300876 & -1990.294193 & -256.5 & 1 \\
\hline $11 c$ & -1990.865810 & -1990.275117 & -1990.234633 & 234.0 & -1990.346609 & -1990.338864 & 23.2 & 0 \\
\hline $12 a$ & -2002.001596 & -2001.408142 & -2001.369403 & 106.1 & -2001.475365 & -2001.469664 & 54.7 & 0 \\
\hline $12 b-T S$ & -2001.965794 & -2001.376231 & -2001.336824 & 107.3 & -2001.445282 & -2001.438362 & -373.7 & 1 \\
\hline $12 c$ & -2001.997328 & -2001.407016 & -2001.366479 & 115.5 & -2001.477675 & -2001.470849 & 32.0 & 0 \\
\hline
\end{tabular}

${ }^{a}$ Energy values calculated at the $\operatorname{CPCM}(o$-dichlorobenzene $)-M N 15 L / B S 2 / / M N 15 L / B S 1$ level, where BS2 $=6-311++\mathrm{G}(2 \mathrm{~d}, \mathrm{p}) / \mathrm{SDD}(\mathrm{Au}, \mathrm{Ag})$ and $\mathrm{BS} 1=6-31+\mathrm{G}(\mathrm{d})(\mathrm{F}, \mathrm{O}) / 6-31 \mathrm{G}(\mathrm{d})(\mathrm{C}, \mathrm{H}, \mathrm{P}) / \mathrm{LANL} 2 \mathrm{DZ}(\mathrm{Au}, \mathrm{Ag}) .1$ Hartree $=627.51 \mathrm{kcal} \mathrm{mol}^{-1}$. Thermal corrections at $298.15 \mathrm{~K}$. ${ }^{\mathrm{b}}$ Solvent-corrected free energy given by $\mathrm{G}[(\mathrm{CPCM}) / \mathrm{MN} 15 \mathrm{~L} / \mathrm{BS} 2]=\mathrm{E}_{\text {elec }}[(\mathrm{CPCM}) / \mathrm{MN} 15 \mathrm{~L} / \mathrm{BS} 2]+\mathrm{G}_{\text {corr }}[\mathrm{MN} 15 \mathrm{~L} / \mathrm{BS} 1]$, where $\mathrm{G}_{\text {corr }}$ is the thermal

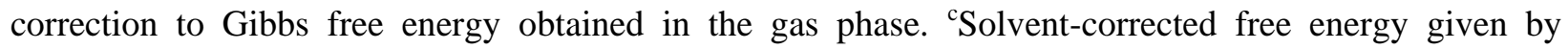
$\mathrm{G}[(\mathrm{CPCM}) / \mathrm{MN} 15 \mathrm{~L} / \mathrm{BS} 2]=\mathrm{E}_{\text {elec }}[(\mathrm{CPCM}) / \mathrm{MN} 15 \mathrm{~L} / \mathrm{BS} 2]+\mathrm{G}_{\text {corr }}$ [MN15L/BS1], where $\mathrm{G}_{\text {corr* }}$ is the thermal correction to Gibbs free energy obtained in the gas phase after applying Cramer and Truhlar's anharmonic correction to frequencies. ${ }^{\mathrm{d}}$ Decarboxylation product geometries were optimized with explicit $\mathrm{CO}_{2}$ (see coordinates). 


\section{References in SI}

(1) Hansch, C.; Leo, A.; Taft, R. W. A Survey of Hammett Substituent Constants and Resonance and Field Parameters. Chem. Rev. 1991, 91, 165-195. https://doi.org/10.1021/cr00002a004.

(2) Li, H.; Liu, J.; Sun, C. L.; Li, B. J.; Shi, Z. J. Palladium-Catalyzed Cross-Coupling of Polyfluoroarenes with Simple Arenes. Org. Lett. 2011, 13, 276-279. https://doi.org/10.1021/ol102688e.

(3) Shang, R.; Xu, Q.; Jiang, Y. Y.; Wang, Y.; Liu, L. Pd-Catalyzed Decarboxylative Cross Coupling of Potassium Polyfluorobenzoates Aryl Bromides, Chlorides, and Triflates. Org. Lett. 2010, 12,1000-1003.

(4) Shang, R.; Fu, Y.; Wang, Y.; Xu, Q.; Yu, H. Z.; Liu, L. Copper-Catalyzed Decarboxylative Cross-Coupling of Potassium Polyfluorobenzoates with Aryl Iodides and Bromides. Angew. Chemie. Int. Ed. 2009, 48, 9350-9354. https://doi.org/10.1002/anie.200904916.

(5) Becht, J. M.; Ngouela, S.; Wagner, A.; Mioskowski, C. A Straightforward Anionic Coupling for the Synthesis of Ortho-Bromobiaryls. Tetrahedron 2004, 60, 6853-6857. https://doi.org/10.1016/j.tet.2004.06.010

(6) Mao, S.; Shi, X.; Soulé, J. F.; Doucet, H. Pd/C as Heterogeneous Catalyst for the Direct Arylation of (Poly)Fluorobenzenes. Chem. Eur. J. 2019, 9504-9513. https://doi.org/10.1002/chem.201900921.

(7) Yan, M. Q.; Yuan, J.; Lan, F.; Zeng, S. H.; Gao, M. Y.; Liu, S. H.; Chen, J.; Yu, G. A. An Active Catalytic System for Suzuki-Miyaura Cross-Coupling Reactions Using Low Level of Palladium Loading. Org. Biomol. Chem. 2017, 15, 3924-3929. https://doi.org/10.1039/c7ob00178a. Arun, V.; Reddy, P. O. V.; Pilania, M.; Kumar, D. Ligand- and Base-Free Access to Diverse Biaryls by the Reductive Coupling of Diaryliodonium Salts. Eur. J. Org. Chem. 2016, 2096-2100. https://doi.org/10.1002/ejoc.201600242.

(9) Song, C.; Dong, X.; Wang, Z.; Liu, K.; Chiang, C.; Lei, A. Visible-Light-Induced [ $4+2$ ] Annulation of Thiophenes and Alkynes to Construct Benzene Rings. 2019, 12206-12210. https://doi.org/10.1002/anie.201905971.

Cornella, J.; Rosillo-Lopez, M.; Larrosa, I. A Novel Mode of Reactivity for Gold(I): The Decarboxylative Activation of (Hetero)Aromatic Carboxylic Acids. Adv. Synth. Catal. 2011, 353, 1359-1366. https://doi.org/10.1002/adsc.201100109.

Baur, A.; Bustin, K. A.; Aguilera, E.; Petersen, J. L.; Hoover, J. M. Copper and Silver Benzoate and Aryl Complexes and Their Implications for Oxidative Decarboxylative Coupling Reactions. Org. Chem. Front. 2017, 4, 519-524. https://doi.org/10.1039/c6qo00678g.

Schmidt, H.; Shen, Y.; Leschke, M.; Haase, T.; Kohse-Höinghaus, K.; Lang, H. Phosphane-Stabilized Silver(I)-Carboxylates: Synthesis and Use in Silver-CVD. J. Organomet. Chem. 2003, 669 (1-2), 25-31. https://doi.org/10.1016/S0022-328X(02)02166-6.

(13) Grirrane, A.; Álvarez, E.; García, H.; Corma, A. Catalytic Activity of Cationic and Neutral Silver(I)-XPhos Complexes with Nitrogen Ligands or Tolylsulfonate for Mannich and Aza-Diels-Alder Coupling Reactions. Chem. Eur. J. 2016, 22, 340-354. https://doi.org/10.1002/chem.201503386.

Frisch, M. J.; Trucks, G. W.; Schlegel, H. B.; Scuseria, G. E.; Robb, M. A.; Cheeseman, J. R.; Scalmani, G.; Barone, V.; Petersson, G. A.; Nakatsuji, H.; Li, X.; Caricato, M.; Marenich, A. V.; Bloino, J.; Janesko, B. G.; Gomperts, R.; Mennucci, B.; Hratch, D. J. Gaussian 16, Revision C.01. Gaussian, Inc., Wallingford CT 2016.

Yu, H. S.; He, X.; Truhlar, D. G. MN15-L: A New Local Exchange-Correlation Functional for Kohn-Sht and Solids. J. Chem. Theory Comput. 2016, 12, 1280-1293. https://doi.org/10.1021/acs.jctc.5b01082.

Hay, P. J.; Wadt, W. R. Ab Initio Effective Core Potentials for Molecular Calculations. Potentials for K to Au Including the Outermost Core Orbitale. J. Chem. Phys. 1985, 82, 299310. https://doi.org/10.1063/1.448975.

Ribeiro, R. F.; Marenich, A. V.; Cramer, C. J.; Truhlar, D. G. Use of Solution-Phase Vibrational Frequencies in Continuum Models for the Free Energy of Solvation. J. Phys. Chem. $B$ 2011, 115, 14556-14562. https://doi.org/10.1021/jp205508z.

Gonzalez, C.; Bernhard Schlegel, H. An Improved Algorithm for Reaction Path Following. J. Chem. Phys. 1989, 90, 2154-2161. https://doi.org/10.1063/1.456010.

Gonzalez, C.; Schlegel, H. B. Reaction Path Following in Mass-Weighted Internal Coordinates. J. Phys. Chem. 1990, 94, 5523-5527. https://doi.org/10.1021/j100377a021.

Fukui, K. The Path of Chemical Reactions - The IRC Approach. Acc. Chem. Res. 1981, 14, 363-368. https://doi.org/10.1021/ar00072a001.

Dolg, M.; Wedig, U.; Stoll, H.; Preuss, H. Energy-Adjusted Ab Initio Pseudopotentials for the First Row Transition Elements. J. Chem. Phys. 1987, 86, 866-872.

Andrae, D.; Häußermann, U.; Dolg, M.; Stoll, H.; Preuß, H. Energy-Adjusted Ab Initio Pseudopotentials for the Second and Third Row Transition Elements. Theor. Chim. Acta 1990, 77, 123-141. https://doi.org/10.1007/BF01114537.

Legault, C. Y. CYLview, 1.0b. Université de Sherbrooke 2009. Addition of Aryl Halides. Nat. Commun. 2017, 8, 565. https://doi.org/10.1038/s41467-017-00672-8. 


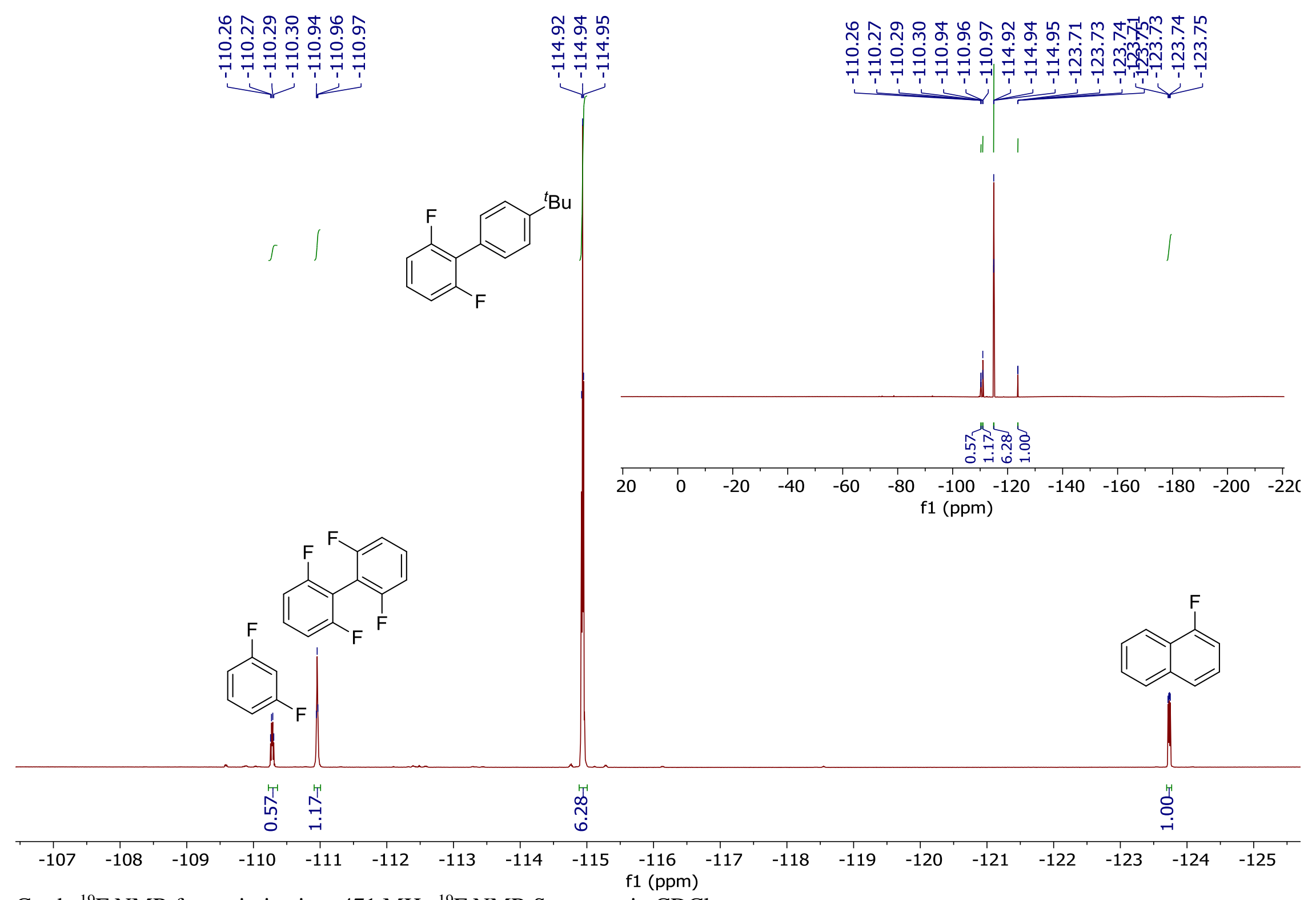

Crude ${ }^{19} \mathrm{~F}$ NMR for optimization: $471 \mathrm{MHz}{ }^{19} \mathrm{~F}$ NMR Spectrum in $\mathrm{CDCl}_{3}$ 


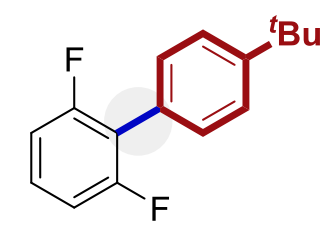

3a $91 \%(86 \%)$

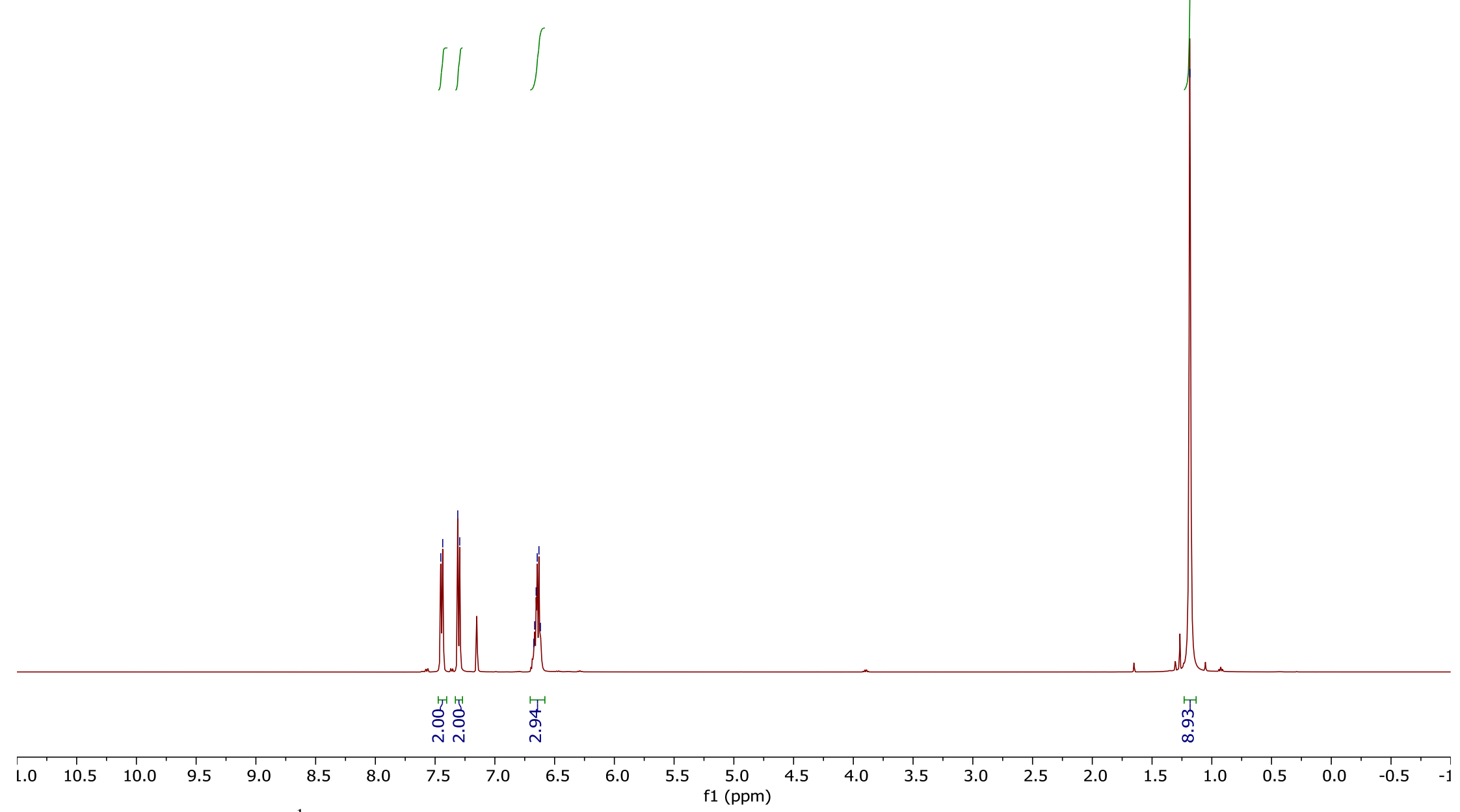

Compound 3a: $500 \mathrm{MHz}{ }^{1} \mathrm{H}$ NMR spectrum in $\mathrm{C}_{6} \mathrm{D}_{6}$ 


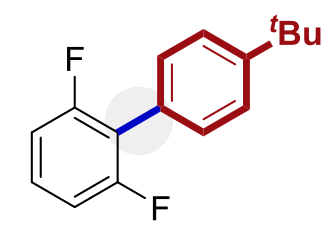

3a $91 \%$ (86\%)

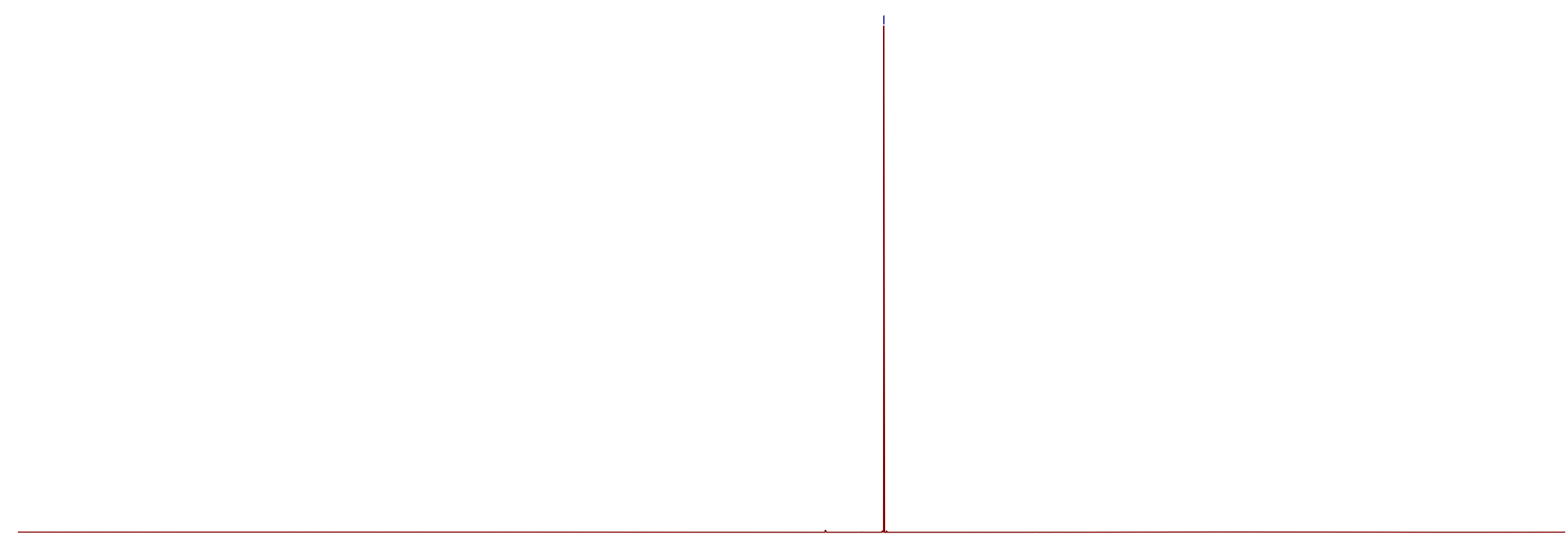

$\begin{array}{llllll}10 & 0 & -10 & -20 & -30 & -40\end{array}$ $\begin{array}{llll}-50 & -60 & -70 & -80\end{array}$ 


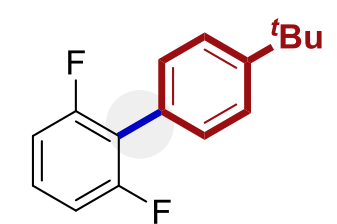

3a $91 \%(86 \%)$

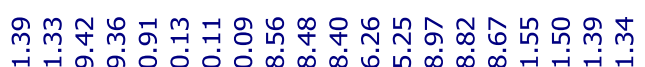

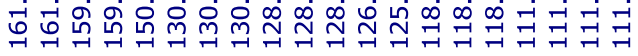

SY
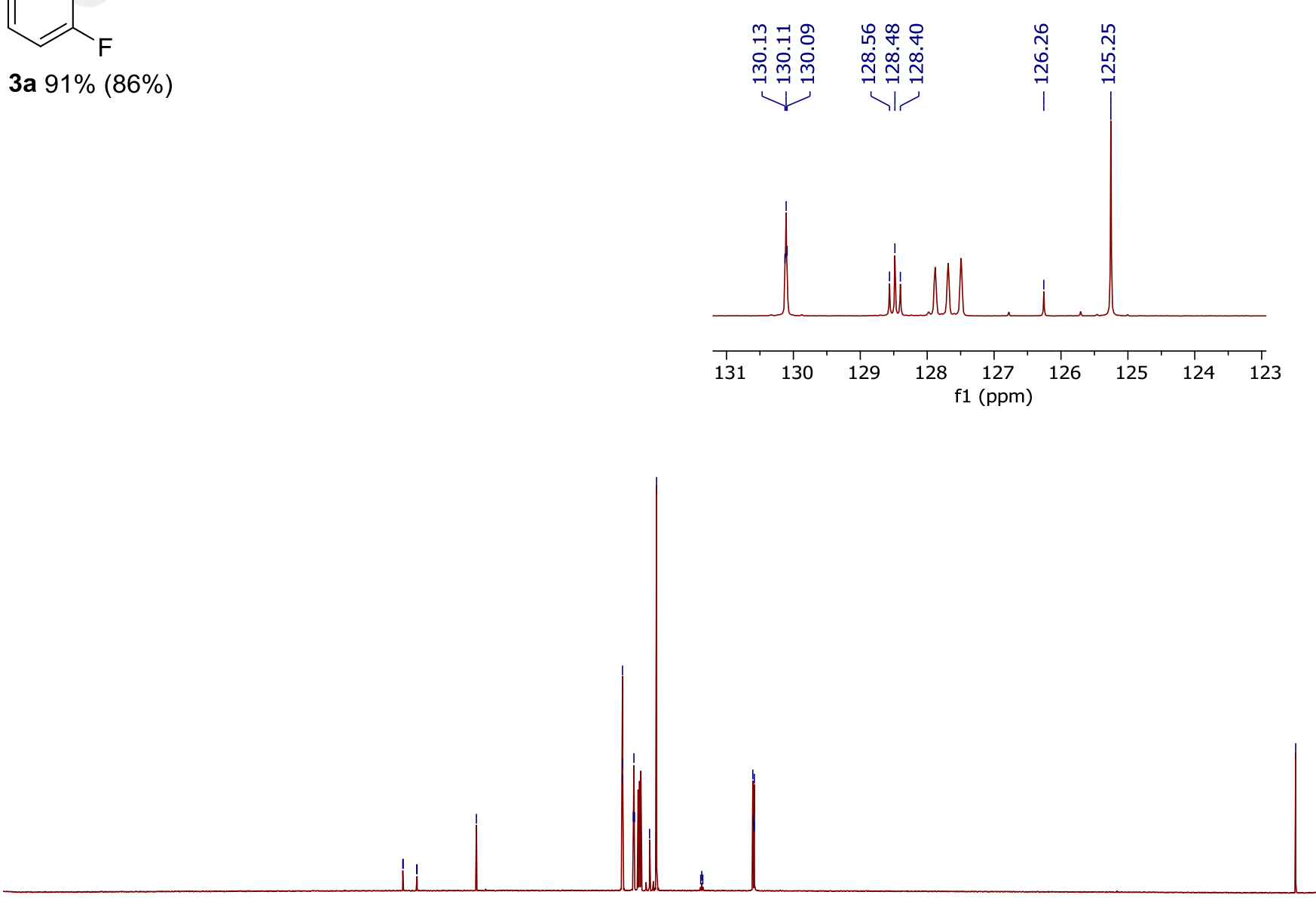

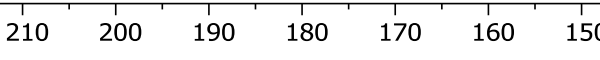
$130 \quad 120$ $110 \begin{array}{cc}100 & 90 \\ \mathrm{f} 1(\mathrm{ppm}) & \end{array}$ 80 $70 \quad 60$ Compound 3a: $126 \mathrm{MHz}{ }^{13} \mathrm{C}$ NMR spectrum in DMSO 


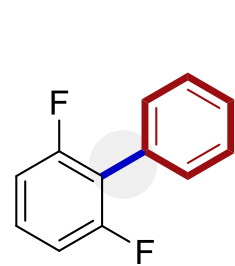

3b $86 \%(84 \%)$
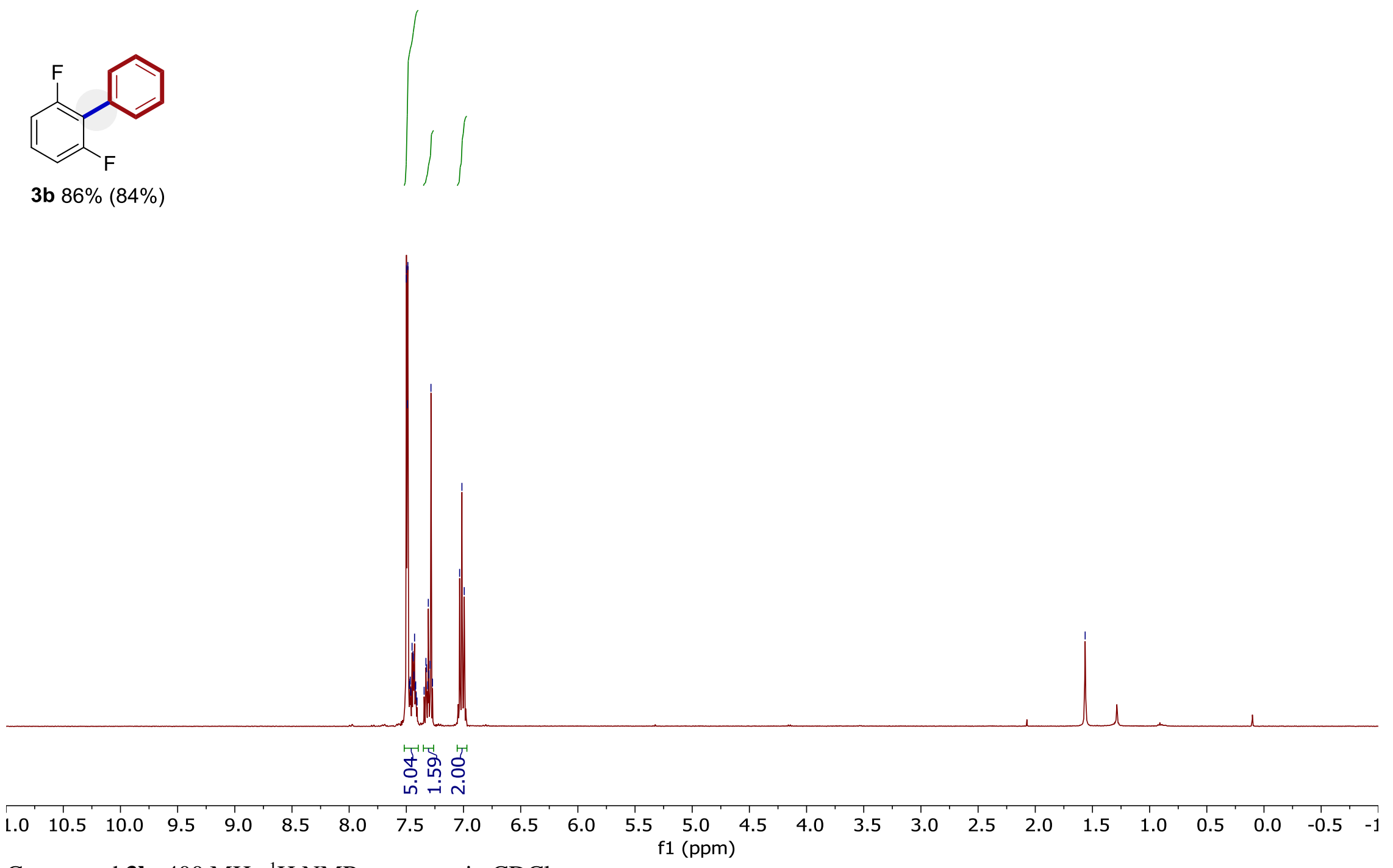

Compound 3b: $400 \mathrm{MHz}{ }^{1} \mathrm{H}$ NMR spectrum in $\mathrm{CDCl}_{3}$ 


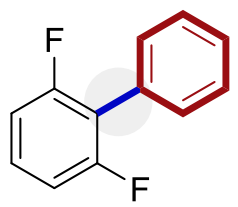

3b $86 \%(84 \%)$

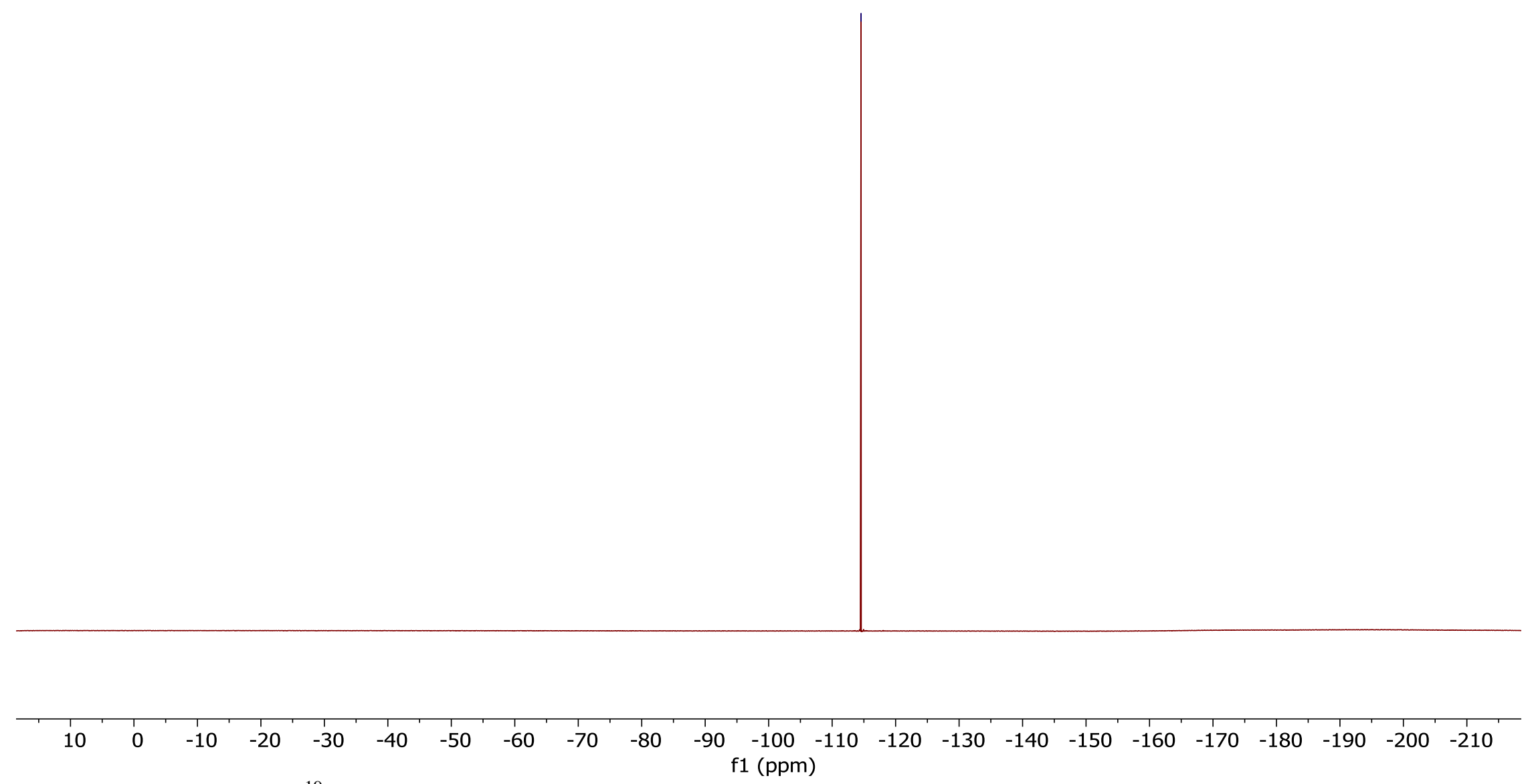

Compound 3b: $376 \mathrm{MHz}{ }^{19} \mathrm{~F}$ NMR spectrum in $\mathrm{CDCl}_{3}$ 


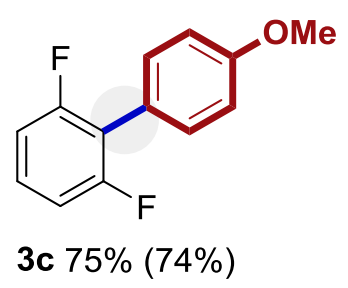

$\underbrace{\underbrace{2}}$

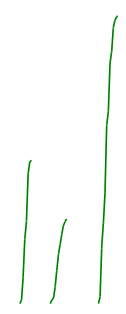

$\stackrel{\infty}{\infty}$

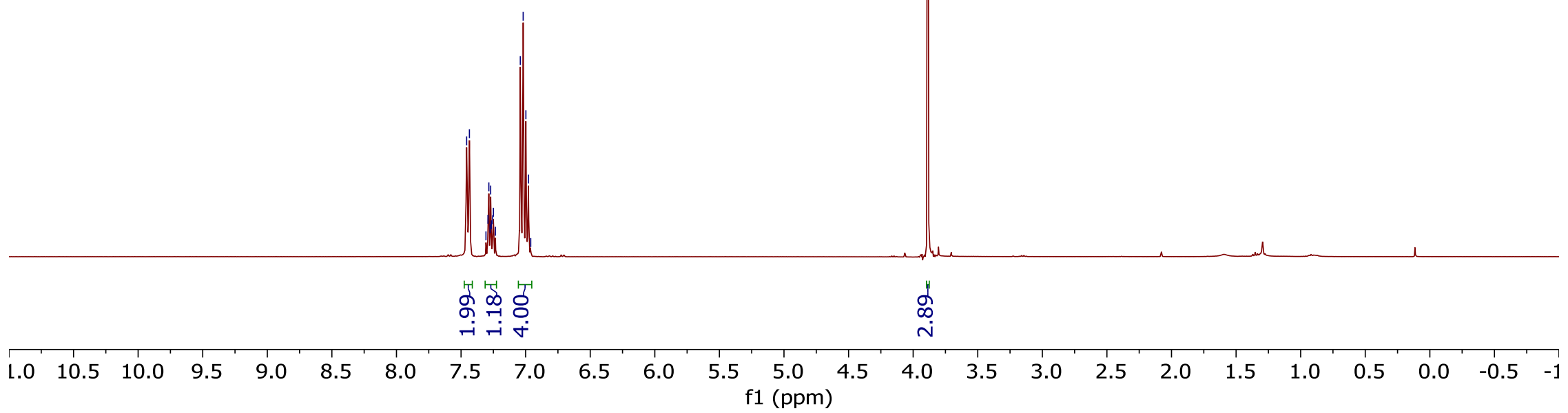

Compound Bc: $400 \mathrm{MHz}{ }^{1} \mathrm{H}$ NMR spectrum in $\mathrm{CDCl}_{3}$

S57 


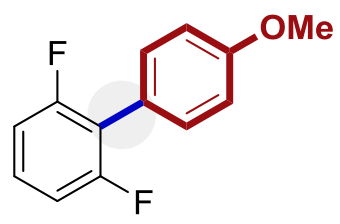

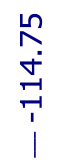

3c $75 \%(74 \%)$

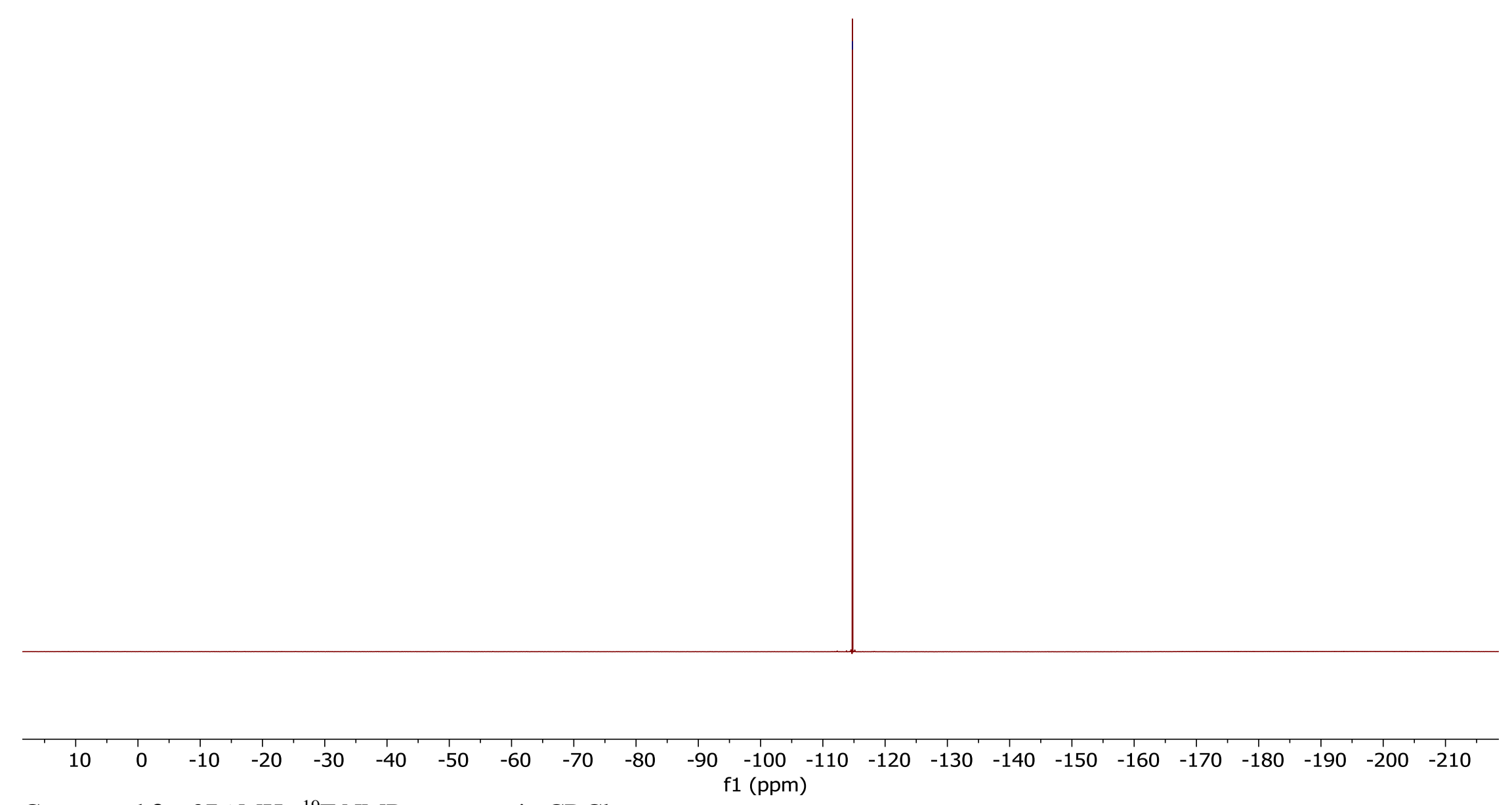

Compound 3c: $376 \mathrm{MHz}{ }^{19} \mathrm{~F}$ NMR spectrum in $\mathrm{CDCl}_{3}$ 


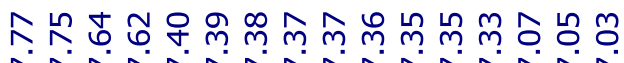

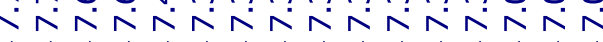

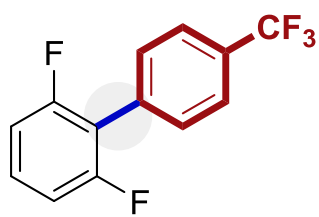

3d n.d. $(70 \%)$
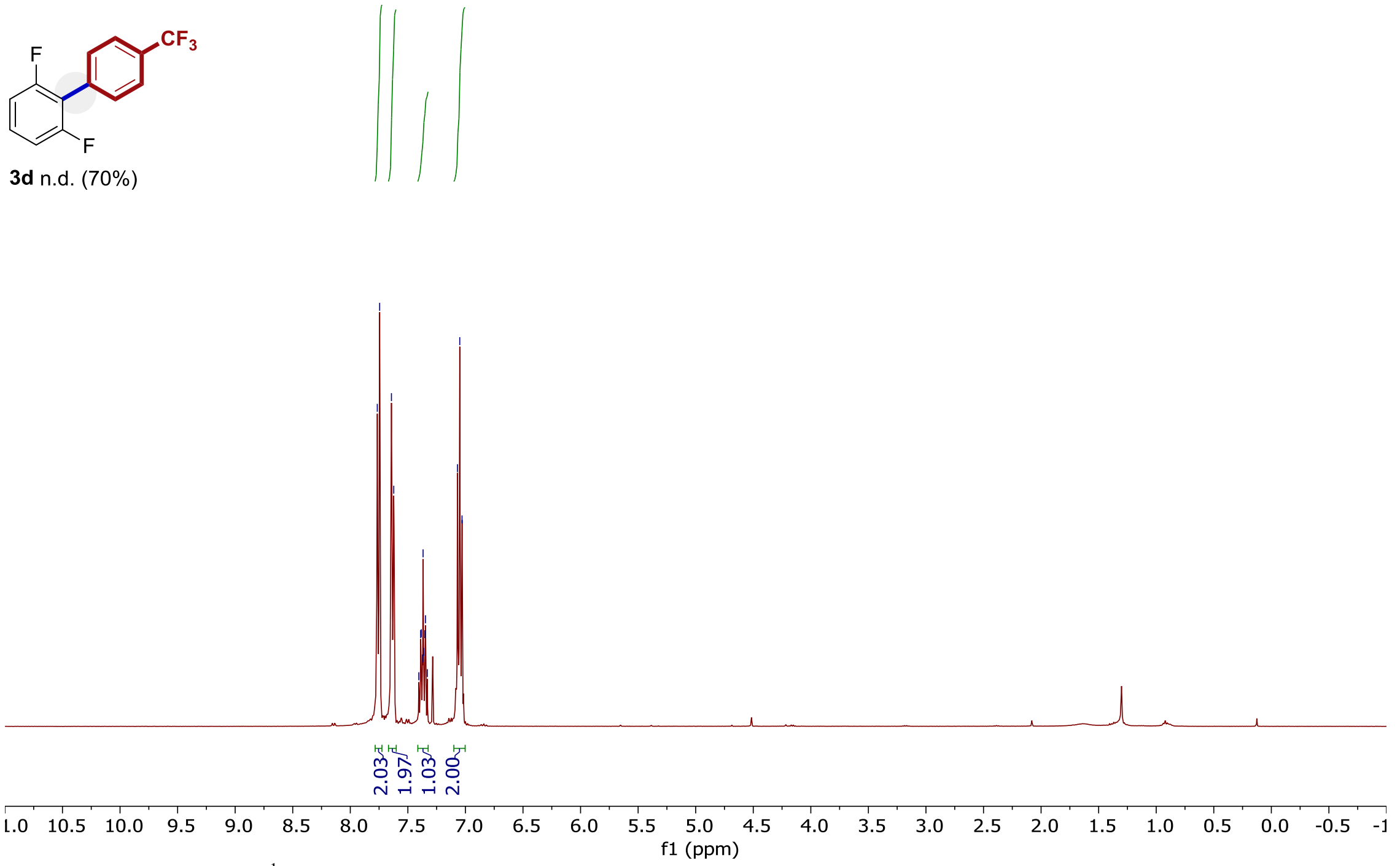

Compound 3d: $400 \mathrm{MHz}{ }^{1} \mathrm{H}$ NMR spectrum in $\mathrm{CDCl}_{3}$ 


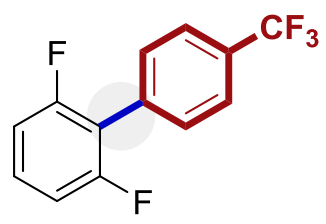

3d n.d. (70\%)

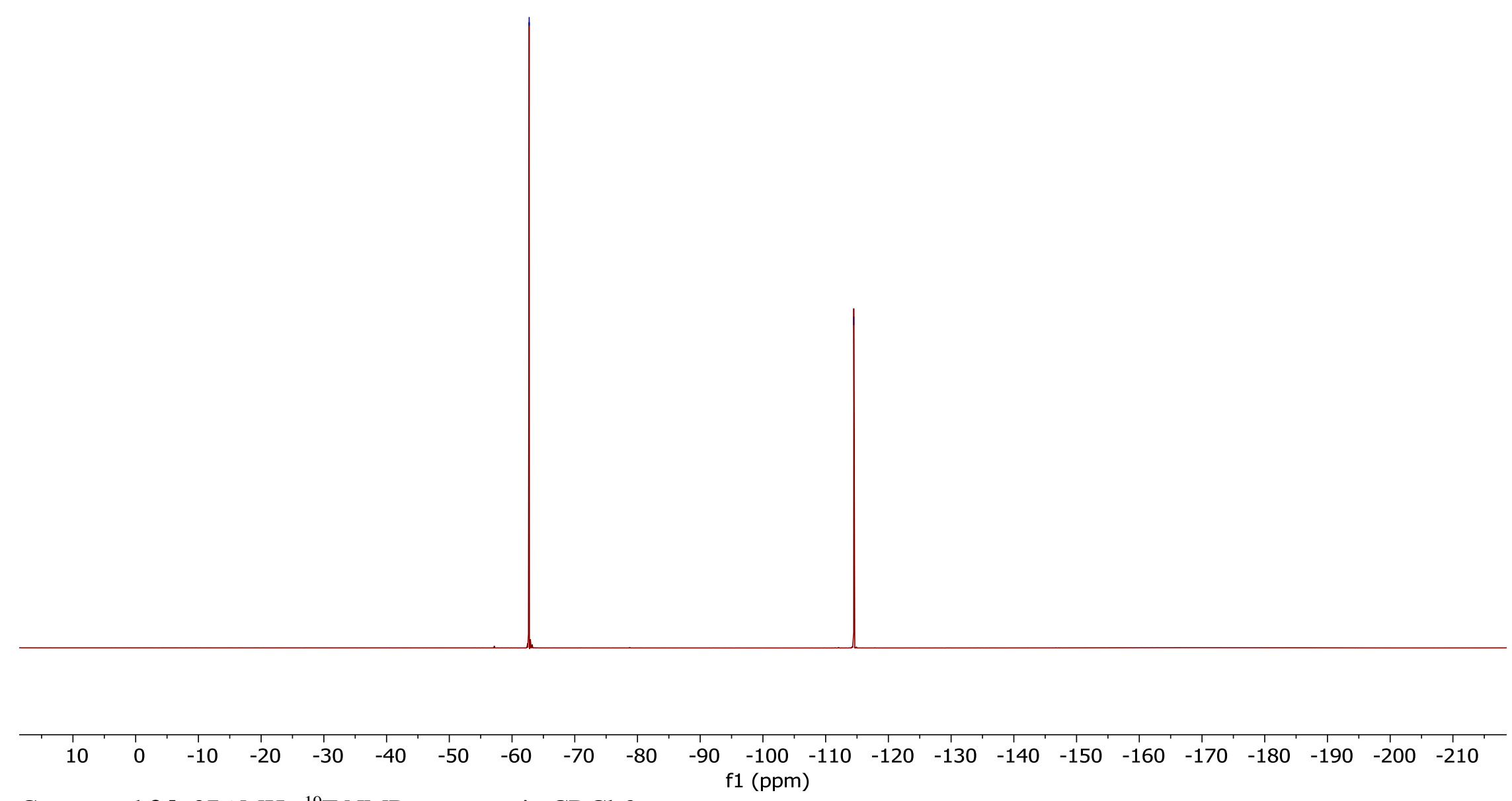

Compound 3d: $376 \mathrm{MHz}{ }^{19} \mathrm{~F}$ NMR spectrum in $\mathrm{CDCl}_{3} 2$ 


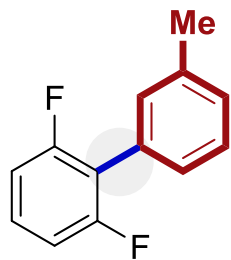

3 e $82 \%(76 \%)$

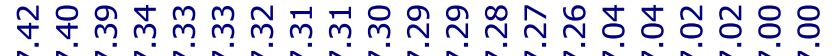

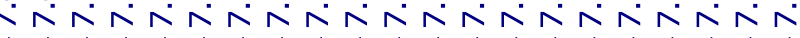

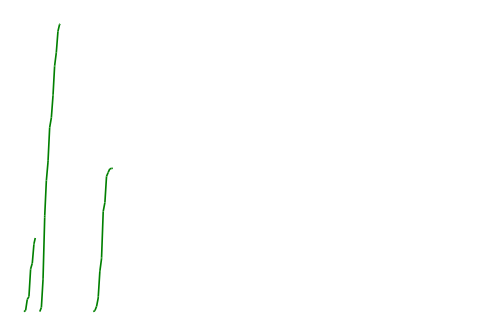

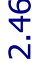

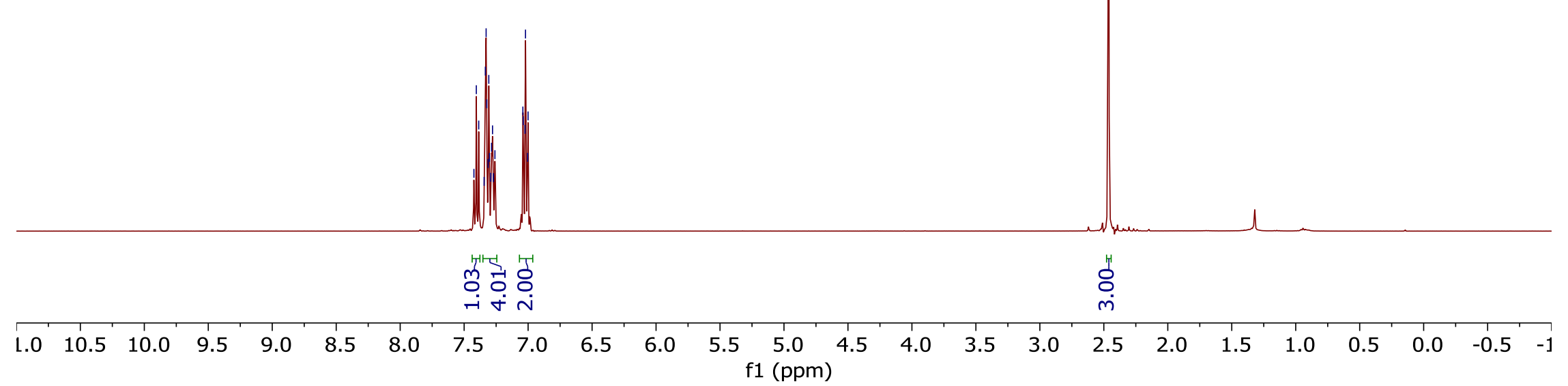

Compound 3e: $400 \mathrm{MHz}{ }^{1} \mathrm{H}$ NMR spectrum in $\mathrm{CDCl}_{3}$ 


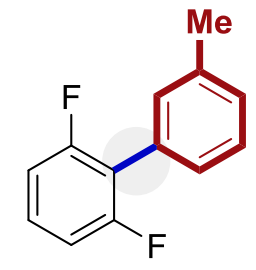

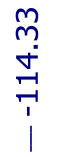

3e $82 \%(76 \%)$

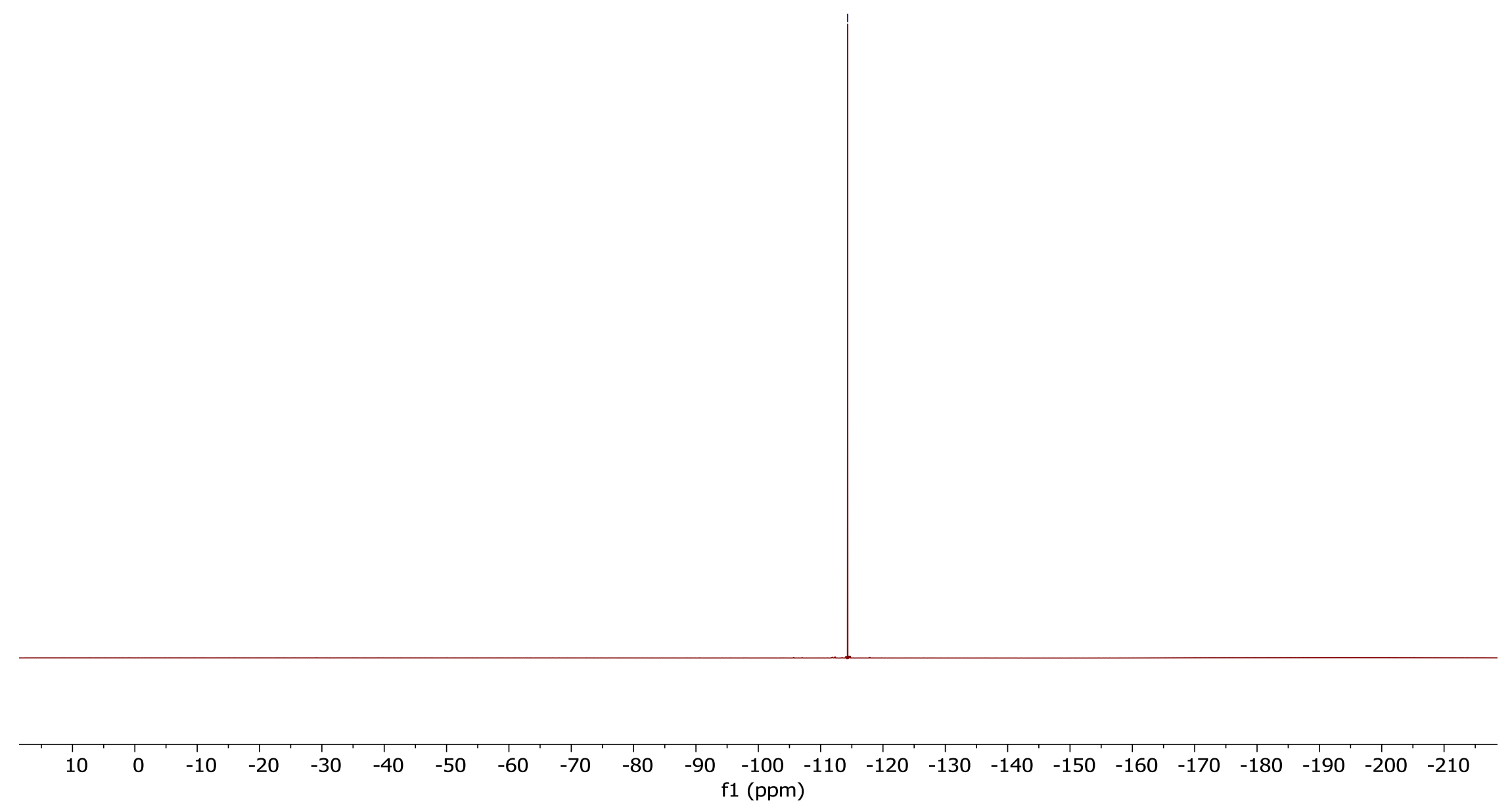
Compound 3e: $376 \mathrm{MHz}{ }^{19} \mathrm{~F}$ NMR spectrum in $\mathrm{CDCl}_{3}$ 


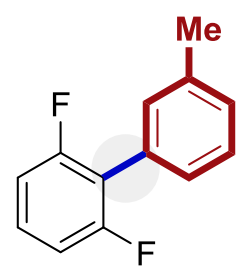

3e $82 \%(76 \%)$
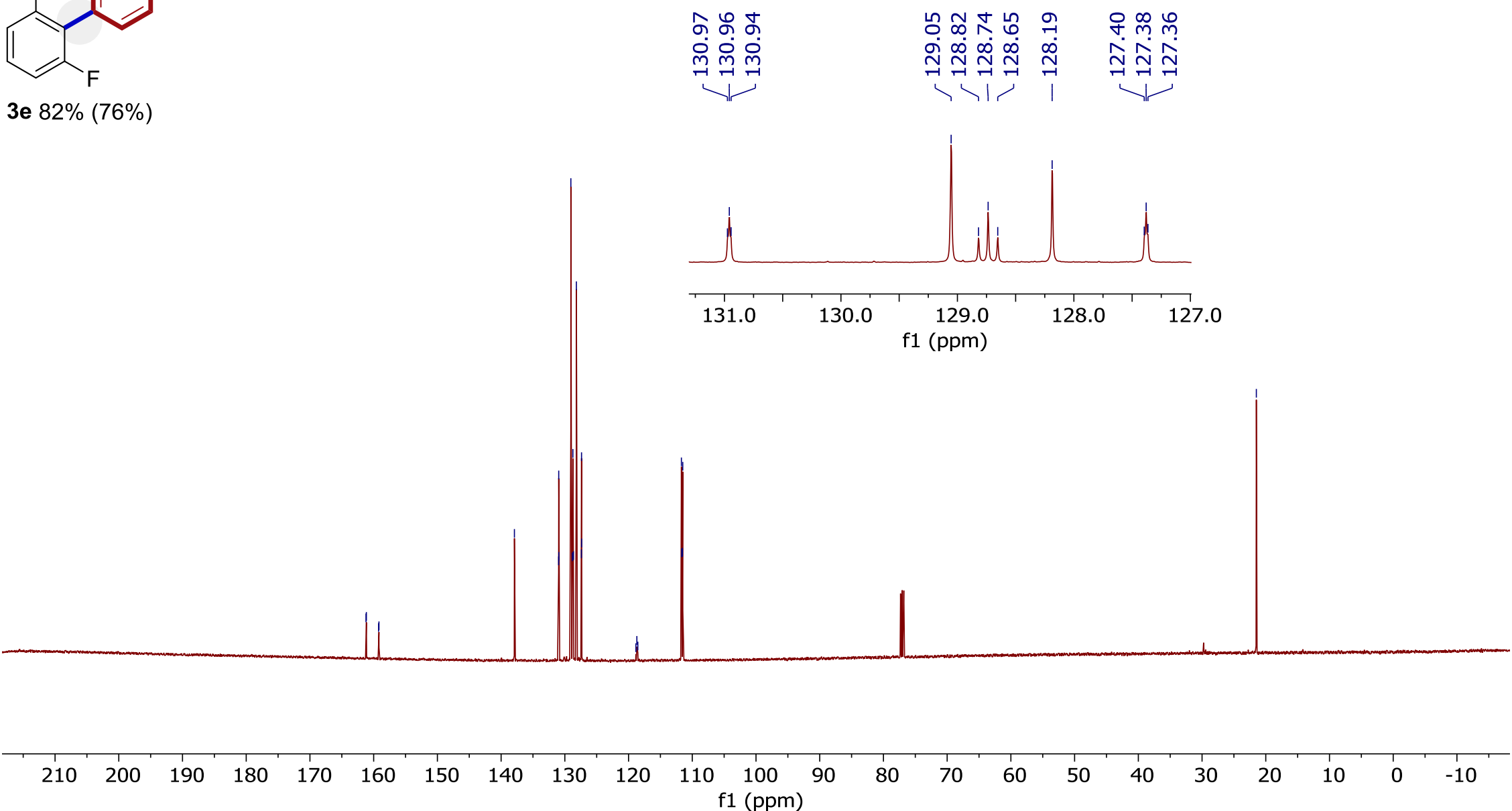

Compound 3e: $126 \mathrm{MHz}{ }^{13} \mathrm{C}$ NMR spectrum in $\mathrm{CDCl}_{3}$ 


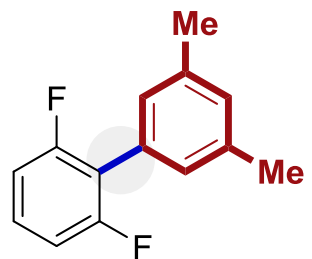

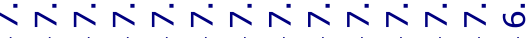

3f $82 \%(71 \%)$
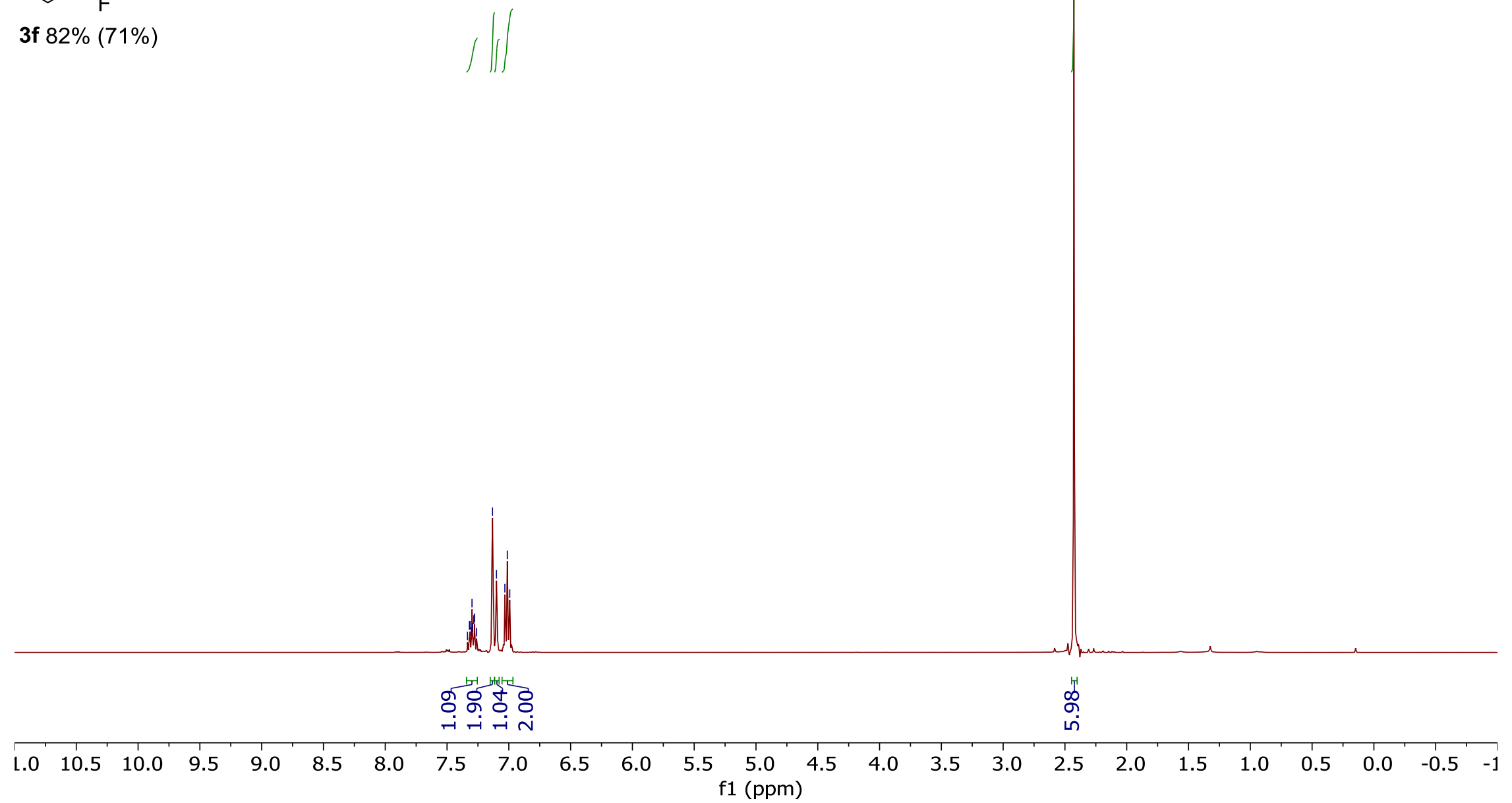

Compound 3f: $400 \mathrm{MHz}{ }^{1} \mathrm{H}$ NMR spectrum in $\mathrm{CDCl}_{3}$ 


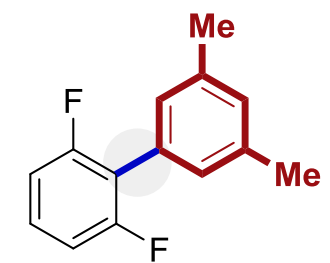

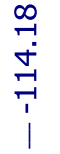

3f $82 \%(71 \%)$

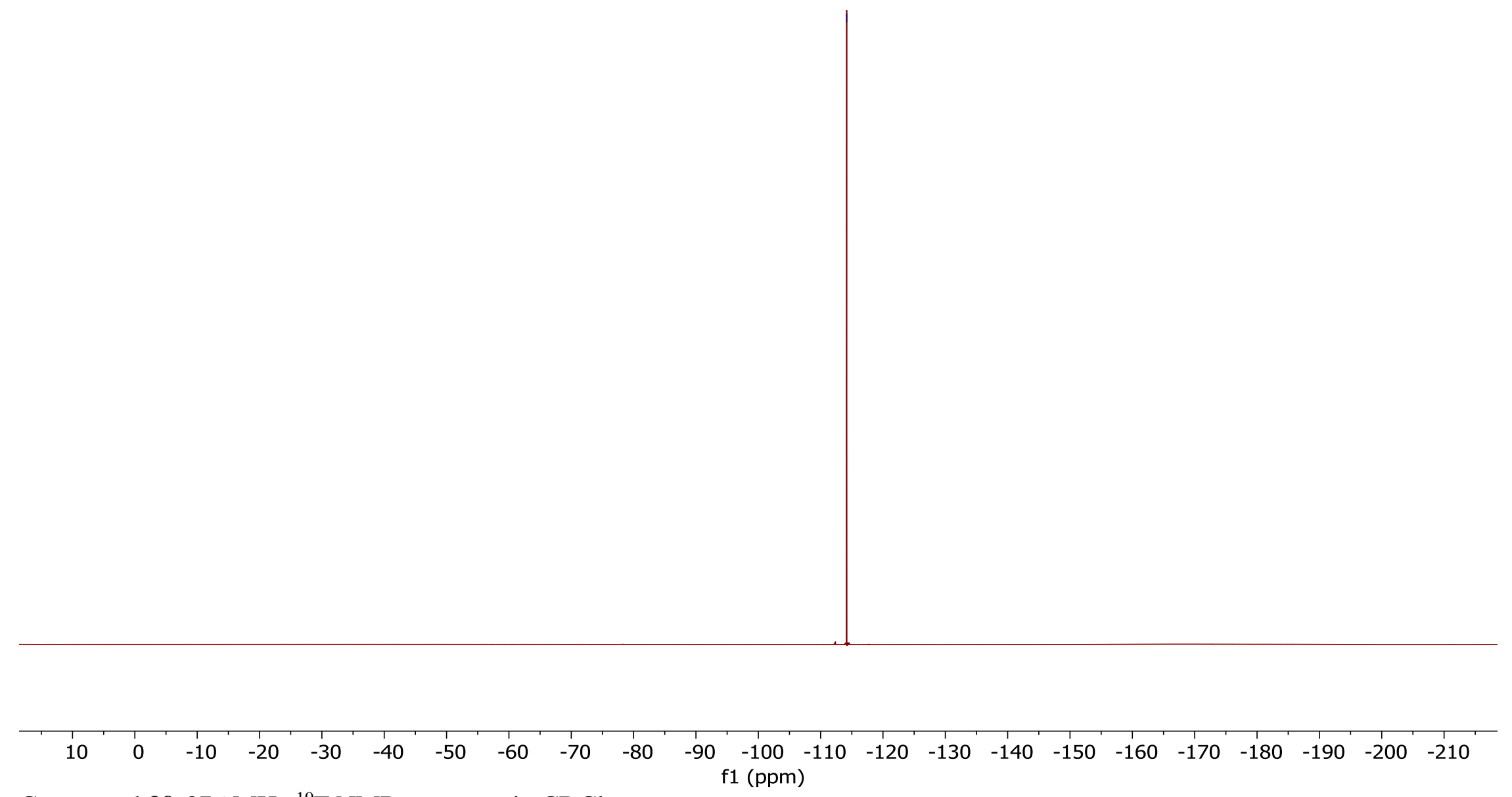

Compound 3f: $376 \mathrm{MHz}{ }^{19} \mathrm{~F}$ NMR spectrum in $\mathrm{CDCl}_{3}$ 


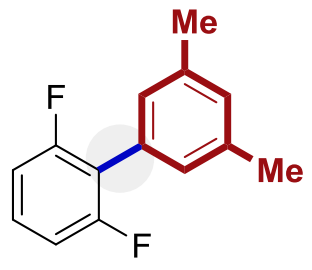

3f $82 \%(71 \%)$

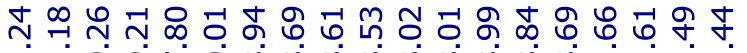

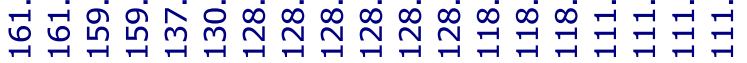

等

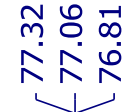

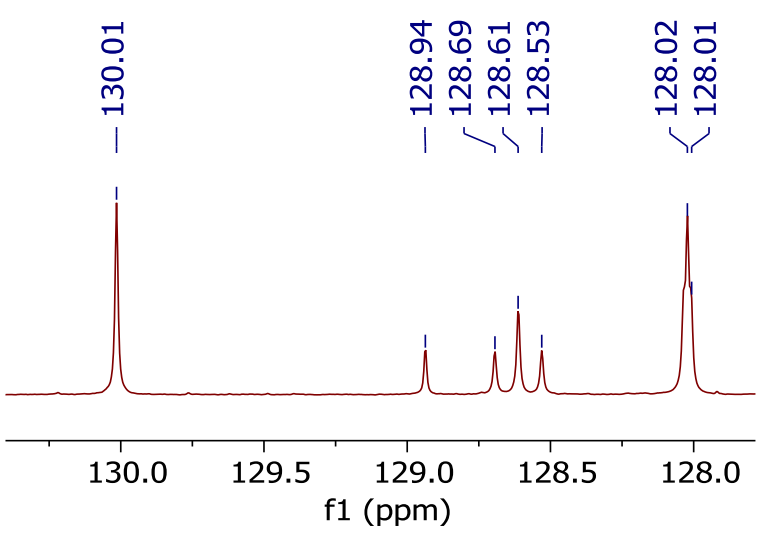

$\begin{array}{lllllllllllllllllllllll}210 & 200 & 190 & 180 & 170 & 160 & 150 & 140 & 130 & 120 & 110 \begin{array}{c}100 \\ \mathrm{f} 1(\mathrm{ppm})\end{array} & 90 & 80 & 70 & 60 & 50 & 40 & 30 & 20 & 10 & 0 & -10\end{array}$ Compound 3f: $126 \mathrm{MHz}{ }^{13} \mathrm{C}$ NMR spectrum in $\mathrm{CDCl}_{3}$ 


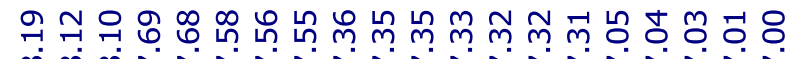

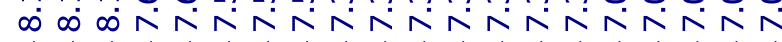

$\stackrel{\wp}{m}$

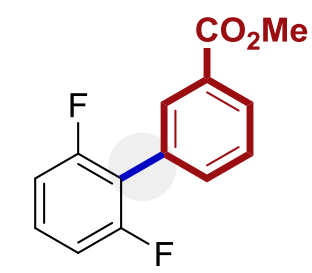

3g $85 \%$ (68\%)

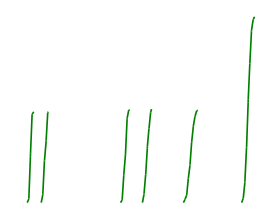

3g $85 \%(68 \%)$

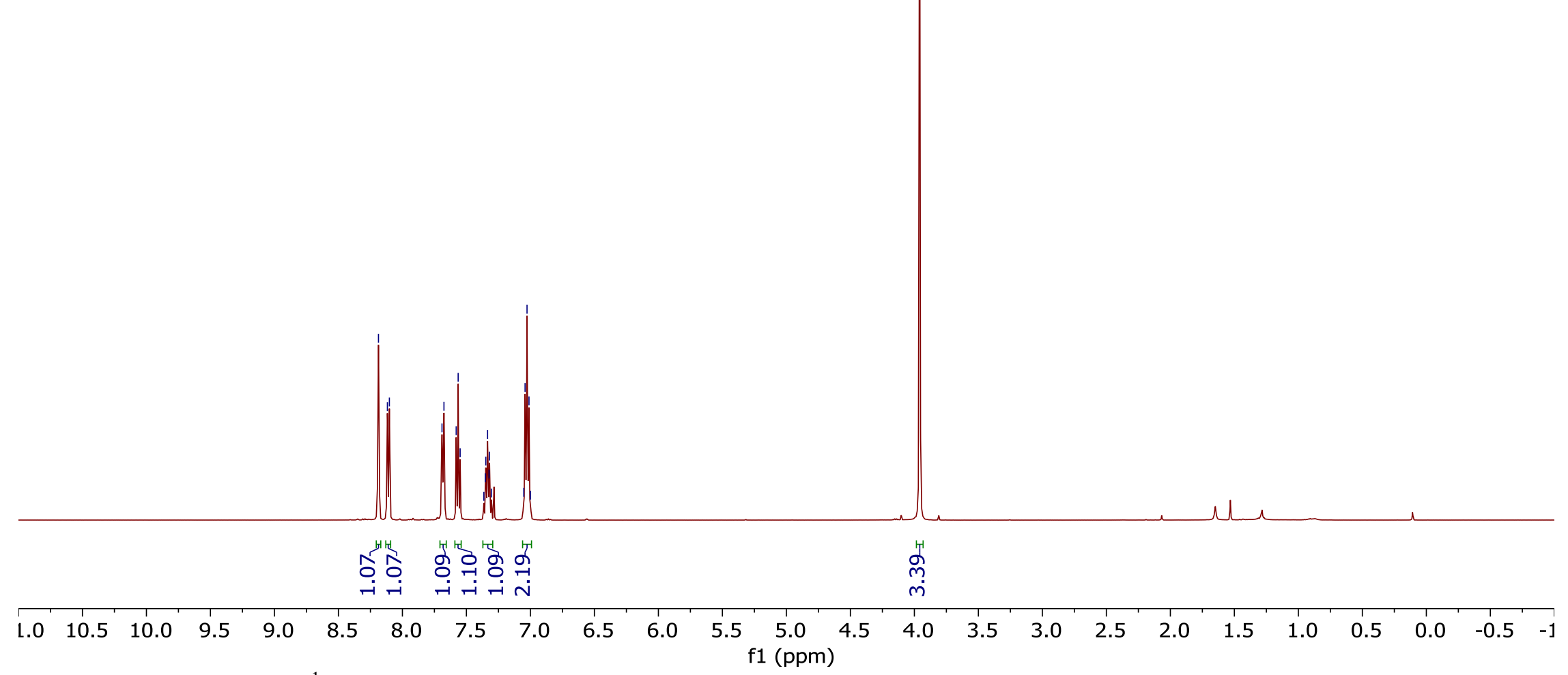

Compound 3g: $500 \mathrm{MHz}{ }^{1} \mathrm{H}$ NMR spectrum in $\mathrm{CDCl}_{3}$ 


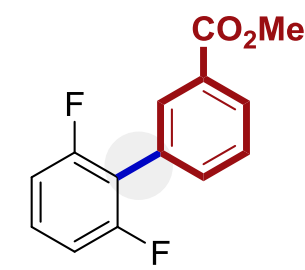



3g $85 \%$ (68\%)

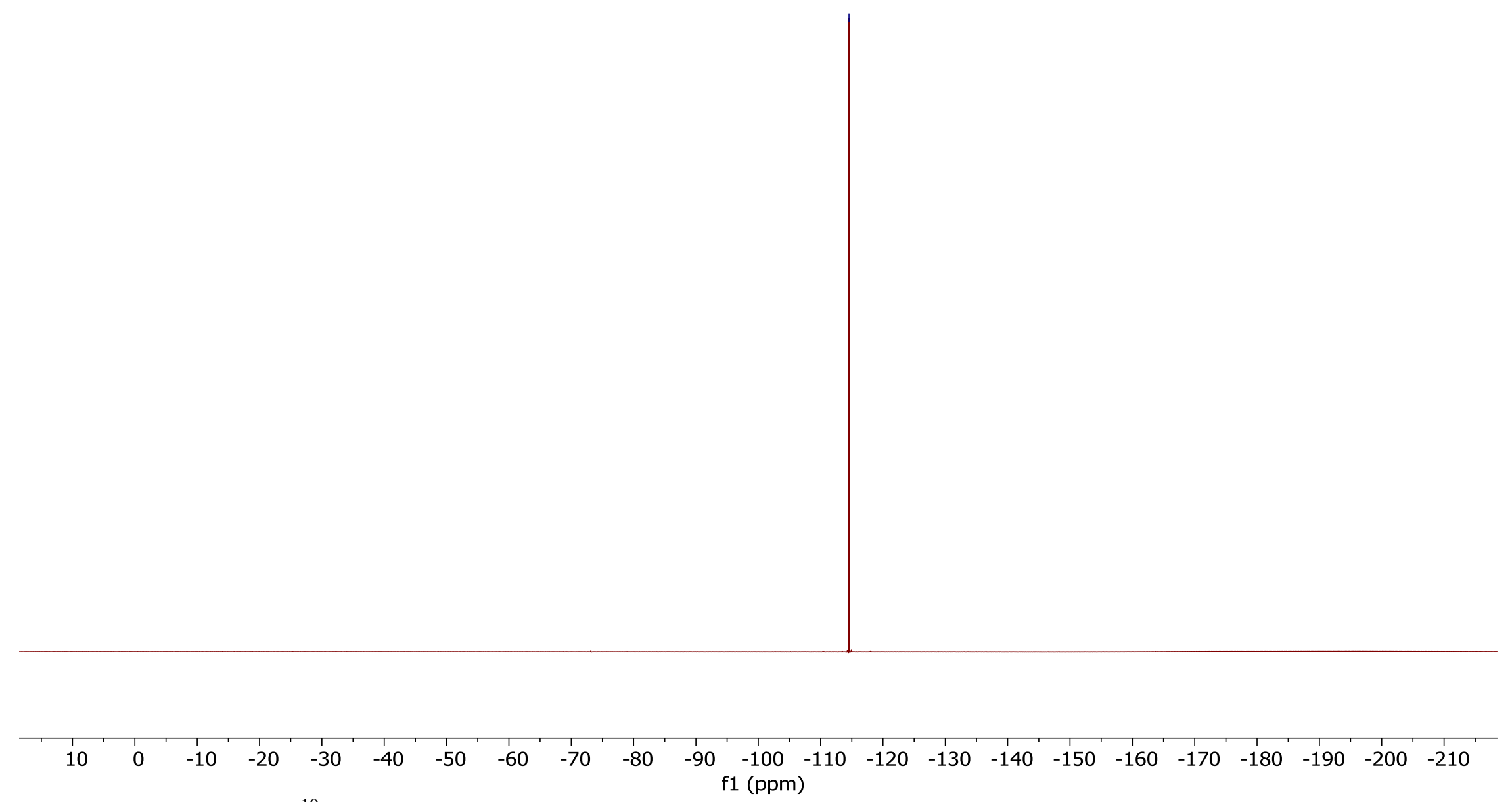

Compound 3g: $376 \mathrm{MHz}{ }^{19} \mathrm{~F}$ NMR spectrum in $\mathrm{CDCl}_{3}$ 


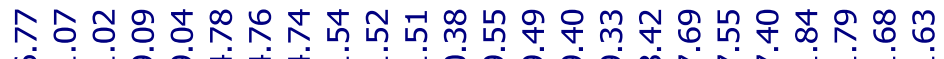

它

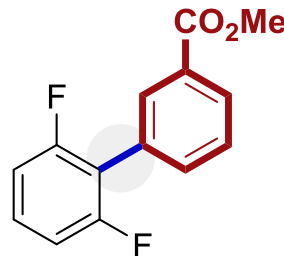

3g $85 \%(68 \%)$
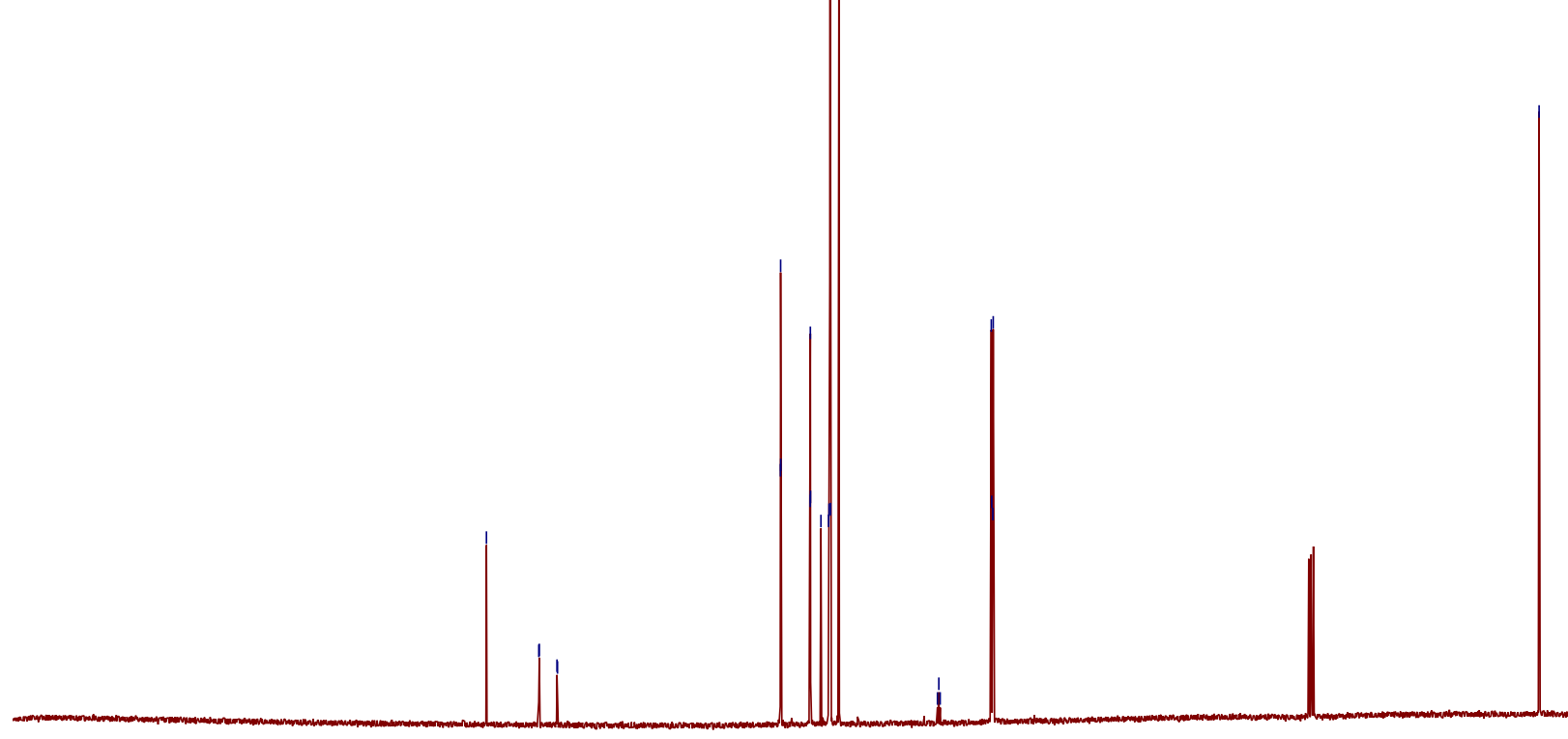

$\begin{array}{lllllllll}210 & 200 & 190 & 180 & 170 & 160 & 150 & 140 & 130\end{array}$ Compound 3g: $126 \mathrm{MHz}{ }^{13} \mathrm{C} \mathrm{NMR}$ spectrum in $\mathrm{CDCl}_{3}$ 
๖ํำ

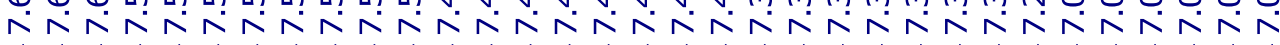

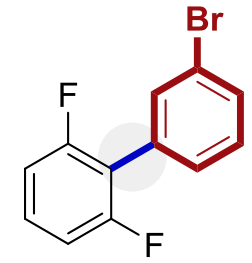

3h $64 \%(59 \%)$
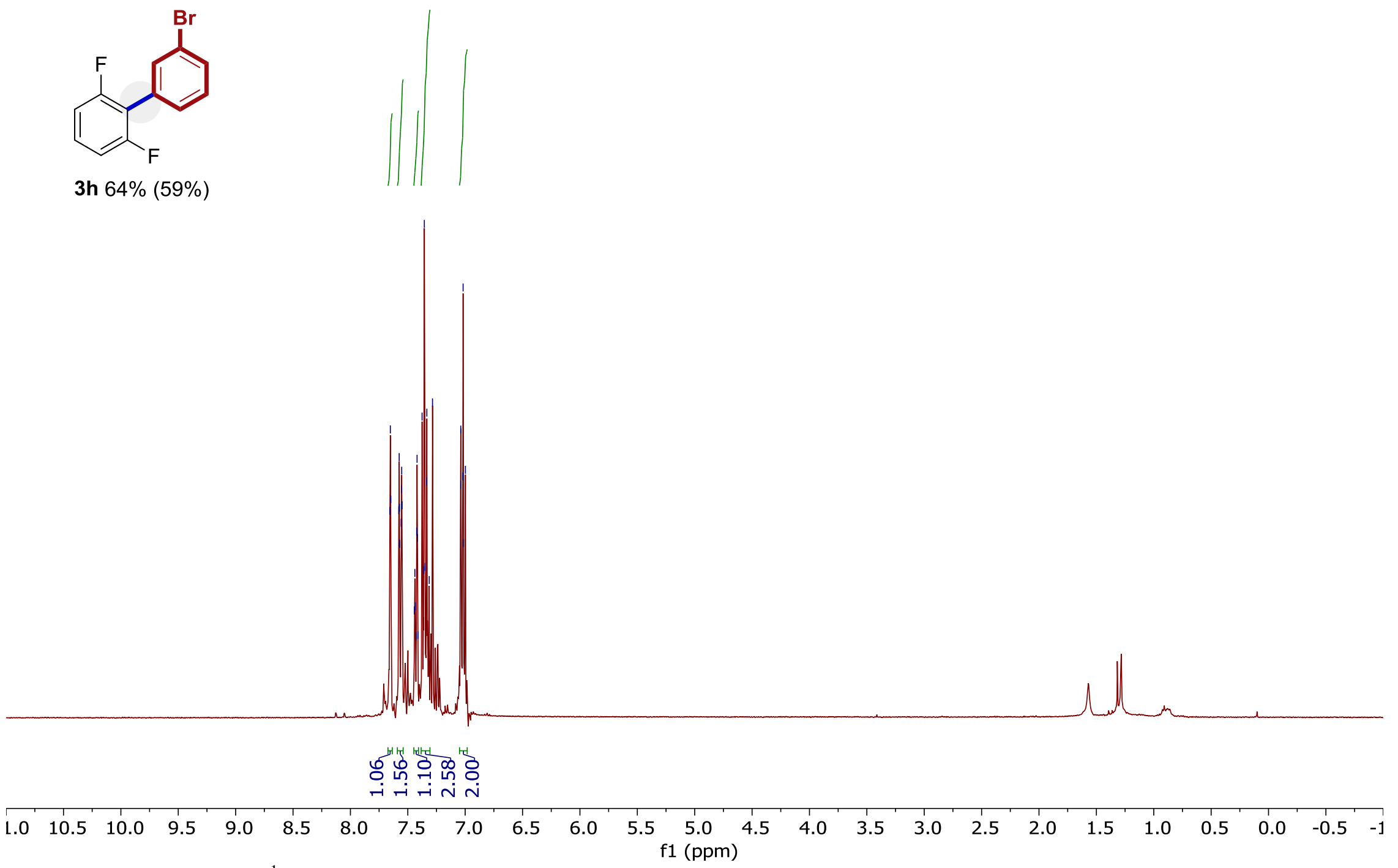

Compound 3h: $400 \mathrm{MHz}{ }^{1} \mathrm{H}$ NMR spectrum in $\mathrm{CDCl}_{3}$ 


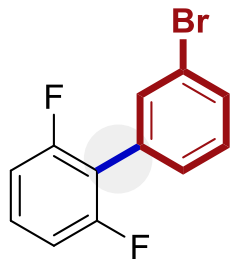

3h $64 \%(59 \%)$

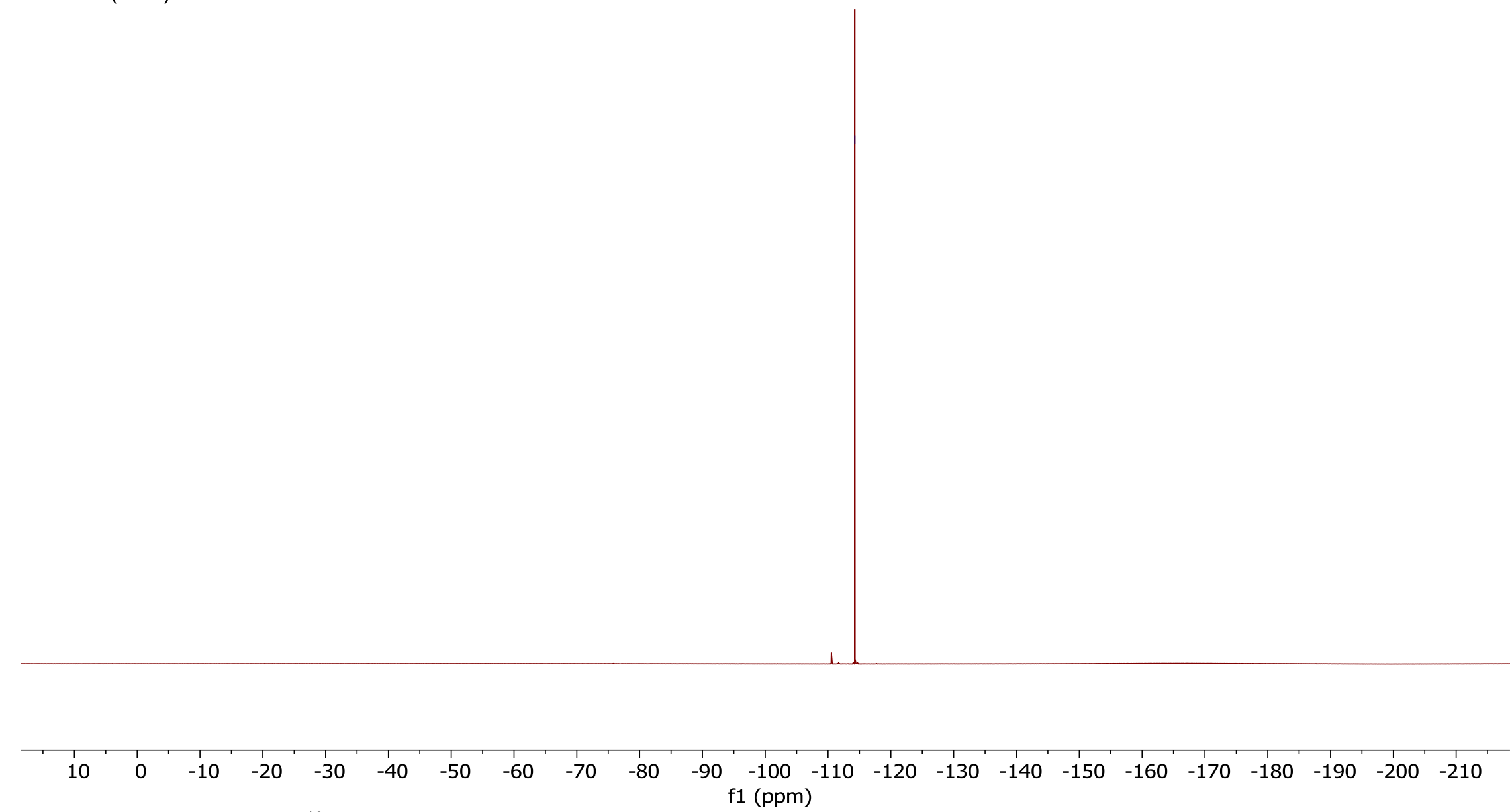

Compound 3h: $376 \mathrm{MHz}{ }^{19} \mathrm{~F}$ NMR spectrum in $\mathrm{CDCl}_{3}$ 


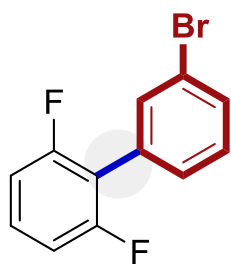

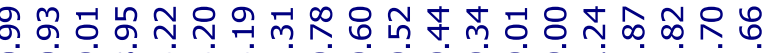

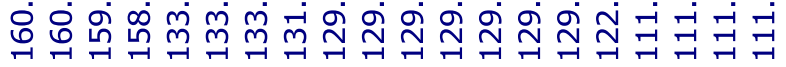

3h $64 \%(59 \%)$

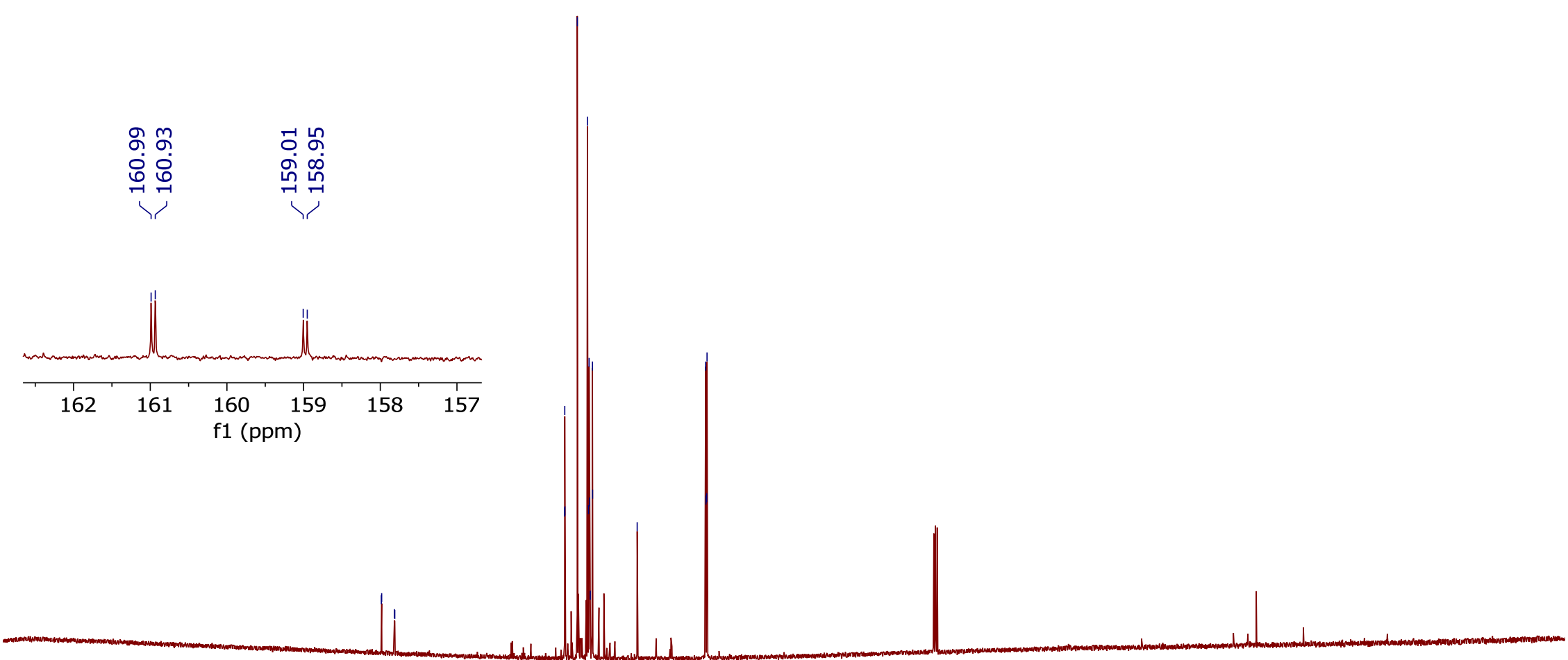

$\begin{array}{lllllllllllllllllllllll}210 & 200 & 190 & 180 & 170 & 160 & 150 & 140 & 130 & 120 & 110 & \begin{array}{c}100 \\ \mathrm{f} 1(\mathrm{ppm})\end{array} & 90 & 80 & 70 & 60 & 50 & 40 & 30 & 20 & 10 & 0 & -10\end{array}$ Compound 3h: $126 \mathrm{MHz}{ }^{13} \mathrm{C}$ NMR spectrum in $\mathrm{CDCl}_{3}$ 


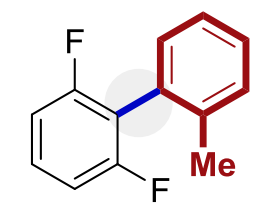

3i $59 \%$ (53\%)

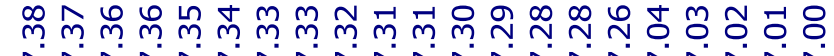

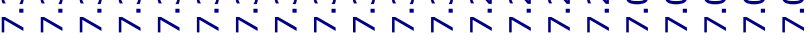

run
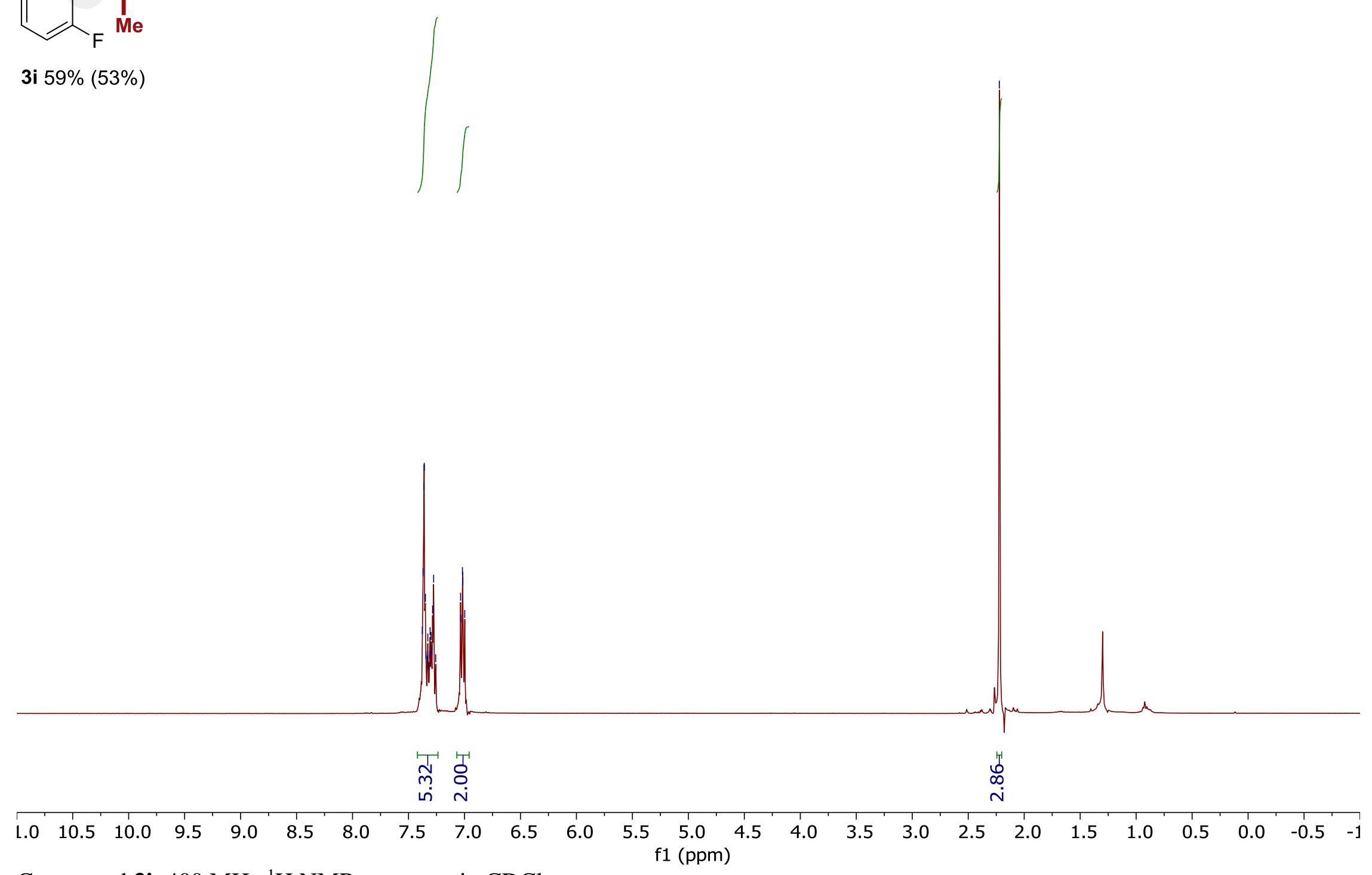

Compound 3i: $400 \mathrm{MHz}{ }^{1} \mathrm{H}$ NMR spectrum in $\mathrm{CDCl}_{3}$ 


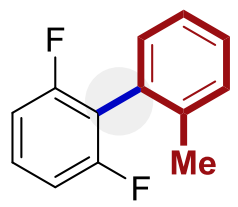

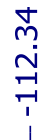

3i $59 \%(53 \%)$

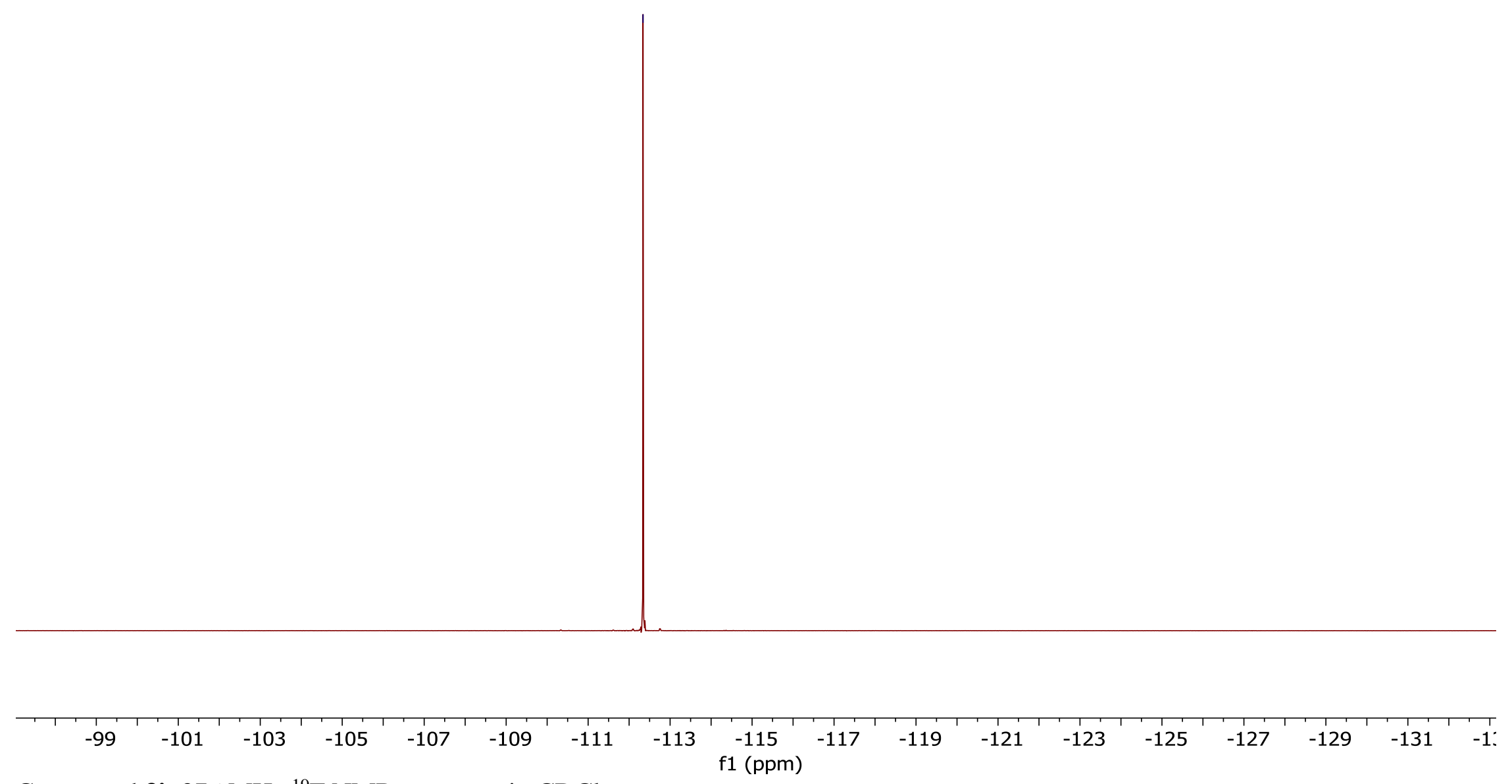

Compound 3i: $376 \mathrm{MHz}{ }^{19} \mathrm{~F}$ NMR spectrum in $\mathrm{CDCl}_{3}$ 


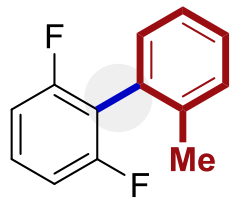

3i $59 \%$ (53\%)

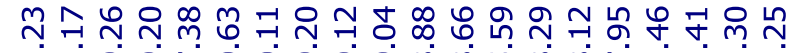

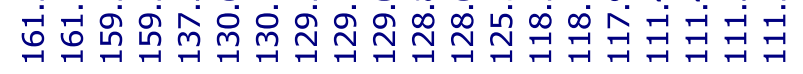

开 $\stackrel{2}{1}$

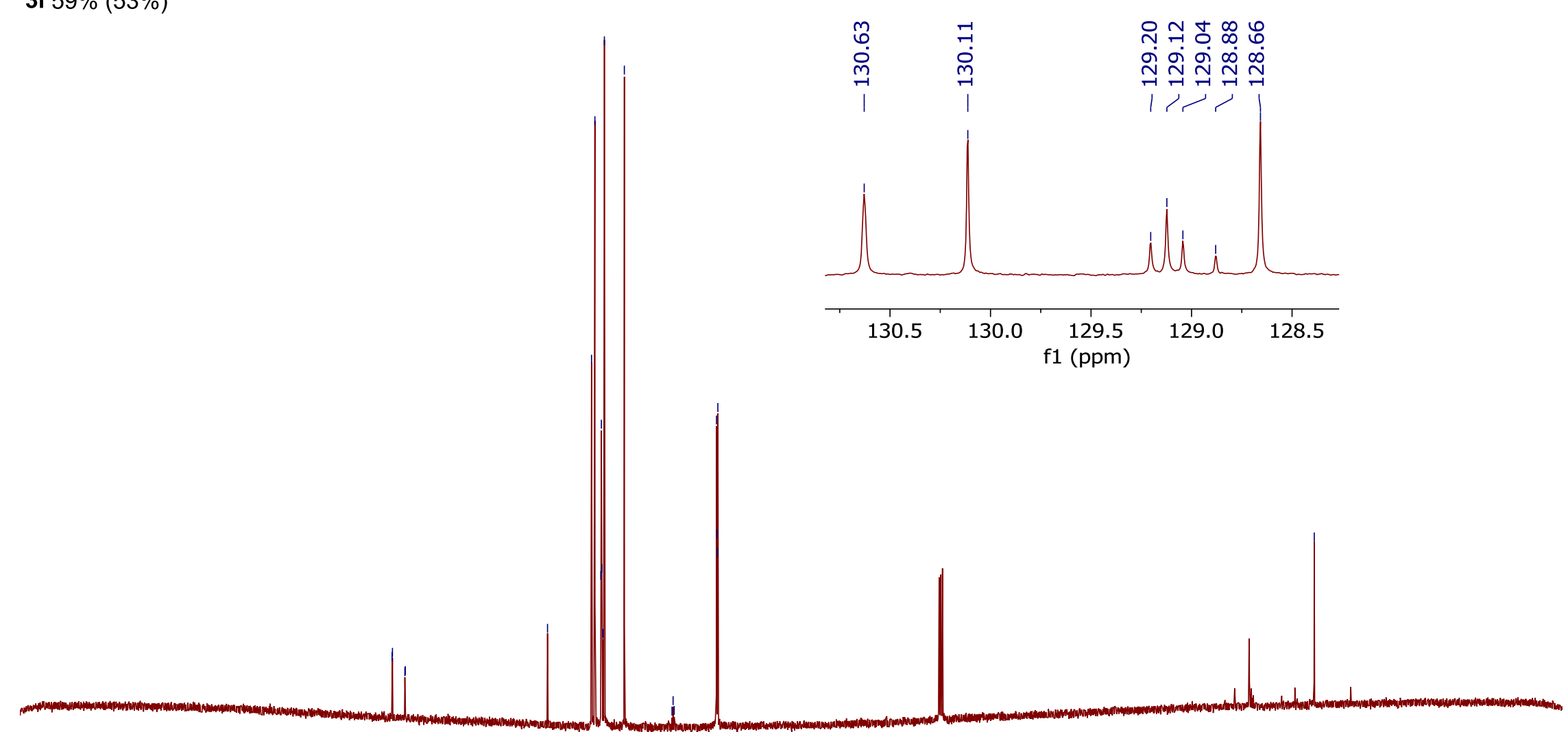

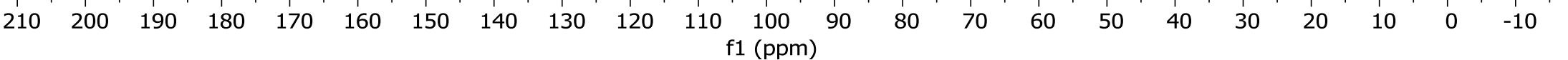
Compound 3i: $126 \mathrm{MHz}{ }^{13} \mathrm{C}$ NMR spectrum in $\mathrm{CDCl}_{3}$ 


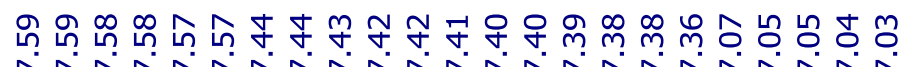

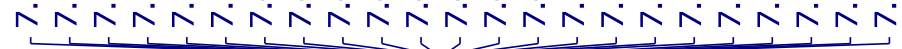

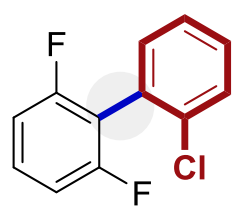

3j n.d. (79\%)

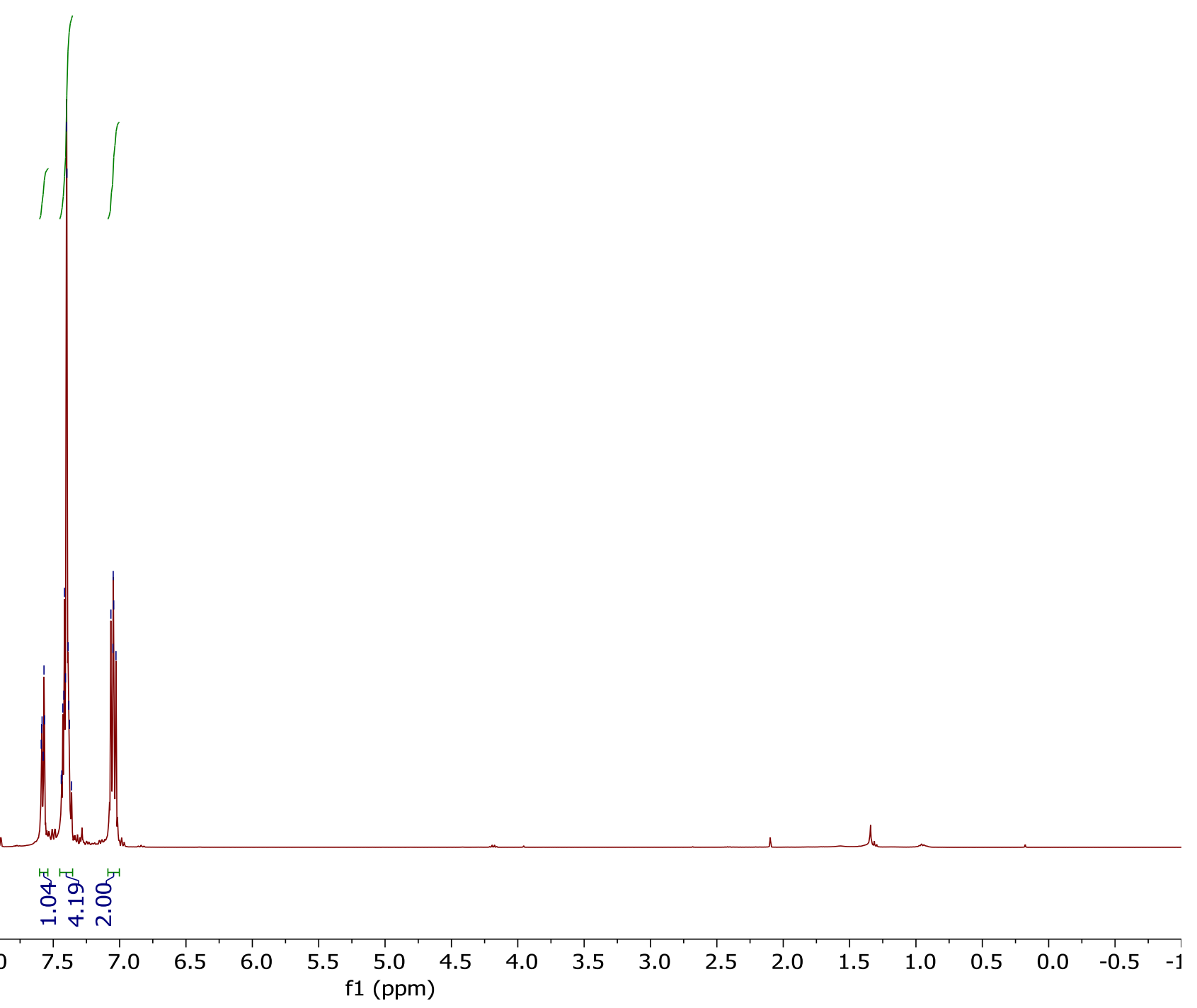

Compound 3j: $400 \mathrm{MHz}{ }^{1} \mathrm{H}$ NMR spectrum in $\mathrm{CDCl}_{3}$ 


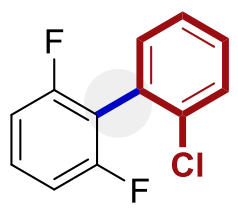

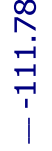

3j n.d. (79\%)

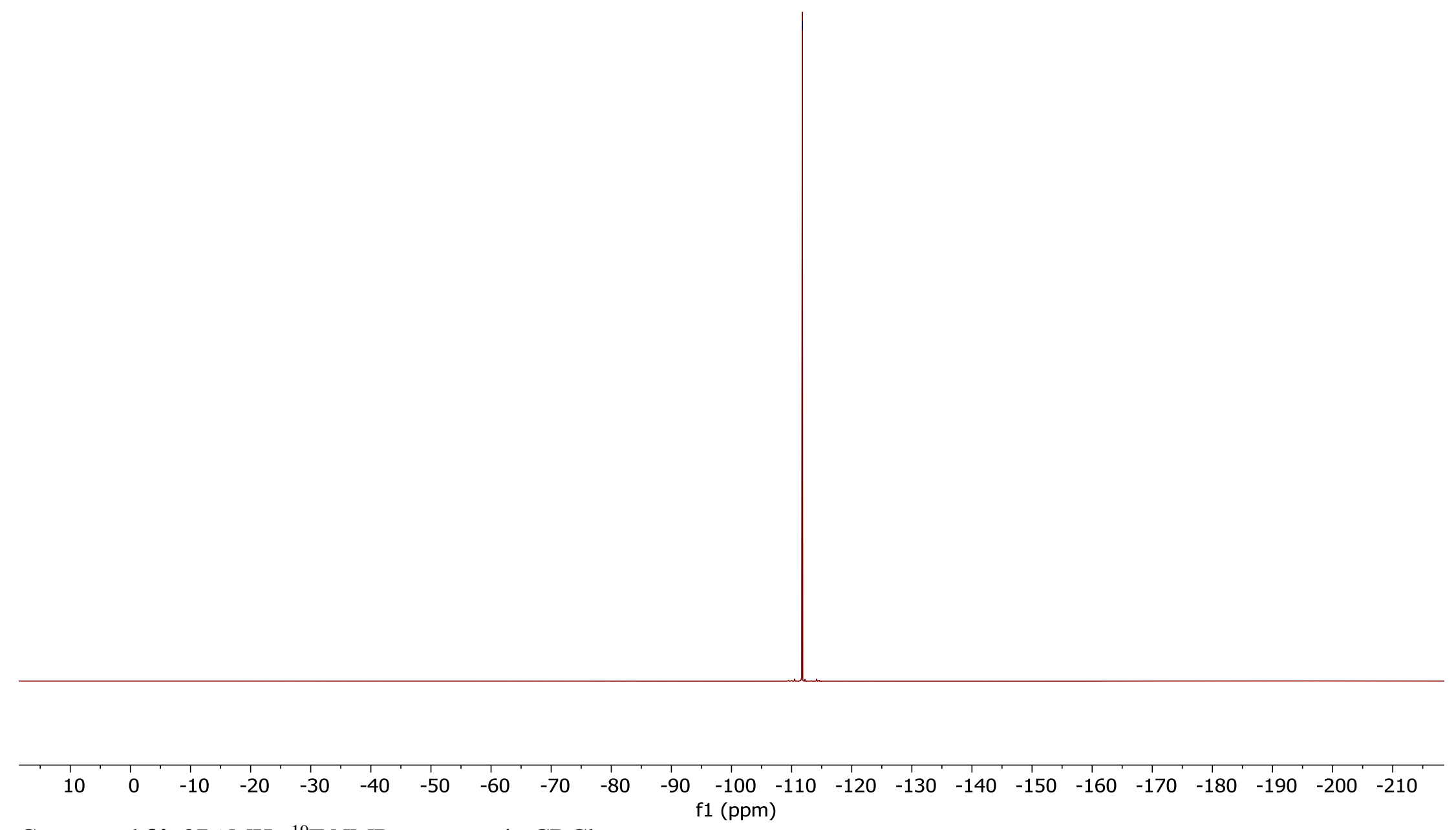

Compound 3j: $376 \mathrm{MHz}{ }^{19} \mathrm{~F}$ NMR spectrum in $\mathrm{CDCl}_{3}$ 


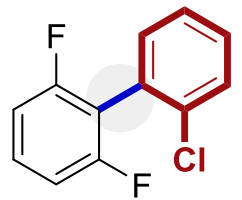

3j n.d. (79\%)

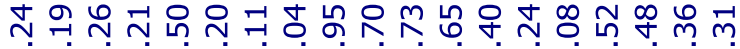

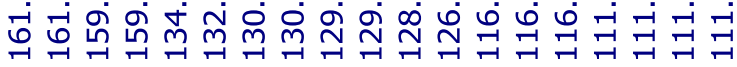

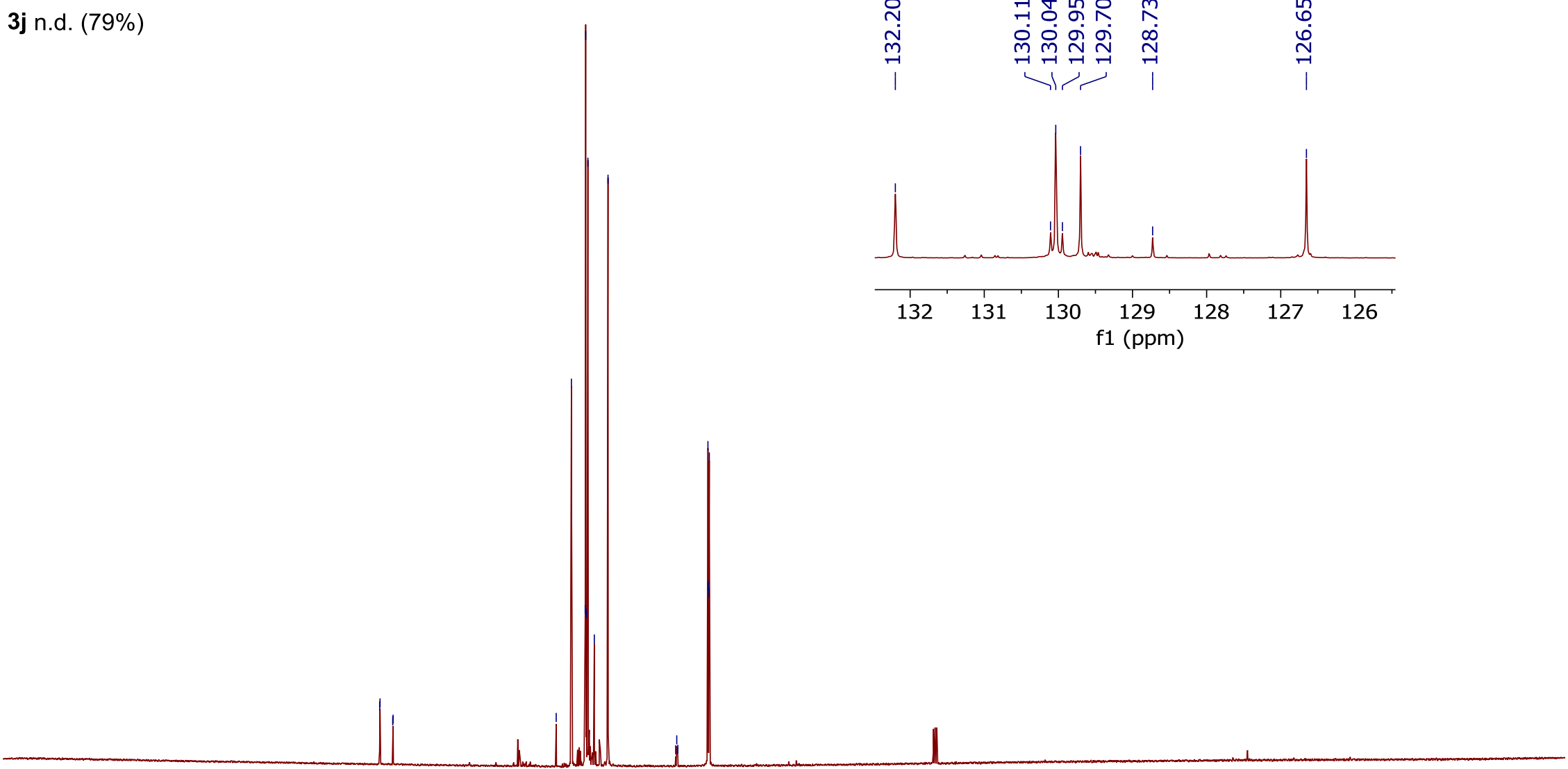

$\begin{array}{lllllllllllllllllllllll}210 & 200 & 190 & 180 & 170 & 160 & 150 & 140 & 130 & 120 & 110 & \begin{array}{c}100 \\ \mathrm{f} 1(\mathrm{ppm})\end{array} & 90 & 80 & 70 & 60 & 50 & 40 & 30 & 20 & 10 & 0 & -10\end{array}$ Compound 3j: $126 \mathrm{MHz}{ }^{13} \mathrm{C}$ NMR spectrum in $\mathrm{CDCl}_{3}$ 


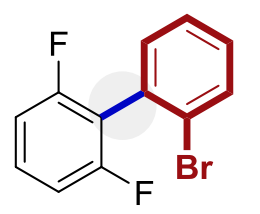

3k $75 \%(78 \%)$
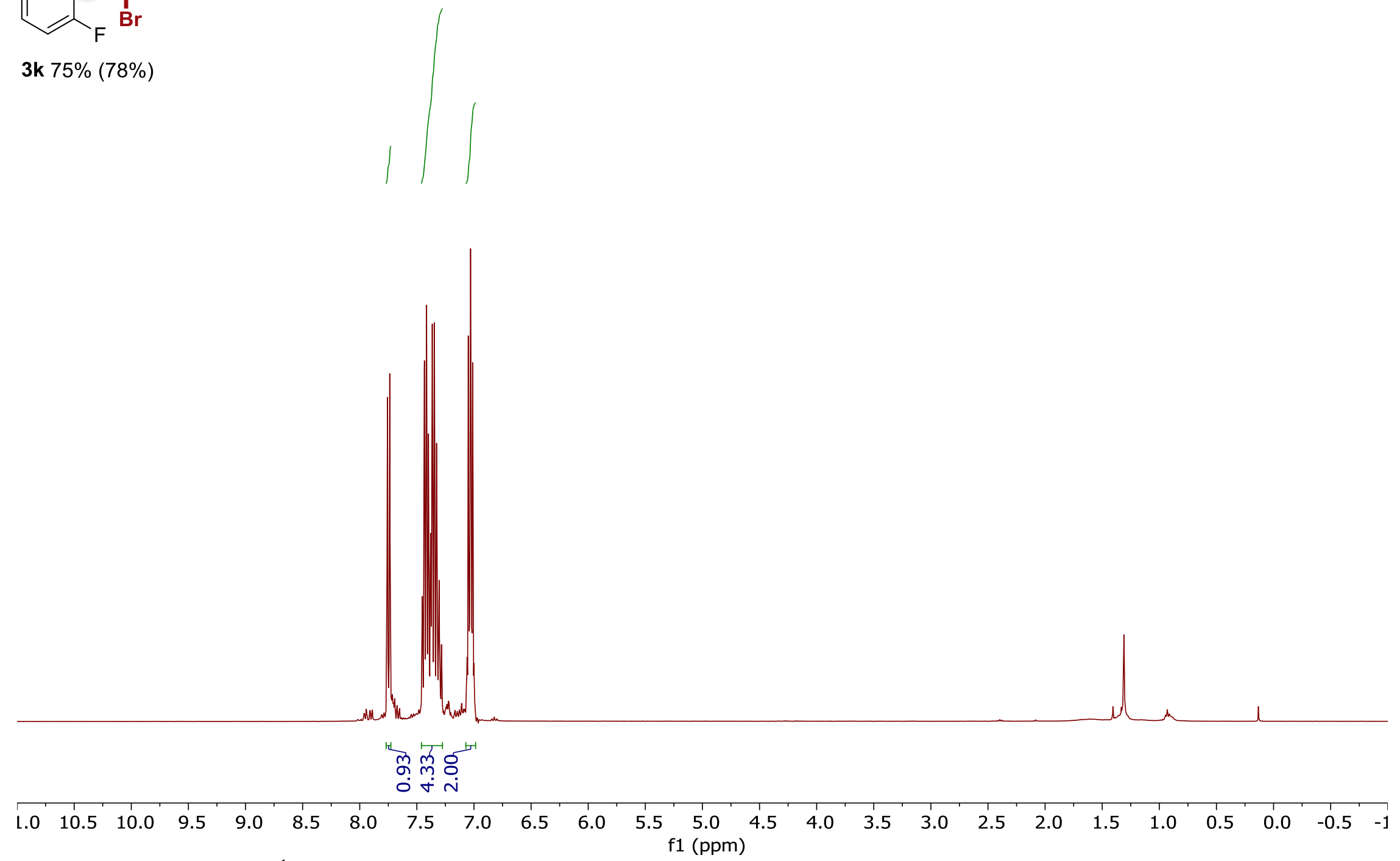

Compound 3k: $400 \mathrm{MHz}{ }^{1} \mathrm{H}$ NMR spectrum in $\mathrm{CDCl}_{3}$ 


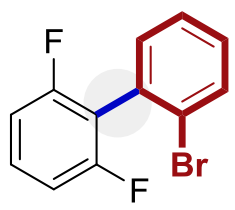

\begin{tabular}{c}
$\infty$ \\
\multirow{1}{7}{} \\
$\stackrel{1}{1}$ \\
1
\end{tabular}

3k $75 \%(78 \%)$

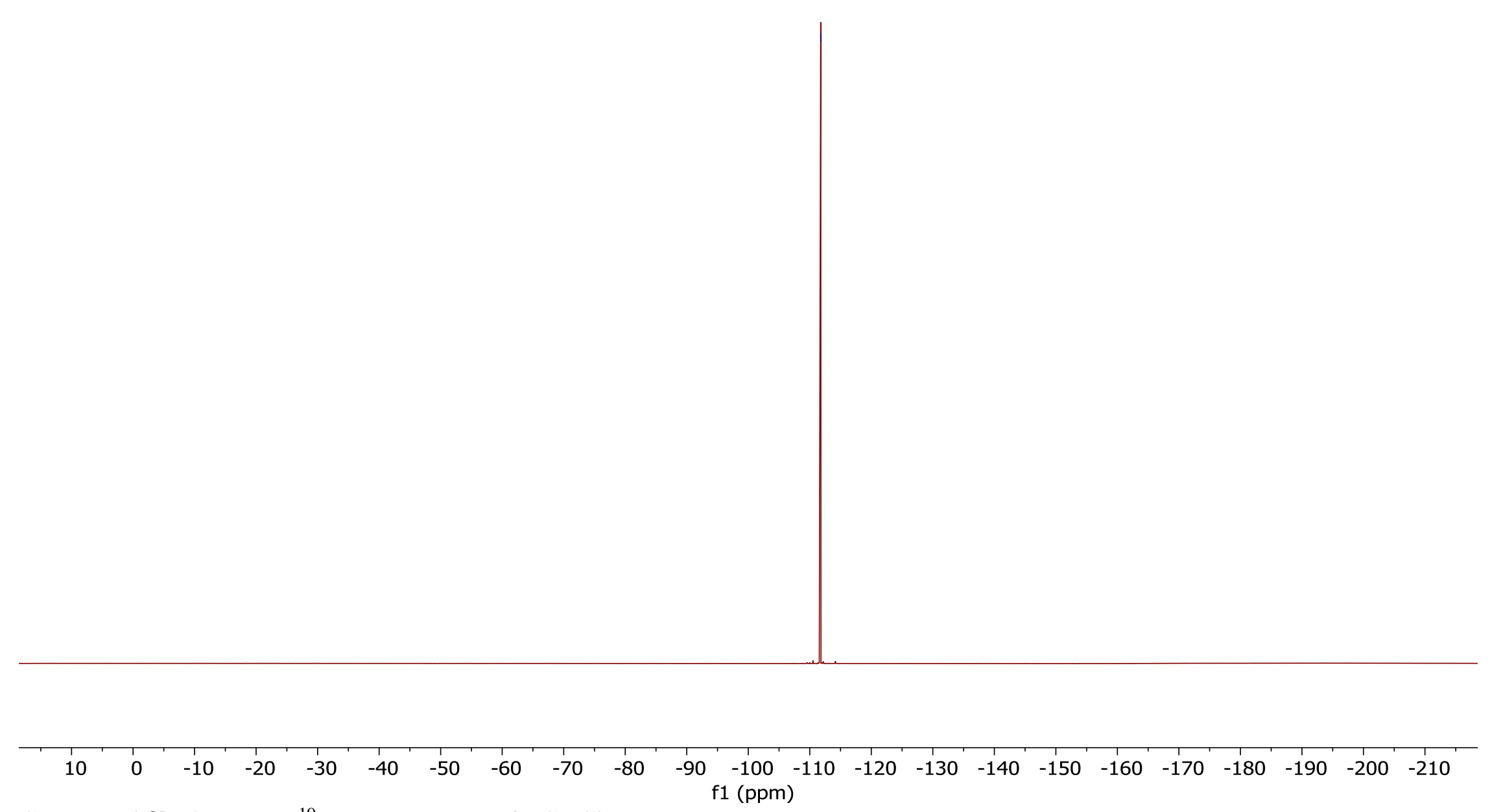

Compound 3k: $376 \mathrm{MHz}{ }^{19} \mathrm{~F}$ NMR spectrum in $\mathrm{CDCl}_{3}$ 


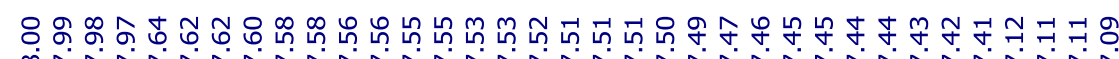

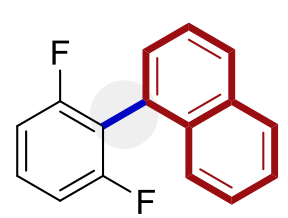

3I n.d. (84\%)
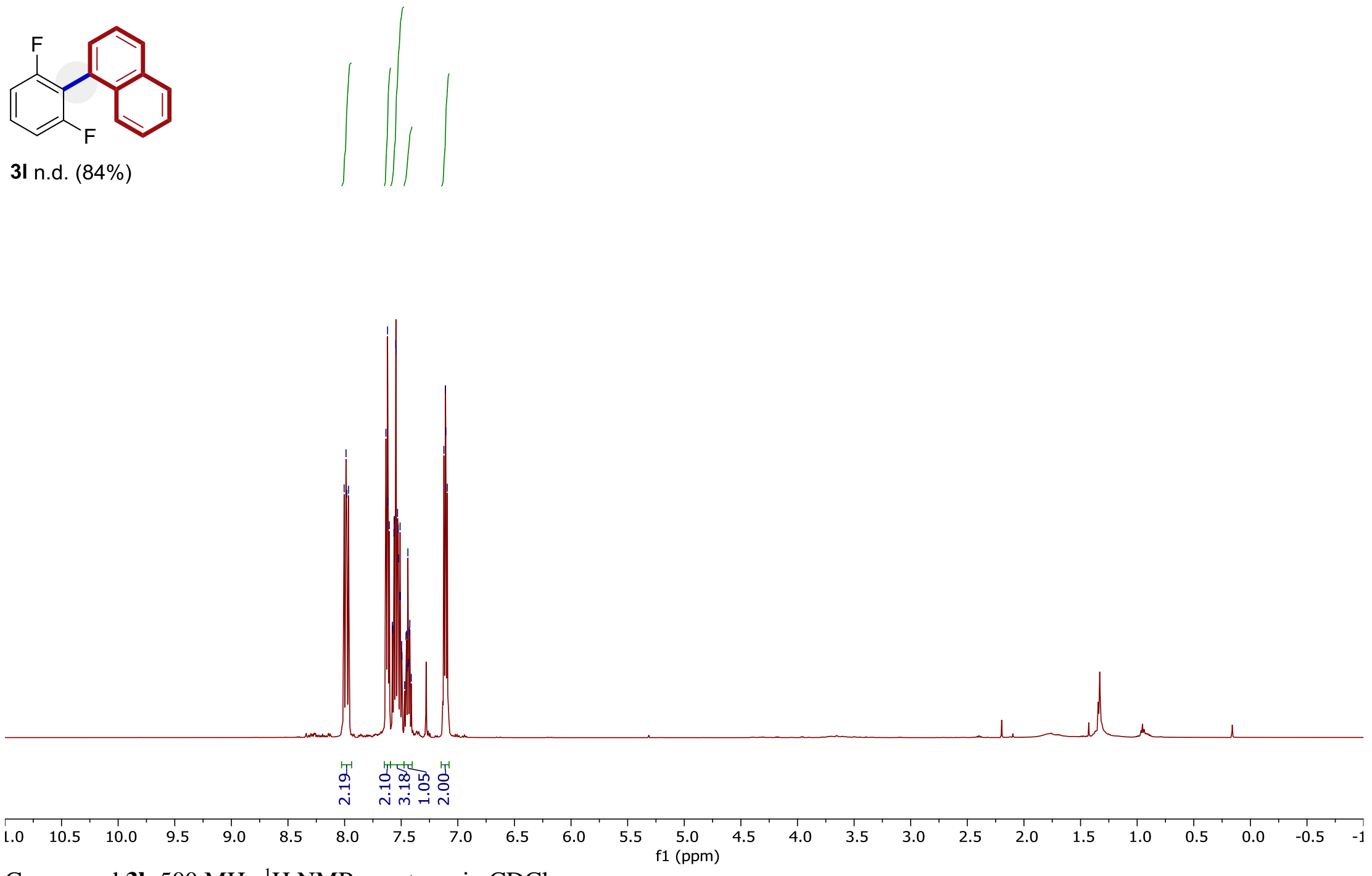

Compound 3I: $500 \mathrm{MHz}{ }^{1} \mathrm{H}$ NMR spectrum in $\mathrm{CDCl}_{3}$ 


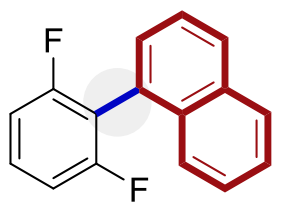

3 I n.d. (84\%)

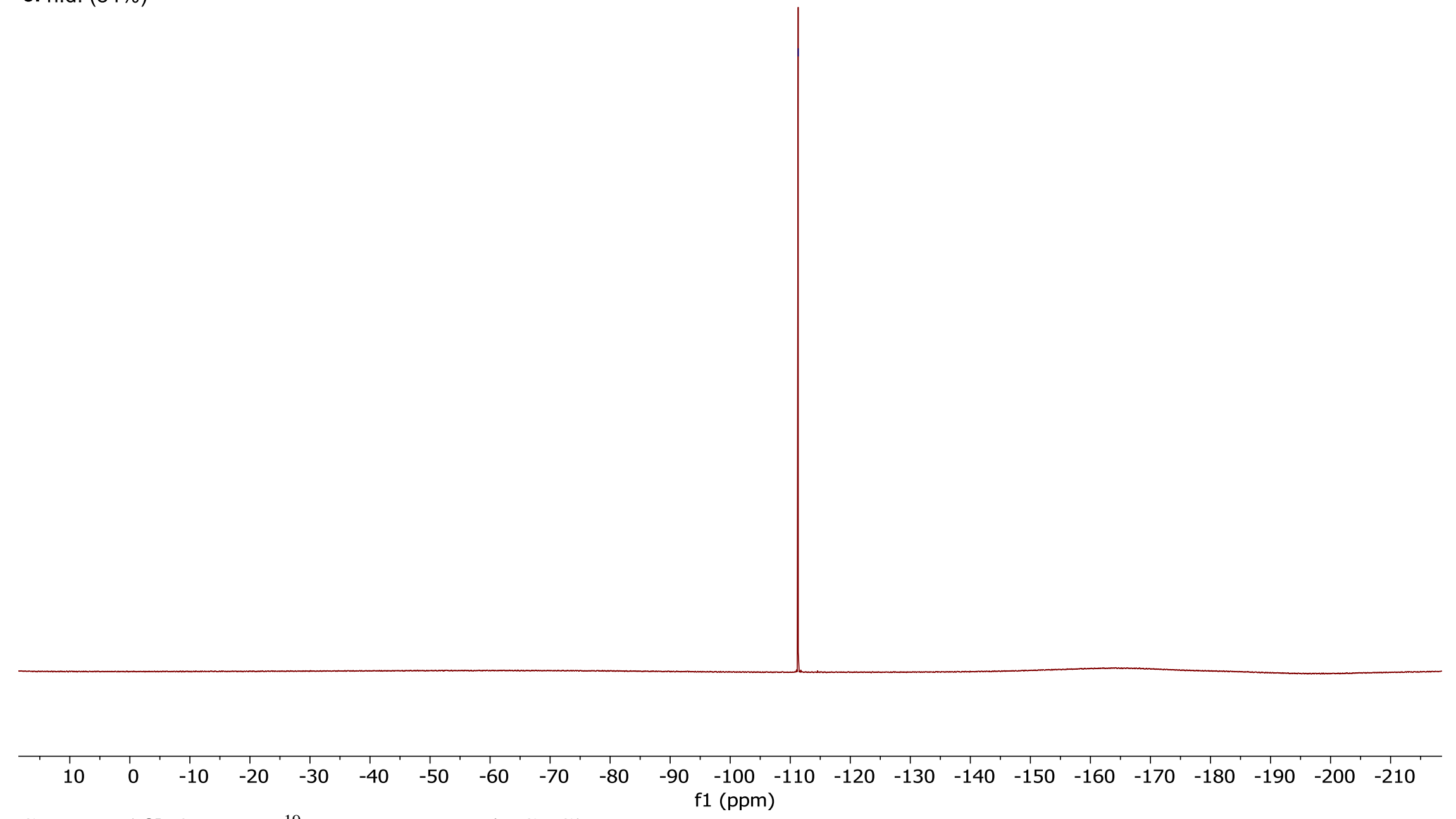

Compound 3l: $376 \mathrm{MHz}{ }^{19} \mathrm{~F}$ NMR spectrum in $\mathrm{CDCl}_{3}$ 


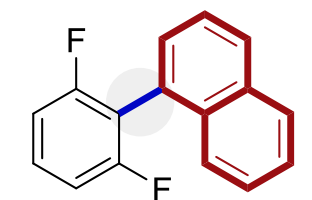

$3 \mathrm{I}$ n.d. (84\%)

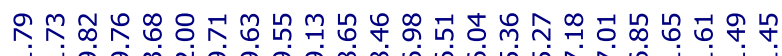

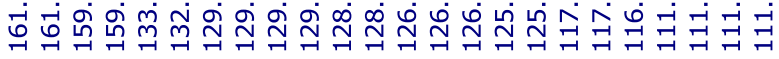

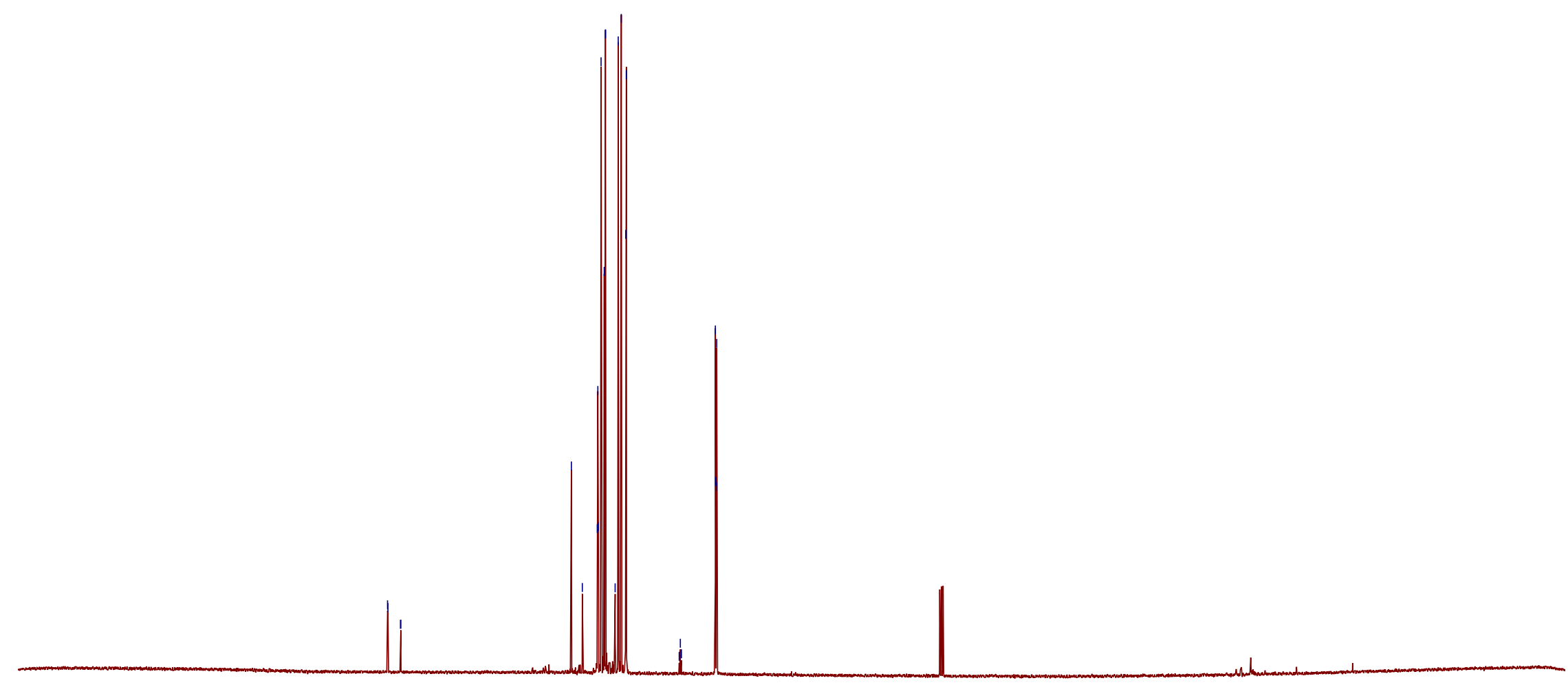

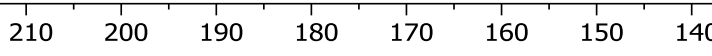

$130 \quad 120$

$110 \quad 100$

$90 \quad 80$

$80 \quad 70$

$60 \quad 50$

$30 \quad 20$

Compound 3I: $126 \mathrm{MHz}{ }^{13} \mathrm{C} \mathrm{NMR}$ spectrum in $\mathrm{CDCl}_{3}$ 


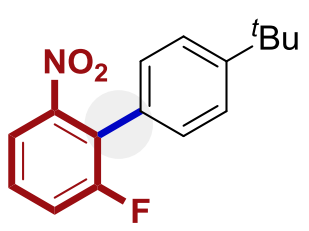

3m 96\% (93\%)
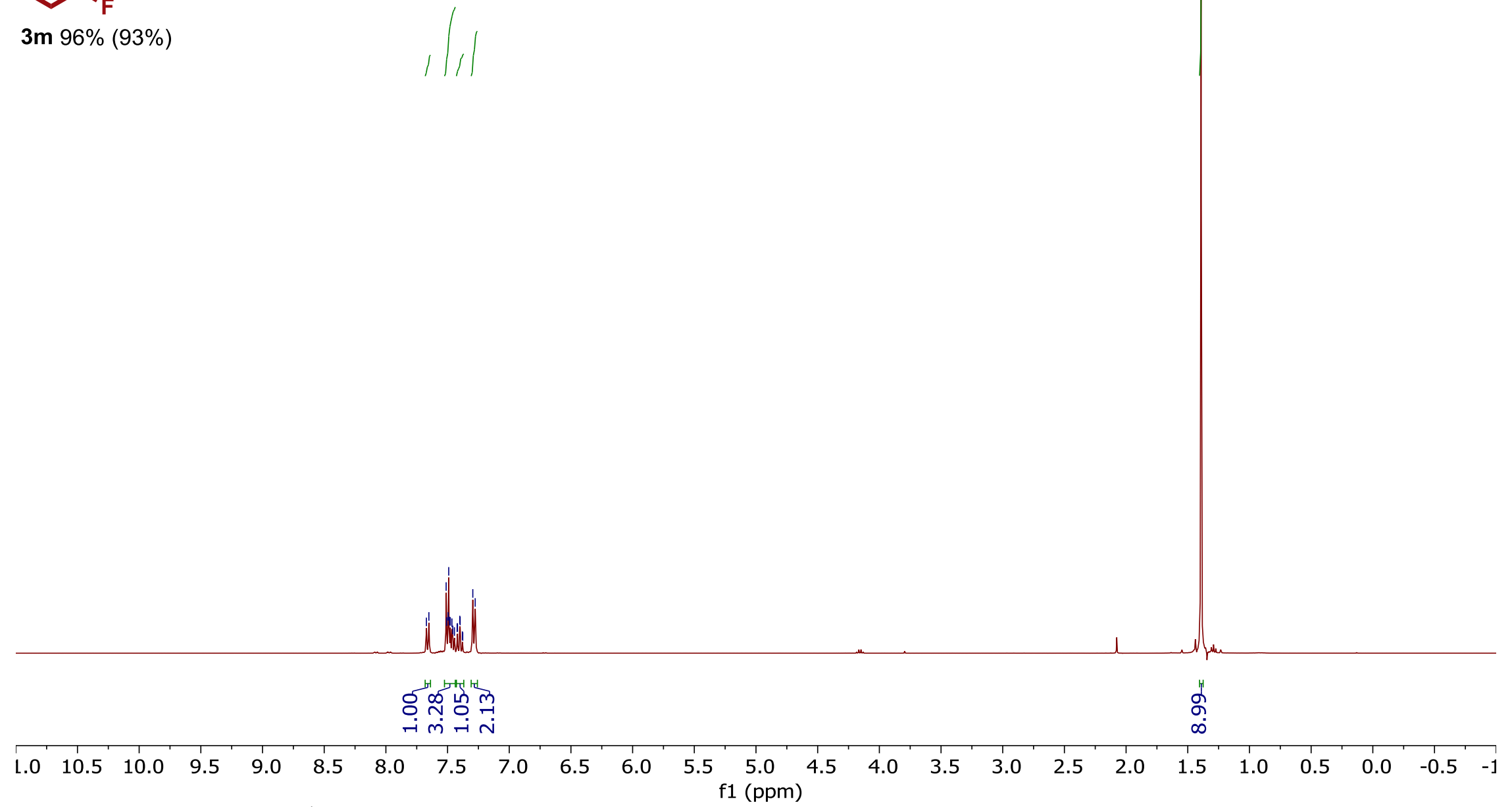

Compound 3m: $400 \mathrm{MHz}{ }^{1} \mathrm{H}$ NMR spectrum in $\mathrm{CDCl}_{3}$ 


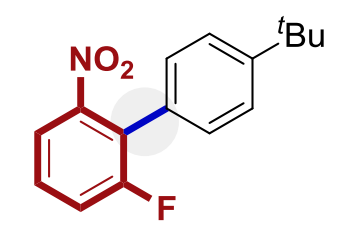

$3 \mathrm{~m} \mathrm{96 \%} \mathrm{(93 \% )}$

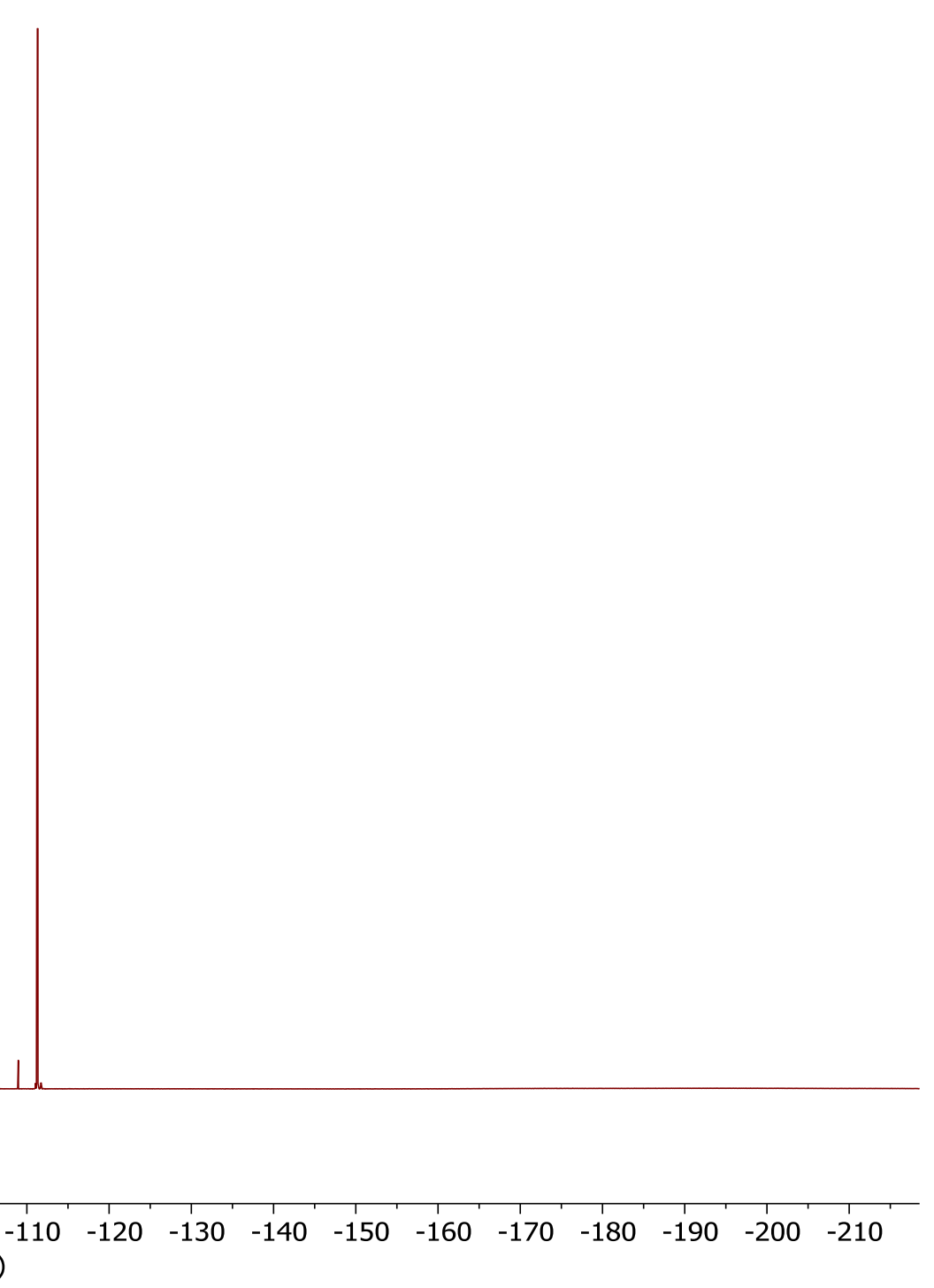

Compound 3m: $376 \mathrm{MHz}{ }^{19} \mathrm{~F}$ NMR spectrum in $\mathrm{CDCl}_{3}$ 


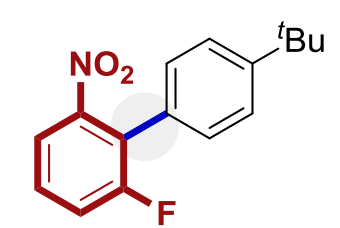

$3 \mathrm{~m}$ 96\% (93\%)
ఐ

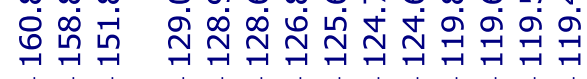

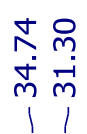

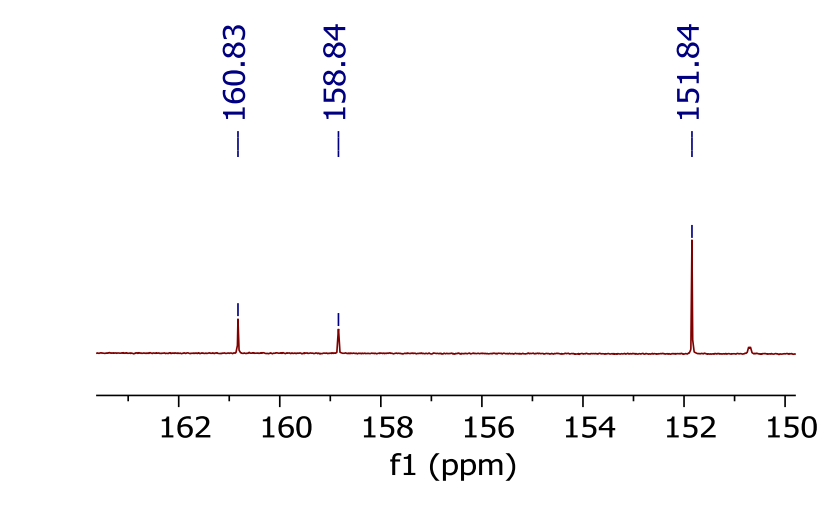

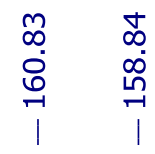

$\begin{array}{llllllll}210 & 200 & 190 & 180 & 170 & 160 & 150 & 140\end{array}$

130

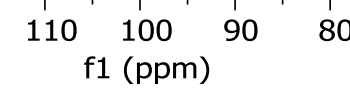

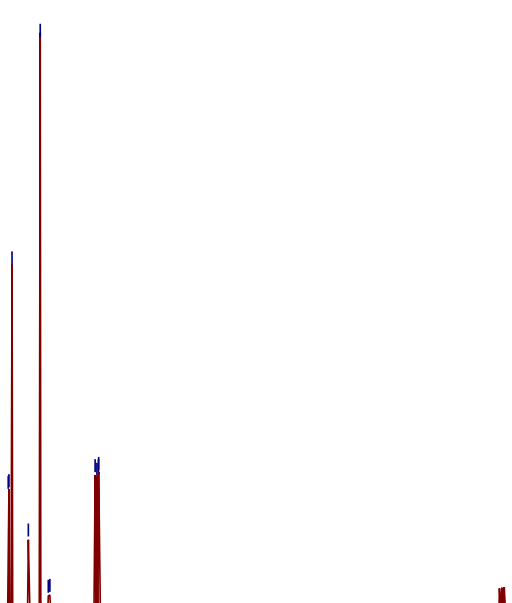

Compound 3m: $126 \mathrm{MHz}{ }^{13} \mathrm{C}$ NMR spectrum in $\mathrm{CDCl}_{3}$ 


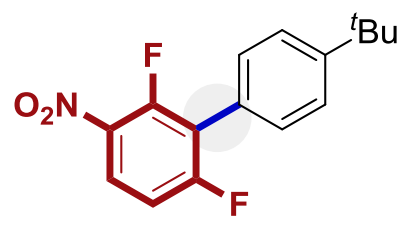

3n $80 \%(81 \%)$
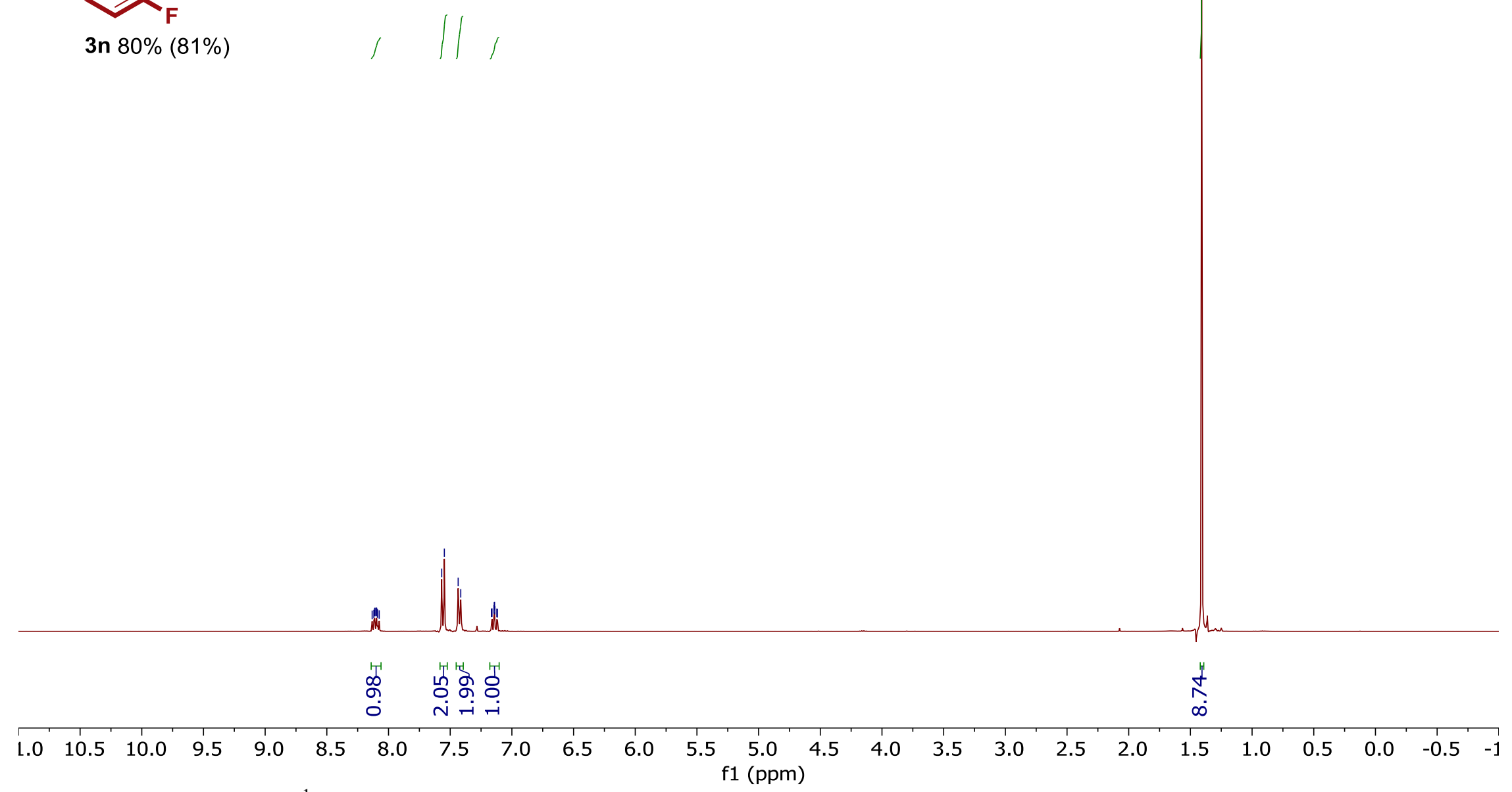

Compound 3n: $400 \mathrm{MHz}{ }^{1} \mathrm{H}$ NMR spectrum in $\mathrm{CDCl}_{3}$ 


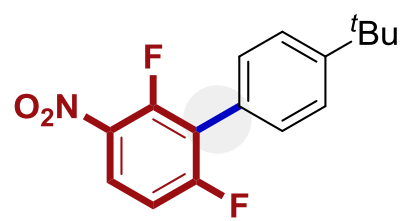

3n $80 \%$ (81\%)
จิ mำ ำ

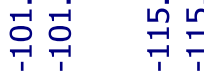

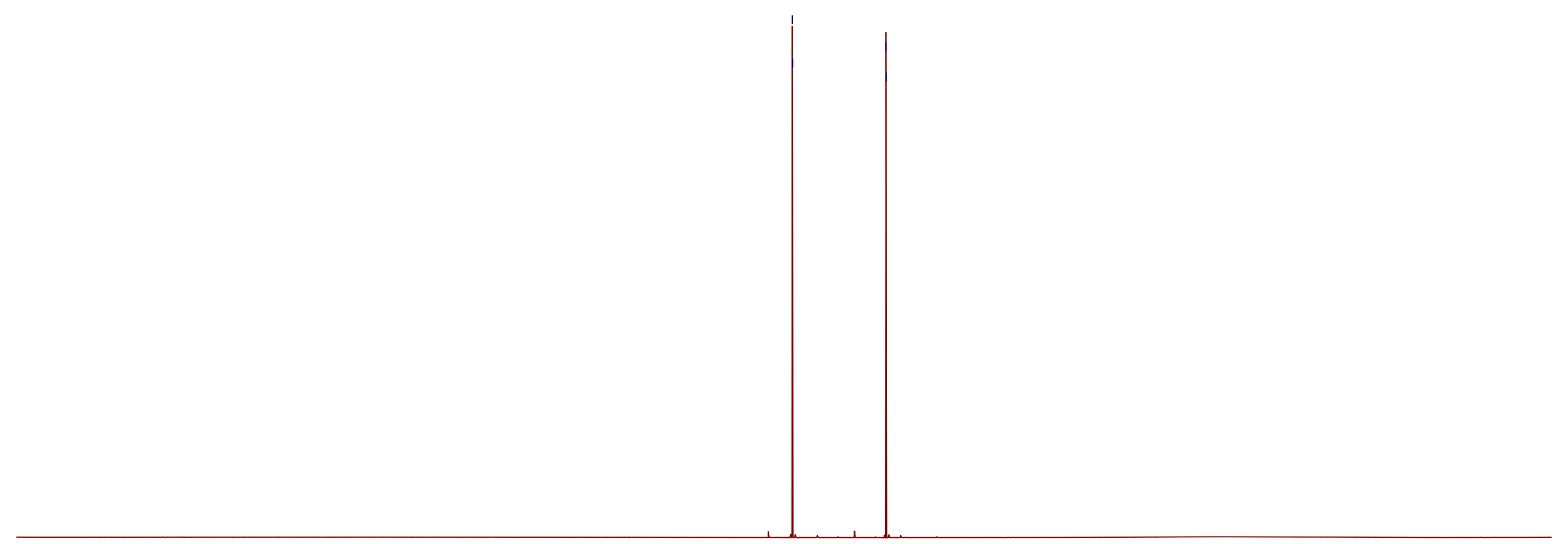

$\begin{array}{lllllllllllllllllllllllllllll}10 & 0 & -10 & -20 & -30 & -40 & -50 & -60 & -70 & -80 & -90 & -100 & -110 & -120 & -130 & -140 & -150 & -160 & -170 & -180 & -190 & -200 & -210\end{array}$ Compound 3n: $376 \mathrm{MHz}{ }^{19} \mathrm{~F}$ NMR spectrum in $\mathrm{CDCl}_{3}$ 

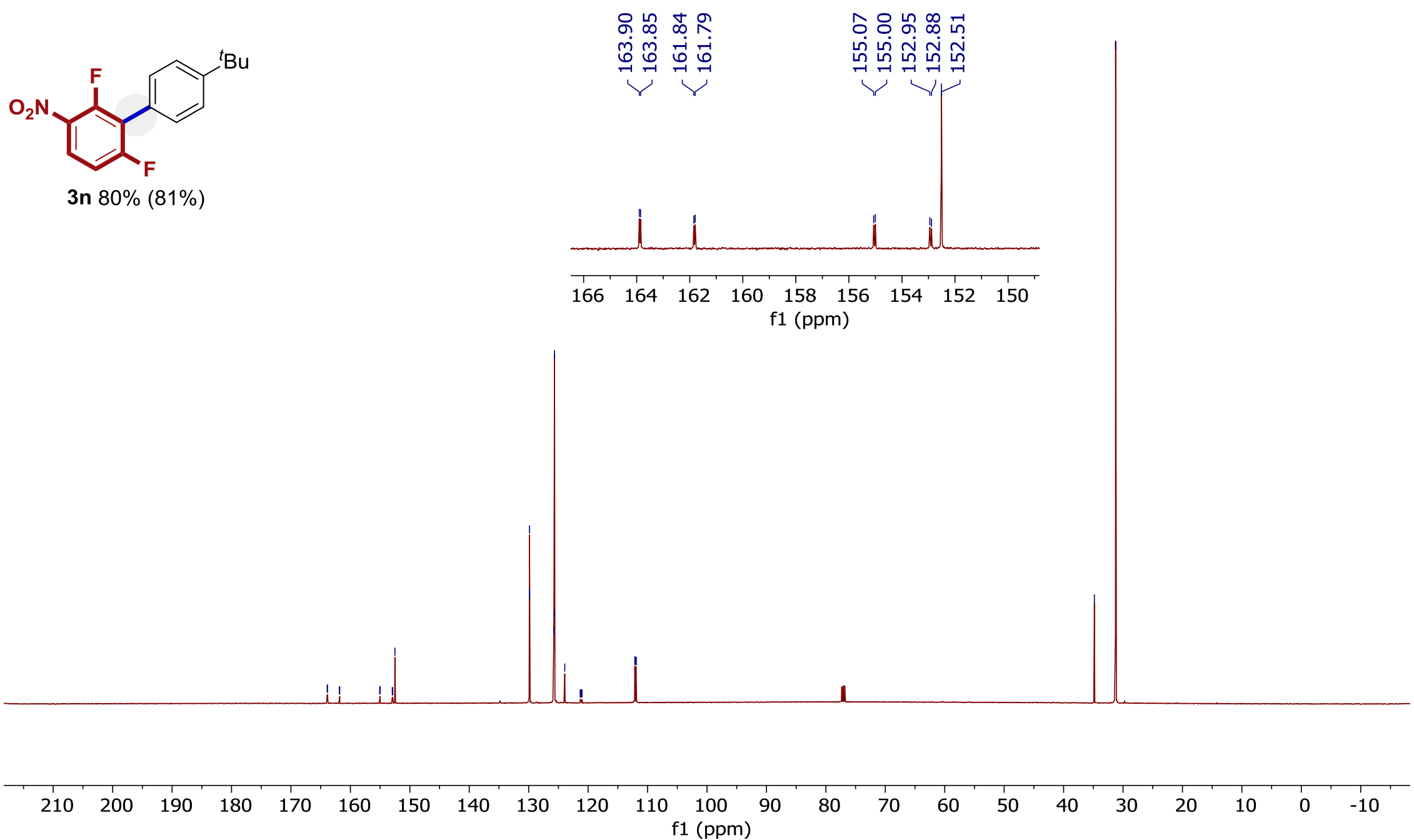

Compound 3n: $126 \mathrm{MHz}{ }^{13} \mathrm{C}$ NMR spectrum in $\mathrm{CDCl}_{3}$ 


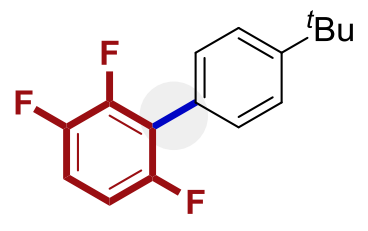

30 $90 \%(74 \%)$

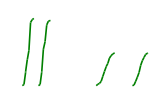

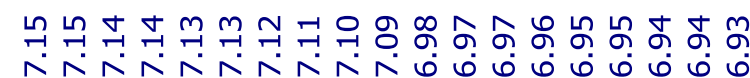

(n)

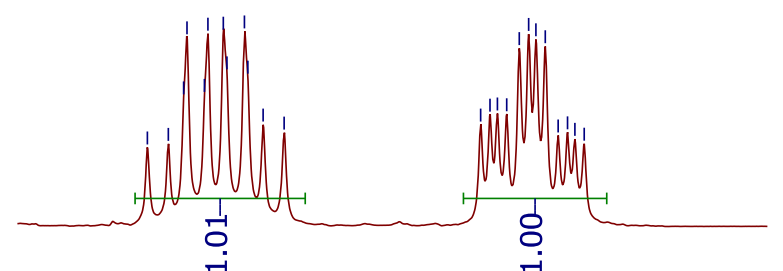

$\begin{array}{llllllll}7.20 & 7.15 & 7.10 & 7.05 & 7.00 & 6.95 & 6.90 & 6.85\end{array}$ $\mathrm{f} 1(\mathrm{ppm})$

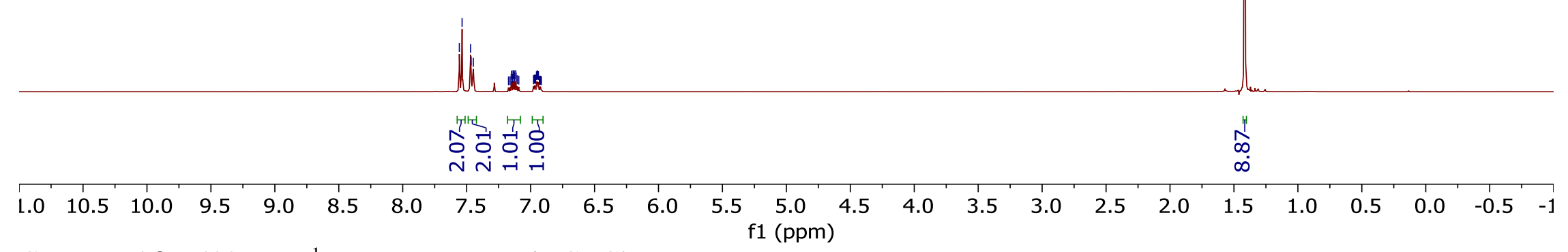

Compound 3o: $400 \mathrm{MHz}{ }^{1} \mathrm{H}$ NMR spectrum in $\mathrm{CDCl}_{3}$ 


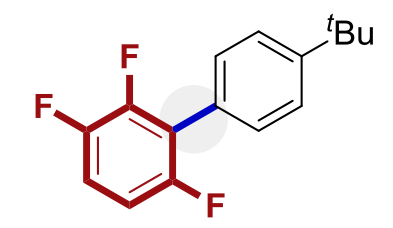

30 $90 \%(74 \%)$

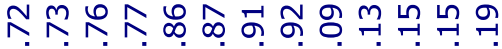

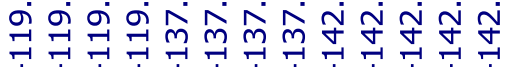

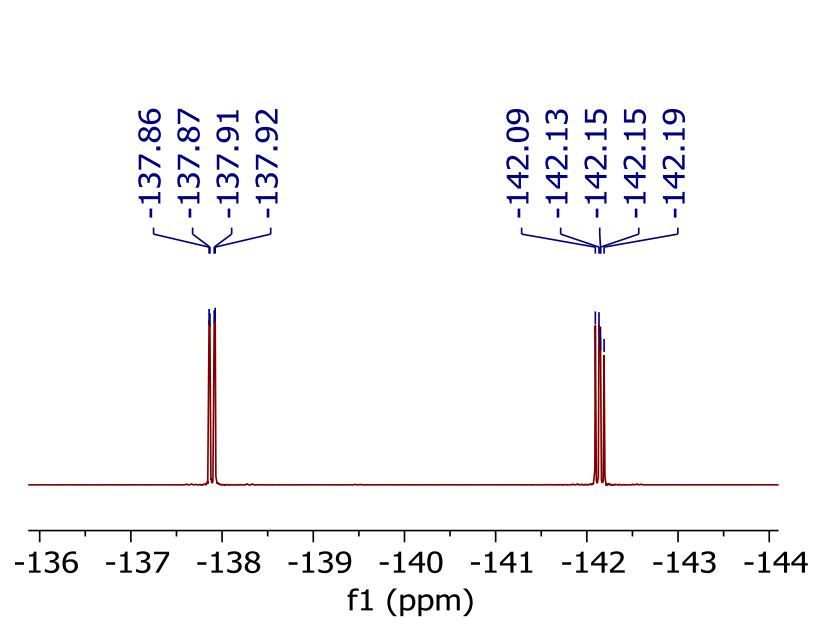

$\begin{array}{llllllllll}10 & 0 & -10 & -20 & -30 & -40 & -50 & -60 & -70 & -80\end{array}$

f1 (ppm)

Compound 3o: $376 \mathrm{MHz}{ }^{19} \mathrm{~F}$ NMR spectrum in $\mathrm{CDCl}_{3}$ 


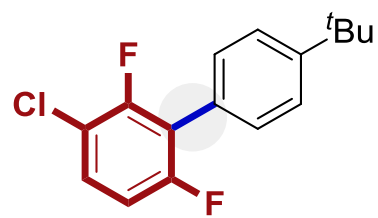

3p $91 \%(81 \%)$
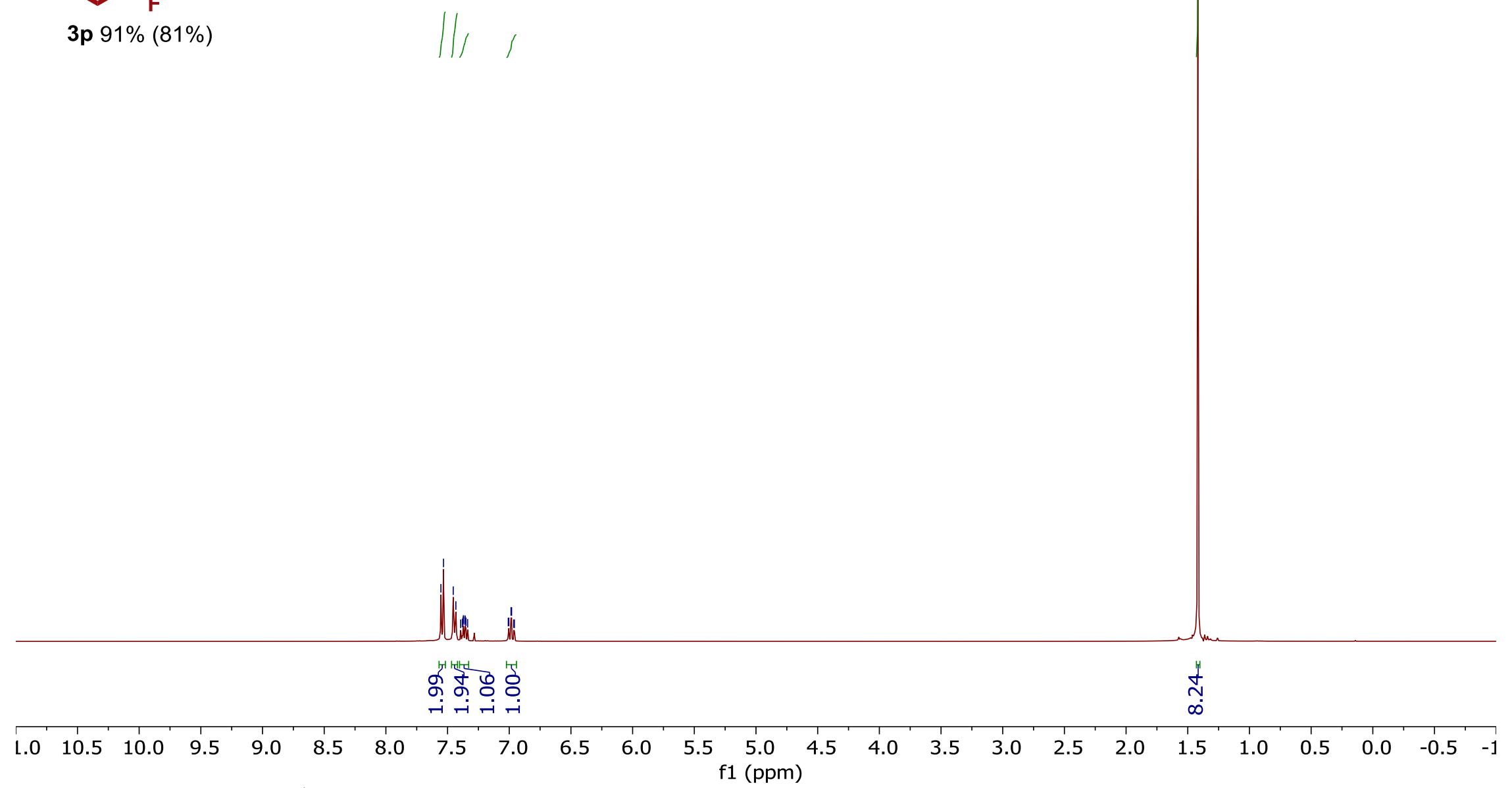

Compound 3p: $400 \mathrm{MHz}{ }^{1} \mathrm{H}$ NMR spectrum in $\mathrm{CDCl}_{3}$ 


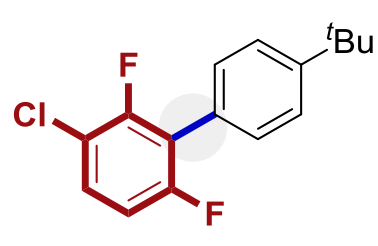

3p $91 \%$ (81\%)

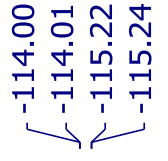

ㅇำ ㄴำ

777
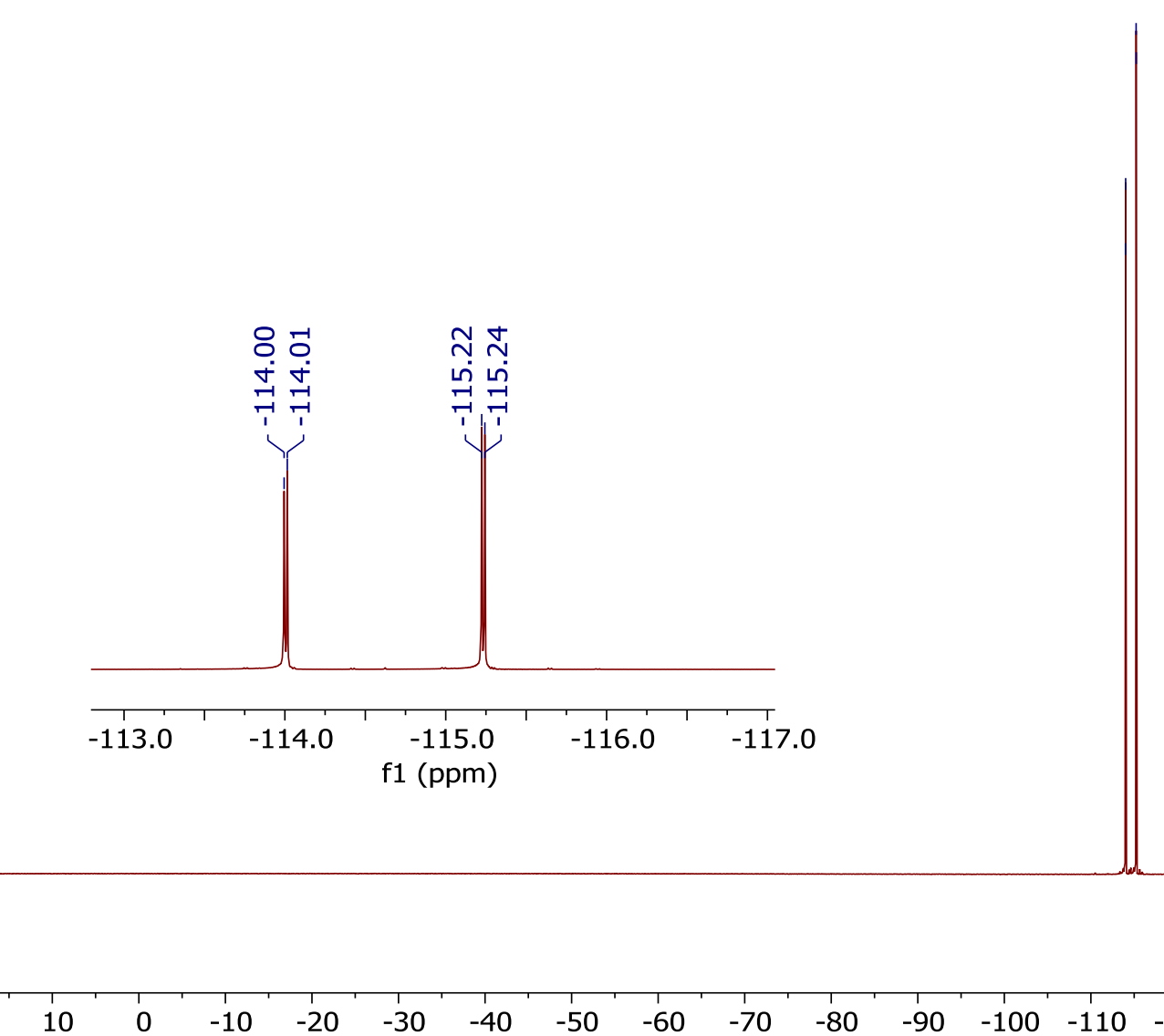

Compound 3p: $376 \mathrm{MHz}{ }^{19} \mathrm{~F}$ NMR spectrum in $\mathrm{CDCl}_{3}$ 


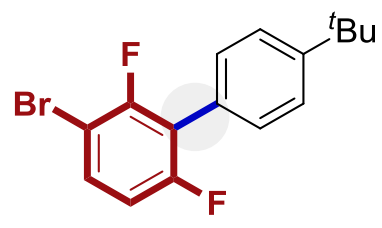

3q $87 \%(71 \%)$
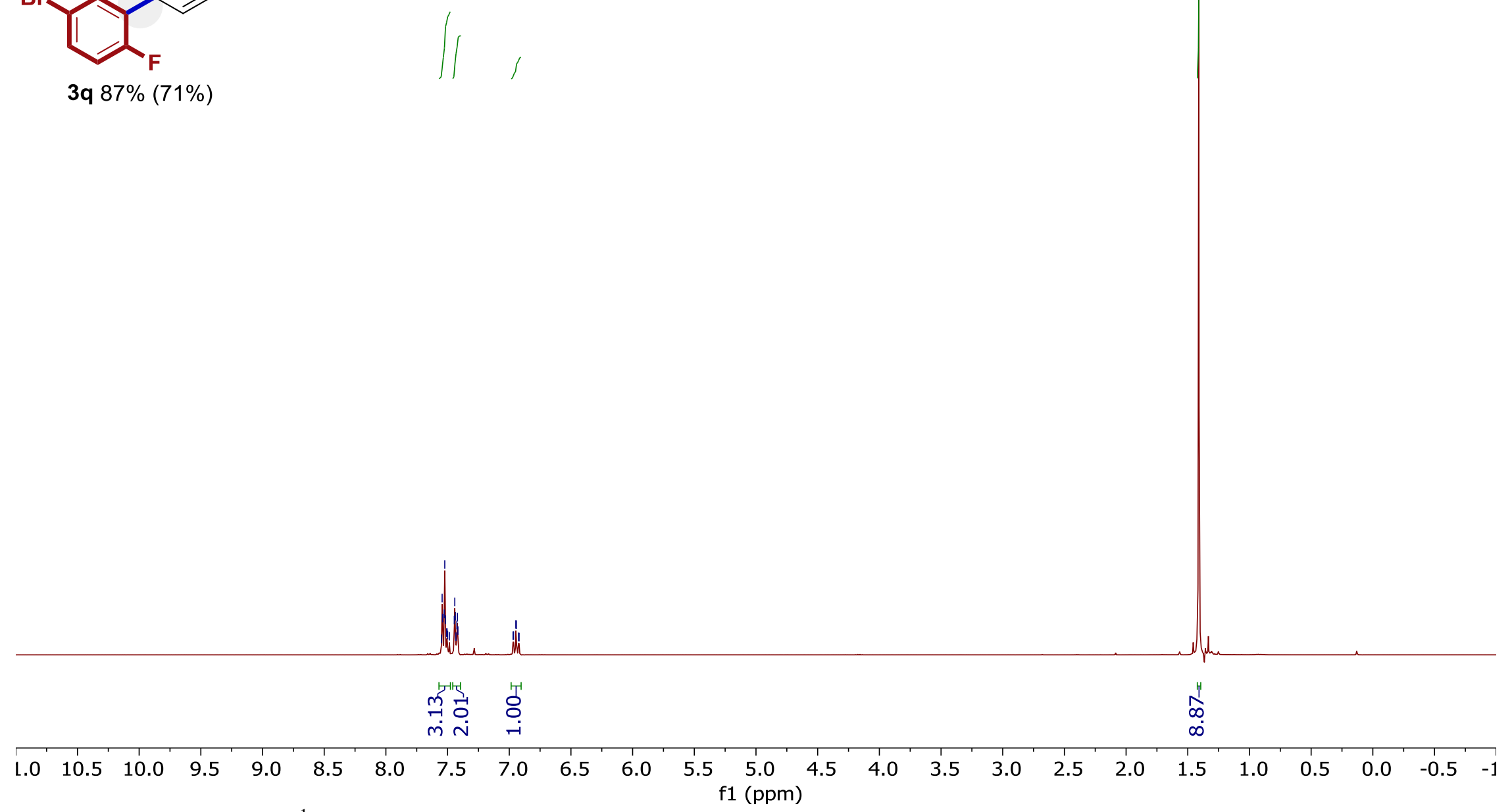

Compound 3q: $400 \mathrm{MHz}{ }^{1} \mathrm{H} \mathrm{NMR}$ spectrum in $\mathrm{CDCl}_{3}$ 


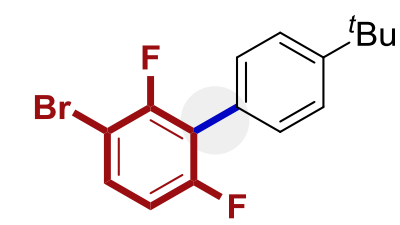

3q $87 \%(71 \%)$
గొ

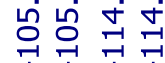

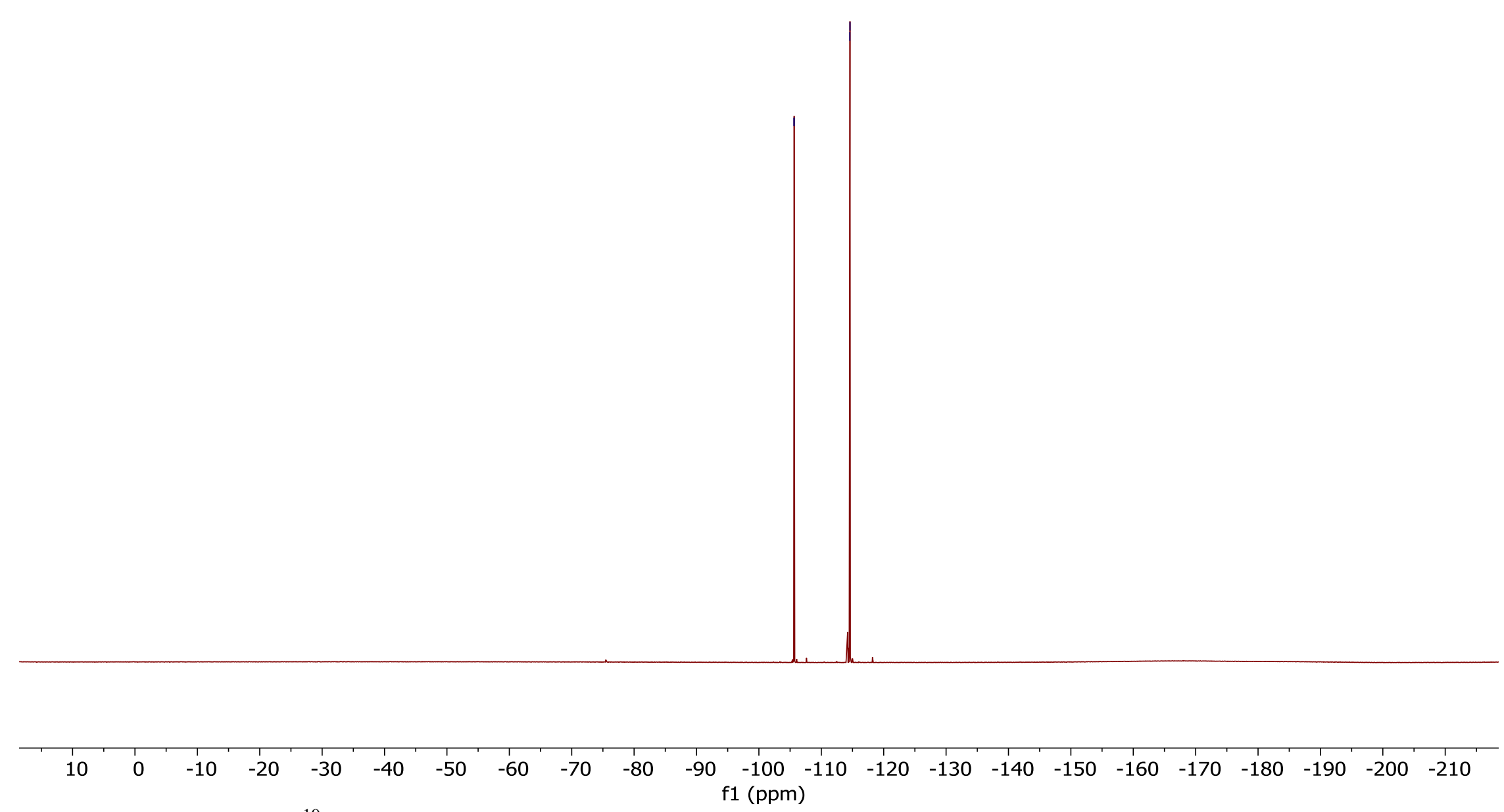

Compound 3q: $376 \mathrm{MHz}{ }^{19} \mathrm{~F}$ NMR spectrum in $\mathrm{CDCl}_{3}$ 


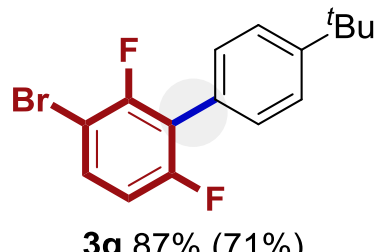

3q $87 \%(71 \%)$

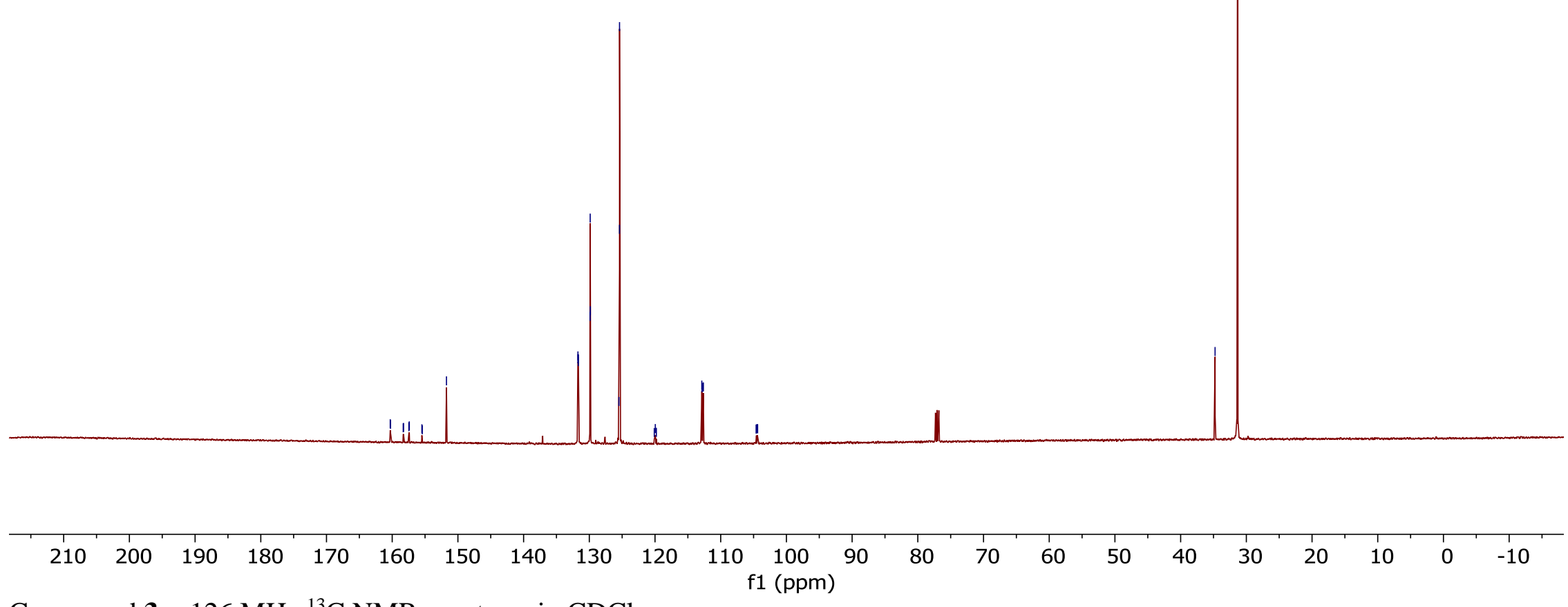

Compound 3q: $126 \mathrm{MHz}{ }^{13} \mathrm{C}$ NMR spectrum in $\mathrm{CDCl}_{3}$ 


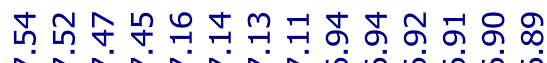

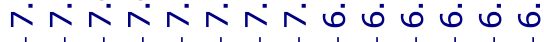

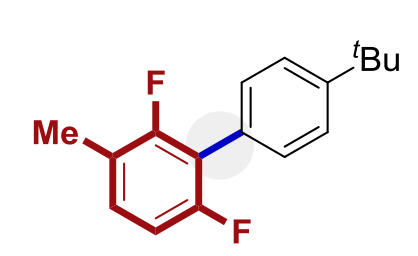

3r $87 \%(70 \%)$

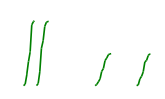

$\stackrel{m}{\stackrel{m}{i}} \quad \stackrel{\mathfrak{F}}{i}$
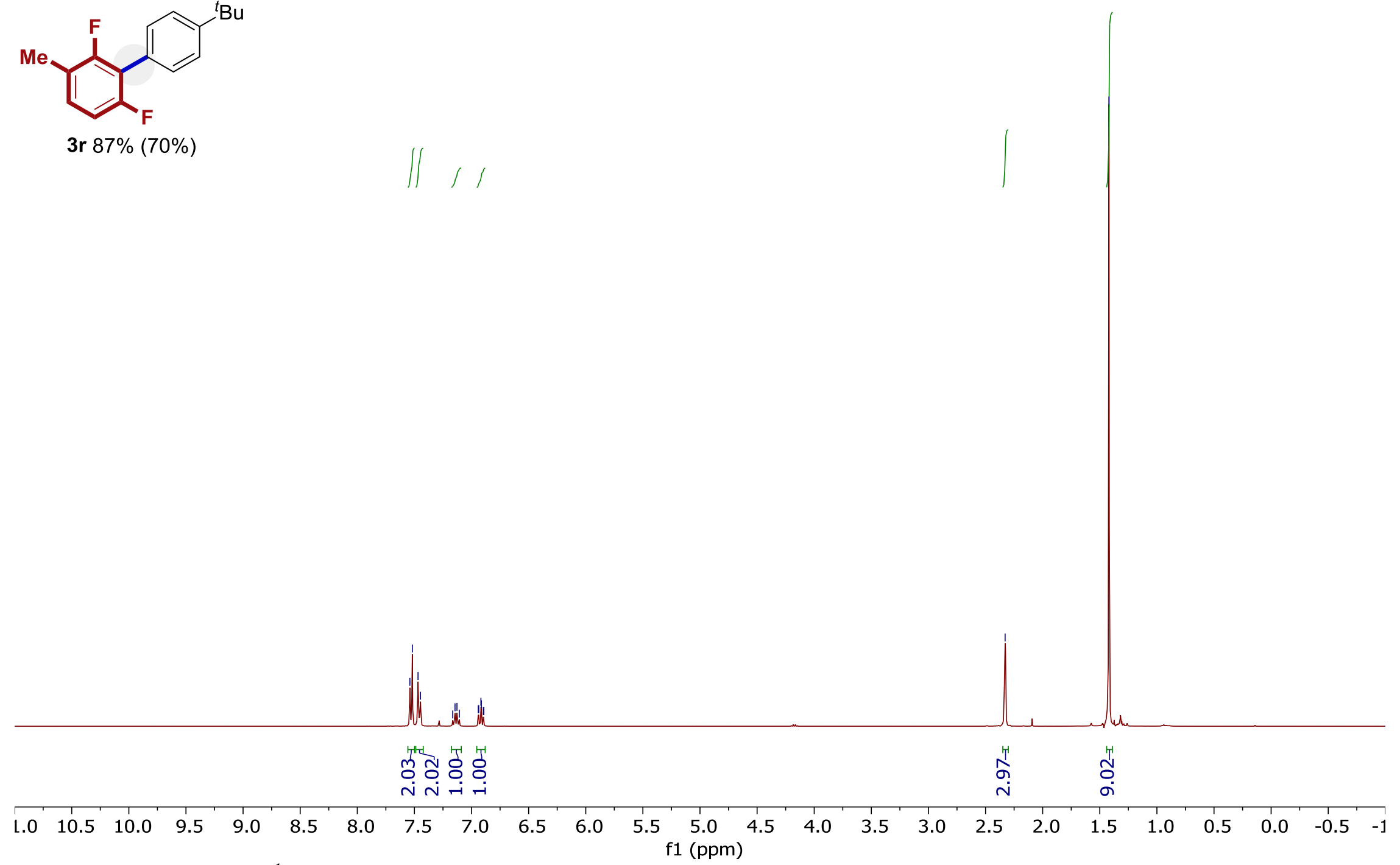

Compound 3r: $400 \mathrm{MHz}{ }^{1} \mathrm{H}$ NMR spectrum in $\mathrm{CDCl}_{3}$ 


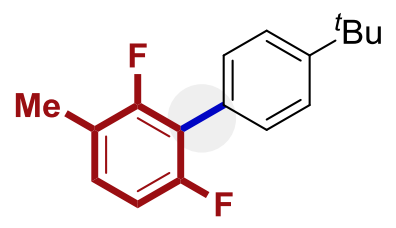

3r $87 \%(70 \%)$
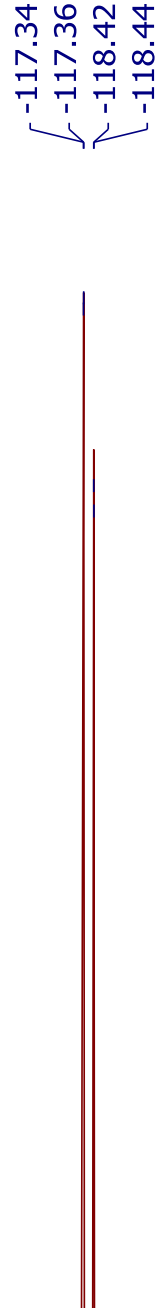


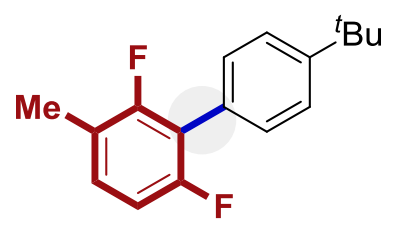

3r $87 \%(70 \%)$

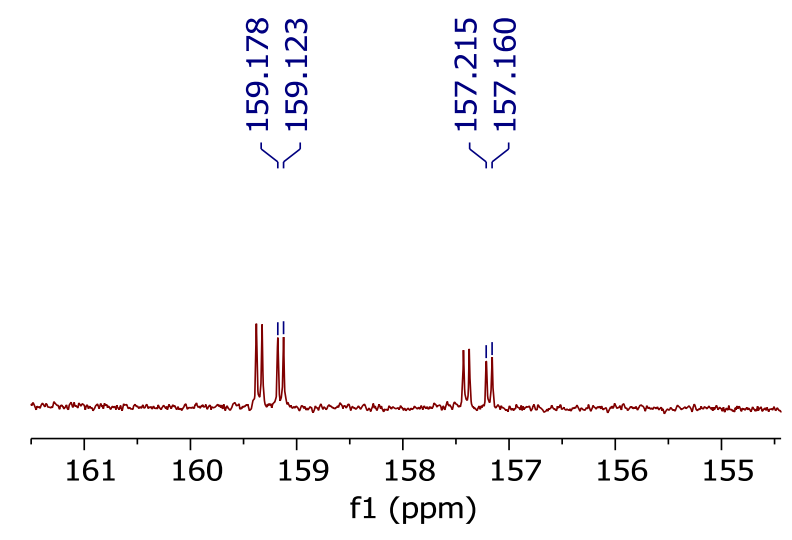

吾

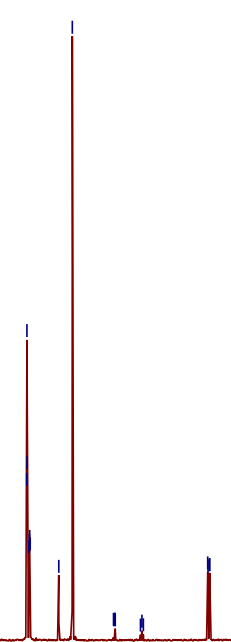
1

$\begin{array}{llllllllll}210 & 200 & 190 & 180 & 170 & 160 & 150 & 140 & 130 & 120\end{array}$ $\mathrm{f} 1(\mathrm{ppm})$

Compound 3r: $126 \mathrm{MHz}{ }^{13} \mathrm{C}$ NMR spectrum in $\mathrm{CDCl}_{3}$ 


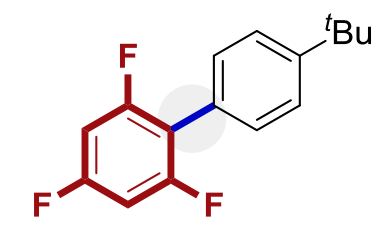

3s $76 \%(66 \%)$

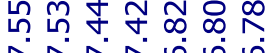

ヘヘヘヘヘ்

$\rightarrow 1$

$\stackrel{\text { \& }}{\mathfrak{2}}$

1
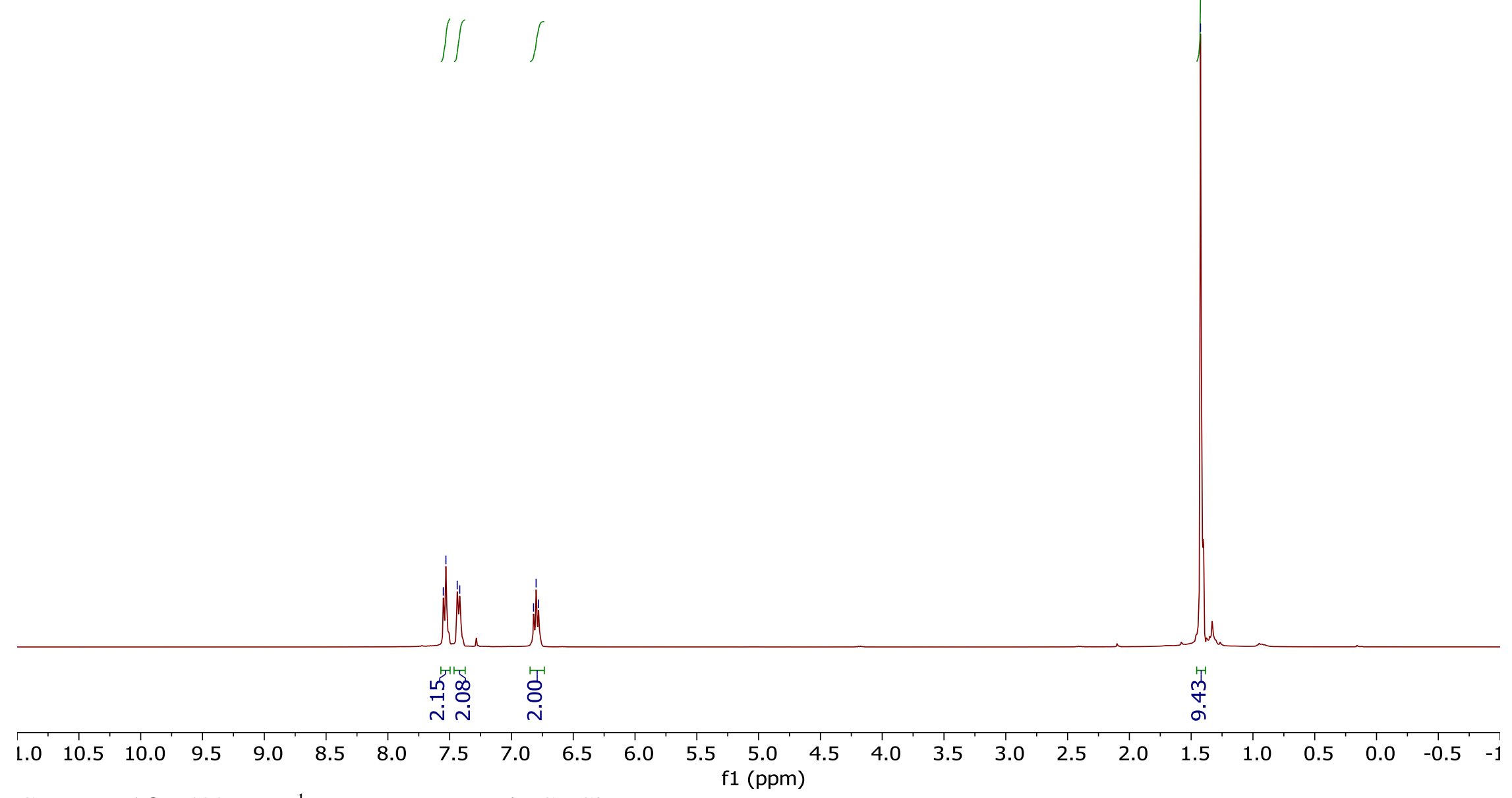

Compound 3s: $400 \mathrm{MHz}{ }^{1} \mathrm{H}$ NMR spectrum in $\mathrm{CDCl}_{3}$ 


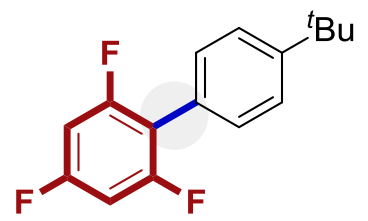

3s $76 \%(66 \%)$

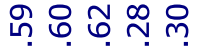

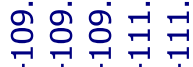
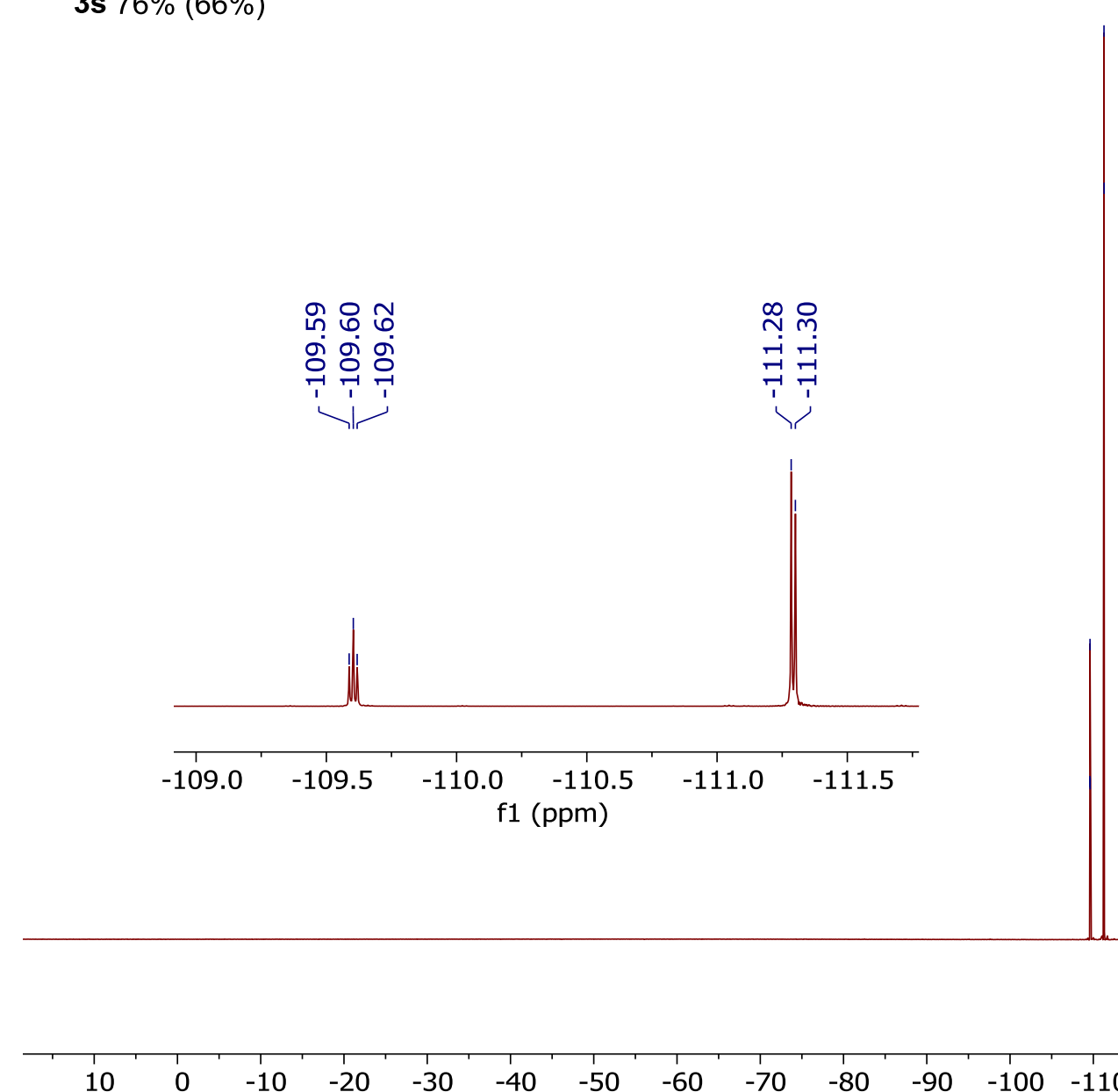

$-10$

$-20-30$

1
-40

$-50 \quad-60$

$-70 \quad-80$

$-90-100-110$
$\mathrm{f} 1$ (ppm)

Compound 3s $376 \mathrm{MHz}{ }^{19} \mathrm{~F}$ NMR spectrum in $\mathrm{CDCl}_{3}$ 


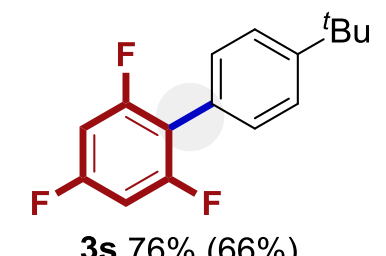

3s $76 \%(66 \%)$

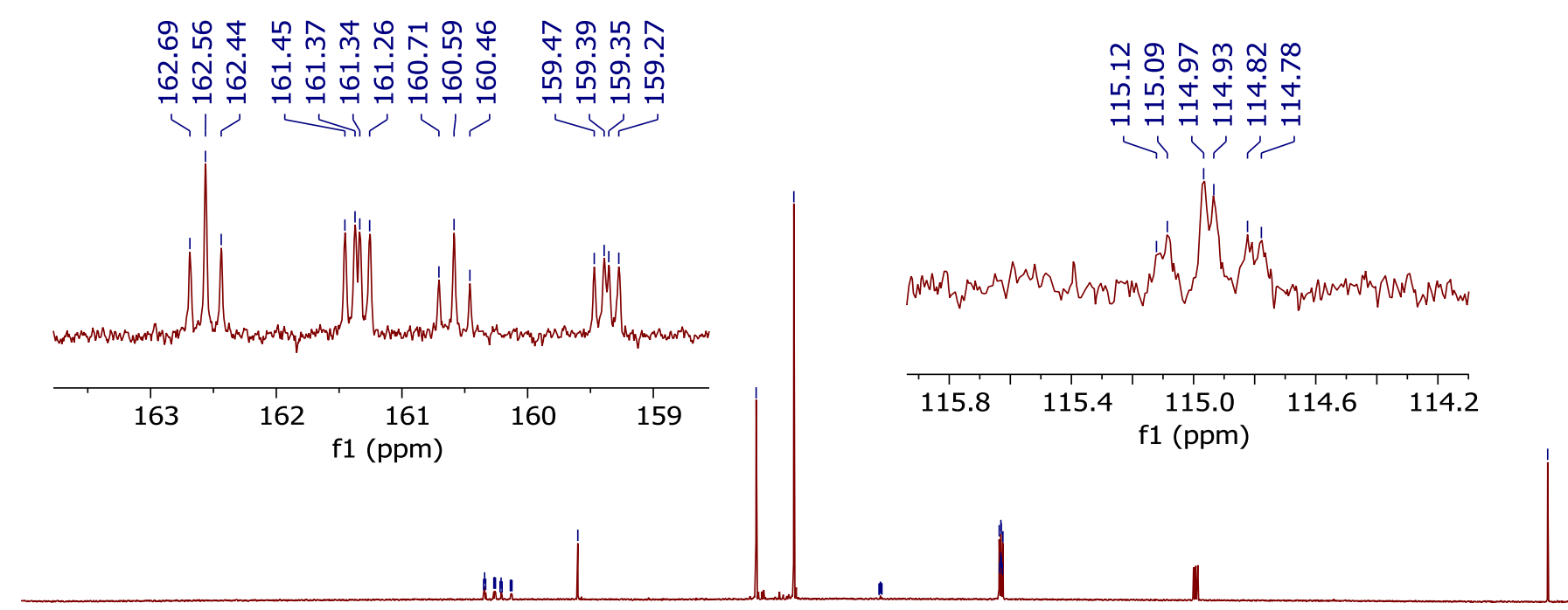

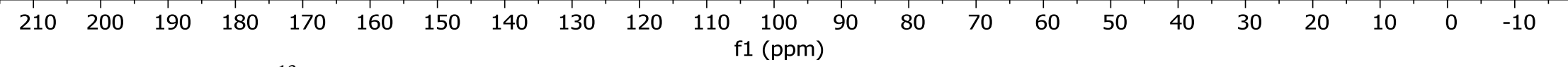

Compound 3s: $126 \mathrm{MHz}{ }^{13} \mathrm{C} \mathrm{NMR}$ spectrum in $\mathrm{CDCl}_{3}$ 


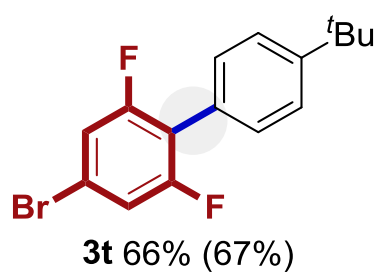

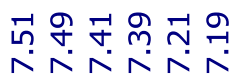

$\rightarrow 1<$

$\stackrel{\text { m}}{i}$

3t $66 \%(67 \%)$
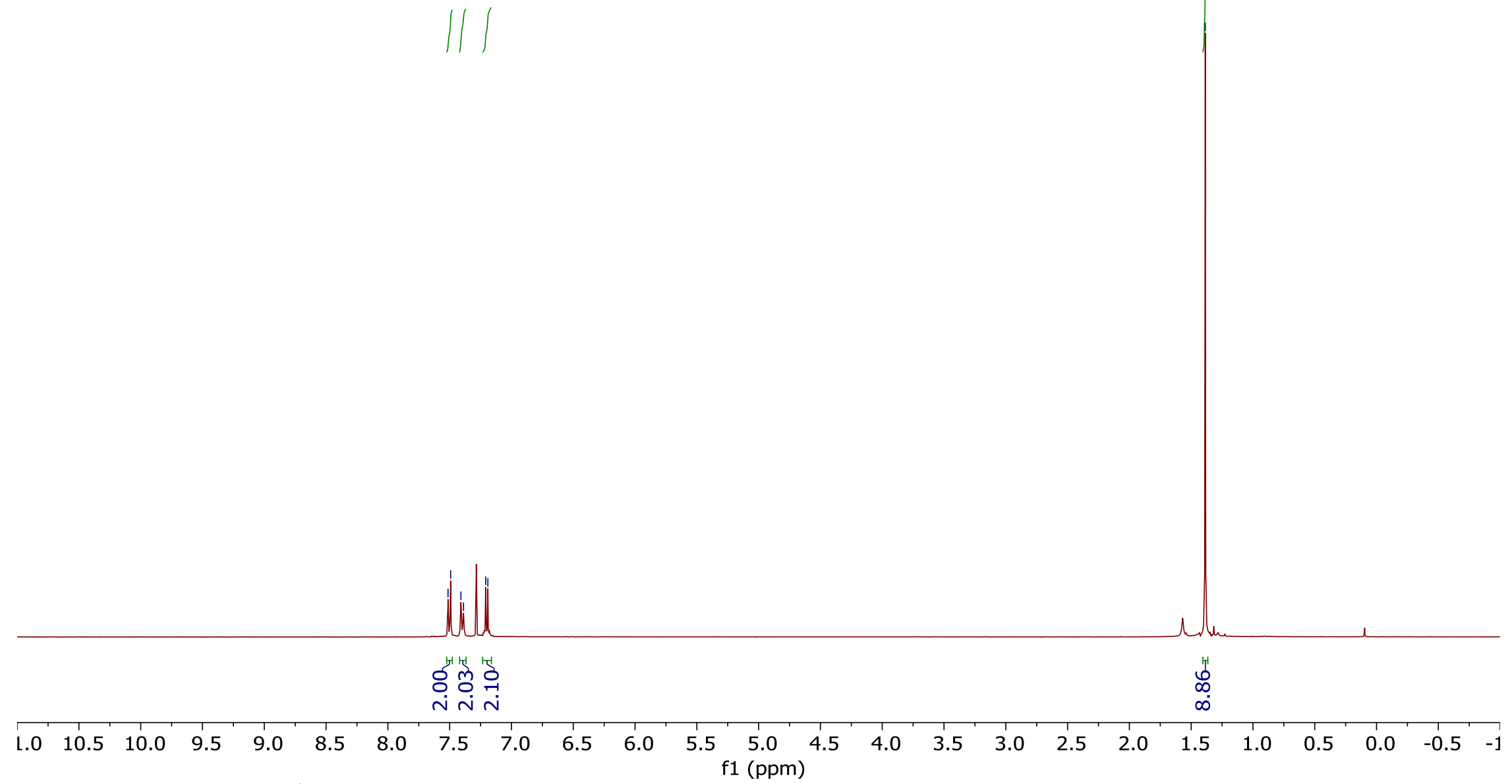

Compound 3t: $400 \mathrm{MHz}{ }^{1} \mathrm{H}$ NMR spectrum in $\mathrm{CDCl}_{3}$ 


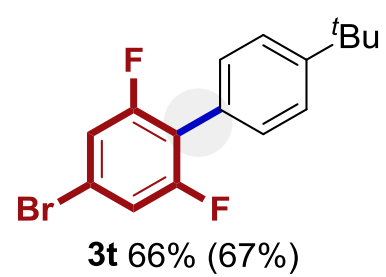

3t $66 \%$ (67\%) 

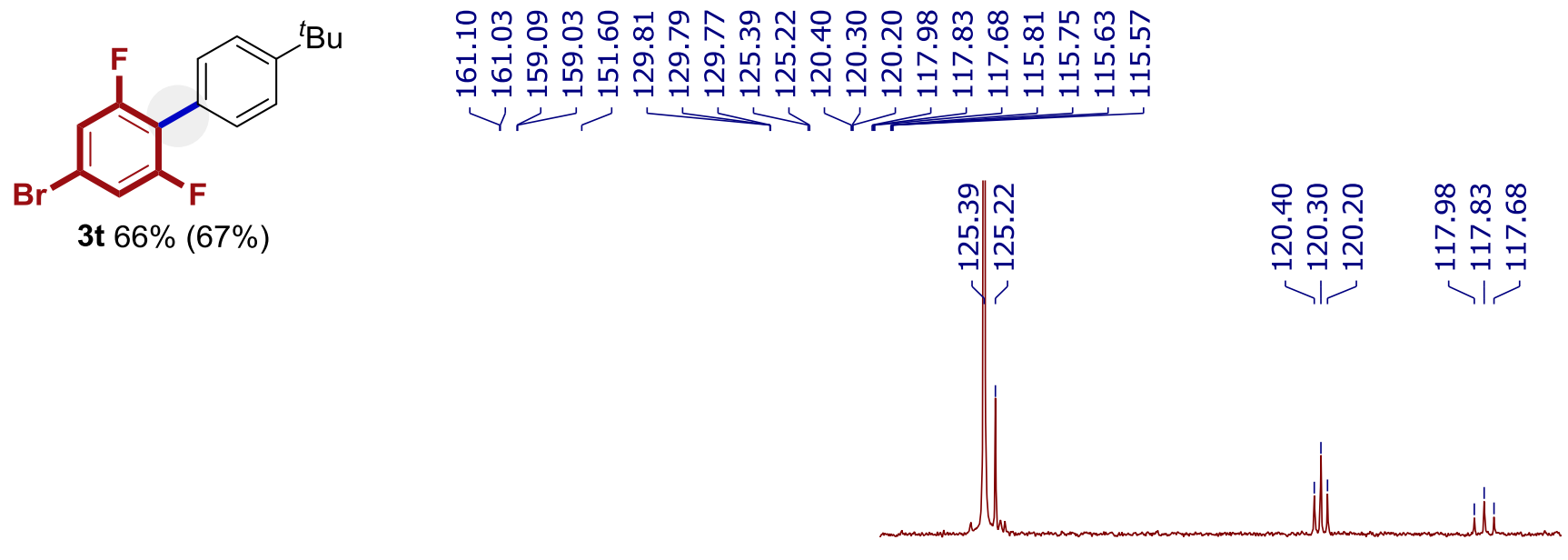

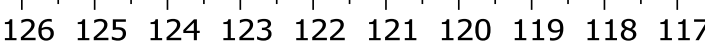
f1 (ppm)

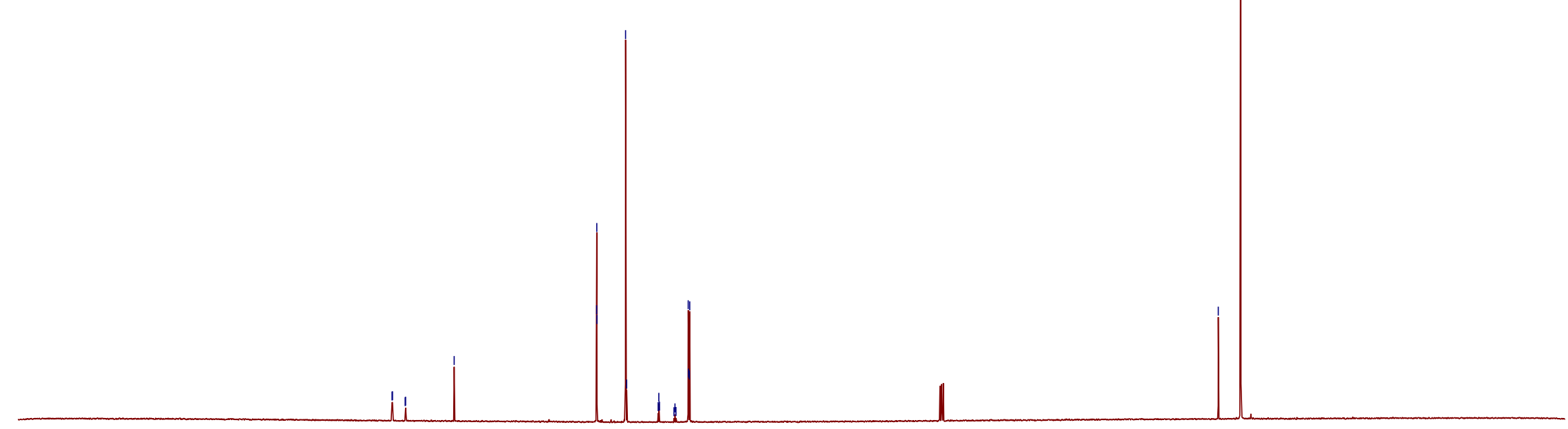

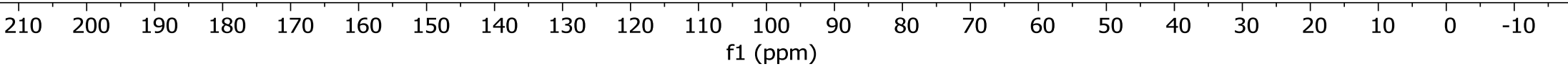
Compound 3t: $126 \mathrm{MHz}{ }^{13} \mathrm{C}$ NMR spectrum in $\mathrm{CDCl}_{3}$ 


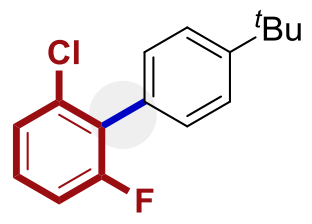

3u $69 \%(63 \%)$
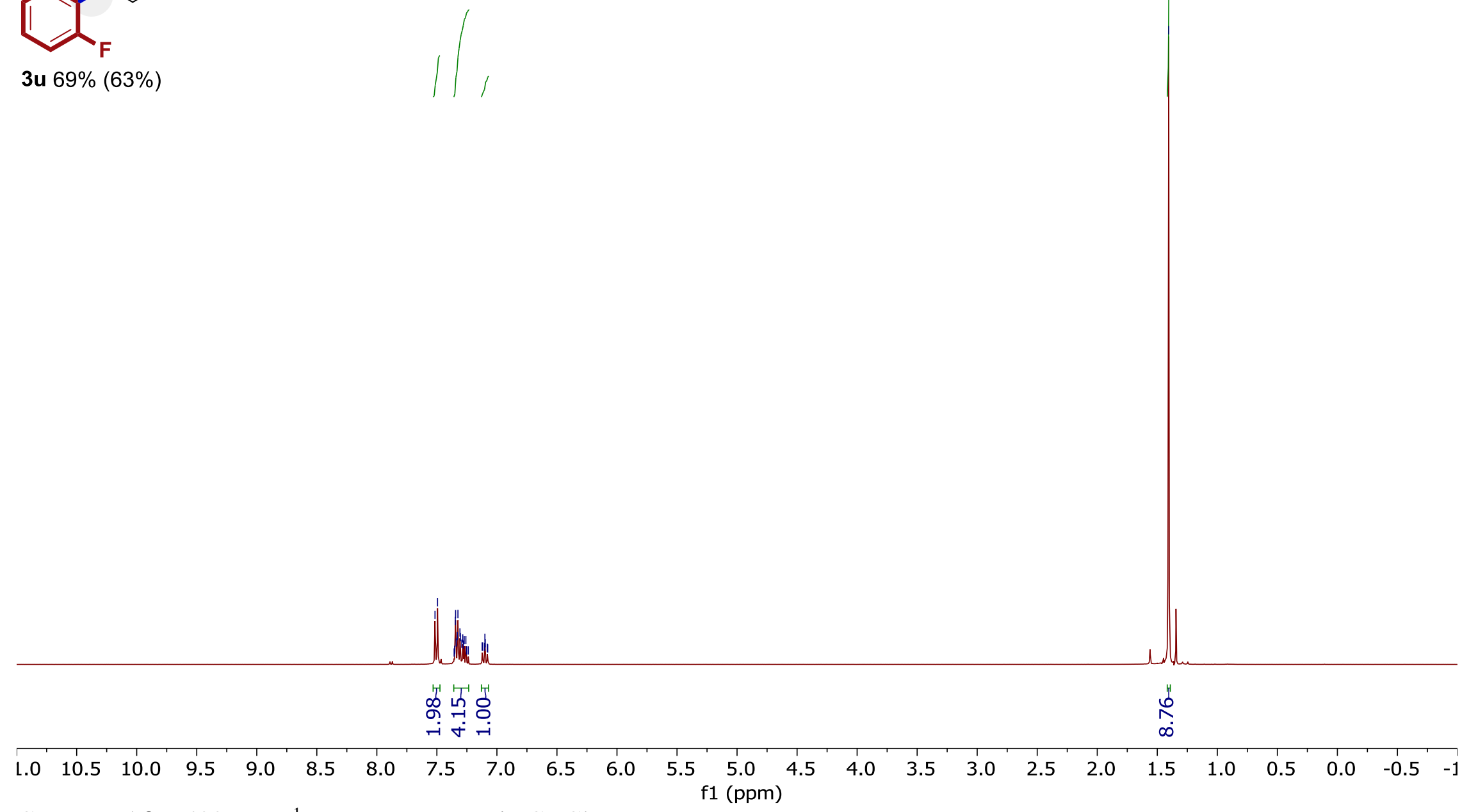

Compound 3u: $400 \mathrm{MHz}{ }^{1} \mathrm{H}$ NMR spectrum in $\mathrm{CDCl}_{3}$ 


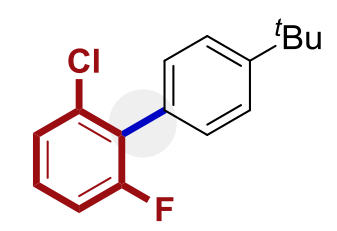

3u $69 \%(63 \%)$

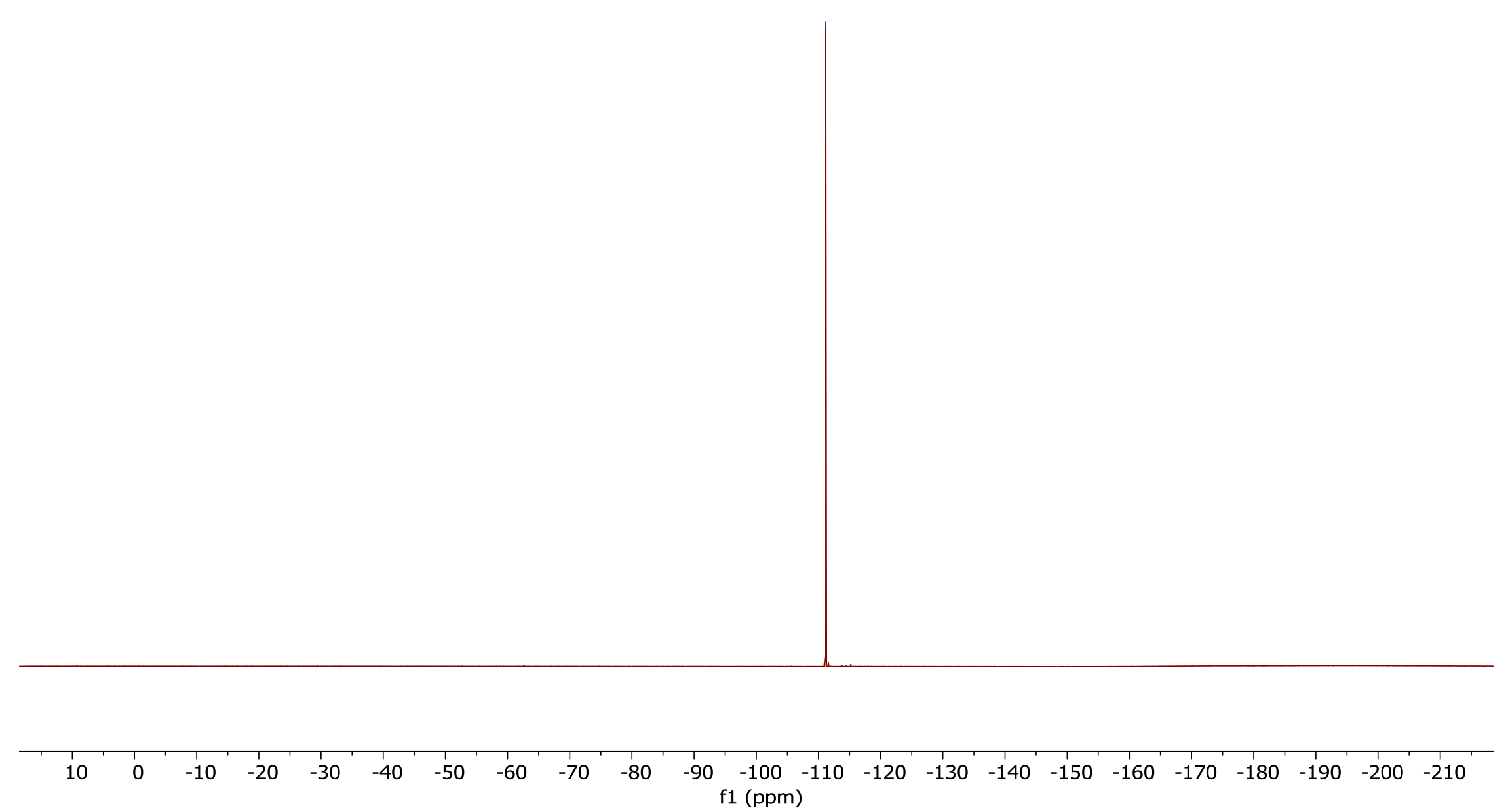

Compound 3u: $376 \mathrm{MHz}{ }^{19} \mathrm{~F}$ NMR spectrum in $\mathrm{CDCl}_{3}$ 

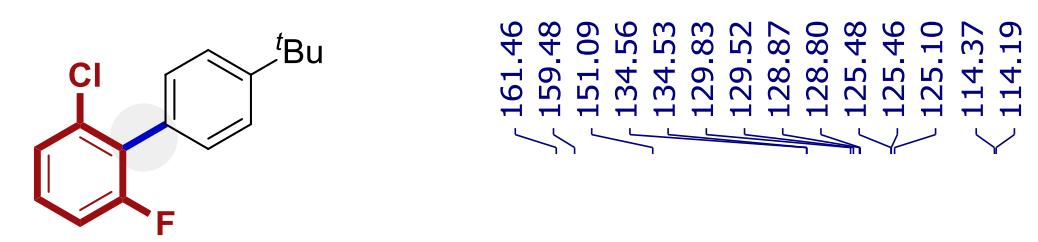

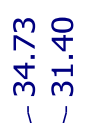

3u $69 \%(63 \%)$
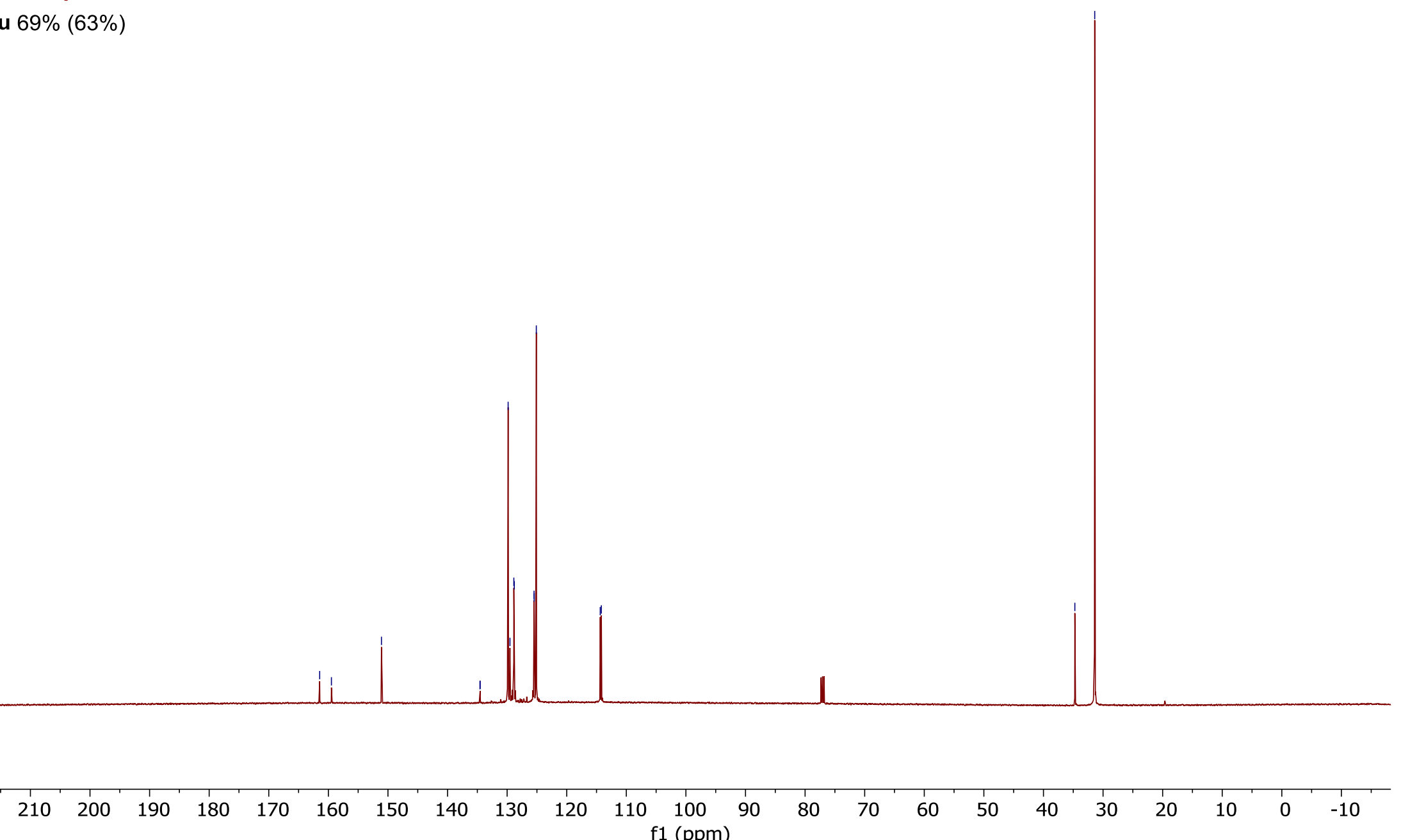

Compound 3u: $126 \mathrm{MHz}{ }^{13} \mathrm{C}$ NMR spectrum in $\mathrm{CDCl}_{3}$ 


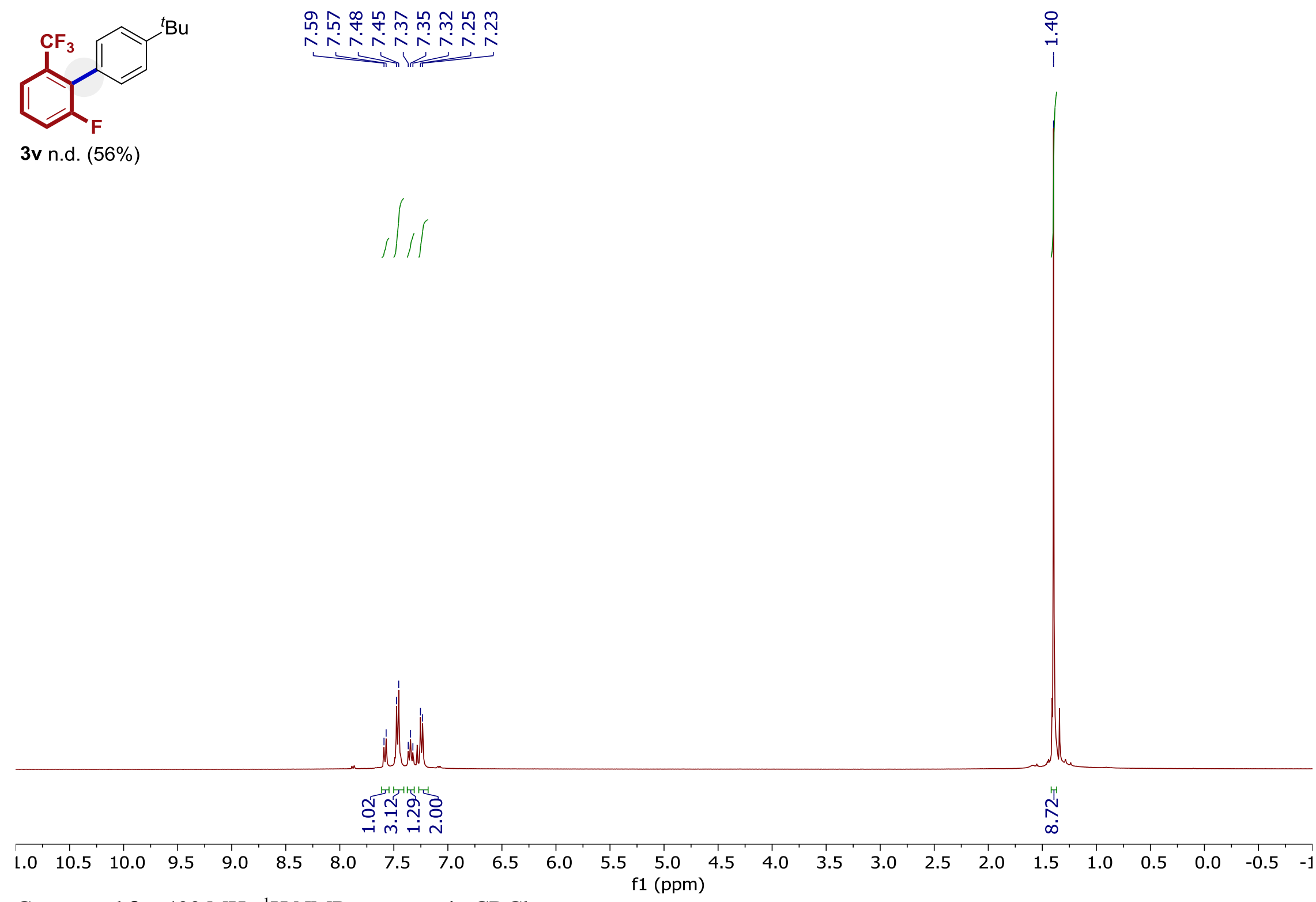

Compound 3v: $400 \mathrm{MHz}{ }^{1} \mathrm{H}$ NMR spectrum in $\mathrm{CDCl}_{3}$ 

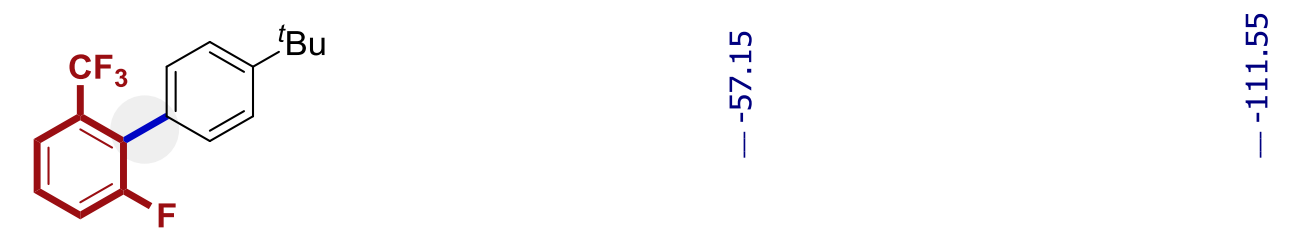

$3 v$ n.d. $(56 \%)$

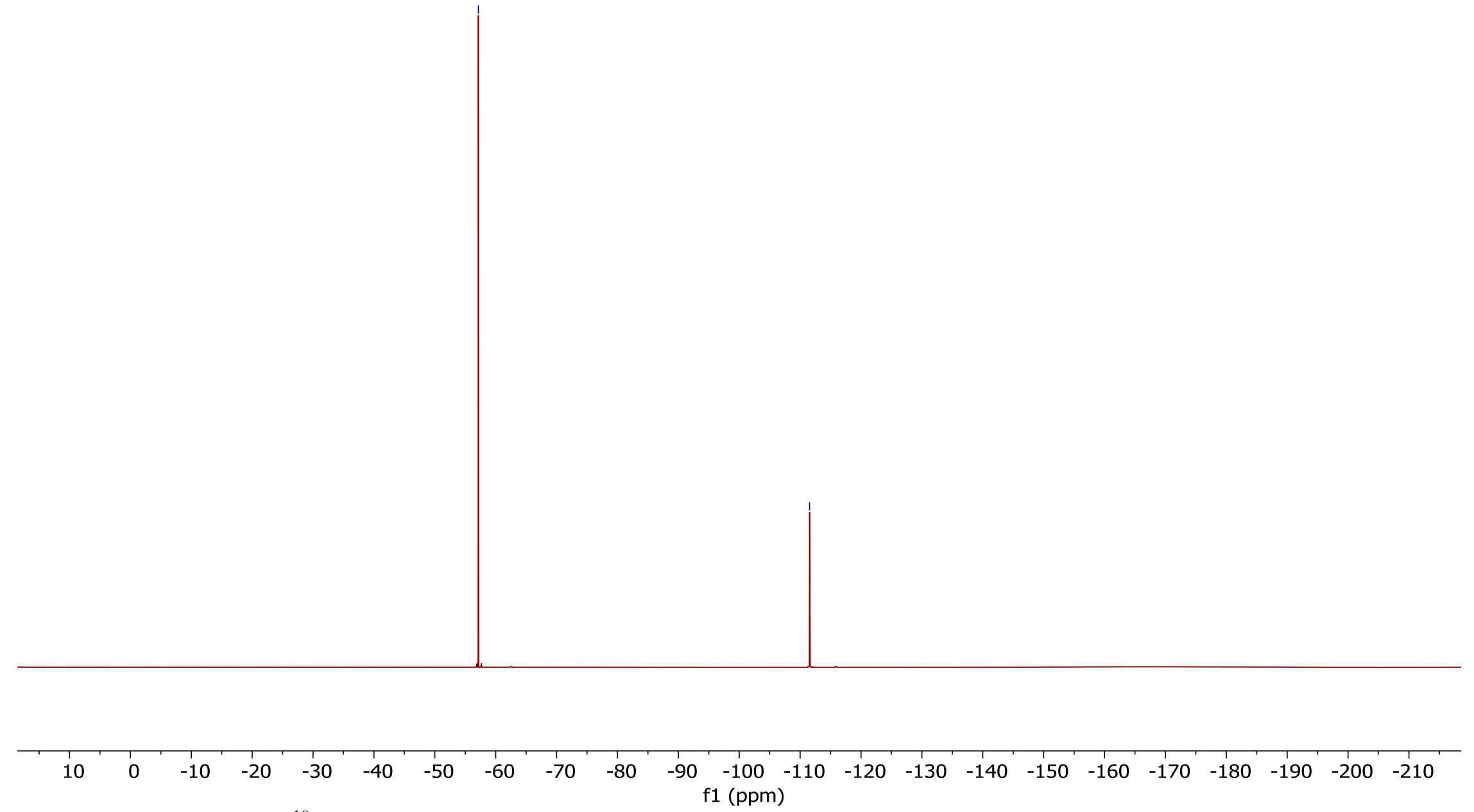

Compound 3v: $376 \mathrm{MHz}{ }^{19} \mathrm{~F}$ NMR spectrum in $\mathrm{CDCl}_{3}$ 


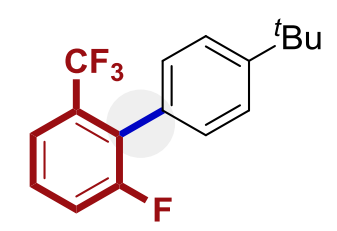

$3 v$ n.d. $(56 \%)$
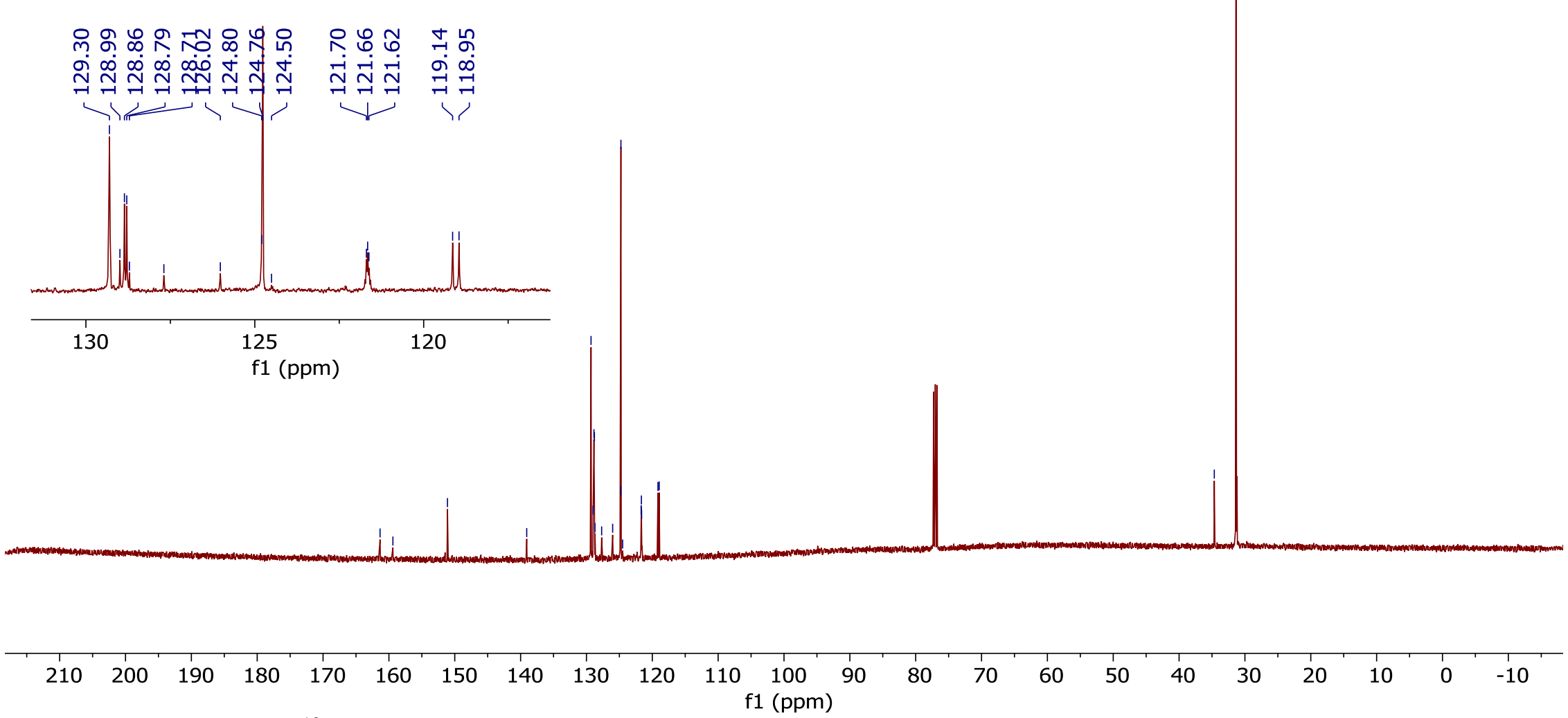

Compound 3v: $126 \mathrm{MHz}{ }^{13} \mathrm{C} \mathrm{NMR}$ spectrum in $\mathrm{CDCl}_{3}$ 


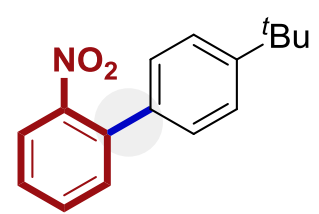

$3 w$ n.d. $(71 \%)$
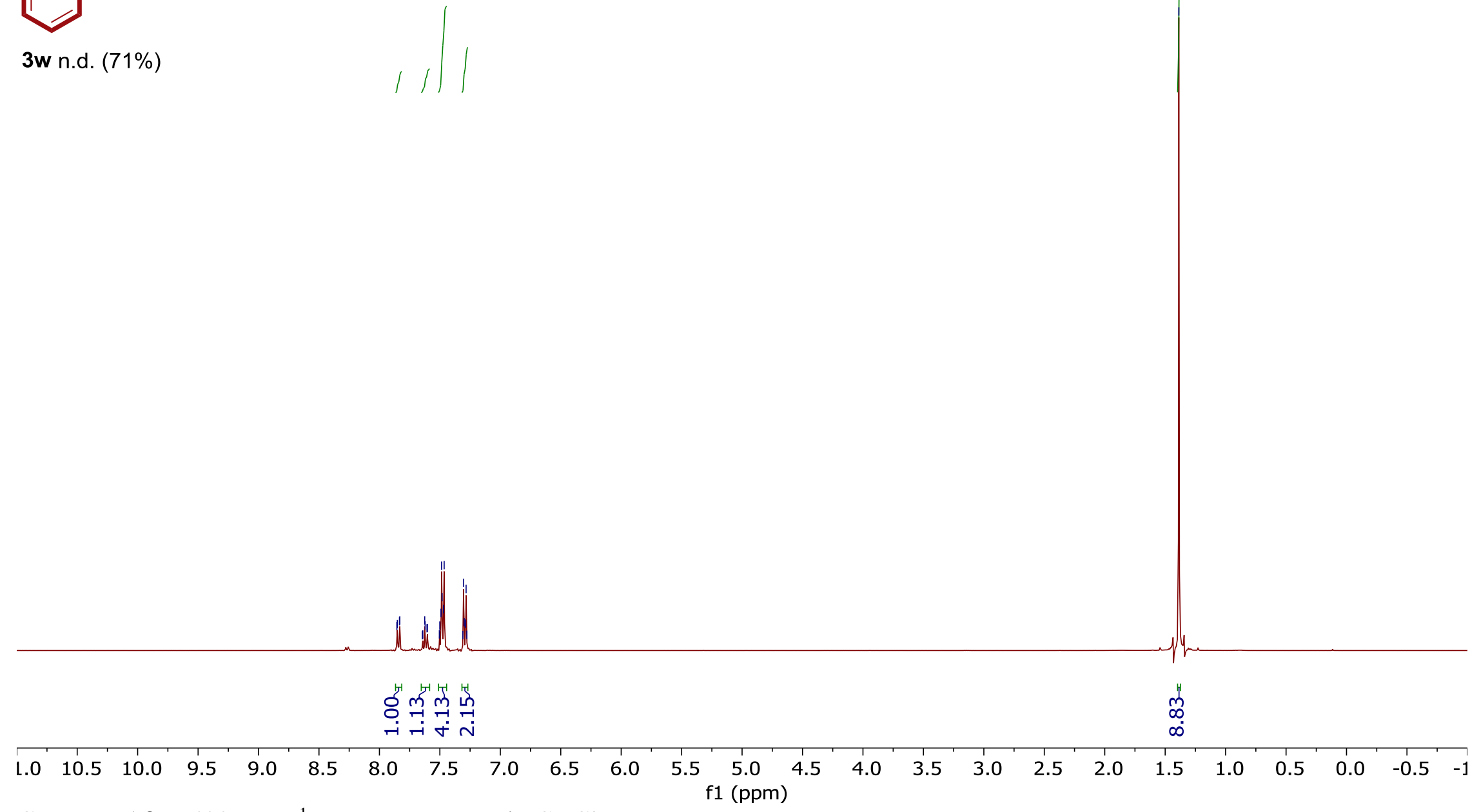

Compound 3w: $400 \mathrm{MHz}{ }^{1} \mathrm{H}$ NMR spectrum in $\mathrm{CDCl}_{3}$ 


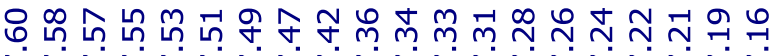

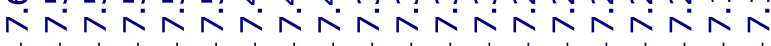

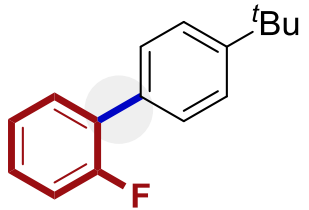

$3 \times 35 \%(41 \%)$
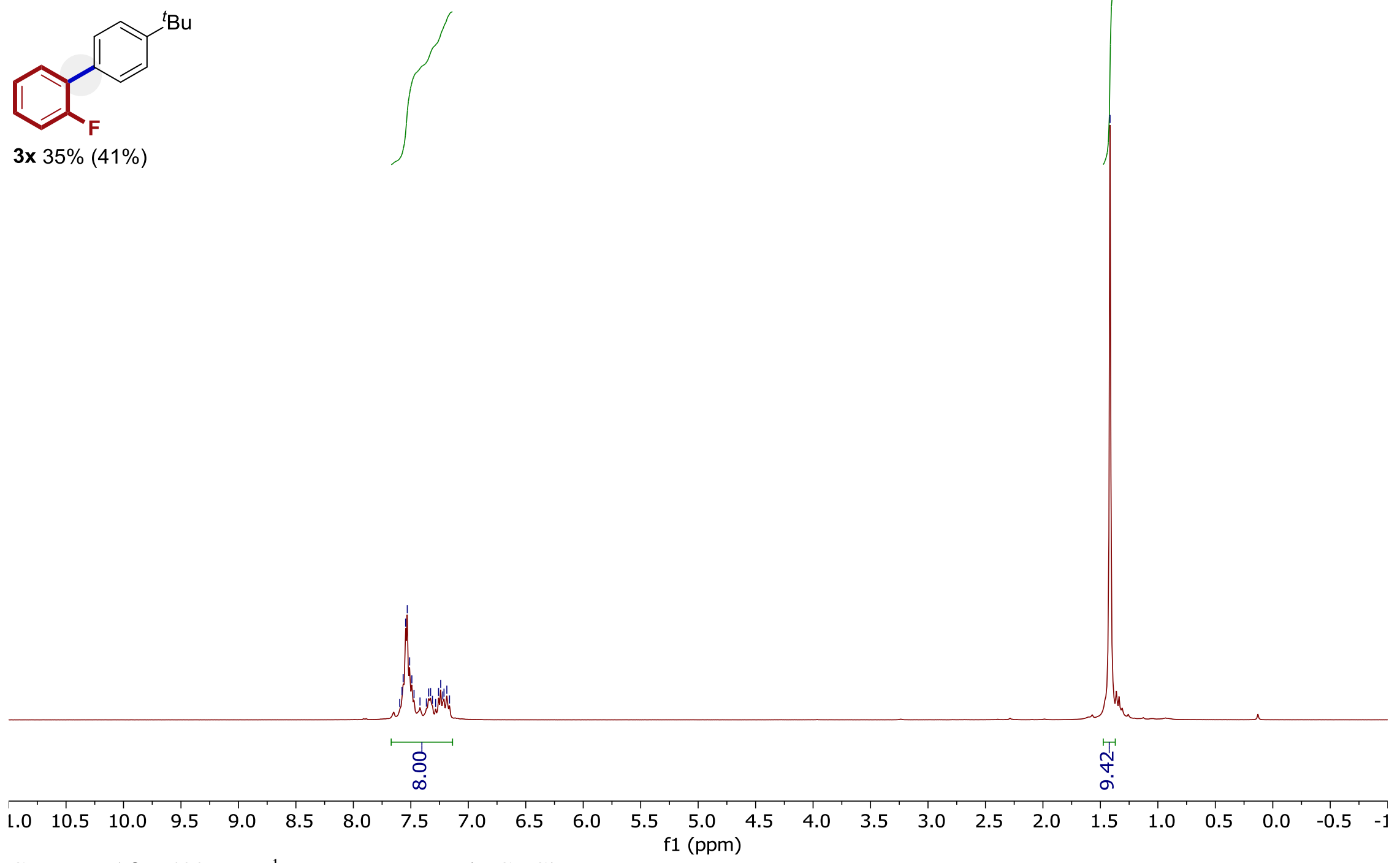

Compound 3x: $400 \mathrm{MHz}{ }^{1} \mathrm{H}$ NMR spectrum in $\mathrm{CDCl}_{3}$ 
3x 35\% (41\%)

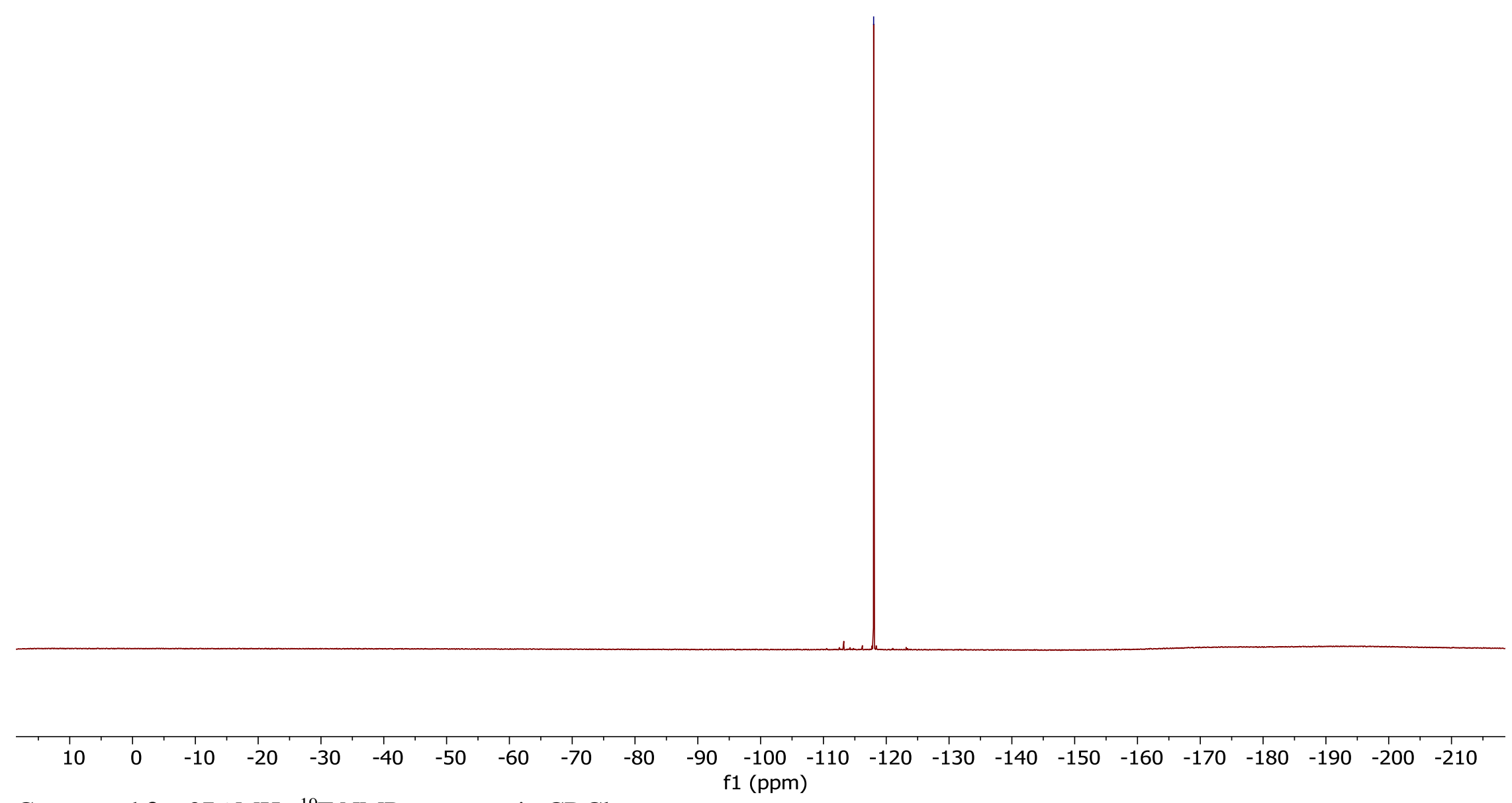

Compound 3x: $376 \mathrm{MHz}{ }^{19} \mathrm{~F}$ NMR spectrum in $\mathrm{CDCl}_{3}$ 


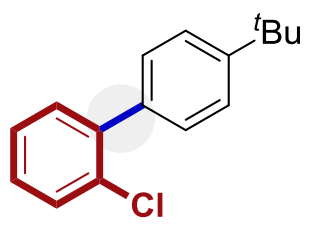

3y n.d. (50\%)

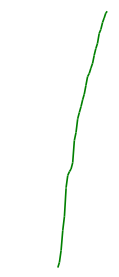

(3y n.d. $(50 \%)$

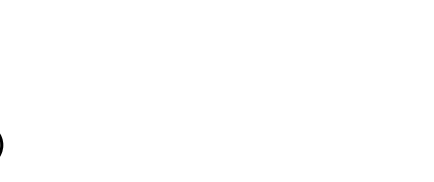



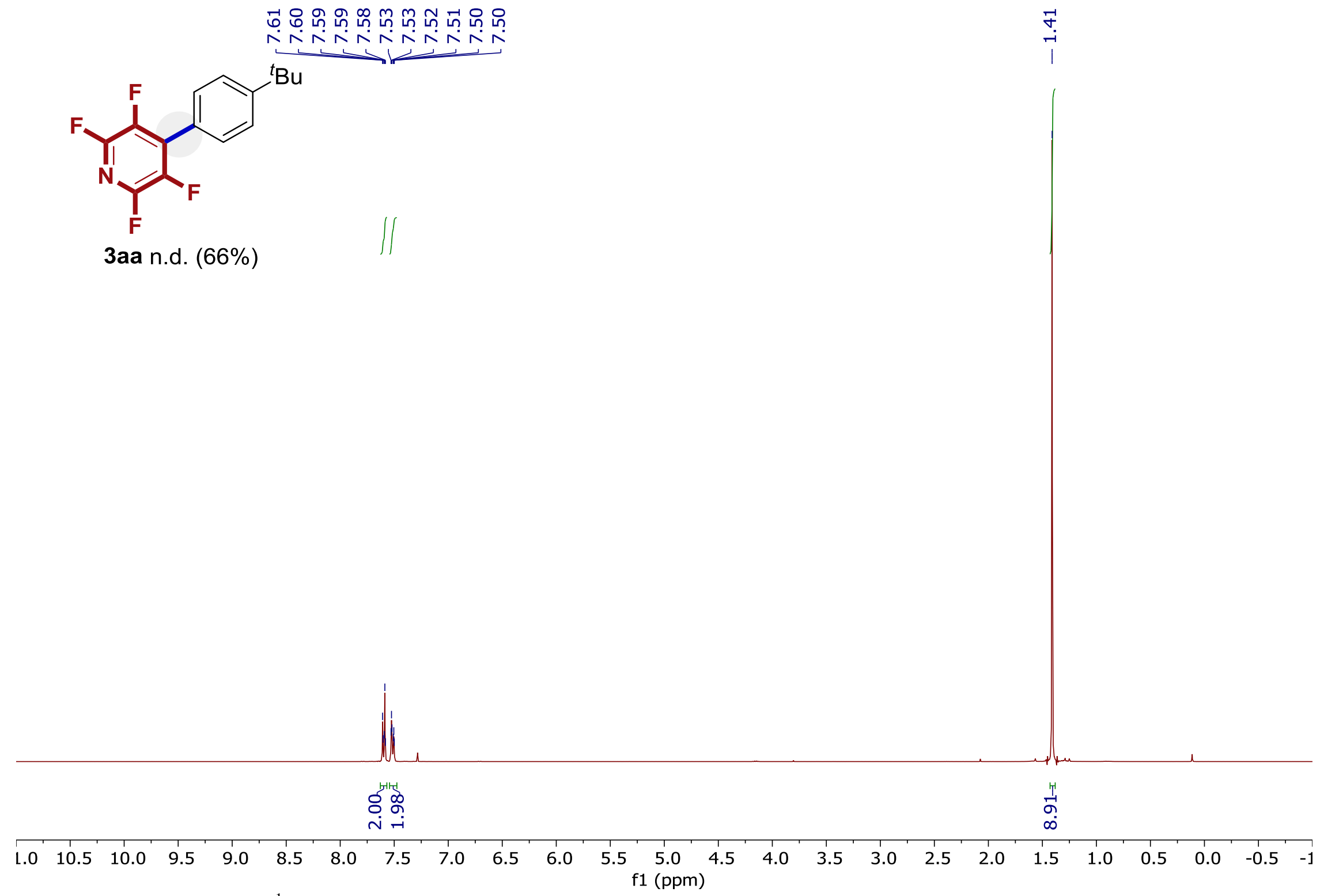

Compound 3aa: $400 \mathrm{MHz}{ }^{1} \mathrm{H}$ NMR spectrum in $\mathrm{CDCl}_{3}$ 


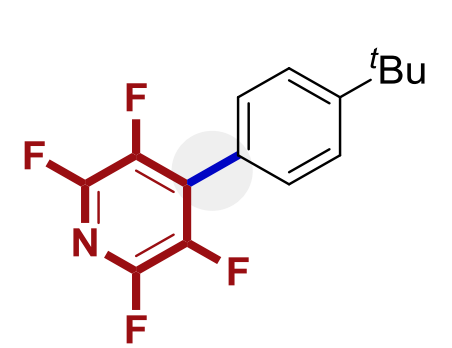

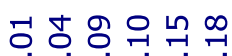 \\ नં}

กึ๋

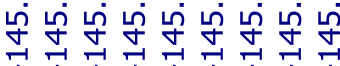

3aa n.d. (66\%)

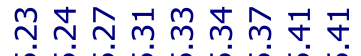

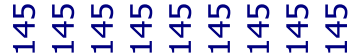

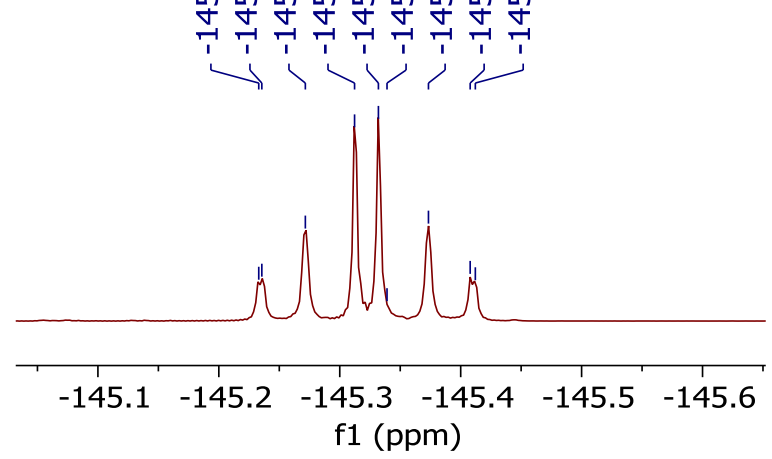

10

$-10-20$

$-30$

$-40$

$-50 \quad-60$

$-70 \quad-80$

$-100-110$
$f 1(\mathrm{ppm})$

Compound 3aa: $376 \mathrm{MHz}{ }^{19} \mathrm{~F}$ NMR spectrum in $\mathrm{CDCl}_{3}$ 


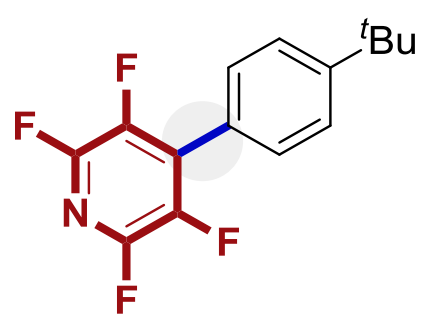

$3 a a$ n.d. $(66 \%)$
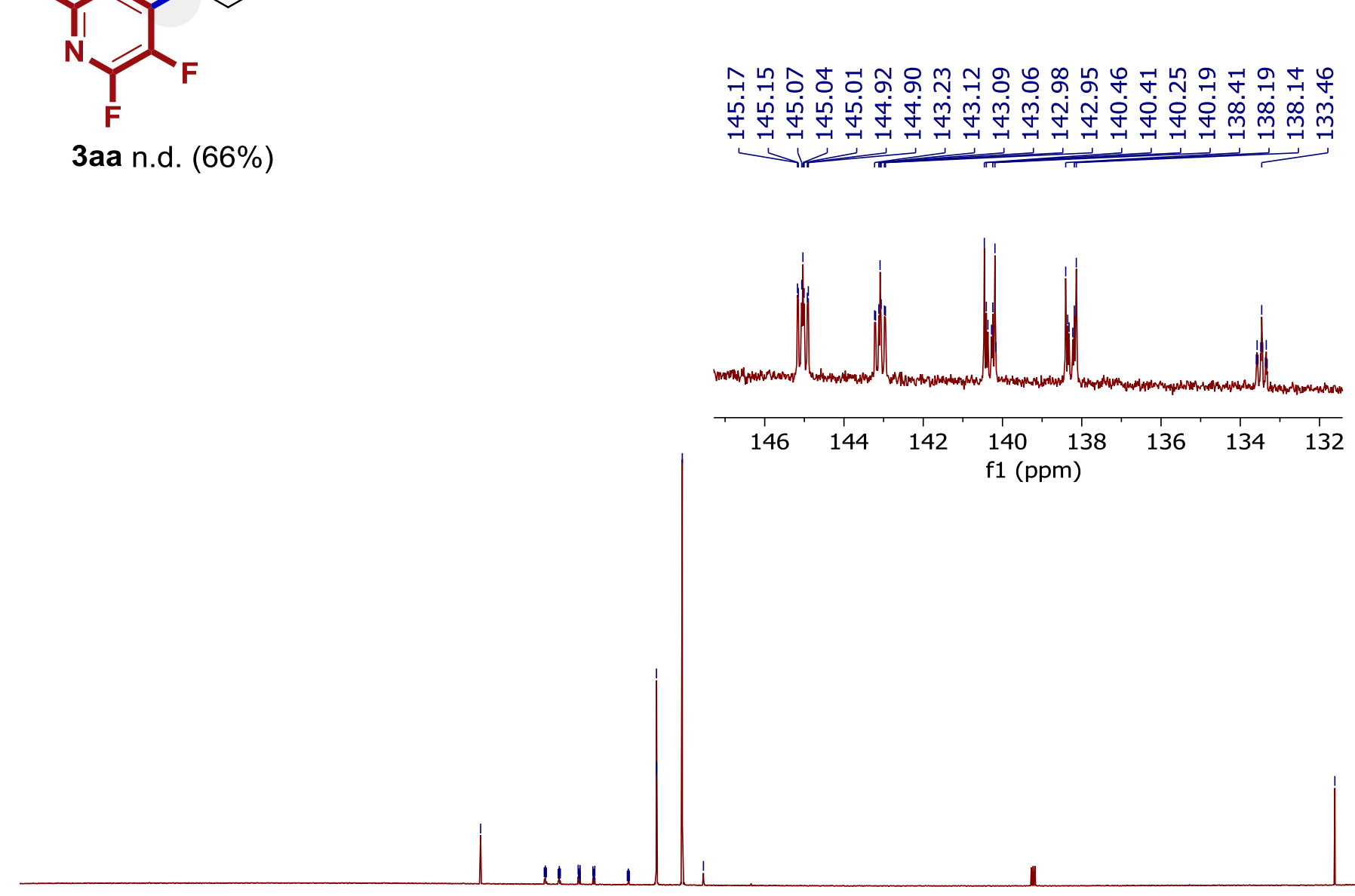

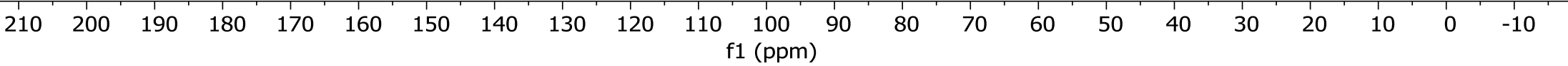
Compound 3aa: $126 \mathrm{MHz}{ }^{13} \mathrm{C}$ NMR spectrum in $\mathrm{CDCl}_{3}$ 


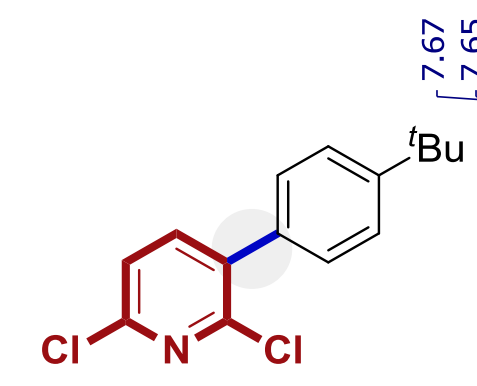

$3 b b$ n.d. (48\%)

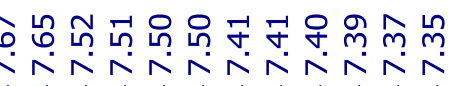

ตे

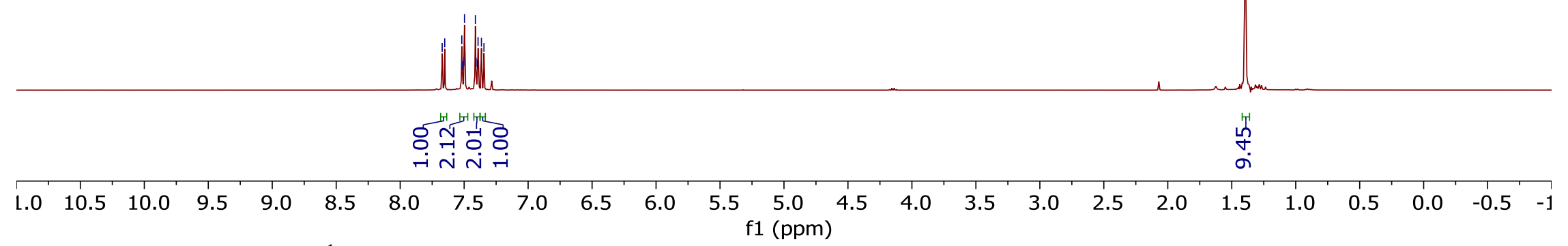

Compound 3bb: $400 \mathrm{MHz}{ }^{1} \mathrm{H}$ NMR spectrum in $\mathrm{CDCl}_{3}$ 


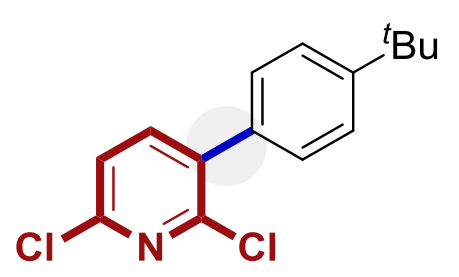

œ

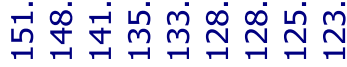

3bb n.d. (48\%)

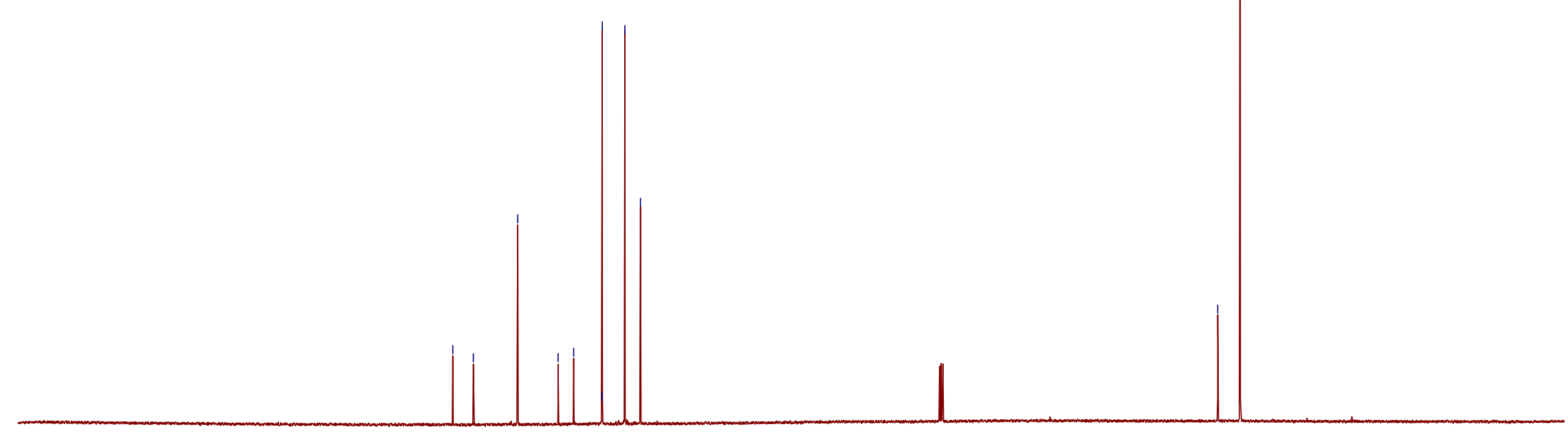

$\begin{array}{llllllllllllllllllllll}210 & 200 & 190 & 180 & 170 & 160 & 150 & 140 & 130 & 120 & 110 \begin{array}{c}100 \\ \mathrm{f} 1(\mathrm{ppm})\end{array} & 90 & 80 & 70 & 60 & 50 & 40 & 30 & 20 & 10 & 0 & -10\end{array}$ Compound 3bb: $126 \mathrm{MHz}{ }^{13} \mathrm{C}$ NMR spectrum in $\mathrm{CDCl}_{3}$ 


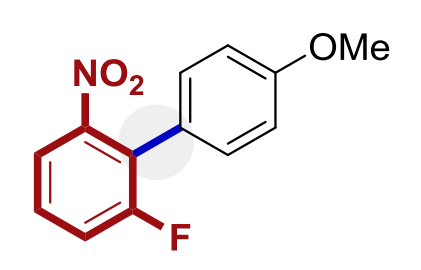

3cc $>95 \%(94 \%)$

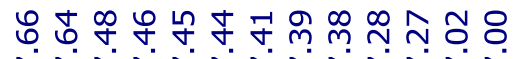

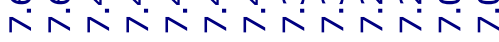

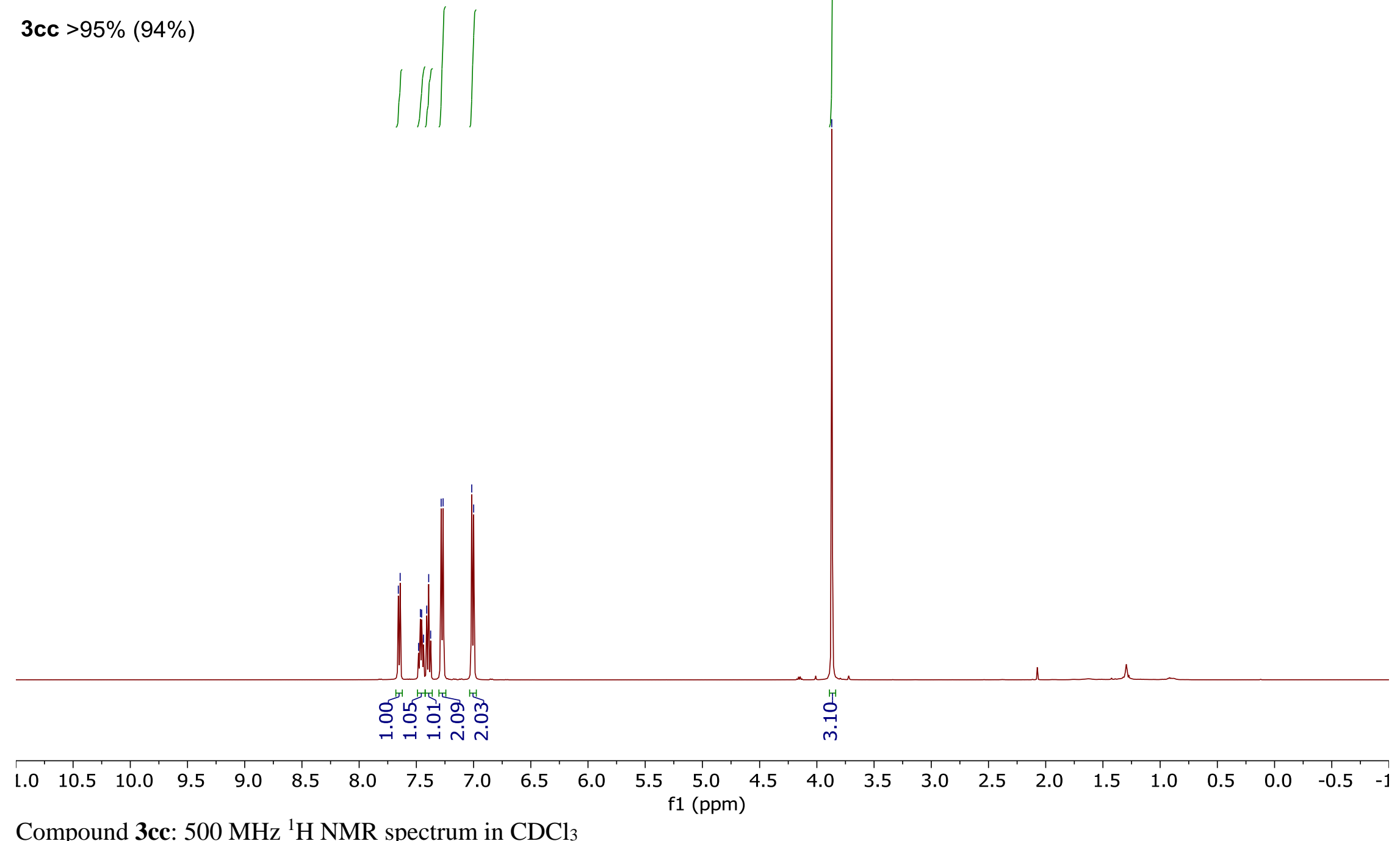




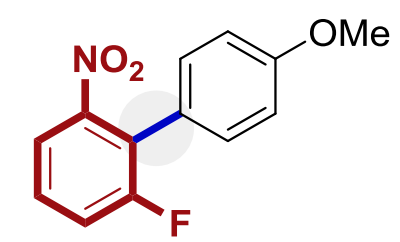

3cc $>95 \%$ (94\%)

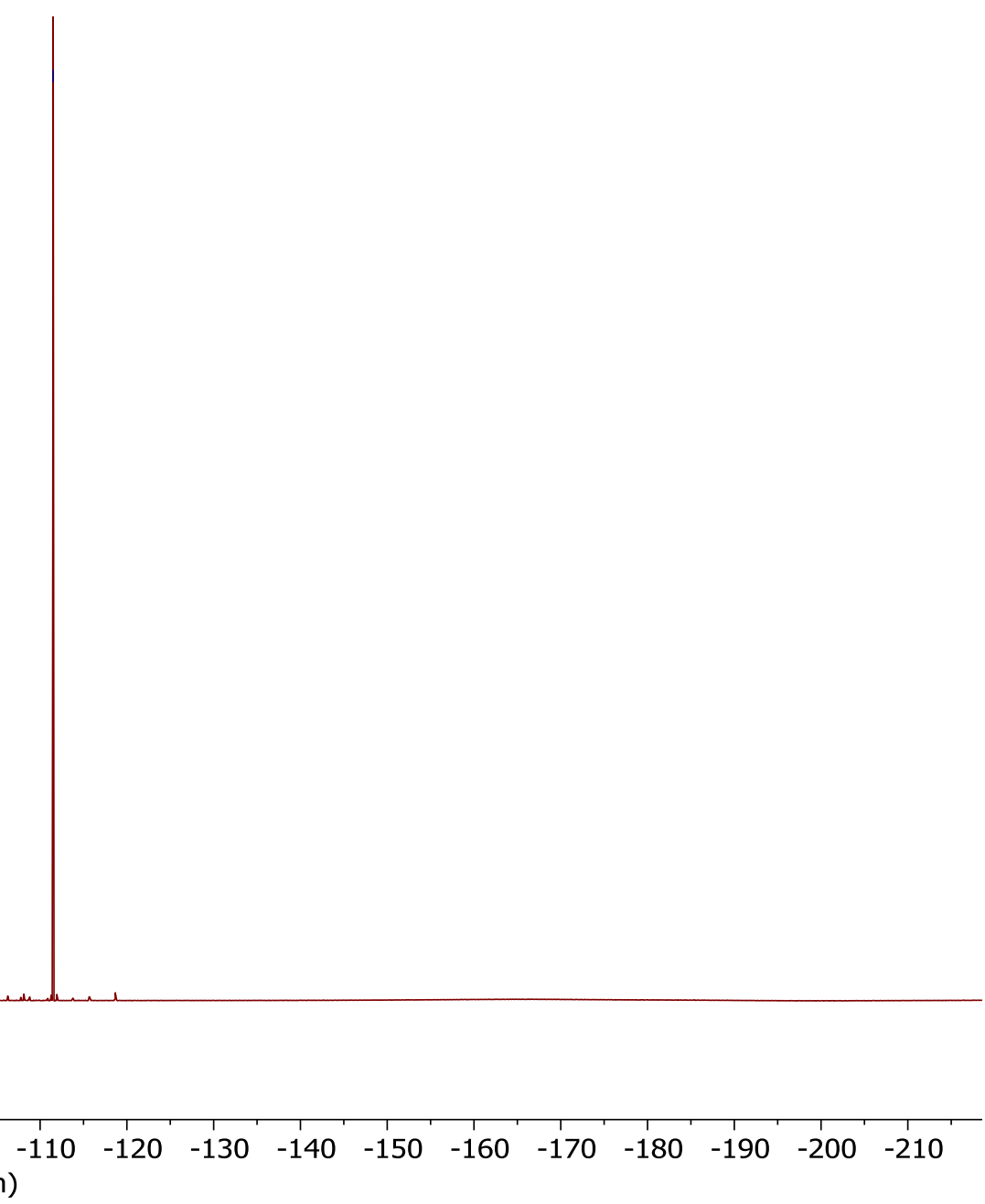

Compound 3cc: $376 \mathrm{MHz}{ }^{19} \mathrm{~F}$ NMR spectrum in $\mathrm{CDCl}_{3}$ 


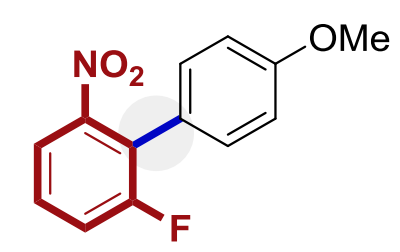

ผ

ợ

$7 \rightarrow 7$.

3cc $>95 \%(94 \%)$

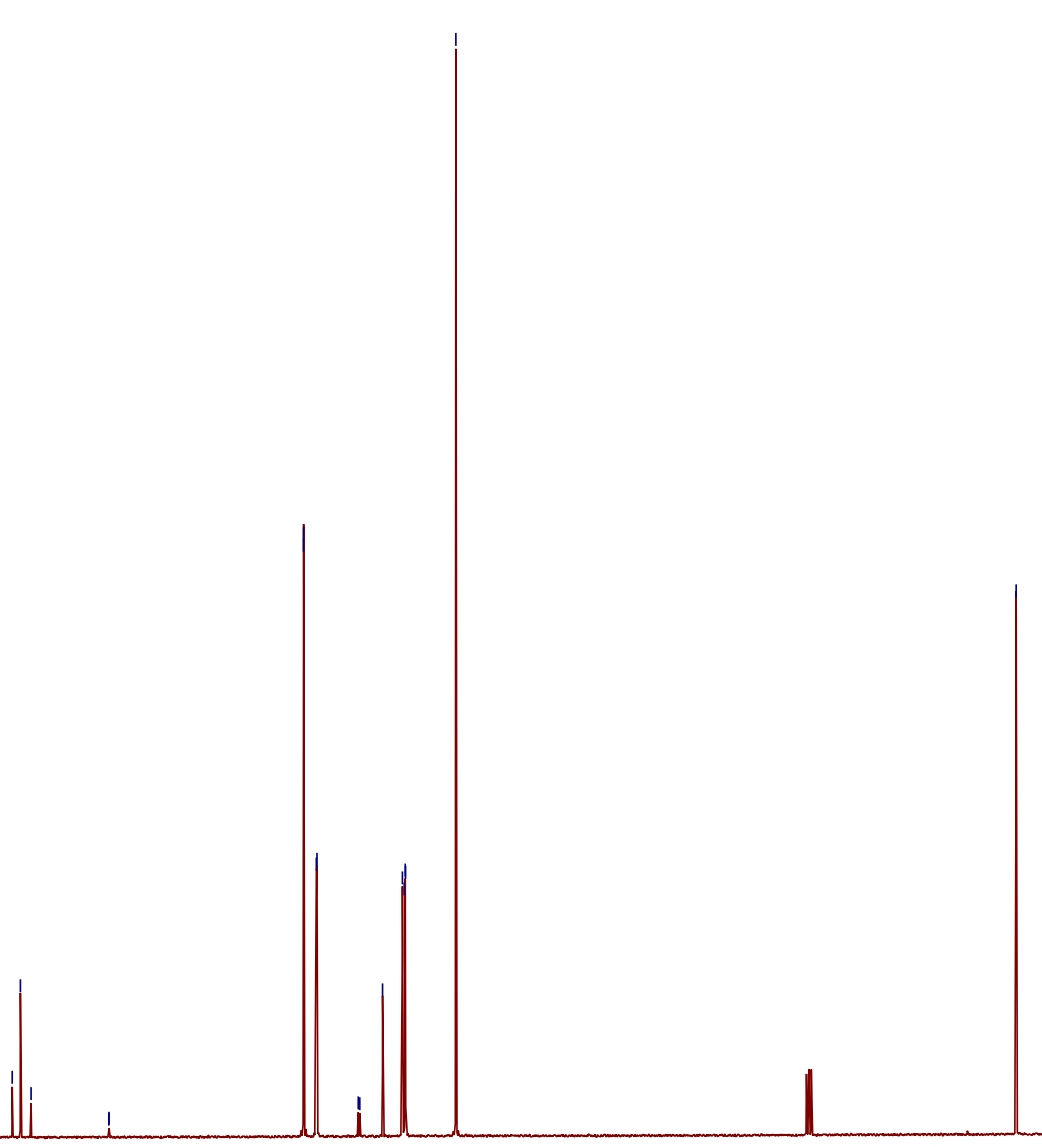

$\begin{array}{llllllllllllllllllllllll}210 & 200 & 190 & 180 & 170 & 160 & 150 & 140 & 130 & 120 & 110 & \begin{array}{c}100 \\ \mathrm{f} 1(\mathrm{ppm})\end{array} & 90 & 80 & 70 & 60 & 50 & 40 & 30 & 20 & 10 & 0 & -10\end{array}$

Compound 3cc: $126 \mathrm{MHz}{ }^{13} \mathrm{C} \mathrm{NMR}$ spectrum in $\mathrm{CDCl}_{3}$ 

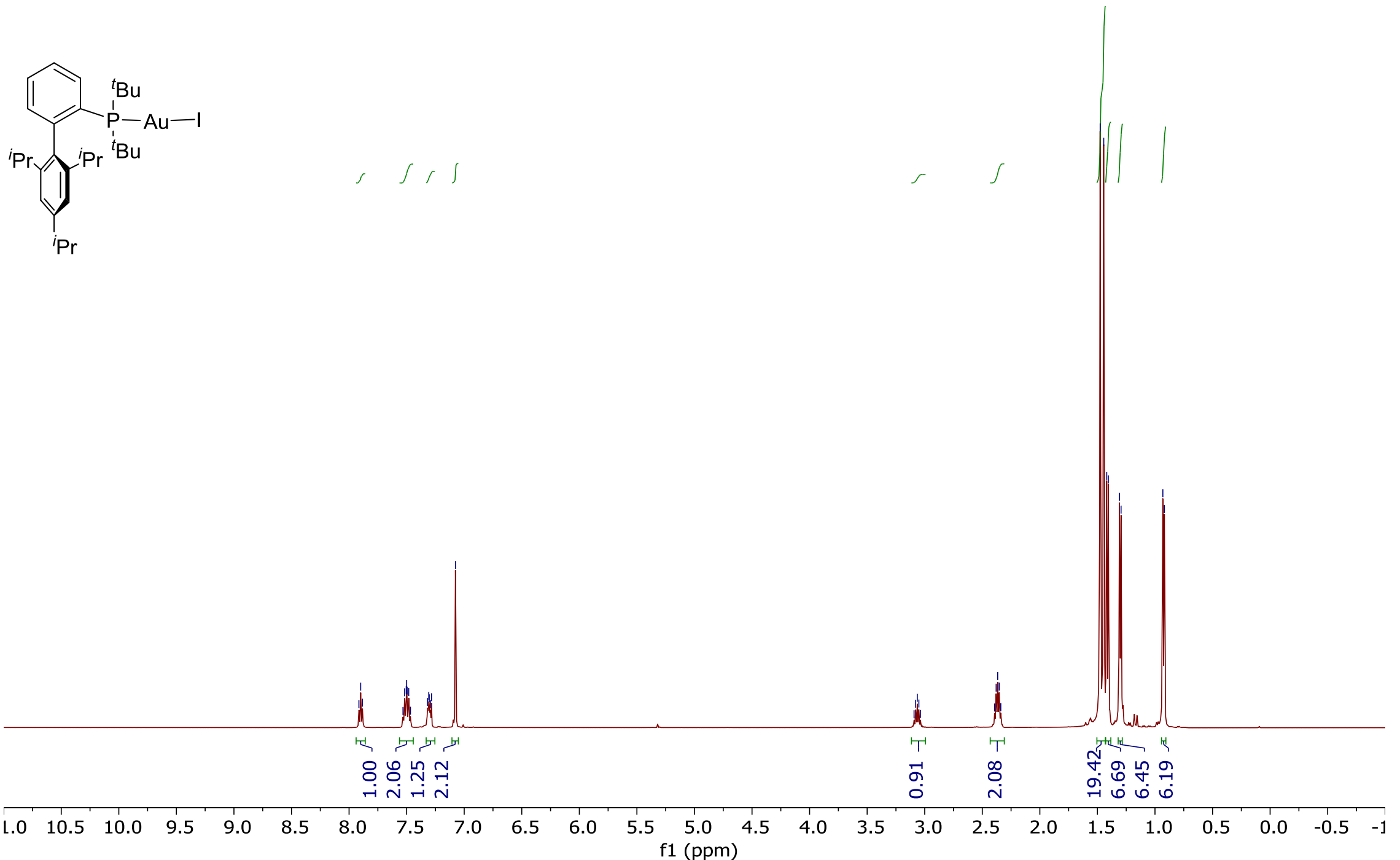

${ }^{t}$ BuXphosAuI: $500 \mathrm{MHz}{ }^{1} \mathrm{H}$ NMR spectrum in $\mathrm{CDCl}_{3}$ 

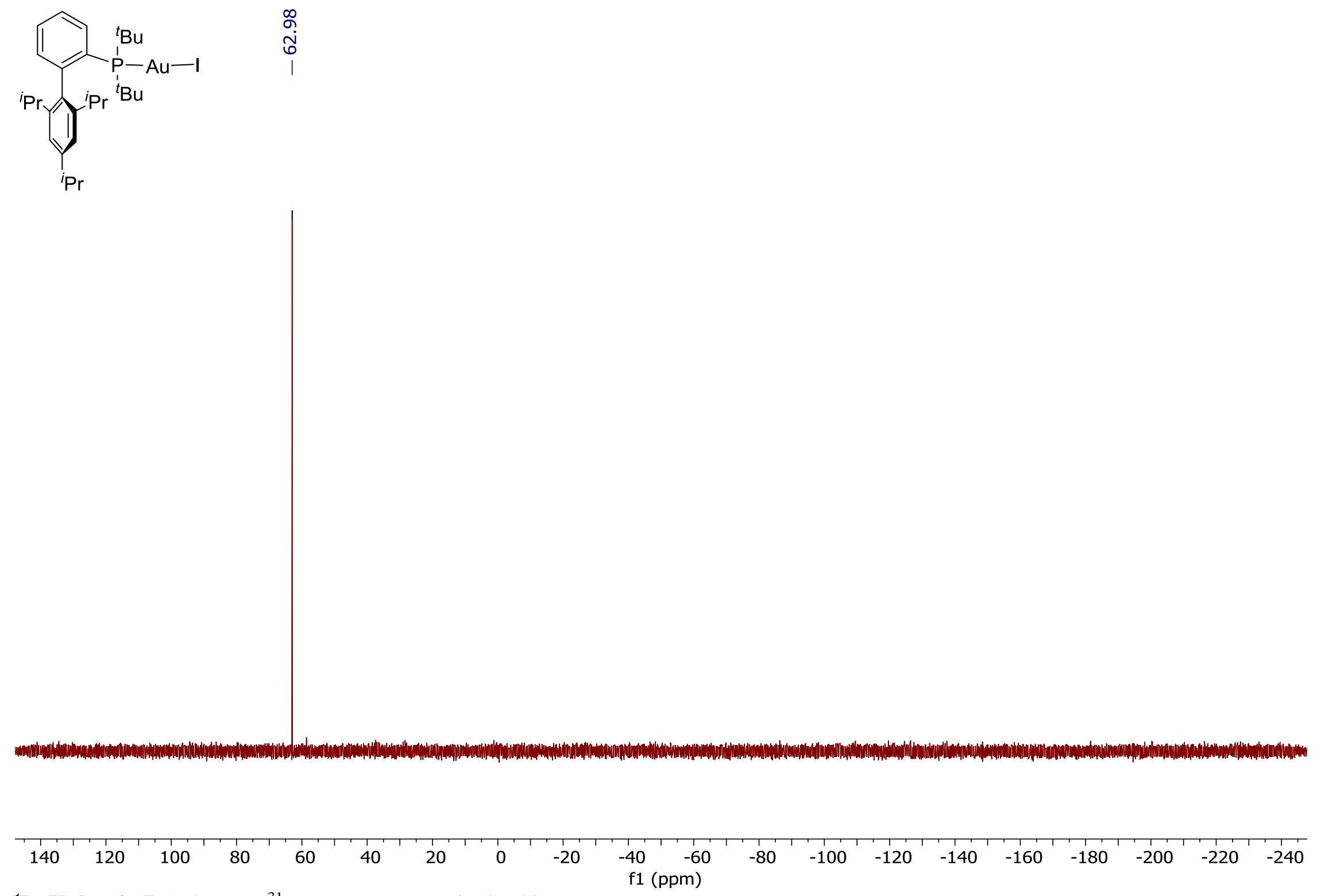

${ }^{t}$ BuXphosAuI: $162 \mathrm{MHz}{ }^{31} \mathrm{P} \mathrm{NMR}$ spectrum in $\mathrm{CDCl}_{3}$ 

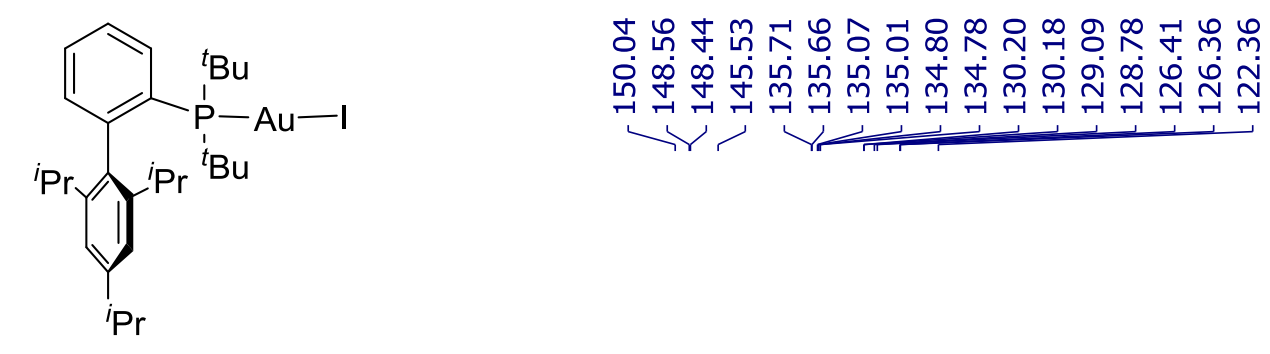

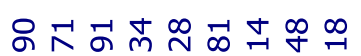
m m m m m m m r

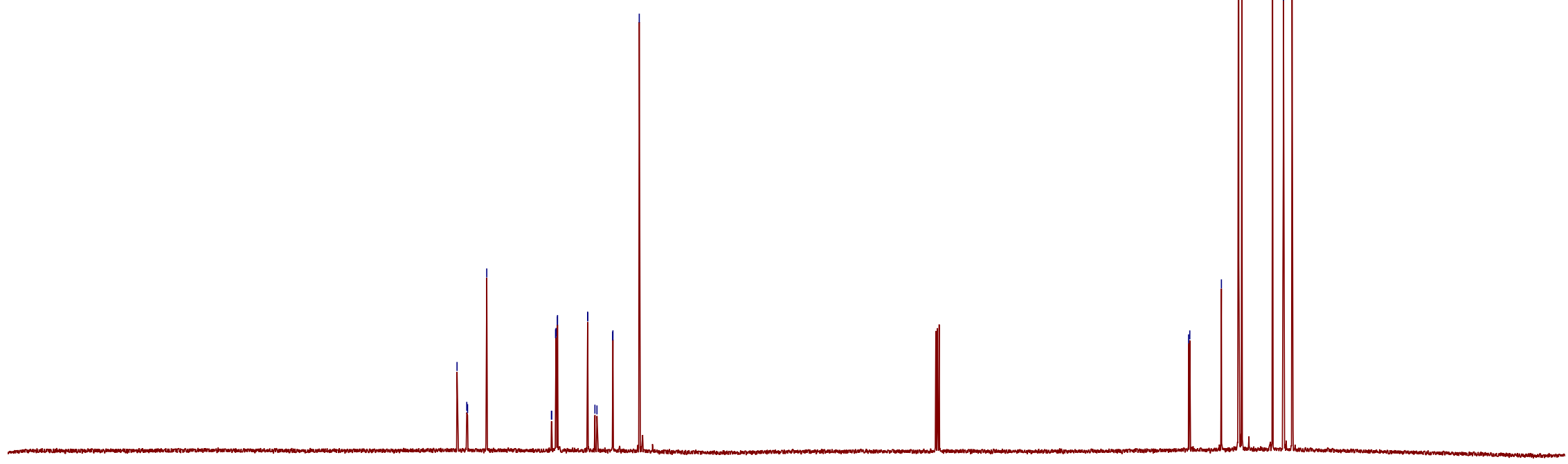

$\begin{array}{llllllllllllllllllllllllllllll}210 & 200 & 190 & 180 & 170 & 160 & 150 & 140 & 130 & 120 & 110 & 100 & 90 & 80 & 70 & 60 & 50 & 40 & 30 & 20 & 10 & 0 & -10 & \end{array}$

${ }^{t}$ BuXphosAuI: $126 \mathrm{MHz}{ }^{1} \mathrm{H}$ NMR spectrum in $\mathrm{CDCl}_{3}$ 


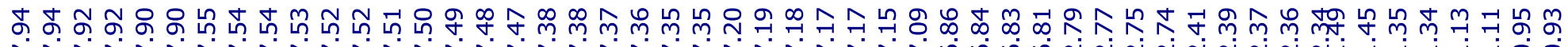
งทังหัง
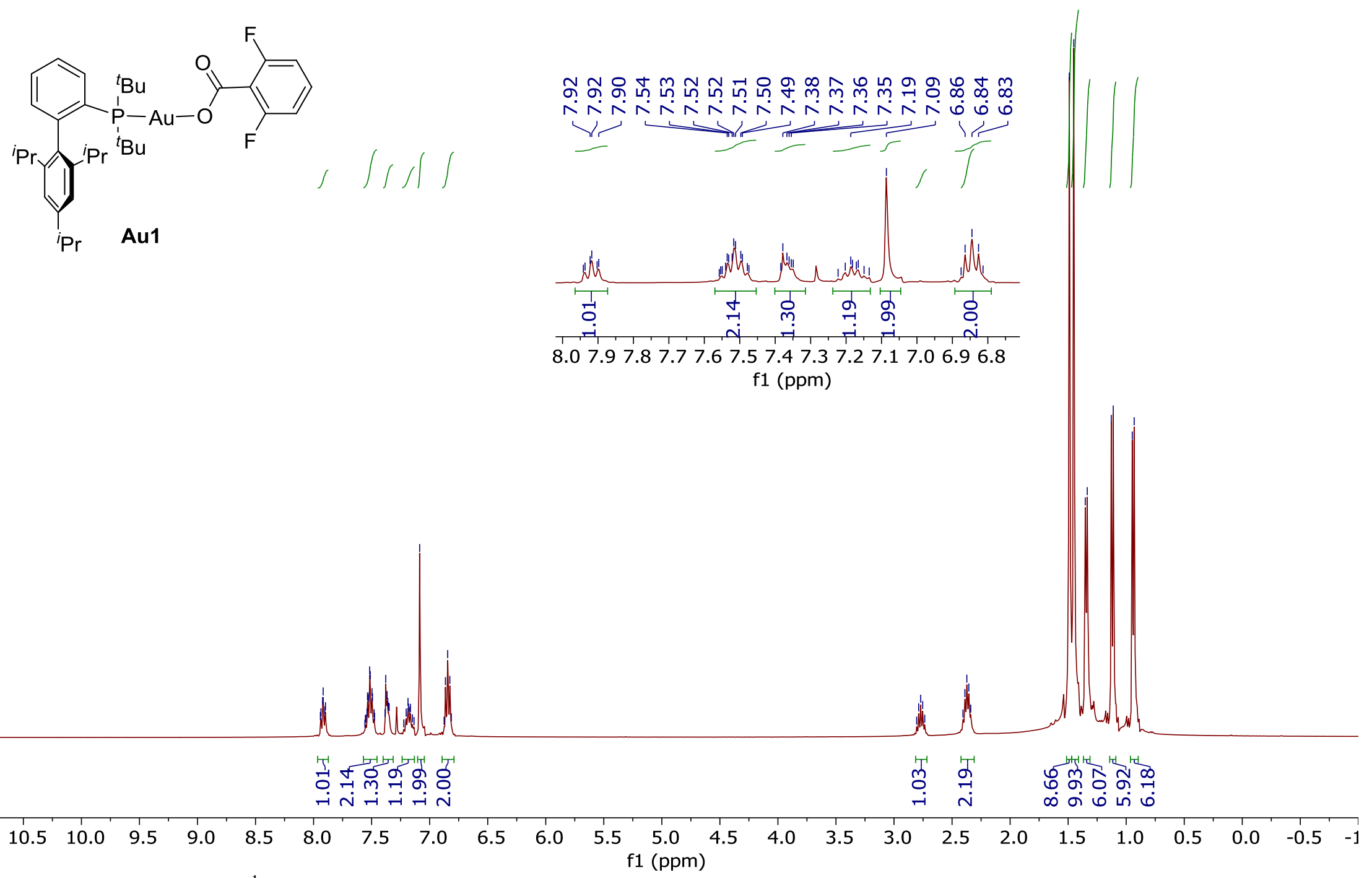

Compound Au1: $400 \mathrm{MHz}{ }^{1} \mathrm{H}$ NMR spectrum in $\mathrm{CDCl}_{3}$ 


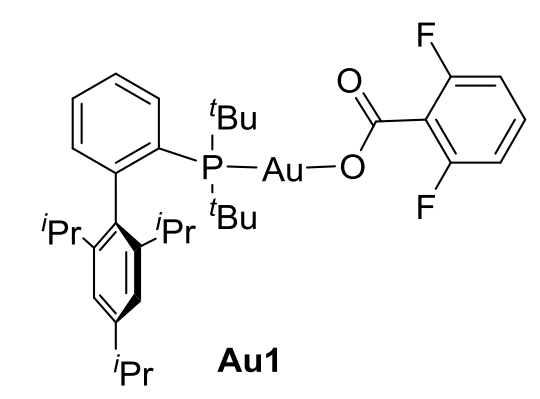

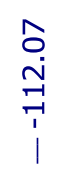

Pr Au1

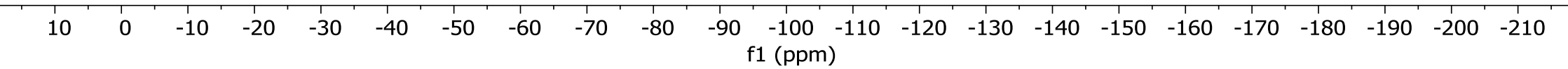

Compound Au1: $376 \mathrm{MHz}{ }^{19} \mathrm{~F}$ NMR spectrum in $\mathrm{CDCl}_{3}$ 


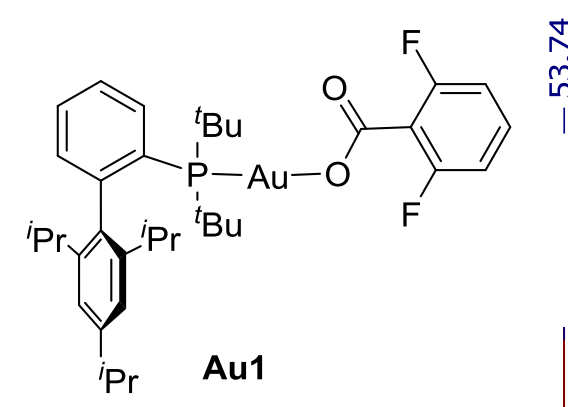

\begin{tabular}{llllllllllllllllllllllll}
\hline 140 & 120 & 100 & 80 & 60 & 40 & 20 & 0 & -20 & -40 & -60 & -80 & -100 & -120 & -140 & -160 & -180 & -200 & -220 & -240 &
\end{tabular}

Compound Au1: $162 \mathrm{MHz}{ }^{31} \mathrm{P}$ NMR spectrum in $\mathrm{CDCl}_{3}$ 


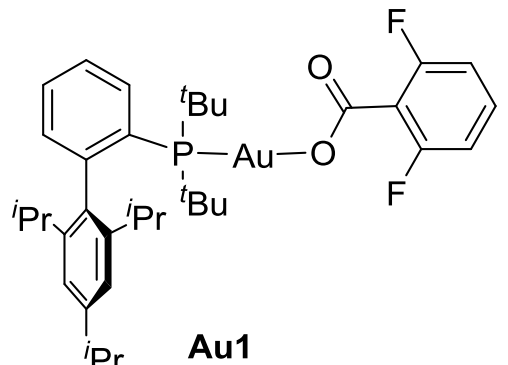

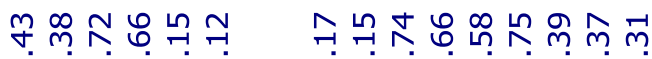
ம்ற户் 

${ }^{i} \mathrm{Pr}$
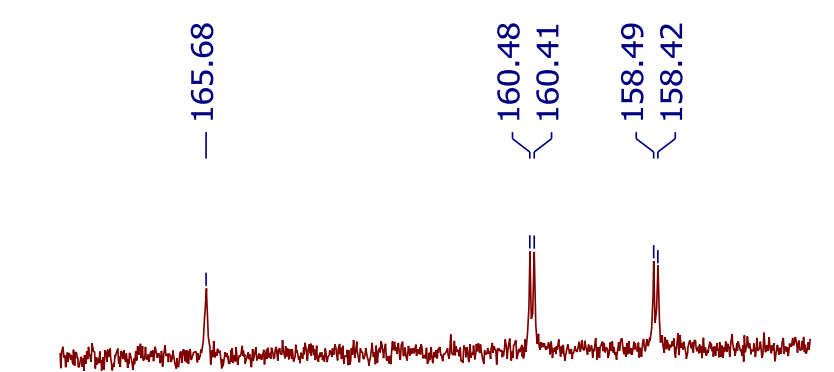

136135134133132131130129128127126125 $\mathrm{f} 1(\mathrm{ppm})$
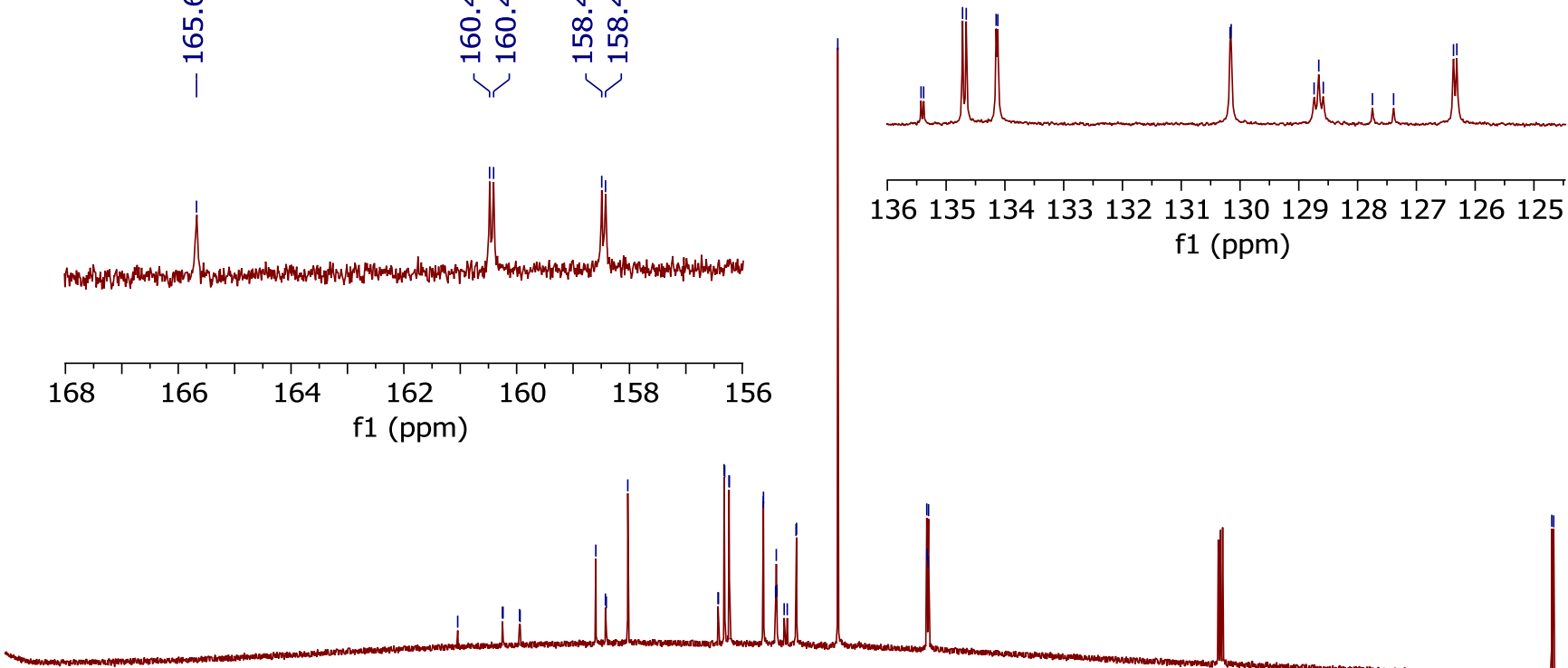

$\begin{array}{llllllllll}210 & 200 & 190 & 180 & 170 & 160 & 150 & 140 & 130 & 120\end{array}$ 100
$\mathrm{f} 1(\mathrm{ppm})$

Compound Au1: $126 \mathrm{MHz}{ }^{13} \mathrm{C}$ NMR spectrum in $\mathrm{CDCl}_{3}$ 


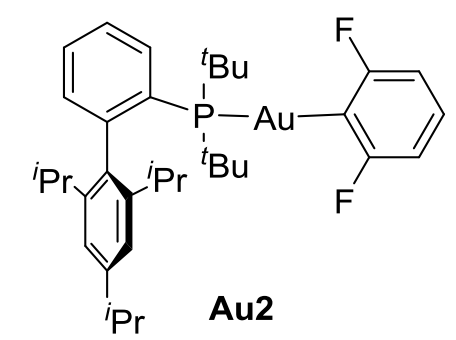

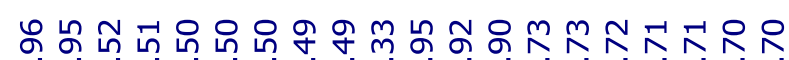

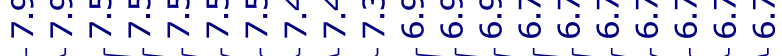
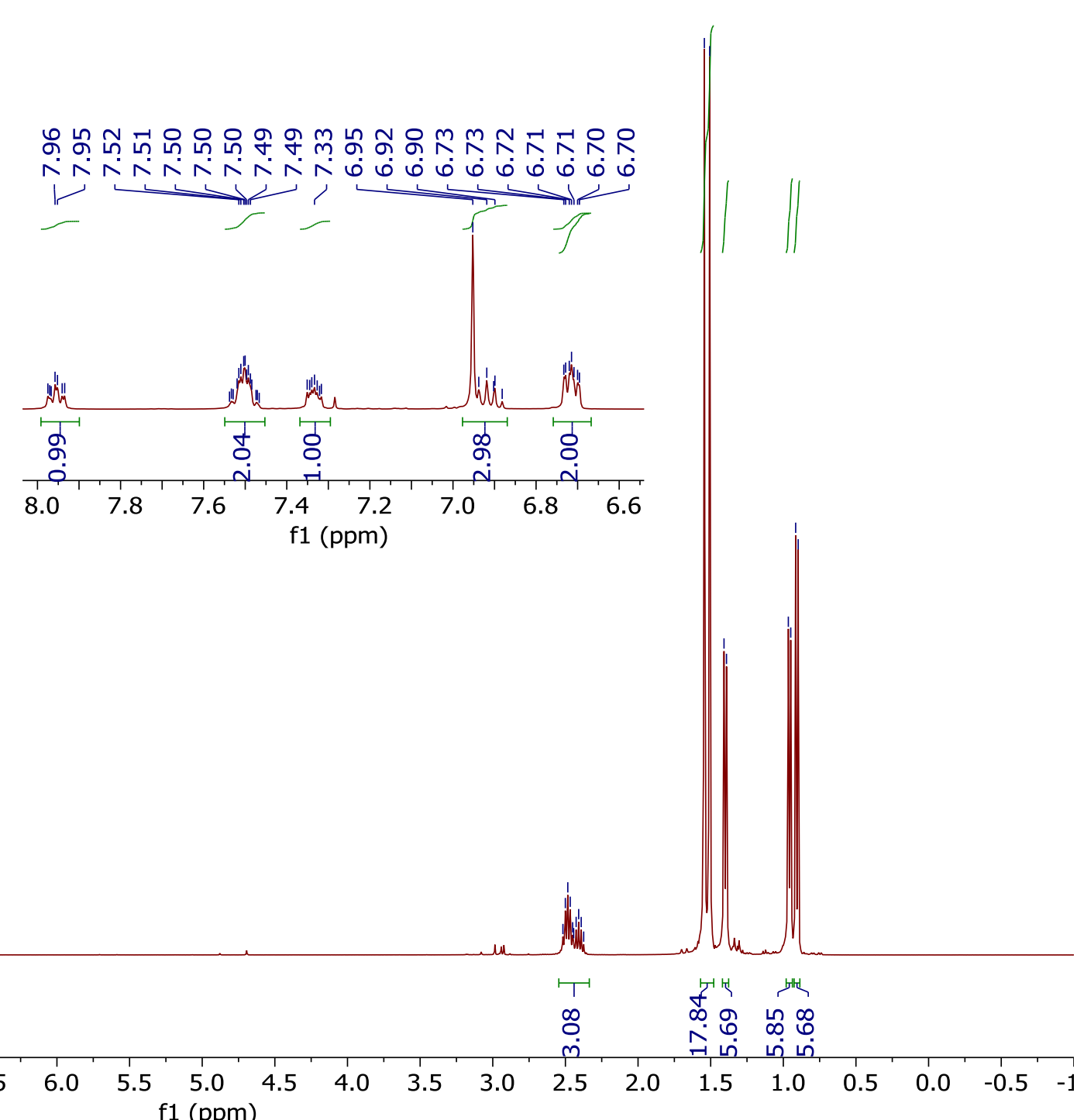

Compound Au2: $400 \mathrm{MHz}{ }^{1} \mathrm{H} \mathrm{NMR}$ spectrum in $\mathrm{CDCl}_{3}$ 

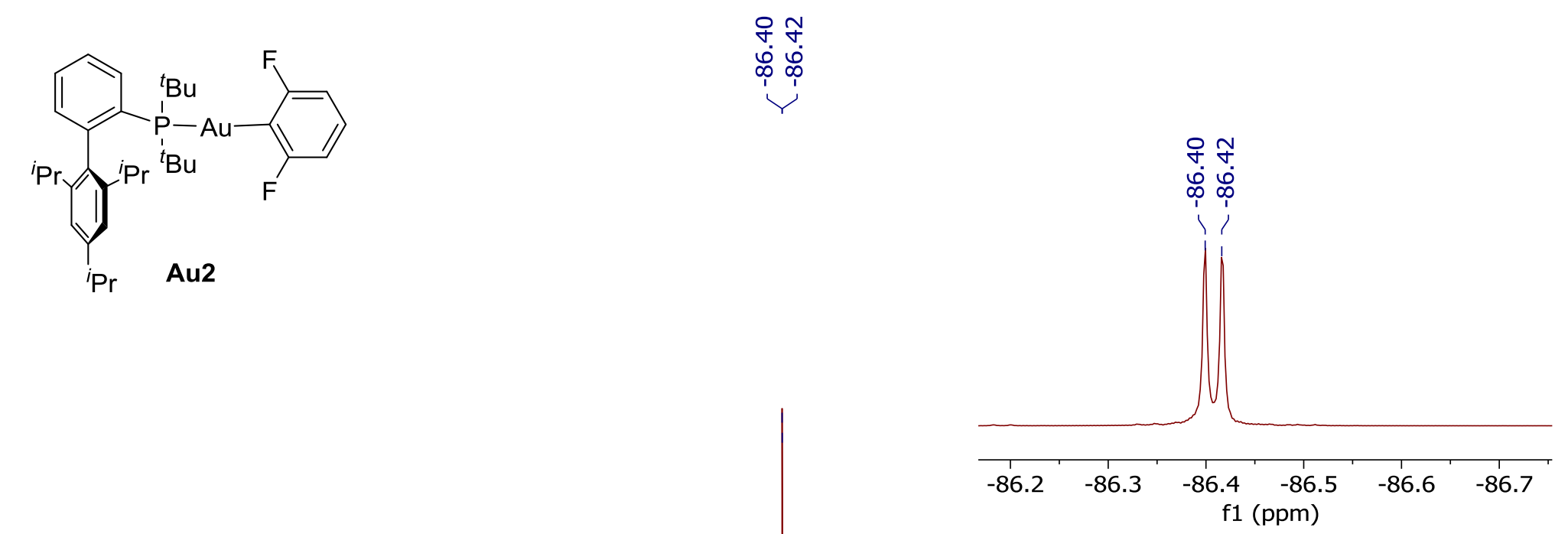

$\begin{array}{lllllllllllllllllllllll}10 & 0 & -10 & -20 & -30 & -40 & -50 & -60 & -70 & -80 & -90 & -100 & -110 & -120 & -130 & -140 & -150 & -160 & -170 & -180 & -190 & -200 & -210\end{array}$ Compound Au2: $376 \mathrm{MHz}{ }^{19} \mathrm{~F}$ NMR spectrum in $\mathrm{CDCl}_{3}$ 


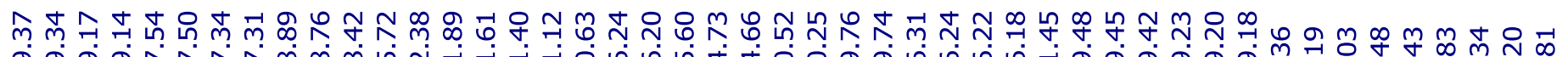

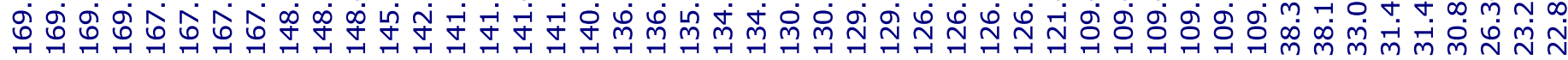
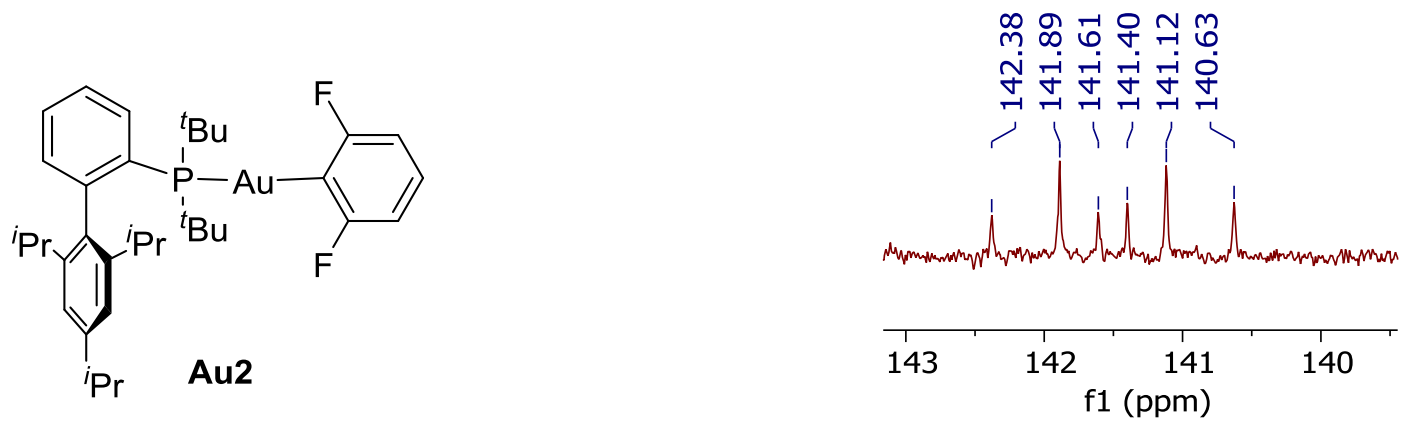

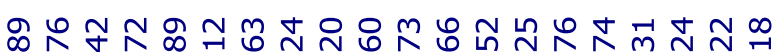

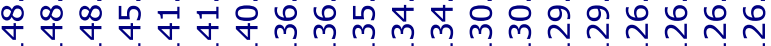

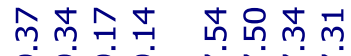
ดิ จิ
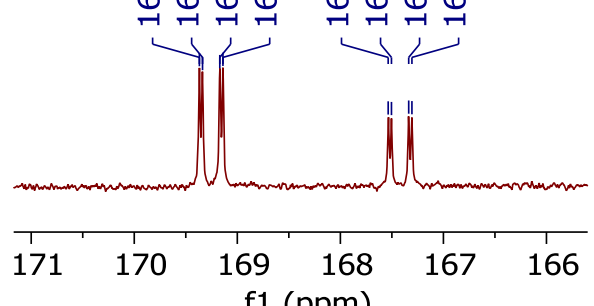

it

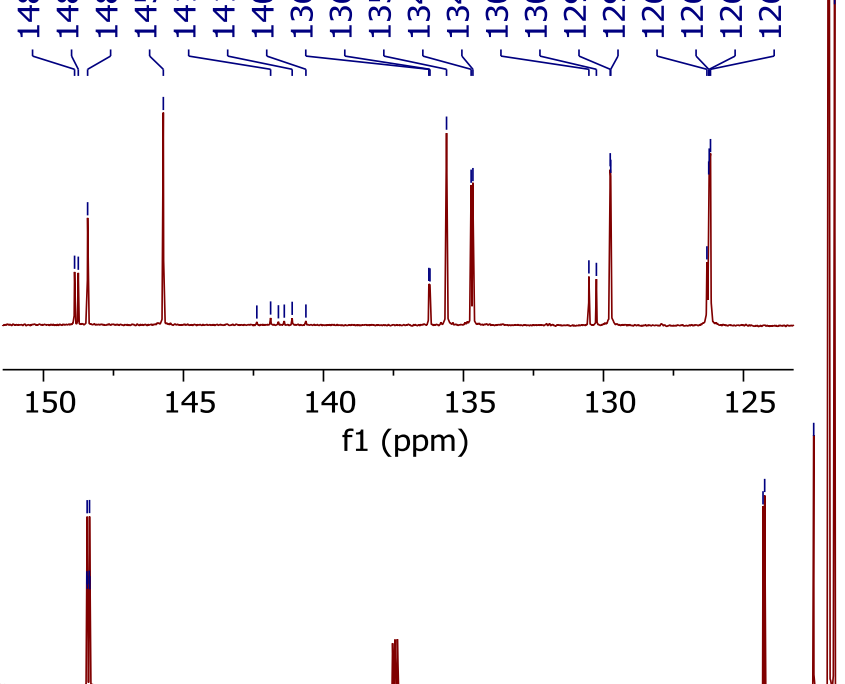

$\begin{array}{llllllllll}210 & 200 & 190 & 180 & 170 & 160 & 150 & 140 & 130 & 120\end{array}$

$110 \underset{f 1(\mathrm{ppm})}{100} 90$

80

60

50

$40 \quad 30$

20

$10 \quad 0 \quad-10$

Compound Au2: $126 \mathrm{MHz}{ }^{13} \mathrm{C}$ NMR spectrum in $\mathrm{CDCl}_{3}$ 


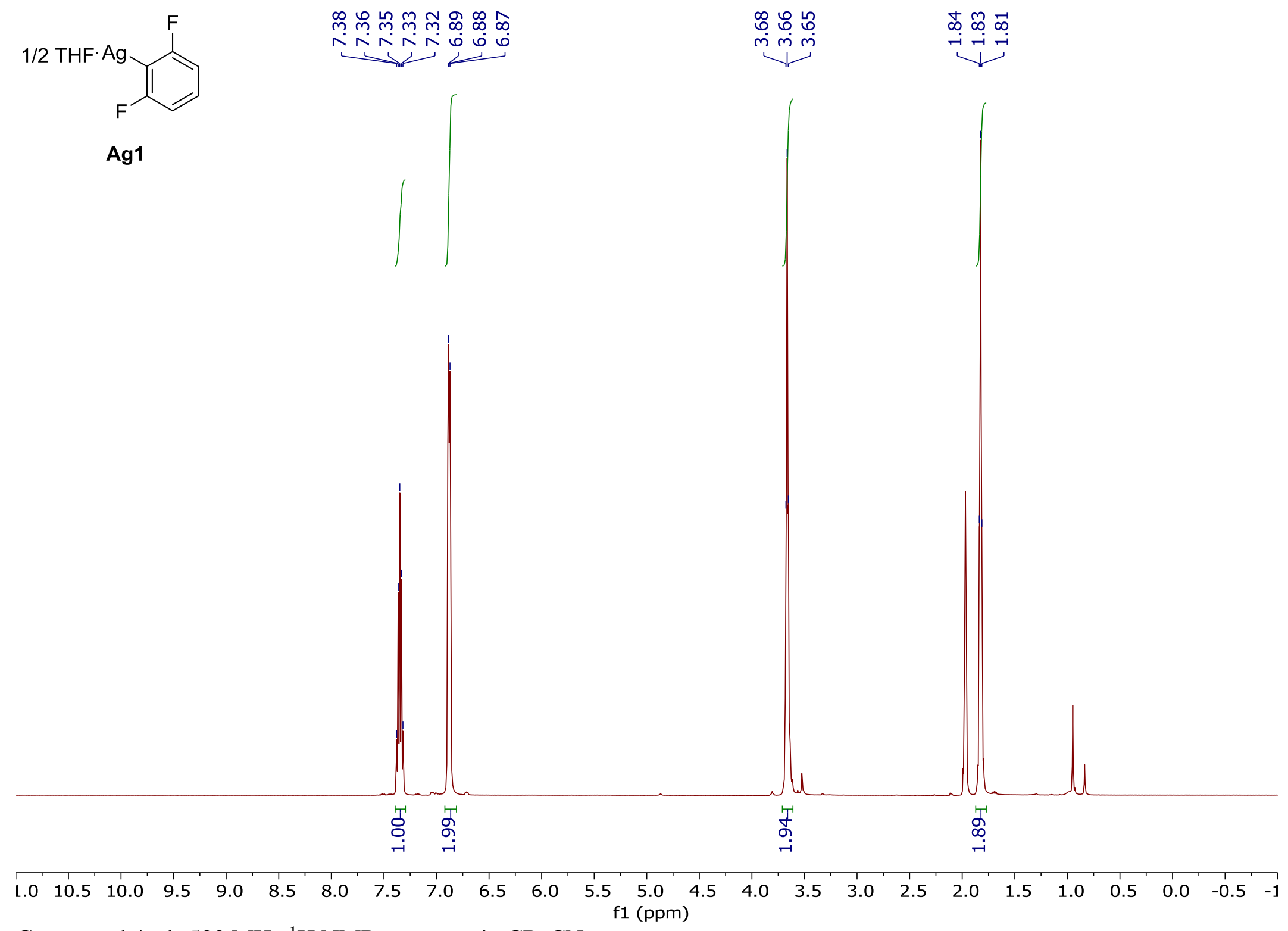

Compound Ag1: $500 \mathrm{MHz}{ }^{1} \mathrm{H}$ NMR spectrum in $\mathrm{CD}_{3} \mathrm{CN}$ 


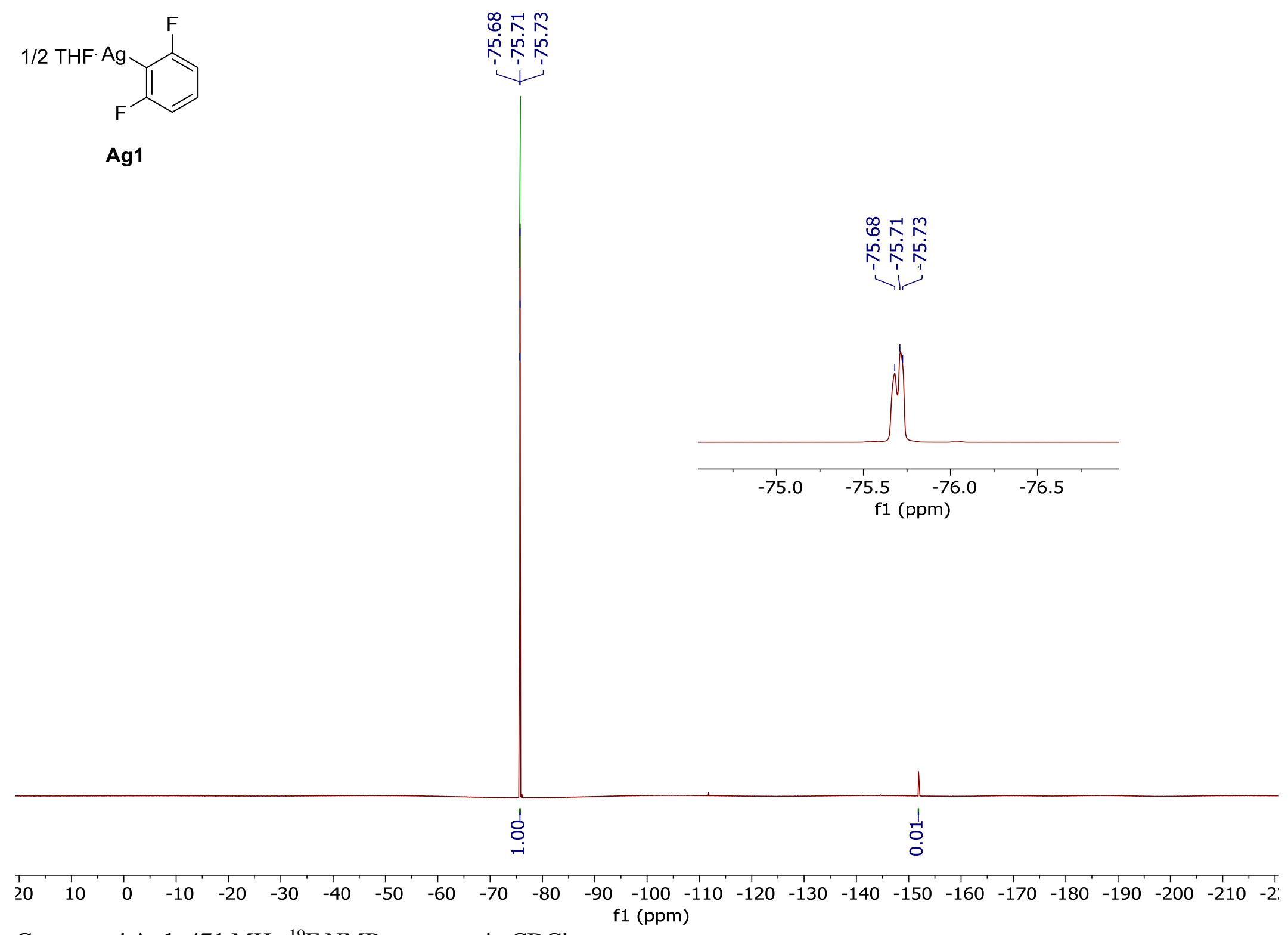




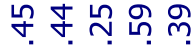

min

각ㄷㄱ

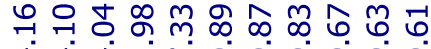

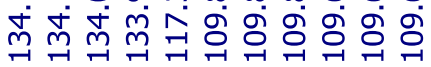

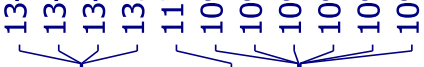

mำ

$\hat{\sigma}$

$\stackrel{\stackrel{\sim}{N}}{\stackrel{\nu}{1}}$

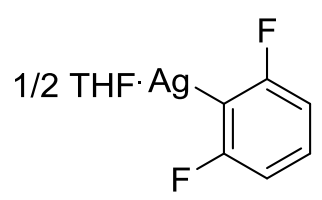

Ag1

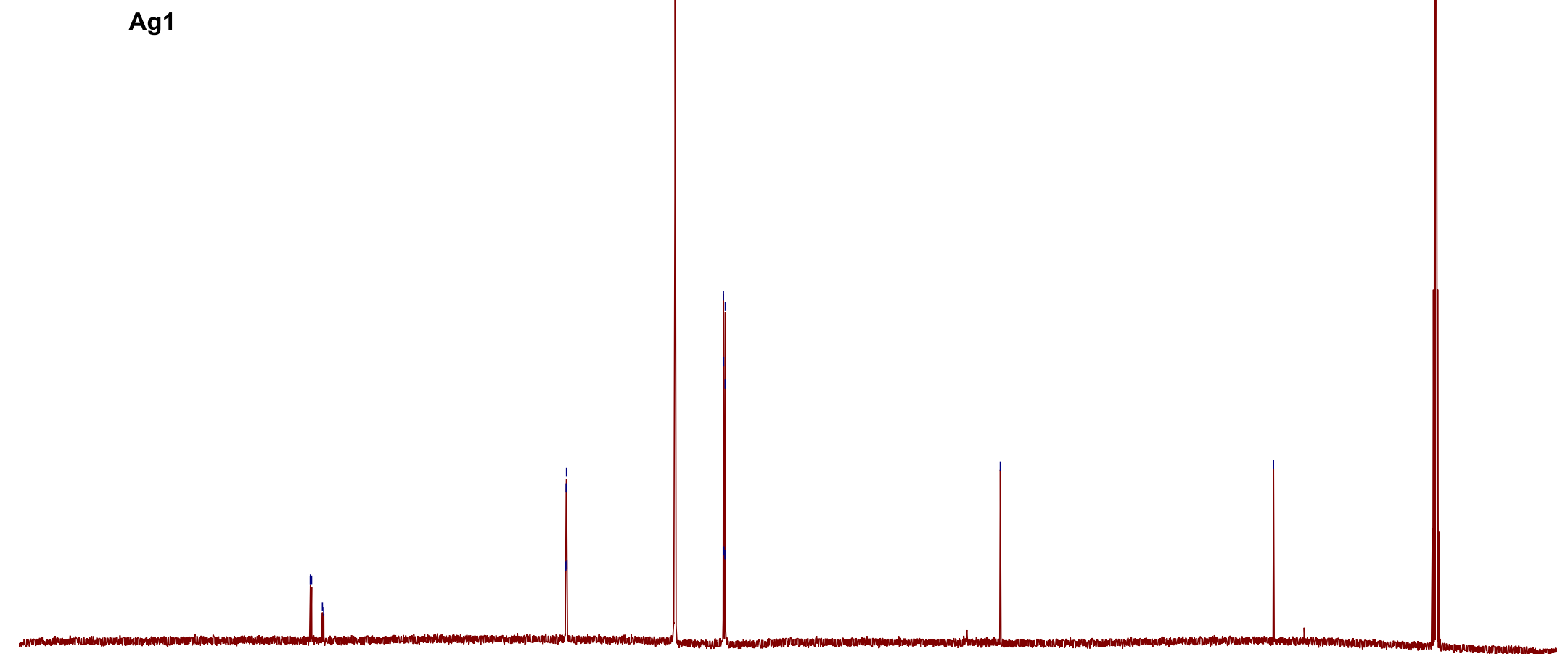

$\begin{array}{lllllllllllllllllllllll}210 & 200 & 190 & 180 & 170 & 160 & 150 & 140 & 130 & 120 & 110 & 100 & 90 & 80 & 70 & 60 & 50 & 40 & 30 & 20 & 10 & 0 & -10\end{array}$

Compound Ag1: $126 \mathrm{MHz}{ }^{13} \mathrm{C}$ NMR spectrum in $\mathrm{CD}_{3} \mathrm{CN}$ 


\section{${ }^{t} \mathrm{BuXPhosAuSbF}_{6} \cdot \mathrm{CH}_{3} \mathrm{CN}$}



${ }^{t}$ BuXPhosAuOCOC ${ }_{6} \mathrm{H}_{3} \mathrm{~F}_{2}$

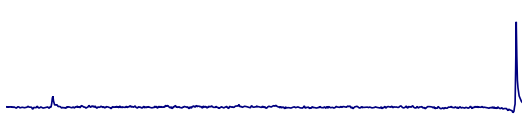

\section{(}

${ }^{t}$ BuXPhosAuNTf 2

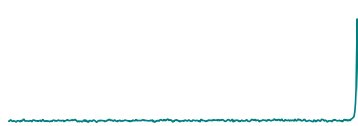

${ }^{t}$ BuXPhosAuOTf $\mathrm{CH}_{3} \mathrm{CN}$

(BuXPhosAuTfCH

${ }^{t}$ BuXPhosAuSbF $6 \cdot \mathrm{CH}_{3} \mathrm{CN}+\mathrm{NaOTf}+\mathrm{NaOCOC}_{6} \mathrm{H}_{3} \mathrm{~F}_{2}$
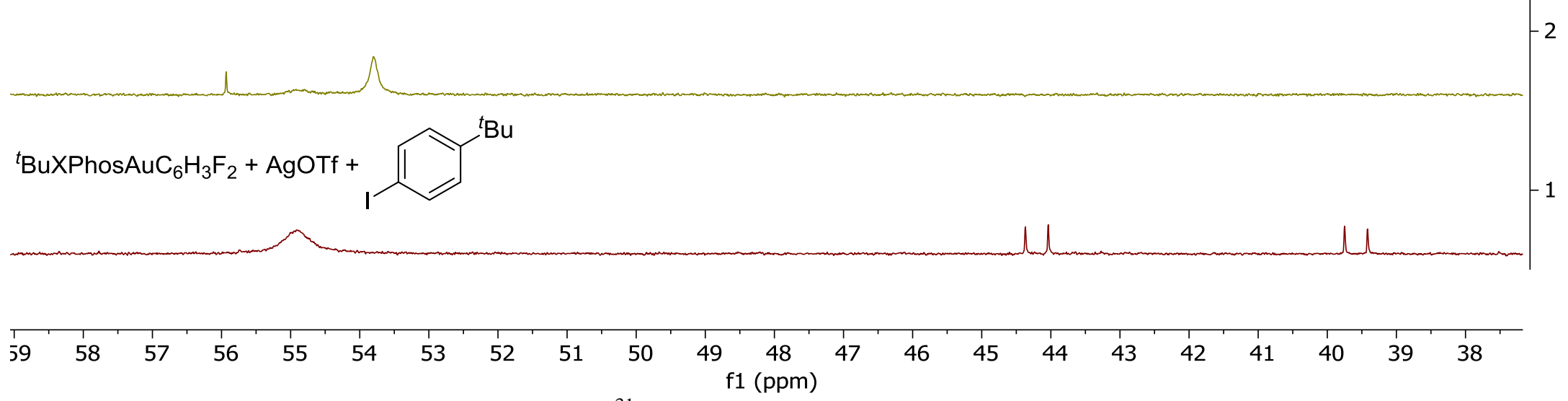

Comparison of cationic $\mathrm{Au}$ complexes: $162 \mathrm{MHz}{ }^{31} \mathrm{P}$ NMR spectrum in $\mathrm{CDCl}_{3}$ 


\section{Cartesian Coordinates: Oxidative Addition}

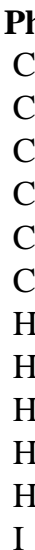

$\begin{array}{lll}1.26144 & -1.22468 & 0.0000\end{array}$

$\begin{array}{llll}2.66635 & -1.21434 & 0.0000\end{array}$

$\begin{array}{lll}3.36985 & 0.0000 & 0.0000\end{array}$

$\begin{array}{lll}2.66635 & 1.21434 & 0.0000\end{array}$

$\begin{array}{lll}1.26144 & 1.22468 & 0.0000\end{array}$

$\begin{array}{llll}0.70711 & -2.17089 & 0.0000\end{array}$

$\begin{array}{lll}3.20938 & -2.16925 & 0.0000\end{array}$

$\begin{array}{llll}4.46762 & 0.0000 & 0.0000\end{array}$

$\begin{array}{lll}3.20938 & 2.16925 & 0.0000\end{array}$

$\begin{array}{lll}0.70711 & 2.17089 & 0.0000\end{array}$

$\begin{array}{lll}-1.56865 & 0.0000 & 0.0000\end{array}$

\section{PhI-dcb}

$\mathrm{C}$

$\begin{array}{lll}-1.26144 & -1.22464 & 0.0000\end{array}$

$\begin{array}{lll}-0.5809 & 0.00002 & 0.0000\end{array}$

$\begin{array}{lll}-1.26146 & 1.22465 & 0.0000\end{array}$

$\begin{array}{lll}-2.66636 & 1.21428 & 0.0000\end{array}$

$\begin{array}{lll}-3.36988 & -0.00001 & 0.0000\end{array}$

$\begin{array}{lll}-2.66633 & -1.2143 & 0.0000\end{array}$

$\begin{array}{lll}-0.70708 & -2.17082 & 0.0000\end{array}$

$\begin{array}{llll}-0.70715 & 2.17086 & 0.0000\end{array}$

$\begin{array}{llll}-3.20939 & 2.16921 & -0.00001\end{array}$

$\begin{array}{llll}-4.46765 & -0.00004 & 0.0000\end{array}$

$\begin{array}{lll}-3.20937 & -2.16922-0.00001\end{array}$

$\begin{array}{lll}1.56866 & 0.0000 & 0.0000\end{array}$

$\begin{array}{lll}2.46825 & 1.68843 & 1.56618\end{array}$

$\begin{array}{llll}3.06641 & 2.61249 & 2.43774\end{array}$

$\begin{array}{llll}3.24499 & 0.68724 & 0.93896\end{array}$

$\begin{array}{llll}4.44238 & 2.54275 & 2.70195\end{array}$

$\begin{array}{llll}2.44928 & 3.38471 & 2.91514\end{array}$

$\begin{array}{lll}4.63379 & 0.63645 & 1.20417\end{array}$

$\begin{array}{lll}5.22566 & 1.55343 & 2.0835\end{array}$
$4.90824 \quad 3.26054 \quad 3.39018$

$\begin{array}{llll}5.26144 & -0.12095 & 0.7153\end{array}$

$\begin{array}{llll}6.30367 & 1.49648 & 2.28445\end{array}$

$2.42587-0.45974-0.22882$

$2.96404 \quad-2.23018 \quad 0.13974$

$2.87259 \quad 0.16706-1.94422$

$2.14301 \quad 1.52634-2.11301$

$\begin{array}{llll}2.47486 & 1.97447 & -3.07298\end{array}$

$1.04153 \quad 1.40486-2.152$

$\begin{array}{llll}2.39608 & 2.23745 & -1.29969\end{array}$

$\begin{array}{llll}2.3354 & -0.80701 & -3.01485\end{array}$

$2.47329-0.33812-4.01107$

$2.87671-1.77342-3.01988$

$\begin{array}{llll}1.25046 & -0.99955 & -2.87907\end{array}$

$\begin{array}{llll}4.38602 & 0.40531 & -2.13679\end{array}$

$4.99614-0.50346-1.97563$

$\begin{array}{llll}4.54917 & 0.7372 & -3.18307\end{array}$

$\begin{array}{llll}4.7552 & 1.20718 & -1.46899\end{array}$

$\begin{array}{llll}1.87237 & -3.19009 & -0.40547\end{array}$

$1.68985-3.06532-1.4898$

$2.21778-4.23104-0.23347$

$\begin{array}{llll}0.90966 & -3.0553 & 0.12711\end{array}$

$4.32546-2.66214-0.44588$

$4.52591-3.69955-0.10611$

$4.31931-2.67016-1.55277$

$\begin{array}{llll}5.16931 & -2.03513 & -0.1023\end{array}$

$\begin{array}{llll}2.98664 & -2.37695 & 1.68027\end{array}$

$\begin{array}{llll}3.0921 & -3.45479 & 1.92205\end{array}$

$\begin{array}{llll}3.82965 & -1.82999 & 2.14323\end{array}$

$\begin{array}{llll}2.039 & -2.01705 & 2.13333\end{array}$

$0.15778-0.34386-0.05765$

$\begin{array}{llll}-1.95463 & -0.10135 & -0.08071\end{array}$

$\begin{array}{llll}-2.82652 & -1.47094 & 0.26196\end{array}$

$\begin{array}{llll}-3.39907 & -2.09104 & -0.91582\end{array}$

$\begin{array}{llll}-1.9927 & -2.21386 & 1.19407\end{array}$

$-2.52823 \quad 0.96784-1.2004$

$\begin{array}{llll}-1.68335 & 1.01261 & -2.38333\end{array}$ 
$\begin{array}{lll}-3.97686 & 0.91167 & -1.2701\end{array}$

$\begin{array}{llll}-4.29245 & -0.83684 & 1.27089\end{array}$

$\begin{array}{llll}-2.11194 & 2.55043 & -0.31053\end{array}$

$\begin{array}{llll}-4.46146 & -1.66422 & 2.30534\end{array}$

$\begin{array}{llll}-5.39343 & -0.83476 & 0.53404\end{array}$

$\begin{array}{llll}-4.06176 & 0.39095 & 1.73521\end{array}$

$\begin{array}{llll}-0.77963 & 2.68484 & -0.1907\end{array}$

$\begin{array}{llll}-2.65721 & 2.59218 & 0.90062\end{array}$

$\begin{array}{llll}-2.57653 & 3.56577 & -1.03987\end{array}$

$\begin{array}{lll}1.38748 & 1.74342 & 1.36608\end{array}$

$\begin{array}{lll}-0.57276 & 3.47855 & 0.06474\end{array}$ $\begin{array}{lll}-1.2356 & 3.64326 & -1.16009\end{array}$

$\begin{array}{lll}-0.84732 & 3.165 & -2.0699\end{array}$

$\begin{array}{lll}1.146 & 2.17535 & 0.13777\end{array}$

$\begin{array}{lll}-0.72492 & 0.12185 & -0.0689\end{array}$

$\begin{array}{lll}-1.04733 & 4.0651 & 1.24494\end{array}$

$\begin{array}{lll}-0.51564 & 3.9205 & 2.19401\end{array}$

$\begin{array}{lll}-2.22431 & 4.83349 & 1.19123\end{array}$

$\begin{array}{lll}-2.60558 & 5.2982 & 2.11038\end{array}$

$\begin{array}{lll}-2.90824 & 5.00294 & -0.02344\end{array}$

$-2.41326 \quad 4.40946-1.19633$

$\begin{array}{llll}-2.94279 & 4.53829 & -2.1506\end{array}$ $\begin{array}{lll}-2.73491 & -0.99172 & -0.2031\end{array}$

$\begin{array}{lll}-3.16302 & -1.76828 & 1.39548\end{array}$ $\begin{array}{lll}-4.05963 & 0.31095 & -0.52196\end{array}$

$\begin{array}{llll}-2.61105 & -2.33417 & -1.5234\end{array}$

$\begin{array}{lll}-4.26837 & -2.64236 & 1.52973\end{array}$

$\begin{array}{lll}-2.3691 & -1.49315 & 2.53151\end{array}$

$\begin{array}{lll}-3.87924 & 1.3978 & 0.56782\end{array}$

$\begin{array}{lll}-5.50743 & -0.21851 & -0.41492\end{array}$

$\begin{array}{llll}-3.82618 & 0.95061 & -1.90789\end{array}$

$\begin{array}{lll}-3.94545 & -2.76455 & -2.16854\end{array}$

$-1.66111-1.82315-2.63806$

$\begin{array}{lll}-1.93891 & -3.55902 & -0.85629\end{array}$

$\begin{array}{lll}-4.89865 & -2.87301 & 0.66012\end{array}$ $\begin{array}{lll}-4.56885 & -3.22334 & 2.769\end{array}$

$\begin{array}{llll}-2.67752 & -2.07177 & 3.77307\end{array}$

$\begin{array}{lll}-3.98778 & 0.97276 & 1.58681\end{array}$

$\begin{array}{llll}-2.8969 & 1.90137 & 0.49358\end{array}$

$\begin{array}{llll}-5.73667 & -0.55384 & 0.61447\end{array}$

$-5.73068-1.04022-1.11963$

$\begin{array}{llll}-4.07724 & 0.26126 & -2.73786\end{array}$

$\begin{array}{llll}-2.77507 & 1.28547 & -2.02761\end{array}$

$\begin{array}{llll}-4.67941 & -3.15028 & -1.43572\end{array}$

$-4.41663-1.94825-2.74929$

$-1.98526-0.85754-3.07413$

$-0.62832-1.71593-2.25564$

$\begin{array}{llll}-2.62396 & -4.07957 & -0.16018\end{array}$

$-1.01438-3.27644-0.31524$

$\begin{array}{llll}-5.42555 & -3.90453 & 2.85679\end{array}$

$\begin{array}{llll}-3.77478 & -2.93729 & 3.89286\end{array}$

$\begin{array}{llll}-2.04791 & -1.85149 & 4.64487\end{array}$

$\begin{array}{llll}-4.01069 & -3.39651 & 4.86203\end{array}$

$\begin{array}{llll}-3.82824 & 5.60122 & -0.05621\end{array}$

$\begin{array}{llll}-6.19225 & 0.62203 & -0.6528\end{array}$

$\begin{array}{llll}-4.47955 & 1.84494 & -1.99536\end{array}$

$\begin{array}{llll}-4.66987 & 2.1654 & 0.42577\end{array}$

$\begin{array}{llll}-3.72178 & -3.59043 & -2.87527\end{array}$

$-1.64826-2.57933-3.45048$

$-1.65418-4.26727-1.66167$

$\begin{array}{llll}2.88004 & -0.37367 & 0.05993\end{array}$ $2.49502-1.73926-0.69196$

$\begin{array}{llll}4.42372 & 0.07408 & 0.30999\end{array}$

$\begin{array}{llll}1.08892 & -2.02321 & -0.37323\end{array}$

$\begin{array}{llll}3.46546 & -2.8172 & -0.68538\end{array}$

$\begin{array}{llll}5.41516 & -0.5447 & -0.5511\end{array}$

$\begin{array}{llll}4.40399 & 1.51416 & 0.52991\end{array}$

$\begin{array}{llll}4.72491 & -0.63768 & 1.99579\end{array}$

$\begin{array}{llll}2.3803 & -1.1861 & -2.45953\end{array}$

$\begin{array}{llll}4.55871 & -1.9617 & 1.98087\end{array}$

$\begin{array}{llll}3.8707 & -0.10874 & 2.88291\end{array}$

$\begin{array}{lll}5.97257 & -0.35953 & 2.3866\end{array}$ 
6c-TS

$\mathrm{C}$

$\mathrm{C}$

$\mathrm{H}$

$\mathrm{Au}$

C
$3.55538-0.76612-2.91675$

$\begin{array}{llll}1.94085 & -2.19478 & -3.22471\end{array}$

$\begin{array}{llll}1.49347 & -0.17325 & -2.56381\end{array}$

$\begin{array}{lll}-1.49741 & -0.82945 & 2.43668\end{array}$

$\begin{array}{lll}-1.0112 & -2.7192 & -0.08191\end{array}$ $\begin{array}{lll}-0.28615 & -3.0152 & 1.07645\end{array}$ $\begin{array}{llll}0.65354 & -2.50414 & 1.32574\end{array}$ $0.46457-2.21053-2.21896$ $\begin{array}{llll}-0.8274 & -0.55481 & -0.52408\end{array}$ $\begin{array}{llll}-2.15505 & -3.41209 & -0.49615\end{array}$ $\begin{array}{llll}-2.63527 & -3.19449 & -1.45718\end{array}$ $\begin{array}{lll}-2.6588 & -4.3968 & 0.37108\end{array}$

$\begin{array}{lll}-3.56117 & -4.95092 & 0.07875\end{array}$ $\begin{array}{lll}-2.01158 & -4.67403 & 1.5873\end{array}$

$\begin{array}{llll}-0.83369 & -3.99121 & 1.93275\end{array}$

$\begin{array}{lll}-0.30586 & -4.22044 & 2.86815\end{array}$ $\begin{array}{llll}-2.27029 & 0.88776 & 0.74081\end{array}$

$\begin{array}{llll}-2.56573 & 2.40041 & -0.24268\end{array}$ $\begin{array}{llll}-3.95353 & 0.06832 & 0.92381\end{array}$

$\begin{array}{lll}-1.46111 & 1.34142 & 2.38076\end{array}$ $\begin{array}{llll}-3.16405 & 3.5499 & 0.32695\end{array}$ $\begin{array}{llll}-2.21534 & 2.42193 & -1.61146\end{array}$ $\begin{array}{llll}-4.36565 & -0.40717 & -0.49016\end{array}$ $\begin{array}{llll}-5.05611 & 1.02641 & 1.42811\end{array}$ $\begin{array}{lll}-3.84001 & -1.15074 & 1.86684\end{array}$ $\begin{array}{llll}-2.40065 & 1.81331 & 3.51125\end{array}$ $\begin{array}{lll}-0.68548 & 0.09397 & 2.87295\end{array}$ $\begin{array}{llll}-0.43677 & 2.45761 & 2.06177\end{array}$ $\begin{array}{llll}-3.45134 & 3.55309 & 1.38698\end{array}$ $\begin{array}{llll}-3.40019 & 4.69001 & -0.452\end{array}$ $\begin{array}{llll}-2.4598 & 3.56366 & -2.39051\end{array}$ $\begin{array}{llll}-4.40267 & 0.43671 & -1.20869\end{array}$ $\begin{array}{llll}-3.67351 & -1.17571 & -0.88256\end{array}$ $\begin{array}{llll}-5.24851 & 1.83868 & 0.70155\end{array}$ $\begin{array}{lll}-4.83014 & 1.47279 & 2.41376\end{array}$ $\begin{array}{lll}-3.7396 & -0.84305 & 2.92549\end{array}$ $\begin{array}{llll}-2.98446 & -1.8044 & 1.61042\end{array}$ $\begin{array}{llll}-2.99419 & 2.70854 & 3.24642\end{array}$ $\begin{array}{llll}-3.0888 & 1.01779 & 3.85537\end{array}$ $\begin{array}{lll}-1.3362 & -0.79195 & 3.01748\end{array}$ $\begin{array}{lll}0.13361 & -0.16544 & 2.1803\end{array}$ $\begin{array}{llll}-0.92863 & 3.44289 & 1.94665\end{array}$ $\begin{array}{lll}0.13499 & 2.2392 & 1.14237\end{array}$ $\begin{array}{llll}-3.85946 & 5.57603 & 0.00592\end{array}$ $\begin{array}{lll}-3.048 \quad 4.69812 & -1.8125\end{array}$

$\begin{array}{llll}-2.17322 & 3.56628 & -3.44996\end{array}$ $\begin{array}{llll}-3.22897 & 5.5945 & -2.42053\end{array}$

$\begin{array}{llll}-2.41074 & -5.44765 & 2.25567\end{array}$ $\begin{array}{lll}2.08149 & 0.56161 & 0.63036\end{array}$ $\begin{array}{llll}2.9366 & -0.72033 & 1.12391\end{array}$ $\begin{array}{llll}2.14938 & 1.17152 & -0.85646\end{array}$ $\begin{array}{llll}3.07195 & -1.78808 & 0.14591\end{array}$ $\begin{array}{llll}2.46168 & -1.0349 & 2.46714\end{array}$ $\begin{array}{llll}0.77208 & 1.53053 & -1.25329\end{array}$ $\begin{array}{llll}3.03574 & 0.54097 & -1.81943\end{array}$ $\begin{array}{llll}4.66234 & -0.09598 & 1.39621\end{array}$ $\begin{array}{llll}2.88954 & 2.84108 & -0.5226\end{array}$ $\begin{array}{llll}4.65057 & 0.9931 & 2.17189\end{array}$ $\begin{array}{llll}5.37553 & -1.04909 & 2.0049\end{array}$ $\begin{array}{llll}5.24211 & 0.20322 & 0.2336\end{array}$ $\begin{array}{llll}2.14055 & 3.53051 & 0.34545\end{array}$ $\begin{array}{llll}4.11861 & 2.71188 & -0.02159\end{array}$ $\begin{array}{llll}2.95581 & 3.5254 & -1.66885\end{array}$ $\begin{array}{llll}-4.76862 & -1.75292 & 1.77665\end{array}$ $\begin{array}{llll}-5.99188 & 0.43814 & 1.53317\end{array}$ $\begin{array}{llll}-5.3808 & -0.85222 & -0.42792\end{array}$ $\begin{array}{llll}-1.75649 & 2.0903 & 4.37165\end{array}$ $\begin{array}{lll}-0.21801 & 0.34081 & 3.84846\end{array}$ $\begin{array}{llll}0.28757 & 2.51467 & 2.90001\end{array}$ $\begin{array}{llll}-1.72896 & 1.54872 & -2.06957\end{array}$ 
$\begin{array}{lll}-2.55948 & -1.47185 & -0.12748\end{array}$

$-3.38249-1.61318-1.25261$

$-3.03184-1.31598-2.24831$

$-0.00579-2.89646-1.45932$

$-0.70223-0.60133-0.17329$

$\begin{array}{llll}-2.93788 & -1.98306 & 1.122\end{array}$

$\begin{array}{llll}-2.24863 & -1.95226 & 1.97528\end{array}$

$\begin{array}{llll}-4.22056 & -2.54551 & 1.26728\end{array}$

$\begin{array}{lll}-4.52667 & -2.93426 & 2.24813\end{array}$

$\begin{array}{llll}-5.09144 & -2.61741 & 0.16956\end{array}$

$\begin{array}{llll}-4.66263 & -2.17147 & -1.09093\end{array}$

$-5.31613-2.27443-1.96806$

$\begin{array}{llll}-1.55928 & 1.67318 & 0.47325\end{array}$

$\begin{array}{llll}-0.48912 & 2.81486 & -0.46474\end{array}$

$\begin{array}{llll}-3.28898 & 2.10084 & -0.17813\end{array}$

$\begin{array}{lll}-1.36952 & 1.97908 & 2.32279\end{array}$

$\begin{array}{llll}-0.15195 & 4.11183 & -0.01047\end{array}$

$\begin{array}{llll}-0.03053 & 2.39492 & -1.73233\end{array}$

$-3.28291 \quad 1.77516-1.6954$

$\begin{array}{llll}-3.59573 & 3.61785 & -0.06608\end{array}$

$\begin{array}{llll}-4.41828 & 1.33786 & 0.55174\end{array}$

$\begin{array}{llll}-2.18318 & 3.16241 & 2.89961\end{array}$

$\begin{array}{lll}-1.85475 & 0.69803 & 3.04722\end{array}$

$\begin{array}{llll}0.14286 & 2.20857 & 2.61578\end{array}$

$\begin{array}{lll}-0.50448 & 4.46942 & 0.96432\end{array}$

$\begin{array}{llll}0.636 & 4.95566 & -0.80473\end{array}$

$\begin{array}{llll}0.76576 & 3.23847 & -2.52069\end{array}$

$\begin{array}{llll}-2.74877 & 2.56376 & -2.25938\end{array}$

$\begin{array}{llll}-2.81312 & 0.80555 & -1.93474\end{array}$

$\begin{array}{llll}-2.78974 & 4.24616 & -0.48982\end{array}$

$\begin{array}{lll}-3.81113 & 3.94147 & 0.9663\end{array}$

$\begin{array}{llll}-4.48199 & 1.63268 & 1.61704\end{array}$

$\begin{array}{llll}-4.33007 & 0.24121 & 0.49173\end{array}$

$\begin{array}{llll}-1.99446 & 4.12658 & 2.39237\end{array}$

$\begin{array}{llll}-3.27198 & 2.96529 & 2.89101\end{array}$

$\begin{array}{llll}-2.89316 & 0.42553 & 2.77023\end{array}$

$\begin{array}{lll}-1.18776 & -0.15492 & 2.84165\end{array}$ $\begin{array}{lll}0.37332 & 3.28844 & 2.68897\end{array}$

$\begin{array}{llll}0.80979 & 1.78955 & 1.84259\end{array}$

$\begin{array}{llll}0.8959 & 5.95725 & -0.43725\end{array}$

$\begin{array}{llll}1.10302 & 4.51809 & -2.05618\end{array}$

$\begin{array}{llll}1.14934 & 2.86908 & -3.48063\end{array}$

$\begin{array}{llll}1.73967 & 5.17407 & -2.66472\end{array}$

$\begin{array}{llll}-6.09202 & -3.0535 & 0.28829\end{array}$

$\begin{array}{llll}-4.3339 & 1.74635 & -2.04987\end{array}$

$\begin{array}{llll}-4.51142 & 3.80111 & -0.66722\end{array}$ $\begin{array}{lll}-5.37701 & 1.62922 & 0.0736\end{array}$

$\begin{array}{lll}-1.87363 & 3.2739 & 3.95976\end{array}$

$\begin{array}{lll}-1.83025 & 0.89533 & 4.13906\end{array}$

$\begin{array}{llll}0.40566 & 1.72734 & 3.5786\end{array}$

$\begin{array}{lll}1.55541 & -0.17544 & 0.14376\end{array}$

$\begin{array}{llll}2.09401 & -0.59813 & 1.645\end{array}$

$2.68336 \quad 0.10658-1.02505$

$\begin{array}{llll}3.04168 & 0.37628 & 2.16218\end{array}$

$\begin{array}{llll}0.88443 & -0.9503 & 2.38401\end{array}$

$\begin{array}{llll}1.96906 & 0.27655 & -2.27657\end{array}$

$3.81943-0.78708-0.89447$

$\begin{array}{llll}3.39383 & 1.80839 & -0.61128\end{array}$

$\begin{array}{llll}3.07659 & -2.21634 & 1.57517\end{array}$

$\begin{array}{llll}4.52757 & 1.69071 & 0.06655\end{array}$

$\begin{array}{llll}2.53082 & 2.54273 & 0.09746\end{array}$

$\begin{array}{llll}3.64841 & 2.44047 & -1.76441\end{array}$

$\begin{array}{llll}4.37781 & -1.97043 & 1.54047\end{array}$

$2.79542-2.86303 \quad 2.71288$

$\begin{array}{llll}2.7208 & -2.97432 & 0.54982\end{array}$

$\begin{array}{lll}-0.27521 & 1.39053 & -2.10613\end{array}$

$\begin{array}{llll}-0.35472 & 2.32787 & -1.23981\end{array}$ $\begin{array}{llll}-1.11556 & 2.29385 & -0.03627\end{array}$ $\begin{array}{llll}-0.48833 & 2.64903 & 1.19144\end{array}$ $\begin{array}{llll}0.87436 & 2.99645 & 1.189\end{array}$ $\begin{array}{lll}1.6404 & 3.04279 & 0.01115\end{array}$ $\begin{array}{llll}1.00698 & 2.68765 & -1.19062\end{array}$ 
$\begin{array}{lll}1.34678 & 3.27055 & 2.1477\end{array}$

$\begin{array}{llll}1.57945 & 2.70375 & -2.13269\end{array}$

$\begin{array}{llll}-2.61459 & 2.08852 & -0.09896\end{array}$

$\begin{array}{llll}-3.3729 & 3.28466 & -0.11977\end{array}$

$\begin{array}{llll}-3.32203 & 0.85033 & -0.1782\end{array}$

$\begin{array}{llll}-4.76803 & 3.28845 & -0.23208\end{array}$

$\begin{array}{llll}-2.82368 & 4.23481 & -0.05373\end{array}$

$\begin{array}{llll}-4.73558 & 0.8743 & -0.30111\end{array}$

$\begin{array}{llll}-5.45885 & 2.07076 & -0.33323\end{array}$

$\begin{array}{llll}-5.3141 & 4.24127 & -0.25038\end{array}$

$\begin{array}{llll}-5.28117 & -0.07598 & -0.37224\end{array}$

$\begin{array}{llll}-6.55183 & 2.05036 & -0.43432\end{array}$

$\begin{array}{llll}-2.50206 & -0.79282 & -0.09909\end{array}$

$\begin{array}{llll}-3.08264 & -1.86349 & -1.55902\end{array}$

$\begin{array}{llll}-2.96515 & -1.54236 & 1.57201\end{array}$

$\begin{array}{lll}-2.32137 & -0.62842 & 2.64026\end{array}$

$\begin{array}{lll}-2.54843 & -1.05222 & 3.6411\end{array}$

$\begin{array}{llll}-1.21992 & -0.56735 & 2.53085\end{array}$

$\begin{array}{llll}-2.74812 & 0.39174 & 2.59533\end{array}$

$\begin{array}{lll}-2.33669 & -2.9498 & 1.69223\end{array}$

$\begin{array}{llll}-2.49313 & -3.30558 & 2.73207\end{array}$

$\begin{array}{llll}-2.80777 & -3.68764 & 1.01435\end{array}$

$\begin{array}{lll}-1.24338 & -2.92862 & 1.49994\end{array}$

$\begin{array}{llll}-4.47663 & -1.59809 & 1.88783\end{array}$

$\begin{array}{lll}-5.06353 & -2.20276 & 1.17422\end{array}$

$\begin{array}{llll}-4.58869 & -2.06393 & 2.88914\end{array}$

$\begin{array}{lll}-4.91371 & -0.5829 & 1.94529\end{array}$

$\begin{array}{llll}-1.96317 & -2.89624 & -1.86309\end{array}$

$\begin{array}{llll}-1.69472 & -3.51628 & -0.98675\end{array}$

$\begin{array}{llll}-2.32817 & -3.5703 & -2.6665\end{array}$

$\begin{array}{llll}-1.0427 & -2.39517 & -2.22211\end{array}$

$-4.40196-2.64147-1.35604$

$\begin{array}{llll}-4.6102 & -3.18998 & -2.29821\end{array}$

$\begin{array}{llll}-4.32984 & -3.39173 & -0.54678\end{array}$

$\begin{array}{llll}-5.27335 & -1.98903 & -1.16033\end{array}$

$\begin{array}{llll}-3.22093 & -0.95962 & -2.80384\end{array}$

$\begin{array}{llll}-3.43649 & -1.61152 & -3.67601\end{array}$ $\begin{array}{llll}-4.04118 & -0.2221 & -2.70919\end{array}$ $\begin{array}{llll}-2.27739 & -0.42096 & -3.01133\end{array}$ $\begin{array}{llll}-1.21766 & 2.70486 & 2.52255\end{array}$ $\begin{array}{llll}-2.3154 & 2.64559 & 2.41563\end{array}$ $\begin{array}{llll}-0.89128 & 1.87679 & 3.18475\end{array}$ $\begin{array}{llll}-0.97668 & 3.64956 & 3.04822\end{array}$ $\begin{array}{llll}3.05749 & 3.57716 & 0.03282\end{array}$ $\begin{array}{llll}3.04792 & 4.67687 & 0.17813\end{array}$ $\begin{array}{llll}3.6471 & 3.14069 & 0.86101\end{array}$ $\begin{array}{llll}3.58309 & 3.36689 & -0.91689\end{array}$ $\begin{array}{llll}-0.94369 & 1.98778 & -2.59489\end{array}$ $\begin{array}{llll}-0.55792 & 1.00486 & -2.93531\end{array}$ $\begin{array}{llll}-2.04865 & 1.95133 & -2.58742\end{array}$ $\begin{array}{lll}-0.627 & 2.73269 & -3.35065\end{array}$ $\begin{array}{lll}-0.23525 & -0.62474 & -0.14634\end{array}$ $1.90265-0.64401-0.0911$ $2.58388-0.84136-1.58845$ $3.04168-2.19326-1.8395$ $\begin{array}{llll}1.69216 & -0.16347 & -2.51783\end{array}$ $\begin{array}{llll}2.57335 & -1.45386 & 1.18703\end{array}$ $\begin{array}{llll}1.67235 & -2.46873 & 1.70986\end{array}$ $3.98734-1.70129 \quad 0.96625$ $\begin{array}{llll}4.14346 & 0.22533 & -1.49584\end{array}$ $\begin{array}{llll}2.46932 & -0.10289 & 2.46369\end{array}$ $\begin{array}{llll}4.0861 & 1.14672 & -2.46562\end{array}$ $\begin{array}{llll}5.21438 & -0.53544 & -1.67966\end{array}$ $\begin{array}{llll}4.24396 & 0.85261 & -0.32694\end{array}$ $\begin{array}{llll}1.18965 & 0.23118 & 2.68444\end{array}$ $\begin{array}{llll}3.14352 & 0.98476 & 2.10042\end{array}$ $\begin{array}{llll}2.98777 & -0.57718 & 3.59947\end{array}$

\section{S7a-dcb}

C

C

$\begin{array}{llll}-0.3211 & 2.32118 & -1.22679\end{array}$

$\begin{array}{llll}-1.09172 & 2.29045 & -0.02873\end{array}$

$\begin{array}{llll}-0.47382 & 2.65131 & 1.20285\end{array}$ $\begin{array}{lll}0.88864 & 3.00299 & 1.21013\end{array}$ $\begin{array}{llll}1.66244 & 3.05078 & 0.03682\end{array}$ 


$\begin{array}{llll}\mathrm{C} & 1.03973 & 2.68691 & -1.16884 \\ \mathrm{H} & 1.35105 & 3.28817 & 2.17041 \\ \mathrm{H} & 1.61598 & 2.71837 & -2.1088 \\ \mathrm{C} & -2.59223 & 2.09964 & -0.10546 \\ \mathrm{C} & -3.33452 & 3.3054 & -0.136 \\ \mathrm{C} & -3.31273 & 0.87026 & -0.19298 \\ \mathrm{C} & -4.72877 & 3.32582 & -0.26514 \\ \mathrm{H} & -2.77748 & 4.25045 & -0.06267 \\ \mathrm{C} & -4.72473 & 0.91027 & -0.33224 \\ \mathrm{C} & -5.43271 & 2.11606 & -0.37382 \\ \mathrm{H} & -5.26243 & 4.28504 & -0.28966 \\ \mathrm{H} & -5.28372 & -0.03109 & -0.40884 \\ \mathrm{H} & -6.5241 & 2.10735 & -0.48725 \\ \mathrm{P} & -2.52901 & -0.78756 & -0.09515 \\ \mathrm{C} & -3.11286 & -1.85885 & -1.55205 \\ \mathrm{C} & -3.01116 & -1.50957 & 1.58109 \\ \mathrm{C} & -2.36663 & -0.59039 & 2.64389 \\ \mathrm{H} & -2.59559 & -1.00726 & 3.64671 \\ \mathrm{H} & -1.26473 & -0.52846 & 2.53464 \\ \mathrm{H} & -2.79203 & 0.42971 & 2.59172 \\ \mathrm{C} & -2.40889 & -2.92604 & 1.72022 \\ \mathrm{H} & -2.57949 & -3.2686 & 2.76182 \\ \mathrm{H} & -2.88571 & -3.66141 & 1.04445 \\ \mathrm{H} & -1.31412 & -2.92313 & 1.53317 \\ \mathrm{C} & -4.52687 & -1.54123 & 1.88207 \\ \mathrm{H} & -5.11315 & -2.15056 & 1.17288 \\ \mathrm{H} & -4.65107 & -1.98928 & 2.88966 \\ \mathrm{H} & -4.95184 & -0.52038 & 1.91933 \\ \mathrm{C} & -2.01134 & -2.91458 & -1.84029 \\ \mathrm{H} & -1.76523 & -3.53454 & -0.957 \\ \mathrm{H} & -2.38443 & -3.58589 & -2.64152 \\ \mathrm{H} & -1.0794 & -2.43212 & -2.19654 \\ \mathrm{C} & -4.44647 & -2.61312 & -1.34982 \\ \mathrm{H} & -4.6579 & -3.16033 & -2.29152 \\ & -4.3889 & -3.36202 & -0.53835 \\ \mathrm{H} & & -1.94612 & -1.16027 \\ \mathrm{H} & & -0.9601 & -2.80312\end{array}$

\begin{tabular}{|c|c|}
\hline $\mathrm{H}$ & $\begin{array}{lll}-3.44109 & -1.61544 & -3.67269\end{array}$ \\
\hline $\mathrm{H}$ & $\begin{array}{llll}-4.042 & -0.21539 & -2.72062\end{array}$ \\
\hline $\mathrm{H}$ & $\begin{array}{lll}-2.27644 & -0.43098 & -3.00304\end{array}$ \\
\hline $\mathrm{C}$ & $\begin{array}{lll}-1.21588 & 2.71916 & 2.52618\end{array}$ \\
\hline $\mathrm{H}$ & $\begin{array}{lll}-2.31227 & 2.6677 & 2.40785\end{array}$ \\
\hline $\mathrm{H}$ & $\begin{array}{lll}-0.90433 & 1.89118 & 3.19543\end{array}$ \\
\hline $\mathrm{H}$ & $\begin{array}{lll}-0.97064 & 3.66359 & 3.04968\end{array}$ \\
\hline $\mathrm{C}$ & $\begin{array}{lll}3.07286 & 3.60349 & 0.06788\end{array}$ \\
\hline $\mathrm{H}$ & $\begin{array}{lll}3.04988 & 4.69904 & 0.23819\end{array}$ \\
\hline $\mathrm{H}$ & $\begin{array}{lll}3.6697 & 3.15854 & 0.887\end{array}$ \\
\hline $\mathrm{H}$ & $\begin{array}{llll}3.59961 & 3.42173 & -0.88754\end{array}$ \\
\hline $\mathrm{C}$ & $\begin{array}{llll}-0.90511 & 1.98165 & -2.58458\end{array}$ \\
\hline $\mathrm{H}$ & $\begin{array}{llll}-0.55724 & 0.97846 & -2.90623\end{array}$ \\
\hline $\mathrm{H}$ & $\begin{array}{llll}-2.0105 & 1.98235 & -2.58904\end{array}$ \\
\hline $\mathrm{H}$ & $\begin{array}{llll}-0.55231 & 2.70263 & -3.34745\end{array}$ \\
\hline $\mathrm{Au}$ & $\begin{array}{llll}-0.25351 & -0.65111 & -0.14097\end{array}$ \\
\hline $\mathrm{N}$ & $\begin{array}{lll}1.911 & -0.67567 & -0.1015\end{array}$ \\
\hline $\mathrm{S}$ & $\begin{array}{llll}2.59985 & -0.85095 & -1.59045\end{array}$ \\
\hline $\mathrm{O}$ & $\begin{array}{lll}3.09444 & -2.19605 & -1.83739\end{array}$ \\
\hline $\mathrm{O}$ & $\begin{array}{lll}1.70251 & -0.20672 & -2.53604\end{array}$ \\
\hline $\mathrm{S}$ & $\begin{array}{lll}2.61079 & -1.45641 & 1.16984\end{array}$ \\
\hline $\mathrm{O}$ & $\begin{array}{lll}1.76897 & -2.52543 & 1.68757\end{array}$ \\
\hline $\mathrm{O}$ & $\begin{array}{llll}4.03671 & -1.65818 & 0.94676\end{array}$ \\
\hline $\mathrm{C}$ & $\begin{array}{llll}4.13691 & 0.25091 & -1.50377\end{array}$ \\
\hline $\mathrm{C}$ & $\begin{array}{lll}2.47268 & -0.12335 & 2.46188\end{array}$ \\
\hline $\mathrm{F}$ & $\begin{array}{llll}4.07115 & 1.14997 & -2.48888\end{array}$ \\
\hline $\mathrm{F}$ & $\begin{array}{llll}5.22663 & -0.49483 & -1.66397\end{array}$ \\
\hline $\mathrm{F}$ & $\begin{array}{llll}4.21282 & 0.89363 & -0.34371\end{array}$ \\
\hline $\mathrm{F}$ & $\begin{array}{lll}1.19318 & 0.19075 & 2.67651\end{array}$ \\
\hline $\mathrm{F}$ & $\begin{array}{lll}3.14534 & 0.96638 & 2.11027\end{array}$ \\
\hline $\mathrm{F}$ & $2.99355-0.61547 \quad 3.59052$ \\
\hline \multicolumn{2}{|l|}{ 7b } \\
\hline $\mathrm{C}$ & $\begin{array}{llll}-0.61501 & 3.32553 & -1.04591\end{array}$ \\
\hline $\mathrm{C}$ & $\begin{array}{llll}-1.2473 & 3.28491 & -2.296\end{array}$ \\
\hline $\mathrm{H}$ & $\begin{array}{lll}-0.81972 & 2.69163 & -3.11558\end{array}$ \\
\hline I & $\begin{array}{lll}1.1417 & 2.12032 & -0.72492\end{array}$ \\
\hline
\end{tabular}




$\begin{array}{llll}\mathrm{Au} & -0.67067 & -0.00288 & -0.39688 \\ \mathrm{C} & -1.13786 & 4.06436 & 0.02331 \\ \mathrm{H} & -0.62453 & 4.07879 & 0.99294 \\ \mathrm{C} & -2.33515 & 4.77721 & -0.17072 \\ \mathrm{H} & -2.75376 & 5.36098 & 0.6607 \\ \mathrm{C} & -2.98856 & 4.74482 & -1.41334 \\ \mathrm{C} & -2.44387 & 4.00104 & -2.47289 \\ \mathrm{H} & -2.94897 & 3.97194 & -3.44844 \\ \mathrm{P} & -2.65587 & -1.16313 & -0.47836 \\ \mathrm{C} & -3.32658 & -1.57024 & 1.19023 \\ \mathrm{C} & -3.93637 & 0.01707 & -1.22411 \\ \mathrm{C} & -2.4367 & -2.73877 & -1.52161 \\ \mathrm{C} & -4.43696 & -2.44932 & 1.25246 \\ \mathrm{C} & -2.83885 & -0.99321 & 2.40343 \\ \mathrm{C} & -3.90121 & 1.29534 & -0.35419 \\ \mathrm{C} & -5.3957 & -0.49385 & -1.20028 \\ \mathrm{C} & -3.52981 & 0.38145 & -2.66885 \\ \mathrm{C} & -3.7007 & -3.2708 & -2.23568 \\ \mathrm{C} & -1.37186 & -2.43227 & -2.60929 \\ \mathrm{C} & -1.84546 & -3.85126 & -0.626 \\ \mathrm{H} & -4.81822 & -2.89742 & 0.32616 \\ \mathrm{C} & -5.07453 & -2.75675 & 2.45991 \\ \mathrm{C} & -3.5094 & -1.309 & 3.60826 \\ \mathrm{H} & -4.23191 & 1.07116 & 0.67798 \\ \mathrm{H} & -2.89548 & 1.75929 & -0.31706 \\ \mathrm{H} & -5.75878 & -0.62903 & -0.16396 \\ \mathrm{H} & -5.5523 & -1.43248 & -1.76049 \\ \mathrm{H} & -3.6856 & -0.45483 & -3.37729 \\ \mathrm{H} & -2.46969 & 0.70186 & -2.72274 \\ \mathrm{H} & -4.51794 & -3.55925 & -1.54924 \\ \mathrm{H} & -4.09767 & -2.55569 & -2.97993 \\ \mathrm{H} & -1.63773 & -1.57035 & -3.25111 \\ \mathrm{H} & -0.38522 & -2.24335 & -2.14942 \\ \mathrm{H} & -2.51075 & -4.13208 & 0.21377 \\ \mathrm{H} & -0.854 & -3.55612 & -0.23356 \\ \mathrm{H} & -5.92822 & -3.44692 & 2.46837 \\ \mathrm{C} & -4.61225 & -2.17102 & 3.64792 \\ & & & \\ & & & \\ & & & \end{array}$

$\begin{array}{llll}\mathrm{H} & -3.12412 & -0.86093 & 4.53597 \\ \mathrm{H} & -5.10144 & -2.39397 & 4.60565 \\ \mathrm{H} & -3.92347 & 5.30238 & -1.55687 \\ \mathrm{C} & -1.59983 & -0.14362 & 2.53844 \\ \mathrm{C} & -0.33712 & -0.81517 & 2.577 \\ \mathrm{C} & -1.65745 & 1.2516 & 2.77504 \\ \mathrm{C} & 0.84085 & -0.06468 & 2.71593 \\ \mathrm{C} & -0.44618 & 1.95803 & 2.94678 \\ \mathrm{C} & 0.80804 & 1.33499 & 2.89114 \\ \mathrm{H} & 1.81019 & -0.58598 & 2.69305 \\ \mathrm{H} & -0.49734 & 3.04121 & 3.15006 \\ \mathrm{H} & -6.02691 & 0.2867 & -1.67463 \\ \mathrm{H} & -4.16218 & 1.23209 & -3.00248 \\ \mathrm{H} & -4.60668 & 2.03472 & -0.79055 \\ \mathrm{H} & -3.40102 & -4.18614 & -2.78661 \\ \mathrm{H} & -1.28165 & -3.32898 & -3.25789 \\ \mathrm{H} & -1.69378 & -4.74793 & -1.26241 \\ \mathrm{C} & -2.95142 & 2.03664 & 2.90467 \\ \mathrm{H} & -2.93922 & 2.62821 & 3.84174 \\ \mathrm{H} & -3.06946 & 2.75795 & 2.06846 \\ \mathrm{H} & -3.84624 & 1.38916 & 2.92422 \\ \mathrm{C} & -0.26754 & -2.32713 & 2.54303 \\ \mathrm{H} & 0.78135 & -2.6694 & 2.52036 \\ \mathrm{H} & -0.77049 & -2.75482 & 3.43609 \\ \mathrm{H} & -0.77741 & -2.74567 & 1.65801 \\ \mathrm{C} & 2.08975 & 2.1271 & 3.01932 \\ \mathrm{H} & 2.67295 & 1.80839 & 3.90602 \\ \mathrm{H} & 2.74136 & 1.97121 & 2.13679 \\ \mathrm{H} & 1.88034 & 3.21087 & 3.11125 \\ \mathrm{~N} & 3.00565 & -0.40333 & -0.04443 \\ \mathrm{~S} & 2.66792 & -1.87614 & -0.60454 \\ \mathrm{~S} & 4.53501 & 0.14866 & 0.017 \\ \mathrm{O} & 1.28675 & -2.16997 & -0.20213 \\ \mathrm{O} & 3.69357 & -2.89453 & -0.46983 \\ \mathrm{O} & 5.46647 & -0.44227 & -0.92764 \\ \mathrm{O} & 4.43536 & 1.59509 & 0.17531 \\ \mathrm{C} & 5.13157 & -0.44176 & 1.67552 \\ & & & \\ & & & \end{array}$




\begin{tabular}{|c|c|c|}
\hline $\mathrm{C}$ & $2.49463-1.63458$ & -2.44012 \\
\hline $\mathrm{F}$ & $\begin{array}{lll}5.15252 & -1.77177\end{array}$ & 1.73333 \\
\hline $\mathrm{F}$ & $4.33791 \quad 0.01172$ & 2.65986 \\
\hline $\mathrm{F}$ & $6.3669 \quad 0.02515$ & 1.88131 \\
\hline $\mathrm{F}$ & $3.64001-1.27758$ & -3.00704 \\
\hline $\mathrm{F}$ & $2.06992-2.78161$ & -2.99048 \\
\hline $\mathrm{F}$ & $1.57338-0.6851$ & -2.70276 \\
\hline \multicolumn{3}{|c|}{ S7b-dcb } \\
\hline $\mathrm{C}$ & $-0.71963 \quad 3.34992$ & -1.015 \\
\hline $\mathrm{C}$ & $-1.36794 \quad 3.2916$ & -2.25492 \\
\hline $\mathrm{H}$ & $-0.944 \quad 2.71172$ & -3.08499 \\
\hline I & $1.073562 .1776-$ & -0.73242 \\
\hline $\mathrm{Au}$ & $-0.72289 \quad 0.02585$ & $5-0.4138$ \\
\hline $\mathrm{C}$ & $-1.23298 \quad 4.06534$ & 0.073 \\
\hline $\mathrm{H}$ & $-0.70139 \quad 4.0919$ & 1.03197 \\
\hline $\mathrm{C}$ & $-2.4529 \quad 4.74734$ & -0.0966 \\
\hline $\mathrm{H}$ & $-2.87053 \quad 5.31377$ & 0.74657 \\
\hline $\mathrm{C}$ & $-3.12855 \quad 4.70208$ & -1.32741 \\
\hline $\mathrm{C}$ & $\begin{array}{ll}-2.58674 & 3.97788\end{array}$ & -2.40249 \\
\hline $\mathrm{H}$ & $\begin{array}{ll}-3.11229 & 3.93477\end{array}$ & -3.36604 \\
\hline $\mathrm{P}$ & $-2.67254-1.19744$ & -0.486 \\
\hline $\mathrm{C}$ & $-3.30521-1.64294$ & +1.18552 \\
\hline $\mathrm{C}$ & $-3.98204-0.03745$ & -1.20783 \\
\hline $\mathrm{C}$ & $-2.41123-2.74996$ & $5-1.55228$ \\
\hline $\mathrm{C}$ & $\begin{array}{ll}-4.39562 & -2.54791\end{array}$ & 1.24124 \\
\hline $\mathrm{C}$ & $-2.82515-1.06952$ & 2.40358 \\
\hline $\mathrm{C}$ & $\begin{array}{ll}-3.97058 & 1.23036\end{array}$ & -0.32235 \\
\hline $\mathrm{C}$ & $\begin{array}{ll}-5.42694 & -0.58808\end{array}$ & -1.17523 \\
\hline $\mathrm{C}$ & -3.597790 .35064 & -2.65271 \\
\hline $\mathrm{C}$ & $-3.66652-3.30762$ & -2.26264 \\
\hline $\mathrm{C}$ & $\begin{array}{ll}-1.36793 & -2.39679\end{array}$ & -2.64634 \\
\hline $\mathrm{C}$ & $-1.78289-3.85672$ & -0.67656 \\
\hline $\mathrm{H}$ & $\begin{array}{ll}-4.77541 & -2.99259\end{array}$ & 9.3131 \\
\hline $\mathrm{C}$ & $\begin{array}{ll}-5.01934 & -2.88439\end{array}$ & 2.44874 \\
\hline $\mathrm{C}$ & $-3.48212-1.41369$ & 3.60791 \\
\hline $\mathrm{H}$ & $-4.28263 \quad 0.98553$ & 0.71081 \\
\hline
\end{tabular}

$\begin{array}{lccl} & & & \\ \mathrm{H} & -2.97848 & 1.72431 & -0.29389 \\ \mathrm{H} & -5.77843 & -0.73853 & -0.13717 \\ \mathrm{H} & -5.56337 & -1.5264 & -1.7405 \\ \mathrm{H} & -3.74419 & -0.48103 & -3.36806 \\ \mathrm{H} & -2.54631 & 0.697 & -2.71681 \\ \mathrm{H} & -4.46653 & -3.62962 & -1.57203 \\ \mathrm{H} & -4.09034 & -2.59285 & -2.99135 \\ \mathrm{H} & -1.67503 & -1.54469 & -3.28222 \\ \mathrm{H} & -0.38697 & -2.16468 & -2.19068 \\ \mathrm{H} & -2.43633 & -4.16937 & 0.16076 \\ \mathrm{H} & -0.80143 & -3.53378 & -0.27955 \\ \mathrm{C} & -5.85772 & -3.59237 & 2.45144 \\ \mathrm{H} & -4.56533 & -2.30174 & 3.64185 \\ \mathrm{H} & -3.10629 & -0.96778 & 4.5404 \\ \mathrm{H} & -5.04575 & -2.54502 & 4.59862 \\ \mathrm{C} & -4.08239 & 5.23134 & -1.44851 \\ \mathrm{C} & -1.60121 & -0.19819 & 2.54652 \\ \mathrm{C} & -0.32822 & -0.84856 & 2.59064 \\ \mathrm{C} & -1.68228 & 1.19526 & 2.78972 \\ \mathrm{C} & 0.83646 & -0.08008 & 2.74377 \\ \mathrm{C} & -0.48291 & 1.9241 & 2.96251 \\ \mathrm{H} & 0.78026 & 1.31944 & 2.91315 \\ \mathrm{H} & 1.81495 & -0.58718 & 2.73545 \\ \mathrm{H} & -0.55304 & 3.00638 & 3.16113 \\ \mathrm{H} & -6.07866 & 0.18052 & -1.64017 \\ \mathrm{H} & -4.25321 & 1.18965 & -2.96885 \\ \mathrm{H} & -4.70213 & 1.9528 & -0.74249 \\ \mathrm{H} & -3.34432 & -4.20512 & -2.82949 \\ \mathrm{H} & -1.24776 & -3.28714 & -3.29849 \\ \mathrm{C} & -1.60642 & -4.73888 & -1.32624 \\ \mathrm{H} & -2.98942 & 1.95565 & 2.92803 \\ \mathrm{H} & -2.9845 & 2.53771 & 3.87064 \\ \mathrm{H} & -3.11853 & 2.6843 & 2.10068 \\ \mathrm{C} & -3.8715 & 1.29168 & 2.94151 \\ \mathrm{H} & -0.23516 & -2.35877 & 2.54088 \\ \mathrm{H} & 0.81947 & -2.68503 & 2.57022 \\ & -0.77606 & -2.80939 & 3.39913 \\ & & & \\ & & & \\ & & & \end{array}$




$\begin{array}{lccl}\text { H } & -0.69382 & -2.76883 & 1.6238 \\ \text { C } & 2.05028 & 2.13143 & 3.04318 \\ \text { H } & 2.64077 & 1.8208 & 3.92863 \\ \text { H } & 2.70007 & 1.9852 & 2.15667 \\ \text { H } & 1.82557 & 3.21169 & 3.13435 \\ \text { N } & 3.10741 & -0.39977 & -0.06154 \\ \text { S } & 2.79435 & -1.87171 & -0.63702 \\ \text { S } & 4.61051 & 0.17863 & 0.02632 \\ \text { O } & 1.45373 & -2.24688 & -0.19263 \\ \text { O } & 3.87469 & -2.84891 & -0.56838 \\ \text { O } & 5.58643 & -0.39148 & -0.89538 \\ \text { O } & 4.50808 & 1.62695 & 0.17165 \\ \text { C } & 5.19384 & -0.39651 & 1.69306 \\ \text { C } & 2.57649 & -1.58424 & -2.45891 \\ \text { F } & 5.22192 & -1.72978 & 1.74863 \\ \text { F } & 4.39672 & 0.05488 & 2.667 \\ \text { F } & 6.43105 & 0.07164 & 1.90102 \\ \text { F } & 3.7231 & -1.19957 & -3.0211 \\ \text { F } & 2.17418 & -2.72769 & -3.03043 \\ \text { F } & 1.6503 & -0.64516 & -2.69085 \\ & & & \\ \text { 7c-TS } & & & \\ \text { C } & 0.21352 & 2.48233 & 0.8655 \\ \text { C } & 1.28352 & 2.76942 & 0.02072 \\ \text { H } & 1.94396 & 1.98445 & -0.35653 \\ \text { I } & 0.82044 & 0.61081 & 2.65616 \\ \text { Au } & -0.76993 & 0.50462 & 0.4754 \\ \text { C } & -0.60672 & 3.44866 & 1.45932 \\ \text { H } & -1.37844 & 3.1736 & 2.18982 \\ \text { C } & -0.39824 & 4.78611 & 1.0735 \\ \text { H } & -1.0363 & 5.56889 & 1.50646 \\ \text { C } & 0.6204 & 5.11673 & 0.16295 \\ \text { C } & 1.45965 & 4.11492 & -0.35434 \\ \text { H } & 2.27877 & 4.35433 & -1.04653 \\ \text { P } & -2.12093 & 0.56004 & -1.49422 \\ \text { C } & -3.40207 & -0.75535 & -1.34832 \\ \text { C } & -3.08962 & 2.18213 & -1.6155 \\ & & & \\ & & & \\ & & & \end{array}$

$\begin{array}{lccc}\mathrm{C} & -1.02705 & 0.28477 & -3.01847 \\ \mathrm{C} & -4.25232 & -0.98748 & -2.46113 \\ \mathrm{C} & -3.62373 & -1.50015 & -0.15176 \\ \mathrm{C} & -3.74436 & 2.41517 & -0.23824 \\ \mathrm{C} & -4.2357 & 2.1941 & -2.65433 \\ \mathrm{C} & -2.11565 & 3.34281 & -1.92184 \\ \mathrm{C} & -1.65848 & 0.59884 & -4.39188 \\ \mathrm{C} & 0.25361 & 1.14288 & -2.87422 \\ \mathrm{C} & -0.59152 & -1.19656 & -2.98125 \\ \mathrm{H} & -4.08427 & -0.43269 & -3.3905 \\ \mathrm{C} & -5.32034 & -1.88893 & -2.40495 \\ \mathrm{C} & -4.73088 & -2.38301 & -0.11093 \\ \mathrm{H} & -4.43018 & 1.5853 & 0.02059 \\ \mathrm{H} & -2.98974 & 2.5249 & 0.56242 \\ \mathrm{H} & -5.06087 & 1.51918 & -2.35927 \\ \mathrm{H} & -3.91309 & 1.93967 & -3.68001 \\ \mathrm{H} & -1.82782 & 3.36162 & -2.99048 \\ \mathrm{H} & -1.19621 & 3.30274 & -1.30907 \\ \mathrm{H} & -2.54348 & -0.01962 & -4.63088 \\ \mathrm{H} & -1.91707 & 1.66876 & -4.50277 \\ \mathrm{H} & 0.07486 & 2.22852 & -2.978 \\ \mathrm{H} & 0.76599 & 0.94273 & -1.9224 \\ \mathrm{H} & -1.44912 & -1.88554 & -3.12279 \\ \mathrm{H} & -0.07068 & -1.43976 & -2.03207 \\ \mathrm{H} & -5.95207 & -2.0442 & -3.2892 \\ \mathrm{C} & -5.57581 & -2.57692 & -1.20909 \\ \mathrm{H} & -4.89498 & -2.94932 & 0.81776 \\ \mathrm{H} & -6.41785 & -3.27831 & -1.13752 \\ \mathrm{H} & 0.77841 & 6.16522 & -0.12103 \\ \mathrm{~N} & 2.45818 & -0.36246 & -0.90465 \\ \mathrm{~S} & 3.84543 & 0.23875 & -1.48107 \\ \mathrm{~S} & 2.47103 & -1.81189 & -0.20455 \\ \mathrm{O} & 3.49837 & 1.50439 & -2.12333 \\ \mathrm{O} & 4.69135 & -0.73777 & -2.15224 \\ \mathrm{O} & 1.0903 & -2.07917 & 0.20128 \\ \mathrm{O} & 3.56522 & -2.03409 & 0.72986 \\ \mathrm{C} & 4.83584 & 0.77571 & 0.02861 \\ & & & \\ & & & \\ & & & \end{array}$


$2.74716-3.06366-1.59143$

$\begin{array}{llll}5.7016 & -0.15446 & 0.4111\end{array}$

$\begin{array}{llll}5.51722 & 1.8887 & -0.28237\end{array}$

$\begin{array}{llll}4.01526 & 1.06335 & 1.05004\end{array}$

$2.41187-2.54897-2.78176$

$\begin{array}{llll}4.00401 & -3.48559 & -1.63277\end{array}$

$\begin{array}{llll}1.95155 & -4.12521 & -1.36613\end{array}$

$-2.63572 \quad 4.29764-1.69616$

$\begin{array}{llll}-4.64022 & 3.22788 & -2.67835\end{array}$

$\begin{array}{llll}-4.33885 & 3.3517 & -0.28662\end{array}$

$\begin{array}{llll}-0.88688 & 0.36847 & -5.15556\end{array}$

$\begin{array}{llll}0.95663 & 0.83759 & -3.67724\end{array}$

$\begin{array}{llll}0.1321 & -1.36292 & -3.80497\end{array}$

$\begin{array}{llll}-2.72982 & -1.58409 & 1.06708\end{array}$

$\begin{array}{llll}-1.73421 & -2.61261 & 1.06549\end{array}$

$\begin{array}{lll}-3.06817 & -0.94465 & 2.29921\end{array}$

$\begin{array}{llll}-1.01903 & -2.87731 & 2.24472\end{array}$

$\begin{array}{llll}-2.34838 & -1.27311 & 3.45836\end{array}$

$\begin{array}{lll}-1.30477 & -2.21685 & 3.45048\end{array}$

$\begin{array}{llll}-0.20766 & -3.61923 & 2.20662\end{array}$

$\begin{array}{llll}-2.59755 & -0.75477 & 4.39846\end{array}$

$\begin{array}{llll}-1.50672 & -3.48244 & -0.15235\end{array}$

$-0.59114-4.08662-0.03163$

$\begin{array}{llll}-2.37297 & -4.16181 & -0.3016\end{array}$

$-1.40203-2.88854-1.0756$

$\begin{array}{llll}-4.1635 & 0.09732 & 2.40648\end{array}$

$\begin{array}{lll}-4.65719 & 0.0328 & 3.39471\end{array}$

$\begin{array}{llll}-3.74508 & 1.12213 & 2.31961\end{array}$

$\begin{array}{lll}-4.93657 & -0.0182 & 1.62391\end{array}$

$\begin{array}{llll}-0.51837 & -2.52384 & 4.70768\end{array}$

$\begin{array}{llll}0.54631 & -2.70855 & 4.4692\end{array}$

$\begin{array}{llll}-0.57522 & -1.68601 & 5.42852\end{array}$

$\begin{array}{lll}-0.90797 & -3.43089 & 5.21319\end{array}$

\section{S7c-TS-iso}

C $\begin{array}{llll}-0.22177 & 2.40364 & -0.80062\end{array}$

$\begin{array}{llll}-1.20486 & 3.33772 & -1.20482\end{array}$ $\begin{array}{llll}-2.0971 & 3.00075 & -1.75471\end{array}$

$\begin{array}{llll}0.48529 & 1.0053 & -2.96351\end{array}$

$\begin{array}{lll}-0.89663 & 0.41067 & -0.60545\end{array}$

$\begin{array}{llll}0.99644 & 2.8144 & -0.21699\end{array}$

$\begin{array}{llll}1.82077 & 2.11029 & -0.0652\end{array}$

$\begin{array}{lll}1.14744 & 4.16582 & 0.12358\end{array}$

$\begin{array}{llll}2.07667 & 4.48967 & 0.6106\end{array}$

$\begin{array}{llll}0.14892 & 5.09781 & -0.21635\end{array}$

$\begin{array}{llll}-1.02751 & 4.68739 & -0.87048\end{array}$

$\begin{array}{llll}-1.79786 & 5.42185 & -1.14468\end{array}$

$\begin{array}{llll}-1.89968 & -1.78933 & -0.55815\end{array}$

$\begin{array}{llll}-3.08544 & -1.88904 & 0.8469\end{array}$

$\begin{array}{llll}-2.99635 & -2.01974 & -2.09066\end{array}$

$\begin{array}{llll}-0.56724 & -3.12927 & -0.45173\end{array}$

$\begin{array}{lll}-3.6945 & -3.13112 & 1.15788\end{array}$

$\begin{array}{lll}-3.49524 & -0.73105 & 1.57134\end{array}$

$\begin{array}{llll}-3.81622 & -0.72175 & -2.25055\end{array}$

$\begin{array}{llll}-4.00679 & -3.18558 & -1.99011\end{array}$

$\begin{array}{llll}-2.13137 & -2.21433 & -3.3543\end{array}$

$\begin{array}{llll}-0.9906 & -4.58111 & -0.75917\end{array}$

$\begin{array}{llll}0.58167 & -2.74192 & -1.4174\end{array}$

$\begin{array}{llll}0.00085 & -3.04667 & 0.98029\end{array}$

$\begin{array}{lll}-3.38304 & -4.02993 & 0.61395\end{array}$

$\begin{array}{llll}-4.7068 & -3.24446 & 2.11706\end{array}$

$\begin{array}{lll}-4.55005 & -0.86133 & 2.50798\end{array}$

$\begin{array}{llll}-4.43123 & -0.53114 & -1.35022\end{array}$

$\begin{array}{llll}-3.16533 & 0.15808 & -2.44092\end{array}$

$\begin{array}{llll}-4.7803 & -2.99451 & -1.22288\end{array}$

$-3.53041-4.16166-1.78099$

$-1.66263-3.21533-3.38965$

$\begin{array}{llll}-1.34013 & -1.44651 & -3.44488\end{array}$

$\begin{array}{llll}-1.73699 & -4.98592 & -0.0502\end{array}$

$\begin{array}{llll}-1.36476 & -4.70789 & -1.7924\end{array}$

$\begin{array}{llll}0.32197 & -2.86672 & -2.48408\end{array}$

$0.93558-1.71274-1.25108$

$\begin{array}{llll}-0.74317 & -3.35367 & 1.74461\end{array}$

$\begin{array}{llll}0.36315 & -2.02357 & 1.19856\end{array}$ 
$\begin{array}{lll}-5.14847 & -4.22577 & 2.33419\end{array}$ $\begin{array}{llll}-5.15767 & -2.09239 & 2.77924\end{array}$ $\begin{array}{lll}-4.86197 & 0.04046 & 3.05583\end{array}$ $\begin{array}{llll}-5.96518 & -2.15452 & 3.52101\end{array}$ $\begin{array}{llll}0.30085 & 6.16304 & 0.00724\end{array}$ $\begin{array}{llll}2.72492 & -0.7975 & 0.33815\end{array}$ $3.75164-0.45934-0.86591$ $\begin{array}{llll}2.56487 & 0.1419 & 1.62635\end{array}$ $\begin{array}{llll}3.92837 & 0.96252 & -1.12615\end{array}$ $3.45541-1.38194-1.95086$ $\begin{array}{llll}1.13524 & 0.35848 & 1.87688\end{array}$ $\begin{array}{llll}3.47424 & 1.27179 & 1.76968\end{array}$ $\begin{array}{llll}5.39896 & -1.03615 & -0.23673\end{array}$ $\begin{array}{llll}3.03426 & -1.03015 & 2.98387\end{array}$ $\begin{array}{llll}5.31583 & -2.30053 & 0.19691\end{array}$ $\begin{array}{llll}6.29642 & -0.9834 & -1.22779\end{array}$ $\begin{array}{llll}5.821 & -0.26643 & 0.76853\end{array}$ $\begin{array}{llll}2.20564 & -2.08432 & 3.01211\end{array}$ $\begin{array}{llll}4.28376 & -1.46844 & 2.83081\end{array}$ $2.93745-0.39267 \quad 4.15912$ $\begin{array}{llll}-2.79837 & -2.12597 & -4.23754\end{array}$ $\begin{array}{llll}-4.5182 & -3.26661 & -2.97227\end{array}$ $-4.50126-0.83886-3.11666$ $\begin{array}{llll}-0.07967 & -5.20779 & -0.66184\end{array}$ $\begin{array}{llll}1.44628 & -3.4021 & -1.19857\end{array}$ $\begin{array}{llll}0.87917 & -3.72113 & 1.0495\end{array}$ $\begin{array}{lll}-2.81638 & 0.62176 & 1.60683\end{array}$ $\begin{array}{llll}-1.72501 & 0.75741 & 2.5315\end{array}$ $\begin{array}{lll}-3.44301 & 1.79862 & 1.09316\end{array}$ $\begin{array}{lll}-1.21047 & 2.03516 & 2.80646\end{array}$ $\begin{array}{llll}-2.93053 & 3.05309 & 1.45373\end{array}$ $\begin{array}{llll}-1.81032 & 3.19838 & 2.29666\end{array}$ $\begin{array}{lll}-0.343 & 2.11434 & 3.47834\end{array}$ $\begin{array}{lll}-3.42036 & 3.95759 & 1.05662\end{array}$ $\begin{array}{llll}-1.23227 & -0.42986 & 3.33038\end{array}$ $\begin{array}{lll}-0.34992 & -0.15317 & 3.93266\end{array}$ $\begin{array}{lll}-2.03914 & -0.784 \quad 4.00678\end{array}$ $\begin{array}{lll}-0.95102 & -1.2816 & 2.69022\end{array}$ $\begin{array}{llll}-4.63656 & 1.75649 & 0.16122\end{array}$ $\begin{array}{llll}-5.28123 & 2.64088 & 0.32436\end{array}$ $\begin{array}{llll}-4.31002 & 1.78236 & -0.90078\end{array}$ $\begin{array}{llll}-5.25149 & 0.84779 & 0.29842\end{array}$ $\begin{array}{lll}-1.33175 & 4.56615 & 2.729\end{array}$

$\begin{array}{llll}-0.22673 & 4.61107 & 2.76582\end{array}$ $\begin{array}{llll}-1.69361 & 5.35592 & 2.04356\end{array}$

$\begin{array}{lll}-1.70824 & 4.80288 & 3.74529\end{array}$

\section{S7c-TS-dcb}

C

$\begin{array}{lll}0.21352 & 2.48233 & 0.8655\end{array}$

$\begin{array}{llll}1.28352 & 2.76942 & 0.02072\end{array}$

$\begin{array}{llll}1.94396 & 1.98445 & -0.35653\end{array}$

$\begin{array}{llll}0.82044 & 0.61081 & 2.65616\end{array}$

$\begin{array}{lll}-0.76993 & 0.50462 & 0.4754\end{array}$

$\begin{array}{llll}-0.60672 & 3.44866 & 1.45932\end{array}$

$\begin{array}{llll}-1.37844 & 3.1736 & 2.18982\end{array}$

$\begin{array}{lll}-0.39824 & 4.78611 & 1.0735\end{array}$

$\begin{array}{llll}-1.0363 & 5.56889 & 1.50646\end{array}$

$\begin{array}{llll}0.6204 & 5.11673 & 0.16295\end{array}$

$\begin{array}{lllll}1.45965 & 4.11492 & -0.35434\end{array}$ $2.27877 \quad 4.35433-1.04653$

$\begin{array}{llll}-2.12093 & 0.56004 & -1.49422\end{array}$ $\begin{array}{llll}-3.40207 & -0.75535 & -1.34832\end{array}$ $\begin{array}{llll}-3.08962 & 2.18213 & -1.6155\end{array}$ $\begin{array}{llll}-1.02705 & 0.28477 & -3.01847\end{array}$

$\begin{array}{llll}-4.25232 & -0.98748 & -2.46113\end{array}$ $-3.62373-1.50015-0.15176$ $\begin{array}{llll}-3.74436 & 2.41517 & -0.23824\end{array}$ $\begin{array}{llll}-4.2357 & 2.1941 & -2.65433\end{array}$

$\begin{array}{llll}-2.11565 & 3.34281 & -1.92184\end{array}$ $\begin{array}{llll}-1.65848 & 0.59884 & -4.39188\end{array}$ $\begin{array}{llll}0.25361 & 1.14288 & -2.87422\end{array}$ $-0.59152-1.19656-2.98125$ $\begin{array}{llll}-4.08427 & -0.43269 & -3.3905\end{array}$ $\begin{array}{llll}-5.32034 & -1.88893 & -2.40495\end{array}$ 


\begin{tabular}{|c|c|c|}
\hline 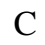 & $\begin{array}{ll}-4.73088 & -2.38301\end{array}$ & -0.11093 \\
\hline $\mathrm{H}$ & $-4.43018 \quad 1.5853$ & 0.02059 \\
\hline $\mathrm{H}$ & $-2.98974 \quad 2.5249$ & 0.56242 \\
\hline $\mathrm{H}$ & $\begin{array}{ll}-5.06087 & 1.51918\end{array}$ & -2.35927 \\
\hline $\mathrm{H}$ & $\begin{array}{ll}-3.91309 & 1.93967\end{array}$ & -3.68001 \\
\hline $\mathrm{H}$ & $-1.82782 \quad 3.36162$ & -2.99048 \\
\hline $\mathrm{H}$ & $-1.19621 \quad 3.30274$ & -1.30907 \\
\hline $\mathrm{H}$ & $\begin{array}{ll}-2.54348 & -0.01962\end{array}$ & -4.63088 \\
\hline $\mathrm{H}$ & $-1.91707 \quad 1.66876$ & -4.50277 \\
\hline $\mathrm{H}$ & $0.07486 \quad 2.22852$ & -2.978 \\
\hline $\mathrm{H}$ & $\begin{array}{ll}0.76599 & 0.94273\end{array}$ & -1.9224 \\
\hline $\mathrm{H}$ & $-1.44912-1.88554$ & -3.12279 \\
\hline $\mathrm{H}$ & $-0.07068-1.43976$ & -2.03207 \\
\hline $\mathrm{H}$ & $\begin{array}{ll}-5.95207 & -2.0442\end{array}$ & -3.2892 \\
\hline $\mathrm{C}$ & $\begin{array}{lll}-5.57581 & -2.57692\end{array}$ & -1.20909 \\
\hline $\mathrm{H}$ & $-4.89498-2.94932$ & 0.81776 \\
\hline $\mathrm{H}$ & $-6.41785-3.27831$ & -1.13752 \\
\hline $\mathrm{H}$ & $0.77841 \quad 6.16522$ & -0.12103 \\
\hline $\mathrm{N}$ & $2.45818-0.36246$ & -0.90465 \\
\hline$S$ & $\begin{array}{ll}3.84543 & 0.23875\end{array}$ & -1.48107 \\
\hline$S$ & $2.47103-1.81189$ & -0.20455 \\
\hline $\mathrm{O}$ & $3.49837 \quad 1.50439$ & -2.12333 \\
\hline $\mathrm{O}$ & $\begin{array}{lll}4.69135 & -0.73777\end{array}$ & -2.15224 \\
\hline $\mathrm{O}$ & $\begin{array}{ll}1.0903 & -2.07917\end{array}$ & 0.20128 \\
\hline $\mathrm{O}$ & $\begin{array}{lll}3.56522 & -2.03409\end{array}$ & 0.72986 \\
\hline $\mathrm{C}$ & $4.83584 \quad 0.77571$ & 0.02861 \\
\hline $\mathrm{C}$ & $2.74716-3.06366$ & -1.59143 \\
\hline $\mathrm{F}$ & $5.7016-0.15446$ & 0.4111 \\
\hline $\mathrm{F}$ & $5.51722 \quad 1.8887$ & -0.28237 \\
\hline $\mathrm{F}$ & $4.01526 \quad 1.06335$ & 1.05004 \\
\hline $\mathrm{F}$ & $2.41187-2.54897$ & -2.78176 \\
\hline $\mathrm{F}$ & $\begin{array}{lll}4.00401 & -3.48559\end{array}$ & -1.63277 \\
\hline $\mathrm{F}$ & $1.95155-4.12521$ & -1.36613 \\
\hline $\mathrm{H}$ & $-2.63572 \quad 4.29764$ & -1.69616 \\
\hline $\mathrm{H}$ & $-4.64022 \quad 3.22788$ & -2.67835 \\
\hline $\mathrm{H}$ & $\begin{array}{ll}-4.33885 & 3.3517\end{array}$ & -0.28662 \\
\hline 1 & $\begin{array}{lll}-0.88688 & 0.36847\end{array}$ & -5.15556 \\
\hline
\end{tabular}

$\begin{array}{cccl}\mathrm{H} & 0.95663 & 0.83759 & -3.67724 \\ \mathrm{H} & 0.1321 & -1.36292 & -3.80497 \\ \mathrm{C} & -2.72982 & -1.58409 & 1.06708 \\ \mathrm{C} & -1.73421 & -2.61261 & 1.06549 \\ \mathrm{C} & -3.06817 & -0.94465 & 2.29921 \\ \mathrm{C} & -1.01903 & -2.87731 & 2.24472 \\ \mathrm{C} & -2.34838 & -1.27311 & 3.45836 \\ \mathrm{C} & -1.30477 & -2.21685 & 3.45048 \\ \mathrm{H} & -0.20766 & -3.61923 & 2.20662 \\ \mathrm{H} & -2.59755 & -0.75477 & 4.39846 \\ \mathrm{C} & -1.50672 & -3.48244 & -0.15235 \\ \mathrm{H} & -0.59114 & -4.08662 & -0.03163 \\ \mathrm{H} & -2.37297 & -4.16181 & -0.3016 \\ \mathrm{H} & -1.40203 & -2.88854 & -1.0756 \\ \mathrm{C} & -4.1635 & 0.09732 & 2.40648 \\ \mathrm{H} & -4.65719 & 0.0328 & 3.39471 \\ \mathrm{H} & -3.74508 & 1.12213 & 2.31961 \\ \mathrm{H} & -4.93657 & -0.0182 & 1.62391 \\ \mathrm{C} & -0.51837 & -2.52384 & 4.70768 \\ \mathrm{H} & 0.54631 & -2.70855 & 4.4692 \\ \mathrm{H} & -0.57522 & -1.68601 & 5.42852 \\ \mathrm{H} & -0.90797 & -3.43089 & 5.21319\end{array}$

\section{S7c-TS-rot}

$\begin{array}{lccl}\mathrm{C} & 1.52708 & -2.70191 & 0.1901 \\ \mathrm{C} & 2.11048 & -2.33937 & 1.40393 \\ \mathrm{H} & 2.4553 & -1.31793 & 1.60657 \\ \mathrm{I} & 2.7295 & -1.61839 & -2.00469 \\ \mathrm{Au} & 0.46714 & -0.99665 & -0.66815 \\ \mathrm{C} & 1.14586 & -4.00035 & -0.16074 \\ \mathrm{H} & 0.77628 & -4.23921 & -1.16454 \\ \mathrm{C} & 1.25044 & -4.98181 & 0.84153 \\ \mathrm{H} & 0.94437 & -6.01113 & 0.60997 \\ \mathrm{C} & 1.74908 & -4.65233 & 2.1135 \\ \mathrm{C} & 2.18186 & -3.34498 & 2.38916 \\ \mathrm{H} & 2.59687 & -3.08166 & 3.37123 \\ \mathrm{P} & -1.76617 & -0.54653 & 0.1903\end{array}$


$\begin{array}{llll}-2.56746 & 0.55848 & -1.08908\end{array}$ $\begin{array}{llll}-2.58909 & -2.22256 & 0.4503\end{array}$

$\begin{array}{llll}-1.54586 & 0.42968 & 1.78885\end{array}$

$\begin{array}{llll}-1.67104 & 0.89998 & -2.13733\end{array}$

$\begin{array}{llll}-3.82378 & 1.25592 & -1.05783\end{array}$

$\begin{array}{llll}-2.41327 & -3.00449 & -0.87521\end{array}$

$\begin{array}{llll}-4.094 & -2.2253 & 0.80713\end{array}$

$\begin{array}{lll}-1.82834 & -2.96677 & 1.57799\end{array}$

$\begin{array}{llll}-2.76481 & 0.37777 & 2.73099\end{array}$ $\begin{array}{lll}-0.30737 & -0.08415 & 2.5631\end{array}$

$\begin{array}{llll}-1.22175 & 1.87647 & 1.34318\end{array}$ $-0.70833 \quad 0.38256-2.23019$

$\begin{array}{llll}-1.92586 & 1.9077 & -3.07649\end{array}$

$\begin{array}{llll}-4.05683 & 2.26935 & -2.01491\end{array}$

$-2.80986-2.44005-1.74418$

$\begin{array}{lll}-1.3506 & -3.24063 & -1.0719\end{array}$

$\begin{array}{llll}-4.71647 & -2.09142 & -0.08993\end{array}$

$\begin{array}{llll}-4.39373 & -1.46605 & 1.55319\end{array}$

$\begin{array}{lll}-2.13656 & -2.60553 & 2.57769\end{array}$

$\begin{array}{llll}-0.72988 & -2.88915 & 1.49694\end{array}$

$\begin{array}{lll}-3.72031 & 0.59475 & 2.22659\end{array}$

$\begin{array}{lll}-2.85018 & -0.61138 & 3.22258\end{array}$

$\begin{array}{lll}-0.39179 & -1.13705 & 2.89012\end{array}$

$\begin{array}{llll}0.61725 & 0.04942 & 1.97886\end{array}$

$\begin{array}{lll}-2.08718 & 2.38384 & 0.88216\end{array}$

$\begin{array}{llll}-0.38556 & 1.88768 & 0.61567\end{array}$

$\begin{array}{llll}-1.16969 & 2.13167 & -3.83893\end{array}$

$\begin{array}{llll}-3.12437 & 2.62222 & -2.99985\end{array}$

$\begin{array}{llll}-5.02916 & 2.78298 & -1.97007\end{array}$

$\begin{array}{llll}-3.34631 & 3.43324 & -3.70614\end{array}$

$\begin{array}{llll}1.8297 & -5.42824 & 2.88561\end{array}$

$\begin{array}{lll}2.32071 & 1.2229 & 0.68161\end{array}$

$\begin{array}{llll}3.41256 & 1.46784 & 1.85353\end{array}$

$2.3843 \quad 2.10645 \quad-0.6692$

$\begin{array}{llll}2.99807 & 0.62267 & 2.9696\end{array}$

$\begin{array}{llll}3.77046 & 2.86408 & 2.05418\end{array}$

$\begin{array}{llll}1.20265 & 1.71009 & -1.44917\end{array}$ $\begin{array}{llll}3.69086 & 2.17103 & -1.30527\end{array}$

$\begin{array}{llll}5.00208 & 0.65202 & 1.28542\end{array}$

$\begin{array}{llll}1.98275 & 3.8891 & -0.19387\end{array}$

$\begin{array}{llll}5.75901 & 1.47081 & 0.56705\end{array}$

$\begin{array}{llll}5.69144 & 0.27698 & 2.37234\end{array}$ $\begin{array}{llll}4.72993 & -0.44652 & 0.5644\end{array}$

$\begin{array}{llll}1.27301 & 3.9372 & 0.93919\end{array}$ $\begin{array}{llll}3.08285 & 4.61709 & -0.06134\end{array}$ $\begin{array}{llll}1.23775 & 4.42203 & -1.17418\end{array}$ $\begin{array}{llll}-2.09829 & -4.04204 & 1.51021\end{array}$ $\begin{array}{llll}-4.32969 & -3.22747 & 1.2241\end{array}$ $\begin{array}{llll}-2.97529 & -3.9588 & -0.79712\end{array}$ $\begin{array}{llll}-2.61081 & 1.13374 & 3.53018\end{array}$ $\begin{array}{lll}-0.20431 & 0.54385 & 3.47269\end{array}$ $\begin{array}{llll}-0.89862 & 2.45199 & 2.23526\end{array}$ $\begin{array}{llll}-5.03557 & 0.93563 & -0.21771\end{array}$ $\begin{array}{llll}-5.92362 & -0.05418 & -0.7269\end{array}$ $\begin{array}{llll}-5.44983 & 1.73458 & 0.88057\end{array}$ $\begin{array}{llll}-7.09096 & -0.3692 & -0.01446\end{array}$ $\begin{array}{lll}-6.62364 & 1.37626 & 1.57555\end{array}$ $\begin{array}{lll}-7.43801 & 0.30696 & 1.17027\end{array}$ $\begin{array}{llll}-7.7604 & -1.15144 & -0.40657\end{array}$ $\begin{array}{llll}-6.92505 & 1.98257 & 2.44489\end{array}$ $\begin{array}{lll}-5.65728 & -0.73102 & -2.05953\end{array}$ $-6.36462-1.56575-2.22268$ $\begin{array}{llll}-5.77897 & -0.00831 & -2.89262\end{array}$ $\begin{array}{llll}-4.62502 & -1.12249 & -2.14251\end{array}$ $\begin{array}{llll}-4.71805 & 2.99357 & 1.31586\end{array}$ $\begin{array}{lll}-5.45515 & 3.7513 & 1.64347\end{array}$ $\begin{array}{lll}-4.03454 & 2.81865 & 2.17075\end{array}$ $\begin{array}{llll}-4.11824 & 3.4308 & 0.49729\end{array}$ $\begin{array}{lll}-8.67233 & -0.08053 & 1.95678\end{array}$ $\begin{array}{llll}-8.44574 & -0.89263 & 2.67724\end{array}$ $\begin{array}{llll}-9.06498 & 0.77527 & 2.53765\end{array}$ $\begin{array}{llll}-9.47533 & -0.44909 & 1.29029\end{array}$ 
$\begin{array}{llll}\text { C } & 1.20033 & 2.26752 & -1.00341\end{array}$

$\begin{array}{llll}1.95307 & 2.6448 & -2.12525\end{array}$

$2.28505 \quad 1.90506-2.86396$

$\begin{array}{llll}-0.85648 & 0.55763 & -2.5382\end{array}$

$\begin{array}{llll}0.97167 & 0.21955 & -0.57764\end{array}$

$\begin{array}{llll}0.62732 & 3.20585 & -0.14459\end{array}$

$\begin{array}{lll}-0.04398 & 2.89911 & 0.66239\end{array}$

$\begin{array}{llll}0.94249 & 4.56608 & -0.33715\end{array}$

$\begin{array}{llll}0.5134 & 5.30948 & 0.34876\end{array}$

$\begin{array}{llll}1.76974 & 4.96469 & -1.39765\end{array}$

$2.25429 \quad 4.00683-2.30275$

$2.85338 \quad 4.31252-3.17157$

$\begin{array}{llll}2.84611 & -0.01234 & 1.00601\end{array}$

$\begin{array}{llll}3.05337 & -1.83167 & 1.10949\end{array}$

$\begin{array}{llll}4.44543 & 0.63939 & 0.21813\end{array}$

$\begin{array}{lll}2.628 & 0.67328 & 2.76584\end{array}$

$\begin{array}{llll}4.04633 & -2.39209 & 1.95665\end{array}$

$\begin{array}{llll}2.23213 & -2.70056 & 0.34879\end{array}$

$\begin{array}{llll}4.43557 & 0.17143 & -1.25357\end{array}$

$\begin{array}{llll}5.75237 & 0.06957 & 0.82517\end{array}$

$\begin{array}{llll}4.50409 & 2.18501 & 0.29184\end{array}$

$\begin{array}{llll}3.92276 & 0.79816 & 3.60291\end{array}$

$\begin{array}{lll}1.97921 & 2.07463 & 2.68853\end{array}$

$\begin{array}{llll}1.64655 & -0.25713 & 3.51064\end{array}$

$\begin{array}{llll}4.67775 & -1.73358 & 2.56176\end{array}$

$\begin{array}{llll}4.25366 & -3.77205 & 2.03123\end{array}$

$2.47434-4.09563 \quad 0.4215$

$\begin{array}{llll}4.42865 & -0.93479 & -1.30871\end{array}$

$\begin{array}{llll}3.57196 & 0.56163 & -1.81858\end{array}$

$\begin{array}{llll}5.85532 & -1.01385 & 0.62905\end{array}$

$\begin{array}{llll}5.86833 & 0.25463 & 1.90714\end{array}$

$\begin{array}{llll}4.76974 & 2.53307 & 1.30805\end{array}$

$\begin{array}{llll}3.56577 & 2.68025 & -0.01376\end{array}$

$\begin{array}{llll}4.44465 & -0.16116 & 3.76979\end{array}$

$\begin{array}{llll}4.63561 & 1.53397 & 3.18898\end{array}$

$\begin{array}{llll}2.56296 & 2.79966 & 2.09145\end{array}$

$\begin{array}{llll}0.95634 & 2.00886 & 2.28977\end{array}$
$2.06328-1.27237 \quad 3.66437$

$\begin{array}{llll}0.68102 & -0.32452 & 2.98016\end{array}$

$\begin{array}{lll}5.02744 & -4.1731 & 2.69857\end{array}$

$\begin{array}{llll}3.46929 & -4.63155 & 1.24389\end{array}$

$\begin{array}{llll}1.83353 & -4.75873 & -0.17805\end{array}$

$\begin{array}{llll}3.62205 & -5.71825 & 1.28431\end{array}$

$\begin{array}{llll}2.00425 & 6.0273 & -1.54387\end{array}$

$\begin{array}{llll}5.36372 & 0.53373 & -1.74291\end{array}$

$\begin{array}{llll}6.59111 & 0.5826 & 0.30934\end{array}$

$\begin{array}{llll}5.30662 & 2.52482 & -0.39595\end{array}$

$\begin{array}{llll}3.61007 & 1.17045 & 4.60059\end{array}$

$\begin{array}{lll}1.91071 & 2.46469 & 3.72555\end{array}$

$\begin{array}{llll}1.44789 & 0.1916 & 4.5058\end{array}$

$\begin{array}{llll}1.02252 & -2.34322 & -0.4975\end{array}$

$\begin{array}{llll}-0.273 & -2.49707 & 0.13066\end{array}$

$1.1198-2.58001-1.92586$

$-1.40031-2.75644-0.66388$

$-0.03024-2.86817-2.65483$

$-1.308-2.94946-2.05078$

$\begin{array}{llll}-2.37826 & -2.84949 & -0.17255\end{array}$

$\begin{array}{llll}0.05555 & -3.02601 & -3.74139\end{array}$

$\begin{array}{llll}-2.70161 & -0.04515 & 0.46558\end{array}$ $\begin{array}{llll}-2.47451 & 0.93659 & 1.70447\end{array}$

$\begin{array}{llll}-4.21185 & -0.39036 & 0.01098\end{array}$ $\begin{array}{lll}-3.29438 & 0.68365 & 2.88224\end{array}$

$\begin{array}{llll}-1.01437 & 1.04293 & 1.85648\end{array}$

$\begin{array}{llll}-4.12027 & -1.19675 & -1.19861\end{array}$

$\begin{array}{llll}-5.13134 & 0.73549 & 0.09255\end{array}$

$\begin{array}{llll}-4.82745 & -1.61193 & 1.30957\end{array}$

$\begin{array}{llll}-2.94803 & 2.67226 & 1.15398\end{array}$

$\begin{array}{lll}-5.57034 & -1.0175 & 2.23528\end{array}$

$\begin{array}{lll}-3.79123 & -2.22642 & 1.91209\end{array}$

$\begin{array}{llll}-5.56731 & -2.55687 & 0.71054\end{array}$

$\begin{array}{llll}-4.1928 & 2.98447 & 1.48267\end{array}$

$\begin{array}{llll}-2.1258 & 3.54783 & 1.77242\end{array}$

$\begin{array}{llll}-2.77788 & 2.80723 & -0.16349\end{array}$

$2.43797-2.46956-2.6604$ 
$\mathrm{H} \quad 2.40197 \quad-3.04197 \quad-3.6056$

$2.63633-1.40888-2.92733$

$\begin{array}{llll}3.29455 & -2.8325 & -2.06118\end{array}$

$\begin{array}{lll}-0.46484 & -2.45416 & 1.62955\end{array}$

$\begin{array}{llll}0.47002 & -2.63211 & 2.1907\end{array}$

$\begin{array}{lll}-0.87994 & -1.47232 & 1.92789\end{array}$

$\begin{array}{lll}-1.21054 & -3.21381 & 1.9305\end{array}$

$\begin{array}{llll}-2.5331 & -3.22856 & -2.88395\end{array}$

$-2.29294-3.88481-3.74251$

$\begin{array}{llll}-3.3393 & -3.67923 & -2.27794\end{array}$

$\begin{array}{llll}-2.93407 & -2.27244 & -3.27468\end{array}$

$\begin{array}{llll}0.15141 & 0.54296 & -2.3349\end{array}$ $\begin{array}{llll}1.54753 & 0.56761 & -2.2433\end{array}$

$\begin{array}{llll}2.05957 & 0.19636 & -1.34865\end{array}$ $\begin{array}{lll}-0.79962 & -2.36252 & -2.00912\end{array}$ $\begin{array}{llll}-1.0078 & 0.0128 & -0.68929\end{array}$ $\begin{array}{llll}-0.52269 & 0.937 & -3.50208\end{array}$

$\begin{array}{llll}-1.6137 & 0.81857 & -3.59391\end{array}$

$\begin{array}{llll}0.22114 & 1.51619 & -4.54438\end{array}$

$\begin{array}{llll}-0.29655 & 1.86907 & -5.44767\end{array}$

$\begin{array}{llll}1.62182 & 1.61554 & -4.44303\end{array}$

$\begin{array}{llll}2.28377 & 1.1264 & -3.30674\end{array}$

$\begin{array}{llll}3.37861 & 1.17654 & -3.21753\end{array}$

$\begin{array}{llll}-2.79915 & -0.49056 & 0.98825\end{array}$

$\begin{array}{lll}-2.9998 & 1.16191 & 1.7657\end{array}$

$\begin{array}{llll}-4.42324 & -0.71238 & 0.00966\end{array}$

$\begin{array}{llll}-2.64523 & -1.83905 & 2.32215\end{array}$

$\begin{array}{llll}-3.89347 & 1.37945 & 2.84378\end{array}$

$\begin{array}{lll}-2.28934 & 2.27016 & 1.23501\end{array}$

$\begin{array}{llll}-4.34959 & 0.25087 & -1.19655\end{array}$

$\begin{array}{llll}-5.69592 & -0.32126 & 0.79837\end{array}$

$\begin{array}{llll}-4.5722 & -2.14878 & -0.53864\end{array}$

$\begin{array}{llll}-3.96764 & -2.28203 & 2.99368\end{array}$

$\begin{array}{llll}-2.00325 & -3.08256 & 1.65326\end{array}$

$\begin{array}{llll}-1.68998 & -1.35487 & 3.43743\end{array}$ $\begin{array}{lll}-4.44147 & 0.52771 & 3.26451\end{array}$

$\begin{array}{lll}-4.11084 & 2.65501 & 3.37462\end{array}$

$\begin{array}{llll}-2.54046 & 3.55959 & 1.76608\end{array}$

$\begin{array}{llll}-4.19531 & 1.29214 & -0.85586\end{array}$

$\begin{array}{llll}-3.54509 & -0.02787 & -1.90967\end{array}$

$\begin{array}{llll}-5.71966 & 0.76287 & 1.01864\end{array}$

$\begin{array}{llll}-5.82729 & -0.87742 & 1.74329\end{array}$

$\begin{array}{llll}-4.78543 & -2.89337 & 0.24901\end{array}$

$\begin{array}{llll}-3.67822 & -2.47308 & -1.10196\end{array}$ $\begin{array}{llll}-4.45389 & -1.48032 & 3.58068\end{array}$

$\begin{array}{llll}-4.70283 & -2.70099 & 2.28514\end{array}$ $\begin{array}{llll}-2.63324 & -3.51018 & 0.85033\end{array}$

$\begin{array}{llll}-1.00456 & -2.85731 & 1.23951\end{array}$

$\begin{array}{lll}-2.04094 & -0.4236 & 3.92587\end{array}$

$\begin{array}{llll}-0.66285 & -1.21917 & 3.06025\end{array}$

$\begin{array}{llll}-4.80661 & 2.78929 & 4.21302\end{array}$

$\begin{array}{llll}-3.44084 & 3.75717 & 2.81819\end{array}$

$\begin{array}{llll}-1.98339 & 4.41161 & 1.34738\end{array}$

$\begin{array}{llll}-3.60625 & 4.76765 & 3.21487\end{array}$

$\begin{array}{llll}2.19871 & 2.04593 & -5.27328\end{array}$

$\begin{array}{llll}-5.31731 & 0.20873 & -1.73963\end{array}$

$\begin{array}{llll}-6.56883 & -0.55111 & 0.15179\end{array}$

$\begin{array}{llll}-5.43428 & -2.15025 & -1.23863\end{array}$

$\begin{array}{llll}-3.70429 & -3.08933 & 3.70834\end{array}$

$\begin{array}{llll}-1.88497 & -3.85755 & 2.43974\end{array}$

$\begin{array}{llll}-1.65316 & -2.15121 & 4.20961\end{array}$

$\begin{array}{lll}-1.13351 & 2.2361 & 0.24199\end{array}$

$\begin{array}{llll}0.19153 & 2.12138 & 0.85722\end{array}$

$\begin{array}{llll}-1.24325 & 3.03763 & -0.97426\end{array}$

$\begin{array}{llll}1.31149 & 2.64125 & 0.20004\end{array}$

$\begin{array}{llll}-0.09201 & 3.5503 & -1.56461\end{array}$

$\begin{array}{llll}1.19485 & 3.36282 & -1.00375\end{array}$

$\begin{array}{llll}2.30133 & 2.51408 & 0.65645\end{array}$

$-0.183794 .11344-2.50661$

$\begin{array}{llll}2.82782 & -0.1034 & 0.76374\end{array}$

$\begin{array}{llll}2.3492 & -1.50536 & 1.38811\end{array}$

$\begin{array}{llll}4.37118 & 0.23355 & 0.47128\end{array}$ 


\section{S7d-dcb}

C

C

$\mathrm{H}$

$\mathrm{Au}$

C

$\mathrm{H}$
$2.99924-1.92483 \quad 2.61946$

$\begin{array}{llll}0.88365 & -1.45193 & 1.32586\end{array}$

$\begin{array}{llll}4.38853 & 1.30639 & -0.5216\end{array}$

$\begin{array}{llll}5.24842 & -0.92005 & 0.34431\end{array}$

$\begin{array}{llll}4.91536 & 1.09611 & 2.02203\end{array}$

$\begin{array}{llll}2.79399 & -2.83474 & 0.1322\end{array}$

$\begin{array}{llll}4.94752 & 0.25981 & 3.05481\end{array}$

$\begin{array}{llll}4.06013 & 2.09807 & 2.3125\end{array}$

$\begin{array}{llll}6.13052 & 1.62432 & 1.84519\end{array}$

$3.93524 \quad-3.43588 \quad 0.44466$

$\begin{array}{llll}1.81941 & -3.75474 & 0.13094\end{array}$

$2.8894-2.31018-1.09514$

$\begin{array}{llll}-2.57189 & 3.29855 & -1.64565\end{array}$

$\begin{array}{llll}-2.50664 & 4.20464 & -2.27554\end{array}$

$\begin{array}{llll}-2.84203 & 2.45365 & -2.31356\end{array}$

$\begin{array}{llll}-3.39639 & 3.42995 & -0.92052\end{array}$

$\begin{array}{lll}0.33202 & 1.591 & 2.26075\end{array}$

$\begin{array}{lll}-0.07729 & 2.33818 & 2.97489\end{array}$

$\begin{array}{llll}-0.23696 & 0.65943 & 2.40544\end{array}$

$\begin{array}{llll}1.39347 & 1.40484 & 2.49958\end{array}$

$\begin{array}{llll}2.41332 & 3.97788 & -1.64408\end{array}$

$2.26964 \quad 4.10013-2.7343$

$\begin{array}{llll}2.59906 & 4.9825 & -1.20964\end{array}$

$\begin{array}{llll}3.30799 & 3.35628 & -1.45707\end{array}$

$\begin{array}{llll}0.83509 & 2.16728 & -1.21794\end{array}$ $\begin{array}{llll}1.61775 & 2.75317 & -2.21647\end{array}$ $\begin{array}{llll}2.43141 & 2.20484 & -2.70851\end{array}$ $\begin{array}{llll}-0.45826 & -0.14689 & -2.90388\end{array}$ $\begin{array}{llll}1.09935 & 0.16183 & -0.65222\end{array}$ $\begin{array}{llll}-0.26892 & 2.81775 & -0.65961\end{array}$ $\begin{array}{llll}-0.90328 & 2.31078 & 0.07624\end{array}$ $\begin{array}{llll}-0.54416 & 4.14028 & -1.05526\end{array}$ $\begin{array}{llll}-1.40566 & 4.65967 & -0.61295\end{array}$ $\begin{array}{llll}0.26182 & 4.77427 & -2.01477\end{array}$ $\begin{array}{llll}1.3349 & 4.08114 & -2.59567\end{array}$ $\begin{array}{lll}1.9551 & 4.55698 & -3.36717\end{array}$ $\begin{array}{llll}2.86442 & 0.47787 & 1.0004\end{array}$ $\begin{array}{llll}3.20533 & -1.24147 & 1.52636\end{array}$ $\begin{array}{llll}4.42907 & 1.056 & 0.09949\end{array}$ $\begin{array}{llll}2.47803 & 1.5436 & 2.51981\end{array}$ $\begin{array}{llll}4.16611 & -1.48719 & 2.54229\end{array}$ $\begin{array}{llll}2.55045 & -2.33939 & 0.91582\end{array}$ $\begin{array}{llll}4.48106 & 0.28798 & -1.24033\end{array}$ $\begin{array}{llll}5.73569 & 0.70456 & 0.85385\end{array}$ $\begin{array}{llll}4.40313 & 2.57752 & -0.16504\end{array}$ $\begin{array}{llll}3.71721 & 2.01829 & 3.31713\end{array}$ $\begin{array}{lll}1.67515 & 2.7855 & 2.06568\end{array}$ $\begin{array}{llll}1.57131 & 0.72673 & 3.46439\end{array}$ $\begin{array}{llll}4.6715 & -0.64834 & 3.03213\end{array}$ $\begin{array}{llll}4.50494 & -2.78865 & 2.92432\end{array}$ $\begin{array}{llll}2.92615 & -3.65011 & 1.29946\end{array}$ $\begin{array}{llll}4.51173 & -0.80431 & -1.06294\end{array}$ $\begin{array}{llll}3.62422 & 0.51658 & -1.90442\end{array}$ $\begin{array}{llll}5.89869 & -0.3874 & 0.9078\end{array}$ $\begin{array}{llll}5.79435 & 1.13254 & 1.87022\end{array}$ $\begin{array}{llll}4.56983 & 3.16707 & 0.75439\end{array}$ $\begin{array}{llll}3.46443 & 2.91679 & -0.63231\end{array}$ $\begin{array}{llll}4.3127 & 1.19147 & 3.74268\end{array}$ $\begin{array}{llll}4.38215 & 2.68375 & 2.7404\end{array}$ $\begin{array}{llll}2.16918 & 3.36861 & 1.26508\end{array}$ $\begin{array}{lll}0.66942 & 2.4882 & 1.72397\end{array}$ $\begin{array}{llll}2.08197 & -0.16451 & 3.8784\end{array}$ $\begin{array}{llll}0.64103 & 0.42025 & 2.95559\end{array}$ $\begin{array}{llll}5.25078 & -2.94727 & 3.71301\end{array}$ $\begin{array}{llll}3.89276 & -3.87949 & 2.28422\end{array}$ $\begin{array}{llll}2.41675 & -4.49687 & 0.81696\end{array}$ $\begin{array}{llll}4.15485 & -4.90765 & 2.56516\end{array}$ $\begin{array}{llll}0.04034 & 5.80333 & -2.32587\end{array}$ $\begin{array}{llll}5.41251 & 0.57571 & -1.76912\end{array}$ $\begin{array}{llll}6.56602 & 1.14011 & 0.2607\end{array}$ $\begin{array}{llll}5.23447 & 2.80718 & -0.86286\end{array}$ $\begin{array}{llll}3.32476 & 2.60542 & 4.17258\end{array}$ 
$\begin{array}{lll}1.55571 & 3.44612 & 2.94875\end{array}$

$\begin{array}{llll}1.28908 & 1.38923 & 4.30839\end{array}$

$\begin{array}{llll}1.36687 & -2.29595 & -0.03419\end{array}$

$\begin{array}{llll}0.05306 & -2.3798 & 0.57554\end{array}$

$\begin{array}{llll}1.54088 & -2.87062 & -1.35651\end{array}$

$\begin{array}{llll}-1.0204 & -2.88971 & -0.16918\end{array}$

$\begin{array}{llll}0.44362 & -3.41523 & -2.02241\end{array}$

$\begin{array}{llll}-0.85256 & -3.41848 & -1.45812\end{array}$

$\begin{array}{llll}-2.01383 & -2.93053 & 0.29905\end{array}$

$\begin{array}{llll}0.58949 & -3.83858 & -3.02805\end{array}$

$\begin{array}{lll}-2.73441 & 0.0489 & 0.53395\end{array}$

$\begin{array}{lll}-2.9203 & 1.0626 & 1.77015\end{array}$

$\begin{array}{llll}-4.08765 & -0.62731 & -0.03616\end{array}$

$\begin{array}{lll}-3.95593 & 0.68632 & 2.73033\end{array}$

$\begin{array}{llll}-1.58408 & 1.40494 & 2.25451\end{array}$

$-3.75703-1.37666-1.23918$

$\begin{array}{llll}-5.24273 & 0.26949 & -0.03121\end{array}$

$\begin{array}{llll}-4.52022 & -1.96839 & 1.23719\end{array}$

$\begin{array}{llll}-3.55561 & 2.67507 & 0.99684\end{array}$

$\begin{array}{lll}-5.64297 & -1.66165 & 1.88577\end{array}$

$\begin{array}{lll}-3.53896 & -2.13714 & 2.13305\end{array}$

$\begin{array}{llll}-4.69979 & -3.13502 & 0.60073\end{array}$

$\begin{array}{llll}-4.82112 & 2.89925 & 1.34426\end{array}$

$\begin{array}{llll}-2.8038 & 3.69592 & 1.43725\end{array}$

$\begin{array}{llll}-3.47096 & 2.64948 & -0.33755\end{array}$

$\begin{array}{llll}2.87922 & -2.85299 & -2.06009\end{array}$

$2.92611-3.65547-2.81843$

$\begin{array}{llll}3.00838 & -1.88654 & -2.59351\end{array}$

$3.73057-2.9713-1.36473$

$\begin{array}{lll}-0.20875 & -2.00258 & 2.01625\end{array}$

$\begin{array}{llll}0.7114 & -1.94803 & 2.62297\end{array}$

$\begin{array}{lll}-0.72643 & -1.02422 & 2.06469\end{array}$

$\begin{array}{llll}-0.88947 & -2.74562 & 2.47311\end{array}$

$\begin{array}{llll}-2.02982 & -3.95434 & -2.23246\end{array}$

$\begin{array}{llll}-1.76104 & -4.86844 & -2.79527\end{array}$

$-2.88816-4.1623-1.56671$

$\begin{array}{llll}-2.35871 & -3.19007 & -2.96607\end{array}$

$\begin{array}{llll}\mathbf{8 a} & & & \\ \mathrm{C} & -1.25982 & 2.77455 & -0.94991 \\ \mathrm{C} & -1.36094 & 2.23324 & 0.36317 \\ \mathrm{C} & -0.23589 & 2.26013 & 1.22728 \\ \mathrm{C} & 1.00351 & 2.70868 & 0.72176 \\ \mathrm{C} & 1.15073 & 3.1472 & -0.60474 \\ \mathrm{C} & -0.00247 & 3.19946 & -1.41442 \\ \mathrm{H} & 1.88508 & 2.68138 & 1.38216 \\ \mathrm{H} & 0.07685 & 3.6004 & -2.43792 \\ \mathrm{C} & -2.68959 & 1.67488 & 0.80213 \\ \mathrm{C} & -3.60649 & 2.58352 & 1.37799 \\ \mathrm{C} & -3.11403 & 0.32588 & 0.58954 \\ \mathrm{C} & -4.91224 & 2.21135 & 1.72023 \\ \mathrm{H} & -3.26562 & 3.61665 & 1.53755 \\ \mathrm{C} & -4.44846 & -0.02566 & 0.92298 \\ \mathrm{C} & -5.3421 & 0.89804 & 1.4771 \\ \mathrm{H} & -5.59671 & 2.94807 & 2.1619 \\ \mathrm{H} & -4.79717 & -1.05053 & 0.75052 \\ \mathrm{H} & -6.3672 & 0.5887 & 1.71942 \\ \mathrm{P} & -2.03734 & -1.00518 & -0.0991 \\ \mathrm{C} & -2.83773 & -1.69213 & -1.67485 \\ \mathrm{C} & -1.8179 & -2.30519 & 1.25417 \\ \mathrm{C} & -0.98012 & -1.63742 & 2.37074 \\ \mathrm{H} & -0.86003 & -2.37538 & 3.19151 \\ \mathrm{H} & 0.02958 & -1.33939 & 2.02407 \\ \mathrm{H} & -1.50043 & -0.75071 & 2.78382 \\ \mathrm{C} & -1.01276 & -3.49649 & 0.6864 \\ \mathrm{H} & -0.74582 & -4.15861 & 1.53595 \\ \mathrm{H} & -1.60061 & -4.09947 & -0.03333 \\ \mathrm{H} & -0.06815 & -3.1661 & 0.20639 \\ \mathrm{C} & -3.11983 & -2.81923 & 1.91063 \\ \mathrm{H} & -3.84519 & -3.24981 & 1.19588 \\ \mathrm{H} & -2.83291 & -3.62362 & 2.6191 \\ \mathrm{H} & -3.61802 & -2.02469 & 2.49741 \\ \mathrm{C} & -1.74452 & -2.36352 & -2.54767 \\ \mathrm{H} & & -3.1771 & -2.02866\end{array}$


$\begin{array}{llll}-2.2439 & -2.79488 & -3.44074\end{array}$

$-0.99765-1.62285-2.89226$

$-3.97441-2.71555-1.46311$

$\begin{array}{llll}-4.37254 & -2.98481 & -2.46351\end{array}$

$\begin{array}{llll}-3.61325 & -3.64777 & -0.98891\end{array}$

$-4.82028-2.31555-0.87393$

$-3.37384-0.48136-2.46934$

$\begin{array}{llll}-3.71549 & -0.84076 & -3.46229\end{array}$

$\begin{array}{llll}-4.22631 & 0.01221 & -1.96257\end{array}$

$\begin{array}{llll}-2.57053 & 0.26706 & -2.63289\end{array}$

$\begin{array}{llll}-0.30751 & 1.83608 & 2.68171\end{array}$

$\begin{array}{lll}-1.33643 & 1.58845 & 3.00056\end{array}$

$\begin{array}{llll}0.34678 & 0.96445 & 2.87126\end{array}$

$\begin{array}{lll}0.05817 & 2.6591 & 3.32748\end{array}$

$\begin{array}{llll}2.50384 & 3.54378 & -1.15336\end{array}$

$\begin{array}{llll}3.1932 & 3.84274 & -0.34289\end{array}$

$\begin{array}{llll}2.97282 & 2.68457 & -1.67217\end{array}$

$\begin{array}{llll}2.41426 & 4.37505 & -1.87954\end{array}$

$\begin{array}{llll}-2.48414 & 2.99415 & -1.82149\end{array}$

$\begin{array}{llll}-3.28988 & 2.26332 & -1.63269\end{array}$

$\begin{array}{llll}-2.91485 & 3.99825 & -1.62168\end{array}$

$\begin{array}{llll}-2.21797 & 2.95973 & -2.89553\end{array}$

$0.02637-0.27848-0.61369$

$\begin{array}{llll}2.13938 & 0.2491 & -1.04423\end{array}$

$\begin{array}{lll}3.41879 & -0.47254 & 0.2742\end{array}$

$\begin{array}{llll}2.51302 & -2.10529 & 0.01442\end{array}$

$\begin{array}{llll}4.5656 & -0.82239 & -1.15045\end{array}$

$\begin{array}{llll}4.57609 & -1.17311 & 1.55108\end{array}$

$\begin{array}{lll}4.058 & 1.27881 \quad 0.43916\end{array}$

$\begin{array}{llll}2.09967 & -0.06902 & 1.56768\end{array}$

$\begin{array}{lll}-1.7323 & 2.806 & 0.48181\end{array}$

$\begin{array}{lll}-1.00282 & 3.9743 & 0.2333\end{array}$

$\begin{array}{llll}-0.26684 & 4.35107 & 0.95535\end{array}$

$\begin{array}{lll}-1.30353 & 1.66817 & 2.2898\end{array}$

$\begin{array}{llll}0.61308 & 0.61059 & 0.48723\end{array}$ $\begin{array}{llll}-2.66023 & 2.26388 & -0.40831\end{array}$

$\begin{array}{llll}-3.20777 & 1.34506 & -0.17666\end{array}$

$\begin{array}{llll}-2.86612 & 2.94223 & -1.62482\end{array}$

$\begin{array}{llll}-3.57412 & 2.51103 & -2.34456\end{array}$

$\begin{array}{llll}-2.16751 & 4.12691 & -1.90663\end{array}$

$\begin{array}{llll}-1.2417 & 4.64162 & -0.98183\end{array}$

$\begin{array}{llll}-0.69117 & 5.5671 & -1.20062\end{array}$

$\begin{array}{llll}2.20067 & 0.45859 & -1.14564\end{array}$

$3.18981-1.09467-1.03812$

$\begin{array}{llll}1.31658 & 0.56091 & -2.81834\end{array}$

$\begin{array}{llll}3.40063 & 1.90234 & -0.8577\end{array}$

$4.15254-1.32494-2.05542$

$\begin{array}{llll}3.10349 & -2.02802 & 0.04467\end{array}$

$\begin{array}{llll}4.26133 & -0.60317 & -2.87202\end{array}$

$\begin{array}{llll}4.98473 & -2.45085 & -2.04873\end{array}$

$3.94928-3.1601 \quad 0.02059$

$\begin{array}{llll}5.7143 & -2.59487 & -2.85636\end{array}$

$4.87488-3.38264-1.00652$

$\begin{array}{llll}3.8676 & -3.87223 & 0.85489\end{array}$

$\begin{array}{llll}5.5149 & -4.27491 & -0.98653\end{array}$

$\begin{array}{llll}-2.33711 & 4.65102 & -2.85653\end{array}$

$\begin{array}{llll}2.19822 & -1.89454 & 1.24412\end{array}$

$2.69692-1.36646 \quad 2.4636$

$\begin{array}{llll}0.85692 & -2.36632 & 1.16927\end{array}$

$\begin{array}{lll}1.7984 & -1.17311 & 3.53365\end{array}$

$\begin{array}{lll}-0.00474 & -2.162 \quad 2.26463\end{array}$

$\begin{array}{llll}0.44323 & -1.53834 & 3.44496\end{array}$

$\begin{array}{llll}2.1803 & -0.73552 & 4.47098\end{array}$

$\begin{array}{lll}-1.05715 & -2.47536 & 2.16521\end{array}$

$\begin{array}{llll}4.17329 & -1.09015 & 2.69365\end{array}$

$4.32053-0.18202 \quad 3.31068$

$\begin{array}{llll}4.62974 & -1.93624 & 3.24866\end{array}$

$\begin{array}{lll}4.74306 & -0.974 \quad 1.75567\end{array}$

$0.35561-3.08212-0.06325$

$\begin{array}{llll}1.04029 & -3.90767 & -0.3464\end{array}$

$\begin{array}{llll}-0.65638 & -3.49117 & 0.10185\end{array}$

$0.28698-2.39925-0.92766$ 


$\begin{array}{llll}\mathrm{C} & -0.508 & -1.29596 & 4.60053 \\ \mathrm{H} & -0.43101 & -2.09838 & 5.36207 \\ \mathrm{H} & -0.28271 & -0.33944 & 5.11441 \\ \mathrm{H} & -1.55845 & -1.27236 & 4.25173 \\ \mathrm{~F} & -1.76109 & -0.8531 & -0.02593 \\ \mathrm{Sb} & -3.24662 & -1.66516 & -0.91928 \\ \mathrm{~F} & -3.14824 & -3.05057 & 0.35069 \\ \mathrm{~F} & -4.36158 & -0.64619 & 0.21016 \\ \mathrm{~F} & -2.03442 & -2.57137 & -2.04123 \\ \mathrm{~F} & -3.21406 & -0.21136 & -2.13449 \\ \mathrm{~F} & -4.71917 & -2.43814 & -1.7671 \\ \mathrm{C} & 0.62917 & 1.94396 & -2.90018 \\ \mathrm{H} & 1.34856 & 2.76987 & -3.06995 \\ \mathrm{H} & -0.07256 & 1.92301 & -3.75985 \\ \mathrm{H} & 0.03277 & 2.15756 & -1.98986 \\ \mathrm{C} & 0.20874 & -0.51647 & -2.81399 \\ \mathrm{H} & 0.63227 & -1.53889 & -2.77026 \\ \mathrm{H} & -0.5067 & -0.38022 & -1.98173 \\ \mathrm{H} & -0.36431 & -0.43152 & -3.7606 \\ \mathrm{C} & 2.17215 & 0.32972 & -4.0852 \\ \mathrm{H} & 1.51974 & 0.54264 & -4.95715 \\ \mathrm{H} & 3.05858 & 0.98611 & -4.16398 \\ \mathrm{H} & 2.49132 & -0.72597 & -4.16739 \\ \mathrm{C} & 4.25378 & 2.28913 & -2.08365 \\ \mathrm{H} & 3.64083 & 2.71662 & -2.89995 \\ \mathrm{H} & 4.9766 & 3.06895 & -1.76444 \\ \mathrm{H} & 4.84193 & 1.43928 & -2.47947 \\ \mathrm{C} & 2.62929 & 3.15818 & -0.373 \\ \mathrm{H} & 1.83384 & 3.48957 & -1.06486 \\ \mathrm{H} & 2.16787 & 2.97787 & 0.61881 \\ \mathrm{H} & 3.36478 & 3.9842 & -0.26867 \\ \mathrm{C} & 4.33103 & 1.47514 & 0.29826 \\ \mathrm{H} & 3.73706 & 1.14903 & 1.17777 \\ \mathrm{H} & 5.01595 & 0.6562 & 0.00377 \\ \mathrm{H} & 4.9413 & 2.35247 & 0.59864\end{array}$

8c-TS $\begin{array}{lll}-0.36273 & 2.4071 & 1.11666\end{array}$

$\begin{array}{lll}0.39093 & 3.50601 & 1.5355\end{array}$

$\begin{array}{llll}1.24806 & 3.39807 & 2.2093\end{array}$

$\begin{array}{lll}-0.67076 & 0.57218 & 3.03661\end{array}$

$\begin{array}{lll}0.72338 & 0.45313 & 0.73283\end{array}$

$\begin{array}{llll}-1.5327 & 2.49101 & 0.36326\end{array}$

$\begin{array}{llll}-2.15261 & 1.61635 & 0.15794\end{array}$

$\begin{array}{llll}-1.88013 & 3.76037 & -0.13856\end{array}$

$\begin{array}{llll}-2.77577 & 3.83264 & -0.77064\end{array}$

$\begin{array}{llll}-1.10945 & 4.88859 & 0.18566\end{array}$

$\begin{array}{llll}0.00739 & 4.76372 & 1.03133\end{array}$

$\begin{array}{lll}0.59161 & 5.64893 & 1.31919\end{array}$

$2.17475 \quad 0.56427-1.14586$

$2.72901-1.13505-1.56902$

$\begin{array}{llll}1.33068 & 1.43793 & -2.59759\end{array}$

$3.78561 \quad 1.43406-0.61779$

$3.60589-1.30951-2.67083$

$2.51396-2.23003-0.67896$

$3.79198-0.4759-3.35531$

$\begin{array}{llll}4.26848 & -2.52076 & -2.90139\end{array}$

$3.20804-3.43817-0.928$

$\begin{array}{llll}4.93649 & -2.62152 & -3.76669\end{array}$

$\begin{array}{llll}4.07909 & -3.58996 & -2.01301\end{array}$

$\begin{array}{llll}3.03255 & -4.27782 & -0.23949\end{array}$

$4.59934-4.54424-2.1701$

$\begin{array}{llll}-1.39682 & 5.87786 & -0.19357\end{array}$

$\begin{array}{llll}1.51793 & -2.29904 & 0.4573\end{array}$

$\begin{array}{llll}1.93317 & -2.4456 & 1.81686\end{array}$

$\begin{array}{llll}0.15827 & -2.60713 & 0.10595\end{array}$

$\begin{array}{llll}0.97296 & -2.77406 & 2.78856\end{array}$

$\begin{array}{lll}-0.76779 & -2.89826 & 1.11827\end{array}$

$\begin{array}{llll}-0.38125 & -2.98025 & 2.46905\end{array}$

$\begin{array}{llll}1.29641 & -2.85886 & 3.83884\end{array}$

$\begin{array}{llll}-1.81722 & -3.06788 & 0.83028\end{array}$

$\begin{array}{llll}3.36627 & -2.25311 & 2.27755\end{array}$

$3.48385-1.2801 \quad 2.80009$

$\begin{array}{llll}3.63917 & -3.03977 & 3.00722\end{array}$ 
$\begin{array}{llll}4.09428 & -2.28382 & 1.44695\end{array}$

$-0.26256-2.71437-1.34075$

$\begin{array}{llll}0.35361 & -3.47354 & -1.86687\end{array}$

$\begin{array}{llll}-1.32694 & -2.9941 & -1.41744\end{array}$

$-0.13661-1.75932-1.87762$

$\begin{array}{lll}-1.40253 & -3.30518 & 3.53799\end{array}$

$\begin{array}{lll}-1.69504 & -4.37375 & 3.49644\end{array}$

$\begin{array}{llll}-1.00589 & -3.09881 & 4.5502\end{array}$

$\begin{array}{llll}-2.32296 & -2.70841 & 3.39059\end{array}$

$-1.92574-0.51429-0.35531$

$-3.55814-0.58916-1.35283$

$\begin{array}{llll}-3.7246 & -2.37976 & -0.79187\end{array}$

$\begin{array}{llll}-4.41959 & 0.04913 & 0.1897\end{array}$

$\begin{array}{llll}-2.55049 & -1.1344 & -2.85061\end{array}$

$-3.2481 \quad 1.20934-1.87285$

$-5.15755-0.66606-2.31174$

$\begin{array}{llll}1.19501 & 2.93797 & -2.24287\end{array}$

$\begin{array}{llll}2.16124 & 3.47625 & -2.29063\end{array}$

$\begin{array}{llll}0.5158 & 3.39655 & -2.99055\end{array}$

$\begin{array}{llll}0.74365 & 3.09376 & -1.24547\end{array}$

$\begin{array}{llll}-0.08819 & 0.84093 & -2.73583\end{array}$

$\begin{array}{llll}-0.05944 & -0.20203 & -3.10002\end{array}$

$\begin{array}{llll}-0.66543 & 0.87604 & -1.79484\end{array}$

$\begin{array}{llll}-0.6478 & 1.43496 & -3.48796\end{array}$

$\begin{array}{llll}2.01826 & 1.29652 & -3.97393\end{array}$

$\begin{array}{llll}1.44001 & 1.91929 & -4.68763\end{array}$

$3.06643 \quad 1.64968-3.99562$

$\begin{array}{llll}1.9739 & 0.25365 & -4.33993\end{array}$

$\begin{array}{llll}4.66734 & 1.92882 & -1.78363\end{array}$

$\begin{array}{llll}4.18971 & 2.73549 & -2.36937\end{array}$

$\begin{array}{llll}5.59992 & 2.34222 & -1.34516\end{array}$

$\begin{array}{llll}4.96316 & 1.11129 & -2.46738\end{array}$

$\begin{array}{llll}3.46184 & 2.62222 & 0.31852\end{array}$

$\begin{array}{lllll}2.77492 & 3.36818 & -0.11949\end{array}$

$\begin{array}{llll}3.01749 & 2.25191 & 1.26365\end{array}$

$\begin{array}{llll}4.41627 & 3.13266 & 0.56643\end{array}$

$\begin{array}{llll}4.59844 & 0.42713 & 0.22628\end{array}$

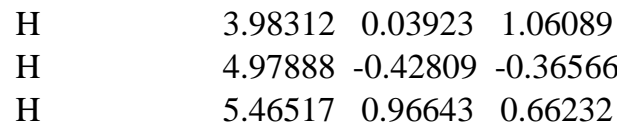

\section{S8c-TS-iso}

$\mathrm{C}$

I

$\mathrm{Au}$

C

$\mathrm{H}$

C

$\mathrm{H}$

C

C

$\mathrm{H}$

$\mathrm{P}$

C

C

C

$\mathrm{H}$

C

C

C

$\mathrm{H}$

$\mathrm{H}$

$\mathrm{H}$

C

C

C

$\mathrm{C}$

C

C $\begin{array}{lll}-0.64503 & 2.09396 & -1.19613\end{array}$

$\begin{array}{llll}-1.8996 & 2.38726 & -0.61647\end{array}$

$\begin{array}{llll}-2.56689 & 1.58064 & -0.28626\end{array}$

$\begin{array}{llll}-1.03259 & 0.17354 & -2.89543\end{array}$

$\begin{array}{llll}0.58675 & 0.44119 & -0.62855\end{array}$

$\begin{array}{llll}0.18663 & 3.10119 & -1.7423\end{array}$

$1.10562 \quad 2.83016-2.28452$

$\begin{array}{llll}-0.17632 & 4.44355 & -1.56069\end{array}$

$\begin{array}{llll}0.4833 & 5.24064 & -1.93028\end{array}$

$\begin{array}{llll}-1.41379 & 4.75672 & -0.96718\end{array}$

$\begin{array}{llll}-2.27021 & 3.73733 & -0.51458\end{array}$

$\begin{array}{llll}-3.24568 & 3.99024 & -0.07747\end{array}$

$\begin{array}{llll}2.31595 & -1.16528 & -0.31539\end{array}$

$\begin{array}{llll}3.03589 & -0.88061 & 1.34903\end{array}$

$\begin{array}{llll}1.74871 & -2.95995 & -0.54977\end{array}$

$\begin{array}{llll}3.7057 & -0.70905 & -1.53659\end{array}$

$\begin{array}{llll}4.14519 & -1.65124 & 1.78448\end{array}$

$\begin{array}{llll}2.62647 & 0.2384 & 2.13554\end{array}$

$\begin{array}{llll}4.47865 & -2.50364 & 1.18301\end{array}$

$\begin{array}{llll}4.8421 & -1.34883 & 2.95983\end{array}$

$\begin{array}{llll}3.35349 & 0.52663 & 3.31663\end{array}$

$\begin{array}{llll}5.69339 & -1.97041 & 3.26685\end{array}$

$\begin{array}{llll}4.44616 & -0.24432 & 3.72893\end{array}$

$\begin{array}{llll}3.02894 & 1.3868 & 3.92033\end{array}$

$\begin{array}{llll}4.98325 & 0.01492 & 4.65113\end{array}$

$\begin{array}{llll}-1.72876 & 5.80656 & -0.89044\end{array}$

$\begin{array}{llll}1.4301 & 1.15124 & 1.93191\end{array}$

$\begin{array}{lll}1.61471 & 2.53946 & 1.62114\end{array}$

$\begin{array}{llll}0.1712 & 0.72682 & 2.48073\end{array}$

$\begin{array}{llll}0.55116 & 3.43306 & 1.819\end{array}$

$\begin{array}{lll}-0.86891 & 1.65456 & 2.63056\end{array}$

$\begin{array}{llll}-0.68825 & 3.01968 & 2.34122\end{array}$ 


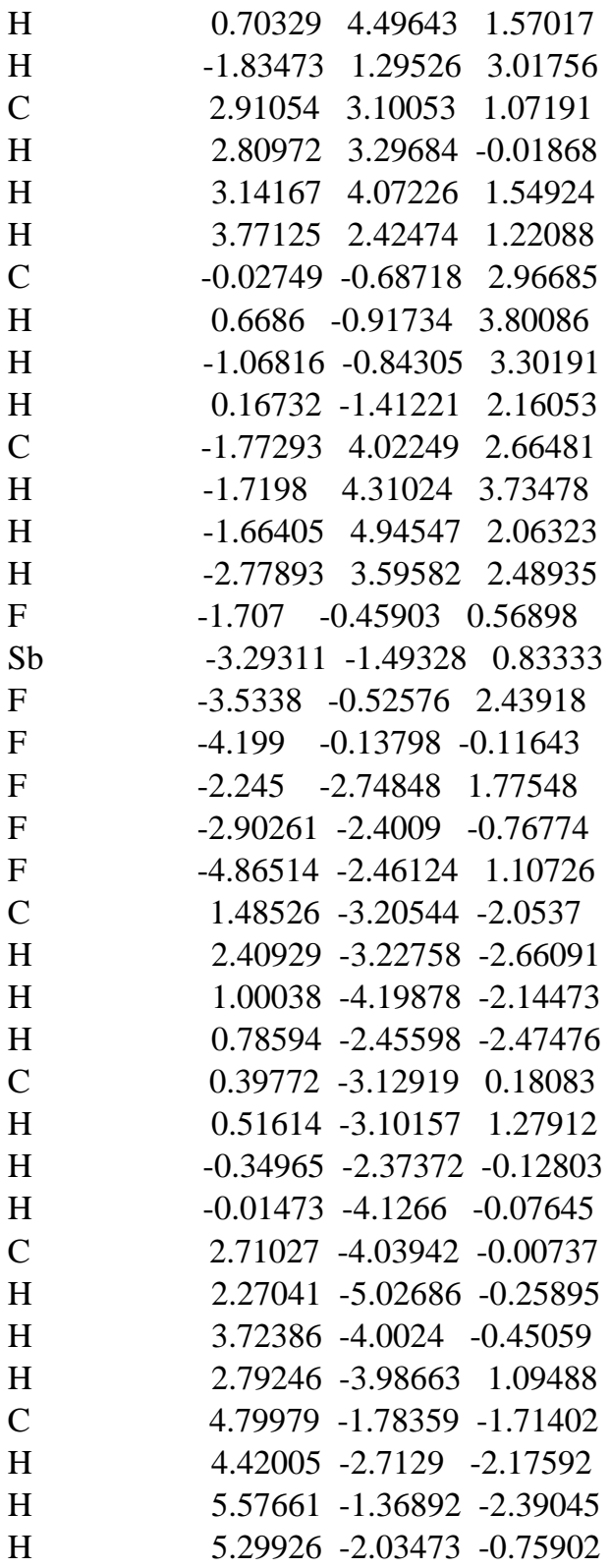

$\begin{array}{llll}\mathrm{C} & 3.10546 & -0.35198 & -2.92189 \\ \mathrm{H} & 2.50189 & -1.15529 & -3.37822 \\ \mathrm{H} & 2.46798 & 0.55296 & -2.85603 \\ \mathrm{H} & 3.94924 & -0.12471 & -3.60719 \\ \mathrm{C} & 4.37155 & 0.58231 & -1.0128 \\ \mathrm{H} & 3.61642 & 1.38382 & -0.89222 \\ \mathrm{H} & 4.89867 & 0.43704 & -0.04941 \\ \mathrm{H} & 5.1104 & 0.92109 & -1.76904 \\ & & & \\ \text { 8d } & & & \\ \mathrm{C} & & & \\ \mathrm{C} & 0.15565 & -1.70078 & -1.64768 \\ \mathrm{H} & 1.08774 & -2.65703 & -2.07486 \\ \mathrm{I} & 1.7711 & -3.13851 & -1.36309 \\ \mathrm{Au} & -1.51166 & -3.34078 & 0.48499 \\ \mathrm{C} & 0.1127 & -1.1535 & 0.3503 \\ \mathrm{H} & -0.81704 & -1.18964 & -2.5162 \\ \mathrm{C} & -1.6196 & -0.53086 & -2.16077 \\ \mathrm{H} & -0.76792 & -1.56532 & -3.87263 \\ \mathrm{C} & -1.5252 & -1.16115 & -4.5578 \\ \mathrm{C} & 0.20914 & -2.45899 & -4.33668 \\ \mathrm{H} & 1.12711 & -3.01721 & -3.43407 \\ \mathrm{P} & 1.86733 & -3.75635 & -3.77229 \\ \mathrm{C} & 1.64968 & 0.7109 & 0.36564 \\ \mathrm{C} & 1.73536 & 1.08346 & 2.15769 \\ \mathrm{C} & 3.36379 & 0.11953 & -0.15958 \\ \mathrm{C} & 1.03197 & 2.30152 & -0.45835 \\ \mathrm{C} & 2.5489 & 2.1395 & 2.64712 \\ \mathrm{C} & 0.87044 & 0.43304 & 3.06142 \\ \mathrm{C} & 3.55494 & -1.29353 & 0.47045 \\ \mathrm{C} & 4.5484 & 0.99322 & 0.34457 \\ \mathrm{C} & 3.419 & 0.01414 & -1.70904 \\ \mathrm{C} & 2.1609 & 3.33476 & -0.72799 \\ \mathrm{C} & 0.32382 & 1.92257 & -1.78972 \\ \mathrm{H} & -0.03334 & 2.957 & 0.47215 \\ \mathrm{C} & 3.20592 & 2.68002 & 1.95846 \\ \mathrm{C} & & 0.82705 & 4.41591\end{array}$




$\begin{array}{lccc}\mathrm{N} & -0.0079 & -0.66067 & 2.62343 \\ \mathrm{H} & 3.52642 & -1.20309 & 1.58299 \\ \mathrm{H} & 2.72512 & -1.96681 & 0.17231 \\ \mathrm{C} & 4.89951 & -1.90705 & 0.01532 \\ \mathrm{C} & 5.89257 & 0.39263 & -0.13687 \\ \mathrm{H} & 4.55332 & 1.00284 & 1.45462 \\ \mathrm{H} & 4.46044 & 2.03964 & -0.01354 \\ \mathrm{C} & 4.76255 & -0.6124 & -2.14563 \\ \mathrm{H} & 3.33015 & 1.02398 & -2.16183 \\ \mathrm{H} & 2.57098 & -0.59232 & -2.08532 \\ \mathrm{H} & 2.65045 & 3.63535 & 0.22291 \\ \mathrm{H} & 2.93957 & 2.90853 & -1.39402 \\ \mathrm{C} & 1.56712 & 4.59548 & -1.39997 \\ \mathrm{C} & -0.21748 & 3.19504 & -2.4812 \\ \mathrm{H} & 1.00982 & 1.3683 & -2.46864 \\ \mathrm{H} & -0.53163 & 1.26003 & -1.5539 \\ \mathrm{C} & -0.62059 & 4.21293 & -0.21901 \\ \mathrm{H} & 0.43434 & 3.26753 & 1.43123 \\ \mathrm{H} & -0.84738 & 2.23363 & 0.69717 \\ \mathrm{H} & 3.15595 & 3.345 & 4.33877 \\ \mathrm{C} & 1.65475 & 1.86272 & 4.87992 \\ \mathrm{H} & 0.1598 & 0.32157 & 5.11392 \\ \mathrm{C} & -1.4396 & -0.33119 & 2.92924 \\ \mathrm{C} & 0.39837 & -1.91127 & 3.33309 \\ \mathrm{H} & 4.99439 & -2.91696 & 0.46708 \\ \mathrm{C} & 6.06606 & -1.01118 & 0.47595 \\ \mathrm{C} & 4.91508 & -2.01691 & -1.52517 \\ \mathrm{H} & 6.70968 & 1.05897 & 0.2123 \\ \mathrm{C} & 5.9164 & 0.29591 & -1.67546 \\ \mathrm{H} & 4.76735 & -0.68989 & -3.25289 \\ \mathrm{H} & 2.39805 & 5.31238 & -1.57544 \\ \mathrm{C} & 0.51368 & 5.22872 & -0.46652 \\ \mathrm{C} & 0.92839 & 4.19098 & -2.74464 \\ \mathrm{C} & -1.27103 & 3.84755 & -1.56618 \\ \mathrm{H} & -0.69004 & 2.88818 & -3.43745 \\ \mathrm{H} & & & \\ & -1.3881 & 4.63992 & 0.45941 \\ & 2.15869 & 5.9361\end{array}$

\begin{tabular}{|c|c|c|c|}
\hline $\mathrm{H}$ & -2.09032 & -1.08133 & 2.44927 \\
\hline $\mathrm{H}$ & -1.6782 & 0.6634 & 2.51265 \\
\hline $\mathrm{H}$ & -1.61006 & -0.33691 & 4.02576 \\
\hline $\mathrm{H}$ & 0.35996 & -1.76728 & 4.43246 \\
\hline $\mathrm{H}$ & 1.43101 & -2.17206 & 3.0288 \\
\hline $\mathrm{H}$ & -0.28958 & -2.72224 & 3.04444 \\
\hline $\mathrm{H}$ & 7.03364 & -1.45163 & 0.15112 \\
\hline $\mathrm{H}$ & 6.08205 & -0.94315 & 1.58594 \\
\hline $\mathrm{H}$ & 4.09059 & -2.67488 & -1.87658 \\
\hline $\mathrm{H}$ & 5.87266 & -2.47413 & -1.85664 \\
\hline $\mathrm{H}$ & 5.80863 & 1.30844 & -2.12411 \\
\hline $\mathrm{H}$ & 6.89221 & -0.11784 & -2.01059 \\
\hline $\mathrm{H}$ & 0.10252 & 6.14953 & -0.93382 \\
\hline $\mathrm{H}$ & 0.99189 & 5.52356 & 0.49492 \\
\hline $\mathrm{H}$ & 1.70018 & 3.73366 & -3.40471 \\
\hline $\mathrm{H}$ & 0.53483 & 5.09235 & -3.26213 \\
\hline $\mathrm{H}$ & -2.12141 & 3.16081 & -1.41098 \\
\hline $\mathrm{H}$ & -1.66439 & 4.77065 & -2.04609 \\
\hline $\mathrm{H}$ & 0.23296 & -2.74801 & -5.39584 \\
\hline $\mathrm{F}$ & -2.07287 & 0.32395 & 0.06544 \\
\hline $\mathrm{Sb}$ & -3.92934 & 0.72342 & -0.20707 \\
\hline $\mathrm{F}$ & -3.508 & 2.43054 & 0.49302 \\
\hline $\mathrm{F}$ & -4.24723 & 0.09625 & 1.53886 \\
\hline $\mathrm{F}$ & -4.16312 & -0.99635 & -0.91048 \\
\hline $\mathrm{F}$ & -5.71019 & 1.20872 & -0.47284 \\
\hline $\mathrm{F}$ & -3.41421 & 1.31036 & -1.93129 \\
\hline \multicolumn{4}{|c|}{ S8d-iso } \\
\hline $\mathrm{C}$ & -0.90154 & -2.96655 & 0.15912 \\
\hline $\mathrm{C}$ & -2.30116 & -2.97622 & 0.09608 \\
\hline $\mathrm{H}$ & -2.87128 & -2.05951 & -0.09829 \\
\hline I & 0.30881 & -1.78346 & -2.45855 \\
\hline $\mathrm{Au}$ & 0.18104 & -1.1878 & 0.15704 \\
\hline $\mathrm{C}$ & -0.16718 & -4.1559 & 0.31117 \\
\hline $\mathrm{H}$ & 0.93472 & -4.13868 & 0.29614 \\
\hline $\mathrm{C}$ & -0.85423 & -5.36657 & 0.50476 \\
\hline $\mathrm{H}$ & -0.28676 & -6.29767 & 0.64293 \\
\hline
\end{tabular}


$\begin{array}{llll}-2.2597 & -5.38404 & 0.49985\end{array}$ $\begin{array}{llll}-2.97792 & -4.19687 & 0.29085\end{array}$ $\begin{array}{llll}-4.07583 & -4.20424 & 0.26144\end{array}$ $\begin{array}{lll}1.67787 & 0.74482 & 0.39349\end{array}$ $\begin{array}{llll}1.65441 & 0.93185 & 2.21685\end{array}$ $\begin{array}{llll}3.44222 & 0.25246 & -0.06394\end{array}$ $\begin{array}{llll}1.04373 & 2.37075 & -0.31065\end{array}$ $\begin{array}{llll}2.38219 & 1.95807 & 2.87434\end{array}$ $\begin{array}{llll}0.78878 & 0.13381 & 2.99377\end{array}$ $\begin{array}{llll}3.5994 & -1.23632 & 0.37415\end{array}$ $\begin{array}{llll}4.56062 & 1.06774 & 0.63963\end{array}$ $\begin{array}{llll}3.63136 & 0.35248 & -1.6023\end{array}$ $\begin{array}{llll}2.07363 & 3.5279 & -0.37479\end{array}$ $\begin{array}{llll}0.48557 & 2.07682 & -1.73514\end{array}$ $\begin{array}{llll}-0.15476 & 2.80397 & 0.58445\end{array}$ $\begin{array}{llll}3.04154 & 2.60507 & 2.28594\end{array}$ $\begin{array}{llll}2.27039 & 2.17472 & 4.25028\end{array}$ $\begin{array}{llll}0.67107 & 0.35777 & 4.38237\end{array}$ $\begin{array}{llll}-0.05853 & -0.92299 & 2.39723\end{array}$ $\begin{array}{llll}3.44278 & -1.31596 & 1.47802\end{array}$ $\begin{array}{llll}2.82877 & -1.8642 & -0.12636\end{array}$ $\begin{array}{llll}4.9954 & -1.76753 & -0.02019\end{array}$ $\begin{array}{llll}5.95303 & 0.54515 & 0.20848\end{array}$ $\begin{array}{llll}4.47268 & 0.95014 & 1.74027\end{array}$ $\begin{array}{llll}4.46962 & 2.14931 & 0.39659\end{array}$ $\begin{array}{llll}5.01612 & -0.20622 & -2.00029\end{array}$ $\begin{array}{llll}3.56176 & 1.41395 & -1.92298\end{array}$ $\begin{array}{llll}2.82979 & -0.20864 & -2.12362\end{array}$ $\begin{array}{llll}2.45874 & 3.76307 & 0.64129\end{array}$ $\begin{array}{llll}2.94031 & 3.25039 & -1.01284\end{array}$ $\begin{array}{llll}1.39571 & 4.79297 & -0.95678\end{array}$ $\begin{array}{llll}-0.15332 & 3.35509 & -2.32246\end{array}$ $\begin{array}{llll}1.29032 & 1.70544 & -2.40704\end{array}$ $\begin{array}{llll}-0.28978 & 1.28452 & -1.66505\end{array}$ $\begin{array}{llll}-0.82344 & 4.06569 & -0.00762\end{array}$ $\begin{array}{llll}0.1967 & 3.03194 & 1.61437\end{array}$ $\begin{array}{llll}-0.90115 & 1.98072 & 0.64119\end{array}$ $\begin{array}{lll}2.84491 & 2.97892 & 4.72736\end{array}$ $\begin{array}{llll}1.4082 & 1.3672 & 5.00827\end{array}$

$\begin{array}{lll}-0.01866 & -0.24903 & 4.98169\end{array}$ $\begin{array}{lll}-1.50622 & -0.57666 & 2.57829\end{array}$ $\begin{array}{llll}0.23942 & -2.24029 & 3.03326\end{array}$ $\begin{array}{llll}5.07552 & -2.82646 & 0.30496\end{array}$ $\begin{array}{llll}6.09587 & -0.92461 & 0.65374\end{array}$ $\begin{array}{llll}5.13419 & -1.67943 & -1.55517\end{array}$ $\begin{array}{llll}6.72695 & 1.16572 & 0.70811\end{array}$ $6.11298 \quad 0.63881-1.32206$ $\begin{array}{llll}5.11588 & -0.14025 & -3.1039\end{array}$ $\begin{array}{llll}2.15111 & 5.60747 & -0.98882\end{array}$ $\begin{array}{llll}0.21343 & 5.20742 & -0.05482\end{array}$ $\begin{array}{llll}0.8903 & 4.48816 & -2.38192\end{array}$ $\begin{array}{llll}-1.33715 & 3.77335 & -1.42958\end{array}$ $\begin{array}{llll}-0.51701 & 3.11923 & -3.3441\end{array}$

$\begin{array}{llll}-1.67585 & 4.33611 & 0.64805\end{array}$ $\begin{array}{llll}1.29666 & 1.52855 & 6.08827\end{array}$ $\begin{array}{llll}-2.11645 & -1.3399 & 2.07139\end{array}$ $\begin{array}{llll}-1.70595 & 0.41137 & 2.12666\end{array}$ $\begin{array}{llll}-1.7609 & -0.55703 & 3.65755\end{array}$ $\begin{array}{llll}0.13573 & -2.17097 & 4.13332\end{array}$ $\begin{array}{llll}1.27416 & -2.53765 & 2.77332\end{array}$ $\begin{array}{llll}-0.4726 & -2.98709 & 2.64751\end{array}$ $\begin{array}{llll}7.0977 & -1.31244 & 0.36762\end{array}$ $\begin{array}{llll}6.01018 & -0.99761 & 1.76047\end{array}$ $\begin{array}{llll}4.33825 & -2.28605 & -2.04243\end{array}$ $\begin{array}{llll}6.11691 & -2.09248 & -1.87055\end{array}$ $\begin{array}{llll}6.03231 & 1.69849 & -1.65112\end{array}$ $\begin{array}{llll}7.11969 & 0.27105 & -1.61759\end{array}$ $\begin{array}{llll}-0.25739 & 6.13072 & -0.45676\end{array}$ $\begin{array}{llll}0.58262 & 5.43773 & 0.9702\end{array}$ $\begin{array}{llll}1.74547 & 4.19362 & -3.0316\end{array}$ $\begin{array}{llll}0.43342 & 5.40118 & -2.82149\end{array}$ $\begin{array}{llll}-2.09719 & 2.96844 & -1.40136\end{array}$ $\begin{array}{llll}-1.82481 & 4.68163 & -1.84588\end{array}$ $\begin{array}{lll}-2.7953 & -6.3332 & 0.63652\end{array}$ 
$\begin{array}{llll}-2.32234 & 0.24266 & -0.41653\end{array}$

$\begin{array}{llll}-4.14341 & 0.79239 & -0.13256\end{array}$

$\begin{array}{lll}-3.39526 & 2.23714 & 0.8356\end{array}$

$\begin{array}{llll}-4.13538 & -0.23753 & 1.45554\end{array}$

$\begin{array}{llll}-4.70297 & -0.74535 & -1.0537\end{array}$

$\begin{array}{llll}-5.8857 & 1.36568 & 0.21637\end{array}$

$\begin{array}{llll}-4.08501 & 1.77091 & -1.72917\end{array}$

$\begin{array}{llll}1.23209 & 1.42512 & -0.23097\end{array}$ $\begin{array}{llll}2.45606 & 2.12311 & -0.38633\end{array}$ $\begin{array}{llll}3.40269 & 1.58325 & -0.25595\end{array}$ $\begin{array}{llll}2.50028 & 3.49044 & -0.68893\end{array}$ $\begin{array}{llll}3.46932 & 3.99272 & -0.80141\end{array}$ $\begin{array}{llll}1.30235 & 4.20341 & -0.83977\end{array}$ $\begin{array}{llll}1.31847 & 5.27513 & -1.07601\end{array}$ $\begin{array}{llll}0.07832 & 3.53715 & -0.6872\end{array}$ $\begin{array}{llll}-0.86673 & 4.08783 & -0.79962\end{array}$ $\begin{array}{llll}0.00839 & 2.16072 & -0.38759\end{array}$ $\begin{array}{llll}1.78842 & -0.46187 & 2.02581\end{array}$ $\begin{array}{llll}0.58258 & 0.14221 & 2.78222\end{array}$ $\begin{array}{llll}0.43976 & 1.20426 & 2.50659\end{array}$ $\begin{array}{llll}-0.36015 & -0.41173 & 2.58797\end{array}$ $\begin{array}{llll}3.03791 & 0.36725 & 2.40381\end{array}$ $\begin{array}{llll}2.87961 & 1.44647 & 2.21783\end{array}$ $\begin{array}{llll}3.95576 & 0.04178 & 1.88182\end{array}$ $\begin{array}{llll}1.96805 & -1.93558 & 2.44647\end{array}$ $\begin{array}{llll}2.88585 & -2.38715 & 2.02385\end{array}$ $\begin{array}{llll}1.09472 & -2.5531 & 2.15011\end{array}$ $2.58101-1.24936-0.94872$ $\begin{array}{llll}4.07202 & -1.15371 & -0.54898\end{array}$ $\begin{array}{llll}4.46025 & -0.12001 & -0.51008\end{array}$ $\begin{array}{llll}4.27587 & -1.64771 & 0.41955\end{array}$ $2.2014 \quad-2.75458-0.98717$ $\begin{array}{llll}2.2264 & -3.23448 & 0.00854\end{array}$ $1.19304-2.90326-1.42131$ $\begin{array}{llll}2.37706 & -0.68439 & -2.37296\end{array}$ $\begin{array}{llll}2.6793 & 0.37594 & -2.46467\end{array}$ $\begin{array}{llll}1.319 & -0.7861 & -2.69306\end{array}$ $\begin{array}{llll}1.35544 & -0.37738 & 0.20097\end{array}$ $\begin{array}{llll}-0.7584 & -1.18327 & -0.22681\end{array}$ $\begin{array}{llll}-1.35394 & 1.53218 & -0.24388\end{array}$ $\begin{array}{llll}-1.84952 & 0.70356 & -1.30524\end{array}$ $\begin{array}{llll}-2.1004 & 1.64794 & 0.95541\end{array}$ $\begin{array}{llll}-2.9377 & -0.18367 & -1.03707\end{array}$ $\begin{array}{llll}-3.21528 & 0.79756 & 1.16212\end{array}$ $\begin{array}{llll}-3.62398 & -0.15268 & 0.21614\end{array}$ $\begin{array}{llll}-3.331 & -0.80547 & -1.85733\end{array}$ $\begin{array}{lll}-3.76672 & 0.8762 & 2.11157\end{array}$ $2.05653-1.97225 \quad 3.5512$ $\begin{array}{llll}3.20911 & 0.23671 & 3.49188\end{array}$ $\begin{array}{llll}0.79701 & 0.09651 & 3.86954\end{array}$ $4.65604-1.69182-1.32299$ $2.93705-3.27333-1.63532$ $2.99655-1.28369-3.0707$

$\begin{array}{lll}-1.76567 & 2.65651 & 2.03676\end{array}$ $\begin{array}{llll}-2.48964 & 3.49524 & 1.99219\end{array}$ $\begin{array}{lll}-1.85732 & 2.2037 & 3.04262\end{array}$ $\begin{array}{lll}-0.75487 & 3.08582 & 1.92955\end{array}$ $\begin{array}{llll}-4.80867 & -1.05965 & 0.4595\end{array}$ $\begin{array}{llll}-5.72399 & -0.62223 & 0.01282\end{array}$ $-4.66148-2.05286-0.00445$ $\begin{array}{llll}-4.9963 & -1.19646 & 1.5396\end{array}$ $\begin{array}{llll}-1.27242 & 0.78465 & -2.70592\end{array}$ $\begin{array}{llll}-1.46743 & -0.14495 & -3.27328\end{array}$ $\begin{array}{llll}-1.75857 & 1.62021 & -3.25004\end{array}$

$\begin{array}{llll}-0.1865 & 0.98614 & -2.70292\end{array}$

$\begin{array}{llll}3.4848 & 0.68674 & 0.24769\end{array}$ $\begin{array}{llll}3.4821 & 1.6887 & -0.72848\end{array}$ $3.24193 \quad 1.46271-1.77558$ $2.90197-1.32397-0.35633$ $0.35004-0.15302-0.38767$ 


$\begin{array}{lcll}\mathrm{C} & 3.76442 & 0.92069 & 1.59646 \\ \mathrm{H} & 3.75062 & 0.10809 & 2.33257 \\ \mathrm{C} & 4.07011 & 2.24086 & 1.97813 \\ \mathrm{H} & 4.30344 & 2.45151 & 3.03 \\ \mathrm{C} & 4.07934 & 3.27416 & 1.02763 \\ \mathrm{C} & 3.78579 & 2.99954 & -0.31867 \\ \mathrm{H} & 3.79647 & 3.8039 & -1.06638 \\ \mathrm{P} & -1.37264 & 1.33965 & -0.0985 \\ \mathrm{C} & -3.0045 & 0.51711 & 0.09707 \\ \mathrm{C} & -1.00425 & 2.21389 & 1.53251 \\ \mathrm{C} & -1.3942 & 2.51312 & -1.59016 \\ \mathrm{C} & -4.15253 & 1.35135 & 0.1011 \\ \mathrm{C} & -3.17641 & -0.89054 & 0.27541 \\ \mathrm{C} & -0.83215 & 1.09751 & 2.5898 \\ \mathrm{C} & -2.14059 & 3.1374 & 2.02868 \\ \mathrm{C} & 0.32119 & 2.99904 & 1.41893 \\ \mathrm{C} & -1.98668 & 3.91859 & -1.33464 \\ \mathrm{C} & 0.06562 & 2.70436 & -2.08578 \\ \mathrm{C} & -2.17946 & 1.81931 & -2.72567 \\ \mathrm{H} & -4.03319 & 2.4345 & -0.02749 \\ \mathrm{C} & -5.44083 & 0.83432 & 0.27652 \\ \mathrm{C} & -4.48658 & -1.38614 & 0.46088 \\ \mathrm{H} & -1.75537 & 0.49579 & 2.68294 \\ \mathrm{H} & 0.01683 & 0.41984 & 2.35608 \\ \mathrm{H} & -3.05893 & 2.56276 & 2.25342 \\ \mathrm{H} & -2.38933 & 3.95265 & 1.32598 \\ \mathrm{H} & 0.23631 & 3.88936 & 0.76631 \\ \mathrm{H} & 1.14438 & 2.35709 & 1.04368 \\ \mathrm{H} & -3.03946 & 3.90283 & -1.00032 \\ \mathrm{H} & -1.39029 & 4.50068 & -0.60758 \\ \mathrm{H} & 0.74648 & 3.08961 & -1.30235 \\ \mathrm{H} & 0.48392 & 1.75317 & -2.47295 \\ \mathrm{H} & -3.25178 & 1.68733 & -2.48578 \\ \mathrm{H} & -1.74187 & 0.8296 & -2.96413 \\ \mathrm{H} & -6.30645 & 1.50869 & 0.27018 \\ \mathrm{C} & -5.60789 & -0.54667 & 0.46319 \\ \mathrm{H} & -4.6084 & -2.46975 & 0.60114 \\ & & & \\ & & & \end{array}$

$\begin{array}{lccc}\text { H } & -6.61039 & -0.97076 & 0.60569 \\ \mathrm{H} & 4.32092 & 4.29896 & 1.33655 \\ \mathrm{C} & -2.06557 & -1.91055 & 0.25366 \\ \mathrm{C} & -1.56178 & -2.37849 & -0.99421 \\ \mathrm{C} & -1.5637 & -2.46347 & 1.4643 \\ \mathrm{C} & -0.50457 & -3.31162 & -1.00354 \\ \mathrm{C} & -0.49321 & -3.37893 & 1.40427 \\ \mathrm{C} & 0.05786 & -3.81028 & 0.18559 \\ \mathrm{H} & -0.11648 & -3.65937 & -1.97551 \\ \mathrm{H} & -0.09519 & -3.78453 & 2.34854 \\ \mathrm{H} & -1.80044 & 3.60573 & 2.97507 \\ \mathrm{H} & 0.60038 & 3.35385 & 2.43292 \\ \mathrm{H} & -0.63548 & 1.57712 & 3.57098 \\ \mathrm{H} & -1.96096 & 4.46724 & -2.29831 \\ \mathrm{H} & 0.04688 & 3.4368 & -2.91928 \\ \mathrm{H} & -2.10129 & 2.45145 & -3.63382 \\ \mathrm{C} & -2.15996 & -2.16625 & 2.82979 \\ \mathrm{H} & -2.60223 & -3.0909 & 3.25117 \\ \mathrm{H} & -1.37996 & -1.83083 & 3.54171 \\ \mathrm{H} & -2.95603 & -1.40285 & 2.79921 \\ \mathrm{C} & -2.1281 & -1.92758 & -2.32951 \\ \mathrm{H} & -1.32358 & -1.53614 & -2.98597 \\ \mathrm{H} & -2.58372 & -2.78783 & -2.85895 \\ \mathrm{H} & -2.90295 & -1.14793 & -2.22734 \\ \mathrm{C} & 1.20239 & -4.80287 & 0.15205 \\ \mathrm{H} & 1.78264 & -4.71772 & -0.7881 \\ \mathrm{H} & 1.8907 & -4.65304 & 1.00618 \\ \mathrm{H} & 0.82934 & -5.84487 & 0.21035 \\ & & & \\ \text { 9c-TS } & & & \\ \mathrm{C} & -2.17249 & 1.60194 & -0.19093 \\ \mathrm{C} & -2.43191 & 2.52974 & 0.82131 \\ \mathrm{H} & -2.36446 & 2.25783 & 1.881 \\ \mathrm{I} & -3.03974 & -0.79465 & 0.44579 \\ \mathrm{Au} & -0.50755 & 0.10049 & 0.13314 \\ \mathrm{C} & -2.34074 & 1.86065 & -1.55627 \\ \mathrm{H} & -2.20254 & 1.07277 & -2.30866 \\ & & & \\ & & & \\ & & & \end{array}$


C $\begin{array}{llll}-2.68059 & 3.17647 & -1.92432\end{array}$

$\begin{array}{llll}-2.79666 & 3.41628 & -2.98974\end{array}$

$\begin{array}{llll}-2.89347 & 4.15807 & -0.94271\end{array}$

$\begin{array}{llll}-2.77868 & 3.83361 & 0.42028\end{array}$

$\begin{array}{lll}-2.97466 & 4.59032 & 1.19187\end{array}$

$\begin{array}{llll}1.66351 & 1.0604 & 0.17812\end{array}$

$\begin{array}{llll}2.88292 & -0.25062 & -0.2097\end{array}$

$\begin{array}{llll}1.84661 & 2.43107 & -1.10943\end{array}$

$\begin{array}{llll}1.95144 & 1.66044 & 1.95131\end{array}$

$4.2645 \quad 0.07984-0.19936$

$\begin{array}{llll}2.49867 & -1.59223 & -0.49502\end{array}$

$\begin{array}{llll}1.34923 & 1.84428 & -2.44956\end{array}$

$\begin{array}{llll}3.28752 & 2.93954 & -1.35013\end{array}$

$\begin{array}{llll}0.94155 & 3.62082 & -0.71757\end{array}$

$\begin{array}{llll}3.11525 & 2.66035 & 2.12086\end{array}$

$\begin{array}{lll}0.65243 & 2.30556 & 2.49444\end{array}$

$\begin{array}{llll}2.23007 & 0.40621 & 2.80759\end{array}$

$\begin{array}{llll}4.57773 & 1.09793 & 0.05734\end{array}$

$\begin{array}{llll}5.24821 & -0.86505 & -0.50983\end{array}$

$\begin{array}{llll}3.51092 & -2.52403 & -0.82696\end{array}$

$\begin{array}{llll}1.93603 & 0.95161 & -2.74333\end{array}$

$\begin{array}{llll}0.27517 & 1.5786 & -2.40925\end{array}$

$\begin{array}{llll}3.91419 & 2.17067 & -1.83859\end{array}$

$\begin{array}{llll}3.79623 & 3.29747 & -0.43687\end{array}$

$\begin{array}{llll}1.34814 & 4.19038 & 0.14018\end{array}$

$\begin{array}{llll}-0.09073 & 3.30256 & -0.48096\end{array}$

$\begin{array}{llll}4.08429 & 2.25343 & 1.77649\end{array}$

$\begin{array}{llll}2.92465 & 3.62298 & 1.61078\end{array}$

$\begin{array}{llll}0.28004 & 3.14436 & 1.87743\end{array}$

$\begin{array}{llll}-0.15324 & 1.54853 & 2.58272\end{array}$

$\begin{array}{llll}3.19424 & -0.07261 & 2.54885\end{array}$

$\begin{array}{llll}1.41555 & -0.34047 & 2.69663\end{array}$

$\begin{array}{llll}6.30715 & -0.57791 & -0.49033\end{array}$

$\begin{array}{llll}4.86589 & -2.17335 & -0.84647\end{array}$

$\begin{array}{llll}3.20641 & -3.55672 & -1.05032\end{array}$

$\begin{array}{llll}5.62313 & -2.92537 & -1.10365\end{array}$

$\begin{array}{llll}-3.17978 & 5.17462 & -1.23971\end{array}$ $\begin{array}{llll}3.21428 & 3.7992 & -2.04768\end{array}$

$\begin{array}{llll}0.89267 & 4.31229 & -1.58399\end{array}$

$\begin{array}{llll}1.48232 & 2.61576 & -3.23575\end{array}$

$\begin{array}{llll}0.86446 & 2.69429 & 3.51174\end{array}$

$\begin{array}{llll}3.21815 & 2.87355 & 3.20477\end{array}$

$\begin{array}{lll}2.26719 & 0.7137 & 3.8727\end{array}$

$\begin{array}{llll}1.11327 & -2.19249 & -0.38944\end{array}$ $\begin{array}{llll}0.79169 & -2.93186 & 0.79403\end{array}$

$\begin{array}{llll}0.28707 & -2.34565 & -1.55213\end{array}$

$\begin{array}{llll}-0.38697 & -3.69841 & 0.82435\end{array}$

$-0.85455-3.15723-1.47969$

$-1.22096-3.83293-0.29888$

$\begin{array}{llll}-0.63575 & -4.2446 & 1.74811\end{array}$

$-1.48661-3.26086-2.37598$

$0.60266-1.6508-2.86241$

$0.31076-2.29015-3.71628$

$0.02999-0.70378-2.95695$

$\begin{array}{llll}1.6758 & -1.40484 & -2.96166\end{array}$

$\begin{array}{llll}1.72992 & -3.02194 & 1.98443\end{array}$

$\begin{array}{llll}1.17886 & -2.88784 & 2.93568\end{array}$

$\begin{array}{llll}2.18626 & -4.03221 & 2.01763\end{array}$

$\begin{array}{llll}2.55494 & -2.29253 & 1.94623\end{array}$

$\begin{array}{llll}-2.45745 & -4.70489 & -0.25722\end{array}$

$\begin{array}{llll}-2.22652 & -5.73147 & -0.60607\end{array}$ $\begin{array}{lll}-2.85745 & -4.78507 & 0.77065\end{array}$

$\begin{array}{llll}-3.25178 & -4.30351 & -0.91466\end{array}$

\section{S9c-TS-iso}

C $\mathrm{H} \quad 3.20814 \quad-0.05282-1.73814$

I

$\mathrm{Au}$

C

$\mathrm{H}$

C

$\mathrm{H}$
$0.07476-0.66311$

$2.44868 \quad-0.38857 \quad 0.28239$ $1.76074-2.78733-0.44359$ $0.33845-0.39895-0.03603$ $\begin{array}{llll}2.70377 & -0.34554 & 1.67438\end{array}$ $\begin{array}{llll}2.00327 & -0.81178 & 2.38394\end{array}$ $\begin{array}{lll}3.85451 & 0.31713 & 2.12428\end{array}$ $\begin{array}{lll}4.04474 & 0.40468 & 3.2022\end{array}$ 
$4.79202 \quad 0.80396 \quad 1.19261$

$\begin{array}{llll}4.566 & 0.6753 & -0.1901\end{array}$

$\begin{array}{llll}5.31388 & 1.03955 & -0.9072\end{array}$

$\begin{array}{lll}-2.04407 & -0.5333 & 0.08981\end{array}$

$\begin{array}{llll}-2.67507 & 1.18316 & 0.08504\end{array}$

$\begin{array}{llll}-2.79962 & -1.45961 & -1.37337\end{array}$

$\begin{array}{llll}-2.48078 & -1.34042 & 1.75142\end{array}$

$\begin{array}{llll}-4.06043 & 1.42456 & 0.2824\end{array}$

$\begin{array}{llll}-1.79637 & 2.29566 & -0.0522\end{array}$

$\begin{array}{llll}-2.13301 & -0.88459 & -2.64212\end{array}$

$\begin{array}{llll}-4.32597 & -1.28515 & -1.54339\end{array}$

$\begin{array}{llll}-2.44957 & -2.96114 & -1.28059\end{array}$

$\begin{array}{llll}-3.93324 & -1.85198 & 1.8727\end{array}$

$\begin{array}{lll}-1.51017 & -2.52114 & 2.017\end{array}$

$\begin{array}{llll}-2.22639 & -0.2968 & 2.86011\end{array}$

$\begin{array}{lll}-4.74304 & 0.57524 & 0.40321\end{array}$

$\begin{array}{llll}-4.58461 & 2.72044 & 0.32475\end{array}$

$\begin{array}{llll}-2.35074 & 3.59842 & -0.01549\end{array}$

$\begin{array}{llll}-2.36692 & 0.19022 & -2.75993\end{array}$

$\begin{array}{llll}-1.03107 & -1.02273 & -2.63029\end{array}$

$\begin{array}{llll}-4.58933 & -0.23928 & -1.7898\end{array}$

$\begin{array}{llll}-4.91199 & -1.60753 & -0.6635\end{array}$

$\begin{array}{llll}-2.9938 & -3.47897 & -0.46916\end{array}$

$\begin{array}{llll}-1.36167 & -3.12483 & -1.1468\end{array}$

$\begin{array}{llll}-4.68274 & -1.04937 & 1.74187\end{array}$

$\begin{array}{llll}-4.1582 & -2.67263 & 1.16762\end{array}$

$\begin{array}{lll}-1.51237 & -3.29308 & 1.22639\end{array}$

$\begin{array}{lll}-0.46796 & -2.16217 & 2.14108\end{array}$

$\begin{array}{lll}-2.89094 & 0.58559 & 2.78033\end{array}$

$\begin{array}{llll}-1.17146 & 0.04289 & 2.84418\end{array}$

$\begin{array}{llll}-5.66029 & 2.87227 & 0.4799\end{array}$

$\begin{array}{llll}-3.72147 & 3.81649 & 0.16697\end{array}$

$\begin{array}{llll}-1.66959 & 4.45415 & -0.12786\end{array}$

$\begin{array}{llll}-4.113 & 4.84174 & 0.19359\end{array}$

$\begin{array}{llll}5.72757 & 1.25452 & 1.55004\end{array}$

$\begin{array}{llll}-4.63782 & -1.91721 & -2.40024\end{array}$

$\begin{array}{llll}-2.74772 & -3.43742 & -2.23702\end{array}$ $\begin{array}{llll}-2.53765 & -1.42075 & -3.5251\end{array}$

$\begin{array}{llll}-1.81567 & -3.00442 & 2.96784\end{array}$

$\begin{array}{llll}-4.06248 & -2.25312 & 2.89897\end{array}$

$\begin{array}{llll}-2.40872 & -0.78296 & 3.84042\end{array}$

$\begin{array}{llll}-0.2865 & 2.29679 & -0.22159\end{array}$

$\begin{array}{llll}0.53591 & 2.58809 & 0.92079\end{array}$

$\begin{array}{llll}0.27515 & 2.46447 & -1.53521\end{array}$

$\begin{array}{llll}1.86376 & 3.00141 & 0.73182\end{array}$

$\begin{array}{llll}1.60938 & 2.87613 & -1.66479\end{array}$

$\begin{array}{llll}2.41248 & 3.18677 & -0.54875\end{array}$

$\begin{array}{llll}2.47714 & 3.22772 & 1.61903\end{array}$

$\begin{array}{llll}2.01662 & 3.02804 & -2.67709\end{array}$

$\begin{array}{llll}-0.5355 & 2.26805 & -2.80033\end{array}$

$\begin{array}{lll}-0.24192 & 3.0161 & -3.56023\end{array}$

$\begin{array}{llll}-0.34543 & 1.26878 & -3.24038\end{array}$

$\begin{array}{llll}-1.6219 & 2.36179 & -2.62499\end{array}$

$\begin{array}{lll}0.02693 & 2.48458 & 2.34321\end{array}$

$\begin{array}{llll}0.50386 & 1.61861 & 2.85282\end{array}$

$\begin{array}{llll}0.30821 & 3.38614 & 2.92016\end{array}$

$\begin{array}{lll}-1.06792 & 2.36123 & 2.4016\end{array}$

$\begin{array}{llll}3.7874 & 3.78734 & -0.72833\end{array}$

$\begin{array}{llll}3.7074 & 4.88569 & -0.85769\end{array}$

$\begin{array}{llll}4.42761 & 3.60294 & 0.15502\end{array}$

$\begin{array}{llll}4.29319 & 3.38743 & -1.62787\end{array}$

$\begin{array}{lll}-0.87656 & 2.36001 & 0.09476\end{array}$ $\begin{array}{llll}-0.90012 & 3.10144 & -1.08723\end{array}$ $\begin{array}{llll}-0.73902 & 2.63004 & -2.06565\end{array}$

$\begin{array}{llll}-3.12725 & 0.27021 & -0.26423\end{array}$ $\begin{array}{lll}-0.43304 & 0.30169 & 0.04679\end{array}$ $\begin{array}{lll}-1.21091 & 2.91142 & 1.33549\end{array}$ $\begin{array}{llll}-1.27833 & 2.28798 & 2.23734\end{array}$ $\begin{array}{llll}-1.45072 & 4.29566 & 1.40488\end{array}$ $\begin{array}{llll}-1.69569 & 4.74689 & 2.37569\end{array}$ $\begin{array}{llll}-1.40437 & 5.08308 & 0.24336\end{array}$ $\begin{array}{llll}-1.14248 & 4.48719 & -0.99874\end{array}$ 
$\begin{array}{lll}-1.14502 & 5.08787 & -1.91815\end{array}$ $\begin{array}{lll}2.01104 & 0.42844 & 0.01152\end{array}$ $\begin{array}{llll}2.48422 & -1.34298 & 0.04867\end{array}$ $\begin{array}{llll}2.57086 & 1.06512 & -1.68779\end{array}$ $\begin{array}{llll}2.87216 & 1.37205 & 1.42111\end{array}$ $\begin{array}{llll}3.8536 & -1.70865 & 0.13085\end{array}$ $\begin{array}{llll}1.50592 & -2.36569 & -0.06198\end{array}$ $\begin{array}{llll}1.60025 & 0.45432 & -2.72225\end{array}$ $\begin{array}{llll}3.99057 & 0.58731 & -2.08116\end{array}$ $\begin{array}{llll}2.51428 & 2.60569 & -1.77972\end{array}$ $\begin{array}{llll}4.36363 & 1.70497 & 1.16586\end{array}$ $\begin{array}{lll}2.1121 & 2.69625 & 1.67998\end{array}$ $\begin{array}{llll}2.77726 & 0.53896 & 2.71799\end{array}$ $\begin{array}{llll}4.61967 & -0.93066 & 0.21468\end{array}$ $\begin{array}{llll}4.26025 & -3.04505 & 0.07458\end{array}$ $1.94147-3.71166-0.14014$ $\begin{array}{llll}1.63087 & -0.65033 & -2.67867\end{array}$ $\begin{array}{llll}0.55252 & 0.79052 & -2.58045\end{array}$ $\begin{array}{llll}4.03442 & -0.50947 & -2.21224\end{array}$ $\begin{array}{llll}4.77944 & 0.89855 & -1.37322\end{array}$ $\begin{array}{llll}3.30637 & 3.09929 & -1.18839\end{array}$ $\begin{array}{llll}1.53892 & 3.01683 & -1.46991\end{array}$ $\begin{array}{llll}5.00619 & 0.81329 & 1.06061\end{array}$ $\begin{array}{llll}4.52067 & 2.36626 & 0.29704\end{array}$ $\begin{array}{llll}1.94392 & 3.31445 & 0.77804\end{array}$ $\begin{array}{llll}1.13184 & 2.49173 & 2.14124\end{array}$ $\begin{array}{lll}3.266 & -0.45151 & 2.63423\end{array}$ $\begin{array}{llll}1.72228 & 0.40455 & 3.02676\end{array}$ $\begin{array}{llll}5.3268 & -3.29418 & 0.14033\end{array}$ $3.29615-4.05483-0.07986$ $\begin{array}{llll}1.17612 & -4.49688 & -0.2296\end{array}$ $\begin{array}{llll}3.59828 & -5.10849 & -0.13845\end{array}$ $\begin{array}{llll}-1.60512 & 6.16025 & 0.30309\end{array}$ $\begin{array}{llll}1.92576 & 0.76449 & -3.73629\end{array}$ $\begin{array}{llll}4.22392 & 1.05213 & -3.06116\end{array}$ $\begin{array}{llll}2.67736 & 2.88007 & -2.84228\end{array}$ $\begin{array}{lll}4.72106 & 2.25176 & 2.06222\end{array}$ $\begin{array}{llll}2.70911 & 3.29295 & 2.39938\end{array}$

$\begin{array}{lll}3.2847 & 1.10759 & 3.5237\end{array}$

$\begin{array}{llll}-0.0046 & -2.22351 & 0.0286\end{array}$

$\begin{array}{llll}-0.56361 & -2.39895 & 1.35691\end{array}$

$-0.81446-2.62559-1.10291$

$\begin{array}{llll}-1.88786 & -2.82433 & 1.50825\end{array}$

$\begin{array}{llll}-2.11577 & -3.08595 & -0.88785\end{array}$ $\begin{array}{llll}-2.67992 & -3.18672 & 0.40169\end{array}$ $\begin{array}{llll}-2.29831 & -2.93129 & 2.52356\end{array}$ $\begin{array}{llll}-2.72323 & -3.37742 & -1.75804\end{array}$ $\begin{array}{llll}0.30979 & -2.26673 & 2.58215\end{array}$ $\begin{array}{lll}-0.30086 & -2.12543 & 3.49189\end{array}$ $\begin{array}{lll}0.91294 & -3.18999 & 2.71319\end{array}$ $\begin{array}{llll}1.02759 & -1.43699 & 2.49399\end{array}$ $\begin{array}{llll}-0.30897 & -2.54744 & -2.52585\end{array}$ $\begin{array}{llll}-0.83272 & -3.2855 & -3.15987\end{array}$ $-0.52205-1.54395-2.95155$ $\begin{array}{llll}0.7789 & -2.72873 & -2.6022\end{array}$ $\begin{array}{llll}-4.10102 & -3.6568 & 0.58894\end{array}$ $\begin{array}{llll}-4.23278 & -4.17286 & 1.55771\end{array}$ $\begin{array}{llll}-4.78536 & -2.78396 & 0.58184\end{array}$ $\begin{array}{llll}-4.41532 & -4.33286 & -0.22712\end{array}$

$\begin{array}{lll}-2.44271 & -0.43242 & -0.09147\end{array}$ $\begin{array}{llll}-3.08041 & -0.43544 & -1.342\end{array}$ $\begin{array}{llll}-2.49148 & -0.45612 & -2.27253\end{array}$ $\begin{array}{llll}-0.79926 & -3.01912 & 0.11142\end{array}$ $\begin{array}{llll}-0.36065 & -0.33587 & -0.043\end{array}$ $\begin{array}{llll}-3.18221 & -0.49156 & 1.10094\end{array}$ $\begin{array}{llll}-2.66913 & -0.56315 & 2.07279\end{array}$ $\begin{array}{llll}-4.58629 & -0.44506 & 1.03999\end{array}$ $\begin{array}{llll}-5.1714 & -0.47808 & 1.96939\end{array}$ $\begin{array}{llll}-5.23522 & -0.39226 & -0.20568\end{array}$ $\begin{array}{llll}-4.4855 & -0.38261 & -1.39444\end{array}$ $\begin{array}{llll}-4.99128 & -0.36084 & -2.36954\end{array}$ $2.12054-0.2376 \quad-0.044$ 


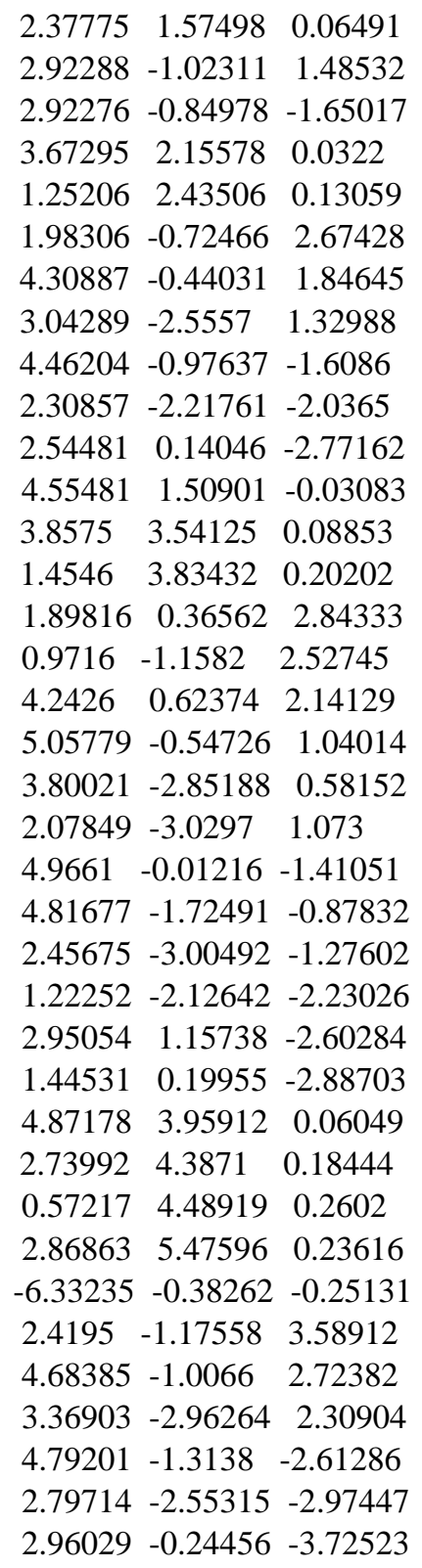

$\begin{array}{llll}\mathrm{C} & -0.22364 & 2.0495 & 0.09326 \\ \mathrm{C} & -0.93369 & 2.33592 & -1.15298 \\ \mathrm{C} & -0.97626 & 2.19433 & 1.34089 \\ \mathrm{C} & -2.30017 & 2.61622 & -1.12577 \\ \mathrm{C} & -2.33602 & 2.49208 & 1.29773 \\ \mathrm{C} & -3.02628 & 2.69671 & 0.08037 \\ \mathrm{H} & -2.82456 & 2.79377 & -2.07764 \\ \mathrm{H} & -2.89311 & 2.5722 & 2.24394 \\ \mathrm{C} & -0.236 & 2.33115 & -2.49346 \\ \mathrm{H} & -0.44397 & 1.3773 & -3.02461 \\ \mathrm{H} & -0.6321 & 3.14295 & -3.13151 \\ \mathrm{H} & 0.8574 & 2.44759 & -2.40842 \\ \mathrm{C} & -0.32227 & 2.00042 & 2.68866 \\ \mathrm{H} & -0.85976 & 2.57729 & 3.46293 \\ \mathrm{H} & -0.36747 & 0.93076 & 2.9859 \\ \mathrm{H} & 0.73936 & 2.30644 & 2.69023 \\ \mathrm{C} & -4.49303 & 3.03625 & 0.07398 \\ \mathrm{H} & -4.98459 & 2.65744 & -0.8412 \\ \mathrm{H} & -5.00572 & 2.61355 & 0.95738 \\ \mathrm{H} & -4.62793 & 4.13756 & 0.09816 \\ & & & \\ \mathrm{S13a} & & & \\ \mathrm{C} & & & \\ \mathrm{C} & 2.78267 & 0.38726 & 1.72526 \\ \mathrm{H} & 4.14882 & 0.7483 & 1.62855 \\ \mathrm{C} & 4.58266 & 0.95657 & 0.64249 \\ \mathrm{H} & 4.97288 & 0.82242 & 2.75831 \\ \mathrm{C} & 6.02869 & 1.10174 & 2.6469 \\ \mathrm{H} & 4.44211 & 0.52917 & 4.02452 \\ \mathrm{C} & 5.07866 & 0.58251 & 4.91828 \\ \mathrm{H} & 3.09341 & 0.17253 & 4.14415 \\ \mathrm{C} & 2.66561 & -0.04517 & 5.13343 \\ \mathrm{C} & 2.25387 & 0.0933 & 3.0129 \\ \mathrm{H} & 0.0718 & 0.8895 & 3.61321 \\ \mathrm{H} & -1.00189 & 0.61809 & 3.58559 \\ \mathrm{C} & 0.22778 & 1.74733 & 2.92784 \\ & 0.34811 & 1.20073 & 4.65224 \\ & & -1.43755 & 3.98204\end{array}$


$\begin{array}{llll}0.75945 & -1.25856 & 5.07627\end{array}$

$\begin{array}{llll}1.27087 & -2.2666 & 3.66325\end{array}$

$\begin{array}{llll}-0.4427 & -1.73987 & 3.8241\end{array}$

$\begin{array}{llll}2.29233 & -1.44033 & -0.5349\end{array}$

$\begin{array}{llll}1.82157 & -2.53943 & 0.46897\end{array}$

$\begin{array}{llll}2.3393 & -2.39004 & 1.44491\end{array}$

$\begin{array}{llll}0.7252 & -2.45725 & 0.64616\end{array}$

$2.14187-3.94298-0.09185$

$\begin{array}{llll}1.79092 & -4.69984 & 0.64107\end{array}$

$\begin{array}{llll}3.66122 & -4.08662 & -0.30996\end{array}$

$\begin{array}{llll}3.89374 & -5.09788 & -0.7099\end{array}$

$\begin{array}{llll}4.19955 & -3.97437 & 0.65718\end{array}$

$\begin{array}{llll}4.13436 & -3.0072 & -1.30429\end{array}$

$\begin{array}{llll}5.23221 & -3.08817 & -1.45428\end{array}$

$3.40704-3.19366-2.6521$

$\begin{array}{llll}3.75257 & -2.42625 & -3.38089\end{array}$

$\begin{array}{llll}3.65066 & -4.19234 & -3.07579\end{array}$

$\begin{array}{llll}1.88444 & -3.06738 & -2.4375\end{array}$

$\begin{array}{llll}1.35456 & -3.19609 & -3.40468\end{array}$

$\begin{array}{llll}1.39948 & -4.13165 & -1.43164\end{array}$

$\begin{array}{llll}0.3036 & -4.03093 & -1.27534\end{array}$

$\begin{array}{llll}1.59767 & -5.14947 & -1.83329\end{array}$

$3.82339-1.60519-0.72562$

$\begin{array}{llll}4.33324 & -1.50043 & 0.2563\end{array}$

$\begin{array}{llll}4.22787 & -0.82621 & -1.40584\end{array}$

$\begin{array}{llll}1.56324 & -1.65917 & -1.89011\end{array}$

$\begin{array}{llll}1.89418 & -0.89697 & -2.62931\end{array}$

$\begin{array}{llll}0.46242 & -1.54779 & -1.75053\end{array}$

$\begin{array}{llll}2.00473 & 1.72327 & -0.90198\end{array}$

$\begin{array}{llll}3.27617 & 1.72712 & -1.79431\end{array}$

$4.19835 \quad 1.62806-1.18495$

$\begin{array}{llll}3.24691 & 0.86738 & -2.49826\end{array}$

$\begin{array}{llll}3.35607 & 3.04161 & -2.60693\end{array}$

$\begin{array}{llll}4.29019 & 3.02301 & -3.20801\end{array}$

$3.37897 \quad 4.24848-1.64552$

$\begin{array}{llll}3.46259 & 5.19145 & -2.22842\end{array}$

$\begin{array}{llll}4.26741 & 4.18656 & -0.97799\end{array}$
$2.0852 \quad 4.26386-0.80317$

$\begin{array}{llll}2.10082 & 5.12939 & -0.10754\end{array}$

$\begin{array}{llll}0.86258 & 4.36227 & -1.73714\end{array}$

$\begin{array}{llll}-0.07496 & 4.38466 & -1.14047\end{array}$

$\begin{array}{llll}0.9124 & 5.3049 & -2.32492\end{array}$

$\begin{array}{llll}0.85128 & 3.14656 & -2.68598\end{array}$

$\begin{array}{llll}-0.04295 & 3.19011 & -3.34194\end{array}$

$\begin{array}{llll}0.76045 & 1.85607 & -1.84111\end{array}$

$\begin{array}{llll}0.67346 & 0.96694 & -2.50225\end{array}$

$\begin{array}{llll}-0.17022 & 1.89797 & -1.23332\end{array}$

$\begin{array}{llll}2.01719 & 2.96669 & 0.03431\end{array}$

$\begin{array}{lll}2.89141 & 2.92874 & 0.71827\end{array}$

$\begin{array}{llll}1.09563 & 2.95853 & 0.665\end{array}$

$\begin{array}{llll}2.13362 & 3.13962 & -3.53966\end{array}$

$\begin{array}{llll}2.12213 & 2.27695 & -4.24217\end{array}$

$2.19265 \quad 4.06848-4.14794$

$\begin{array}{llll}0.86831 & -0.25867 & 3.15451\end{array}$

$\begin{array}{llll}1.75607 & 0.20539 & 0.20793\end{array}$

$\begin{array}{lll}-0.48634 & -0.027 & 0.55661\end{array}$

$\begin{array}{llll}-2.61083 & -0.39742 & 0.55999\end{array}$

$\begin{array}{llll}-3.3778 & 1.07082 & 0.6259\end{array}$

$\begin{array}{llll}-2.86993 & 1.71142 & 1.8284\end{array}$

$\begin{array}{llll}-3.37896 & 1.76884 & -0.6497\end{array}$

$\begin{array}{llll}-3.01431 & -1.61879 & -0.47254\end{array}$ $\begin{array}{llll}-1.90501 & -2.56211 & -0.41967\end{array}$

$\begin{array}{llll}-4.38969 & -2.04139 & -0.29796\end{array}$ $\begin{array}{llll}-5.17096 & 0.68222 & 0.97697\end{array}$ $\begin{array}{llll}-2.94684 & -0.93009 & -2.2146\end{array}$ $\begin{array}{lll}-2.82044 & -1.9659 & -3.05132\end{array}$

$\begin{array}{llll}-1.89312 & -0.12304 & -2.37714\end{array}$ $\begin{array}{llll}-4.06531 & -0.27528 & -2.50265\end{array}$ $\begin{array}{llll}-5.80496 & 0.37816 & -0.15057\end{array}$ $\begin{array}{llll}-5.28392 & -0.31071 & 1.8528\end{array}$

$\begin{array}{lll}-5.71311 & 1.78771 & 1.49537\end{array}$

S13b

C

$\begin{array}{lll}-0.18699 & -3.5978 & -0.11312\end{array}$ 
$\begin{array}{lll}0.30761 & -3.14779 & 1.11525\end{array}$

$\begin{array}{llll}1.15482 & -2.45764 & 1.17062\end{array}$

$0.72719-2.79888-1.89762$

$\begin{array}{llll}-0.34966 & -0.24254 & -0.95507\end{array}$

$\begin{array}{llll}-1.26891 & -4.47679 & -0.21969\end{array}$

$-1.63719-4.80819-1.1988$

$\begin{array}{lll}-1.88135 & -4.91511 & 0.96936\end{array}$

$\begin{array}{llll}-2.7407 & -5.59778 & 0.90762\end{array}$

$\begin{array}{lll}-1.41376 & -4.47476 & 2.21852\end{array}$

$\begin{array}{lll}-0.3211 & -3.59497 & 2.28968\end{array}$

$\begin{array}{llll}0.06122 & -3.24207 & 3.25759\end{array}$

$\begin{array}{lll}-1.89674 & 1.0127 & 0.17788\end{array}$

$\begin{array}{lll}-2.41656 & 2.56046 & -0.68191\end{array}$

$\begin{array}{lll}-3.46407 & -0.03917 & 0.36795\end{array}$

$\begin{array}{lll}-1.01069 & 1.55316 & 1.75409\end{array}$

$\begin{array}{lll}-3.42342 & 3.38388 & -0.11264\end{array}$

$\begin{array}{lll}-1.80395 & 3.00283 & -1.88735\end{array}$

$\begin{array}{lll}-3.82239 & -0.54692 & -1.06209\end{array}$

$\begin{array}{lll}-4.72368 & 0.67681 & 0.9297\end{array}$

$\begin{array}{lll}-3.13595 & -1.26362 & 1.26599\end{array}$

$\begin{array}{lll}-1.92705 & 2.14679 & 2.85238\end{array}$

$\begin{array}{lll}-0.18977 & 0.37322 & 2.35733\end{array}$

$\begin{array}{lll}0.00887 & 2.63511 & 1.27909\end{array}$

$\begin{array}{lll}-3.86232 & 3.11645 & 0.8528\end{array}$

$\begin{array}{llll}-3.87019 & 4.55242 & -0.74257\end{array}$

$\begin{array}{llll}-2.29596 & 4.15735 & -2.53336\end{array}$

$\begin{array}{llll}-4.03888 & 0.32516 & -1.72358\end{array}$

$\begin{array}{lll}-2.95132 & -1.0914 & -1.49359\end{array}$

$-5.03604-1.50345-1.0052$

$\begin{array}{lll}-5.91503 & -0.30734 & 1.01857\end{array}$

$\begin{array}{lll}-5.02239 & 1.49357 & 0.24296\end{array}$

$\begin{array}{lll}-4.51773 & 1.11713 & 1.92987\end{array}$

$\begin{array}{lll}-4.336 & -2.23736 & 1.30231\end{array}$

$\begin{array}{lll}-2.92046 & -0.92005 & 2.30245\end{array}$

$\begin{array}{lll}-2.22949 & -1.78427 & 0.88266\end{array}$

$\begin{array}{lll}-2.51402 & 3.0008 & 2.45269\end{array}$

$\begin{array}{lll}-2.63911 & 1.36871 & 3.21143\end{array}$ $\begin{array}{lll}-1.06724 & 2.64674 & 4.03894\end{array}$

$\begin{array}{lll}0.64552 & 0.86827 & 3.5609\end{array}$

$\begin{array}{lll}-0.85777 & -0.45447 & 2.67941\end{array}$

$\begin{array}{lll}0.50537 & -0.02963 & 1.59133\end{array}$

$\begin{array}{lll}0.85586 & 3.12297 & 2.4755\end{array}$

$\begin{array}{llll}-0.53109 & 3.50171 & 0.83621\end{array}$

$\begin{array}{lll}0.66728 & 2.19749 & 0.49052\end{array}$

$\begin{array}{llll}-4.64635 & 5.16403 & -0.26419\end{array}$

$\begin{array}{llll}-3.32349 & 4.92767 & -1.97817\end{array}$

$\begin{array}{llll}-1.83463 & 4.46256 & -3.48314\end{array}$

$\begin{array}{llll}-5.26366 & -1.84211 & -2.03823\end{array}$

$\begin{array}{lll}-6.2618 & -0.78747 & -0.40488\end{array}$

$\begin{array}{llll}-4.67031 & -2.71701 & -0.1254\end{array}$

$\begin{array}{llll}-6.78019 & 0.23791 & 1.45243\end{array}$

$\begin{array}{lll}-5.55622 & -1.5139 & 1.90579\end{array}$

$\begin{array}{lll}-4.05907 & -3.10631 & 1.93604\end{array}$

$\begin{array}{lll}-1.74615 & 3.08073 & 4.80429\end{array}$

$\begin{array}{lll}-0.08188 & 3.72744 & 3.54253\end{array}$

$\begin{array}{lll}-0.28409 & 1.46189 & 4.63782\end{array}$

$\begin{array}{lll}1.64131 & 1.94259 & 3.07831\end{array}$

$\begin{array}{lll}1.20417 & 0.0012 & 3.96556\end{array}$

$\begin{array}{lll}1.56081 & 3.89867 & 2.1064\end{array}$

$\begin{array}{llll}-3.67905 & 5.82947 & -2.49507\end{array}$

$\begin{array}{lll}-7.12808 & -1.48391 & -0.37312\end{array}$ $\begin{array}{llll}-6.54934 & 0.08007 & -1.03866\end{array}$

$\begin{array}{llll}-3.79572 & -3.24629 & -0.56162\end{array}$ $\begin{array}{llll}-5.52149 & -3.43256 & -0.09402\end{array}$ $\begin{array}{llll}-5.32281 & -1.17272 & 2.93878\end{array}$ $\begin{array}{lll}-6.42259 & -2.2082 & 1.96835\end{array}$ $\begin{array}{llll}0.516 & 4.10826 & 4.39905\end{array}$ $\begin{array}{llll}-0.64533 & 4.58786 & 3.11643\end{array}$ $\begin{array}{lll}-0.99428 & 0.68626 & 5.00395\end{array}$ $\begin{array}{llll}0.31475 & 1.80662 & 5.50902\end{array}$ $\begin{array}{lll}2.32506 & 1.51127 & 2.31771\end{array}$ $\begin{array}{lll}2.2586 & 2.29671 & 3.93309\end{array}$ $\begin{array}{llll}-1.90431 & -4.82102 & 3.13811\end{array}$ $\begin{array}{llll}-0.64982 & 2.32316 & -2.41836\end{array}$ 


\begin{tabular}{|c|c|c|}
\hline $\mathrm{C}$ & $-0.95916 \quad 1.56286$ & -3.63478 \\
\hline $\mathrm{H}$ & $-1.24396 \quad 2.22274$ & -4.49358 \\
\hline $\mathrm{H}$ & $\begin{array}{ll}-0.06048 & 0.97607\end{array}$ & -3.91412 \\
\hline $\mathrm{H}$ & -1.798310 .866 & -3.42895 \\
\hline $\mathrm{C}$ & $0.47364 \quad 3.24305$ & -2.64769 \\
\hline $\mathrm{H}$ & $1.36243 \quad 2.64314$ & -2.90729 \\
\hline $\mathrm{H}$ & $0.28442 \quad 3.96938$ & -3.47603 \\
\hline $\mathrm{H}$ & $0.67739 \quad 3.80591$ & -1.71672 \\
\hline $\mathrm{N}$ & $2.76315-0.01632$ & 0.15885 \\
\hline $\mathrm{S}$ & $3.51689-1.12741$ & 1.06306 \\
\hline$S$ & $\begin{array}{ll}3.17738 & 0.28228\end{array}$ & -1.36698 \\
\hline $\mathrm{O}$ & $\begin{array}{lll}3.83069 & -2.36864\end{array}$ & +0.37443 \\
\hline $\mathrm{O}$ & $2.80444-1.15981$ & 2.3375 \\
\hline $\mathrm{O}$ & $1.9522 \quad 0.46134$ & -2.1643 \\
\hline $\mathrm{O}$ & $4.27929-0.47573$ & -1.93375 \\
\hline $\mathrm{C}$ & $5.15439-0.38625$ & 1.52915 \\
\hline $\mathrm{C}$ & 3.788962 .02766 & -1.19391 \\
\hline $\mathrm{F}$ & $4.96966 \quad 0.83427$ & 2.04992 \\
\hline $\mathrm{F}$ & $5.73034-1.16185$ & 2.453 \\
\hline $\mathrm{F}$ & $\begin{array}{lll}5.96401 & -0.29234\end{array}$ & 0.47615 \\
\hline $\mathrm{F}$ & $2.89771 \quad 2.78141$ & -0.53317 \\
\hline $\mathrm{F}$ & $4.944 \quad 2.05667-$ & -0.53022 \\
\hline $\mathrm{F}$ & 2.5585 & -2.41019 \\
\hline \multicolumn{3}{|c|}{ S13c-TS } \\
\hline $\mathrm{C}$ & $-0.8436-2.89522$ & 0.55732 \\
\hline $\mathrm{C}$ & $-0.50452-2.76339$ & 1.91203 \\
\hline $\mathrm{H}$ & $0.42813-2.27571$ & 2.21416 \\
\hline I & $0.98984-3.08483$ & -1.06003 \\
\hline $\mathrm{Au}$ & $-0.54303-0.8844$ & $4-0.6041$ \\
\hline $\mathrm{C}$ & $-1.99023-3.57846$ & 50.11611 \\
\hline $\mathrm{H}$ & $\begin{array}{ll}-2.1924 & -3.70773\end{array}$ & -0.95523 \\
\hline $\mathrm{C}$ & $-2.86195-4.0972$ & 1.09085 \\
\hline $\mathrm{H}$ & $-3.75854-4.64273$ & 30.7654 \\
\hline $\mathrm{C}$ & $\begin{array}{ll}-2.59062 & -3.92467\end{array}$ & $7 \quad 2.45725$ \\
\hline $\mathrm{C}$ & $-1.41721-3.26067$ & $7 \quad 2.85854$ \\
\hline $\mathrm{H}$ & $-1.18552-3.13929$ & 3.92568 \\
\hline
\end{tabular}

$\begin{array}{lcll}\mathrm{P} & -1.83384 & 1.02347 & -0.09302 \\ \mathrm{C} & -1.76977 & 2.14825 & -1.53679 \\ \mathrm{C} & -3.63682 & 0.51687 & 0.0809 \\ \mathrm{C} & -1.06228 & 1.90907 & 1.38131 \\ \mathrm{C} & -2.38586 & 3.42461 & -1.4888 \\ \mathrm{C} & -1.07991 & 1.77575 & -2.71805 \\ \mathrm{C} & -3.98641 & -0.30593 & -1.19633 \\ \mathrm{C} & -4.65745 & 1.68378 & 0.17648 \\ \mathrm{C} & -3.77508 & -0.40247 & 1.32425 \\ \mathrm{C} & -2.00099 & 2.85919 & 2.1674 \\ \mathrm{C} & -0.51456 & 0.82231 & 2.35257 \\ \mathrm{C} & 0.16138 & 2.70261 & 0.8343 \\ \mathrm{H} & -2.89126 & 3.74549 & -0.56918 \\ \mathrm{C} & -2.35405 & 4.29169 & -2.58649 \\ \mathrm{C} & -1.06013 & 2.65415 & -3.8219 \\ \mathrm{H} & -3.8648 & 0.33795 & -2.0983 \\ \mathrm{H} & -3.28196 & -1.16508 & -1.29523 \\ \mathrm{C} & -5.43382 & -0.84245 & -1.1088 \\ \mathrm{C} & -6.09356 & 1.12112 & 0.30797 \\ \mathrm{H} & -4.60741 & 2.29621 & -0.74821 \\ \mathrm{H} & -4.4325 & 2.34245 & 1.04017 \\ \mathrm{C} & -5.21053 & -0.97039 & 1.40104 \\ \mathrm{H} & -3.5697 & 0.18063 & 2.24885 \\ \mathrm{H} & -3.02781 & -1.22407 & 1.27478 \\ \mathrm{H} & -2.40937 & 3.65401 & 1.50534 \\ \mathrm{H} & -2.85895 & 2.28834 & 2.58584 \\ \mathrm{C} & -1.21889 & 3.52017 & 3.32845 \\ \mathrm{C} & 0.24486 & 1.48342 & 3.52373 \\ \mathrm{H} & -1.34236 & 0.18488 & 2.73967 \\ \mathrm{H} & 0.18679 & 0.16594 & 1.79918 \\ \mathrm{C} & 0.91987 & 3.36829 & 2.00489 \\ \mathrm{H} & -0.1682 & 3.48514 & 0.11731 \\ \mathrm{H} & 0.84215 & 2.00303 & 0.29279 \\ \mathrm{H} & -2.83609 & 5.27565 & -2.51994 \\ \mathrm{C} & -1.69694 & 3.89872 & -3.76433 \\ \mathrm{H} & -0.51155 & 2.35714 & -4.727 \\ \mathrm{H} & -5.65297 & -1.41827 & -2.03303\end{array}$




$\begin{array}{lccl}\mathrm{C} & -6.43094 & 0.32432 & -0.96767 \\ \mathrm{C} & -5.54903 & -1.76466 & 0.12152 \\ \mathrm{H} & -6.79448 & 1.97622 & 0.41331 \\ \mathrm{C} & -6.20051 & 0.20536 & 1.5462 \\ \mathrm{H} & -5.27385 & -1.64124 & 2.28534 \\ \mathrm{H} & -1.91041 & 4.20164 & 3.86904 \\ \mathrm{C} & -0.03221 & 4.3224 & 2.75542 \\ \mathrm{C} & -0.70367 & 2.42767 & 4.28959 \\ \mathrm{C} & 1.43934 & 2.28655 & 2.96972 \\ \mathrm{H} & 0.61515 & 0.67768 & 4.19199 \\ \mathrm{H} & 1.77268 & 3.9381 & 1.58238 \\ \mathrm{H} & -1.66359 & 4.57202 & -4.6313 \\ \mathrm{H} & -7.46775 & -0.07287 & -0.90885 \\ \mathrm{H} & -6.37458 & 0.99014 & -1.85671 \\ \mathrm{H} & -4.85602 & -2.62374 & 0.00972 \\ \mathrm{H} & -6.58223 & -2.16954 & 0.19523 \\ \mathrm{H} & -5.9708 & 0.78456 & 2.46804 \\ \mathrm{H} & -7.23982 & -0.17811 & 1.64049 \\ \mathrm{H} & 0.51422 & 4.82697 & 3.58142 \\ \mathrm{H} & -0.4067 & 5.11369 & 2.06773 \\ \mathrm{H} & -1.56364 & 1.85683 & 4.70741 \\ \mathrm{H} & -0.16725 & 2.89955 & 5.14115 \\ \mathrm{H} & 2.14576 & 1.61411 & 2.44362 \\ \mathrm{H} & 1.99653 & 2.76105 & 3.80647 \\ \mathrm{H} & -3.27631 & -4.33484 & 3.20985 \\ \mathrm{~N} & -0.34169 & 0.53308 & -2.78124 \\ \mathrm{C} & -0.79892 & -0.35639 & -3.85797 \\ \mathrm{H} & -0.61801 & 0.0687 & -4.87302 \\ \mathrm{H} & -0.24326 & -1.31175 & -3.77611 \\ \mathrm{H} & -1.88255 & -0.55423 & -3.7338 \\ \mathrm{C} & 1.11359 & 0.78373 & -2.85278 \\ \mathrm{H} & 1.65466 & -0.1725 & -2.72075 \\ \mathrm{H} & 1.41735 & 1.24344 & -3.82157 \\ \mathrm{H} & 1.40383 & 1.45564 & -2.02556 \\ \mathrm{~N} & 3.07816 & 0.21813 & -0.1483 \\ \mathrm{~S} & 3.4563 & -0.55379 & 1.22449 \\ \mathrm{~S} & 4.29097 & 0.96909 & -0.92231 \\ & & & \\ & & & \\ & & & \end{array}$

\begin{tabular}{|c|c|c|c|}
\hline $\mathrm{O}$ & 2.20425 & -1.12552 & 1.72448 \\
\hline $\mathrm{O}$ & 4.31646 & 0.15424 & 2.15947 \\
\hline $\mathrm{O}$ & 3.96858 & 1.07243 & -2.33888 \\
\hline $\mathrm{O}$ & 5.62192 & 0.56232 & -0.49418 \\
\hline $\mathrm{C}$ & 4.48691 & -2.04958 & 0.68069 \\
\hline $\mathrm{C}$ & 4.08501 & 2.71977 & -0.33312 \\
\hline $\mathrm{F}$ & 5.74179 & -1.92648 & 1.09625 \\
\hline $\mathrm{F}$ & 3.9666 & -3.16134 & 1.22403 \\
\hline $\mathrm{F}$ & 4.48322 & -2.19793 & -0.65034 \\
\hline $\mathrm{F}$ & 2.90083 & 3.20677 & -0.75908 \\
\hline $\mathrm{F}$ & 4.10773 & 2.79992 & 0.99909 \\
\hline $\mathrm{F}$ & 5.05607 & 3.49104 & -0.83125 \\
\hline \multicolumn{4}{|c|}{ S13d } \\
\hline C & 1.68639 & -1.75987 & -1.58153 \\
\hline C & 2.97274 & -2.30864 & -1.69167 \\
\hline $\mathrm{H}$ & 3.59136 & -2.4879 & -0.80269 \\
\hline I & 0.29008 & -3.84139 & 0.36316 \\
\hline $\mathrm{Au}$ & 1.00408 & $8-1.19663$ & $\begin{array}{l}30.2933 \\
\end{array}$ \\
\hline $\mathrm{C}$ & 0.83966 & -1.67151 & -2.69339 \\
\hline $\mathrm{H}$ & -0.20637 & -1.3619 & -2.5811 \\
\hline $\mathrm{C}$ & 1.34656 & -2.02489 & -3.95876 \\
\hline $\mathrm{H}$ & 0.68793 & -1.94695 & -4.83458 \\
\hline $\mathrm{C}$ & 2.6622 & -2.49147 & -4.10029 \\
\hline $\mathrm{C}$ & 3.46799 & -2.65132 & -2.96284 \\
\hline $\mathrm{H}$ & 4.48291 & -3.06514 & -3.04896 \\
\hline $\mathrm{P}$ & 1.73832 & 1.10831 & 0.37912 \\
\hline $\mathrm{C}$ & 1.36226 & 1.5333 & 2.11781 \\
\hline $\mathrm{C}$ & 3.60118 & 1.22915 & 0.15099 \\
\hline $\mathrm{C}$ & 0.68046 & 2.27262 & -0.66326 \\
\hline $\mathrm{C}$ & 1.60944 & 2.83881 & 2.61804 \\
\hline $\mathrm{C}$ & 0.63468 & 0.63405 & 2.92306 \\
\hline $\mathrm{C}$ & 4.22396 & 0.03462 & 0.93331 \\
\hline $\mathrm{C}$ & 4.2488 & 2.52268 & 0.72431 \\
\hline $\mathrm{C}$ & 3.93784 & 1.11901 & -1.36227 \\
\hline $\mathrm{C}$ & 1.27541 & 3.69095 & -0.8654 \\
\hline $\mathrm{C}$ & 0.42981 & 1.59532 & -2.0382 \\
\hline
\end{tabular}




$\begin{array}{lccl}\mathrm{C} & -0.695 & 2.3898 & 0.05558 \\ \mathrm{H} & 2.13544 & 3.5682 & 1.99387 \\ \mathrm{C} & 1.16623 & 3.22821 & 3.88502 \\ \mathrm{C} & 0.19045 & 1.03087 & 4.20111 \\ \mathrm{~N} & 0.33526 & -0.72953 & 2.46109 \\ \mathrm{H} & 3.98992 & 0.15147 & 2.01865 \\ \mathrm{H} & 3.77668 & -0.9237 & 0.6001 \\ \mathrm{C} & 5.75403 & -0.0049 & 0.71496 \\ \mathrm{C} & 5.77963 & 2.49586 & 0.48685 \\ \mathrm{H} & 4.07137 & 2.57122 & 1.81883 \\ \mathrm{H} & 3.81225 & 3.43067 & 0.25718 \\ \mathrm{C} & 5.46964 & 1.06357 & -1.5553 \\ \mathrm{H} & 3.53845 & 2.00724 & -1.897 \\ \mathrm{H} & 3.46028 & 0.22223 & -1.80537 \\ \mathrm{H} & 1.43224 & 4.19297 & 0.11342 \\ \mathrm{H} & 2.25407 & 3.64261 & -1.38951 \\ \mathrm{C} & 0.29137 & 4.5383 & -1.71111 \\ \mathrm{C} & -0.50118 & 2.47374 & -2.90365 \\ \mathrm{H} & 1.3838 & 1.38729 & -2.57133 \\ \mathrm{H} & -0.07672 & 0.62951 & -1.84933 \\ \mathrm{C} & -1.66712 & 3.22665 & -0.80883 \\ \mathrm{H} & -0.57961 & 2.89353 & 1.03875 \\ \mathrm{H} & -1.1164 & 1.37671 & 0.23425 \\ \mathrm{H} & 1.36457 & 4.24611 & 4.24375 \\ \mathrm{C} & 0.45187 & 2.31809 & 4.68011 \\ \mathrm{H} & -0.3772 & 0.32887 & 4.82433 \\ \mathrm{C} & -1.13829 & -0.99662 & 2.52335 \\ \mathrm{C} & 1.07696 & -1.69419 & 3.32882 \\ \mathrm{H} & 6.16566 & -0.87755 & 1.26454 \\ \mathrm{C} & 6.38711 & 1.2975 & 1.24357 \\ \mathrm{C} & 6.05231 & -0.14597 & -0.79403 \\ \mathrm{H} & 6.20342 & 3.44344 & 0.88166 \\ \mathrm{C} & 6.0889 & 2.36954 & -1.0183 \\ \mathrm{H} & 5.68161 & 0.96017 & -2.6399 \\ \mathrm{H} & 0.73165 & 5.55132 & -1.83292 \\ \mathrm{C} & -1.06959 & 4.63916 & -0.98752 \\ \mathrm{C} & 0.11213 & 3.87429 & -3.09157 \\ & & & \\ & & & \end{array}$

\begin{tabular}{|c|c|c|c|}
\hline C & -1.86489 & 2.58495 & -2.19558 \\
\hline $\mathrm{H}$ & -0.62393 & 1.97702 & -3.88909 \\
\hline $\mathrm{H}$ & -2.6372 & 3.27398 & -0.27079 \\
\hline $\mathrm{H}$ & 0.0859 & 2.61294 & 5.67197 \\
\hline $\mathrm{H}$ & -1.32954 & -1.97833 & $\begin{array}{ll}3 & 2.05969\end{array}$ \\
\hline $\mathrm{H}$ & -1.6743 & -0.21258 & 1.95937 \\
\hline $\mathrm{H}$ & -1.48817 & -1.01567 & 7 3.57575 \\
\hline $\mathrm{H}$ & 0.79615 & -1.5516 & 4.39274 \\
\hline $\mathrm{H}$ & 2.16395 & -1.51916 & 3.20622 \\
\hline $\mathrm{H}$ & 0.82672 & -2.7209 & 3.01513 \\
\hline $\mathrm{H}$ & 7.48813 & 1.27234 & 1.09306 \\
\hline $\mathrm{H}$ & 6.19821 & 1.39963 & 2.33481 \\
\hline $\mathrm{H}$ & 5.61254 & -1.08709 & -1.19037 \\
\hline $\mathrm{H}$ & 7.15141 & -0.19681 & -0.95276 \\
\hline $\mathrm{H}$ & 5.67224 & 3.24149 & -1.56949 \\
\hline $\mathrm{H}$ & 7.18923 & 2.36691 & -1.17603 \\
\hline $\mathrm{H}$ & -1.76223 & 5.27207 & -1.58309 \\
\hline $\mathrm{H}$ & -0.93612 & 5.12882 & 0.0029 \\
\hline $\mathrm{H}$ & 1.09626 & 3.80178 & -3.60794 \\
\hline $\mathrm{H}$ & -0.55505 & 4.49718 & -3.72538 \\
\hline $\mathrm{H}$ & -2.32806 & 1.58298 & -2.09958 \\
\hline $\mathrm{H}$ & -2.56041 & 3.20983 & -2.79725 \\
\hline $\mathrm{H}$ & 3.04698 & -2.76495 & -5.09168 \\
\hline $\mathrm{N}$ & -3.41251 & 0.52308 & 0.30834 \\
\hline S & -3.22991 & -0.6848 & -0.7183 \\
\hline S & -4.82064 & 1.10631 & 0.83485 \\
\hline $\mathrm{O}$ & -1.78936 & -0.98215 & $5-0.71735$ \\
\hline $\mathrm{O}$ & -3.9079 & -0.54555 & -2.00029 \\
\hline $\mathrm{O}$ & -4.50526 & 2.33363 & 1.55268 \\
\hline $\mathrm{O}$ & -5.69592 & 0.10428 & 1.4264 \\
\hline $\mathrm{C}$ & -3.99863 & -2.20986 & 0.03267 \\
\hline $\mathrm{C}$ & -5.7371 & 1.69078 & -0.68189 \\
\hline $\mathrm{F}$ & -3.44727 & -3.29135 & -0.52926 \\
\hline $\mathrm{F}$ & -3.7673 & -2.25409 & 1.35284 \\
\hline $\mathrm{F}$ & -5.30935 & -2.23114 & -0.1876 \\
\hline $\mathrm{F}$ & -6.64309 & 2.60511 & -0.31174 \\
\hline $\mathrm{F}$ & -6.36903 & 0.68458 & -1.2817 \\
\hline
\end{tabular}




\section{S14a}

C

C $\begin{array}{lll}-1.95534 & 1.07356 & 1.76163\end{array}$

$\begin{array}{lll}-3.29566 & 1.51049 & 1.9019\end{array}$

$\begin{array}{llll}-4.01746 & 1.29947 & 1.10408\end{array}$

$\begin{array}{llll}-3.72813 & 2.22648 & 3.02417\end{array}$

$\begin{array}{llll}-4.77381 & 2.55287 & 3.09404\end{array}$

$\begin{array}{llll}-2.8144 & 2.52384 & 4.04645\end{array}$

$\begin{array}{lll}-3.13877 & 3.07764 & 4.93798\end{array}$

$\begin{array}{llll}-1.48034 & 2.11899 & 3.92001\end{array}$

$\begin{array}{lll}-0.7589 & 2.35607 & 4.7141\end{array}$

$\begin{array}{lll}-1.02566 & 1.41252 & 2.78548\end{array}$

$\begin{array}{lll}0.69304 & -0.13583 & 3.4475\end{array}$

$\begin{array}{lll}1.72209 & -0.45686 & 3.1855\end{array}$

$\begin{array}{lll}-0.01709 & -0.95314 & 3.20965\end{array}$

$\begin{array}{llll}0.64282 & 0.06875 & 4.54697\end{array}$

$\begin{array}{lll}1.28692 & 2.1474 & 3.00018\end{array}$

$\begin{array}{lll}1.33653 & 2.3441 & 4.09922\end{array}$

$\begin{array}{lll}0.97667 & 3.07739 & 2.4891\end{array}$

$\begin{array}{llll}2.29436 & 1.86252 & 2.65211\end{array}$

$\begin{array}{llll}-1.09162 & 1.59561 & -1.00955\end{array}$

$\begin{array}{llll}0.14762 & 2.3655 & -0.45419\end{array}$

$\begin{array}{llll}-0.12313 & 2.81887 & 0.52487\end{array}$ $1.00458 \quad 1.67616-0.28355$

$\begin{array}{llll}0.56071 & 3.48028 & -1.44123\end{array}$

$\begin{array}{llll}1.45039 & 3.99707 & -1.02446\end{array}$

$\begin{array}{llll}-0.60101 & 4.48004 & -1.60677\end{array}$

$-0.31008 \quad 5.2902 \quad-2.31072$

$\begin{array}{llll}-0.84173 & 4.95297 & -0.62892\end{array}$

$\begin{array}{llll}-1.83621 & 3.73422 & -2.1492\end{array}$

$\begin{array}{llll}-2.68823 & 4.43941 & -2.25487\end{array}$

$\begin{array}{llll}-1.50052 & 3.11013 & -3.51994\end{array}$

$\begin{array}{llll}-2.39153 & 2.57891 & -3.92502\end{array}$

$\begin{array}{llll}-1.23165 & 3.912 & -4.2415\end{array}$

$-0.3241 \quad 2.12386-3.36533$

$\begin{array}{llll}-0.08085 & 1.66939 & -4.34861\end{array}$ $\begin{array}{llll}0.91367 & 2.85405 & -2.80602\end{array}$

$\begin{array}{llll}1.75378 & 2.13724 & -2.6882\end{array}$

$\begin{array}{llll}1.23537 & 3.64893 & -3.5139\end{array}$

$\begin{array}{llll}-2.24912 & 2.62052 & -1.15447\end{array}$

$\begin{array}{llll}-2.46906 & 3.07582 & -0.16428\end{array}$

$\begin{array}{llll}-3.17617 & 2.13318 & -1.52016\end{array}$

$\begin{array}{llll}-0.732 & 0.99288 & -2.39466\end{array}$

$\begin{array}{llll}-1.60584 & 0.44953 & -2.81679\end{array}$

$\begin{array}{llll}0.10668 & 0.26826 & -2.28299\end{array}$

$\begin{array}{llll}-2.82432 & -1.00086 & -0.3088\end{array}$

$-4.00846-0.39053-1.11252$

$\begin{array}{lll}-4.51062 & 0.42621 & -0.556\end{array}$

$\begin{array}{llll}-3.6308 & 0.04348 & -2.06296\end{array}$

$-5.05404-1.48263-1.44128$

$-5.89913-1.00154-1.97797$

$\begin{array}{llll}-5.5642 & -2.12637 & -0.13531\end{array}$

$\begin{array}{llll}-6.33972 & -2.88781 & -0.36843\end{array}$

$\begin{array}{llll}-6.03728 & -1.35286 & 0.51037\end{array}$

$\begin{array}{llll}-4.38602 & -2.78775 & 0.612\end{array}$

$\begin{array}{llll}-4.75194 & -3.25223 & 1.55192\end{array}$

$\begin{array}{llll}-3.74063 & -3.85968 & -0.28752\end{array}$

$\begin{array}{llll}-2.89911 & -4.35098 & 0.24794\end{array}$

$-4.48654-4.64558-0.5368$

$\begin{array}{llll}-3.22627 & -3.19004 & -1.57766\end{array}$

$-2.72366-3.94382-2.21925$

$-2.18351-2.11216-1.20388$

$-1.74164-1.66838-2.12129$

$\begin{array}{llll}-1.35602 & -2.59956 & -0.64563\end{array}$

$\begin{array}{llll}-3.34979 & -1.70119 & 0.97892\end{array}$

$\begin{array}{llll}-3.82458 & -0.97092 & 1.66411\end{array}$

$\begin{array}{llll}-2.48586 & -2.1529 & 1.52281\end{array}$

$\begin{array}{llll}-4.40576 & -2.55505 & -2.33726\end{array}$

$\begin{array}{llll}-4.04907 & -2.0936 & -3.28435\end{array}$

$\begin{array}{llll}-5.15271 & -3.33457 & -2.60241\end{array}$

$\begin{array}{llll}0.36274 & 1.05766 & 2.65318\end{array}$

$\begin{array}{llll}-1.45089 & 0.21001 & 0.21311\end{array}$

$\begin{array}{llll}0.47642 & -0.95378 & 0.3466\end{array}$ 


\begin{tabular}{|c|c|c|}
\hline $\mathrm{F}$ & $2.46939-1.94971$ & 0.28461 \\
\hline $\mathrm{Sb}$ & $3.89333-0.68815$ & -0.24222 \\
\hline $\mathrm{F}$ & $4.94188-1.41684$ & 1.11454 \\
\hline $\mathrm{F}$ & $3.06409 \quad 0.45853$ & 1.01203 \\
\hline $\mathrm{F}$ & 5.149690 .59856 & -0.72144 \\
\hline $\mathrm{F}$ & $2.63077-0.04394$ & -1.49734 \\
\hline $\mathrm{F}$ & $4.48502-1.9545$ & -1.47122 \\
\hline \multicolumn{3}{|c|}{ S14b } \\
\hline $\mathrm{C}$ & $\begin{array}{lll}1.58288 & -3.77679\end{array}$ & -0.46756 \\
\hline $\mathrm{C}$ & $1.93492-4.27214$ & -1.73005 \\
\hline $\mathrm{H}$ & $1.1791 \quad-4.38412$ & -2.51741 \\
\hline I & $-0.47755-3.29475$ & -0.06889 \\
\hline $\mathrm{Au}$ & $-0.03247-0.53566$ & $\begin{array}{ll}6 & 0.10818\end{array}$ \\
\hline $\mathrm{C}$ & $2.52646-3.61956$ & 0.55783 \\
\hline $\mathrm{H}$ & $2.22609-3.22049$ & 1.53653 \\
\hline $\mathrm{C}$ & $\begin{array}{lll}3.86064 & -3.98447\end{array}$ & 0.30799 \\
\hline $\mathrm{H}$ & $\begin{array}{lll}4.60749 & -3.87138\end{array}$ & 1.10573 \\
\hline $\mathrm{C}$ & $4.23419-4.49525$ & -0.94607 \\
\hline $\mathrm{C}$ & $3.27469-4.633$ & -1.96134 \\
\hline $\mathrm{H}$ & $3.56192-5.02664$ & -2.94544 \\
\hline $\mathrm{P}$ & $0.99253 \quad 1.52585$ & 0.23699 \\
\hline $\mathrm{C}$ & 1.290692 .07602 & 1.96471 \\
\hline $\mathrm{C}$ & $2.72047 \quad 1.21261$ & -0.45481 \\
\hline $\mathrm{C}$ & $-0.03545 \quad 2.83591$ & -0.66246 \\
\hline $\mathrm{C}$ & 1.839113 .36096 & 2.20052 \\
\hline $\mathrm{C}$ & $1.05056 \quad 1.22828$ & 3.08048 \\
\hline $\mathrm{C}$ & $\begin{array}{ll}3.32117 & 0.04867\end{array}$ & 0.39366 \\
\hline $\mathrm{C}$ & $3.72588 \quad 2.39405$ & -0.37243 \\
\hline $\mathrm{C}$ & 0.75313 & -1.93217 \\
\hline $\mathrm{C}$ & $0.75897 \quad 4.00098$ & -1.31148 \\
\hline $\mathrm{C}$ & $-0.84196 \quad 2.10534$ & -1.78332 \\
\hline $\mathrm{C}$ & -1.046793 .4208 & 0.36677 \\
\hline $\mathrm{H}$ & $2.02434 \quad 4.03091$ & 1.35026 \\
\hline $\mathrm{C}$ & $2.15667 \quad 3.798$ & 3.49235 \\
\hline $\mathrm{C}$ & $1.37443 \quad 1.68013$ & 4.37728 \\
\hline $\mathrm{N}$ & $0.44072-0.05794$ & 2.88672 \\
\hline
\end{tabular}

$\begin{array}{lccl}\mathrm{H} & 3.44122 & 0.38817 & 1.44884 \\ \mathrm{H} & 2.62597 & -0.81955 & 0.39654 \\ \mathrm{C} & 4.68314 & -0.38957 & -0.18443 \\ \mathrm{C} & 5.09441 & 1.9628 & -0.96037 \\ \mathrm{H} & 3.8702 & 2.68569 & 0.68974 \\ \mathrm{H} & 3.35242 & 3.27985 & -0.92567 \\ \mathrm{C} & 3.95187 & 0.32088 & -2.48836 \\ \mathrm{H} & 2.17054 & 1.58153 & -2.55076 \\ \mathrm{H} & 1.85997 & -0.09625 & -1.9923 \\ \mathrm{H} & 1.35118 & 4.55458 & -0.55063 \\ \mathrm{H} & 1.46922 & 3.60921 & -2.07198 \\ \mathrm{C} & -0.21891 & 4.98477 & -2.00007 \\ \mathrm{C} & -1.79529 & 3.09173 & -2.49093 \\ \mathrm{H} & -0.14354 & 1.64753 & -2.51971 \\ \mathrm{H} & -1.44525 & 1.28532 & -1.34475 \\ \mathrm{C} & -2.02462 & 4.38182 & -0.34777 \\ \mathrm{H} & -0.50274 & 3.98372 & 1.15495 \\ \mathrm{H} & -1.60485 & 2.59444 & 0.85705 \\ \mathrm{H} & 2.58002 & 4.79972 & 3.64209 \\ \mathrm{C} & 1.92873 & 2.94884 & 4.58702 \\ \mathrm{H} & 1.16576 & 1.02143 & 5.23265 \\ \mathrm{C} & -0.99509 & -0.02582 & 3.2142 \\ \mathrm{C} & 1.12006 & -1.16795 & 3.54651 \\ \mathrm{H} & 5.06968 & -1.23392 & 0.42725 \\ \mathrm{C} & 5.66998 & 0.79389 & -0.13564 \\ \mathrm{C} & 4.48451 & -0.85397 & -1.64258 \\ \mathrm{H} & 5.78309 & 2.83288 & -0.90944 \\ \mathrm{C} & 4.92493 & 1.51592 & -2.42656 \\ \mathrm{H} & 3.81976 & -0.00428 & -3.54189 \\ \mathrm{H} & 0.37649 & 5.81552 & -2.43663 \\ \mathrm{C} & -1.21656 & 5.54396 & -0.96374 \\ \mathrm{C} & -0.99 & 4.2484 & -3.11388 \\ \mathrm{H} & -2.79832 & 3.6384 & -1.45475 \\ & -2.34075 & 2.53371 & -3.27993 \\ \mathrm{H} & -2.73478 & 4.77722 & 0.4086 \\ \mathrm{H} & 2.17071 & 3.2814 & 5.60567 \\ \mathrm{H} & -0.97397 & 2.88101\end{array}$




\section{S14c-TS}

C

$\mathrm{H} \quad-1.63767 \quad-1.36653 \quad-2.18782$

I $\quad \begin{array}{llll}-1.55882 & -3.04353 & 0.68379\end{array}$

$\begin{array}{lllll}\mathrm{Au} & 0.17984 & -0.94207 & 0.50439\end{array}$

C $\quad 1.03252-3.36705-1.28228$

$\mathrm{H} \quad 1.46557 \quad-3.83201-0.38623$

C $\quad 1.59008-3.57588-2.55586$

$\mathrm{H} \quad 2.47575 \quad-4.22032 \quad-2.65134$

C $\quad 1.02677 \quad-2.96603 \quad-3.68899$

$\begin{array}{llll}\mathrm{C} & -0.12618 & -2.17027 & -3.55875 \\ \mathrm{H} & -0.58804 & -1.71239 & -4.44432 \\ \mathrm{P} & 1.71806 & 0.83662 & 0.29864 \\ \mathrm{C} & 1.83377 & 1.63205 & 1.94726 \\ \mathrm{C} & 3.40988 & 0.12588 & -0.10536 \\ \mathrm{C} & 1.04276 & 2.14167 & -0.88523 \\ \mathrm{C} & 2.66781 & 2.76084 & 2.15606 \\ \mathrm{C} & 0.99889 & 1.20971 & 3.01418 \\ \mathrm{C} & 3.61762 & -1.0779 & 0.86304 \\ \mathrm{C} & 4.62368 & 1.07743 & 0.07075 \\ \mathrm{C} & 3.37419 & -0.39117 & -1.56844 \\ \mathrm{C} & 2.06688 & 3.19924 & -1.36979 \\ \mathrm{C} & 0.4185 & 1.42636 & -2.12056 \\ \mathrm{C} & -0.11449 & 2.85256 & -0.11948 \\ \mathrm{H} & 3.30588 & 3.11982 & 1.34083 \\ \mathrm{C} & 2.68966 & 3.43951 & 3.37975 \\ \mathrm{C} & 1.02999 & 1.90005 & 4.24376 \\ \mathrm{H} & 3.62226 & -0.70666 & 1.9153 \\ \mathrm{H} & 2.7708 & -1.79444 & 0.76224 \\ \mathrm{C} & 4.93767 & -1.81062 & 0.53689 \\ \mathrm{C} & 5.93214 & 0.33628 & -0.30302 \\ \mathrm{H} & 4.695 & 1.39585 & 1.13237 \\ \mathrm{H} & 4.5096 & 1.98713 & -0.55698 \\ \mathrm{C} & 4.67235 & -1.16443 & -1.88781 \\ \mathrm{H} & 3.29756 & 0.47422 & -2.2626 \\ \mathrm{H} & 2.47661 & -1.02891 & -1.7294 \\ \mathrm{H} & 2.52165 & 3.7311 & -0.50654 \\ \mathrm{H} & 2.88448 & 2.70872 & -1.9439 \\ \mathrm{C} & 1.35766 & 4.23229 & -2.28029 \\ \mathrm{C} & -0.25541 & 2.46337 & -3.04827 \\ \mathrm{H} & 1.18575 & 0.85394 & -2.68527 \\ \mathrm{H} & -0.34858 & 0.70971 & -1.76806 \\ \mathrm{C} & -0.81127 & 3.87328 & -1.04666 \\ \mathrm{H} & 0.28742 & 3.38676 & 0.76881 \\ \mathrm{H} & 3.00613 & 4.43112\end{array}$


$\begin{array}{llll}0.37633 & 1.56077 \quad 5.05976\end{array}$

$\begin{array}{llll}5.05628 & -2.65836 & 1.24461\end{array}$

$\begin{array}{llll}6.13075 & -0.84455 & 0.66867\end{array}$

$\begin{array}{llll}4.8586 & -2.34348 & -0.90917\end{array}$

$\begin{array}{llll}6.77742 & 1.04994 & -0.20445\end{array}$

$5.86342-0.19165-1.75232$

$\begin{array}{llll}4.60548 & -1.54874 & -2.92859\end{array}$

$2.10935 \quad 4.98465-2.60281$

$\begin{array}{llll}0.22241 & 4.92657 & -1.49699\end{array}$

$\begin{array}{llll}0.77954 & 3.50702 & -3.5126\end{array}$

$\begin{array}{llll}-1.39543 & 3.15796 & -2.27896\end{array}$

$\begin{array}{llll}-0.66848 & 1.92179 & -3.92583\end{array}$

$\begin{array}{llll}-1.63085 & 4.35072 & -0.47091\end{array}$ $\begin{array}{llll}1.87033 & 3.53385 & 5.39421\end{array}$ $\begin{array}{llll}7.07711 & -1.378 & 0.43197\end{array}$ $\begin{array}{llll}6.20722 & -0.46951 & 1.71289\end{array}$ $\begin{array}{llll}4.00853 & -3.0539 & -1.00057\end{array}$ $\begin{array}{llll}5.78974 & -2.89663 & -1.16108\end{array}$ $\begin{array}{llll}5.74243 & 0.65606 & -2.46246\end{array}$ $\begin{array}{llll}6.81386 & -0.70967 & -2.00635\end{array}$ $\begin{array}{llll}-0.26645 & 5.68656 & -2.14453\end{array}$ $\begin{array}{llll}0.64264 & 5.45807 & -0.6136\end{array}$ $\begin{array}{llll}1.60078 & 3.01294 & -4.07997\end{array}$ $0.29701 \quad 4.24326-4.19146$ $\begin{array}{llll}-2.15449 & 2.41646 & -1.96302\end{array}$ $\begin{array}{llll}-1.90115 & 3.89736 & -2.93753\end{array}$ $1.46728-3.13583-4.67982$ $\begin{array}{llll}-2.2343 & 0.14652 & -0.48564\end{array}$ $\begin{array}{llll}-4.09323 & 0.52146 & -0.18639\end{array}$ $\begin{array}{llll}-3.48892 & 2.19991 & 0.4492\end{array}$ $\begin{array}{llll}-4.18969 & 1.20643 & -1.93522\end{array}$ $\begin{array}{llll}-3.92007 & -0.19398 & 1.5495\end{array}$ $\begin{array}{llll}-4.47748 & -1.19518 & -0.84935\end{array}$ $\begin{array}{llll}-5.88413 & 0.94499 & 0.13032\end{array}$ $\begin{array}{llll}0.11578 & 0.07064 & 2.86605\end{array}$ $\begin{array}{llll}0.50647 & -1.03416 & 3.75828\end{array}$ $\begin{array}{llll}0.38336 & -0.77353 & 4.83557\end{array}$

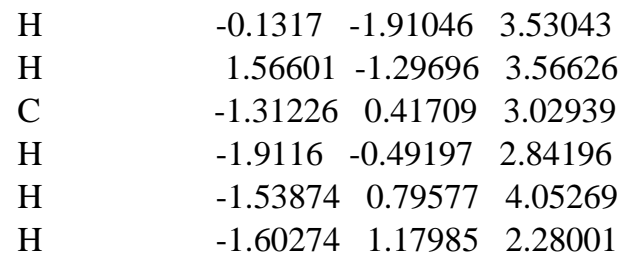

S14d

C

C $\begin{array}{llll}0.15565 & -1.70078 & -1.64768\end{array}$ $1.08774-2.65703-2.07486$ $\begin{array}{llll}1.7711 & -3.13851 & -1.36309\end{array}$ $\begin{array}{llll}-1.51166 & -3.34078 & 0.48499\end{array}$ $\begin{array}{llll}0.1127 & -1.1535 & 0.3503\end{array}$ $-0.81704-1.18964-2.5162$ $\begin{array}{llll}-1.6196 & -0.53086 & -2.16077\end{array}$ $\begin{array}{llll}-0.76792 & -1.56532 & -3.87263\end{array}$ $\begin{array}{llll}-1.5252 & -1.16115 & -4.5578\end{array}$ $0.20914-2.45899-4.33668$ $\begin{array}{llll}1.12711 & -3.01721 & -3.43407\end{array}$ $\begin{array}{llll}1.86733 & -3.75635 & -3.77229\end{array}$ $\begin{array}{llll}1.64968 & 0.7109 & 0.36564\end{array}$ $\begin{array}{llll}1.73536 & 1.08346 & 2.15769\end{array}$ $\begin{array}{llll}3.36379 & 0.11953 & -0.15958\end{array}$ $\begin{array}{llll}1.03197 & 2.30152 & -0.45835\end{array}$ $\begin{array}{lll}2.5489 & 2.1395 & 2.64712\end{array}$ $\begin{array}{llll}0.87044 & 0.43304 & 3.06142\end{array}$ $\begin{array}{llll}3.55494 & -1.29353 & 0.47045\end{array}$ $\begin{array}{llll}4.5484 & 0.99322 & 0.34457\end{array}$ $\begin{array}{llll}3.419 & 0.01414 & -1.70904\end{array}$ $\begin{array}{llll}2.1609 & 3.33476 & -0.72799\end{array}$ $\begin{array}{llll}0.32382 & 1.92257 & -1.78972\end{array}$ $\begin{array}{llll}-0.03334 & 2.957 & 0.47215\end{array}$ $\begin{array}{llll}3.20592 & 2.68002 & 1.95846\end{array}$ $\begin{array}{llll}2.51724 & 2.52333 & 3.99049\end{array}$ $\begin{array}{llll}0.83876 & 0.82705 & 4.41591\end{array}$ $\begin{array}{llll}-0.0079 & -0.66067 & 2.62343\end{array}$ $\begin{array}{llll}3.52642 & -1.20309 & 1.58299\end{array}$ 
$\begin{array}{llll}2.72512 & -1.96681 & 0.17231\end{array}$

$\begin{array}{llll}4.89951 & -1.90705 & 0.01532\end{array}$

$\begin{array}{llll}5.89257 & 0.39263 & -0.13687\end{array}$

$\begin{array}{llll}4.55332 & 1.00284 & 1.45462\end{array}$

$\begin{array}{llll}4.46044 & 2.03964 & -0.01354\end{array}$

$\begin{array}{llll}4.76255 & -0.6124 & -2.14563\end{array}$

$\begin{array}{llll}3.33015 & 1.02398 & -2.16183\end{array}$

$\begin{array}{llll}2.57098 & -0.59232 & -2.08532\end{array}$

$\begin{array}{llll}2.65045 & 3.63535 & 0.22291\end{array}$

$2.93957 \quad 2.90853-1.39402$

$\begin{array}{llll}1.56712 & 4.59548 & -1.39997\end{array}$

$\begin{array}{lll}-0.21748 & 3.19504 & -2.4812\end{array}$

$\begin{array}{llll}1.00982 & 1.3683 & -2.46864\end{array}$

$\begin{array}{llll}-0.53163 & 1.26003 & -1.5539\end{array}$

$\begin{array}{llll}-0.62059 & 4.21293 & -0.21901\end{array}$

$\begin{array}{llll}0.43434 & 3.26753 & 1.43123\end{array}$

$\begin{array}{lll}-0.84738 & 2.23363 & 0.69717\end{array}$

$\begin{array}{lll}3.15595 & 3.345 & 4.33877\end{array}$

$\begin{array}{llll}1.65475 & 1.86272 & 4.87992\end{array}$

$\begin{array}{llll}0.1598 & 0.32157 & 5.11392\end{array}$

$\begin{array}{lll}-1.4396 & -0.33119 & 2.92924\end{array}$

$\begin{array}{llll}0.39837 & -1.91127 & 3.33309\end{array}$ $\begin{array}{llll}4.99439 & -2.91696 & 0.46708\end{array}$ $\begin{array}{llll}6.06606 & -1.01118 & 0.47595\end{array}$ $\begin{array}{llll}4.91508 & -2.01691 & -1.52517\end{array}$ $\begin{array}{llll}6.70968 & 1.05897 & 0.2123\end{array}$ $\begin{array}{lll}5.9164 & 0.29591 & -1.67546\end{array}$ $\begin{array}{llll}4.76735 & -0.68989 & -3.25289\end{array}$ $\begin{array}{llll}2.39805 & 5.31238 & -1.57544\end{array}$ $\begin{array}{llll}0.51368 & 5.22872 & -0.46652\end{array}$ $\begin{array}{llll}0.92839 & 4.19098 & -2.74464\end{array}$ $\begin{array}{llll}-1.27103 & 3.84755 & -1.56618\end{array}$ $\begin{array}{llll}-0.69004 & 2.88818 & -3.43745\end{array}$ $\begin{array}{llll}-1.3881 & 4.63992 & 0.45941\end{array}$ $\begin{array}{lll}1.61041 & 2.15869 & 5.9361\end{array}$ $\begin{array}{lll}-2.09032 & -1.08133 & 2.44927\end{array}$ $\begin{array}{lll}-1.6782 & 0.6634 & 2.51265\end{array}$ $\begin{array}{lll}-1.61006 & -0.33691 & 4.02576\end{array}$ $\begin{array}{llll}0.35996 & -1.76728 & 4.43246\end{array}$ $\begin{array}{llll}1.43101 & -2.17206 & 3.0288\end{array}$

$\begin{array}{llll}-0.28958 & -2.72224 & 3.04444\end{array}$ $\begin{array}{llll}7.03364 & -1.45163 & 0.15112\end{array}$ $\begin{array}{llll}6.08205 & -0.94315 & 1.58594\end{array}$ $4.09059-2.67488-1.87658$ $5.87266-2.47413-1.85664$ $\begin{array}{llll}5.80863 & 1.30844 & -2.12411\end{array}$ $6.89221-0.11784-2.01059$ $0.10252 \quad 6.14953-0.93382$ $\begin{array}{llll}0.99189 & 5.52356 & 0.49492\end{array}$ $\begin{array}{llll}1.70018 & 3.73366 & -3.40471\end{array}$ $\begin{array}{llll}0.53483 & 5.09235 & -3.26213\end{array}$

$\begin{array}{llll}-2.12141 & 3.16081 & -1.41098\end{array}$ $\begin{array}{lll}-1.66439 & 4.77065 & -2.04609\end{array}$ $\begin{array}{llll}0.23296 & -2.74801 & -5.39584\end{array}$ $\begin{array}{llll}-2.07287 & 0.32395 & 0.06544\end{array}$ $\begin{array}{llll}-3.92934 & 0.72342 & -0.20707\end{array}$ $\begin{array}{llll}-3.508 & 2.43054 & 0.49302\end{array}$ $\begin{array}{lll}-4.24723 & 0.09625 & 1.53886\end{array}$ $\begin{array}{llll}-4.16312 & -0.99635 & -0.91048\end{array}$ $\begin{array}{llll}-5.71019 & 1.20872 & -0.47284\end{array}$ $\begin{array}{llll}-3.41421 & 1.31036 & -1.93129\end{array}$

$\begin{array}{lll}-0.23229 & 1.14698 & 1.5493\end{array}$ $\begin{array}{llll}0.0167 & 0.68893 & 2.87061\end{array}$ $\begin{array}{lll}0.3669 & -0.33764 & 3.03248\end{array}$ $\begin{array}{lll}-0.18602 & 1.51315 & 3.9823\end{array}$ $\begin{array}{llll}0.01513 & 1.12774 & 4.98966\end{array}$ $\begin{array}{lll}-0.64717 & 2.82665 & 3.79781\end{array}$ $\begin{array}{llll}-0.81201 & 3.48349 & 4.6618\end{array}$ $\begin{array}{lll}-0.89048 & 3.29822 & 2.5028\end{array}$ $\begin{array}{llll}-1.24041 & 4.32957 & 2.35271\end{array}$ $\begin{array}{lll}-0.69024 & 2.48166 & 1.37034\end{array}$ $\begin{array}{llll}0.04967 & 4.08272 & -0.26695\end{array}$ 
$-0.09888 \quad 4.39525-1.32006$

$\begin{array}{llll}1.07558 & 3.67975 & -0.15119\end{array}$

$\begin{array}{lll}-0.0589 & 4.98208 & 0.38403\end{array}$

$\begin{array}{llll}-2.30468 & 3.48903 & -0.14502\end{array}$

$\begin{array}{lll}-2.56011 & 4.38091 & 0.47415\end{array}$

$\begin{array}{lll}-3.00656 & 2.66992 & 0.09918\end{array}$

$\begin{array}{llll}-2.43153 & 3.762 & -1.21113\end{array}$

$\begin{array}{lll}-1.34862 & -1.28467 & 0.22793\end{array}$

$\begin{array}{llll}-2.66952 & -0.51103 & -0.06653\end{array}$

$\begin{array}{lll}-2.82923 & 0.2623 & 0.72002\end{array}$

$\begin{array}{llll}-2.59527 & 0.01127 & -1.0489\end{array}$

$\begin{array}{llll}-3.86033 & -1.49649 & -0.10184\end{array}$

$\begin{array}{llll}-4.7821 & -0.91924 & -0.32212\end{array}$

$\begin{array}{llll}-3.99368 & -2.20228 & 1.26253\end{array}$

$\begin{array}{lll}-4.85294 & -2.90544 & 1.24011\end{array}$

$\begin{array}{lll}-4.19105 & -1.4569 & 2.06339\end{array}$

$\begin{array}{llll}-2.69197 & -2.97107 & 1.56228\end{array}$

$\begin{array}{lll}-2.76433 & -3.46423 & 2.55383\end{array}$

$\begin{array}{llll}-2.44326 & -4.02744 & 0.46707\end{array}$

$\begin{array}{llll}-1.51217 & -4.59537 & 0.68591\end{array}$

$\begin{array}{llll}-3.28158 & -4.75541 & 0.45071\end{array}$

$\begin{array}{llll}-2.32555 & -3.32842 & -0.90353\end{array}$

$-2.14396-4.08132-1.69781$

$\begin{array}{llll}-3.61839 & -2.54424 & -1.20881\end{array}$

$\begin{array}{llll}-3.53539 & -2.04315 & -2.19832\end{array}$

$\begin{array}{llll}-4.48011 & -3.2427 & -1.25993\end{array}$

$\begin{array}{lll}-1.51028 & -1.97033 & 1.61715\end{array}$

$\begin{array}{llll}-1.72979 & -1.20159 & 2.38747\end{array}$

$\begin{array}{lll}-0.5821 & -2.5036 & 1.91076\end{array}$

$-1.12373-2.35759-0.86983$

$-0.19633-2.93256-0.65848$

$\begin{array}{llll}-0.99706 & -1.85981 & -1.85975\end{array}$

$\begin{array}{llll}1.81854 & -0.68065 & 0.23332\end{array}$

$\begin{array}{llll}2.02586 & -1.8762 & 1.20891\end{array}$

$\begin{array}{llll}1.72738 & -1.60495 & 2.24247\end{array}$

$\begin{array}{llll}1.40612 & -2.7415 & 0.88963\end{array}$

$\begin{array}{lll}3.51784 & -2.2921 & 1.21244\end{array}$ $\begin{array}{llll}3.63525 & -3.12719 & 1.93388\end{array}$ $\begin{array}{llll}4.39127 & -1.09689 & 1.64646\end{array}$ $\begin{array}{llll}5.45799 & -1.40377 & 1.67654\end{array}$ $\begin{array}{llll}4.10965 & -0.76862 & 2.67107\end{array}$ $\begin{array}{llll}4.20877 & 0.0663 & 0.64794\end{array}$ $\begin{array}{llll}4.83014 & 0.93096 & 0.95995\end{array}$ $\begin{array}{llll}4.61705 & -0.39448 & -0.76531\end{array}$ $\begin{array}{llll}4.50079 & 0.44123 & -1.48972\end{array}$ $\begin{array}{llll}5.68631 & -0.69418 & -0.76972\end{array}$ $3.73291-1.58573-1.18566$ $3.99746-1.90999-2.21328$ $2.25434-1.13583-1.19429$ $1.60369-1.95706-1.56184$ $2.1428 \quad-0.2825 \quad-1.89985$ $\begin{array}{llll}2.72703 & 0.50857 & 0.66012\end{array}$ $\begin{array}{lll}2.45691 & 0.85565 & 1.6795\end{array}$ $\begin{array}{llll}2.56931 & 1.36417 & -0.04142\end{array}$ $3.92262-2.75521-0.19968$ $3.30198-3.62422-0.50993$ $4.98325-3.08393-0.20172$ $\begin{array}{llll}-0.92339 & 3.02324 & 0.05117\end{array}$ $\begin{array}{llll}0.04428 & -0.02996 & 0.17531\end{array}$ $\begin{array}{llll}-0.17549 & 1.09567 & -1.79877\end{array}$

$\begin{array}{llll}3.80816 & -0.0653 & -0.86843\end{array}$ $\begin{array}{llll}3.18956 & 0.51557 & -1.9804\end{array}$ $2.39285-0.00743-2.52657$ $3.18934-2.07382-0.2891$

$\begin{array}{llll}0.58902 & -1.09902 & 0.01703\end{array}$ $\begin{array}{llll}4.82496 & 0.55453 & -0.13734\end{array}$ $\begin{array}{llll}5.29118 & 0.06414 & 0.7253\end{array}$ $\begin{array}{llll}5.24182 & 1.8321 & -0.55641\end{array}$ $\begin{array}{llll}6.0441 & 2.33809 & -0.0039\end{array}$

$\begin{array}{llll}4.64259 & 2.45047 & -1.66549\end{array}$ $\begin{array}{llll}3.61719 & 1.79817 & -2.36935\end{array}$

$\begin{array}{llll}3.14587 & 2.27698 & -3.23833\end{array}$ 
$\begin{array}{lll}-1.3145 & 0.19054 & 0.25792\end{array}$

$\begin{array}{lll}-2.21646 & -0.21468 & 1.8011\end{array}$

$\begin{array}{llll}-0.64666 & 1.93218 & 0.50562\end{array}$

$-2.44715-0.07916-1.23099$

$\begin{array}{llll}-3.46842 & 0.40086 & 2.05615\end{array}$

$\begin{array}{lll}-1.67926 & -1.08822 & 2.78494\end{array}$

$\begin{array}{llll}0.36355 & 1.84007 & 1.69155\end{array}$

$\begin{array}{llll}-1.70185 & 3.00968 & 0.88052\end{array}$

$\begin{array}{llll}0.10158 & 2.36943 & -0.78149\end{array}$

$\begin{array}{llll}-3.3985 & 1.10254 & -1.56774\end{array}$

$\begin{array}{llll}-1.56147 & -0.36382 & -2.485\end{array}$

$-3.28338-1.3596-0.942$

$\begin{array}{lll}-3.89588 & 1.08662 & 1.31343\end{array}$

$\begin{array}{lll}-4.17093 & 0.16496 & 3.24362\end{array}$

$\begin{array}{llll}-2.39785 & -1.31824 & 3.97601\end{array}$

$\begin{array}{llll}-0.42251 & -1.75945 & 2.55568\end{array}$

$\begin{array}{llll}-0.17882 & 1.52687 & 2.61301\end{array}$

$\begin{array}{lll}1.14301 & 1.07018 & 1.47742\end{array}$

$\begin{array}{lll}1.05586 & 3.20249 & 1.90889\end{array}$

$\begin{array}{lll}-0.99869 & 4.37885 & 1.07179\end{array}$

$\begin{array}{lll}-2.20229 & 2.72838 & 1.83165\end{array}$

$\begin{array}{llll}-2.47957 & 3.09828 & 0.09416\end{array}$

$\begin{array}{llll}0.81522 & 3.71694 & -0.54668\end{array}$

$\begin{array}{llll}-0.62056 & 2.47699 & -1.6207\end{array}$

$0.84221 \quad 1.58956-1.06641$

$\begin{array}{llll}-4.04908 & 1.35111 & -0.70341\end{array}$

$\begin{array}{llll}-2.80449 & 2.00857 & -1.81549\end{array}$

$\begin{array}{llll}-4.28863 & 0.73394 & -2.77908\end{array}$

$-2.44568-0.69593-3.7081$

$\begin{array}{llll}-0.90661 & 0.5076 & -2.70616\end{array}$

$\begin{array}{llll}-0.8976 & -1.23144 & -2.27251\end{array}$

$-4.15572-1.70964-2.16932$

$\begin{array}{llll}-3.93905 & -1.20195 & -0.06025\end{array}$ $\begin{array}{llll}-2.59197 & -2.20385 & -0.70036\end{array}$ $\begin{array}{llll}-5.13727 & 0.6566 & 3.41272\end{array}$ $\begin{array}{llll}-3.63075 & -0.69753 & 4.21146\end{array}$ $\begin{array}{llll}-1.97575 & -2.00491 & 4.72407\end{array}$

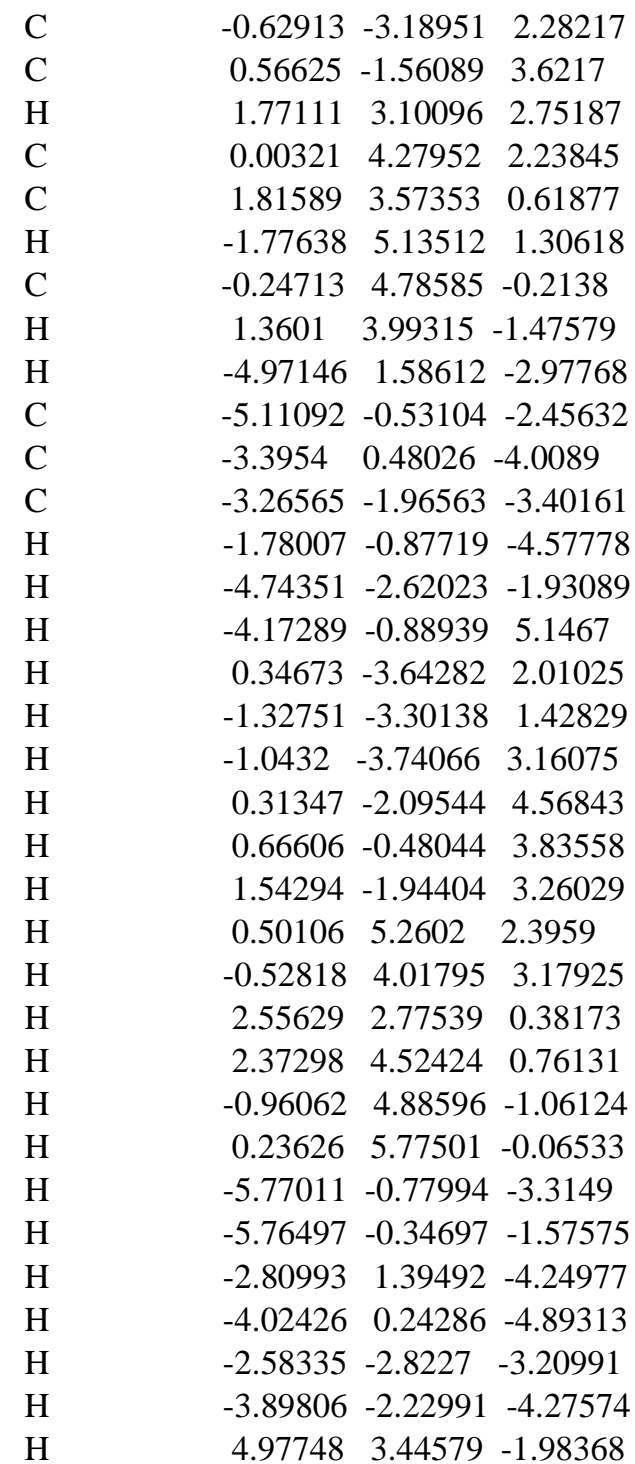

S15c-TS

C 
$\mathrm{Au}$ $\begin{array}{llll}-2.33749 & 0.75733 & 2.39762\end{array}$ $\begin{array}{lll}-2.21841 & -0.22595 & 2.86822\end{array}$ $\begin{array}{lll}-3.82536 & -0.97808 & -0.00743\end{array}$ $\begin{array}{llll}-1.15769 & -0.45891 & -0.2615\end{array}$ $\begin{array}{llll}-2.83751 & 2.10485 & 0.38886\end{array}$ $\begin{array}{lll}-3.09911 & 2.15264 & -0.67599\end{array}$ $\begin{array}{lll}-2.72987 & 3.27217 & 1.16859\end{array}$ $\begin{array}{lll}-2.91421 & 4.24506 & 0.6932\end{array}$ $\begin{array}{lll}-2.40107 & 3.1965 & 2.53104\end{array}$ $\begin{array}{lll}-2.20775 & 1.94265 & 3.13999\end{array}$ $\begin{array}{lll}-1.97434 & 1.87439 & 4.21111\end{array}$ $1.17306-0.11084-0.27516$ $\begin{array}{llll}1.84974 & -1.00739 & -1.71935\end{array}$ $\begin{array}{llll}1.4908 & 1.71903 & -0.5534\end{array}$ $\begin{array}{lll}1.91881 & -0.87183 & 1.28629\end{array}$ $3.24846-1.02661-1.95679$ $\begin{array}{llll}1.00639 & -1.73067 & -2.60209\end{array}$ $\begin{array}{llll}0.63567 & 2.12478 & -1.79295\end{array}$ $\begin{array}{llll}2.96321 & 2.10953 & -0.85769\end{array}$ $\begin{array}{lll}0.9844 & 2.49993 & 0.68994\end{array}$ $\begin{array}{lll}3.31675 & -0.3248 & 1.67956\end{array}$ $\begin{array}{llll}0.93052 & -0.64031 & 2.46804\end{array}$ $\begin{array}{llll}2.01527 & -2.40786 & 1.05137\end{array}$ $\begin{array}{llll}3.92051 & -0.49595 & -1.271\end{array}$ $\begin{array}{llll}3.79496 & -1.7152 & -3.04556\end{array}$ $\begin{array}{llll}1.56641 & -2.41132 & -3.70251\end{array}$ $-0.42732-1.79516-2.38099$ $\begin{array}{llll}0.97767 & 1.54895 & -2.6844\end{array}$ $\begin{array}{llll}-0.43695 & 1.87219 & -1.61392\end{array}$ $0.75734 \quad 3.64446-2.05195$ $\begin{array}{llll}3.0662 & 3.64055 & -1.06929\end{array}$ $\begin{array}{llll}3.29458 & 1.60518 & -1.78984\end{array}$ $\begin{array}{llll}3.63956 & 1.79827 & -0.03526\end{array}$ $\begin{array}{llll}1.07091 & 4.0199 & 0.42333\end{array}$ $\begin{array}{lll}1.61589 & 2.25491 & 1.57231\end{array}$ $\begin{array}{lll}-0.05989 & 2.19985 & 0.93049\end{array}$ $\begin{array}{llll}4.04401 & -0.48221 & 0.8543\end{array}$ $\begin{array}{lll}3.2584 & 0.76662 & 1.87956\end{array}$ $\begin{array}{llll}3.82374 & -1.04511 \quad 2.952\end{array}$ $1.45614-1.32 \quad 3.75174$ $\begin{array}{llll}0.75782 & 0.44499 & 2.6398\end{array}$ $\begin{array}{lll}-0.05096 & -1.0922 & 2.19938\end{array}$ $\begin{array}{llll}2.51374 & -3.10868 & 2.3367\end{array}$ $\begin{array}{llll}2.71811 & -2.62737 & 0.22018\end{array}$ $\begin{array}{llll}1.01047 & -2.80026 & 0.75659\end{array}$ $\begin{array}{llll}4.88089 & -1.71401 & -3.20333\end{array}$ $2.94786-2.40405-3.92919$ $0.9023-2.96008-4.38546$ $-0.89302-3.17703-2.16236$

$\begin{array}{llll}-1.18837 & -1.14169 & -3.46242\end{array}$ $\begin{array}{llll}0.14141 & 3.89893 & -2.93974\end{array}$ $\begin{array}{llll}2.22844 & 4.02805 & -2.30363\end{array}$ $\begin{array}{llll}0.23135 & 4.40012 & -0.81474\end{array}$ $\begin{array}{llll}4.13256 & 3.89407 & -1.24322\end{array}$ $\begin{array}{llll}2.54839 & 4.39226 & 0.17593\end{array}$ $\begin{array}{llll}0.68294 & 4.55286 & 1.31811\end{array}$ $\begin{array}{lll}4.82901 & -0.64555 & 3.19985\end{array}$ $\begin{array}{llll}3.91329 & -2.56315 & 2.69209\end{array}$ $\begin{array}{lll}2.84868 & -0.76557 & 4.11326\end{array}$ $\begin{array}{lll}1.5449 & -2.84008 & 3.5056\end{array}$ $\begin{array}{llll}0.74098 & -1.11198 & 4.57549\end{array}$ $\begin{array}{llll}2.5741 & -4.19886 & 2.13818\end{array}$ $3.36438-2.94284-4.79018$ $\begin{array}{lll}-1.9617 & -3.14383 & -1.87089\end{array}$ $\begin{array}{llll}-0.30697 & -3.62981 & -1.33981\end{array}$ $\begin{array}{llll}-0.79398 & -3.81005 & -3.07328\end{array}$ $\begin{array}{llll}-1.07117 & -1.66474 & -4.43923\end{array}$ $\begin{array}{lll}-0.84258 & -0.09518 & -3.56789\end{array}$ $\begin{array}{llll}-2.26182 & -1.14436 & -3.18582\end{array}$ $\begin{array}{llll}2.30412 & 5.12053 & -2.49008\end{array}$ $\begin{array}{llll}2.61481 & 3.50591 & -3.20589\end{array}$ $\begin{array}{lll}-0.83663 & 4.145 & -0.64798\end{array}$ $\begin{array}{lll}0.29295 & 5.49607 & -0.98653\end{array}$ $\begin{array}{lll}3.16138 & 4.12645 \quad 1.06534\end{array}$ 


\begin{tabular}{|c|c|c|c|}
\hline H & 2.64534 & . 5.4876 & 0.01874 \\
\hline $\mathrm{H}$ & 4.30006 & -3.07809 & 3.597 \\
\hline $\mathrm{H}$ & 4.62488 & -2.76679 & 1.8621 \\
\hline $\mathrm{H}$ & 2.7885 & 0.32864 & 4.30436 \\
\hline $\mathrm{H}$ & 3.21723 & -1.24776 & 5.04341 \\
\hline $\mathrm{H}$ & 0.53695 & -3.24705 & 3.26945 \\
\hline $\mathrm{H}$ & 1.90739 & -3.35441 & 4.42093 \\
\hline $\mathrm{H}$ & -2.32752 & 4.11318 & 3.12926 \\
\hline \multicolumn{4}{|c|}{ S15d } \\
\hline $\mathrm{C}$ & -1.6142 & 1.37359 & 1.1704 \\
\hline $\mathrm{C}$ & -1.91204 & 2.60477 & 0.56635 \\
\hline $\mathrm{H}$ & -2.05987 & 2.68738 & -0.51871 \\
\hline I & -4.00763 & -0.43799 & 0.09801 \\
\hline $\mathrm{Au}$ & -1.3083 & $1-0.1957$ & $5-0.1588$ \\
\hline $\mathrm{C}$ & -1.5639 & 1.24223 & 2.56181 \\
\hline $\mathrm{H}$ & -1.44838 & 0.26652 & 2 3.04441 \\
\hline $\mathrm{C}$ & -1.68862 & 2.39816 & 3.35663 \\
\hline $\mathrm{H}$ & -1.6356 & 2.29976 & 4.44923 \\
\hline $\mathrm{C}$ & -1.89832 & 3.65312 & 2.76673 \\
\hline $\mathrm{C}$ & -2.03475 & 3.75036 & 1.37414 \\
\hline $\mathrm{H}$ & -2.25524 & $\begin{array}{r}4.71639 \\
+\end{array}$ & 0.8995 \\
\hline$P$ & 1.10496 & -0.209 & -0.30666 \\
\hline $\mathrm{C}$ & 1.3697 & -1.25577 & -1.78161 \\
\hline $\mathrm{C}$ & 1.81208 & 1.4972 & -0.66194 \\
\hline $\mathrm{C}$ & 1.84495 & -1.17237 & 1.14014 \\
\hline $\mathrm{C}$ & 2.68275 & -1.56371 & -2.22539 \\
\hline $\mathrm{C}$ & 0.2803 & -1.87934 & -2.42502 \\
\hline $\mathrm{C}$ & 0.89008 & 2.11525 & -1.7562 \\
\hline $\mathrm{C}$ & 3.25862 & 1.50337 & -1.23809 \\
\hline $\mathrm{C}$ & 1.76922 & 2.36022 & 0.63219 \\
\hline $\mathrm{C}$ & 3.37728 & -0.98266 & 1.2999 \\
\hline $\mathrm{C}$ & 1.12039 & -0.73827 & 2.44121 \\
\hline $\mathrm{C}$ & 1.53449 & -2.6824 & 0.92096 \\
\hline $\mathrm{H}$ & 3.54579 & -1.1306 & -1.70904 \\
\hline $\mathrm{C}$ & 2.90165 & -2.42665 & -3.30379 \\
\hline $\mathrm{C}$ & 0.50526 & -2.73565 & -3.52205 \\
\hline
\end{tabular}

$\begin{array}{lrll}\mathrm{N} & -1.10334 & -1.65435 & -1.9711 \\ \mathrm{H} & 0.95093 & 1.49233 & -2.68037 \\ \mathrm{H} & -0.16582 & 2.11363 & -1.41556 \\ \mathrm{C} & 1.32995 & 3.56696 & -2.05934 \\ \mathrm{C} & 3.70515 & 2.96097 & -1.51851 \\ \mathrm{H} & 3.27513 & 0.95236 & -2.20081 \\ \mathrm{H} & 3.97411 & 1.01887 & -0.54102 \\ \mathrm{C} & 2.19402 & 3.80979 & 0.30089 \\ \mathrm{H} & 2.47307 & 1.94009 & 1.3839 \\ \mathrm{H} & 0.75514 & 2.35525 & 1.0818 \\ \mathrm{H} & 3.90926 & -1.31066 & 0.3813 \\ \mathrm{H} & 3.61879 & 0.08689 & 1.47402 \\ \mathrm{C} & 3.87706 & -1.81928 & 2.50299 \\ \mathrm{C} & 1.65659 & -1.53619 & 3.65001 \\ \mathrm{H} & 1.21533 & 0.35601 & 2.61289 \\ \mathrm{H} & 0.04089 & -0.96781 & 2.31443 \\ \mathrm{C} & 2.03794 & -3.50216 & 2.13304 \\ \mathrm{H} & 2.02982 & -3.05466 & -0.00037 \\ \mathrm{H} & 0.43169 & -2.81634 & 0.79484 \\ \mathrm{H} & 3.92659 & -2.64818 & -3.62635 \\ \mathrm{C} & 1.80552 & -3.00514 & -3.9632 \\ \mathrm{H} & -0.34333 & -3.2036 & -4.03696 \\ \mathrm{C} & -1.76196 & -2.95739 & -1.65151 \\ \mathrm{C} & -1.86333 & -0.94577 & -3.04894 \\ \mathrm{H} & 0.64432 & 3.98604 & -2.82498 \\ \mathrm{C} & 2.77785 & 3.5724 & -2.58761 \\ \mathrm{C} & 1.24891 & 4.40448 & -0.76481 \\ \mathrm{H} & 4.74746 & 2.92739 & -1.89832 \\ \mathrm{C} & 3.64194 & 3.80099 & -0.22754 \\ \mathrm{H} & 2.13177 & 4.40886 & 1.23268 \\ \mathrm{H} & 4.97364 & -1.67355 & 2.59078 \\ \mathrm{C} & 3.56383 & -3.31087 & 2.26497 \\ \mathrm{C} & 3.17824 & -1.32851 & 3.78705 \\ \mathrm{C} & 1.3471 & -3.03052 & 3.42805 \\ \mathrm{H} & 1.14056 & -1.17386 & 4.56349 \\ \mathrm{H} & 1.80686 & -4.57145 & 1.94719 \\ \mathrm{H} & 1.96093 & -3.67767 & -4.81632 \\ & & & \\ & & & \\ & & & \end{array}$


S16a

$\mathrm{C}$

$\mathrm{C}$ $\begin{array}{llll}-2.77142 & -2.75417 & -1.25752\end{array}$

$\begin{array}{llll}-1.1591 & -3.48151 & -0.88814\end{array}$

$\begin{array}{llll}-1.84679 & -3.59272 & -2.55551\end{array}$

$\begin{array}{llll}-1.86609 & -1.54379 & -3.98301\end{array}$

$\begin{array}{llll}-1.37669 & 0.03072 & -3.23934\end{array}$

$\begin{array}{llll}-2.90131 & -0.78829 & -2.70858\end{array}$

$\begin{array}{llll}3.093 & 4.61323 & -2.81303\end{array}$

$\begin{array}{llll}2.84563 & 2.98921 & -3.53188\end{array}$

$\begin{array}{llll}0.20652 & 4.42026 & -0.38052\end{array}$

$\begin{array}{llll}1.54244 & 5.45356 & -0.98183\end{array}$

$\begin{array}{llll}4.32534 & 3.37671 & 0.54071\end{array}$

$\begin{array}{llll}3.97923 & 4.83792 & -0.43846\end{array}$

$\begin{array}{llll}3.94654 & -3.91626 & 3.11355\end{array}$

$\begin{array}{llll}4.07573 & -3.66607 & 1.34375\end{array}$

$\begin{array}{llll}3.40564 & -0.25312 & 3.95689\end{array}$

$\begin{array}{llll}3.5586 & -1.89274 & 4.66448\end{array}$

$\begin{array}{llll}0.24817 & -3.18551 & 3.35675\end{array}$

$\begin{array}{llll}1.71394 & -3.62891 & 4.28862\end{array}$

$\begin{array}{llll}-1.99596 & 4.54811 & 3.39418\end{array}$

$\begin{array}{llll}-2.62149 & 0.8429 & -0.15048\end{array}$ $\begin{array}{llll}-4.04049 & 0.89027 & -0.15784\end{array}$

$\begin{array}{llll}-4.61024 & -0.03487 & -0.02041\end{array}$ $\begin{array}{llll}-4.74799 & 2.08475 & -0.33885\end{array}$

$\begin{array}{llll}-5.84614 & 2.07543 & -0.33487\end{array}$ $\begin{array}{llll}-4.04167 & 3.28215 & -0.52698\end{array}$

$\begin{array}{llll}-4.57794 & 4.22847 & -0.68098\end{array}$ $\begin{array}{llll}-2.6426 & 3.26461 & -0.49084\end{array}$

$\begin{array}{llll}-2.07488 & 4.20054 & -0.59683\end{array}$

$\begin{array}{llll}-1.90738 & 2.07341 & -0.28686\end{array}$

$-2.37809-1.86788-1.3995$

$-1.68876-1.28763-2.65765$

$\begin{array}{llll}-1.98995 & -0.23447 & -2.8289\end{array}$

$\begin{array}{llll}-0.58364 & -1.33633 & -2.58179\end{array}$

$-3.89282-1.91726-1.69948$

$\begin{array}{llll}-4.26542 & -0.94367 & -2.0695\end{array}$ $\begin{array}{lll}-4.50839 & -2.23428 & -0.83693\end{array}$

$\begin{array}{llll}-1.86098 & -3.30935 & -1.18691\end{array}$

$\begin{array}{lll}-2.42102 & -3.8419 & -0.39336\end{array}$

$\begin{array}{llll}-0.78003 & -3.32507 & -0.93794\end{array}$

$\begin{array}{llll}-2.33417 & -1.51019 & 1.72548\end{array}$

$\begin{array}{lll}-3.74753 & -2.12238 & 1.80098\end{array}$

$\begin{array}{llll}-4.54599 & -1.40228 & 1.54074\end{array}$

$\begin{array}{lll}-3.84983 & -3.02014 & 1.16137\end{array}$

$\begin{array}{lll}-1.31116 & -2.58885 & 2.1702\end{array}$

$\begin{array}{lll}-1.23565 & -3.43692 & 1.46549\end{array}$

$\begin{array}{llll}-0.29949 & -2.15645 & 2.29714\end{array}$

$\begin{array}{lll}-2.22687 & -0.34936 & 2.73852\end{array}$

$\begin{array}{lll}-3.00531 & 0.42112 & 2.57208\end{array}$

$\begin{array}{lll}-1.22649 & 0.13036 & 2.68217\end{array}$

$\begin{array}{llll}-1.78749 & -0.79938 & 0.05067\end{array}$

$\begin{array}{lll}0.57494 & -0.78142 & 0.01101\end{array}$

$\begin{array}{llll}-0.41871 & 2.24393 & -0.1143\end{array}$

$\begin{array}{llll}0.0749 & 2.55908 & 1.18168\end{array}$

$\begin{array}{llll}0.47716 & 2.19196 & -1.2132\end{array}$

$\begin{array}{lll}1.46455 & 2.66896 & 1.3738\end{array}$

$\begin{array}{llll}1.85411 & 2.36554 & -0.98212\end{array}$

$\begin{array}{llll}2.37391 & 2.55847 & 0.30781\end{array}$

$\begin{array}{lll}1.845 & 2.86178 & 2.39008\end{array}$

$\begin{array}{llll}2.54602 & 2.27638 & -1.83645\end{array}$

$\begin{array}{lll}-2.00624 & -3.87141 & -2.13357\end{array}$

$\begin{array}{llll}-4.04699 & -2.66039 & -2.51033\end{array}$

$\begin{array}{llll}-2.0086 & -1.88452 & -3.53832\end{array}$

$\begin{array}{llll}-3.9252 & -2.44158 & 2.85\end{array}$

$\begin{array}{lll}-1.64586 & -2.98844 & 3.15153\end{array}$

$\begin{array}{lll}-2.35423 & -0.76143 & 3.76176\end{array}$

$\begin{array}{llll}0.02132 & 1.89731 & -2.62857\end{array}$

$\begin{array}{llll}0.50843 & 2.59132 & -3.34153\end{array}$

$\begin{array}{llll}0.32182 & 0.87058 & -2.92202\end{array}$

$\begin{array}{llll}-1.07397 & 1.99017 & -2.74956\end{array}$

$\begin{array}{llll}3.86774 & 2.64405 & 0.53858\end{array}$

$\begin{array}{llll}4.23244 & 3.68919 & 0.45832\end{array}$

$\begin{array}{llll}4.13464 & 2.27053 & 1.54585\end{array}$ 


\begin{tabular}{|c|c|c|c|}
\hline H & 4.41486 & 2.03531 & -0.20661 \\
\hline $\mathrm{C}$ & -0.84674 & 2.88256 & 2.34563 \\
\hline $\mathrm{H}$ & -0.40333 & 2.55336 & 53.30551 \\
\hline $\mathrm{H}$ & -0.99334 & 3.98153 & 2.41261 \\
\hline $\mathrm{H}$ & -1.84927 & 2.43276 & 5.24766 \\
\hline $\mathrm{C}$ & 2.62036 & -0.82849 & -0.06393 \\
\hline $\mathrm{C}$ & 3.32287 & -0.66353 & -1.26501 \\
\hline $\mathrm{C}$ & 3.45145 & -0.94804 & 1.05664 \\
\hline $\mathrm{C}$ & 4.71607 & -0.63341 & -1.38944 \\
\hline $\mathrm{C}$ & 4.85158 & -0.92476 & 1.0243 \\
\hline $\mathrm{C}$ & 5.48256 & -0.77105 & -0.21969 \\
\hline $\mathrm{H}$ & 5.17855 & -0.50834 & -2.37627 \\
\hline $\mathrm{H}$ & 5.42274 & -1.0283 & 1.95508 \\
\hline $\mathrm{H}$ & 6.57883 & -0.7552 & -0.27906 \\
\hline $\mathrm{F}$ & 2.86298 & -1.09474 & 2.27944 \\
\hline $\mathrm{F}$ & 2.59363 & -0.50374 & -2.41325 \\
\hline \multicolumn{4}{|c|}{ S16c-TS } \\
\hline C & 2.64151 & 0.13071 & -1.11342 \\
\hline $\mathrm{C}$ & 3.52144 & -0.96085 & -1.10057 \\
\hline $\mathrm{H}$ & 3.19091 & -1.95426 & -1.43089 \\
\hline I & 1.03105 & 0.08035 & -3.02246 \\
\hline $\mathrm{Au}$ & 0.55283 & -0.37023 & $3-0.12632$ \\
\hline $\mathrm{C}$ & 3.0331 & 1.42535 & -0.74992 \\
\hline $\mathrm{H}$ & 2.32958 & 2.25911 & -0.83317 \\
\hline $\mathrm{C}$ & 4.31272 & 1.59558 & -0.19839 \\
\hline $\mathrm{H}$ & 4.61566 & 2.59803 & 0.13966 \\
\hline $\mathrm{C}$ & 5.18779 & 0.50305 & -0.07165 \\
\hline $\mathrm{C}$ & 4.79468 & -0.76201 & -0.54404 \\
\hline $\mathrm{H}$ & 5.48072 & -1.61796 & -0.47119 \\
\hline $\mathrm{P}$ & -1.90298 & -1.10592 & 0.17747 \\
\hline $\mathrm{C}$ & -3.39324 & 0.0096 & 0.06983 \\
\hline $\mathrm{C}$ & -2.14056 & -2.57607 & $7-1.02261$ \\
\hline $\mathrm{C}$ & -2.03761 & -1.71587 & 71.9739 \\
\hline $\mathrm{C}$ & -4.67341 & -0.56598 & -0.12547 \\
\hline $\mathrm{C}$ & -3.32438 & 1.42064 & 0.27939 \\
\hline $\mathrm{C}$ & -2.57442 & -2.00259 & -2.39227 \\
\hline
\end{tabular}

$\begin{array}{llll}\text { C } & -3.09684 & -3.73063 & -0.63149 \\ \mathrm{C} & -0.74145 & -3.22831 & -1.21961 \\ \mathrm{C} & -3.45148 & -2.16926 & 2.40559 \\ \mathrm{C} & -1.03824 & -2.85858 & 2.24784 \\ \mathrm{C} & -1.67227 & -0.50149 & 2.85769 \\ \mathrm{H} & -4.75708 & -1.6477 & -0.26919 \\ \mathrm{C} & -5.84979 & 0.19345 & -0.11487 \\ \mathrm{C} & -4.52508 & 2.16808 & 0.30754 \\ \mathrm{H} & -3.59262 & -1.56872 & -2.37302 \\ \mathrm{H} & -1.86413 & -1.22923 & -2.74515 \\ \mathrm{H} & -4.14992 & -3.43249 & -0.4871 \\ \mathrm{H} & -2.7598 & -4.2655 & 0.2751 \\ \mathrm{H} & -0.27712 & -3.55779 & -0.27089 \\ \mathrm{H} & -0.03723 & -2.54377 & -1.72811 \\ \mathrm{H} & -4.17969 & -1.3375 & 2.36687 \\ \mathrm{H} & -3.84536 & -3.01421 & 1.8116 \\ \mathrm{H} & -1.33286 & -3.80646 & 1.75882 \\ \mathrm{H} & -0.01412 & -2.59968 & 1.93206 \\ \mathrm{H} & -2.45793 & 0.26898 & 2.76981 \\ \mathrm{H} & -0.69277 & -0.04969 & 2.59814 \\ \mathrm{H} & -6.81806 & -0.29962 & -0.27454 \\ \mathrm{C} & -5.77804 & 1.57478 & 0.11554 \\ \mathrm{H} & -4.44396 & 3.2533 & 0.47097 \\ \mathrm{H} & -6.6895 & 2.1874 & 0.13728 \\ \mathrm{H} & 6.18357 & 0.64065 & 0.36882 \\ \mathrm{H} & -2.56341 & -2.82913 & -3.1342 \\ \mathrm{H} & -3.08174 & -4.46175 & -1.46754 \\ \mathrm{H} & -0.86961 & -4.12061 & -1.86899 \\ \mathrm{H} & -3.38403 & -2.5074 & 3.46178 \\ \mathrm{H} & -1.02222 & -3.04161 & 3.34313 \\ \mathrm{H} & -1.63959 & -0.83418 & 3.91718 \\ \mathrm{C} & -2.0461 & 2.21036 & 0.36438 \\ \mathrm{C} & -1.60779 & 2.83262 & 1.56134 \\ \mathrm{C} & -1.36483 & 2.47326 & -0.85676 \\ \mathrm{C} & -0.41251 & 3.57393 & 1.53853 \\ \mathrm{C} & -0.17445 & 3.22152 & -0.83222 \\ \mathrm{C} & 0.34022 & 3.74743 & 0.36837 \\ & & & \\ & & & \\ & & & \end{array}$




\section{S16d}

$\mathrm{C}$

$\mathrm{C}$ $\begin{array}{lll}-0.05344 & 4.02394 & 2.47901\end{array}$

$\begin{array}{llll}0.35654 & 3.40537 & -1.78158\end{array}$

$\begin{array}{llll}-2.39299 & 2.82014 & 2.86337\end{array}$

$\begin{array}{lll}-1.80098 & 2.36537 & 3.68263\end{array}$

$\begin{array}{lll}-2.62061 & 3.86147 & 3.16795\end{array}$

$\begin{array}{llll}-3.35067 & 2.27611 & 2.78682\end{array}$

$\begin{array}{llll}-1.97766 & 2.04996 & -2.17763\end{array}$

$\begin{array}{llll}-1.36387 & 2.40509 & -3.02472\end{array}$

$\begin{array}{llll}-2.07375 & 0.95011 & -2.26499\end{array}$

$\begin{array}{llll}-3.00097 & 2.46779 & -2.27781\end{array}$

$\begin{array}{llll}1.65694 & 4.49524 & 0.41753\end{array}$

$\begin{array}{llll}2.41227 & 3.90251 & 0.97622\end{array}$

$\begin{array}{llll}2.05379 & 4.68824 & -0.59852\end{array}$

$\begin{array}{llll}1.55169 & 5.46719 & 0.93847\end{array}$

$\begin{array}{llll}1.81324 & -0.68418 & 1.53715\end{array}$

$\begin{array}{llll}2.4629 & -1.90591 & 1.74072\end{array}$

$\begin{array}{llll}2.26628 & 0.34498 & 2.36596\end{array}$

$\begin{array}{llll}3.46429 & -2.13291 & 2.68873\end{array}$

$\begin{array}{lll}3.26666 & 0.2043 & 3.33587\end{array}$

$\begin{array}{llll}3.86375 & -1.05476 & 3.49476\end{array}$

$\begin{array}{llll}3.92067 & -3.12672 & 2.77617\end{array}$

$\begin{array}{llll}3.56745 & 1.07033 & 3.93854\end{array}$

$\begin{array}{llll}4.65108 & -1.19622 & 4.24649\end{array}$

$\begin{array}{llll}1.71623 & 1.58193 & 2.20419\end{array}$

$2.12096-2.95345 \quad 0.92549$

$2.75368 \quad 0.21525-0.19666$ $3.62588-0.14547-1.23305$ $3.2476-0.65633-2.12843$ $\begin{array}{llll}0.77012 & 1.73733 & -2.38946\end{array}$ $0.72954-0.21246-0.34554$ $\begin{array}{llll}3.21461 & 0.86254 & 0.95485\end{array}$ $\begin{array}{llll}2.52647 & 1.0893 & 1.77801\end{array}$

$\begin{array}{lll}4.57434 & 1.21788 & 1.04109\end{array}$ $\begin{array}{llll}4.93452 & 1.74853 & 1.93514\end{array}$ $\begin{array}{llll}5.45955 & 0.88529 & 0.0055\end{array}$
$4.98492 \quad 0.19572-1.12291$

$5.67274-0.06988-1.93801$

$\begin{array}{llll}-1.85352 & -0.89256 & -0.48757\end{array}$

$\begin{array}{llll}-3.18878 & 0.20625 & 0.20669\end{array}$ $\begin{array}{llll}-2.27226 & -1.30992 & -2.30837\end{array}$ $\begin{array}{llll}-2.11471 & -2.43484 & 0.60275\end{array}$ $\begin{array}{lll}-4.52964 & -0.10375 & -0.13426\end{array}$ $\begin{array}{llll}-2.96834 & 1.2277 & 1.17898\end{array}$ $\begin{array}{llll}-2.75823 & -0.02529 & -3.01938\end{array}$ $-3.29614-2.44174-2.56858$ $\begin{array}{llll}-0.9583 & -1.78026 & -2.9922\end{array}$ $\begin{array}{llll}-3.55016 & -3.00077 & 0.73955\end{array}$ $\begin{array}{llll}-1.20193 & -3.58669 & 0.09573\end{array}$ $\begin{array}{lll}-1.72649 & -1.95244 & 2.02545\end{array}$ $\begin{array}{llll}-4.7251 & -0.88731 & -0.8738\end{array}$ $\begin{array}{llll}-5.62509 & 0.53442 & 0.45995\end{array}$ $\begin{array}{llll}-4.08863 & 1.84076 & 1.78811\end{array}$ $\begin{array}{llll}-3.74761 & 0.31011 & -2.65377\end{array}$ $\begin{array}{llll}-2.03536 & 0.80376 & -2.90919\end{array}$ $\begin{array}{llll}-4.3127 & -2.24554 & -2.18374\end{array}$ $\begin{array}{llll}-2.94859 & -3.41449 & -2.17384\end{array}$ $\begin{array}{llll}-0.57989 & -2.7281 & -2.56316\end{array}$ $\begin{array}{llll}-0.15666 & -1.0228 & -2.94554\end{array}$ $\begin{array}{llll}-4.24966 & -2.27017 & 1.18414\end{array}$ $\begin{array}{llll}-3.97385 & -3.38266 & -0.20567\end{array}$ $\begin{array}{llll}-1.78047 & -4.29479 & -0.53026\end{array}$ $\begin{array}{llll}-0.3476 & -3.23759 & -0.50152\end{array}$ $\begin{array}{llll}-2.5997 & -1.46677 & 2.50162\end{array}$ $\begin{array}{lll}-0.90097 & -1.2215 & 2.02581\end{array}$ $\begin{array}{llll}-6.64479 & 0.26197 & 0.1569\end{array}$ $\begin{array}{llll}-5.40373 & 1.50473 & 1.44754\end{array}$ $\begin{array}{llll}-3.89223 & 2.62595 & 2.53356\end{array}$ $\begin{array}{lll}-6.24803 & 2.00846 & 1.93738\end{array}$ $\begin{array}{llll}6.52149 & 1.15648 & 0.07815\end{array}$ $\begin{array}{llll}-2.84973 & -0.24899 & -4.10338\end{array}$ $\begin{array}{llll}-3.38323 & -2.54692 & -3.67075\end{array}$ $\begin{array}{llll}-1.18457 & -1.96594 & -4.06365\end{array}$ 
S17a $\begin{array}{lll}-3.4814 & -3.86068 & 1.44085\end{array}$

$\begin{array}{llll}-0.78961 & -4.1521 & 0.95861\end{array}$

$\begin{array}{lll}-1.42574 & -2.81993 & 2.65011\end{array}$

$\begin{array}{lll}-1.63158 & 1.83776 & 1.5061\end{array}$

$\begin{array}{llll}-0.95733 & 1.62433 & 2.73359\end{array}$

$\begin{array}{llll}-1.14908 & 2.82219 & 0.59566\end{array}$

$\begin{array}{llll}0.2758 & 2.27703 & 2.94829\end{array}$

$\begin{array}{llll}0.07046 & 3.46236 & 0.86091\end{array}$

$\begin{array}{llll}0.81742 & 3.1778 & 2.0195\end{array}$

$\begin{array}{lll}0.81909 & 2.0742 & 3.88713\end{array}$

$\begin{array}{llll}0.45379 & 4.19402 & 0.13294\end{array}$

$\begin{array}{lll}-1.53468 & 0.80927 & 3.87884\end{array}$

$\begin{array}{llll}-0.91794 & -0.08269 & 4.10388\end{array}$

$\begin{array}{lll}-1.55205 & 1.43046 & 4.79662\end{array}$

$\begin{array}{llll}-2.56755 & 0.4738 & 3.68009\end{array}$

$\begin{array}{llll}-1.9893 & 3.24872 & -0.59257\end{array}$

$\begin{array}{llll}-1.45143 & 4.00005 & -1.19778\end{array}$

$\begin{array}{llll}-2.24476 & 2.40092 & -1.25625\end{array}$

$\begin{array}{llll}-2.94932 & 3.68628 & -0.24512\end{array}$

$\begin{array}{llll}2.14896 & 3.86066 & 2.26054\end{array}$

$\begin{array}{llll}2.71193 & 3.3633 & 3.07552\end{array}$

$\begin{array}{llll}2.774 & 3.83535 & 1.34615\end{array}$

$\begin{array}{lll}2.01253 & 4.92418 & 2.54343\end{array}$

$\begin{array}{llll}1.4479 & -1.78691 & 0.80195\end{array}$

$\begin{array}{llll}1.99133 & -2.88773 & 0.12684\end{array}$

$\begin{array}{llll}1.59053 & -1.82147 & 2.19197\end{array}$

$\begin{array}{llll}2.53956 & -4.00518 & 0.75858\end{array}$

$\begin{array}{llll}2.11643 & -2.91334 & 2.89172\end{array}$

$\begin{array}{llll}2.59063 & -4.01258 & 2.16148\end{array}$

$\begin{array}{llll}2.91623 & -4.83925 & 0.15485\end{array}$

$\begin{array}{llll}2.16576 & -2.8757 & 3.98658\end{array}$

$\begin{array}{llll}3.01515 & -4.87624 & 2.68851\end{array}$

$\begin{array}{llll}1.18249 & -0.74748 & 2.91425\end{array}$

$1.92598-2.89034-1.23253$

$-1.74966-0.24234-0.09068$ $\begin{array}{llll}-2.89868 & 0.54924 & -0.33847\end{array}$

$\begin{array}{llll}-2.8108 & 1.63577 & -0.46912\end{array}$

$\begin{array}{llll}-4.16385 & -0.04816 & -0.40601\end{array}$

$\begin{array}{llll}-5.04625 & 0.57396 & -0.60193\end{array}$

$\begin{array}{llll}-4.3006 & -1.43496 & -0.22263\end{array}$

$\begin{array}{llll}-5.29324 & -1.89948 & -0.27999\end{array}$

$\begin{array}{llll}-3.16969 & -2.22578 & 0.03452\end{array}$

$\begin{array}{llll}-3.2725 & -3.3083 & 0.18066\end{array}$

$\begin{array}{llll}-1.89898 & -1.63575 & 0.0988\end{array}$

$\begin{array}{lll}0.02243 & 1.2633 & 1.77637\end{array}$

$\begin{array}{llll}-0.0018 & 0.07304 & 2.76681\end{array}$

$\begin{array}{lll}-0.8953 & -0.56795 & 2.62884\end{array}$

$\begin{array}{llll}0.90869 & -0.55361 & 2.67782\end{array}$

$\begin{array}{lll}-1.18797 & 2.17777 & 2.09121\end{array}$

$\begin{array}{llll}-2.13527 & 1.60665 & 2.10177\end{array}$

$\begin{array}{lll}-1.28561 & 3.03172 & 1.39595\end{array}$

$\begin{array}{llll}1.34877 & 2.03447 & 1.93533\end{array}$

$\begin{array}{lll}1.37587 & 2.96194 & 1.33233\end{array}$

$\begin{array}{lll}2.22371 & 1.4056 & 1.66737\end{array}$

$\begin{array}{llll}0.20513 & 1.72142 & -1.37983\end{array}$

$\begin{array}{llll}-0.39954 & 3.13272 & -1.17959\end{array}$

$\begin{array}{llll}-1.49293 & 3.12753 & -1.02058\end{array}$ $\begin{array}{llll}0.08095 & 3.68057 & -0.34733\end{array}$

$\begin{array}{llll}1.73478 & 1.87886 & -1.5849\end{array}$

$\begin{array}{llll}2.26708 & 2.21595 & -0.67618\end{array}$

$\begin{array}{llll}2.19441 & 0.93388 & -1.93694\end{array}$

$\begin{array}{llll}-0.38953 & 1.0635 & -2.64799\end{array}$

$\begin{array}{llll}-1.49487 & 1.05397 & -2.64084\end{array}$ $\begin{array}{llll}-0.02896 & 0.02096 & -2.77527\end{array}$

$\begin{array}{llll}-0.11888 & 0.54482 & 0.05436\end{array}$

$\begin{array}{llll}1.47566 & -1.07684 & -0.11851\end{array}$

$\begin{array}{llll}1.45433 & 2.32317 & 3.00024\end{array}$

$\begin{array}{lll}-1.03119 & 2.5914 & 3.10784\end{array}$

$\begin{array}{llll}-0.03293 & 0.48624 & 3.79505\end{array}$

$\begin{array}{llll}-0.20655 & 3.70379 & -2.11003\end{array}$

$\begin{array}{llll}1.89042 & 2.64192 & -2.37389\end{array}$

$\begin{array}{lll}-0.05053 & 1.65 & -3.5254\end{array}$ 
$\begin{array}{lll}-3.1546 & 0.43195 & -0.2371\end{array}$

$\begin{array}{llll}-3.16018 & 1.28382 & 0.87277\end{array}$

$\begin{array}{llll}-3.04643 & 0.89347 & 1.89227\end{array}$

$\begin{array}{lll}-2.86904 & -1.70339 & 0.11779\end{array}$

$\begin{array}{lll}-0.23234 & -0.75245 & 0.18198\end{array}$

$\begin{array}{llll}-3.27905 & 0.87416 & -1.55757\end{array}$

$\begin{array}{llll}-3.26215 & 0.17178 & -2.39969\end{array}$

$\begin{array}{llll}-3.44428 & 2.25654 & -1.76576\end{array}$

$\begin{array}{llll}-3.55972 & 2.63107 & -2.79124\end{array}$

$\begin{array}{llll}-3.47092 & 3.14366 & -0.67726\end{array}$

$\begin{array}{llll}-3.32338 & 2.66109 & 0.63399\end{array}$

$\begin{array}{lll}-3.34479 & 3.35185 & 1.48728\end{array}$

$\begin{array}{llll}1.65733 & 0.55661 & 0.13369\end{array}$

$\begin{array}{llll}3.13735 & -0.42198 & -0.27355\end{array}$

$\begin{array}{llll}1.39089 & 1.78316 & -1.2638\end{array}$

$\begin{array}{lll}1.82895 & 1.3202 & 1.84949\end{array}$

$\begin{array}{llll}4.43895 & 0.12594 & -0.16321\end{array}$

$\begin{array}{llll}2.98892 & -1.75211 & -0.72919\end{array}$

$\begin{array}{llll}0.97352 & 0.95195 & -2.50406\end{array}$

$\begin{array}{llll}2.67331 & 2.56991 & -1.61773\end{array}$

$\begin{array}{llll}0.23535 & 2.74256 & -0.90949\end{array}$

$\begin{array}{llll}2.66723 & 2.61749 & 1.90243\end{array}$

$\begin{array}{llll}0.41708 & 1.62681 & 2.41772\end{array}$

$\begin{array}{lll}2.48014 & 0.24186 & 2.74889\end{array}$

$\begin{array}{llll}4.5801 & 1.16172 & 0.17245\end{array}$

$5.56087-0.64556-0.49283$

$\begin{array}{llll}4.11586 & -2.51711 & -1.06692\end{array}$

$\begin{array}{llll}1.67995 & 0.12284 & -2.71311\end{array}$

$\begin{array}{llll}-0.04758 & 0.53221 & -2.38301\end{array}$

$\begin{array}{llll}3.4579 & 1.90172 & -2.02039\end{array}$

$\begin{array}{llll}3.0879 & 3.13694 & -0.76331\end{array}$

$\begin{array}{llll}0.5092 & 3.4647 & -0.1162\end{array}$

$\begin{array}{llll}-0.66991 & 2.18482 & -0.59214\end{array}$

$\begin{array}{llll}3.69768 & 2.48452 & 1.52518\end{array}$

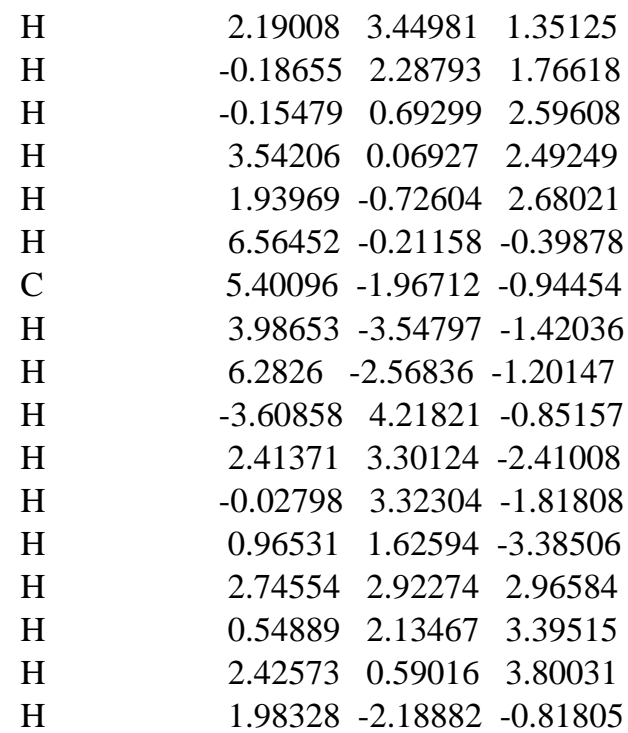

\section{S17c-TS}

C

C

$\mathrm{H}$

Au

C

$\mathrm{H}$

C

$\mathrm{H}$

C

C

$\mathrm{H}$

$\mathrm{P}$

C

$\mathrm{C}$

$\mathrm{C}$

C

$\begin{array}{llll}2.19008 & 3.44981 & 1.35125\end{array}$

$\begin{array}{llll}3.54206 & 0.06927 & 2.49249\end{array}$

$\begin{array}{lll}1.93969 & -0.72604 & 2.68021\end{array}$

$\begin{array}{lll}-0.21158 & -0.39878\end{array}$

$3.98653-3.54797-1.42036$

$6.2826-2.56836-1.20147$

$\begin{array}{llll}-3.60858 & 4.21821 & -0.85157\end{array}$

$2.41371 \quad 3.30124 \quad-2.41008$

$\begin{array}{llll}-0.02798 & 3.32304 & -1.81808\end{array}$

$\begin{array}{lll}0.54889 & 2.13467 & 3.39515\end{array}$

$\begin{array}{llll}1.98328 & -2.18882 & -0.81805\end{array}$

$\begin{array}{llll}-2.16115 & 0.86781 & -0.29392\end{array}$ $\begin{array}{llll}-2.57088 & 1.65062 & 0.78105\end{array}$

$\begin{array}{llll}-2.42931 & 1.34196 & 1.82269\end{array}$

$\begin{array}{llll}-2.76581 & -1.91545 & 0.1991\end{array}$

$\begin{array}{lll}-0.51554 & -0.48458 & 0.1136\end{array}$ $\begin{array}{lll}-2.40664 & 1.12599 & -1.6398\end{array}$

$\begin{array}{llll}-2.1426 & 0.41621 & -2.43211\end{array}$

$\begin{array}{llll}-2.9975 & 2.37368 & -1.92854\end{array}$

$\begin{array}{llll}-3.18518 & 2.63575 & -2.97818\end{array}$

$\begin{array}{llll}-3.36005 & 3.24928 & -0.89282\end{array}$

$\begin{array}{llll}-3.15966 & 2.88872 & 0.44959\end{array}$

$\begin{array}{llll}-3.47343 & 3.55583 & 1.26341\end{array}$

$\begin{array}{llll}1.62354 & 0.59297 & 0.17333\end{array}$

$2.84534-0.67056-0.31468$

$\begin{array}{llll}1.74515 & 1.97446 & -1.09027\end{array}$

$\begin{array}{llll}1.89379 & 1.10686 & 1.96714\end{array}$

$\begin{array}{lll}4.2221 & -0.53313 & -0.01452\end{array}$

$2.41364-1.80442-1.04316$ 
$\begin{array}{llll}1.28426 & 1.36612 & -2.437\end{array}$

$\begin{array}{llll}3.19661 & 2.47678 & -1.26656\end{array}$

$\begin{array}{llll}0.81189 & 3.14446 & -0.70958\end{array}$

$\begin{array}{llll}2.97856 & 2.18394 & 2.19163\end{array}$

$\begin{array}{llll}0.54931 & 1.6459 & 2.5221\end{array}$

$\begin{array}{llll}2.24978 & -0.17358 & 2.76049\end{array}$

$\begin{array}{llll}4.585 & 0.34709 & 0.53297\end{array}$

$\begin{array}{llll}5.13632 & -1.51392 & -0.42129\end{array}$

$\begin{array}{llll}3.33306 & -2.78239 & -1.45205\end{array}$

$\begin{array}{llll}1.91054 & 0.50242 & -2.73631\end{array}$

$\begin{array}{llll}0.22418 & 1.0474 & -2.40258\end{array}$

$\begin{array}{llll}3.86278 & 1.67287 & -1.63314\end{array}$

$\begin{array}{llll}3.62437 & 2.90839 & -0.34352\end{array}$

$\begin{array}{llll}1.15804 & 3.67706 & 0.19721\end{array}$

$\begin{array}{llll}-0.23502 & 2.81414 & -0.55351\end{array}$

$\begin{array}{llll}3.97324 & 1.89206 & 1.8082\end{array}$

$\begin{array}{llll}2.69904 & 3.15739 & 1.74596\end{array}$

$\begin{array}{llll}0.10978 & 2.45307 & 1.90355\end{array}$

$\begin{array}{llll}-0.19399 & 0.82755 & 2.61667\end{array}$

$\begin{array}{llll}3.26498 & -0.54577 & 2.53149\end{array}$

$\begin{array}{llll}1.52481 & -0.99266 & 2.56294\end{array}$

$6.20065-1.39656-0.18071$

$4.69303-2.64029-1.13675$

$\begin{array}{llll}2.98258 & -3.65673 & -2.0148\end{array}$

$\begin{array}{llll}5.41245 & -3.40734 & -1.45086\end{array}$

$\begin{array}{llll}-3.83553 & 4.20833 & -1.13284\end{array}$

$\begin{array}{llll}3.18342 & 3.2776 & -2.03402\end{array}$

$\begin{array}{llll}0.81544 & 3.87341 & -1.54551\end{array}$

$\begin{array}{llll}1.38157 & 2.14565 & -3.2199\end{array}$

$\begin{array}{llll}0.73284 & 2.05088 & 3.53801\end{array}$

$\begin{array}{lll}3.07837 & 2.33474 & 3.28593\end{array}$

$\begin{array}{llll}2.20124 & 0.06743 & 3.8418\end{array}$

$\begin{array}{llll}1.34988 & -1.92003 & -1.30587\end{array}$

$\begin{array}{lll}1.90666 & 1.1196 & 0.31201\end{array}$

$\begin{array}{lll}2.1963 & 1.3256 & 1.65752\end{array}$

\begin{tabular}{|c|c|c|}
\hline $\mathrm{H}$ & 1.885690 .62516 & 2.44118 \\
\hline I & $2.69486-2.00934$ & -0.21728 \\
\hline $\mathrm{Au}$ & $\begin{array}{lll}0.5641 & -0.43287\end{array}$ & $7-0.12041$ \\
\hline $\mathrm{C}$ & $2.37209 \quad 1.89289$ & -0.74518 \\
\hline $\mathrm{H}$ & 2.19733 & -1.79362 \\
\hline $\mathrm{C}$ & $3.08808 \quad 3.05781$ & -0.39506 \\
\hline $\mathrm{H}$ & 3.45609 & -1.19938 \\
\hline $\mathrm{C}$ & 3.339673 .36598 & 0.95027 \\
\hline $\mathrm{C}$ & $2.912 \quad 2.50087$ & 1.96845 \\
\hline $\mathrm{H}$ & $3.14299 \quad 2.71195$ & 3.0209 \\
\hline $\mathrm{P}$ & $\begin{array}{ll}-1.60197 & 0.62777\end{array}$ & -0.18151 \\
\hline $\mathrm{C}$ & $-2.68274-0.73597$ & $7 \quad 0.36962$ \\
\hline $\mathrm{C}$ & -1.879762 .04746 & 1.01273 \\
\hline $\mathrm{C}$ & -1.905631 .01394 & -2.00065 \\
\hline $\mathrm{C}$ & $\begin{array}{ll}-4.03917 & -0.82912\end{array}$ & -0.0255 \\
\hline $\mathrm{C}$ & $-2.15789-1.71603$ & 31.24913 \\
\hline $\mathrm{C}$ & $-1.42254 \quad 1.54143$ & 2.4019 \\
\hline $\mathrm{C}$ & $-3.37924 \quad 2.41566$ & 1.11406 \\
\hline $\mathrm{C}$ & $-1.05188 \quad 3.28702$ & 0.60897 \\
\hline $\mathrm{C}$ & $\begin{array}{ll}-3.08889 & 1.96694\end{array}$ & -2.28231 \\
\hline $\mathrm{C}$ & $-0.61483 \quad 1.65846$ & -2.56931 \\
\hline $\mathrm{C}$ & $-2.11472-0.3306$ & -2.73995 \\
\hline $\mathrm{H}$ & $-4.47722-0.06955$ & $5-0.68643$ \\
\hline $\mathrm{C}$ & $-4.83855-1.88474$ & $4 \quad 0.43222$ \\
\hline $\mathrm{C}$ & $-2.96168-2.7734$ & 1.7019 \\
\hline $\mathrm{H}$ & $\begin{array}{ll}-2.03513 & 0.68708\end{array}$ & 2.74988 \\
\hline $\mathrm{H}$ & $\begin{array}{ll}-0.35589 & 1.24779\end{array}$ & 2.40625 \\
\hline $\mathrm{H}$ & $\begin{array}{ll}-3.99443 & 1.54974\end{array}$ & 1.4254 \\
\hline $\mathrm{H}$ & $\begin{array}{ll}-3.78861 & 2.83681\end{array}$ & 0.17895 \\
\hline $\mathrm{H}$ & $-1.3945 \quad 3.72166$ & -0.35016 \\
\hline $\mathrm{H}$ & $0.03306 \quad 3.07085$ & 0.53993 \\
\hline $\mathrm{H}$ & $-4.05043 \quad 1.61462$ & -1.86615 \\
\hline $\mathrm{H}$ & $\begin{array}{ll}-2.89485 & 2.98901\end{array}$ & -1.90485 \\
\hline $\mathrm{H}$ & $-0.25197 \quad 2.5189$ & -1.97357 \\
\hline $\mathrm{H}$ & $0.19773 \quad 0.90702$ & -2.64048 \\
\hline $\mathrm{H}$ & $\begin{array}{ll}-3.0912 & -0.79716\end{array}$ & -2.51934 \\
\hline $\mathrm{H}$ & $-1.31549-1.06385$ & $5-2.49484$ \\
\hline
\end{tabular}


$\begin{array}{lll}-5.88917 & -1.94341 & 0.12056\end{array}$

$\begin{array}{llll}-4.29962 & -2.86178 & 1.28858\end{array}$

$\begin{array}{lll}-2.53857 & -3.52596 & 2.37894\end{array}$

$\begin{array}{lll}-4.92884 & -3.68999 & 1.63872\end{array}$

$\begin{array}{lll}3.90424 & 4.2713 & 1.20561\end{array}$

$\begin{array}{lll}-1.55083 & 2.3698 & 3.12781\end{array}$

$\begin{array}{lll}-3.47614 & 3.19348 & 1.89909\end{array}$

$\begin{array}{lll}-1.19309 & 4.05983 & 1.39172\end{array}$

$\begin{array}{llll}-3.20727 & 2.03524 & -3.38297\end{array}$

$\begin{array}{lll}-0.83098 & 2.01601 & -3.59638\end{array}$

$\begin{array}{llll}-2.06227 & -0.13141 & -3.82953\end{array}$

$\begin{array}{lll}-1.11821 & -1.6419 & 1.60698\end{array}$

\section{Cartesian Coordinates: Decarboxylation}

\section{$10 \mathbf{a}$}

$\begin{array}{lllll}\text { C } & 3.53144 & -1.21577 & 0.08149\end{array}$

$\begin{array}{llll}\text { C } & 2.13476 & -1.19132 & 0.06843\end{array}$

$\begin{array}{llll}\text { C } & 1.38768 & -0.00005 & -0.00027\end{array}$

$\begin{array}{lllll}\mathrm{C} & 2.13463 & 1.19127 & -0.0689\end{array}$

$\begin{array}{lllll}\text { C } & 3.53131 & 1.21594 & -0.08154\end{array}$

$\begin{array}{llll}\mathrm{C} & 4.22519 & 0.00014 & 0.00007\end{array}$

$\mathrm{H} \quad 4.04861 \quad-2.17902 \quad 0.15542$

$\mathrm{H} \quad 4.04834 \quad 2.17929-0.15512$

$\begin{array}{llll}\mathrm{H} & 5.32266 & 0.00019 & 0.00029\end{array}$

C $\quad-0.1241 \quad-0.00011 \quad-0.00008$

$\begin{array}{lllll}\mathrm{O} & & -0.70811 & 0.86367 & 0.72248\end{array}$

$\begin{array}{lllll}\mathrm{O} & -0.70829 & -0.86387 & -0.72249\end{array}$

$\begin{array}{llll}\text { Ag } & -2.75901 & 0.00002 & 0.00002\end{array}$

F $\quad \begin{array}{llll}1.48095 & 2.36158 & -0.16771\end{array}$

$\begin{array}{llll}F & 1.48122 & -2.3616 & 0.1681\end{array}$

\section{0b-TS}

$\begin{array}{llll}\mathrm{O} & 0.07318 & -1.82666 & 2.00474\end{array}$

C $\quad 0.66246-0.87965 \quad 1.55693$

$\begin{array}{llll}\mathrm{O} & 1.6942 & -0.21732 & 1.64921\end{array}$

$\begin{array}{llll}\text { C } & -0.4876 & -0.11517 & 0.20377\end{array}$

$\begin{array}{llll}\text { C } & -1.3679 & -0.99574 & -0.46662\end{array}$

$\begin{array}{llll}\mathrm{C} & -1.05811 & 1.13677 & 0.52107 \\ \mathrm{C} & -2.69916 & -0.71086 & -0.75996 \\ \mathrm{C} & -2.38763 & 1.48998 & 0.27405 \\ \mathrm{C} & -3.20151 & 0.54668 & -0.37287 \\ \mathrm{~F} & -0.87642 & -2.20241 & -0.818 \\ \mathrm{~F} & -0.26113 & 2.04906 & 1.13059 \\ \mathrm{H} & -3.32446 & -1.45161 & -1.27179 \\ \mathrm{H} & -2.76451 & 2.47349 & 0.57775 \\ \mathrm{H} & -4.24867 & 0.7964 & -0.58818 \\ \mathrm{Ag} & 1.48241 & 0.27833 & -0.77662\end{array}$

10c

$\begin{array}{llll}1.87478 & 1.66642 & -1.63189\end{array}$ $0.88434 \quad 2.14151-1.2255$

$\begin{array}{llll}-0.10601 & 2.63521 & -0.83243\end{array}$

$\begin{array}{llll}0.14005 & -0.54827 & 0.31566\end{array}$

$\begin{array}{llll}0.89036 & -1.41329 & -0.48367\end{array}$

$\begin{array}{llll}0.87119 & 0.17089 & 1.26611\end{array}$

$2.27692-1.57472-0.37312$

$\begin{array}{llll}2.25621 & 0.0629 & 1.43707\end{array}$

$2.95373-0.82293 \quad 0.59966$

$\begin{array}{llll}0.24203 & -2.13848 & -1.43453\end{array}$

$\begin{array}{llll}0.1997 & 1.04746 & 2.06377\end{array}$

$\begin{array}{llll}2.80172 & -2.26902 & -1.04014\end{array}$ $\begin{array}{llll}2.76283 & 0.65906 & 2.20557\end{array}$

$\begin{array}{llll}4.04096 & -0.92808 & 0.70693\end{array}$

$\begin{array}{lll}-1.90145 & -0.21601 & 0.06302\end{array}$

$-2.06476-1.31112-0.83516$ $\begin{array}{llll}-2.44216 & -1.05206 & 0.36203\end{array}$

$\begin{array}{llll}-1.70288 & -0.99174 & 1.37019\end{array}$

$\begin{array}{llll}-3.9175 & -0.71677 & 0.5198\end{array}$

$\begin{array}{llll}-4.91581 & -1.19926 & -0.35399\end{array}$

$\begin{array}{llll}-4.36465 & 0.20783 & 1.48867\end{array}$

$-6.25523-0.80011-0.29042$

$\begin{array}{llll}-5.68887 & 0.6539 & 1.57384\end{array}$ 
$\begin{array}{lll}-6.63562 & 0.13958 & 0.67749\end{array}$

$\begin{array}{llll}-4.58674 & -2.07992 & -1.30733\end{array}$

$\begin{array}{lll}-3.49023 & 0.75143 & 2.35144\end{array}$

$\begin{array}{llll}2.42347 & -0.72722 & 0.09343\end{array}$

$\begin{array}{llll}2.90003 & 1.04804 & 0.15192\end{array}$

$2.41704-1.25231 \quad 1.92133$

$\begin{array}{llll}3.71339 & -1.68658 & -0.93024\end{array}$

$\begin{array}{llll}1.94219 & 2.08969 & -0.04198\end{array}$

$\begin{array}{llll}4.22419 & 1.3941 & 0.52011\end{array}$

$\begin{array}{llll}0.52225 & 1.90689 & -0.52801\end{array}$

$\begin{array}{llll}2.35635 & 3.4248 & 0.17761\end{array}$

$\begin{array}{llll}4.96465 & 0.59268 & 0.65887\end{array}$

$\begin{array}{llll}4.61558 & 2.7244 & 0.71249\end{array}$

$\begin{array}{llll}0.28149 & 1.64009 & -1.91214\end{array}$

$\begin{array}{lll}-0.58766 & 2.14008 & 0.3275\end{array}$

$\begin{array}{llll}1.61155 & 4.22116 & 0.03383\end{array}$

$\begin{array}{llll}3.66673 & 3.74665 & 0.5529\end{array}$

$\begin{array}{lll}5.65116 & 2.95926 & 0.9923\end{array}$

$\begin{array}{llll}-1.03754 & 1.53977 & -2.38129\end{array}$

$\begin{array}{llll}-1.89422 & 2.03909 & -0.19548\end{array}$

$\begin{array}{llll}3.94984 & 4.79634 & 0.70998\end{array}$

$\begin{array}{llll}-1.20183 & 1.30371 & -3.44539\end{array}$

$\begin{array}{llll}-2.14773 & 1.7134 & -1.53325\end{array}$

$\begin{array}{llll}-2.73985 & 2.20175 & 0.48961\end{array}$ $-6.97015-1.22546-1.00424$

$\begin{array}{llll}-5.95142 & 1.39059 & 2.34195\end{array}$

$\begin{array}{llll}1.40305 & 1.40197 & -2.90541\end{array}$

$\begin{array}{llll}1.5698 & 0.3103 & -3.03811\end{array}$

$\begin{array}{llll}1.13078 & 1.80748 & -3.89869\end{array}$

$\begin{array}{llll}2.36242 & 1.85354 & -2.5915\end{array}$

$\begin{array}{lll}-0.47744 & 2.45245 & 1.80828\end{array}$

$\begin{array}{lll}-1.03628 & 3.37999 & 2.04475\end{array}$

$\begin{array}{llll}-0.94965 & 1.63054 & 2.38524\end{array}$

$\begin{array}{lll}0.56306 & 2.57984 & 2.15284\end{array}$

$\begin{array}{llll}-3.55294 & 1.48502 & -2.04579\end{array}$

$\begin{array}{llll}-3.75149 & 2.06589 & -2.96854\end{array}$

$\begin{array}{llll}-3.68098 & 0.40909 & -2.28473\end{array}$ $\begin{array}{lll}-4.31223 & 1.7543 & -1.28405\end{array}$ $\begin{array}{llll}2.9242 & -2.81354 & -1.6461\end{array}$

$2.17564-2.3885 \quad-2.34621$

$\begin{array}{llll}3.63365 & -3.4428 & -2.22489\end{array}$

$2.38382-3.46508-0.92905$ $\begin{array}{llll}4.86603 & -2.33707 & -0.13698\end{array}$ $\begin{array}{llll}5.48142 & -1.59428 & 0.40707\end{array}$ $\begin{array}{llll}4.50609 & -3.09492 & 0.58429\end{array}$ $\begin{array}{llll}5.52927 & -2.85454 & -0.86242\end{array}$ $\begin{array}{llll}4.33809 & -0.78307 & -2.01736\end{array}$ $\begin{array}{llll}4.91837 & -1.43283 & -2.70623\end{array}$ $3.57445-0.25474-2.61486$ $5.02912-0.03009-1.59543$ $\begin{array}{lll}1.42653 & -0.28508 & 2.61308\end{array}$ $\begin{array}{llll}1.86037 & 0.73119 & 2.69516\end{array}$ $\begin{array}{lll}0.4501 & -0.23314 & 2.09384\end{array}$ $\begin{array}{llll}1.23932 & -0.66296 & 3.64042\end{array}$ $\begin{array}{lll}1.83052 & -2.68113 & 2.00257\end{array}$ $\begin{array}{llll}2.4403 & -3.4273 & 1.45306\end{array}$ $\begin{array}{llll}1.80098 & -2.98957 & 3.06895\end{array}$ $\begin{array}{lll}0.7911 & -2.70603 & 1.61352\end{array}$ $\begin{array}{llll}3.73797 & -1.17786 & 2.71849\end{array}$ $\begin{array}{llll}3.48365 & -1.35888 & 3.78444\end{array}$ $\begin{array}{llll}4.482 & -1.93838 & 2.42867\end{array}$ $\begin{array}{lll}4.19844 & -0.17289 & 2.66498\end{array}$ $\begin{array}{llll}-7.67999 & 0.47291 & 0.73517\end{array}$ $\begin{array}{lll}0.1167 & -1.05697 & -0.54301\end{array}$

11b-TS

$\begin{array}{llll}-2.05677 & -2.05067 & -2.16224\end{array}$ $\begin{array}{llll}-2.17288 & -2.36987 & -0.9845\end{array}$ $\begin{array}{llll}-2.03528 & -3.32596 & -0.24077\end{array}$ $\begin{array}{llll}-2.80466 & -0.92616 & 0.00865\end{array}$ $\begin{array}{llll}-3.76153 & -0.08861 & -0.60731\end{array}$ $\begin{array}{llll}-3.03834 & -1.10861 & 1.39335\end{array}$ $\begin{array}{llll}-4.89575 & 0.42899 & 0.02867\end{array}$

$\begin{array}{lll}-4.12459 & -0.59454 & 2.10266\end{array}$ 
$\begin{array}{lll}-5.06951 & 0.16746 & 1.39521\end{array}$

$\begin{array}{llll}-3.58906 & 0.24468 & -1.90577\end{array}$

$\begin{array}{lll}-2.13523 & -1.83136 & 2.09704\end{array}$

$\begin{array}{llll}1.78534 & -0.8252 & 0.0378\end{array}$

$\begin{array}{llll}2.84123 & 0.68501 & 0.0332\end{array}$

$\begin{array}{llll}1.83335 & -1.45801 & 1.82102\end{array}$

$2.51471-2.09886-1.17142$

$\begin{array}{llll}2.27375 & 1.99243 & -0.04032\end{array}$

$\begin{array}{llll}4.2504 & 0.56234 & 0.12231\end{array}$

$\begin{array}{llll}0.79709 & 2.28627 & -0.15154\end{array}$

$\begin{array}{llll}3.14029 & 3.10949 & -0.01403\end{array}$

$\begin{array}{llll}4.69449 & -0.44014 & 0.18781\end{array}$

$\begin{array}{llll}5.09229 & 1.68074 & 0.13609\end{array}$

$\begin{array}{llll}0.12536 & 2.13852 & -1.40097\end{array}$

$\begin{array}{llll}0.08288 & 2.80629 & 0.96303\end{array}$

$2.68959 \quad 4.11171-0.06418$

$\begin{array}{llll}4.5307 & 2.96573 & 0.07065\end{array}$

$\begin{array}{lll}6.1804 & 1.54846 & 0.20172\end{array}$

$\begin{array}{llll}-1.24204 & 2.46557 & -1.49639\end{array}$

$\begin{array}{lll}-1.28786 & 3.1053 & 0.82317\end{array}$

$\begin{array}{llll}5.17493 & 3.85528 & 0.08309\end{array}$

$\begin{array}{llll}-1.75008 & 2.33666 & -2.46579\end{array}$

$\begin{array}{llll}-1.96852 & 2.95673 & -0.39607\end{array}$

$\begin{array}{llll}-1.82941 & 3.50496 & 1.69631\end{array}$

$\begin{array}{lll}-5.60523 & 1.04285 & -0.54014\end{array}$

$\begin{array}{llll}-4.22267 & -0.79449 & 3.17627\end{array}$

$\begin{array}{llll}0.82002 & 1.64517 & -2.65867\end{array}$

$\begin{array}{llll}0.44435 & 0.63893 & -2.94461\end{array}$

$\begin{array}{llll}0.59606 & 2.32111 & -3.50699\end{array}$

$\begin{array}{llll}1.91695 & 1.58443 & -2.54426\end{array}$

$\begin{array}{llll}0.73106 & 3.11906 & 2.30236\end{array}$

$\begin{array}{llll}0.69155 & 4.2103 & 2.4959\end{array}$

$\begin{array}{llll}0.18199 & 2.62402 & 3.12805\end{array}$

$\begin{array}{lll}1.78846 & 2.80941 & 2.35628\end{array}$

$\begin{array}{lll}-3.40763 & 3.4 & -0.55163\end{array}$

$\begin{array}{llll}-3.45404 & 4.4852 & -0.77831\end{array}$

$\begin{array}{llll}-3.90229 & 2.86259 & -1.38268\end{array}$ $\begin{array}{llll}-3.98687 & 3.22511 & 0.37446\end{array}$

$\begin{array}{llll}1.3291 & -2.99841 & -1.61439\end{array}$

$\begin{array}{llll}0.56827 & -2.41857 & -2.17447\end{array}$

$1.72281-3.78801-2.28919$

$\begin{array}{llll}0.81302 & -3.49527 & -0.76989\end{array}$

$\begin{array}{llll}3.64889 & -3.00791 & -0.64757\end{array}$

$\begin{array}{llll}4.55452 & -2.4482 & -0.34508\end{array}$

$\begin{array}{llll}3.32947 & -3.64598 & 0.19607\end{array}$

$\begin{array}{llll}3.94409 & -3.68302 & -1.47839\end{array}$

$3.0289-1.36233-2.42881$

$\begin{array}{llll}3.31309 & -2.12907 & -3.1797\end{array}$

$2.24021-0.73223-2.87995$

$\begin{array}{llll}3.91608 & -0.73208 & -2.2249\end{array}$

$1.07134-0.40184 \quad 2.6574$

$\begin{array}{llll}1.58537 & 0.57765 & 2.6147\end{array}$

$\begin{array}{llll}0.01965 & -0.27435 & 2.32385\end{array}$

$\begin{array}{lll}1.05614 & -0.73685 & 3.71611\end{array}$

$\begin{array}{lll}1.06773 & -2.7982 & 1.90862\end{array}$

$\begin{array}{llll}1.62997 & -3.63659 & 1.45513\end{array}$

$\begin{array}{lll}0.9186 & -3.03905 & 2.98249\end{array}$

$\begin{array}{llll}0.06729 & -2.74946 & 1.43207\end{array}$

$\begin{array}{llll}3.23803 & -1.59563 & 2.44727\end{array}$

$3.11352-1.97476 \quad 3.48375$

$\begin{array}{llll}3.89317 & -2.30558 & 1.91109\end{array}$ $\begin{array}{llll}3.74921 & -0.61518 & 2.51047\end{array}$

$\begin{array}{llll}-5.94583 & 0.57116 & 1.91959\end{array}$

$-0.60606-0.45184-0.3413$

$\begin{array}{llll}-2.72876 & -3.25517 & -1.28081\end{array}$ $\begin{array}{llll}-2.47187 & -3.28002 & -0.13728\end{array}$ $\begin{array}{llll}-2.20623 & -3.35121 & 1.00393\end{array}$ $\begin{array}{llll}-2.7472 & -0.16439 & -0.01695\end{array}$ $\begin{array}{llll}-3.41947 & 0.21815 & -1.18102\end{array}$ $\begin{array}{llll}-3.57045 & -0.26309 & 1.10783\end{array}$ $\begin{array}{llll}-4.78315 & 0.52787 & -1.2606\end{array}$ $\begin{array}{lll}-4.94618 & 0.01761 & 1.12005\end{array}$ 
$\begin{array}{lll}-5.54541 & 0.42219 & -0.08422\end{array}$ $\begin{array}{llll}-2.68943 & 0.30979 & -2.33385\end{array}$ $\begin{array}{lll}-3.00232 & -0.65066 & 2.28113\end{array}$ $\begin{array}{llll}1.73339 & -0.91682 & 0.06245\end{array}$ $\begin{array}{llll}2.91533 & 0.46552 & -0.26053\end{array}$ $\begin{array}{llll}2.09561 & -1.4484 & 1.84139\end{array}$ $\begin{array}{llll}2.09923 & -2.32047 & -1.17087\end{array}$ $2.49128 \quad 1.82766-0.31716$ $\begin{array}{llll}4.29274 & 0.17824 & -0.43634\end{array}$ $\begin{array}{llll}1.06398 & 2.29153 & -0.1598\end{array}$ $\begin{array}{llll}3.46476 & 2.82914 & -0.5406\end{array}$ $\begin{array}{llll}4.63085 & -0.86514 & -0.38546\end{array}$ $\begin{array}{llll}5.23865 & 1.18402 & -0.66582\end{array}$ $\begin{array}{llll}0.16593 & 2.23569 & -1.26154\end{array}$ $\begin{array}{llll}0.62974 & 2.88149 & 1.05981\end{array}$ $\begin{array}{llll}3.12435 & 3.87442 & -0.57625\end{array}$ $\begin{array}{llll}4.81988 & 2.52293 & -0.71496\end{array}$ $\begin{array}{llll}6.29661 & 0.92245 & -0.80097\end{array}$ $\begin{array}{llll}-1.15311 & 2.69892 & -1.1022\end{array}$ $\begin{array}{llll}-0.71738 & 3.2701 & 1.19092\end{array}$ $\begin{array}{llll}5.54718 & 3.32709 & -0.89124\end{array}$ $\begin{array}{llll}-1.84302 & 2.62417 & -1.95632\end{array}$ $\begin{array}{llll}-1.6327 & 3.17066 & 0.12958\end{array}$ $\begin{array}{llll}-1.05258 & 3.68532 & 2.15578\end{array}$ $\begin{array}{llll}-5.2324 & 0.82635 & -2.21627\end{array}$ $\begin{array}{llll}-5.52316 & -0.07996 & 2.04842\end{array}$ $\begin{array}{llll}0.54392 & 1.65117 & -2.61019\end{array}$ $\begin{array}{llll}-0.0363 & 0.71999 & -2.79135\end{array}$ $\begin{array}{llll}0.27683 & 2.35385 & -3.42414\end{array}$ $\begin{array}{llll}1.62103 & 1.41818 & -2.69378\end{array}$ $\begin{array}{llll}1.56063 & 3.18022 & 2.22446\end{array}$ $\begin{array}{llll}1.65098 & 4.2774 & 2.35988\end{array}$ $\begin{array}{lll}1.15597 & 2.77043 & 3.17147\end{array}$ $\begin{array}{llll}2.57927 & 2.78044 & 2.08141\end{array}$ $\begin{array}{llll}-3.09513 & 3.51062 & 0.31448\end{array}$ $\begin{array}{llll}-3.23064 & 4.40432 & 0.95469\end{array}$ $\begin{array}{llll}-3.59089 & 3.68987 & -0.6587\end{array}$ $\begin{array}{lll}-3.62421 & 2.66363 & 0.79826\end{array}$

$\begin{array}{llll}0.78293 & -3.13354 & -1.31216\end{array}$

$\begin{array}{llll}-0.02131 & -2.5133 & -1.75693\end{array}$

$0.96927-3.99487-1.98868$

$\begin{array}{llll}0.41778 & -3.52943 & -0.34263\end{array}$ $\begin{array}{llll}3.23052 & -3.31481 & -0.82956\end{array}$ $\begin{array}{llll}4.22334 & -2.83772 & -0.73207\end{array}$ $\begin{array}{llll}3.0232 & -3.88693 & 0.09422\end{array}$ $\begin{array}{llll}3.29951 & -4.04617 & -1.66274\end{array}$ $\begin{array}{llll}2.3852 & -1.68868 & -2.55197\end{array}$ $2.41794-2.50308-3.30622$ $\begin{array}{llll}1.57799 & -0.98942 & -2.84567\end{array}$ $\begin{array}{llll}3.3502 & -1.14777 & -2.58199\end{array}$ $\begin{array}{llll}1.64482 & -0.25547 & 2.71739\end{array}$ $\begin{array}{llll}2.29066 & 0.6234 & 2.53454\end{array}$ $\begin{array}{lll}0.58752 & 0.0323 & 2.53314\end{array}$ $\begin{array}{lll}1.74801 & -0.5418 & 3.78561\end{array}$ $\begin{array}{llll}1.21879 & -2.6698 & 2.19476\end{array}$ $\begin{array}{lll}1.53581 & -3.58916 & 1.66507\end{array}$ $\begin{array}{lll}1.31324 & -2.86336 & 3.28422\end{array}$ $\begin{array}{llll}0.14735 & -2.48418 & 1.97284\end{array}$ $\begin{array}{llll}3.57194 & -1.73198 & 2.19037\end{array}$ $\begin{array}{lll}3.62171 & -2.005 \quad 3.26607\end{array}$ $\begin{array}{llll}4.00944 & -2.5681 & 1.61547\end{array}$ $\begin{array}{lll}4.19998 & -0.83169 & 2.04751\end{array}$ $\begin{array}{llll}-6.61924 & 0.65132 & -0.10852\end{array}$ $\begin{array}{lll}-0.6583 & -0.41649 & 0.00512\end{array}$

$-1.98963-1.00646-0.65652$ $\begin{array}{lll}-2.55924 & -0.99057 & 0.50957\end{array}$ $\begin{array}{lll}-2.00454 & -1.14351 & 1.60683\end{array}$ $\begin{array}{lll}-4.04546 & -0.67712 & 0.44798\end{array}$ $\begin{array}{llll}-4.87647 & -1.05425 & -0.62748\end{array}$ $\begin{array}{llll}-4.66921 & 0.11754 & 1.43339\end{array}$ $\begin{array}{lll}-6.21452 & -0.66856 & -0.74336\end{array}$ $\begin{array}{llll}-5.99834 & 0.54561 & 1.35274\end{array}$ 
$\begin{array}{lll}-6.77001 & 0.14616 & 0.25306\end{array}$ $-4.37658-1.83326-1.60259$ $\begin{array}{lll}-3.9554 & 0.54652 & 2.49161\end{array}$ $\begin{array}{llll}2.33094 & -0.71661 & 0.04853\end{array}$ $\begin{array}{llll}2.91278 & 1.01046 & 0.36651\end{array}$ $\begin{array}{llll}2.64328 & -1.66632 & 1.65642\end{array}$ $\begin{array}{llll}3.3092 & -1.4233 & -1.41591\end{array}$ $\begin{array}{llll}2.053 & 2.15278 & 0.3734\end{array}$ $\begin{array}{llll}4.29059 & 1.20532 & 0.64621\end{array}$ $\begin{array}{llll}0.62174 & 2.17145 & -0.10078\end{array}$ $\begin{array}{llll}2.60291 & 3.40723 & 0.72623\end{array}$ $\begin{array}{lll}4.97156 & 0.34703 & 0.6215\end{array}$ $\begin{array}{llll}4.81683 & 2.46227 & 0.96669\end{array}$ $\begin{array}{llll}0.38769 & 2.39265 & -1.48841\end{array}$ $\begin{array}{lll}-0.47663 & 2.07395 & 0.7898\end{array}$ $\begin{array}{llll}1.92635 & 4.27417 & 0.73134\end{array}$ $\begin{array}{llll}3.95975 & 3.57121 & 1.02859\end{array}$ $\begin{array}{llll}5.89009 & 2.56939 & 1.17255\end{array}$ $\begin{array}{llll}-0.93065 & 2.34997 & -1.97257\end{array}$ $\begin{array}{llll}-1.78416 & 2.09611 & 0.26357\end{array}$ $\begin{array}{llll}4.35009 & 4.56384 & 1.29126\end{array}$ $\begin{array}{llll}-1.10291 & 2.47685 & -3.05383\end{array}$ $\begin{array}{llll}-2.03284 & 2.17089 & -1.11477\end{array}$ $\begin{array}{llll}-2.62878 & 2.00101 & 0.96385\end{array}$ $\begin{array}{llll}-6.7939 & -1.00885 & -1.60928\end{array}$ $\begin{array}{llll}-6.40168 & 1.17985 & 2.15043\end{array}$ $\begin{array}{llll}1.50658 & 2.77666 & -2.44154\end{array}$ $\begin{array}{llll}1.28068 & 2.4426 & -3.47275\end{array}$ $\begin{array}{llll}1.61254 & 3.88217 & -2.46985\end{array}$ $2.49085 \quad 2.37383 \quad-2.14738$ $\begin{array}{llll}-0.31674 & 1.88978 & 2.28588\end{array}$ $\begin{array}{lll}-1.00901 & 2.56389 & 2.82791\end{array}$ $\begin{array}{llll}-0.58868 & 0.85349 & 2.57241\end{array}$ $\begin{array}{llll}0.71284 & 2.09902 & 2.63163\end{array}$ $\begin{array}{llll}-3.43028 & 2.01627 & -1.67558\end{array}$ $\begin{array}{llll}-3.63169 & 2.74987 & -2.48121\end{array}$ $\begin{array}{llll}-3.5412 & 1.00019 & -2.10874\end{array}$

\begin{tabular}{|c|c|c|c|}
\hline $\mathrm{H}$ & -4.20398 & 2.12822 & -0.88969 \\
\hline $\mathrm{C}$ & 2.50642 & -2.60405 & -2.02271 \\
\hline $\mathrm{H}$ & 1.52396 & -2.26545 & -2.40351 \\
\hline $\mathrm{H}$ & 3.09256 & -3.01109 & -2.87409 \\
\hline $\mathrm{H}$ & 2.33157 & -3.42553 & -1.30401 \\
\hline $\mathrm{C}$ & 4.74043 & -1.9219 & -1.12446 \\
\hline $\mathrm{H}$ & 5.40638 & -1.13326 & -0.72782 \\
\hline $\mathrm{H}$ & 4.74963 & -2.78322 & -0.42975 \\
\hline $\mathrm{H}$ & 5.1795 & -2.26597 & -2.08464 \\
\hline $\mathrm{C}$ & 3.36222 & -0.31298 & -2.48771 \\
\hline $\mathrm{H}$ & 3.77528 & -0.74653 & -3.42266 \\
\hline $\mathrm{H}$ & 2.34359 & 0.07166 & -2.70558 \\
\hline $\mathrm{H}$ & 4.00679 & 0.53397 & -2.17998 \\
\hline $\mathrm{C}$ & 1.63935 & -1.09796 & 2.68916 \\
\hline $\mathrm{H}$ & 1.80773 & -0.01414 & 2.85042 \\
\hline $\mathrm{H}$ & 0.58452 & -1.25874 & 2.38814 \\
\hline $\mathrm{H}$ & 1.81223 & -1.61735 & 3.65574 \\
\hline $\mathrm{C}$ & 2.31385 & -3.1591 & 1.42782 \\
\hline $\mathrm{H}$ & 3.07653 & -3.6693 & 0.80683 \\
\hline $\mathrm{H}$ & 2.29762 & -3.66135 & 2.41763 \\
\hline $\mathrm{H}$ & 1.31662 & -3.29074 & 0.96046 \\
\hline $\mathrm{C}$ & 4.05235 & -1.54434 & 2.27863 \\
\hline $\mathrm{H}$ & 4.08495 & -2.22386 & 3.15595 \\
\hline $\mathrm{H}$ & 4.87176 & -1.84158 & 1.59779 \\
\hline $\mathrm{H}$ & 4.24433 & -0.51953 & 2.64789 \\
\hline $\mathrm{H}$ & -7.81665 & 0.46742 & 0.17521 \\
\hline $\mathrm{Au}$ & 0.10467 & -0.8725 & -0.37048 \\
\hline
\end{tabular}

\section{2b-TS}

$\mathrm{O}$

$\begin{array}{lll}-2.89258 & -3.32147 & -0.4322\end{array}$

$\begin{array}{lll}-2.50015 & -2.52244 & 0.41745\end{array}$

$\begin{array}{llll}-1.96229 & -2.59991 & 1.53511\end{array}$

$\begin{array}{llll}-2.78896 & -0.9341 & -0.07514\end{array}$

$\begin{array}{llll}-2.96774 & -0.6242 & -1.46067\end{array}$

$\begin{array}{llll}-3.48065 & -0.04414 & 0.79731\end{array}$

$\begin{array}{llll}-3.75613 & 0.41401 & -1.9479\end{array}$

$\begin{array}{llll}-4.30934 & 0.9966 & 0.36318\end{array}$ 
$-4.44579 \quad 1.21128-1.01461$ $-2.31024-1.38196-2.35824$ $\begin{array}{llll}-3.37343 & -0.23231 & 2.11929\end{array}$ $\begin{array}{lll}1.6769 & -0.88004 & 0.15173\end{array}$ $\begin{array}{llll}2.79771 & 0.48314 & -0.40067\end{array}$ $\begin{array}{llll}2.16328 & -1.32358 & 1.9189\end{array}$ $\begin{array}{llll}1.8788 & -2.33964 & -1.05714\end{array}$ $\begin{array}{lllll}2.37256 & 1.82957 & -0.60259\end{array}$ $\begin{array}{llll}4.15233 & 0.16109 & -0.67727\end{array}$ $\begin{array}{llll}1.01071 & 2.37281 & -0.25976\end{array}$ $\begin{array}{llll}3.30709 & 2.77136 & -1.09246\end{array}$ $4.50985-0.85753-0.49401$ $\begin{array}{llll}5.06158 & 1.10859 & -1.15995\end{array}$ $\begin{array}{llll}-0.0651 & 2.31265 & -1.17999\end{array}$ $\begin{array}{llll}0.85078 & 3.06082 & 0.97471\end{array}$ $\begin{array}{llll}2.96111 & 3.80559 & -1.23534\end{array}$ $\begin{array}{llll}4.63248 & 2.42624 & -1.37956\end{array}$ $\begin{array}{llll}6.10041 & 0.81533 & -1.36078\end{array}$ $\begin{array}{llll}-1.30365 & 2.88403 & -0.82251\end{array}$ $\begin{array}{llll}-0.41449 & 3.57133 & 1.31013\end{array}$ $\begin{array}{llll}5.32925 & 3.18396 & -1.76268\end{array}$ $\begin{array}{llll}-2.12961 & 2.84884 & -1.54994\end{array}$ $\begin{array}{lll}-1.50748 & 3.49265 & 0.42594\end{array}$ $\begin{array}{llll}-0.53911 & 4.0878 & 2.27587\end{array}$ $\begin{array}{lll}-3.83172 & 0.5838 & -3.02874\end{array}$ $\begin{array}{llll}-4.83366 & 1.61503 & 1.10131\end{array}$ $\begin{array}{llll}0.06755 & 1.67155 & -2.55018\end{array}$ $\begin{array}{llll}-0.67379 & 0.85407 & -2.67816\end{array}$ $\begin{array}{llll}-0.12884 & 2.41759 & -3.34687\end{array}$ $\begin{array}{llll}1.07439 & 1.2491 & -2.72093\end{array}$ $\begin{array}{llll}2.02561 & 3.36667 & 1.89009\end{array}$ $\begin{array}{llll}2.4647 & 4.35157 & 1.62444\end{array}$ $\begin{array}{lll}1.69715 & 3.42612 & 2.94537\end{array}$ $\begin{array}{llll}2.84402 & 2.62823 & 1.81557\end{array}$ $\begin{array}{llll}-2.83965 & 4.11012 & 0.80092\end{array}$ $\begin{array}{lll}-2.72992 & 5.19135 & 1.01863\end{array}$ $\begin{array}{llll}-3.57839 & 3.99598 & -0.01537\end{array}$ $\begin{array}{llll}-3.25925 & 3.63545 & 1.71026\end{array}$ $\begin{array}{llll}0.62652 & -3.2598 & -0.95028\end{array}$ $-0.27469-2.77504-1.37364$ $\begin{array}{llll}0.8281 & -4.168 & -1.55624\end{array}$

$\begin{array}{lll}0.37795 & -3.58063 & 0.07809\end{array}$ $\begin{array}{llll}3.13447 & -3.22324 & -0.86809\end{array}$ $\begin{array}{llll}4.0865 & -2.68467 & -1.02364\end{array}$ $\begin{array}{llll}3.16049 & -3.71814 & 0.12021\end{array}$ $3.09163-4.02378-1.63538$ $\begin{array}{llll}1.87702 & -1.75466 & -2.48912\end{array}$ $\begin{array}{llll}1.86999 & -2.60352 & -3.20425\end{array}$ $\begin{array}{llll}0.9577 & -1.15878 & -2.66805\end{array}$ $2.76482-1.12659-2.7009$ $\begin{array}{llll}1.59848 & -0.19171 & 2.8109\end{array}$ $\begin{array}{llll}1.97276 & 0.80089 & 2.49938\end{array}$ $\begin{array}{llll}0.49015 & -0.17707 & 2.79036\end{array}$ $\begin{array}{lll}1.9282 & -0.37351 & 3.85556\end{array}$ $\begin{array}{lll}1.48123 & -2.64139 & 2.34967\end{array}$ $\begin{array}{llll}1.89797 & -3.52755 & 1.83456\end{array}$ $1.66903-2.77066 \quad 3.43664$ $\begin{array}{llll}0.38429 & -2.61505 & 2.19331\end{array}$ $\begin{array}{llll}3.68704 & -1.40571 & 2.14947\end{array}$ $3.85518-1.698693 .20672$ $\begin{array}{llll}4.18177 & -2.16303 & 1.5106\end{array}$ $4.17796-0.42605 \quad 1.98696$ $\begin{array}{llll}-5.0865 & 2.02942 & -1.37247\end{array}$ $\begin{array}{lll}-0.59301 & -0.50444 & 0.14494\end{array}$

$-4.14496-2.83269-0.63976$ $\begin{array}{llll}-3.19137 & -3.09398 & -0.01078\end{array}$ $\begin{array}{lll}-2.24547 & -3.39072 & 0.61854\end{array}$ $\begin{array}{lll}-2.52938 & 0.0152 & -0.04024\end{array}$ $\begin{array}{llll}-3.26079 & 0.40674 & -1.16934\end{array}$ $\begin{array}{llll}-3.3004 & -0.07374 & 1.12683\end{array}$ $\begin{array}{llll}-4.63008 & 0.69237 & -1.17995\end{array}$ $\begin{array}{llll}-4.67403 & 0.18846 & 1.20427\end{array}$ 
$\begin{array}{lll}-5.33695 & 0.57597 & 0.02824\end{array}$

$\begin{array}{llll}-2.59428 & 0.50941 & -2.35867\end{array}$

$\begin{array}{lll}-2.67629 & -0.46843 & 2.27662\end{array}$

$\begin{array}{llll}1.75854 & -0.96732 & 0.0268\end{array}$

$\begin{array}{llll}2.97706 & 0.40745 & -0.19435\end{array}$

$2.06261 \quad-1.61553 \quad 1.77695$

$\begin{array}{llll}2.11239 & -2.29818 & -1.28851\end{array}$

$\begin{array}{llll}2.60625 & 1.78671 & -0.2125\end{array}$

$\begin{array}{llll}4.34962 & 0.07757 & -0.33482\end{array}$

$\begin{array}{llll}1.19897 & 2.31778 & -0.0885\end{array}$

$\begin{array}{llll}3.62566 & 2.75625 & -0.3644\end{array}$

$4.64923-0.97758-0.31311$

$\begin{array}{llll}5.34055 & 1.053 & -0.4919\end{array}$

$\begin{array}{llll}0.35862 & 2.39027 & -1.2326\end{array}$

$\begin{array}{llll}0.73729 & 2.84638 & 1.14868\end{array}$

$\begin{array}{llll}3.32454 & 3.81399 & -0.37145\end{array}$

$\begin{array}{llll}4.97407 & 2.40764 & -0.50386\end{array}$

$\begin{array}{llll}6.39172 & 0.75457 & -0.60078\end{array}$

$\begin{array}{llll}-0.94141 & 2.9124 & -1.10115\end{array}$

$\begin{array}{llll}-0.59185 & 3.29898 & 1.24521\end{array}$

$\begin{array}{llll}5.73562 & 3.1902 & -0.62375\end{array}$

$\begin{array}{llll}-1.58977 & 2.93864 & -1.99156\end{array}$

$\begin{array}{llll}-1.45705 & 3.32115 & 0.138\end{array}$

$\begin{array}{llll}-0.95303 & 3.66489 & 2.22067\end{array}$

$\begin{array}{llll}-5.12459 & 0.98397 & -2.11454\end{array}$

$\begin{array}{llll}-5.20071 & 0.08804 & 2.16122\end{array}$

$\begin{array}{llll}0.77345 & 1.87294 & -2.5975\end{array}$

$\begin{array}{llll}0.16422 & 0.98064 & -2.85896\end{array}$

$\begin{array}{llll}0.57805 & 2.63521 & -3.37758\end{array}$

$\begin{array}{llll}1.84176 & 1.59275 & -2.64724\end{array}$

$\begin{array}{llll}1.62458 & 3.01017 & 2.37242\end{array}$

$\begin{array}{llll}1.74993 & 4.08787 & 2.60305\end{array}$

$\begin{array}{llll}1.16344 & 2.54093 & 3.26427\end{array}$

$\begin{array}{llll}2.6329 & 2.58175 & 2.23812\end{array}$

$\begin{array}{llll}-2.9076 & 3.72794 & 0.28404\end{array}$

$\begin{array}{llll}-3.01774 & 4.64726 & 0.89274\end{array}$

$\begin{array}{llll}-3.37632 & 3.89867 & -0.70405\end{array}$ $\begin{array}{lll}-3.48261 & 2.92259 & 0.78641\end{array}$

$\begin{array}{llll}0.79971 & -3.10619 & -1.48868\end{array}$

$\begin{array}{llll}-0.00541 & -2.46549 & -1.89881\end{array}$

$1.00538-3.92074-2.21597$

$\begin{array}{llll}0.42362 & -3.56213 & -0.55281\end{array}$

$3.23783-3.31745-1.00241$

$4.23514-2.85855-0.87305$

$\begin{array}{llll}3.01953 & -3.94402 & -0.11724\end{array}$

$\begin{array}{llll}3.30385 & -3.99619 & -1.87901\end{array}$

$2.4087-1.57723-2.62303$

$2.44418-2.34033-3.42904$

$\begin{array}{llll}1.60351 & -0.85819 & -2.87221\end{array}$

$3.37535-1.03772-2.61157$

$\begin{array}{llll}1.61059 & -0.47711 & 2.72304\end{array}$

$\begin{array}{llll}2.25605 & 0.41191 & 2.59409\end{array}$

$\begin{array}{llll}0.55301 & -0.18208 & 2.55848\end{array}$

$\begin{array}{llll}1.71916 & -0.82991 & 3.77082\end{array}$

$\begin{array}{llll}1.16489 & -2.84806 & 2.02987\end{array}$

$\begin{array}{llll}1.49544 & -3.73772 & 1.45903\end{array}$

$\begin{array}{llll}1.22755 & -3.10319 & 3.10901\end{array}$

$\begin{array}{llll}0.10218 & -2.6418 & 1.78552\end{array}$

$3.52743-1.9446 \quad 2.13749$

$3.54268-2.3124 \quad 3.18542$

$3.97533-2.73129 \quad 1.50338$

$\begin{array}{llll}4.16708 & -1.04219 & 2.09375\end{array}$

$\begin{array}{llll}-6.41428 & 0.78574 & 0.05274\end{array}$

$\begin{array}{llll}-0.52344 & -0.38392 & -0.06915\end{array}$ 